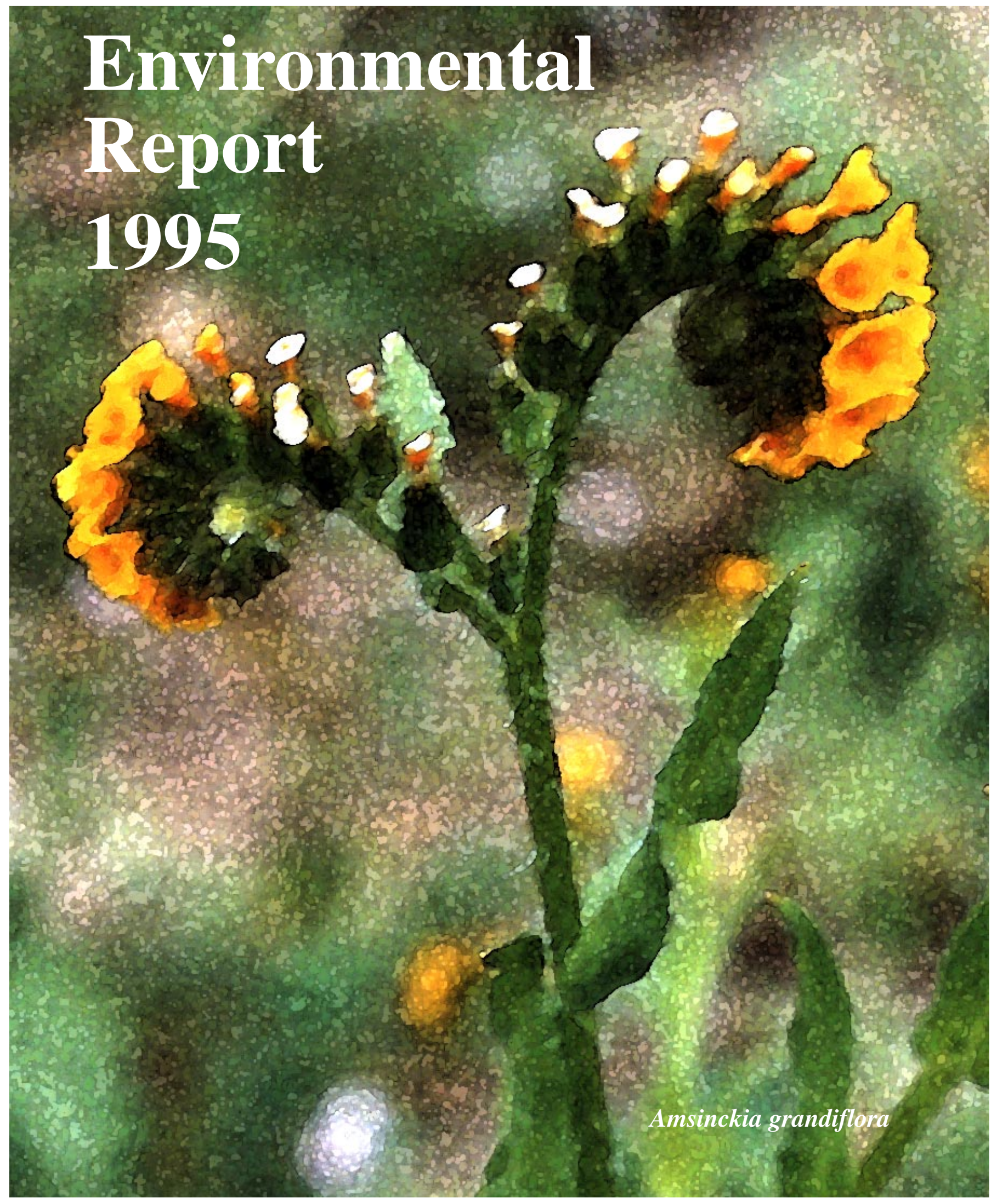


Lead Compositor

Beverly L. Chamberlain

\section{Art and Design}

Lee Dravidzius

\section{Proofreader}

Jill S. Sprinkle

\section{Publication Services \\ Candy K. Justin \\ Brenda M. Staley}

\section{Cover Design:}

Amsinckia grandiflora (large-flowered fiddleneck) at Site 300 , by Lee Dravidzius. Photo credit: Don Gonzalez.

This report was created using electronic publishing. The word processing and layout were performed using Microsoft Word on the Macintosh, and the art was created using Adobe Illustrator. This report can be accessed on the Internet at http://www.llnl.gov/saer.

For additional information about this report, please contact:

Bert Heffner, Area Relations Manager, LLNL Public Affairs Department

P.O. Box 808, L-404

Livermore, CA 94550

(510) 424-4026

\section{DISCLAIMER}

This document was prepared as an account of work sponsored by an agency of the United States Government. Neither the United States Government nor the University of California nor any of their employees, makes any warranty, express or implied, or assumes any legal liability or responsibility for any apparatus, product, or process disclosed, or represents that its use would not infringe on privately owned rights. References herein to any specific commercial products, process or service by trade name, trademark, manufacturer, or otherwise, does not necessarily constitute or imply its endorsement, recommendation, or favoring by the United States Government or the University of California. The views and opinions of authors expressed herein shall not be used for advertising or product endorsement purposes.

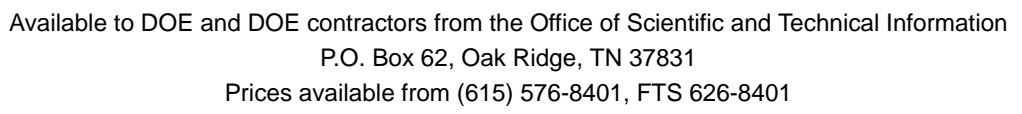

Available to the public from the National Technical Information Service U.S. Department of Commerce 5285 Port Royal Road Springfield, VA 22161 


\section{Environmental Report 1995, Volume 2}

\section{Authors}

Robert J. Harrach

Rebecca A. Failor Gretchen M. Gallegos

Paula J. Tate

Eric Christofferson Erich R. Brandstetter Jennifer M. Larson Arthur H. Biermann

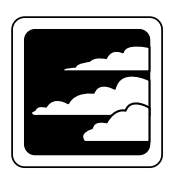

Richard A. Brown

Barbara C. Fields Lucinda M. Garcia Allen R. Grayson

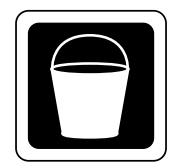

Editor

Howard L. Lentzner

\section{Contributing Authors}

Michael J. Taffet Richard G. Blake

Kris A. Surano Joel $\mathrm{H}$. White

Sabre J. Coleman Constance E. DeGrange John Celeste

Donald H. MacQueen Ellen Eagan Karen J. Folks
Frank J. Gouveia Stephen P. Harris Dawn M. Chase Jamie M. Bennett Mathew Mlekush Saverio P. Mancieri Jim S. Woollett, Jr. Kenneth C. Zahn Robert J. Vellinger

Tina M. Carlsen
Charlotte van Warmerdam Joseph R. Mclntyre Sandra Mathews Stephanie S. Goodwin David Rice William G. Hoppes Bern J. Qualheim Charlene H. Grandfield Richard Ragaini Jack Sims
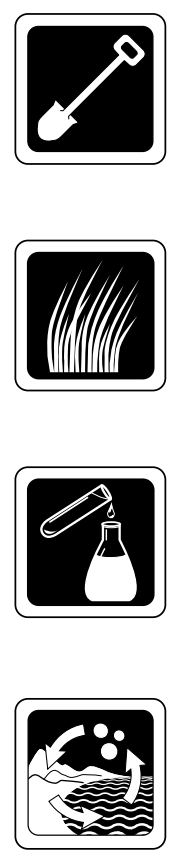

This is Volume 2 of the Lawrence Livermore National Laboratory's (LLNL's) annual Environmental Report 1995, prepared for the U.S. Department of Energy. Volume 1, Environmental Report 1995 (with no volume number designation) is intended to provide all information on LLNL's environmental impact and compliance activities that is of interest to most readers. This second volume, entitled Environmental Report 1995, Volume 2, supports Volume 1 summary data and is essentially a detailed data report that provides individual data points, where applicable. Some summary data are also included in Volume 2, and more detailed accounts are given of sample collection and analytical methods. Not all of the data in Volume 2 tables have been reduced to the proper number of significant figures; however, summary data in both volumes are expressed using the proper number of significant figures.

The two volumes are parallel in their organization to assist with crossreferencing between them. Volume 2 includes information in the eight chapters on monitoring of air, air effluent, sewage, surface water, ground water, soil and sediment, vegetation and foodstuff, and environmental radiation, as well as the three chapters on ground water protection, compliance self-monitoring and quality assurance. The other four chapters in Volume 1 contain no additional information in Volume 2.

As in last year's annual report, data are presented in Système International (SI) units. In particular, the primary units used for radiological results are becquerels and sieverts for activity and dose, with curies and rem used secondarily $\left(1 \mathrm{~Bq}=2.7 \times 10^{-11} \mathrm{Ci} ; 1 \mathrm{~Sv}=100 \mathrm{rem}\right)$. 

1. Site Overview ................................................................................................................ 1-1

2. Compliance Summary .............................................................................. 2-1

3. Environmental Program Information............................................................ 3-1

4. Air Monitoring ................................................................................................ 4-1

Air Surveillance Sampling Methods.............................................................. $4-1$

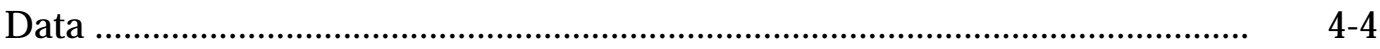

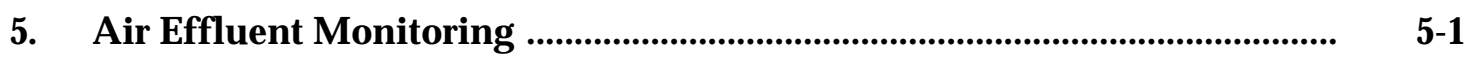

Air Effluent Sampling Methods ................................................................... $5-1$

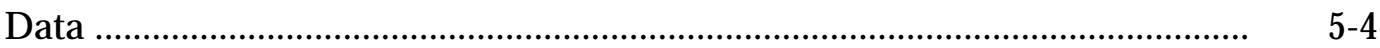

6. Sewage Monitoring................................................................................ 6 6-1

Methods ......................................................................................... 6

7. Surface Water Monitoring ......................................................................... $\quad$ 7-1

Introduction .......................................................................................

Surface Water Methods ....................................................................................

Rainfall Methods ..................................................................................... $\quad$ 7-1

Storm Water Methods ................................................................................... $\quad$ 7-2

8. Routine Ground Water Monitoring …............................................................ 8-1

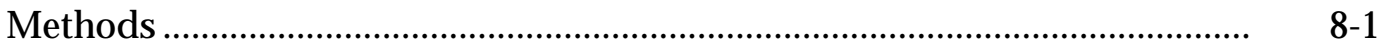

Site 300 Pit 1, Pit 7, and HE Process Areas .................................................... 8 8-2

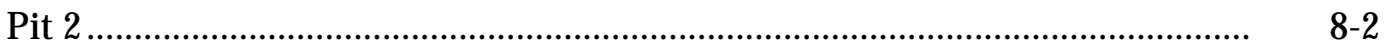

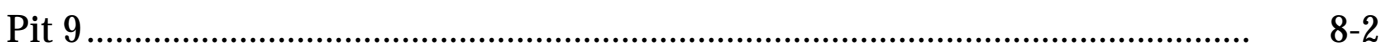

Elk Ravine Drainage Area ....................................................................... 8-3

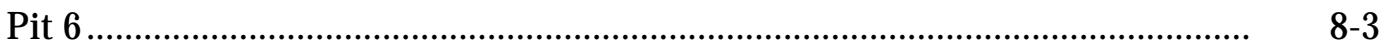

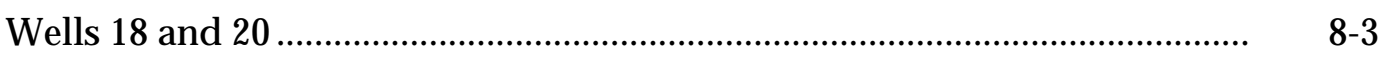

Off-Site Water Supply Wells ......................................................................... $\quad 8-4$

9. Ground Water Protection Management Program .......................................... 9-1

Methods ................................................................................................. 9-1

Livermore Valley Wells ................................................................................... 9 9-1

10. Soil and Sediment Monitoring ................................................................ 10-1

Soil Methods .................................................................................... 10 1

Sediment Methods .............................................................................. 10-2

Data ...................................................................................... $10-3$

11. Vegetation and Foodstuff Monitoring ............................................................ 11-1

Vegetation Sampling Methods ..................................................................... 11-1

Wine Sampling Methods ........................................................................ 11-1

12. Environmental Radiation Monitoring ................................................................... 12-1

Methods of Gamma Radiation Monitoring .............................................. $12-1$

Indicates no supplemental data in Volume 2. Please see Volume 1 for detailed information on this subject. 


\section{Table of Contents}

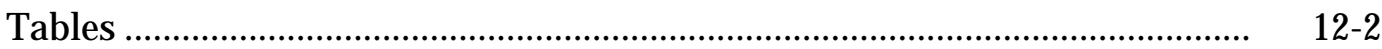

13. Radiological Dose Assessment ..................................................................... 13-1

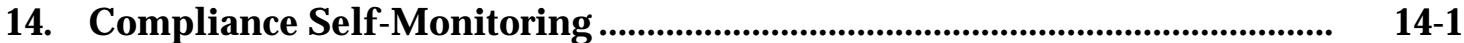

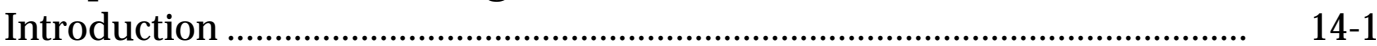

Drainage Retention Basin .............................................................................. 14-1

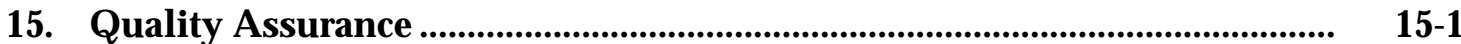

Sampling Location Designators .................................................................... 15-1

Participation in Laboratory Intercomparison Studies ................................... 15-1

Indicates no supplemental data in Volume 2. Please see Volume 1 for detailed information on this subject. 
Table 4-1. Median gross alpha and gross beta activities (Bq/mL), summarized by month and location

Table 4-2a. Median gross alpha activities (Bq/L) for the Livermore Valley 1995

Table 4-2b. Median gross beta activities (Bq/L) for the Livermore Valley 1995

Table 4-3. Gross alpha and gross beta activities (Bq/mL) summarized by month and location, Site 300 ....

Table 4-4. Gamma activity $(\mathrm{Bq} / \mathrm{mL})$ in air particulate samples, Livermore site perimeter, 1995

Table 4-5. Gamma activity $(\mathrm{Bq} / \mathrm{mL})$ in air particulate samples, Site 300, 1995

Table 4-6. Plutonium-239 activity in air particulate samples, Livermore Valley, 1995.

Table 4-7. Plutonium activity in air particulate samples, Livermore site perimeter, 1995

Table 4-8. Plutonium activity in air particulate samples, diffuse sources

Table 4-9. Plutonium activity in air particulate samples, Site 300, 1995

Table 4-10. Uranium activity in air particulate samples, Livermore site perimeter, 1995

Table 4-11. Uranium activity in air particulate samples, Site 300, 1995.

4-21

Table 4-12. Tritium in air, Livermore Valley, 1995.

$4-22$

Table 4-13. Tritium in air, Livermore site perimeter, 1995

$4-23$

Table 4-14. Tritium in air locations near diffuse sources, 1995

Table 4-15. Beryllium in air particulate samples (in $\mathrm{pg} / \mathrm{m}^{3}$ ), Livermore site perimeters, 1995

Table 4-16. Beryllium in air particulate samples (in pg/ $\mathrm{m}^{3}$ ), Site 300, 1995

Table 5-1. Calculated radioactive air emissions from the Livermore site for 1995

Table 5-2. Gross alpha and gross beta in air effluent samples from B166 monitored emission points summarized for 1995 .

Table 5-3. Gross alpha and gross beta $(\mathrm{Bq} / \mathrm{mL})$ in air effluent samples from B175 monitored emission points summarized for 1995

Table 5-4. Gross alpha and gross beta in air effluent samples from B231 monitored emission points summarized for 1995 ...

Table 5-5. Gross alpha and gross beta in air effluent samples from B251 monitored emission points summarized for 1995 .

Table 5-6. Tritium in air effluent samples from B331 monitored emission points summarized for 1995 
Table 5-7. Gross alpha and gross beta in air effluent samples from B332 summarized for 1995 .

Table 5-8. Gross alpha and gross beta in air effluent samples from B419 monitored emission points summarized for 1995 .

Table 5-9. Gross alpha and gross beta in air effluent samples from B490 monitored emission points summarized for 1995 .

Table 5-10. Gross alpha and gross beta in air effluent samples from B491 monitored emission points summarized for 1995

Table 6-1. Daily monitoring results for gross alpha, gross beta, and tritium in the sanitary sewer effluent, 1995

Table 6-2. Weekly and 24-hour composite results for metals in the sanitary sewer effluent, 1995

Table 6-3. Monthly monitoring results for physical and chemical characteristics of the sanitary sewer effluent, 1995

Tabe 6-4. Daily flow totals for sanitary sewer effluent in megaliters (ML), 1995

Table 6-5. Weekly composite results for tritium (in mBq/L) for the LWRP effluent, 1995

Table 7-1. Radioactivity in surface and drinking waters $(\mathrm{Bq} / \mathrm{L})$, Livermore Valley, 1995.

Table 7-2. Radioactivity in storm water runoff (Bq/L) at Livermore site, 1995.

Table 7-3. Tritium in rain $(\mathrm{Bq} / \mathrm{L})$, Livermore site and Livermore Valley

Table 7-4. Storm water runoff, detected nonradioactive parameters, Livermore site, 1995

Table 7-5. Storm water runoff, nonradioactive parameters,

Livermore site

Table 8-1. List of ground water analyses showing inorganic constituent, EPA, or other standard measurement method used, and typical reporting limit used by analytical laboratory

Table 8-2. List of ground water analyses showing EPA Method, organic constituent, and typical reporting limit used by

Table 8-3. analytical laboratory

\section{Table 8-4.}

Table 8-5.

Pit 6 Well K6-03

Pit 6 Well K6-04

Table 8-11. $\quad$ Pit 2 Barcad K1-02A …............................................................... 8 8-20

Table 8-12. $\quad$ Pit 2 Barcad K2-01A …............................................................. 8-21

Table 8-13. $\quad$ Pit 2 Barcad K2-01B .............................................................. 8-22

Table 8-14. Pit 2 Barcad K2-02A ............................................................... 8 8

Table 8-15. $\quad$ Pit 2 Barcad K2-02B .................................................................... 8- 8-24 
Table 8-17. $\quad$ Elk Ravine Well K7-07 …………………………………….. $\quad 8-26$

Table 8-18. $\quad$ Elk Ravine Well NC7-61 ......................................................... $\quad 8-27$

Table 8-19. $\quad$ Elk Ravine Well NC7-69 .......................................................... $\quad 8-28$

Table 8-20. $\quad$ Elk Ravine Well K2-04D ........................................................... $\quad 8-29$

Table 8-21. Elk Ravine Well K2-04S ............................................................ $\quad 8$ 8-30

Table 8-22. $\quad$ Elk Ravine Well K2-01C ……………………………………... $\quad 8-31$

Table 8-23. $\quad$ Elk Ravine Well NC2-11D ......................................................... $\quad 8-32$

Table 8-24. $\quad$ Elk Ravine Well NC2-12D ....................................................... $\quad 8$ 8-33

Table 8-25. $\quad$ Elk Ravine Spring 812CRK ..................................................... 8-. 8-34

Table 8-26. $\quad$ Elk Ravine Well NC2-07 ............................................................ $\quad$ 8-35

Table 8-27. Water Supply Well 20 ……………………………………….. $\quad 8-36$

Table 8-28. Standby Supply Well 18 ……………………………………. $\quad$ 8-37

Table 8-29. Off-site Well CARNRW2 ........................................................... $\quad$ 8-38

Table 8-30. Off-site Well CDF1 ………………………………………….... $\quad 8-39$

Table 8-31. Off-site Well CON1 ................................................................... $\quad 8-40$

Table 8-32. Off-site Well GALLO1 ……………………………………….. $\quad 8-41$

Table 8-33. Off-site Well CARNRW1 .......................................................... $\quad 8-42$

Table 8-34. Off-site Well CON2 ………………………………………..... $\quad$ 8-42

Table 8-35. Annually monitored off-site surveillance wells ....................... $\quad$ 8-43

Table 9-1. Analyses for organic compounds in upgradient wells in the southeastern corner of the Livermore site, 1995 ............... $\quad 9-2$

Table 9-2. Analyses for organic compounds in downgradient wells in the southeastern corner of the Livermore site, 1995 ............ 9-3

Table 9-3. Analyses for inorganic constituents in upgradient wells ........ 9-4

Table 9-4. Analyses for inorganic compounds in downgradient wells in the southeastern corner of the Livermore site, 1995

Table 9-5. Radiological analyses for upgradient wells in the southeastern corner of the Livermore site, 1995

Table 9-6. Radiological analyses for downgradient wells in the southeastern corner of the Livermore site, 1995

Table 10-1. Radionuclides and beryllium in soils and sediments, 1995

$10-4$

Table 11-1. Tritium (in Bq/L) in vegetation, 1995 ...................................... 11-3

Table 11-2. Tritium (in Bq/L) in retail wine, 1995 ....................................... 11-4

Table 12-1. TLD environmental radiation measurements (in mSv), Livermore-site perimeter, 1995 ................................................. 12-3

Table 12-2. TLD environmental radiation measurements (in mSv), Livermore Valley, 1995

Table 12-3. TLD environmental radiation measurements (in $\mathrm{mSv}$ ), Site 300 perimeter location, 1995

Table 12-4. TLD environmental radiation measurements (in $\mathrm{mSv}$ ), Site 300 vicinity, 1995

Table 14-1. Compliance monitoring data for the single release from the DRB

Table 14-2a. Annual maintenance monitoring data collected at sampling location CDBE 
Table 14-2b. Semiannual maintenance monitoring data collected at sampling location $\mathrm{CDBE}$

Table 14-2c. Quarterly maintenance monitoring data collected at sampling location CDBE

Table 14-2d. Monthly maintenance monitoring data collected at sampling location CDBE

Table 14-3. Field data collected from Drainage Retention Basin locations.....

Table 15-1. Livermore site and Livermore Valley sampling location designators for 1995 ....

Table 15-2. Site 300 sampling location designators for 1995

Table 15-3. Previously used sampling location designators not used in 1995

Table 15-4. LLNL Chemistry and Materials Science's Environmental Services Environmental Monitoring Laboratory (CES EMRL) performance in the EPA Environmental Monitoring Systems Laboratory (EMSL) Intercomparison Program for Water, 1995

Table 15-5. LLNL Hazards Control Analytical Laboratory (HCAL) performance in the EPA Environmental Monitoring Systems Laboratory (EMSL) Intercomparison Program for Water, 1995.

Table 15-6. LLNL's Chemistry and Materials Science Environmental Services's Environmental Monitoring Radiation Laboratory's results from the DOE Environmental Measurements Laboratory (EML) Quality Assurance Program, 1995

Table 15-7. LLNL's Hazards Control Analytical Laboratory results from the DOE Environmental Measurements Laboratory (EML) Quality Assurance Program, 1995

Table 15-8. Hazards Control Department Analytical Laboratory results from the Environmental Protection Agency (EPA) Water Pollution and Water Supply Studies 
There is no supplemental data in this chapter.

Please see Volume 1 for details about

Site Overview. 



\section{Compliance Summary $\left[\begin{array}{ll}{[\mathrm{c}} \\ \hline\end{array}\right.$}

There is no supplemental data in this chapter.

Please see Volume 1 for details about

Compliance Summary 

There is no supplemental data in this chapter.

Please see Volume 1 for details about Environmental Program Information. 



\section{Air Monitoring}

Paula J. Tate

Joel White

\section{Air Surveillance Sampling Methods}

For air surveillance monitoring, two networks monitor the air particulates in the environs of LLNL; and one network monitors the environs of Site 300, including one sampler in the City of Tracy. All the networks use continuously operating, high volume samplers located as shown in Figures 4-1, 4-2, and 4-3 in Volume 1. The LLNL site perimeter network maintains six samplers at the perimeter and two at areas of special interest (diffuse sources); the Livermore Valley network consists of five samplers located in the least prevalent wind directions (FCC, FIRE, HOSP, RRCH, and ERCH) considered to be upwind or background and four samplers located in the most prevalent downwind directions (PATT, ZON7, TANK, and ALTA). An additional sampler is located in an area of special interest (LWRP) because of a release in 1967 (see Results Section in Volume 1). These air samplers are positioned to ensure reasonable probability that any significant concentration of particulate effluents from LLNL operations will be detected.

One of the sampling locations, ERCH, was removed from service in October of 1995 because of logistical problems at the location. The geographical details of the particulate sampling locations are outlined in a procedure in the Appendix A of the Environmental Monitoring Plan (Tate et al. 1995).

Each air particulate sampler pulls air continuously at a constant rate of $400 \mathrm{~L} / \mathrm{min}$ through a $20.3 \mathrm{~cm} \times 25.4 \mathrm{~cm}$ Whatman- 41 cellulose filter. The flow is maintained at better than the DOE requirement of $\pm 20 \%$ of the nominal flow by using a mass flow controller that adjusts motor speed. These flow rates are verified at regular intervals with a portable field calibration unit. If a sampler fails, it is repaired and then calibrated with a spirometer that itself was calibrated using a unit traceable to the National Institute for Standards and Technology.

An easily dissolvable filter with a low trace-metal background is required for airborne beryllium analyses. Whatman- 41 filters provide a balance between such requirements and particulate collection efficiency (Lindeken et al. 1963).

Particulate filters are changed each week at all locations. After each particulate filter is removed from a sampler, it is identified by location, date on, date off, elapsed time, and flow rate and is given a sample identifier (a four-field code) that accompanies it throughout the analysis. Filters are then placed in glassine envelopes, and the sample information is recorded in a field tracking notebook. After a four-day delay for decay of the radon-thoron daughters, gross alpha and gross beta activities on the filters are determined with a gas flow proportional 
counter. The gross alpha, gross beta, and beryllium analyses are completed by a contract laboratory.

The analytical laboratory uses ${ }^{241} \mathrm{Am}$ and ${ }^{137} \mathrm{Cs}$ as calibration sources to determine alpha and beta counting efficiencies, respectively. Cross checks using ${ }^{230} \mathrm{Th}$ and ${ }^{90} \mathrm{Sr}$ are also completed periodically. These standards are certified by EPA. Counting-efficiency measurements are made for each set of counted filters. A background count is taken at the beginning of each run and between each set of 20 samples. Records are kept of background and counting-efficiency variations that occur in the counting equipment. The analytical laboratory reports the actual instrumentation values, including negative results that arise when background measurements are higher than those for the filters.

Monthly composites of filters from each of the Livermore site perimeter locations (SALV, MESQ, CAFE, MET, VIS, and COW) are placed into individual plastic bags. The six bags are then combined and sealed in a $214-\mathrm{cm}^{3}$ aluminum can and are counted for gamma-emitting radionuclides using low-background $\mathrm{Ge}(\mathrm{Li})$ detectors. The Site 300 filters are sealed and counted in a similar manner. Following gamma counting, the composited filters from each Livermore site perimeter location are analyzed by LLNL's Chemistry and Materials Science Environmental Services Laboratory for the presence of ${ }^{239} \mathrm{Pu},{ }^{235} \mathrm{U}$, and ${ }^{238} \mathrm{U}$. The off-site samples from the Livermore Valley are analyzed for ${ }^{239} \mathrm{Pu}$, and all of the Site 300 samples are composited and analyzed for ${ }^{239} \mathrm{Pu},{ }^{235} \mathrm{U}$, and ${ }^{238} \mathrm{U}$. The filters are ashed and then dissolved in a mixture of nitric acid and hydrochloric and / or hydrofluoric acids. Plutonium and uranium are separated by an ionexchange process. Each separated element is purified further by ion exchange. Then plutonium is electroplated onto a stainless steel disk and submitted for alpha spectrometry, while uranium solutions are submitted for analysis by mass spectrometry.

Replicate samples are processed to confirm the results obtained from the samplers. In addition, a duplicate quality control (QC) sampler is operated for two months in parallel with the permanent sampler at a given site. The QC filters also are exchanged weekly, and both filter sets are submitted for analysis in the usual manner. After two months, the QC sampler is rotated to another location.

A total volume of approximately $4 \mathrm{ML}$ of air is sampled at each location each week. The details of air particulate sampling and sample change-out are described in Appendix A of the Environmental Monitoring Plan (Tate et al. 1995). Details of high-volume sampler flow calibration are also discussed in a procedure, and details of air sample analysis procedures are outlined in Hall and Edwards (1994). 
As outlined in U.S. Department of Energy (1991), gross alpha and gross beta air filter results are used only as trend indicators; specific radionuclide analysis is done for plutonium, uranium, and all gamma emitters. All analytical results are reported as a measured concentration per volume of air, or at the minimum detection limit (MDL) when no activity is detected. In all cases, the MDL is more than adequate for demonstrating compliance with the pertinent regulatory requirements for radionuclides that are present or may be present in the air sample. Particle size distributions are not determined because the estimated effective dose equivalent to the maximally exposed individual is well below the $0.01 \mathrm{mSv}$ (1 mrem) allowable limit.

Beryllium measurements are made on portions of each of the weekly air filters from the Livermore site perimeter and Site 300 samplers that are composited by sampling location every month. The analytical laboratory adds $40 \mathrm{~mL}$ of $10 \%$ nitric acid to each composite. The solution is heated for 30 minutes and decanted into a separate beaker where more nitric acid is added. This step is repeated two more times and the solution is evaporated to less than $20 \mathrm{~mL}$ (care is taken to prevent the samples from boiling or baking dry). The samples are diluted to $20 \mathrm{~mL}$ with deionized water. Quantification is accomplished by graphite furnace atomic absorption spectroscopy.

LLNL also maintains 11 continuously operating airborne tritium samplers on the Livermore site (Volume 1, Figure 4-1) and 5 samplers in the Livermore Valley (Volume 1, Figure 4-2). Four of the Livermore site locations (B331, B292, B514, and B624) monitor diffuse source emissions. The tritium sample locations are detailed in Appendix B of the Environmental Monitoring Plan (Tate et al. 1995). The tritium samplers, operating at a flow rate of $700 \mathrm{~mL} / \mathrm{min}$, use silica gel in flasks to collect water vapor. These flasks are changed every 2 weeks, and the samples are identified by location, date on, date off, elapsed sampling time, and flow rate. The flow rate is the average of the initial and final flow rates, which are measured biweekly with a rotometer that is calibrated once a year. Each sample is given a sample identifier that accompanies it through analysis. Two additional samplers are rotated among the locations at 2-month intervals to provide duplicate QC samples. Details of the actual tritium sampling and a description of tritium sampler calibration can be found in Appendix A of the Environmental Monitoring Plan (Tate et al. 1995).

Once the samples are taken, the water is separated from the silica gel by freezedried vacuum distillation, and the tritium concentration in the water is determined by liquid-scintillation counting. Airborne tritium sample analysis is done by LLNL's Chemistry and Materials Science Environmental Services Laboratory. All analytical results are reported as a measured concentration per unit volume of air flow through the sampling medium. Details of the analytical procedure are described in Hall and Edwards (1994). 
Monthly summaries of gross alpha and gross beta data are presented in Tables 4-1, 4-2, and 4-3. Tables 4-4 and 4-5 present monthly gamma activity on air filters for the Livermore site perimeter and Site 300. Monthly plutonium data for each sampling location are shown in Tables 4-6 through 4-9. Monthly uranium data for the Livermore site perimeter and Site 300 are presented in Tables 4-10 and 4-11. Biweekly tritium data for sampling locations in the Livermore Valley, Livermore site perimeter, and diffuse sources are shown in Tables 4-12, 4-13, and 4-14. Tables 4-15 and 4-16 present monthly beryllium data for Livermore site perimeter and Site 300 sampling locations.

The data generally reflect historic data values for these analytes at these locations. A detailed discussion of these results is provided in Volume 1 of this report. 
Table 4-1. Median gross alpha and gross beta activities $(\mathrm{Bq} / \mathrm{mL})$ at the $\mathrm{LLNL}$ perimeter, summarized by month and location, 1995.

\begin{tabular}{|c|c|c|c|c|c|c|}
\hline Month & SALV & MESQ & CAFE & MET & VIS & cow \\
\hline \multicolumn{7}{|l|}{ Gross alpha } \\
\hline Jan & $-3.1 \times 10^{-12}$ & $-3.1 \times 10^{-11}$ & $-1.3 \times 10^{-11}$ & $-9.0 \times 10^{-11}$ & $4.3 \times 10^{-13}$ & $-2.4 \times 10^{-11}$ \\
\hline Feb & $-3.2 \times 10^{-11}$ & $-5.0 \times 10^{-11}$ & $1.4 \times 10^{-12}$ & $-2.8 \times 10^{-11}$ & $-4.2 \times 10^{-11}$ & $-3.5 \times 10^{-11}$ \\
\hline Mar & $7.8 \times 10^{-12}$ & $1.7 \times 10^{-11}$ & $-1.4 \times 10^{-11}$ & $8.3 \times 10^{-12}$ & $2.0 \times 10^{-11}$ & $3.9 \times 10^{-12}$ \\
\hline Apr & $9.8 \times 10^{-12}$ & $-1.7 \times 10^{-11}$ & $-5.6 \times 10^{-12}$ & $-5.4 \times 10^{-12}$ & $-1.0 \times 10^{-11}$ & $-1.1 \times 10^{-11}$ \\
\hline May & $-1.0 \times 10^{-11}$ & $-9.5 \times 10^{-12}$ & $3.5 \times 10^{-12}$ & $1.2 \times 10^{-11}$ & $-1.1 \times 10^{-11}$ & $-1.5 \times 10^{-11}$ \\
\hline Jun & $6.3 \times 10^{-12}$ & $7.9 \times 10^{-12}$ & $8.6 \times 10^{-12}$ & $2.8 \times 10^{-12}$ & $1.9 \times 10^{-11}$ & $2.0 \times 10^{-11}$ \\
\hline Jul & $2.5 \times 10^{-11}$ & $-3.1 \times 10^{-11}$ & $-5.3 \times 10^{-12}$ & $-8.0 \times 10^{-12}$ & $1.1 \times 10^{-12}$ & $-7.7 \times 10^{-12}$ \\
\hline Aug & $1.1 \times 10^{-11}$ & $-3.8 \times 10^{-11}$ & $6.2 \times 10^{-12}$ & $-2.2 \times 10^{-11}$ & $-1.3 \times 10^{-11}$ & $-1.1 \times 10^{-11}$ \\
\hline Sep & $1.7 \times 10^{-11}$ & $3.2 \times 10^{-11}$ & $-2.1 \times 10^{-11}$ & $5.4 \times 10^{-12}$ & $-4.9 \times 10^{-11}$ & $4.2 \times 10^{-11}$ \\
\hline Oct & $3.7 \times 10^{-11}$ & $3.0 \times 10^{-11}$ & $7.9 \times 10^{-11}$ & $5.5 \times 10^{-11}$ & $3.6 \times 10^{-11}$ & $-8.0 \times 10^{-13}$ \\
\hline Nov & $2.0 \times 10^{-11}$ & $3.8 \times 10^{-11}$ & $5.7 \times 10^{-11}$ & $2.4 \times 10^{-11}$ & $6.4 \times 10^{-11}$ & $1.4 \times 10^{-11}$ \\
\hline Dec & $1.6 \times 10^{-12}$ & $-1.3 \times 10^{-11}$ & $-1.3 \times 10^{-11}$ & $1.0 \times 10^{-11}$ & $-5.5 \times 10^{-11}$ & $-4.0 \times 10^{-11}$ \\
\hline Annual median(a) & $5.2 \times 10^{-12}$ & $-8.1 \times 10^{-12}$ & $3.7 \times 10^{-12}$ & $1.7 \times 10^{-12}$ & $-4.8 \times 10^{-12}$ & $-7.8 \times 10^{-12}$ \\
\hline$I_{Q}{ }^{(b)}$ & $<2.5 \times 10^{-11}$ & $<2.6 \times 10^{-11}$ & $<2.5 \times 10^{-11}$ & $<3.8 \times 10^{-11}$ & $<3.1 \times 10^{-11}$ & $<2.1 \times 10^{-11}$ \\
\hline Annual maximum ${ }^{(c)}$ & $1.1 \times 10^{-10}$ & $1.1 \times 10^{-10}$ & $1.1 \times 10^{-10}$ & $1.5 \times 10^{-10}$ & $1.3 \times 10^{-10}$ & $1.6 \times 10^{-10}$ \\
\hline \multicolumn{7}{|l|}{ Gross beta } \\
\hline Jan & $8.4 \times 10^{-11}$ & $3.5 \times 10^{-10}$ & $1.9 \times 10^{-10}$ & $2.7 \times 10^{-10}$ & $1.8 \times 10^{-10}$ & $1.9 \times 10^{-10}$ \\
\hline Feb & $6.0 \times 10^{-10}$ & $8.3 \times 10^{-10}$ & $7.5 \times 10^{-10}$ & $7.5 \times 10^{-10}$ & $6.2 \times 10^{-10}$ & $7.2 \times 10^{-10}$ \\
\hline Mar & $2.7 \times 10^{-10}$ & $2.7 \times 10^{-10}$ & $3.3 \times 10^{-10}$ & $2.0 \times 10^{-10}$ & $2.9 \times 10^{-10}$ & $2.4 \times 10^{-10}$ \\
\hline Apr & $1.9 \times 10^{-10}$ & $2.9 \times 10^{-10}$ & $3.0 \times 10^{-10}$ & $2.0 \times 10^{-10}$ & $2.4 \times 10^{-10}$ & $3.2 \times 10^{-10}$ \\
\hline May & $2.8 \times 10^{-10}$ & $2.1 \times 10^{-10}$ & $2.1 \times 10^{-10}$ & $2.5 \times 10^{-10}$ & $3.0 \times 10^{-10}$ & $2.6 \times 10^{-10}$ \\
\hline Jun & $2.5 \times 10^{-10}$ & $2.6 \times 10^{-10}$ & $2.8 \times 10^{-10}$ & $2.6 \times 10^{-10}$ & $1.9 \times 10^{-10}$ & $4.4 \times 10^{-11}$ \\
\hline Jul & $2.8 \times 10^{-10}$ & $2.7 \times 10^{-10}$ & $2.4 \times 10^{-10}$ & $3.2 \times 10^{-10}$ & $2.3 \times 10^{-10}$ & $2.0 \times 10^{-10}$ \\
\hline Aug & $5.3 \times 10^{-10}$ & $5.3 \times 10^{-10}$ & $4.6 \times 10^{-10}$ & $4.7 \times 10^{-10}$ & $4.1 \times 10^{-10}$ & $5.6 \times 10^{-10}$ \\
\hline Sep & $8.8 \times 10^{-10}$ & $8.5 \times 10^{-10}$ & $7.1 \times 10^{-10}$ & $8.0 \times 10^{-10}$ & $7.1 \times 10^{-10}$ & $6.9 \times 10^{-10}$ \\
\hline Oct & $8.6 \times 10^{-10}$ & $8.1 \times 10^{-10}$ & $8.1 \times 10^{-10}$ & $8.8 \times 10^{-10}$ & $6.4 \times 10^{-10}$ & $8.0 \times 10^{-10}$ \\
\hline Nov & $7.6 \times 10^{-10}$ & $7.4 \times 10^{-10}$ & $7.3 \times 10^{-10}$ & $7.6 \times 10^{-10}$ & $6.6 \times 10^{-10}$ & $8.4 \times 10^{-10}$ \\
\hline Dec & $3.9 \times 10^{-10}$ & $5.4 \times 10^{-10}$ & $4.2 \times 10^{-10}$ & $6.0 \times 10^{-10}$ & $4.4 \times 10^{-10}$ & $4.0 \times 10^{-10}$ \\
\hline Annual median(a) & $4.1 \times 10^{-10}$ & $4.0 \times 10^{-10}$ & $4.6 \times 10^{-10}$ & $4.3 \times 10^{-10}$ & $3.6 \times 10^{-10}$ & $4.2 \times 10^{-10}$ \\
\hline IQR $^{(\mathbf{b})}$ & $4.3 \times 10^{-10}$ & $4.6 \times 10^{-10}$ & $4.3 \times 10^{-10}$ & $5.0 \times 10^{-10}$ & $3.6 \times 10^{-10}$ & $4.4 \times 10^{-10}$ \\
\hline Annual maximum(c) & $2.0 \times 10^{-9}$ & $2.0 \times 10^{-9}$ & $1.9 \times 10^{-9}$ & $2.4 \times 10^{-9}$ & $1.6 \times 10^{-9}$ & $1.9 \times 10^{-9}$ \\
\hline
\end{tabular}

a The annual median is determined from the data for the 52-week period.

b The interquartile range is determined from the data for the 52-week period. See Chapter 15, Quality Assurance.

c The annual maximum is determined from the data for the 52-week period. 
Table 4-2a. Median gross alpha activities $(\mathrm{Bq} / \mathrm{mL})$ for the Livermore Valley, 1995.

\begin{tabular}{|c|c|c|c|c|c|c|c|}
\hline \multirow[b]{2}{*}{ Month } & \multicolumn{7}{|c|}{ Livermore Valley downwind } \\
\hline & \multicolumn{7}{|c|}{\begin{tabular}{l|l} 
ZON7 & TANK \\
\end{tabular}} \\
\hline Jan & $-1.0 \times 10^{-11}$ & \multicolumn{2}{|c|}{$-8.2 \times 10^{-11}$} & \multicolumn{2}{|c|}{$-4.1 \times 10^{-12}$} & \multicolumn{2}{|c|}{$-1.8 \times 10^{-11}$} \\
\hline Feb & $-4.5 \times 10^{-11}$ & \multicolumn{2}{|c|}{$-4.9 \times 10^{-11}$} & \multicolumn{2}{|c|}{$-6.7 \times 10^{-11}$} & \multicolumn{2}{|c|}{$-1.4 \times 10^{-11}$} \\
\hline Mar & $1.4 \times 10^{-11}$ & \multicolumn{2}{|c|}{$1.2 \times 10^{-11}$} & \multicolumn{2}{|c|}{$-1.6 \times 10^{-11}$} & \multicolumn{2}{|c|}{$-4.2 \times 10^{-12}$} \\
\hline Apr & $-4.0 \times 10^{-11}$ & \multicolumn{2}{|c|}{$-1.4 \times 10^{-11}$} & \multicolumn{2}{|c|}{$7.1 \times 10^{-12}$} & \multicolumn{2}{|c|}{$2.4 \times 10^{-11}$} \\
\hline May & $-3.0 \times 10^{-13}$ & \multicolumn{2}{|c|}{$-7.1 \times 10^{-12}$} & \multicolumn{2}{|c|}{$-1.3 \times 10^{-11}$} & \multicolumn{2}{|c|}{$-2.1 \times 10^{-11}$} \\
\hline Jun & $2.0 \times 10^{-11}$ & \multicolumn{2}{|c|}{$1.0 \times 10^{-11}$} & \multicolumn{2}{|c|}{$-3.2 \times 10^{-12}$} & \multicolumn{2}{|c|}{$2.6 \times 10^{-11}$} \\
\hline Jul & $-2.2 \times 10^{-11}$ & \multicolumn{2}{|c|}{$-2.1 \times 10^{-11}$} & \multicolumn{2}{|c|}{$1.1 \times 10^{-11}$} & \multicolumn{2}{|c|}{$-1.1 \times 10^{-11}$} \\
\hline Aug & $-6.5 \times 10^{-11}$ & \multicolumn{2}{|c|}{$-3.2 \times 10^{-11}$} & \multicolumn{2}{|c|}{$3.5 \times 10^{-12}$} & -9 . & $1 \times 10^{-12}$ \\
\hline Sep & $-4.3 \times 10^{-11}$ & $-1.2 \times 10^{-}$ & & $7.6 \times$ & $10^{-13}$ & -5 & $6 \times 10^{-11}$ \\
\hline Oct & $-1.4 \times 10^{-11}$ & $6.6 \times 10^{-}$ & & $4.8 \times$ & $10^{-11}$ & & $5 \times 10^{-11}$ \\
\hline Nov & $5.8 \times 10^{-11}$ & $2.5 \times 10^{-}$ & & $3.5 \times$ & $10^{-11}$ & & $1 \times 10^{-11}$ \\
\hline Dec & $-1.5 \times 10^{-12}$ & $-3.3 \times 10^{-}$ & & $-2.0 \times$ & $10^{-11}$ & -1. & $4 \times 10^{-11}$ \\
\hline Annual median $(a)$ & $-1.2 \times 10^{-11}$ & $-6.3 \times 10$ & & $-8.0 \times$ & $10^{-13}$ & & $6 \times 10^{-13}$ \\
\hline $\operatorname{IQR}^{(\mathbf{b})}$ & $<2.3 \times 10^{-11}$ & $<1.5 \times 10$ & & $<3.1 \times$ & $10^{-11}$ & $<3$. & $0 \times 10^{-11}$ \\
\hline Annual maximum(c) & $1.2 \times 10^{-10}$ & $1.2 \times 10^{-}$ & & $9.1 \times$ & $10^{-11}$ & & $2 \times 10^{-10}$ \\
\hline & & Liver & (1) & alley up & owind & & \\
\hline & FCC & FIRE & & SP & RRCH & & $\mathrm{ERCH}$ \\
\hline Jan & $-6.5 \times 10^{-11}$ & $-1.3 \times 10^{-11}$ & -1.7 & $10^{-11}$ & $-1.9 \times 10^{-1}$ & & $-2.5 \times 10^{-11}$ \\
\hline Feb & $-3.5 \times 10^{-12}$ & $4.6 \times 10^{-12}$ & -4.1 & $10^{-11}$ & $-3.6 \times 10^{-1}$ & & $-3.4 \times 10^{-11}$ \\
\hline Mar & $2.0 \times 10^{-11}$ & $-3.1 \times 10^{-12}$ & -2.2 & $10^{-11}$ & $-1.9 \times 10^{-1}$ & & $-1.1 \times 10^{-11}$ \\
\hline Apr & $-4.6 \times 10^{-12}$ & $-2.1 \times 10^{-11}$ & 3.8 & $10^{-11}$ & $-2.7 \times 10^{-1}$ & & $-1.3 \times 10^{-11}$ \\
\hline May & $2.9 \times 10^{-12}$ & $2.5 \times 10^{-11}$ & -1.7 & $10^{-11}$ & $-9.9 \times 10^{-1}$ & & $-3.4 \times 10^{-11}$ \\
\hline Jun & $-1.5 \times 10^{-12}$ & $6.6 \times 10^{-12}$ & -8.3 & $10^{-12}$ & $-2.1 \times 10^{-1}$ & & $-8.0 \times 10^{-12}$ \\
\hline Jul & $-2.2 \times 10^{-11}$ & $5.2 \times 10^{-12}$ & -2.4 & $10^{-11}$ & $-2.4 \times 10^{-1}$ & & $-7.6 \times 10^{-12}$ \\
\hline Aug & $-5.8 \times 10^{-11}$ & $-4.9 \times 10^{-11}$ & -7.8 & $10^{-12}$ & $-2.3 \times 10^{-1}$ & & $-1.5 \times 10^{-11}$ \\
\hline Sep & $-6.4 \times 10^{-11}$ & $-1.3 \times 10^{-11}$ & -3.3 & $10^{-11}$ & $9.4 \times 10^{-1}$ & & $-5.4 \times 10^{-12}$ \\
\hline Oct & $4.4 \times 10^{-11}$ & $5.4 \times 10^{-11}$ & -1.1 & $10^{-11}$ & $3.9 \times 10^{-1}$ & & $7.6 \times 10^{-12}$ \\
\hline Nov & $6.4 \times 10^{-11}$ & $-5.6 \times 10^{-13}$ & -3.9 & $10^{-14}$ & $9.0 \times 10^{-1}$ & & $-d$ \\
\hline Dec & $6.5 \times 10^{-12}$ & $-1.0 \times 10^{-11}$ & 2.0 & $10^{-11}$ & $-4.5 \times 10^{-1}$ & & $-^{d}$ \\
\hline Annual median(a) & $2.8 \times 10^{-12}$ & $-7.3 \times 10^{-12}$ & -1.1 & $10^{-11}$ & $-1.6 \times 10^{-1}$ & & $-1.2 \times 10^{-11}$ \\
\hline$I_{Q} R^{(b)}$ & $<4.0 \times 10^{-11}$ & $<2.5 \times 10^{-11}$ & $<1.2$ & $10^{-11}$ & $<1.4 \times 10^{-1}$ & & $-^{e}$ \\
\hline Annual maximum ${ }^{(c)}$ & $8.6 \times 10^{-11}$ & $1.2 \times 10^{-10}$ & 7.3 & $10^{-11}$ & $1.2 \times 10^{-1}$ & & $7.1 \times 10^{-11}$ \\
\hline
\end{tabular}


Table 4-2a. Median gross alpha activities $(\mathrm{Bq} / \mathrm{mL})$ for the Livermore Valley, 1995 (concluded).

\begin{tabular}{|c|c|}
\hline \multirow[b]{2}{*}{ Month } & Special interest \\
\hline & LWRP \\
\hline Jan & $-3.5 \times 10^{-11}$ \\
\hline Feb & $-4.8 \times 10^{-11}$ \\
\hline Mar & $-1.1 \times 10^{-11}$ \\
\hline Apr & $-8.8 \times 10^{-12}$ \\
\hline May & $-5.8 \times 10^{-12}$ \\
\hline Jun & $-2.0 \times 10^{-12}$ \\
\hline Jul & $-4.7 \times 10^{-11}$ \\
\hline Aug & $-2.0 \times 10^{-12}$ \\
\hline Sep & $2.1 \times 10^{-11}$ \\
\hline Oct & $1.0 \times 10^{-10}$ \\
\hline Nov & $4.3 \times 10^{-11}$ \\
\hline Dec & $6.1 \times 10^{-12}$ \\
\hline Annual median(a) & $-5.8 \times 10^{-12}$ \\
\hline $\mathrm{IQR}^{(\mathbf{b})}$ & $<2.7 \times 10^{-11}$ \\
\hline Annual maximum(c) & $1.5 \times 10^{-10}$ \\
\hline
\end{tabular}

a The annual median is determined from the data for the 52-week period.

b The interquartile range is determined from the data for the 52-week period. See Chapter 15, Quality Assurance.

c The annual maximum is determined from the data for the 52-week period.

d Sample location was discontinued because of logistical problems.

e Interquarterile range not calculated. See Chapter 15, Quality Assurance. 
Table 4-2b. Median gross beta activities (Bq/mL) for the Livermore Valley, 1995.

\begin{tabular}{|c|c|c|c|c|c|c|}
\hline \multirow[b]{2}{*}{ Month } & \multicolumn{6}{|c|}{ Livermore Valley downwind } \\
\hline & \multicolumn{5}{|c|}{\begin{tabular}{l|l} 
ZON7 & TANK \\
\end{tabular}} & ALTA \\
\hline Jan & \multicolumn{3}{|l|}{$2.7 \times 10^{-10}$} & \multicolumn{2}{|c|}{$1.1 \times 10^{-10}$} & $2.6 \times 10^{-10}$ \\
\hline Feb & \multicolumn{3}{|l|}{$6.2 \times 10^{-10}$} & \multicolumn{2}{|c|}{$6.7 \times 10^{-10}$} & $6.8 \times 10^{-10}$ \\
\hline Mar & \multicolumn{3}{|l|}{$2.3 \times 10^{-10}$} & \multicolumn{2}{|c|}{$3.1 \times 10^{-10}$} & $3.1 \times 10^{-10}$ \\
\hline Apr & \multicolumn{3}{|l|}{$1.8 \times 10^{-10}$} & \multicolumn{2}{|c|}{$2.7 \times 10^{-10}$} & $2.7 \times 10^{-10}$ \\
\hline May & \multicolumn{3}{|l|}{$3.0 \times 10^{-10}$} & \multicolumn{2}{|c|}{$3.5 \times 10^{-10}$} & $1.5 \times 10^{-10}$ \\
\hline Jun & \multicolumn{3}{|l|}{$2.2 \times 10^{-10}$} & \multicolumn{2}{|c|}{$3.2 \times 10^{-10}$} & $2.8 \times 10^{-10}$ \\
\hline Jul & \multicolumn{3}{|l|}{$1.9 \times 10^{-10}$} & \multicolumn{2}{|c|}{$3.0 \times 10^{-10}$} & $3.2 \times 10^{-10}$ \\
\hline Aug & \multicolumn{3}{|l|}{$4.3 \times 10^{-10}$} & \multicolumn{2}{|c|}{$4.5 \times 10^{-10}$} & $4.6 \times 10^{-10}$ \\
\hline Sep & \multicolumn{3}{|l|}{$5.7 \times 10^{-10}$} & $5.3 \times$ & $0^{-10}$ & $.6 \times 10^{-10}$ \\
\hline Oct & $7.0 \times 10^{-10}$ & $7.4 \times 10$ & & $9.8 \times$ & $0^{-10}$ & $.1 \times 10^{-10}$ \\
\hline Nov & $4.4 \times 10^{-10}$ & $6.4 \times 10$ & & $6.3 \times$ & $0^{-10}$ & $.9 \times 10^{-10}$ \\
\hline Dec & $2.2 \times 10^{-10}$ & $4.3 \times 10^{-}$ & & $4.3 \times$ & $0^{-10}$ & $.6 \times 10^{-10}$ \\
\hline Annual median $(a)$ & $3.1 \times 10^{-10}$ & $3.9 \times 10$ & & $4.1 \times$ & $0^{-10}$ & $.9 \times 10^{-10}$ \\
\hline$I_{Q} R^{b)}$ & $3.0 \times 10^{-10}$ & $3.8 \times 10$ & & $3.5 \times$ & $0^{-10}$ & $.0 \times 10^{-10}$ \\
\hline Annual maximum(c) & $1.5 \times 10^{-9}$ & $1.7 \times 10$ & & $1.6 \times$ & $0^{-9}$ & $.4 \times 10^{-9}$ \\
\hline & & Liver & 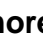 & Illey up & Nind & \\
\hline & FCC & FIRE & & & RRCH & ERCH \\
\hline Jan & $2.5 \times 10^{-10}$ & $2.2 \times 10^{-10}$ & & $10^{-10}$ & $2.5 \times 10^{-10}$ & $1.4 \times 10^{-10}$ \\
\hline Feb & $6.7 \times 10^{-10}$ & $6.4 \times 10^{-10}$ & & $10^{-10}$ & $7.7 \times 10^{-10}$ & $5.6 \times 10^{-10}$ \\
\hline Mar & $2.2 \times 10^{-10}$ & $2.5 \times 10^{-10}$ & & $10^{-10}$ & $2.2 \times 10^{-10}$ & $2.3 \times 10^{-10}$ \\
\hline Apr & $2.0 \times 10^{-10}$ & $1.9 \times 10^{-10}$ & & $10^{-10}$ & $2.0 \times 10^{-10}$ & $1.3 \times 10^{-10}$ \\
\hline May & $2.3 \times 10^{-10}$ & $1.1 \times 10^{-10}$ & & $10^{-10}$ & $1.9 \times 10^{-10}$ & $3.4 \times 10^{-10}$ \\
\hline Jun & $1.8 \times 10^{-10}$ & $1.7 \times 10^{-10}$ & & $10^{-10}$ & $1.1 \times 10^{-10}$ & $8.3 \times 10^{-11}$ \\
\hline Jul & $2.3 \times 10^{-10}$ & $2.5 \times 10^{-10}$ & & $10^{-10}$ & $3.9 \times 10^{-10}$ & $2.1 \times 10^{-10}$ \\
\hline Aug & $5.2 \times 10^{-10}$ & $4.2 \times 10^{-10}$ & & $10^{-10}$ & $5.4 \times 10^{-10}$ & $4.4 \times 10^{-10}$ \\
\hline Sep & $6.6 \times 10^{-10}$ & $7.7 \times 10^{-10}$ & & $10^{-10}$ & $7.7 \times 10^{-10}$ & $4.8 \times 10^{-10}$ \\
\hline Oct & $8.6 \times 10^{-10}$ & $8.8 \times 10^{-10}$ & & $10^{-10}$ & $6.7 \times 10^{-10}$ & $2.9 \times 10^{-10}$ \\
\hline Nov & $8.8 \times 10^{-10}$ & $7.1 \times 10^{-10}$ & & $10^{-10}$ & $7.2 \times 10^{-10}$ & $-^{d}$ \\
\hline Dec & $4.9 \times 10^{-10}$ & $5.2 \times 10^{-10}$ & & $10^{-10}$ & $3.8 \times 10^{-10}$ & $-d$ \\
\hline Annual median(a) & $3.6 \times 10^{-10}$ & $4.0 \times 10^{-10}$ & & $10^{-10}$ & $3.8 \times 10^{-10}$ & $2.8 \times 10^{-10}$ \\
\hline$I_{Q} R^{(b)}$ & $4.7 \times 10^{-10}$ & $4.0 \times 10^{-10}$ & & $10^{-10}$ & $4.5 \times 10^{-10}$ & $3.0 \times 10^{-10}$ \\
\hline Annual maximum(c) & $1.9 \times 10^{-9}$ & $2.1 \times 10^{-9}$ & & $10^{-9}$ & $1.8 \times 10^{-9}$ & $1.2 \times 10^{-9}$ \\
\hline
\end{tabular}


Table 4-2b. Median gross beta activities $(\mathrm{Bq} / \mathrm{mL})$ for the Livermore Valley, 1995 (concluded).

\begin{tabular}{|c|c|}
\hline & Special interest \\
\hline Month & LWRP \\
\hline Jan & $2.9 \times 10^{-10}$ \\
\hline Feb & $9.4 \times 10^{-10}$ \\
\hline Mar & $3.6 \times 10^{-10}$ \\
\hline Apr & $3.3 \times 10^{-10}$ \\
\hline May & $3.3 \times 10^{-10}$ \\
\hline Jun & $2.1 \times 10^{-10}$ \\
\hline Jul & $3.5 \times 10^{-10}$ \\
\hline Aug & $5.1 \times 10^{-10}$ \\
\hline Sep & $8.4 \times 10^{-10}$ \\
\hline Oct & $7.9 \times 10^{-10}$ \\
\hline Nov & $7.9 \times 10^{-10}$ \\
\hline Dec & $6.4 \times 10^{-10}$ \\
\hline Annual median(a) & $4.8 \times 10^{-10}$ \\
\hline $\operatorname{IQR}^{(\mathbf{b})}$ & $4.3 \times 10^{-10}$ \\
\hline Annual maximum(c) & $2.3 \times 10^{-9}$ \\
\hline
\end{tabular}

a The annual median is determined from the data for the 52-week period.

b The interquartile range is determined from the data for the 52-week period. See Chapter 15, Quality Assurance.

c The annual maximum is determined from the data for the 52-week period.

d Sample location was discontinued because of logistical problems. 
Table 4-3. Gross alpha and gross beta activities $(\mathrm{Bq} / \mathrm{mL})$ summarized by month and location, Site 300 , 1995.

\begin{tabular}{|c|c|c|c|c|c|c|c|c|c|}
\hline Month & 801E & ECP & EOBS & GOLF & LIN & NPS & WCP & WOBS & TFIR \\
\hline \multicolumn{10}{|l|}{ Gross alpha } \\
\hline Jan & $7.5 \times 10^{-12}$ & $5.4 \times 10^{-12}$ & $-1.4 \times 10^{-11}$ & $3.1 \times 10^{-13}$ & $-1.5 \times 10^{-11}$ & $-2.9 \times 10^{-11}$ & $-2.6 \times 10^{-11}$ & $-2.6 \times 10^{-11}$ & $-8.6 \times 10^{-11}$ \\
\hline Feb & $-2.5 \times 10^{-11}$ & $2.2 \times 10^{-11}$ & $6.1 \times 10^{-12}$ & $-3.3 \times 10^{-11}$ & $-3.0 \times 10^{-11}$ & $-3.3 \times 10^{-11}$ & $-2.9 \times 10^{-11}$ & $-1.8 \times 10^{-11}$ & $-1.4 \times 10^{-11}$ \\
\hline Mar & $-3.0 \times 10^{-12}$ & $-6.6 \times 10^{-12}$ & $-1.3 \times 10^{-11}$ & $-2.4 \times 10^{-11}$ & $-2.3 \times 10^{-11}$ & $3.8 \times 10^{-13}$ & $-2.2 \times 10^{-11}$ & $-1.5 \times 10^{-11}$ & $-5.2 \times 10^{-11}$ \\
\hline Apr & $-2.0 \times 10^{-11}$ & $-1.3 \times 10^{-11}$ & $-1.2 \times 10^{-11}$ & $-2.0 \times 10^{-12}$ & $-1.3 \times 10^{-11}$ & $-2.8 \times 10^{-11}$ & $-1.7 \times 10^{-11}$ & $-3.3 \times 10^{-11}$ & $-3.1 \times 10^{-11}$ \\
\hline May & $4.1 \times 10^{-11}$ & $6.2 \times 10^{-12}$ & $1.4 \times 10^{-11}$ & $1.9 \times 10^{-11}$ & $4.1 \times 10^{-12}$ & $4.5 \times 10^{-11}$ & $1.3 \times 10^{-11}$ & $1.2 \times 10^{-12}$ & $2.1 \times 10^{-11}$ \\
\hline Jun & $-1.6 \times 10^{-11}$ & $-1.7 \times 10^{-11}$ & $8.8 \times 10^{-12}$ & $3.6 \times 10^{-11}$ & $3.1 \times 10^{-11}$ & $-9.5 \times 10^{-12}$ & $3.4 \times 10^{-11}$ & $3.4 \times 10^{-12}$ & $1.3 \times 10^{-11}$ \\
\hline July & $1.7 \times 10^{-11}$ & $1.8 \times 10^{-11}$ & $-2.1 \times 10^{-11}$ & $-1.0 \times 10^{-11}$ & $-9.6 \times 10^{-12}$ & $5.3 \times 10^{-12}$ & $-1.0 \times 10^{-11}$ & $9.2 \times 10^{-12}$ & $1.6 \times 10^{-11}$ \\
\hline Aug & $-2.8 \times 10^{-11}$ & $-6.3 \times 10^{-11}$ & $-2.7 \times 10^{-11}$ & $-1.2 \times 10^{-11}$ & $-1.5 \times 10^{-11}$ & $-6.5 \times 10^{-11}$ & $-1.3 \times 10^{-11}$ & $2.8 \times 10^{-12}$ & $2.0 \times 10^{-12}$ \\
\hline Sept & $-6.0 \times 10^{-12}$ & $9.2 \times 10^{-12}$ & $-2.0 \times 10^{-11}$ & $-1.6 \times 10^{-11}$ & $3.5 \times 10^{-11}$ & $-9.7 \times 10^{-12}$ & $2.1 \times 10^{-11}$ & $-1.7 \times 10^{-12}$ & $7.0 \times 10^{-11}$ \\
\hline Oct & $7.2 \times 10^{-11}$ & $2.9 \times 10^{-11}$ & $2.0 \times 10^{-11}$ & $3.9 \times 10^{-11}$ & $9.9 \times 10^{-11}$ & $3.5 \times 10^{-11}$ & $5.9 \times 10^{-11}$ & $1.9 \times 10^{-11}$ & $5.5 \times 10^{-11}$ \\
\hline Nov & $5.7 \times 10^{-11}$ & $-1.6 \times 10^{-12}$ & $3.4 \times 10^{-11}$ & $3.6 \times 10^{-11}$ & $3.0 \times 10^{-11}$ & $-1.8 \times 10^{-12}$ & $5.8 \times 10^{-11}$ & $1.5 \times 10^{-11}$ & $7.5 \times 10^{-11}$ \\
\hline $\mathrm{Dec}$ & $-1.4 \times 10^{-11}$ & $-1.4 \times 10^{-11}$ & $-4.9 \times 10^{-11}$ & $-4.0 \times 10^{-11}$ & $2.4 \times 10^{-11}$ & $-2.5 \times 10^{-11}$ & $1.7 \times 10^{-11}$ & $-1.3 \times 10^{-11}$ & $-5.1 \times 10^{-11}$ \\
\hline Annual median ${ }^{(a)}$ & $1.5 \times 10^{-11}$ & $-1.7 \times 10^{-12}$ & $-1.2 \times 10^{-11}$ & $-8.7 \times 10^{-12}$ & $1.9 \times 10^{-12}$ & $-1.8 \times 10^{-11}$ & $1.4 \times 10^{-12}$ & $-5.4 \times 10^{-12}$ & $2.0 \times 10^{-12}$ \\
\hline $\mathrm{IQR}^{(\mathrm{b})}$ & $3.5 \times 10^{-10}$ & $6.0 \times 10^{-11}$ & $5.3 \times 10^{-11}$ & $6.2 \times 10^{-11}$ & $1.3 \times 10^{-10}$ & $5.9 \times 10^{-11}$ & $1.6 \times 10^{-10}$ & $6.0 \times 10^{-11}$ & $2.3 \times 10^{-10}$ \\
\hline $\begin{array}{l}\text { Annual } \\
\text { maximum }^{(c)}\end{array}$ & $2.7 \times 10^{-9}$ & $2.1 \times 10^{-9}$ & $3.5 \times 10^{-9}$ & $2.5 \times 10^{-9}$ & $4.2 \times 10^{-9}$ & $4.0 \times 10^{-9}$ & $2.9 \times 10^{-9}$ & $4.4 \times 10^{-9}$ & $5.5 \times 10^{-9}$ \\
\hline \multicolumn{10}{|l|}{ Gross beta } \\
\hline Jan & $1.5 \times 10^{-10}$ & $8.0 \times 10^{-11}$ & $1.6 \times 10^{-10}$ & $1.7 \times 10^{-10}$ & $1.2 \times 10^{-10}$ & $2.9 \times 10^{-10}$ & $1.1 \times 10^{-10}$ & $2.0 \times 10^{-10}$ & $2.5 \times 10^{-10}$ \\
\hline Feb & $3.8 \times 10^{-10}$ & $6.0 \times 10^{-10}$ & $3.6 \times 10^{-10}$ & $5.7 \times 10^{-10}$ & $5.6 \times 10^{-10}$ & $5.4 \times 10^{-10}$ & $6.2 \times 10^{-10}$ & $5.6 \times 10^{-10}$ & $7.6 \times 10^{-10}$ \\
\hline Mar & $3.6 \times 10^{-10}$ & $2.7 \times 10^{-10}$ & $4.0 \times 10^{-10}$ & $2.4 \times 10^{-10}$ & $2.9 \times 10^{-10}$ & $4.2 \times 10^{-10}$ & $1.2 \times 10^{-10}$ & $2.8 \times 10^{-10}$ & $4.5 \times 10^{-10}$ \\
\hline Apr & $2.3 \times 10^{-10}$ & $2.0 \times 10^{-10}$ & $2.2 \times 10^{-10}$ & $2.1 \times 10^{-10}$ & $2.0 \times 10^{-10}$ & $2.6 \times 10^{-10}$ & $2.8 \times 10^{-10}$ & $2.4 \times 10^{-10}$ & $3.4 \times 10^{-10}$ \\
\hline May & $3.9 \times 10^{-10}$ & $2.3 \times 10^{-10}$ & $2.4 \times 10^{-10}$ & $3.0 \times 10^{-10}$ & $2.8 \times 10^{-10}$ & $3.6 \times 10^{-10}$ & $1.3 \times 10^{-10}$ & $2.5 \times 10^{-10}$ & $3.1 \times 10^{-10}$ \\
\hline Jun & $2.1 \times 10^{-10}$ & $3.8 \times 10^{-10}$ & $2.4 \times 10^{-10}$ & $2.7 \times 10^{-10}$ & $9.9 \times 10^{-10}$ & $1.9 \times 10^{-10}$ & $2.2 \times 10^{-10}$ & $1.1 \times 10^{-10}$ & $3.1 \times 10^{-10}$ \\
\hline July & $3.0 \times 10^{-10}$ & $3.0 \times 10^{-10}$ & $3.6 \times 10^{-10}$ & $3.0 \times 10^{-10}$ & $3.1 \times 10^{-10}$ & $2.7 \times 10^{-10}$ & $3.5 \times 10^{-10}$ & $2.8 \times 10^{-10}$ & $4.2 \times 10^{-10}$ \\
\hline Aug & $5.6 \times 10^{-10}$ & $5.1 \times 10^{-10}$ & $5.5 \times 10^{-10}$ & $4.8 \times 10^{-10}$ & $5.3 \times 10^{-10}$ & $4.6 \times 10^{-10}$ & $4.0 \times 10^{-10}$ & $5.0 \times 10^{-10}$ & $6.7 \times 10^{-10}$ \\
\hline Sept & $6.9 \times 10^{-10}$ & $6.2 \times 10^{-10}$ & $7.9 \times 10^{-10}$ & $7.3 \times 10^{-10}$ & $7.1 \times 10^{-10}$ & $7.0 \times 10^{-10}$ & $5.7 \times 10^{-10}$ & $6.5 \times 10^{-10}$ & $8.4 \times 10^{-10}$ \\
\hline Oct & $7.2 \times 10^{-10}$ & $6.5 \times 10^{-10}$ & $6.2 \times 10^{-10}$ & $5.2 \times 10^{-10}$ & $8.2 \times 10^{-10}$ & $7.6 \times 10^{-10}$ & $7.1 \times 10^{-10}$ & $6.6 \times 10^{-10}$ & $9.3 \times 10^{-10}$ \\
\hline Nov & $6.3 \times 10^{-10}$ & $6.0 \times 10^{-10}$ & $5.9 \times 10^{-10}$ & $7.3 \times 10^{-10}$ & $8.7 \times 10^{-10}$ & $5.8 \times 10^{-10}$ & $5.4 \times 10^{-10}$ & $7.1 \times 10^{-10}$ & $1.1 \times 10^{-10}$ \\
\hline Dec & $3.1 \times 10^{-10}$ & $4.3 \times 10^{-10}$ & $4.2 \times 10^{-10}$ & $5.5 \times 10^{-10}$ & $5.04 \times 10^{-10}$ & $4.5 \times 10^{-10}$ & $3.6 \times 10^{-10}$ & $4.4 \times 10^{-10}$ & $6.8 \times 10^{-10}$ \\
\hline Annual median ${ }^{(a)}$ & $4.4 \times 10^{-10}$ & $4.2 \times 10^{-10}$ & $4.2 \times 10^{-10}$ & $4.5 \times 10^{-10}$ & $4.1 \times 10^{-10}$ & $4.6 \times 10^{-10}$ & $3.1 \times 10^{-10}$ & $3.8 \times 10^{-10}$ & $5.5 \times 10^{-10}$ \\
\hline$I_{Q} R^{(b)}$ & $3.9 \times 10^{-10}$ & $3.8 \times 10^{-10}$ & $3.5 \times 10^{-10}$ & $3.2 \times 10^{-10}$ & $4.0 \times 10^{-10}$ & $3.8 \times 10^{-10}$ & $4.4 \times 10^{-10}$ & $4.3 \times 10^{-10}$ & $4.9 \times 10^{-10}$ \\
\hline $\begin{array}{l}\text { Annual } \\
\text { maximum }\end{array}$ & $1.6 \times 10^{-9}$ & $1.5 \times 10^{-9}$ & $1.8 \times 10^{-9}$ & $1.5 \times 10^{-9}$ & $1.7 \times 10^{-9}$ & $1.5 \times 10^{-9}$ & $1.7 \times 10^{-9}$ & $1.6 \times 10^{-9}$ & $1.6 \times 10^{-9}$ \\
\hline
\end{tabular}

a The annual median is determined from the data for the 52 -week period.

b The interquartile range is determined from the data for the 52-week period. See Chapter 15, Quality Assurance.

c The annual maximum is determined from the data for the 52-week period. 


\section{Air Monitoring}

Table 4-4. Gamma activity in particulate air samples, Livermore site perimeter, 1995.(a)

\begin{tabular}{|c|c|c|c|c|c|c|c|}
\hline \multirow[b]{2}{*}{ Month } & \multirow{2}{*}{$\begin{array}{c}\left(10^{-9} \mathrm{~Bq} / \mathrm{mL}\right) \\
{ }^{7} \mathrm{Be} \\
\end{array}$} & \multicolumn{6}{|c|}{$\left(10^{-12} \mathrm{~Bq} / \mathrm{mL}\right)$} \\
\hline & & ${ }^{40} \mathrm{~K}$ & ${ }^{137} \mathrm{Cs}$ & ${ }^{22} \mathrm{Na}$ & ${ }^{226} \mathrm{Ra}$ & ${ }^{228} \mathrm{Ra}$ & ${ }^{228} \mathrm{Th}$ \\
\hline Jan & $2.6 \pm 0.05$ & $<2.99$ & $<0.14$ & $<0.35$ & $<0.42$ & $<0.55$ & $<0.38$ \\
\hline Feb & $4.5 \pm 0.07$ & $<6.62$ & $<0.22$ & $<0.23$ & $<0.48$ & $<1.03$ & $<0.55$ \\
\hline Mar & $4.5 \pm 0.12$ & $<6.40$ & $1.33 \pm 0.61$ & $<0.27$ & $<0.51$ & $<1.11$ & $<0.61$ \\
\hline Apr & $4.7 \pm 0.08$ & $<5.29$ & $<0.19$ & $<0.63$ & $<0.41$ & $<1.37$ & $<0.46$ \\
\hline May & $3.8 \pm 0.06$ & $<5.55$ & $<0.17$ & $<0.42$ & $<0.45$ & $<0.89$ & $<0.46$ \\
\hline Jun & $3.7 \pm 0.07$ & $21.1 \pm 7.0$ & $<0.15$ & $<0.16$ & $<0.42$ & $<1.43$ & $<0.39$ \\
\hline Jul & $4.4 \pm 0.07$ & $16.0 \pm 8.2$ & $<0.17$ & $<0.19$ & $<0.51$ & $<1.81$ & $<1.11$ \\
\hline Aug & $5.5 \pm 0.09$ & $27.4 \pm 14.0$ & $0.38 \pm 0.29$ & $0.56 \pm 0.34$ & $1.74 \pm 0.70$ & $<1.59$ & $<0.85$ \\
\hline Sep & $5.6 \pm 0.09$ & $22.1 \pm 7.4$ & $<0.16$ & $<0.17$ & $<0.50$ & $2.45 \pm 1.06$ & $1.48 \pm 0.72$ \\
\hline Oct & $6.5 \pm 0.20$ & $41.4 \pm 9.4$ & $0.47 \pm 0.37$ & $0.39 \pm 0.31$ & $<3.00$ & $<3.17$ & $<2.25$ \\
\hline Nov & $5.0 \pm 0.09$ & $28.8 \pm 7.0$ & $<0.16$ & $<0.17$ & $<1.61$ & $<2.31$ & $<1.04$ \\
\hline Dec & $3.8 \pm 0.06$ & $<5.99$ & $<0.19$ & $<0.22$ & $<0.47$ & $<0.95$ & $<0.50$ \\
\hline Median & 4.4 & $<11.30$ & $<0.18$ & $<0.25$ & $<0.49$ & $<1.40$ & $<0.58$ \\
\hline $\mathrm{IQR}^{(\mathrm{c})}$ & 1.3 & $<23.4$ & -(b) & -(b) $^{(\mathrm{b}}$ & $-^{(b)}$ & -(b) & -(b) \\
\hline Maximum & 6.5 & 41.44 & 1.33 & $<0.63$ & $<3.00$ & $<3.17$ & $<2.25$ \\
\hline $\mathrm{DCG}^{(\mathrm{d})}(\mathrm{Bq} / \mathrm{mL})$ & $1.5 \times 10^{-3}$ & $3.3 \times 10^{-5}$ & $1.5 \times 10^{-5}$ & $3.7 \times 10^{-5}$ & $3.7 \times 10^{-8}$ & $1.1 \times 10^{-7}$ & $1.5 \times 10^{-9}$ \\
\hline Fraction of DCG & $3.0 \times 10^{-6}$ & $<3.4 \times 10^{-7}$ & $<1.2 \times 10^{-8}$ & $<6.8 \times 10^{-9}$ & $<1.3 \times 10^{-5}$ & $<1.3 \times 10^{-5}$ & $<3.9 \times 10^{-4}$ \\
\hline \multicolumn{8}{|c|}{$(\mu \mathrm{Ci} / \mathrm{mL})$} \\
\hline Median & $1.2 \times 10^{-13}$ & $<3.1 \times 10^{-16}$ & $<4.9 \times 10^{-18}$ & $<6.8 \times 10^{-18}$ & $<1.3 \times 10^{-17}$ & $<3.8 \times 10^{-17}$ & $<1.6 \times 10^{-17}$ \\
\hline $\mathrm{IQR}^{(\mathrm{c})}$ & $3.6 \times 10^{-14}$ & $<6.3 \times 10^{-16}$ & -(b) $^{(\mathbf{b}}$ & -(b) $^{\text {(b) }}$ & -(b) $^{\text {(b) }}$ & -(b) $^{(\mathbf{b})}$ & $-^{(b)}$ \\
\hline Maximum & $1.8 \times 10^{-13}$ & $1.1 \times 10^{-15}$ & $3.6 \times 10^{-17}$ & $<1.7 \times 10^{-17}$ & $<8.1 \times 10^{-17}$ & $<8.6 \times 10^{-17}$ & $<6.1 \times 10^{-17}$ \\
\hline DCG ${ }^{(d)}$ & $4 \times 10^{-8}$ & $9 \times 10^{-10}$ & $4 \times 10^{-10}$ & $1 \times 10^{-9}$ & $1 \times 10^{-12}$ & $3 \times 10^{-12}$ & $4 \times 10^{-14}$ \\
\hline
\end{tabular}

Note: Radionuclide results are reported $\pm 2 \sigma$; see Chapter 15, Quality Assurance.

a All Livermore site perimeter samples composited. See Figure 4-1, Volume I for sampling locations.

b No measure of dispersion calculated; see Chapter 15, Quality Assurance.

c Interquartile Range.

d Derived Concentration Guide. 


\section{Air Monitoring}

Table 4-5. Gamma activity in particulate air samples, Site 300, 1995. (a)

\begin{tabular}{|c|c|c|c|c|c|c|c|}
\hline \multirow[b]{2}{*}{ Month } & \multirow{2}{*}{$\frac{\left(10^{-9} \mathrm{~Bq} / \mathrm{mL}\right)}{{ }^{7} \mathrm{Be}}$} & \multicolumn{6}{|c|}{$\left(10^{-12} \mathrm{~Bq} / \mathrm{mL}\right)$} \\
\hline & & ${ }^{40} K$ & ${ }^{137} \mathrm{Cs}$ & ${ }^{22} \mathrm{Na}$ & ${ }^{226} \mathrm{Ra}$ & ${ }^{228} \mathrm{Ra}$ & ${ }^{228} \mathrm{Th}$ \\
\hline Jan & $2.2 \pm 0.05$ & $<2.1$ & $<0.11$ & $0.25 \pm 0.17$ & $<0.28$ & $<0.41$ & $<0.35$ \\
\hline Feb & $4.0 \pm 0.09$ & $6.1 \pm 4.1$ & $<0.11$ & $0.33 \pm 0.21$ & $<0.31$ & $<0.45$ & $<0.37$ \\
\hline Mar & $4.7 \pm 0.08$ & $<2.0$ & $<0.10$ & $0.61 \pm 0.30$ & $<0.22$ & $<0.35$ & $<0.27$ \\
\hline Apr & $4.6 \pm 0.07$ & 5.4 & $<0.18$ & $<0.61$ & $<0.38$ & $<0.87$ & $<0.46$ \\
\hline May & $4.4 \pm 0.10$ & $11.4 \pm 8.3$ & $<0.11$ & $0.70 \pm 0.37$ & $<0.69$ & $<0.53$ & $<0.32$ \\
\hline Jun & $3.5 \pm 0.06$ & $<4.6$ & $<0.17$ & $<0.39$ & $<0.37$ & $<1.63$ & $<0.84$ \\
\hline Jul & $5.5 \pm 0.12$ & $<4.6$ & $<0.15$ & $0.60 \pm 0.34$ & $<0.35$ & $<1.67$ & $<0.40$ \\
\hline Aug & $6.7 \pm 0.15$ & $17.5 \pm 6.5$ & $0.40 \pm 0.31$ & $0.75 \pm 0.36$ & $1.67 \pm 1.06$ & $<0.53$ & $<1.19$ \\
\hline Sep & $6.3 \pm 0.13$ & $18.1 \pm 8.0$ & $<0.15$ & $0.48 \pm 0.30$ & $<1.97$ & $<0.61$ & $<0.41$ \\
\hline Oct & $7.2 \pm 0.13$ & $34.9 \pm 5.1$ & $0.52 \pm 0.23$ & $0.56 \pm 0.26$ & $<2.22$ & $2.32 \pm 0.67$ & $<1.85$ \\
\hline Nov & $4.1 \pm 0.11$ & $17.7 \pm 6.8$ & $<0.17$ & $<0.17$ & $<1.94$ & $<1.52$ & $<1.47$ \\
\hline Dec & $2.7 \pm 0.04$ & $<3.6$ & $<0.16$ & $<0.44$ & $<0.36$ & $<0.64$ & $<0.33$ \\
\hline Median & 4.5 & 5.77 & $<0.15$ & $<0.52$ & $<0.38$ & $<0.62$ & $<0.41$ \\
\hline $\operatorname{IQR}^{(\mathrm{c})}$ & 1.80 & $<17.54$ & -(b) & -(b) $^{(\mathbf{b}}$ & $-^{(b)}$ & -(b) & -(b) \\
\hline Maximum & 7.18 & 34.89 & 0.52 & 0.75 & $<2.22$ & 2.32 & $<1.85$ \\
\hline$D C G^{(d)}(B q / m L)$ & $1.5 \times 10^{-3}$ & $3.3 \times 10^{-5}$ & $1.5 \times 10^{-5}$ & $3.7 \times 10^{-5}$ & $3.7 \times 10^{-8}$ & $1.1 \times 10^{-7}$ & $1.5 \times 10^{-9}$ \\
\hline Fraction of DCG & $3.0 \times 10^{-6}$ & $1.7 \times 10^{-7}$ & $<1.0 \times 10^{-8}$ & $<1.4 \times 10^{-8}$ & $<1.0 \times 10^{-5}$ & $<5.7 \times 10^{-6}$ & $<2.7 \times 10^{-4}$ \\
\hline \multicolumn{8}{|c|}{$(\mu \mathrm{Ci} / \mathrm{mL})$} \\
\hline Median & $1.2 \times 10^{-13}$ & $1.56 \times 10^{-16}$ & $<4.2 \times 10^{-18}$ & $<1.4 \times 10^{-17}$ & $<1.0 \times 10^{-17}$ & $<1.7 \times 10^{-17}$ & $<1.1 \times 10^{-17}$ \\
\hline $\mathrm{IQR}^{(\mathrm{c})}$ & $4.9 \times 10^{-14}$ & $<4.7 \times 10^{-16}$ & $-^{(\mathbf{b})}$ & -(b) $^{\text {(b) }}$ & $-^{(\text {b) }}$ & $-^{(\text {b) }}$ & $-^{(\mathbf{b})}$ \\
\hline Maximum & $1.9 \times 10^{-13}$ & $9.4 \times 10^{-16}$ & $1.4 \times 10^{-17}$ & $2.0 \times 10^{-17}$ & $<6.0 \times 10^{-17}$ & $6.3 \times 10^{-17}$ & $<5.0 \times 10^{-17}$ \\
\hline DCG(d) & $4 \times 10^{-8}$ & $9 \times 10^{-10}$ & $4 \times 10^{-10}$ & $1 \times 10^{-9}$ & $1 \times 10^{-12}$ & $3 \times 10^{-12}$ & $4 \times 10^{-14}$ \\
\hline
\end{tabular}

Note: Radionuclide results are reported $\pm 2 \sigma$; see Chapter 15 , Quality Assurance.

a All Site 300 perimeter samples composited. See Figure 4-3, Volume I for sampling locations.

b No measure of dispersion calculated; see Chapter 15, Quality Assurance.

c Interquartile Range.

c Derived Concentration Guide. 


\section{Air Monitoring}

Table 4-6. Plutonium-239 activity in air particulate samples, Livermore Valley, 1995.

\begin{tabular}{|c|c|c|c|c|c|c|}
\hline \multirow[b]{3}{*}{ Month } & \multicolumn{6}{|c|}{ Livermore Valley downwind(a) } \\
\hline & ALTA & \multicolumn{2}{|c|}{ PATT } & \multicolumn{2}{|c|}{ TANK } & ZON7 \\
\hline & \multicolumn{6}{|c|}{$\left(10^{-15} \mathrm{~Bq} / \mathrm{mL}\right)$} \\
\hline Jan & $16.5 \pm 15.4$ & \multicolumn{2}{|c|}{$11.6 \pm 47.4$} & \multicolumn{2}{|c|}{$-5.5 \pm 12.9$} & $5.7 \pm 11.1$ \\
\hline Feb & $12.0 \pm 10.0$ & \multicolumn{2}{|c|}{$-0.7 \pm 4.2$} & \multicolumn{2}{|r|}{$0.7 \pm 8.0$} & $0.7 \pm 7.7$ \\
\hline Mar & $24.1 \pm 14.8$ & \multicolumn{2}{|c|}{$-7.1 \pm 9.3$} & \multicolumn{2}{|c|}{$9.4 \pm 9.7$} & $5.3 \pm 13.5$ \\
\hline Apr & $1.7 \pm 10.1$ & \multicolumn{2}{|c|}{$-12.1 \pm 12.2$} & \multicolumn{2}{|c|}{$12.7 \pm 16.6$} & $43.7 \pm 30.8$ \\
\hline May & $2.3 \pm 6.1$ & \multicolumn{2}{|c|}{$7.1 \pm 7.1$} & \multicolumn{2}{|c|}{$-2.6 \pm 6.8$} & $4.6 \pm 6.9$ \\
\hline Jun & $17.5 \pm 14.9$ & \multicolumn{2}{|c|}{$61.4 \pm 31.5$} & \multicolumn{2}{|c|}{$22.5 \pm 17.0$} & $3.1 \pm 8.9$ \\
\hline Jul & $117.7 \pm 40.3$ & \multicolumn{2}{|c|}{$13.9 \pm 11.4$} & \multicolumn{2}{|c|}{$10.8 \pm 23.3$} & $6.2 \pm 7.2$ \\
\hline Aug & $11.6 \pm 8.8$ & 5.0 & \pm 5.8 & & $5.2 \pm 6.0$ & $8.6 \pm 14.1$ \\
\hline Sep & $-3.0 \pm 6.8$ & -3.6 & \pm 9.1 & & $2.3 \pm 13.1$ & $11.7 \pm 10.9$ \\
\hline Oct & $5.4 \pm 6.2$ & 12.3 & \pm 15.6 & & $1.2 \pm 14.7$ & $21.8 \pm 15.9$ \\
\hline Nov & $7.2 \pm 11$. & 15.8 & \pm 17.2 & & $5.5 \pm 15.1$ & $11.2 \pm 14.2$ \\
\hline Dec & $-1.7 \pm 6.0$ & 4.6 & \pm 9.5 & & $5.6 \pm 6.4$ & $5.7 \pm 11.1$ \\
\hline $\begin{array}{l}\text { Median } \\
\text { IQR }^{(b)} \\
\text { Fraction of } \mathrm{DCG}^{(\mathrm{c})}\end{array}$ & $\begin{array}{c}9.4 \\
14.7 \\
1.3 \times 10^{-5} \\
\end{array}$ & $\begin{array}{r}6.1 \\
<12 . \\
8.2 \times 10 \\
\end{array}$ & & $9.9 \times$ & $\begin{array}{l}7.3 \\
11.6 \\
10^{-6}\end{array}$ & $\begin{array}{c}6.0 \\
6.2 \\
8.1 \times 10^{-6} \\
\end{array}$ \\
\hline & & $(\mu \mathbf{C i} / \mathbf{n}$ & $\mathrm{mL})$ & & & \\
\hline $\begin{array}{l}\text { Median } \\
\text { IQR }^{(b)}\end{array}$ & $\begin{array}{l}2.5 \times 10^{-19} \\
4.0 \times 10^{-19}\end{array}$ & $\begin{array}{r}1.6 \times 10^{-} \\
<3.4 \times 10^{-}\end{array}$ & & $\begin{array}{r}2.0 \times \\
<3.1 \times \\
\end{array}$ & $\begin{array}{c}10^{-19} \\
10^{-19}\end{array}$ & $\begin{array}{l}1.6 \times 10^{-19} \\
1.7 \times 10^{-19}\end{array}$ \\
\hline & & Livern & more $\mathrm{Va}$ & lley upw & ind $^{(a)}$ & \\
\hline & ERCH & FCC & $\mathbf{F I}$ & RE & HOSP & RRCH \\
\hline & & $\left(10^{-15} \mathrm{~B}\right.$ & $q / m L)$ & & & \\
\hline Jan & $3.9 \pm 10.5$ & $2.9 \pm 14.5$ & 45. & $5 \pm 26.6$ & $0.5 \pm 10.0$ & $-0.9 \pm 5.3$ \\
\hline Feb & $11.9 \pm 14.1$ & $0.5 \pm 9.7$ & & $6 \pm 7.5$ & $-1.4 \pm 5.8$ & $5.4 \pm 8.4$ \\
\hline Mar & $-6.4 \pm 11.4$ & $-3.4 \pm 11.4$ & & $2 \pm 12.4$ & $-1.1 \pm 12.2$ & $0.4 \pm 8.9$ \\
\hline Apr & $10.5 \pm 10.8$ & $-1.9 \pm 12.4$ & -2 & $1 \pm 9.4$ & $6.8 \pm 13.0$ & $1.9 \pm 11.0$ \\
\hline May & $-2.0 \pm 7.9$ & $-3.2 \pm 3.6$ & -3 & $2 \pm 8.0$ & $6.5 \pm 8.0$ & $-0.8 \pm 5.2$ \\
\hline Jun & $13.2 \pm 20.0$ & $6.7 \pm 14.3$ & 21. & $0 \pm 17.1$ & $-2.0 \pm 7.1$ & $5.8 \pm 13.4$ \\
\hline Jul & $9.3 \pm 9.3$ & $13.4 \pm 11.0$ & & $0 \pm 0.0$ & $4.5 \pm 16.8$ & $9.5 \pm 9.5$ \\
\hline Aug & $10.9 \pm 15.4$ & $7.3 \pm 8.4$ & -0.000 & $6 \pm 12.8$ & $10.8 \pm 8.8$ & $1.9 \pm 19.0$ \\
\hline Sep & $4.3 \pm 14.8$ & $4.4 \pm 11.5$ & -3 & $6 \pm 9.3$ & $3.9 \pm 12.7$ & $0.8 \pm 4.8$ \\
\hline Oct & - (d) $^{(\mathrm{d})}$ & $6.7 \pm 8.4$ & 12. & $1 \pm 13.1$ & $7.4 \pm 11.0$ & $20.1 \pm 13.3$ \\
\hline Nov & -(d) $^{(\mathrm{d}}$ & $7.6 \pm 11.7$ & 22. & $6 \pm 18.7$ & $-2.4 \pm 8.7$ & $0.6 \pm 18.1$ \\
\hline Dec & -(d) $^{(\mathrm{d}}$ & $1.7 \pm 7.0$ & 14. & $6 \pm 16.0$ & $-3.3 \pm 7.3$ & $-6.2 \pm 9.8$ \\
\hline Median & 9.3 & 3.7 & & .9 & 2.2 & 1.4 \\
\hline $\mathrm{IQR}^{(\mathbf{b})}$ & 7.0 & $<6.8$ & $<16$ & & $<6.6$ & $<5.5$ \\
\hline Fraction of DCG(c) & $1.3 \times 10^{-5}$ & $4.9 \times 10^{-6}$ & 1.2 & $10^{-6}$ & $3.0 \times 10^{-6}$ & $1.8 \times 10^{-6}$ \\
\hline & & $(\mu \mathrm{Ci} / \mathbf{n}$ & $\mathrm{nL})$ & & & \\
\hline $\begin{array}{l}\text { Median } \\
\text { IQR }^{(b)}\end{array}$ & $\begin{array}{l}2.5 \times 10^{-19} \\
1.9 \times 10^{-19}\end{array}$ & $\begin{array}{r}9.9 \times 10^{-20} \\
<1.9 \times 10^{-19}\end{array}$ & $\begin{array}{r}2.5> \\
<4.4>\end{array}$ & $\begin{array}{l}10^{-20} \\
10^{-19}\end{array}$ & $\begin{array}{r}5.9 \times 10^{-20} \\
<1.8 \times 10^{-19}\end{array}$ & $\begin{array}{r}3.7 \times 10^{-20} \\
<1.5 \times 10^{-19}\end{array}$ \\
\hline
\end{tabular}


Table 4-6. Plutonium-239 activity in air particulate samples Livermore Valley, 1995 (concluded).

\begin{tabular}{|c|c|c|}
\hline \multirow[b]{3}{*}{ Month } & \multicolumn{2}{|c|}{ Special interest $^{(a)}$} \\
\hline & LWRP & TFIR \\
\hline & \multicolumn{2}{|c|}{$\left(10^{-15} \mathrm{~Bq} / \mathrm{mL}\right)$} \\
\hline Jan & $9.0 \pm 14.0$ & $6.6 \pm 12.5$ \\
\hline Feb & $2.3 \pm 8.8$ & $1.6 \pm 7.1$ \\
\hline Mar & $13.8 \pm 16.4$ & $3.6 \pm 9.7$ \\
\hline Apr & $6.8 \pm 12.4$ & $-4.6 \pm 11.7$ \\
\hline May & $4.1 \pm 8.5$ & $4.1 \pm 9.5$ \\
\hline Jun & $11.7 \pm 12.7$ & $-7.2 \pm 22.0$ \\
\hline Jul & $29.7 \pm 17.2$ & $14.7 \pm 12.0$ \\
\hline Aug & $32.2 \pm 15.2$ & $12.7 \pm 13.7$ \\
\hline Sep & $20.6 \pm 14.2$ & $-2.6 \pm 10.0$ \\
\hline Oct & $125.1 \pm 33.9$ & $10.5 \pm 15.6$ \\
\hline Nov & $11.8 \pm 12.8$ & $4.9 \pm 10.1$ \\
\hline Dec & $132.1 \pm 41.1$ & $-4.4 \pm 12.0$ \\
\hline Median & 12.8 & 3.9 \\
\hline $\mathrm{IQR}^{(\mathbf{b})}$ & 21.9 & $<7.6$ \\
\hline \multirow[t]{2}{*}{ Fraction of DCG(c) } & $1.7 \times 10^{-5}$ & $5.2 \times 10^{-6}$ \\
\hline & \multicolumn{2}{|c|}{$(\mu \mathrm{Ci} / \mathrm{mL})$} \\
\hline Median & $3.5 \times 10^{-19}$ & $1.0 \times 10^{-19}$ \\
\hline $\mathrm{IQR}^{(\mathbf{b})}$ & $5.9 \times 10^{-19}$ & $<2.1 \times 10^{-19}$ \\
\hline
\end{tabular}

Note: Radionuclide results are reported $\pm 2 \sigma$. See Chapter 15 , Quality Assurance.

a See Figure 4-2, Volume 1 for sampling locations. Location TFIR is in Tracy.

b Interquartile range.

c Derived Concentration Guide (DCG) $=7.4 \times 10^{-10} \mathrm{~Bq} / \mathrm{mL}$ for ${ }^{239} \mathrm{Pu}$ activity in air $\left(2 \times 10^{-14} \mu \mathrm{Ci} / \mathrm{mL}\right)$.

d No data due to loss of sample during analysis; location ERCH was eliminated in October. See Chapter 15, Quality Assurance. 


\section{Air Monitoring}

Table 4-7. Plutonium activity in air particulate samples, Livermore site perimeter, 1995.

\begin{tabular}{|c|c|c|c|c|c|c|}
\hline \multirow[b]{3}{*}{ Month } & \multicolumn{6}{|c|}{ Sampling location(a) } \\
\hline & SALV & MESQ & CAFE & MET & VIS & cow \\
\hline & \multicolumn{6}{|c|}{$\left(10^{-15} \mathrm{~Bq} / \mathrm{mL}\right)$} \\
\hline Jan & $20.7 \pm 13.1$ & $29.6 \pm 20.7$ & $10.7 \pm 17.6$ & $8.2 \pm 10.7$ & $20.7 \pm 12.2$ & $23.0 \pm 14.8$ \\
\hline Feb & $18.4 \pm 10.6$ & $22.9 \pm 12.9$ & $14.9 \pm 13.5$ & $23.1 \pm 14.9$ & $13.3 \pm 14.8$ & $25.2 \pm 14.8$ \\
\hline Mar & $57.7 \pm 25.7$ & $12.8 \pm 11.1$ & $22.6 \pm 13.9$ & $22.6 \pm 12.4$ & $25.7 \pm 13.4$ & $20.5 \pm 11.8$ \\
\hline Apr & $30.9 \pm 14.9$ & $18.6 \pm 11.4$ & $20.2 \pm 13.0$ & $20.6 \pm 12.4$ & $21.5 \pm 12.6$ & $11.7 \pm 13.4$ \\
\hline May & $543.9 \pm 410.7$ & $15.7 \pm 79.9$ & $49.6 \pm 35.1$ & $22.8 \pm 20.5$ & $23.9 \pm 14.5$ & $72.5 \pm 36.4$ \\
\hline Jun & $39.2 \pm 21.2$ & $22.5 \pm 16.0$ & $8.1 \pm 30.2$ & $34.1 \pm 19.0$ & $12.8 \pm 21.1$ & $758.5 \pm 109.5$ \\
\hline Jul & $-0.005 \pm 39.6$ & $18.0 \pm 13.6$ & $40.0 \pm 25.3$ & $16.6 \pm 13.6$ & $22.0 \pm 31.1$ & $69.6 \pm 37.4$ \\
\hline Aug & $19.2 \pm 14.0$ & $17.8 \pm 15.9$ & $38.1 \pm 18.9$ & $50.7 \pm 21.6$ & $48.5 \pm 21.7$ & $13.9 \pm 16.8$ \\
\hline Sep & $19.3 \pm 20.9$ & $23.9 \pm 23.0$ & $38.1 \pm 22.5$ & $273.1 \pm 61.4$ & $36.0 \pm 22.9$ & $229.4 \pm 53.3$ \\
\hline Oct & $23.3 \pm 15.1$ & $38.5 \pm 17.6$ & $26.4 \pm 14.8$ & $9.3 \pm 12.8$ & $18.3 \pm 12.2$ & $45.1 \pm 17.7$ \\
\hline Nov & $23.6 \pm 20.8$ & $27.8 \pm 21.2$ & $30.5 \pm 19.4$ & $3.8 \pm 26.6$ & $50.0 \pm 24.6$ & $58.8 \pm 26.2$ \\
\hline Dec & $16.4 \pm 15.9$ & $28.4 \pm 20.4$ & $13.8 \pm 15.1$ & $79.6 \pm 36.4$ & $105.5 \pm 35.3$ & $19.8 \pm 16.8$ \\
\hline Median & 22.0 & 22.7 & 24.5 & 22.7 & 22.9 & 35.2 \\
\hline$I R^{(b)}$ & 14.0 & 10.0 & 23.4 & 23.4 & 19.0 & 50.0 \\
\hline Fraction of $\mathrm{DCG}^{(\mathrm{c})}$ & $3.0 \times 10^{-5}$ & $3.1 \times 10^{-5}$ & $3.3 \times 10^{-5}$ & $3.1 \times 10^{-5}$ & $3.1 \times 10^{-5}$ & $4.8 \times 10^{-5}$ \\
\hline & & & $(\mu \mathrm{Ci} / \mathbf{m L})$ & & & \\
\hline Median & $6.0 \times 10^{-19}$ & $6.1 \times 10^{-19}$ & $6.6 \times 10^{-19}$ & $6.1 \times 10^{-19}$ & $6.2 \times 10^{-19}$ & $9.5 \times 10^{-19}$ \\
\hline IQR & $3.8 \times 10^{-19}$ & $2.7 \times 10^{-19}$ & $6.3 \times 10^{-19}$ & $6.3 \times 10^{-19}$ & $5.1 \times 10^{-19}$ & $1.4 \times 10^{-18}$ \\
\hline
\end{tabular}

Note: Radionuclide results are reported $\pm 2 \sigma$. See Chapter 15, Quality Assurance.

a See Figure 4-2, Volume 1 for sampling locations.

b Interquartile range.

c Derived Concentration Guide $(D C G)=7.4 \times 10^{-10} \mathrm{~Bq} / \mathrm{mL}$ for ${ }^{239} \mathrm{Pu}$ activity in air $\left(2 \times 0^{-14} \mu \mathrm{Ci} / \mathrm{mL}\right)$. 
Table 4-8. Plutonium activity in air particulate samples, diffuse sources, 1995.

\begin{tabular}{|c|c|c|}
\hline \multirow[b]{3}{*}{ Month } & \multicolumn{2}{|c|}{ Location $^{(a)}$} \\
\hline & B531 & CRED \\
\hline & \multicolumn{2}{|c|}{$\left(10^{-15} \mathrm{~Bq} / \mathrm{mL}\right)$} \\
\hline Jan & $8.5 \pm 13.4$ & $1.2 \pm 9.7$ \\
\hline Feb & $26.9 \pm 12.8$ & $5.4 \pm 8.3$ \\
\hline Mar & $25.0 \pm 12.9$ & $2.7 \pm 6.8$ \\
\hline Apr & $27.8 \pm 15.1$ & $1.2 \pm 7.0$ \\
\hline May & $59.9 \pm 28.2$ & $-1.6 \pm 5.9$ \\
\hline Jun & $211.3 \pm 47.4$ & $6.7 \pm 10.2$ \\
\hline Jul & $488.4 \pm 74.4$ & $9.1 \pm 9.2$ \\
\hline Aug & $621.6 \pm 78.8$ & $15.9 \pm 11.6$ \\
\hline Sep & $1061.9 \pm 106.2$ & $23.8 \pm 17.3$ \\
\hline Oct & $1047.1 \pm 109.5$ & $29.9 \pm 14.5$ \\
\hline Nov & $384.8 \pm 65.1$ & $21.0 \pm 17.2$ \\
\hline Dec & $44.0 \pm 26.8$ & $13.4 \pm 14.7$ \\
\hline Median & 135.6 & 7.9 \\
\hline $\operatorname{IQR}^{(\mathbf{b})}$ & 494.1 & 14.9 \\
\hline Fraction of DCG(c) & $1.8 \times 10^{-4}$ & $1.1 \times 10^{-5}$ \\
\hline \multicolumn{3}{|c|}{$(\mu \mathrm{Ci} / \mathrm{mL})$} \\
\hline Median & $3.7 \times 10^{-18}$ & $2.1 \times 10^{-19}$ \\
\hline $\operatorname{IQR}^{(\mathbf{b})}$ & $1.3 \times 10^{-17}$ & $4.0 \times 10^{-19}$ \\
\hline
\end{tabular}

Note: Radionuclide results are reported $\pm 2 \sigma$. See Chapter 15, Quality Assurance.

a See Figure 4-1, Volume 1 for sampling locations.

b Interquartile range.

c Derived Concentration Guide (DCG) $=7.4 \times 10^{-10} \mathrm{~Bq} / \mathrm{mL}$ for ${ }^{239} \mathrm{Pu}$ activity in air $\left(2 \times 10^{-14} \mu \mathrm{Ci} / \mathrm{mL}\right)$. 
Table 4-9. Plutonium activity in air particulate samples, Site 300, 1995. (a)

\begin{tabular}{|c|c|}
\hline Month & $\begin{array}{c}\left(10^{-15} \mathrm{~Bq} / \mathrm{mL}\right) \\
239 \mathrm{Pu}\end{array}$ \\
\hline Jan & $3.2 \pm 1.9$ \\
\hline Feb & $10.9 \pm 4.1$ \\
\hline Mar & $3.7 \pm 1.9$ \\
\hline Apr & $5.5 \pm 2.9$ \\
\hline May & $5.8 \pm 2.5$ \\
\hline Jun & $4.4 \pm 4.8$ \\
\hline Jul & $4.7 \pm 3.9$ \\
\hline Aug & $4.4 \pm 2.6$ \\
\hline Sep & $6.9 \pm 3.4$ \\
\hline Oct & $12.3 \pm 5.0$ \\
\hline Nov & $4.8 \pm 3.2$ \\
\hline Dec & $3.4 \pm 3.0$ \\
\hline Median & 4.8 \\
\hline$I R^{(b)}$ & 1.9 \\
\hline Fraction of $\mathrm{DCG}(\mathrm{c})$ & $6.4 \times 10^{-6}$ \\
\hline \multicolumn{2}{|c|}{$(\mu \mathrm{Ci} / \mathrm{mL})$} \\
\hline Median & $1.3 \times 10^{-19}$ \\
\hline $\mathrm{IQR}^{(\mathbf{b})}$ & $5.1 \times 10^{-20}$ \\
\hline
\end{tabular}

Note: Radionuclide results are reported $\pm 2 \sigma$. See Chapter 15 , Quality Assurance.

a See Figure 4-3, Volume 1, for sampling locations.

b Interquartile range.

c Derived Concentration Guide $(\mathrm{DCG})=7.4 \times 10^{-10} \mathrm{~Bq} / \mathrm{mL}$ for ${ }^{239} \mathrm{Pu}$ activity in air $\left(2 \times 10^{-14} \mu \mathrm{Ci} / \mathrm{mL}\right)$. 
Table 4-10. Uranium activity in air particulate samples, Livermore site perimeter, 1995.

\begin{tabular}{|c|c|c|c|c|}
\hline Location $^{(\mathrm{a})}$ & Month & $\begin{array}{l}{\left[10^{-5} \mu \mathrm{g} / \mathrm{m}^{3}\right]} \\
\text { Uranium-238 }\end{array}$ & $\begin{array}{l}{\left[10^{-7} \mu \mathrm{g} / \mathrm{m}^{3}\right]} \\
\text { Uranium-235 }\end{array}$ & $\begin{array}{c}{\left[10^{-3}\right]} \\
\text { Uranium-235/238 }\end{array}$ \\
\hline SALV & $\begin{array}{l}\text { Jan } \\
\text { Feb } \\
\text { Mar } \\
\text { Apr } \\
\text { May } \\
\text { Jun } \\
\text { Jul } \\
\text { Aug } \\
\text { Sep } \\
\text { Oct } \\
\text { Nov } \\
\text { Dec }\end{array}$ & $\begin{array}{r}0.77 \\
1.92 \\
1.01 \\
2.45 \\
-^{(b)} \\
4.14 \\
4.10 \\
8.48 \\
8.29 \\
13.90 \\
7.66 \\
2.48 \\
\end{array}$ & $\begin{array}{r}0.55 \\
1.35 \\
0.60 \\
1.79 \\
-^{(b)} \\
3.03 \\
2.90 \\
6.03 \\
6.19 \\
10.30 \\
5.72 \\
1.80 \\
\end{array}$ & $\begin{array}{l}7.15 \\
7.01 \\
5.92 \\
7.31 \\
-(b) \\
7.32 \\
7.08 \\
7.11 \\
7.46 \\
7.42 \\
7.47 \\
7.28 \\
\end{array}$ \\
\hline $\begin{array}{l}\text { Median } \\
\text { IQR } \\
\text { Maximum } \\
\text { Fraction of DCG }\end{array}$ & & $\begin{array}{c}4.10 \\
5.79 \\
13.90 \\
1.4 \times 10^{-4(c)}\end{array}$ & $\begin{array}{c}2.90 \\
4.31 \\
10.30 \\
6.2 \times 10^{-6(d)}\end{array}$ & $\begin{array}{l}7.28 \\
0.28 \\
7.47\end{array}$ \\
\hline MESQ & $\begin{array}{l}\text { Jan } \\
\text { Feb } \\
\text { Mar } \\
\text { Apr } \\
\text { May } \\
\text { Jun } \\
\text { Jul } \\
\text { Aug } \\
\text { Sep } \\
\text { Oct } \\
\text { Nov } \\
\text { Dec }\end{array}$ & $\begin{array}{r}1.40 \\
2.16 \\
1.41 \\
3.67 \\
-(b) \\
4.45 \\
4.45 \\
7.79 \\
6.84 \\
13.40 \\
6.55 \\
2.53\end{array}$ & $\begin{array}{l}0.96 \\
1.59 \\
0.99 \\
2.68 \\
-(b) \\
3.25 \\
3.18 \\
5.58 \\
5.00 \\
9.93 \\
4.88 \\
1.87 \\
\end{array}$ & $\begin{array}{l}6.86 \\
7.36 \\
7.01 \\
7.30 \\
-(\text { b) } \\
7.30 \\
7.14 \\
7.17 \\
7.32 \\
7.40 \\
7.44 \\
7.40 \\
\end{array}$ \\
\hline $\begin{array}{l}\text { Median } \\
\text { IQR } \\
\text { Maximum } \\
\text { Fraction of DCG }\end{array}$ & & $\begin{array}{c}4.45 \\
4.35 \\
13.40 \\
1.5 \times 10^{-4(c)}\end{array}$ & $\begin{array}{c}3.18 \\
3.21 \\
9.93 \\
6.8 \times 10^{-6(d)}\end{array}$ & $\begin{array}{l}7.30 \\
0.23 \\
7.44\end{array}$ \\
\hline
\end{tabular}

...continued on next page 
Table 4-10. Uranium activity in air particulate samples, Livermore site perimeter, 1995 (continued).

\begin{tabular}{|c|c|c|c|c|}
\hline Location $^{(a)}$ & Month & $\begin{array}{l}{\left[10^{-5} \mu \mathrm{g} / \mathrm{m}^{3}\right]} \\
\text { Uranium-238 }\end{array}$ & $\begin{array}{l}{\left[10^{-7} \mu \mathrm{g} / \mathrm{m}^{3}\right]} \\
\text { Uranium-235 }\end{array}$ & $\begin{array}{c}{\left[10^{-3}\right]} \\
\text { Uranium-235/238 }\end{array}$ \\
\hline \multirow[t]{12}{*}{ CAFE } & Jan & 1.92 & 1.40 & 7.28 \\
\hline & Feb & 3.23 & 2.24 & 6.94 \\
\hline & Mar & 2.16 & 1.49 & 6.91 \\
\hline & Apr & 4.08 & 2.95 & 7.25 \\
\hline & May & 4.04 & 2.95 & 7.31 \\
\hline & Jun & 4.86 & 3.69 & 7.60 \\
\hline & Jul & 6.55 & 4.73 & 7.22 \\
\hline & Aug & 7.65 & 5.34 & 6.98 \\
\hline & Sep & 10.60 & 7.47 & 7.06 \\
\hline & Oct & 14.20 & 10.50 & 7.37 \\
\hline & Nov & 7.89 & 5.92 & 7.49 \\
\hline & $\mathrm{Dec}$ & 3.91 & 2.77 & 7.09 \\
\hline Median & & 4.47 & 3.32 & 7.24 \\
\hline IQR & & 3.97 & 2.85 & 0.28 \\
\hline Maximum & & 14.20 & 10.50 & 7.60 \\
\hline Fraction of DCG & & $1.5 \times 10^{-4(c)}$ & $7.1 \times 10^{-6(d)}$ & \\
\hline \multirow[t]{12}{*}{ MET } & Jan & 1.07 & 0.74 & 6.93 \\
\hline & Feb & 2.20 & 1.57 & 7.13 \\
\hline & Mar & 1.13 & 0.79 & 7.01 \\
\hline & Apr & 2.73 & 2.03 & 7.44 \\
\hline & May & 1.96 & 1.51 & 7.70 \\
\hline & Jun & 4.59 & 3.24 & 7.06 \\
\hline & Jul & 4.49 & 3.22 & 7.19 \\
\hline & Aug & 11.20 & 7.71 & 6.88 \\
\hline & Sep & 8.43 & 7.28 & 8.64 \\
\hline & Oct & 14.30 & 10.50 & 7.36 \\
\hline & Nov & 7.37 & 5.49 & 7.44 \\
\hline & $\mathrm{Dec}$ & 2.81 & 2.08 & 7.38 \\
\hline Median & & 3.65 & 2.65 & 7.28 \\
\hline IQR & & 5.50 & 4.38 & 0.39 \\
\hline Maximum & & 14.30 & 10.50 & 8.64 \\
\hline Fraction of DCG & & $1.2 \times 10^{-4(c)}$ & $5.6 \times 10^{-6(d)}$ & \\
\hline
\end{tabular}


Table 4-10. Uranium activity in air particulate samples, Livermore site perimeter, 1995 (concluded).

\begin{tabular}{|c|c|c|c|c|}
\hline Location $^{(\mathrm{a})}$ & Month & $\begin{array}{l}{\left[10^{-5} \mu \mathrm{g} / \mathrm{m}^{3}\right]} \\
\text { Uranium-238 }\end{array}$ & $\begin{array}{l}{\left[10^{-7} \mu \mathrm{g} / \mathrm{m}^{3}\right]} \\
\text { Uranium-235 }\end{array}$ & $\begin{array}{c}{\left[10^{-3}\right]} \\
\text { Uranium-235/238 }\end{array}$ \\
\hline VIS & $\begin{array}{l}\text { Jan } \\
\text { Feb } \\
\text { Mar } \\
\text { Apr } \\
\text { May } \\
\text { Jun } \\
\text { Jul } \\
\text { Aug } \\
\text { Sep } \\
\text { Oct } \\
\text { Nov } \\
\text { Dec }\end{array}$ & $\begin{array}{r}1.59 \\
2.77 \\
1.09 \\
2.43 \\
1.71 \\
2.86 \\
2.97 \\
6.09 \\
6.13 \\
12.10 \\
7.58 \\
2.81 \\
\end{array}$ & $\begin{array}{r}1.06 \\
1.97 \\
0.68 \\
1.82 \\
1.09 \\
15.50 \\
2.29 \\
4.40 \\
5.28 \\
9.04 \\
5.47 \\
4.50 \\
\end{array}$ & $\begin{array}{r}6.70 \\
7.11 \\
6.22 \\
7.50 \\
6.38 \\
54.20 \\
7.70 \\
7.23 \\
8.61 \\
7.49 \\
7.22 \\
16.00 \\
\end{array}$ \\
\hline $\begin{array}{l}\text { Median } \\
\text { IQR } \\
\text { Maximum } \\
\text { Fraction of DCG }\end{array}$ & & $\begin{array}{c}2.84 \\
3.85 \\
12.10 \\
9.5 \times 10^{-5(c)} \\
\end{array}$ & $\begin{array}{c}3.35 \\
3.69 \\
15.50 \\
7.1 \times 10^{-6(d)} \\
\end{array}$ & $\begin{array}{r}7.36 \\
0.92 \\
54.20\end{array}$ \\
\hline cow & $\begin{array}{l}\text { Jan } \\
\text { Feb } \\
\text { Mar } \\
\text { Apr } \\
\text { May } \\
\text { Jun } \\
\text { Jul } \\
\text { Aug } \\
\text { Sep } \\
\text { Oct } \\
\text { Nov } \\
\text { Dec }\end{array}$ & $\begin{array}{r}1.16 \\
1.65 \\
1.64 \\
5.82 \\
4.07 \\
4.69 \\
4.68 \\
12.40 \\
12.10 \\
19.40 \\
11.90 \\
5.60\end{array}$ & $\begin{array}{r}0.56 \\
1.12 \\
1.17 \\
4.37 \\
3.03 \\
4.16 \\
3.37 \\
8.97 \\
8.73 \\
14.30 \\
8.74 \\
4.06\end{array}$ & $\begin{array}{l}4.84 \\
6.80 \\
7.11 \\
7.50 \\
7.44 \\
8.89 \\
7.20 \\
7.23 \\
7.24 \\
7.36 \\
7.35 \\
7.26\end{array}$ \\
\hline $\begin{array}{l}\text { Median } \\
\text { IQR } \\
\text { Maximum } \\
\text { Fraction of DCG }\end{array}$ & & $\begin{array}{c}5.15 \\
8.49 \\
19.40 \\
1.7 \times 10^{-4(c)}\end{array}$ & $\begin{array}{c}4.11 \\
6.17 \\
14.30 \\
8.7 \times 10^{-6(d)}\end{array}$ & $\begin{array}{l}7.25 \\
0.20 \\
8.87\end{array}$ \\
\hline
\end{tabular}

\footnotetext{
a See Figure 4-1, Volume 1, for sampling locations.

b Sample lost during analytical processing.

c Derived Concentration Guide (DCG) $=0.3 \mu \mathrm{g} / \mathrm{m}^{3}$ for ${ }^{238} \mathrm{U}$ activity in air.

d Derived Concentration Guide (DCG) $=0.047 \mu \mathrm{g} / \mathrm{m}^{3}$ for ${ }^{235} \mathrm{U}$ activity in air.
} 
Table 4-11. Uranium activity in air particulate samples, Site 300, 1995.

\begin{tabular}{|l|c|c|c|c|}
\hline \multicolumn{1}{|c|}{ Location } & Month & $\begin{array}{c}{\left[\mathbf{1 0}^{-\mathbf{5}} \mu \mathbf{g} / \mathbf{m}^{\mathbf{3}}\right]} \\
\text { Uranium-238 }\end{array}$ & $\begin{array}{c}{\left[\mathbf{1 0}^{-\mathbf{7}} \mu \mathbf{g} / \mathbf{m}^{\mathbf{3}}\right]} \\
\text { Uranium-235 }\end{array}$ & $\begin{array}{c}{\left[\mathbf{1 0}^{-3}\right]} \\
\text { Uranium-235/238 }\end{array}$ \\
\hline Site 300(a) & Jan & 0.90 & 0.42 & 4.65 \\
& Feb & 2.27 & 1.03 & 4.51 \\
& Mar & 4.20 & 1.27 & 3.03 \\
& Apr & 2.27 & 1.57 & 6.91 \\
& May & 11.40 & 3.56 & 3.11 \\
& Jun & 4.23 & 2.50 & 5.91 \\
& Jul & 4.16 & 2.84 & 6.82 \\
& Aug & 10.10 & 5.48 & 5.42 \\
& Sep & 8.47 & 5.33 & 6.29 \\
& Oct & 14.50 & 10.3 & 7.08 \\
& Nov & 7.81 & 5.54 & 7.10 \\
Median & Dec & 1.90 & 1.24 & 6.54 \\
IQR & & $\mathbf{4 . 2 2}$ & $\mathbf{2 . 6 7}$ & $\mathbf{6 . 1 0}$ \\
Maximum & & $\mathbf{6 . 6 1}$ & $\mathbf{4 . 1 1}$ & $\mathbf{2 . 2 3}$ \\
Fraction of DCG & & $\mathbf{1 4 . 5 0}$ & $\mathbf{1 0 . 3 0}$ & $\mathbf{7 . 1 0}$ \\
\hline
\end{tabular}

a Composite of all Site 300 samples. See Figure 4-3, Volume 1, for sampling locations.

b Derived Concentration Guide (DCG) $=0.3 \mu \mathrm{g} / \mathrm{m}^{3}$ for ${ }^{238} \mathrm{U}$ activity in air.

c Derived Concentration Guide (DCG) $=0.047 \mu \mathrm{g} / \mathrm{m}^{3}$ for ${ }^{235} \mathrm{U}$ activity in air. 
Table 4-12. Tritium in air, Livermore Valley, 1995.

\begin{tabular}{|c|c|c|c|c|c|}
\hline \multirow[b]{3}{*}{ Month } & \multicolumn{5}{|c|}{ Sampling location ${ }^{(a)}$} \\
\hline & ZON7 & ALTA & FIRE & XRDS & VET \\
\hline & \multicolumn{5}{|c|}{$\left(10^{-9} \mathrm{~Bq} / \mathrm{mL}\right)$} \\
\hline \multirow[t]{2}{*}{ Jan } & $22.4 \pm 12.1$ & $17.9 \pm 14.9$ & $23.5 \pm 16.1$ & $<14.2$ & $74.0 \pm 23.8$ \\
\hline & $318.9 \pm 35.7$ & $24.1 \pm 18.4$ & $74.0 \pm 14.5$ & $87.7 \pm 13.7$ & $357.1 \pm 22.5$ \\
\hline \multirow[t]{2}{*}{ Feb } & $42.6 \pm 20.9$ & $<20.8$ & $42.6 \pm 18.0$ & $62.9 \pm 18.9$ & $192.4 \pm 22.1$ \\
\hline & $59.2 \pm 15.3$ & $24.1 \pm 15.0$ & $42.6 \pm 12.2$ & $45.5 \pm 12.7$ & $79.6 \pm 14.4$ \\
\hline \multirow[t]{2}{*}{ Mar } & $15.4 \pm 14.4$ & -(b) $^{(\mathrm{b})}$ & $27.9 \pm 15.0$ & $<12.8$ & $77.0 \pm 21.6$ \\
\hline & $<19.8$ & $<16.5$ & $<16.0$ & $<25.6$ & $<19.6$ \\
\hline \multirow[t]{2}{*}{ Apr } & $9.6 \pm 9.5$ & $20.9 \pm 11.7$ & $13.5 \pm 9.6$ & $19.7 \pm 11.3$ & $35.6 \pm 11.1$ \\
\hline & $22.1 \pm 13.9$ & $<12.0$ & $<11.1$ & $<11.4$ & $<10.3$ \\
\hline \multirow[t]{2}{*}{ May } & $35.4 \pm 17.9$ & $18.2 \pm 15.8$ & $<14.5$ & $<15.7$ & $16.1 \pm 14.4$ \\
\hline & $30.0 \pm 14.0$ & -(b) $^{(\mathrm{b})}$ & $<12.1$ & $<10.3$ & $<11.5$ \\
\hline \multirow[t]{3}{*}{ Jun } & $<14.8$ & $<10.7$ & $<12.7$ & $<13.1$ & $<14.2$ \\
\hline & $21.3 \pm 13.4$ & —(b) & $<11.4$ & $<11.5$ & $<11.8$ \\
\hline & $44.4 \pm 16.1$ & -(b) & $40.3 \pm 21.9$ & —(b) & $60.7 \pm 18.3$ \\
\hline \multirow[t]{2}{*}{ Jul } & $28.3 \pm 17.8$ & $<15.2$ & $<16.2$ & $<15.5$ & $<16.5$ \\
\hline & $<17.0$ & $<15.6$ & $<16.2$ & $<6.0$ & $<16.1$ \\
\hline \multirow[t]{2}{*}{ Aug } & $20.4 \pm 14.8$ & $15.1 \pm 13.8$ & $<14.6$ & $<13.1$ & $21.7 \pm 15.8$ \\
\hline & $40.0 \pm 16.2$ & $15.9 \pm 14.4$ & $<15.9$ & $<13.7$ & $26.0 \pm 16.8$ \\
\hline Sept & $\begin{array}{c}44.0 \pm 14.4 \\
\text { (b) }^{(\mathrm{b})}\end{array}$ & $\begin{array}{l}<11.5 \\
<14.7\end{array}$ & $\begin{array}{c}21.1 \pm 13.1 \\
\text { (b) }^{(\mathrm{s})}\end{array}$ & $\begin{array}{l}10.4 \pm 10.2 \\
17.8 \pm 14.4\end{array}$ & $\begin{array}{l}15.3 \pm 12.5 \\
22.8 \pm 16.0\end{array}$ \\
\hline \multirow[t]{2}{*}{ Oct } & $17.9 \pm 14.4$ & $15.6 \pm 13.5$ & $<16.1$ & $<12.8$ & $<15.4$ \\
\hline & $22.8 \pm 11.3$ & $<10.9$ & $14.2 \pm 12.4$ & $<11.1$ & $17.4 \pm 12.4$ \\
\hline \multirow[t]{3}{*}{ Nov } & $<10.1$ & $<11.5$ & $<12.8$ & $<9.4$ & -(b) \\
\hline & $<13.5$ & $<13.2$ & $18.3 \pm 16.2$ & $<15.8$ & $31.3 \pm 16.6$ \\
\hline & $<13.5$ & $<13.3$ & $<15.1$ & $<10.9$ & $33.1 \pm 17.9$ \\
\hline \multirow[t]{2}{*}{$\mathrm{Dec}$} & -(b) $^{(\mathrm{b})}$ & $<15.3$ & $24.8 \pm 18.2$ & $<16.2$ & $27.8 \pm 18.0$ \\
\hline & -(b) $^{(\mathrm{n})}$ & $<13.7$ & $<11.1$ & $<11.5$ & $<11.7$ \\
\hline $\operatorname{Median}^{(\mathrm{c})}$ & $\begin{array}{r}22.1 \\
-377\end{array}$ & $\begin{array}{r}<15.3 \\
\text { (e) }\end{array}$ & $<16.0$ & $\begin{array}{r}<13.1 \\
\text { (e) }\end{array}$ & $\begin{array}{r}21.7 \\
-356\end{array}$ \\
\hline $\begin{array}{l}\text { IQR } \\
\text { Fraction of } \mathrm{DCG}^{(\mathrm{f})}\end{array}$ & $\begin{array}{l}<37.7 \\
6.0 \times 10^{-6}\end{array}$ & $<41 \times 10^{-6}$ & $\begin{aligned} &<23.5 \\
&<4.3 \times 10^{-6}\end{aligned}$ & $<3.6 \times 10^{-6}$ & $\begin{array}{l}<35.6 \\
5.9 \times 10^{-6}\end{array}$ \\
\hline Dose $(m S v)^{(g)}$ & $4.7 \times 10^{-6}$ & $3.3 \times 10^{-6}$ & $3.4 \times 10^{-6}$ & $2.8 \times 10^{-6}$ & $4.7 \times 10^{-6}$ \\
\hline \multicolumn{6}{|c|}{$(\mu \mathbf{C i} / \mathbf{m L})$} \\
\hline Median(c) & $6.0 \times 10^{-13}$ & $<4.1 \times 10^{-13}$ & $<4.3 \times 10^{-13}$ & $<3.6 \times 10^{-13}$ & $5.9 \times 10^{-13}$ \\
\hline $\operatorname{IQR}^{(\mathrm{d})}$ & $<1.0 \times 10^{-12}$ & -(e) & $<6.4 \times 10^{-13}$ & -(e) & $<9.6 \times 10^{-13}$ \\
\hline Dose $(\mathrm{mrem})^{(\mathrm{g})}$ & $4.7 \times 10^{-4}$ & $3.3 \times 10^{-4}$ & $3.4 \times 10^{-4}$ & $2.8 \times 10^{-4}$ & $4.7 \times 10^{-4}$ \\
\hline
\end{tabular}

Note: Radionuclide results are reported $\pm 2 \sigma$; see Chapter 15, Quality Assurance.

\footnotetext{
a See Figure 4-2 for sampling locations.

b No data; see Chapter 15, Quality Assurance.

c Livermore Valley overall median $=16.1 \times 10^{-9} \mathrm{~Bq} / \mathrm{mL}\left(4.3 \times 10^{-13} \mu \mathrm{Ci} / \mathrm{mL}\right)$.

d Interquartile range.

e No measure of dispersion calculated; see Chapter 15, Quality Assurance.

f Derived Concentration Guide (DCG) $=3.7 \times 10^{-3} \mathrm{~Bq} / \mathrm{mL}\left(1 \times 10^{-7} \mu \mathrm{Ci} / \mathrm{mL}\right)$.

$g$ This dose is the effective dose equivalent.
} 
Table 4-13. Tritium in air, Livermore site perimeter, 1995.

\begin{tabular}{|c|c|c|c|c|c|c|c|}
\hline \multirow[b]{3}{*}{ Month } & \multicolumn{7}{|c|}{ Sampling location ${ }^{(a)}$} \\
\hline & SALV & MESQ & CAFE & MET & VIS & cow & POOL \\
\hline & \multicolumn{7}{|c|}{$\left(10^{-9} \mathrm{~Bq} / \mathrm{mL}\right)$} \\
\hline \multirow[t]{2}{*}{ Jan } & $558.7 \pm 39.7$ & $32.3 \pm 11.6$ & $555.0 \pm 28.9$ & $125.1 \pm 19.8$ & $209.1 \pm 24.0$ & $101.0 \pm 24.4$ & $510.6 \pm 31.7$ \\
\hline & $499.5 \pm 24.0$ & & $540.2 \pm 26.5$ & $148.4 \pm 19.4$ & $373.7 \pm 23.5$ & $226.4 \pm 19.9$ & $921.3 \pm 32.2$ \\
\hline \multirow[t]{2}{*}{ Feb } & $161.3 \pm 27.6$ & $141.0 \pm 22.4$ & $217.2 \pm 23.7$ & $91.8 \pm 22.5$ & $103.6 \pm 23.3$ & $83.3 \pm 21.6$ & $253.1 \pm 25.1$ \\
\hline & $227.2 \pm 23.6$ & $98.1 \pm 15.0$ & $120.6 \pm 15.9$ & $90.3 \pm 15.6$ & $129.5 \pm 18.3$ & $75.9 \pm 14.9$ & $188.0 \pm 17.9$ \\
\hline \multirow[t]{2}{*}{ Mar } & $81.8 \pm 17.0$ & $39.2 \pm 14.4$ & $92.5 \pm 14.7$ & $18.6 \pm 12.7$ & $38.5 \pm 12.7$ & $41.1 \pm 16.3$ & $113.6 \pm 16.9$ \\
\hline & $51.4 \pm 16.3$ & $<17.7$ & $71.4 \pm 20.1$ & $<15.1$ & $69.6 \pm 17.7$ & $71.4 \pm 24.0$ & $136.2 \pm 20.7$ \\
\hline \multirow[t]{2}{*}{ Apr } & $47.0 \pm 11.3$ & $37.7 \pm 10.7$ & $78.4 \pm 11.3$ & $20.9 \pm 10.0$ & $31.6 \pm 10.2$ & $36.0 \pm 10.3$ & $203.1 \pm 15.4$ \\
\hline & $102.9 \pm 19.4$ & $<11.0$ & $27.0 \pm 11.7$ & $<12.1$ & $67.3 \pm 14.3$ & $48.8 \pm 14.7$ & $74.0 \pm 13.9$ \\
\hline \multirow[t]{2}{*}{ May } & $370.0 \pm 29.6$ & $30.9 \pm 15.9$ & $55.5 \pm 15.4$ & $21.9 \pm 15.2$ & $74.7 \pm 18.4$ & $55.1 \pm 15.9$ & $128.0 \pm 21.4$ \\
\hline & $59.6 \pm 18.6$ & $31.9 \pm 13.4$ & $21.0 \pm 12.3$ & $15.5 \pm 13.8$ & $40.3 \pm 14.9$ & $<12.0$ & $89.9 \pm 15.3$ \\
\hline \multirow[t]{3}{*}{ Jun } & $61.1 \pm 19.2$ & $<14.1$ & $21.5 \pm 14.0$ & $<13.7$ & $79.2 \pm 17.2$ & $40.0 \pm 14.8$ & $65.9 \pm 15.9$ \\
\hline & $150.6 \pm 22.0$ & $<13.3$ & $18.9 \pm 13.1$ & $<16.8$ & $68.8 \pm 16.0$ & $44.8 \pm 13.8$ & $68.5 \pm 14.6$ \\
\hline & $97.3 \pm 30.0$ & $83.3 \pm 18.4$ & $223.5 \pm 30.4$ & $55.1 \pm 17.9$ & $102.9 \pm 27.5$ & $71.4 \pm 18.1$ & $525.4 \pm 30.5$ \\
\hline \multirow[t]{2}{*}{ Jul } & $81.8 \pm 26.2$ & $<16.2$ & $67.3 \pm 26.8$ & $20.8 \pm 18.4$ & $96.9 \pm 21.9$ & $69.9 \pm 20.7$ & $178.3 \pm 33.2$ \\
\hline & $100.6 \pm 20.1$ & $33.2 \pm 18.4$ & $145.0 \pm 23.1$ & $27.6 \pm 19.0$ & $77.7 \pm 20.3$ & $70.7 \pm 20.6$ & $303.4 \pm 26.7$ \\
\hline \multirow[t]{2}{*}{ Aug } & $75.9 \pm 19.2$ & $47.0 \pm 16.9$ & $203.9 \pm 23.4$ & $38.9 \pm 16.3$ & $112.1 \pm 18.4$ & $67.3 \pm 17.4$ & —(b) $^{(\mathrm{b})}$ \\
\hline & $81.4 \pm 20.2$ & $60.7 \pm 18.1$ & $160.6 \pm 21.4$ & $<110.6$ & $172.8 \pm 21.1$ & $114.3 \pm 27.0$ & $432.9 \pm 28.1$ \\
\hline \multirow[t]{2}{*}{ Sep } & $69.2 \pm 19.2$ & $38.5 \pm 13.8$ & $107.7 \pm 17.9$ & $42.9 \pm 16.4$ & $84.0 \pm 16.7$ & $74.7 \pm 16.7$ & $268.6 \pm 21.5$ \\
\hline & $158.0 \pm 26.2$ & $17.1 \pm 16.0$ & $62.9 \pm 20.4$ & $87.3 \pm 30.2$ & $77.7 \pm 20.6$ & $392.2 \pm 29.0$ & $143.9 \pm 22.6$ \\
\hline \multirow[t]{2}{*}{ Oct } & $33.8 \pm 18.3$ & $19.8 \pm 16.5$ & $35.6 \pm 16.8$ & $38.9 \pm 17.2$ & $41.8 \pm 17.1$ & $111.0 \pm 19.0$ & $126.5 \pm 18.9$ \\
\hline & $59.2 \pm 17.5$ & $39.2 \pm 13.9$ & $64.0 \pm 14.4$ & $44.8 \pm 15.2$ & $65.5 \pm 15.3$ & $54.4 \pm 15.0$ & $127.3 \pm 16.9$ \\
\hline \multirow[t]{3}{*}{ Nov } & $41.4 \pm 15.2$ & $14.0 \pm 12.1$ & $76.6 \pm 15.4$ & $<108.4$ & $68.1 \pm 15.5$ & $48.8 \pm 14.3$ & $151.7 \pm 17.9$ \\
\hline & $36.1 \pm 15.5$ & $24.3 \pm 15.0$ & $86.2 \pm 17.7$ & $39.6 \pm 17.0$ & $48.5 \pm 17.4$ & $22.8 \pm 16.2$ & $98.4 \pm 17.1$ \\
\hline & $68.5 \pm 21.4$ & $34.4 \pm 15.9$ & $74.4 \pm 18.5$ & $41.4 \pm 16.8$ & $43.7 \pm 17.9$ & $<16.9$ & $143.9 \pm 20.4$ \\
\hline \multirow[t]{2}{*}{ Dec } & $46.3 \pm 20.7$ & $42.6 \pm 24.1$ & $98.8 \pm 28.0$ & $41.8 \pm 18.8$ & $72.9 \pm 22.5$ & $34.1 \pm 19.1$ & $111.0 \pm 20.3$ \\
\hline & $38.9 \pm 16.6$ & $<14.4$ & $47.7 \pm 16.7$ & $22.2 \pm 15.1$ & $40.7 \pm 14.6$ & $29.6 \pm 14.4$ & $70.7 \pm 14.3$ \\
\hline Median(c) & 78.6 & 32.3 & 77.5 & $<39.2$ & 73.8 & 61.2 & 143.9 \\
\hline $\mathrm{IQR}^{(\mathrm{d})}$ & 85.3 & $<39.2$ & 81.6 & -(e) $^{(\mathrm{e})}$ & 48.7 & 35.3 & 142.1 \\
\hline $\begin{array}{l}\text { Fraction of } \\
\text { DCG }^{(f)}\end{array}$ & $2.1 \times 10^{-5}$ & $8.7 \times 10^{-6}$ & $2.1 \times 10^{-5}$ & $1.1 \times 10^{-5}$ & $2.0 \times 10^{-5}$ & $1.7 \times 10^{-5}$ & $3.9 \times 10^{-5}$ \\
\hline Dose $(m S v)^{g}$ & $1.7 \times 10^{-5}$ & $6.9 \times 10^{-6}$ & $1.7 \times 10^{-5}$ & $8.4 \times 10^{-6}$ & $1.6 \times 10^{-5}$ & $1.3 \times 10^{-5}$ & $3.1 \times 10^{-5}$ \\
\hline \multicolumn{8}{|c|}{$\mu \mathrm{Ci} / \mathrm{mL}$} \\
\hline Median $^{(c)}$ & $2.1 \times 10^{-12}$ & $8.7 \times 10^{-13}$ & $2.1 \times 10^{-12}$ & $<1.1 \times 10^{-12}$ & $2.0 \times 10^{-12}$ & $1.7 \times 10^{-12}$ & $3.9 \times 10^{-12}$ \\
\hline $1 Q R^{(d)}$ & $2.3 \times 10^{-12}$ & $<1.1 \times 10^{-12}$ & $2.2 \times 10^{-12}$ & —(e) & $1.3 \times 10^{-12}$ & $9.6 \times 10^{-13}$ & $3.8 \times 10^{-12}$ \\
\hline Dose $(\text { mrem })^{(\mathrm{g})}$ & $1.7 \times 10^{-3}$ & $6.9 \times 10^{-4}$ & $1.7 \times 10^{-3}$ & $8.4 \times 10^{-4}$ & $1.6 \times 10^{-3}$ & $1.3 \times 10^{-3}$ & $3.1 \times 10^{-3}$ \\
\hline
\end{tabular}

Note: Radionuclide results are reported $\pm 2 \sigma$; see Chapter 15, Quality Assurance.

a See Figure 4-2 for sampling locations.

b No data; see Chapter 15, Quality Assurance.

c Livermore site perimeter overall median $=69.4 \times 10^{-9} \mathrm{~Bq} / \mathrm{mL}\left(1.8 \times 10^{-12} \mu \mathrm{Ci} / \mathrm{mL}\right)$.

d Interquartile range.

e No measure of dispersion calculated; see Chapter 15, Quality Assurance.

$f$ Derived Concentration Guide (DCG) $=3.7 \times 10^{-3} \mathrm{~Bq} / \mathrm{mL}\left(1 \times 0^{-7} \mu \mathrm{Ci} / \mathrm{mL}\right)$.

$\mathrm{g}$ This dose is the effective dose equivalent. 
Table 4-14. Tritium in air at locations near diffuse sources, 1995.

\begin{tabular}{|c|c|c|c|c|}
\hline \multirow[b]{3}{*}{ Month } & \multicolumn{4}{|c|}{ Sampling locations $(a)$} \\
\hline & B292 & B331 & B514 & B624 \\
\hline & \multicolumn{4}{|c|}{$\left(10^{-9} \mathrm{~Bq} / \mathrm{mL}\right)$} \\
\hline Jan & $\begin{array}{c}280.8 \pm 18.8 \\
\text { —(b) }\end{array}$ & $\begin{array}{l}3496.5 \pm 52.4 \\
2490.1 \pm 49.8\end{array}$ & $\begin{array}{l}239.8 \pm 14.1 \\
525.4 \pm 24.2\end{array}$ & $\begin{array}{r}865.8 \pm 28.6 \\
1113.7 \pm 35.6\end{array}$ \\
\hline Feb & $\begin{array}{l}359.3 \pm 30.9 \\
330.4+22.5\end{array}$ & $1813.0 \pm 54.4$ & $202.8 \pm 23.5$ & $777.0 \pm 37.3$ \\
\hline Mar & $\begin{array}{l}196.8 \pm 22.2 \\
179.1 \pm 21.7\end{array}$ & $\begin{array}{l}2035.0 \pm 50.9 \\
3296.7 \pm 69.2\end{array}$ & $\begin{array}{c}156.9 \pm 19.3 \\
—^{(\mathrm{b})}\end{array}$ & $\begin{array}{l}662.3 \pm 31.1 \\
921.3 \pm 35.9\end{array}$ \\
\hline Apr & $\begin{array}{r}141.3 \pm 13.7 \\
79.2 \pm 14.6\end{array}$ & $\begin{array}{r}1820.4 \pm 38.2 \\
695.6 \pm 26.4\end{array}$ & $\begin{array}{l}72.9 \pm 9.4 \\
29.4 \pm 11.6\end{array}$ & $\begin{array}{l}647.5 \pm 24.6 \\
447.7 \pm 22.8\end{array}$ \\
\hline May & $\begin{array}{r}150.2 \pm 18.5 \\
68.8 \pm 15.7\end{array}$ & $\begin{array}{l}1420.8 \pm 39.8 \\
1191.4 \pm 36.9\end{array}$ & $\begin{array}{l}85.8 \pm 16.1 \\
41.4 \pm 10.7\end{array}$ & $\begin{array}{l}614.2 \pm 28.9 \\
425.5 \pm 23.4\end{array}$ \\
\hline June & $\begin{array}{r}57.4 \pm 16.1 \\
42.6 \pm 13.7 \\
1439+? 00\end{array}$ & $\begin{array}{r}1931.4 \pm 46.4 \\
1679.8 \pm 42.0 \\
24605+172 ?\end{array}$ & $\begin{array}{r}53.3 \pm 14.1 \\
58.5 \pm 14.3 \\
168.4+2 ? 7\end{array}$ & $\begin{array}{l}536.5 \pm 27.4 \\
484.7 \pm 25.7 \\
9657 \pm 367\end{array}$ \\
\hline July & $\begin{array}{r}34.3 \pm 18.4 \\
113.2 \pm 20.5\end{array}$ & $\begin{array}{l}28601 \pm 257.4 \\
24753 \pm 173.3\end{array}$ & $\begin{array}{r}73.6 \pm 20.1 \\
129.5 \pm 19.6\end{array}$ & $\begin{array}{l}503.2 \pm 28.2 \\
865.8 \pm 37.2\end{array}$ \\
\hline Aug & $\begin{array}{l}116.6 \pm 19.6 \\
138.4 \pm 20.3\end{array}$ & $\begin{array}{l}37740 \pm 226.4 \\
43660 \pm 218.3\end{array}$ & $\begin{array}{l}172.8 \pm 21.3 \\
159.8 \pm 21.3\end{array}$ & $\begin{array}{r}939.8 \pm 34.8 \\
1024.9 \pm 35.9\end{array}$ \\
\hline Sept & $\begin{array}{c}146.9 \pm 18.4 \\
\text { (b) }^{(\mathrm{b})}\end{array}$ & $\begin{array}{c}15947 \pm 127.6 \\
5476 \pm 82.1\end{array}$ & $\begin{array}{l}152.1 \pm 19.3 \\
159.8 \pm 22.7\end{array}$ & $\begin{array}{c}684.5 \pm 27.4 \\
\text { (b) }^{(\mathrm{b})}\end{array}$ \\
\hline Oct & $\begin{array}{r}78.4 \pm 13.0 \\
118.4 \pm 15.3\end{array}$ & $\begin{array}{l}119.1 \pm 15.7 \\
179.8 \pm 16.7\end{array}$ & $\begin{array}{l}147.6 \pm 19.5 \\
171.3 \pm 17.3\end{array}$ & $\begin{array}{l}1409.7 \pm 40.9 \\
2279.2 \pm 43.3\end{array}$ \\
\hline Nov & $\begin{array}{r}97.3 \pm 15.4 \\
169.8 \pm 20.2 \\
139.1 \pm 20.0 \\
109.2 \pm 21.1 \\
65.1 \pm 13.2\end{array}$ & $\begin{array}{r}92.5 \pm 10.9 \\
122.1 \pm 11.7 \\
279.7 \pm 20.7 \\
-^{(b)} \\
173.2 \pm 15.9\end{array}$ & $\begin{array}{l}126.9 \pm 15.5 \\
193.1 \pm 20.5 \\
222.4 \pm 22.2 \\
111.4 \pm 20.6 \\
125.8 \pm 15.0\end{array}$ & $\begin{array}{l}1554.0 \pm 34.2 \\
2471.6 \pm 42.0 \\
3540.9 \pm 53.1 \\
1920.3 \pm 48.0 \\
1864.8 \pm 42.9\end{array}$ \\
\hline Median(c) & 128.4 & 1931.4 & 152.1 & 921.3 \\
\hline $\operatorname{IQR}^{(\mathrm{d})}$ & 76.1 & 4780.4 & 85.5 & 762.2 \\
\hline Fraction of DCG(e) & $3.5 \times 10^{-5}$ & $5.2 \times 10^{-4}$ & $4.1 \times 10^{-5}$ & $2.5 \times 10^{-4}$ \\
\hline Dose (mSv) ${ }^{(f)}$ & $2.8 \times 10^{-5}$ & $4.1 \times 10^{-4}$ & $3.3 \times 10^{-5}$ & $2.0 \times 10^{-4}$ \\
\hline & & $(\mu \mathrm{Ci} / \mathrm{mL})$ & & \\
\hline $\begin{array}{l}\operatorname{Median}^{(\mathrm{c})} \\
\text { IQR }^{(\mathrm{d})} \\
\text { Dose (mrem) }\end{array}$ & $\begin{array}{l}3.5 \times 10^{-12} \\
2.1 \times 10^{-12} \\
2.8 \times 10^{-3}\end{array}$ & $\begin{array}{l}5.2 \times 10^{-11} \\
1.3 \times 10^{-10} \\
4.1 \times 10^{-2}\end{array}$ & $\begin{array}{l}4.1 \times 10^{-12} \\
2.3 \times 10^{-12} \\
3.3 \times 10^{-3}\end{array}$ & $\begin{array}{l}2.5 \times 10^{-11} \\
2.1 \times 10^{-11} \\
2.0 \times 10^{-2}\end{array}$ \\
\hline
\end{tabular}

Note: Radionuclide results are reported $\pm 2 \sigma$; see Chapter 15, Quality Assurance.

a See Figure 4-2 for sampling locations.

b No data; see Chapter 15, Quality Assurance.

c Diffuse source overall median $=279.7 \times 10^{-9} \mathrm{~Bq} / \mathrm{mL}\left(7.6 \times 10^{-12} \mu \mathrm{Ci} / \mathrm{mL}\right)$.

d Interquartile range.

e Derived Concentration Guide (DCG) $=3.7 \times 10^{-3} \mathrm{~Bq} / \mathrm{mL}\left(1 \times 10^{-7} \mu \mathrm{Ci} / \mathrm{mL}\right)$.

$f$ This dose is the effective dose equivalent. 
Table 4-15. Beryllium in air particulate samples (in $\mathrm{pg} / \mathrm{m}^{3}$ ), Livermore site perimeter, 1995.

\begin{tabular}{|c|c|c|c|c|c|c|}
\hline \multirow{2}{*}{ Month } & \multicolumn{7}{|c|}{ Sampling location ${ }^{\text {(a) }}$} \\
\cline { 2 - 7 } Jan & SALV & MESQ & CAFE & MET & VIS & COW \\
Feb & 0.7 & 1.9 & 3.0 & 1.3 & 0.7 & 2.1 \\
Mar & 3.0 & 3.7 & 6.2 & 3.6 & 3.2 & 4.4 \\
Apr & 1.6 & 2.1 & 3.3 & 1.8 & 1.6 & 2.1 \\
May & 4.2 & 4.9 & 5.3 & 4.3 & 3.4 & 5.7 \\
Jun & 3.9 & 4.5 & 5.6 & 4.5 & 2.6 & 7.4 \\
Jul & 9.0 & 9.2 & 9.2 & 10.5 & 5.7 & 9.2 \\
Aug & 8.1 & 10.0 & 15.9 & 12.9 & 6.8 & 10.8 \\
Sep & 15.9 & 17.0 & 18.2 & 17.3 & 15.0 & 32.5 \\
Oct & 13.1 & 11.2 & 15.4 & 15.2 & 10.2 & 16.8 \\
Nov & 54.8 & 25.6 & 22.6 & 47.5 & 23.7 & 34.2 \\
Dec & 20.0 & 17.6 & 23.5 & 20.9 & 19.3 & 18.5 \\
\hline Median $^{(\mathbf{b})}$ & 3.6 & 4.9 & 6.7 & 5.7 & 4.7 & 9.9 \\
IQR $^{\text {(c) }}$ & $\mathbf{6 . 1}$ & $\mathbf{7 . 0}$ & $\mathbf{8 . 0}$ & $\mathbf{8 . 1}$ & $\mathbf{5 . 2}$ & $\mathbf{9 . 5}$ \\
\hline
\end{tabular}

Note: The monthly ambient concentration guide (ACG) set by the BAAQMD is $10,000 \mathrm{pg} / \mathrm{m}^{3}$. To determine the fraction each value is of the monthly standard, divide the reported value for the month by 10,000 ; e.g., $35.0 \div 10,000=0.0035$.

a See Figure 4-1 for sampling locations.

b Livermore site perimeter overall annual median is $7.1 \mathrm{pg} / \mathrm{m}^{3}$.

c Interquartile range. 
Table 4-16. Beryllium in air particulate samples (in pg/m³), Site 300, 1995.

\begin{tabular}{|c|c|c|c|c|c|c|c|c|c|}
\hline \multirow[b]{2}{*}{ Month } & \multicolumn{9}{|c|}{ Sampling location ${ }^{(a)}$} \\
\hline & EOBS & ECP & WCP & LIN & GOLF & TFIR & NPS & WOBS & $801 E$ \\
\hline Jan & 0.7 & 0.6 & 0.5 & 0.7 & 1.7 & 3.0 & 0.6 & 0.7 & 0.5 \\
\hline Feb & 1.4 & 1.4 & 1.7 & 1.7 & 3.2 & 5.4 & 1.8 & 1.4 & 1.7 \\
\hline Mar & 1.3 & 1.0 & 1.2 & 1.5 & 2.2 & 4.2 & 1.5 & 1.4 & 2.1 \\
\hline Apr & 3.2 & 2.6 & 2.8 & 3.5 & 5.2 & 9.9 & 3.5 & 3.3 & 2.9 \\
\hline May & 6.1 & 5.7 & 2.8 & 6.3 & 5.6 & 9.9 & 4.8 & 3.6 & 14.3 \\
\hline Jun & 5.7 & 4.1 & 5.3 & 18.3 & 6.7 & 13.9 & 6.7 & 5.1 & 11.5 \\
\hline Jul & 8.7 & 6.7 & 8.0 & 8.0 & 9.9 & 21.0 & 9.5 & 9.1 & 13.4 \\
\hline Aug & 10.5 & 9.9 & 13.5 & 14.4 & 16.2 & 26.8 & 12.3 & 13.2 & 16.0 \\
\hline Sep & 8.8 & 8.1 & 8.5 & 10.8 & 10.9 & 24.3 & 9.0 & 15.2 & 11.8 \\
\hline Oct & 44.7 & 33.7 & 38.6 & 21.6 & 20.0 & 73.9 & 29.0 & 57.1 & 43.5 \\
\hline Nov & 17.7 & 12.2 & 10.5 & 14.8 & 13.0 & 19.0 & 16.1 & 19.0 & 18.1 \\
\hline Dec & 2.2 & 1.8 & 2.1 & 2.4 & 2.5 & 5.4 & 1.5 & 2.4 & 2.1 \\
\hline Median(b) & 5.9 & 4.9 & 4.1 & 7.2 & 6.1 & 11.9 & 5.7 & 4.4 & 11.6 \\
\hline$I R^{(c)}$ & 7.2 & 6.8 & 7.0 & 12.2 & 8.4 & 16.4 & 8.5 & 11.6 & 12.6 \\
\hline
\end{tabular}

Note: The monthly ambient concentration guide (ACG) set by the BAAQMD is $10,000 \mathrm{pg} / \mathrm{m}^{3}$. To determine the fraction each value is of the monthly standard, divide the reported value for the month by 10,000 ; e.g., $35.0 \div 10,000=0.0035$.

a See Figure 4-3 for sampling locations.

b Site 300 overall annual median is $6.3 \mathrm{pg} / \mathrm{m}^{3}$.

c Interquartile range. 


\section{Air Effluent Sampling Methods}

LLNL maintains 103 continuously operating radiological sampling systems on air exhausts at 9 facilities at the Livermore site (Volume 1, Table 5-1). These samplers are used to determine actual emissions from operations involving radioactive materials at the facilities and to verify the integrity of emission control systems.

Air samples for particulate emissions are extracted downstream of high efficiency particulate air (HEPA) filters and prior to the discharge point to the atmosphere. In most cases, simple, filter-type aerosol collection systems are used. However, in some facilities (Buildings 251 and 332) continuous air monitors for alpha activity (CAMs) are used for sampling. In addition to collecting a sample of particles, the CAM units provide an alarm capability for the facility in the event of a release of alpha activity. Both types of sampling systems, the simple filter type and alpha alarm monitors, are used to monitor discharge points from Building 332. The air sampling systems in critical facilities would be switched to auxiliary power in the event of a power outage and continue to operate.

The sample filters, either 47- or 100-mm-diameter membrane filters, are changed weekly or biweekly depending on the facility. After sample collection, filters are placed in glassine envelopes; each envelope is tagged with a unique bar code label. Filter samples are logged into the Hazards Control Department (HCD) sample tracking and receiving (STAR) computer system along with information including location, equipment identification, bar code, sampling start date, sampling stop date, and flow rate. Filters are analyzed at the HCD Radiological Measurements Laboratory (RML) for gross alpha and beta activity using gas proportional counters. Analysis is delayed for at least 4 days from sample termination to allow for the decay of naturally occurring radon daughters. For verification of the operation of the counting system, calibration sources, as well as background samples, are intermixed with the sample filters for analysis. Analytical techniques are consistent with EPA-recommended procedures. Further details of sampling and analysis are discussed in the Environmental Monitoring Plan (Tate et al. 1995).

Each stack of the Tritium Facility (Building 331) is monitored for tritium release by both a continuous monitoring alarm system and continuous molecular sieve samplers. The alarmed samplers, Overhoff ion chambers, provide real-time tritium concentration release levels (HT and HTO combined). The sieve samplers, which can discriminate between tritiated water (HTO) vapor and 
tritiated hydrogen gas (HT), provide the values used for environmental reporting. Each sieve sampler (unalarmed) is in parallel with an alarmed monitor and consists of two molecular sieves. The first sieve collects tritiated water vapor; then a palladium-coated catalyst converts tritiated hydrogen to tritiated water and collects the tritiated water on a second sieve. Sieves are exchanged weekly or biweekly. The sieve samples are logged into the HCD STAR sample tracking system and submitted to the HCD Analytical Laboratory, where tritiated water is baked out and collected. The retrieved tritium is analyzed by RML for beta activity using scintillation counting techniques.

The need for air effluent monitoring at other discharge points having the potential to release radionuclides to the atmosphere is evaluated on an annual basis according to the 40 CFR 61.93 National Emissions Standards for Hazardous Air Pollutants (NESHAPs) regulatory requirements. For the evaluation, estimates of emissions from individual discharge points are calculated using: (1) measured emissions from discharges having continuous sampling systems or (2) radionuclide inventories from discharges not having sampling systems. The radionuclide inventory approach uses isotope-specific inventory data along with EPAaccepted release factors for operations and EPA-suggested reduction factors for emission control devices to arrive at the potential release estimates. For 1995, calculated potential emissions for isotopes, including diffuse and point discharges, for the Livermore site are listed in Table 5-1. Since dose to individuals is isotope specific, the radionuclides have been ordered by weighting the emissions according to the inhalation committed dose equivalent of the particular isotope. The total calculated emission is estimated to be $3.9 \mathrm{TBq}$ (105 Ci). Calculated emissions for radionuclides used in Site 300 operations are given in Volume 1, Table 5-4.

The need for air effluent monitoring at an atmospheric discharge point requires that an assessment of dose to the nearest member of the public be made based on the estimated emissions. Dose assessment results due to LLNL radionuclide emissions are discussed in Chapter 13 of Volume 1. Further details of the 1995 evaluation of calculated emissions and dose assessment are published in the LLNL NESHAPs 1995 Annual Report (Gallegos et al. 1996). As discussed in Chapter 5 Volume I, a new sampler was installed in Building 166 as a result of NESHAPs evaluations of new operations in 1995. No discharge points at Site 300 were found to require air effluent sampling systems. 
Table 5-1. Calculated radioactive air emissions from the Livermore site for 1995. Radionuclides have been ordered by weighting the emissions according to the inhalation dose rate conversion factor for the isotope.

\begin{tabular}{|c|c|c|c|c|c|}
\hline Radionuclide & $\begin{array}{l}\text { Calculated } \\
\text { emissions } \\
(\mathrm{Bq}) \\
(\mathrm{Bq})\end{array}$ & $\begin{array}{l}\text { Relative to } \\
{ }^{3} \mathrm{H}(\mathrm{HTO})^{(\mathrm{b})}\end{array}$ & Radionuclide & $\begin{array}{l}\text { Calculated } \\
\text { emissions }(a) \\
(B q)\end{array}$ & $\begin{array}{l}\text { Relative to } \\
{ }^{3} \mathrm{H}(\mathrm{HTO})^{(\mathrm{b})}\end{array}$ \\
\hline $\mathrm{H}-3^{(\mathrm{c})}$ & $2.6 \times 10^{12}$ & 1.0 & Co-60 & $2.4 \times 10^{2}$ & $1.6 \times 10^{-7}$ \\
\hline U-238 & $5.4 \times 10^{5}$ & 0.19 & Ru-106 & $1.1 \times 10^{2}$ & $1.6 \times 10^{-7}$ \\
\hline U-234 & $2.6 \times 10^{5}$ & 0.11 & Eu-155 & $2.6 \times 10^{2}$ & $3.3 \times 10^{-8}$ \\
\hline Gross Alpha(d) & $2.1 \times 10^{4}$ & $2.2 \times 10^{-2}$ & Pu-240 & $2.2 \times 10^{-2}$ & $2.3 \times 10^{-8}$ \\
\hline $\mathrm{N}-13$ & $1.6 \times 10^{11}$ & $9.9 \times 10^{-3}$ & $\mathrm{Ce}-144$ & 17.0 & $2.0 \times 10^{-8}$ \\
\hline $\mathrm{Ni}-63$ & $1.1 \times 10^{9}$ & $7.5 \times 10^{-3}$ & U-236 & $3.3 \times 10^{-2}$ & $1.2 \times 10^{-8}$ \\
\hline U-235 & $1.4 \times 10^{4}$ & $5.3 \times 10^{-3}$ & Th-232 & $1.1 \times 10^{-2}$ & $1.2 \times 10^{-8}$ \\
\hline Am-241 & $2.7 \times 10^{3}$ & $4.5 \times 10^{-3}$ & Pu-244 & $1.1 \times 10^{-2}$ & $1.1 \times 10^{-8}$ \\
\hline O-15 & $8.5 \times 10^{10}$ & $1.7 \times 10^{-3}$ & $\mathrm{Bi}-207$ & $3.0 \times 10^{2}$ & $1.1 \times 10^{-8}$ \\
\hline Th-228 & $1.6 \times 10^{3}$ & $1.2 \times 10^{-3}$ & Pu-236 & $1.7 \times 10^{-2}$ & $4.5 \times 10^{-9}$ \\
\hline Np-237 & $4.8 \times 10^{2}$ & $7.3 \times 10^{-4}$ & C-14 & $9.7 \times 10^{4}$ & $3.6 \times 10^{-9}$ \\
\hline Pu-242 & $4.1 \times 10^{2}$ & $4.1 \times 10^{-4}$ & $\mathrm{Cm}-244$ & $3.7 \times 10^{-3}$ & $3.3 \times 10^{-9}$ \\
\hline Pu-238 & $3.7 \times 10^{2}$ & $3.6 \times 10^{-4}$ & Tc-99 & 74.0 & $1.9 \times 10^{-9}$ \\
\hline P-32 & $1.9 \times 10^{7}$ & $3.5 \times 10^{-4}$ & $\mathrm{Na}-22$ & 74.0 & $1.9 \times 10^{-9}$ \\
\hline Am-243 & 82.0 & $1.4 \times 10^{-4}$ & $K-40$ & 37.0 & $1.5 \times 10^{-9}$ \\
\hline Pu-239 & 71.0 & $7.5 \times 10^{-5}$ & Y-90 & 18.0 & $5.2 \times 10^{-10}$ \\
\hline $\operatorname{Gross} \operatorname{Beta}^{(\mathrm{d})}$ & $1.0 \times 10^{5}$ & $7.1 \times 10^{-5}$ & Th-230 & $8.0 \times 10^{-4}$ & $6.2 \times 10^{-10}$ \\
\hline $\mathrm{H}-3(\mathrm{HT})^{(\mathrm{c})}$ & $1.1 \times 10^{12}$ & $1.7 \times 10^{-5}$ & Cf-252 & $6.2 \times 10^{-4}$ & $3.0 \times 10^{-10}$ \\
\hline U-233 & 37.0 & $1.5 \times 10^{-5}$ & Eu-156 & 6.3 & $2.8 \times 10^{-10}$ \\
\hline Eu-152 & $6.7 \times 10^{3}$ & $4.6 \times 10^{-6}$ & Pm-147 & 0.54 & $6.4 \times 10^{-11}$ \\
\hline Eu-154 & $3.4 \times 10^{3}$ & $3.0 \times 10^{-6}$ & Sb-125 & 1.7 & $6.3 \times 10^{-11}$ \\
\hline P-33 & $1.5 \times 10^{5}$ & $2.8 \times 10^{-6}$ & U-232 & $3.7 \times 10^{-5}$ & $5.5 \times 10^{-11}$ \\
\hline Sr-90 & $2.0 \times 10^{3}$ & $1.4 \times 10^{-6}$ & Mn-54 & 2.5 & $5.2 \times 10^{-11}$ \\
\hline Bi-214 & $2.9 \times 10^{4}$ & $1.0 \times 10^{-6}$ & Cs-134 & 0.22 & $3.1 \times 10^{-11}$ \\
\hline $\mathrm{Pb}-214$ & $2.9 \times 10^{4}$ & $7.7 \times 10^{-7}$ & Co-57 & 0.30 & $8.3 \times 10^{-12}$ \\
\hline S-35 & $6.9 \times 10^{5}$ & $6.3 \times 10^{-7}$ & I-129 & $2.2 \times 10^{-3}$ & $1.2 \times 10^{-12}$ \\
\hline Cs-137 & $5.2 \times 10^{3}$ & $4.9 \times 10^{-7}$ & I-125 & $1.3 \times 10^{-2}$ & $9.4 \times 10^{-13}$ \\
\hline Ra-226 & 10.0 & $2.8 \times 10^{-7}$ & Np-239 & $4.1 \times 10^{-3}$ & $3.4 \times 10^{-14}$ \\
\hline Po-218 & $2.9 \times 10^{4}$ & $2.7 \times 10^{-7}$ & $\mathrm{Ba}-133$ & $1.5 \times 10^{-5}$ & $4.1 \times 10^{-16}$ \\
\hline \multirow[t]{2}{*}{ Pa-231 } & \multirow[t]{2}{*}{0.11} & \multirow[t]{2}{*}{$1.7 \times 10^{-7}$} & $\mathrm{Ni}-59$ & $2.6 \times 10^{-7}$ & $7.3 \times 10^{-19}$ \\
\hline & & & Total & $3.9 \times 10^{12}$ & \\
\hline
\end{tabular}

a Calculated emissions are estimates made according to the National Emmision Standards for Hazardous Air Pollutants 40 CFR 61.93 except those noted as measured. Values are considered conservative.

b The importance of the emissions (as weighted by the dose rate conversion factor) relative to $\mathrm{H}-3$ (HTO) emission.

c Includes measured emissions.

d Gross alpha and gross beta activitties are reported in inventories where specific isotopic content is unknown. 


\section{Air Effluent Monitoring}

Data

Annual summaries of gross alpha and gross beta data for each monitored facility are presented in Tables 5-2 through 5-10. A detailed discussion of these results is provided in Volume 1 of this report.

Table 5-2. Gross alpha and gross beta in air effluent samples from B166 monitored emission points summarized for 1995.

\begin{tabular}{|l|c|c|c|c|}
\hline $\begin{array}{c}\text { Sampler } \\
\text { no. }\end{array}$ & $\begin{array}{c}\text { No. }>\text { MDC(a)/ } \\
\text { Total samples }\end{array}$ & $\begin{array}{c}\text { Minimum } \\
(\mathrm{Bq} / \mathrm{mL})\end{array}$ & $\begin{array}{c}\text { Median } \\
(\mathrm{Bq} / \mathrm{mL})\end{array}$ & $\begin{array}{c}\text { Maximum } \\
(\mathrm{Bq} / \mathrm{mL})\end{array}$ \\
\hline $\begin{array}{c}\text { Gross alpha } \\
1\end{array}$ & $4 / 28$ & $-1.01 \times 10^{-11}$ & $1.11 \times 10^{-11}$ & $8.07 \times 10^{-11}$ \\
\hline $\begin{array}{c}\text { Gross beta } \\
1\end{array}$ & $8 / 28$ & $-1.20 \times 10^{-11}$ & $1.02 \times 10^{-10}$ & $3.01 \times 10^{-10}$ \\
\hline
\end{tabular}

Table 5-3. Gross alpha and gross beta in air effluent samples from B175 monitored emission points summarized for 1995.

\begin{tabular}{|c|c|c|c|c|}
\hline $\begin{array}{c}\text { Sampler } \\
\text { no. }\end{array}$ & $\begin{array}{c}\text { No. >MDC(a)/ } \\
\text { Total samples }\end{array}$ & $\begin{array}{c}\text { Minimum } \\
(\mathrm{Bq} / \mathbf{m L})\end{array}$ & $\begin{array}{c}\text { Median } \\
\mathbf{( B q} / \mathbf{m L})\end{array}$ & $\begin{array}{c}\text { Maximum } \\
(\mathbf{B q} / \mathbf{m L})\end{array}$ \\
\hline $\begin{array}{c}\text { Gross alpha } \\
1\end{array}$ & $2 / 25$ & $-1.04 \times 10^{-11}$ & $6.73 \times 10^{-12}$ & $5.62 \times 10^{-11}$ \\
2 & $5 / 25$ & $-2.41 \times 10^{-12}$ & $1.43 \times 10^{-11}$ & $1.19 \times 10^{-10}$ \\
3 & $0 / 25$ & $-1.27 \times 10^{-11}$ & $1.05 \times 10^{-11}$ & $3.45 \times 10^{-11}$ \\
4 & $0 / 25$ & $-1.04 \times 10^{-11}$ & $7.13 \times 10^{-12}$ & $2.67 \times 10^{-11}$ \\
5 & $0 / 25$ & $-1.27 \times 10^{-11}$ & $1.78 \times 10^{-12}$ & $6.27 \times 10^{-11}$ \\
6 & $0 / 25$ & $-1.27 \times 10^{-11}$ & $1.99 \times 10^{-12}$ & $2.78 \times 10^{-11}$ \\
\hline Gross beta & & & & \\
1 & $16 / 25$ & $1.84 \times 10^{-12}$ & $1.15 \times 10^{-10}$ & $5.03 \times 10^{-10}$ \\
2 & $18 / 25$ & $-1.57 \times 10^{-11}$ & $2.10 \times 10^{-10}$ & $5.59 \times 10^{-10}$ \\
3 & $9 / 25$ & $-4.16 \times 10^{-11}$ & $5.85 \times 10^{-11}$ & $5.07 \times 10^{-10}$ \\
4 & $14 / 25$ & $-3.38 \times 10^{-11}$ & $6.92 \times 10^{-11}$ & $2.09 \times 10^{-10}$ \\
5 & $1 / 25$ & $-9.33 \times 10^{-11}$ & $2.86 \times 10^{-12}$ & $1.10 \times 10^{-10}$ \\
6 & $2 / 25$ & $-3.54 \times 10^{-11}$ & $-8.81 \times 10^{-13}$ & $1.22 \times 10^{-10}$ \\
\hline
\end{tabular}

a Minimum detectible concentration.

Table 5-4. Gross alpha and gross beta in air effluent samples from B231 monitored emission points summarized for 1995.

\begin{tabular}{|c|c|c|c|c|}
\hline $\begin{array}{c}\text { Sampler } \\
\text { no. }\end{array}$ & $\begin{array}{c}\text { No. }>\text { MDC(a)/ } \\
\text { Total samples }\end{array}$ & $\begin{array}{c}\text { Minimum } \\
(\mathrm{Bq} / \mathbf{m L})\end{array}$ & $\begin{array}{c}\text { Median } \\
(\mathbf{B q} / \mathbf{m L})\end{array}$ & $\begin{array}{c}\text { Maximum } \\
(\mathrm{Bq} / \mathrm{mL})\end{array}$ \\
\hline $\begin{array}{c}\text { Gross alpha } \\
1\end{array}$ & $1 / 45$ & $-1.56 \times 10^{-11}$ & $-6.36 \times 10^{-12}$ & $2.74 \times 10^{-10}$ \\
\hline $\begin{array}{c}\text { Gross beta } \\
1\end{array}$ & $5 / 45$ & $-7.22 \times 10^{-11}$ & $2.27 \times 10^{-11}$ & $5.18 \times 10^{-10}$ \\
\hline
\end{tabular}

a Minimum detectible concentration. 
Table 5-5. Gross alpha and gross beta in air effluent samples from B251 monitored emission points summarized for 1995.

\begin{tabular}{|c|c|c|c|c|}
\hline $\begin{array}{c}\text { Sampler } \\
\text { no. }\end{array}$ & $\begin{array}{l}\text { No. >MDC(a)/ } \\
\text { Total samples }\end{array}$ & $\begin{array}{c}\text { Minimum } \\
(\mathrm{Bq} / \mathrm{mL})\end{array}$ & $\begin{array}{l}\text { Median } \\
(\mathrm{Bq} / \mathrm{mL})\end{array}$ & $\begin{array}{c}\text { Maximum } \\
\text { (Bq/mL) }\end{array}$ \\
\hline \multicolumn{5}{|l|}{ Gross alpha } \\
\hline 1 & $2 / 25$ & $-4.74 \times 10^{-11}$ & $1.96 \times 10^{-11}$ & $7.51 \times 10^{-10}$ \\
\hline 2 & $0 / 25$ & $-1.22 \times 10^{-11}$ & $4.29 \times 10^{-11}$ & $1.20 \times 10^{-10}$ \\
\hline 3 & $0 / 25$ & $-2.18 \times 10^{-11}$ & $1.67 \times 10^{-11}$ & $1.18 \times 10^{-10}$ \\
\hline 4 & $4 / 25$ & $-1.61 \times 10^{-11}$ & $3.92 \times 10^{-11}$ & $1.55 \times 10^{-10}$ \\
\hline 5 & $1 / 25$ & $-9.81 \times 10^{-11}$ & $1.20 \times 10^{-10}$ & $7.66 \times 10^{-10}$ \\
\hline 6 & $1 / 25$ & $-4.44 \times 10^{-11}$ & $7.73 \times 10^{-11}$ & $4.14 \times 10^{-10}$ \\
\hline 7 & $1 / 25$ & $-2.55 \times 10^{-11}$ & $2.45 \times 10^{-11}$ & $1.97 \times 10^{-10}$ \\
\hline 8 & $0 / 25$ & $-1.69 \times 10^{-10}$ & $1.44 \times 10^{-10}$ & $7.22 \times 10^{-10}$ \\
\hline 10 & $1 / 25$ & $-4.77 \times 10^{-11}$ & $9.55 \times 10^{-11}$ & $3.51 \times 10^{-10}$ \\
\hline 11 & $0 / 25$ & $-1.89 \times 10^{-10}$ & $1.45 \times 10^{-10}$ & $1.13 \times 10^{-9}$ \\
\hline 12 & $0 / 25$ & $-9.51 \times 10^{-12}$ & $7.25 \times 10^{-12}$ & $6.44 \times 10^{-11}$ \\
\hline 13 & $0 / 25$ & $-2.66 \times 10^{-11}$ & $1.86 \times 10^{-11}$ & $7.10 \times 10^{-11}$ \\
\hline 14 & $4 / 25$ & $-2.17 \times 10^{-11}$ & $6.07 \times 10^{-11}$ & $1.01 \times 10^{-9}$ \\
\hline 15 & $0 / 25$ & $-1.69 \times 10^{-10}$ & $1.75 \times 10^{-10}$ & $6.92 \times 10^{-10}$ \\
\hline 16 & $0 / 25$ & $-2.33 \times 10^{-11}$ & $2.45 \times 10^{-11}$ & $1.31 \times 10^{-10}$ \\
\hline 17 & $0 / 25$ & $-1.61 \times 10^{-11}$ & $1.93 \times 10^{-11}$ & $1.48 \times 10^{-10}$ \\
\hline 18 & $0 / 25$ & $-1.02 \times 10^{-11}$ & $1.08 \times 10^{-11}$ & $7.99 \times 10^{-11}$ \\
\hline 19 & $0 / 25$ & $-1.95 \times 10^{-10}$ & $1.63 \times 10^{-10}$ & $1.28 \times 10^{-9}$ \\
\hline 20 & $0 / 25$ & $-9.73 \times 10^{-12}$ & $5.44 \times 10^{-12}$ & $6.55 \times 10^{-11}$ \\
\hline 21 & $1 / 25$ & $-5.18 \times 10^{-11}$ & $7.66 \times 10^{-11}$ & $7.22 \times 10^{-10}$ \\
\hline 22 & $1 / 25$ & $-9.73 \times 10^{-12}$ & $1.44 \times 10^{-11}$ & $6.62 \times 10^{-11}$ \\
\hline 23 & $0 / 25$ & $-1.47 \times 10^{-10}$ & $1.44 \times 10^{-10}$ & $9.84 \times 10^{-10}$ \\
\hline 24 & $0 / 25$ & $-1.98 \times 10^{-11}$ & $2.47 \times 10^{-11}$ & $2.31 \times 10^{-10}$ \\
\hline 25 & $1 / 25$ & $-2.15 \times 10^{-11}$ & $1.35 \times 10^{-11}$ & $1.50 \times 10^{-10}$ \\
\hline 26 & $0 / 25$ & $-3.21 \times 10^{-11}$ & $5.66 \times 10^{-11}$ & $2.26 \times 10^{-10}$ \\
\hline 27 & $1 / 25$ & $-4.26 \times 10^{-11}$ & $3.39 \times 10^{-11}$ & $3.68 \times 10^{-10}$ \\
\hline 28 & $0 / 25$ & $-3.00 \times 10^{-11}$ & $2.63 \times 10^{-11}$ & $1.42 \times 10^{-10}$ \\
\hline 29 & $0 / 25$ & $-2.81 \times 10^{-11}$ & $1.86 \times 10^{-11}$ & $8.84 \times 10^{-11}$ \\
\hline 30 & $0 / 25$ & $-2.08 \times 10^{-11}$ & $2.16 \times 10^{-11}$ & $1.11 \times 10^{-10}$ \\
\hline 31 & $0 / 25$ & $-2.00 \times 10^{-10}$ & $1.45 \times 10^{-10}$ & $1.02 \times 10^{-9}$ \\
\hline 32 & $1 / 25$ & $-1.61 \times 10^{-11}$ & $1.67 \times 10^{-11}$ & $1.95 \times 10^{-10}$ \\
\hline 33 & $4 / 25$ & $-8.88 \times 10^{-12}$ & $5.00 \times 10^{-11}$ & $1.23 \times 10^{-10}$ \\
\hline 34 & $2 / 25$ & $-1.79 \times 10^{-11}$ & $4.07 \times 10^{-11}$ & $2.06 \times 10^{-10}$ \\
\hline 35 & $0 / 25$ & $-1.72 \times 10^{-11}$ & $1.02 \times 10^{-11}$ & $4.92 \times 10^{-11}$ \\
\hline 36 & $20 / 25$ & $1.40 \times 10^{-11}$ & $4.08 \times 10^{-10}$ & $1.18 \times 10^{-10}$ \\
\hline 37 & $0 / 25$ & $-1.89 \times 10^{-11}$ & $4.26 \times 10^{-11}$ & $1.75 \times 10^{-10}$ \\
\hline
\end{tabular}

...continued on next page 
Table 5-5. Gross alpha and gross beta in air effluent samples from B251 monitored emission points summarized for 1995 (continued).

\begin{tabular}{|c|c|c|c|c|}
\hline $\begin{array}{c}\text { Sampler } \\
\text { no. }\end{array}$ & $\begin{array}{l}\text { No. >MDC(a)/ } \\
\text { Total samples }\end{array}$ & $\begin{array}{l}\text { Minimum } \\
(\mathrm{Bq} / \mathrm{mL})\end{array}$ & $\begin{array}{l}\text { Median } \\
(\mathrm{Bq} / \mathrm{mL})\end{array}$ & $\begin{array}{c}\text { Maximum } \\
\text { (Bq/mL) }\end{array}$ \\
\hline \multicolumn{5}{|c|}{ Gross alpha (continued) } \\
\hline 38 & $0 / 25$ & $-1.22 \times 10^{-11}$ & $6.85 \times 10^{-12}$ & $6.22 \times 10^{-11}$ \\
\hline 39 & $1 / 25$ & $-8.40 \times 10^{-12}$ & $1.24 \times 10^{-11}$ & $8.07 \times 10^{-11}$ \\
\hline 40 & $0 / 25$ & $-1.17 \times 10^{-11}$ & $8.44 \times 10^{-12}$ & $5.99 \times 10^{-11}$ \\
\hline 41 & $0 / 25$ & $-2.39 \times 10^{-11}$ & $2.04 \times 10^{-11}$ & $1.44 \times 10^{-10}$ \\
\hline 42 & $0 / 25$ & $-3.95 \times 10^{-12}$ & $1.38 \times 10^{-11}$ & $5.51 \times 10^{-11}$ \\
\hline 43 & $0 / 25$ & $-1.02 \times 10^{-11}$ & $4.22 \times 10^{-12}$ & $4.44 \times 10^{-11}$ \\
\hline 44 & $1 / 25$ & $-1.81 \times 10^{-11}$ & $4.35 \times 10^{-11}$ & $1.82 \times 10^{-10}$ \\
\hline 45 & $0 / 25$ & $-2.08 \times 10^{-11}$ & $1.18 \times 10^{-11}$ & $1.54 \times 10^{-10}$ \\
\hline CAM 251034 & $2 / 50$ & $-2.47 \times 10^{-11}$ & $7.33 \times 10^{-12}$ & $1.26 \times 10^{-10}$ \\
\hline CAM 251035 & $2 / 50$ & $-2.81 \times 10^{-11}$ & $1.21 \times 10^{-11}$ & $1.61 \times 10^{-10}$ \\
\hline CAM 251036 & $1 / 50$ & $-3.19 \times 10^{-11}$ & $9.05 \times 10^{-12}$ & $1.17 \times 10^{-10}$ \\
\hline CAM 251037 & $4 / 50$ & $-2.47 \times 10^{-11}$ & $1.84 \times 10^{-11}$ & $1.77 \times 10^{-10}$ \\
\hline \multicolumn{5}{|l|}{ Gross beta } \\
\hline 1 & $5 / 25$ & $7.59 \times 10^{-11}$ & $3.11 \times 10^{-10}$ & $2.09 \times 10^{-9}$ \\
\hline 2 & $17 / 25$ & $1.31 \times 10^{-10}$ & $3.89 \times 10^{-10}$ & $1.15 \times 10^{-9}$ \\
\hline 3 & $2 / 25$ & $-1.37 \times 10^{-11}$ & $9.69 \times 10^{-11}$ & $3.07 \times 10^{-10}$ \\
\hline 4 & $24 / 25$ & $2.15 \times 10^{-10}$ & $5.26 \times 10^{-10}$ & $1.12 \times 10^{-9}$ \\
\hline 5 & $4 / 25$ & $-3.39 \times 10^{-10}$ & $6.44 \times 10^{-10}$ & $2.73 \times 10^{-9}$ \\
\hline 6 & $1 / 25$ & $-3.30 \times 10^{-11}$ & $2.71 \times 10^{-10}$ & $6.81 \times 10^{-10}$ \\
\hline 7 & $7 / 25$ & $3.69 \times 10^{-11}$ & $2.26 \times 10^{-10}$ & $6.81 \times 10^{-10}$ \\
\hline 8 & $3 / 25$ & $-3.34 \times 10^{-10}$ & $9.55 \times 10^{-10}$ & $3.22 \times 10^{-9}$ \\
\hline 10 & $12 / 25$ & $7.70 \times 10^{-11}$ & $6.88 \times 10^{-10}$ & $1.55 \times 10^{-9}$ \\
\hline 11 & $0 / 25$ & $-5.07 \times 10^{-10}$ & $6.11 \times 10^{-10}$ & $2.57 \times 10^{-9}$ \\
\hline 12 & $5 / 25$ & $-1.41 \times 10^{-11}$ & $5.70 \times 10^{-11}$ & $1.61 \times 10^{-10}$ \\
\hline 13 & $3 / 25$ & $-2.69 \times 10^{-11}$ & $1.48 \times 10^{-10}$ & $4.29 \times 10^{-10}$ \\
\hline 14 & $13 / 25$ & $8.92 \times 10^{-11}$ & $4.03 \times 10^{-10}$ & $2.31 \times 10^{-9}$ \\
\hline 15 & $3 / 25$ & $1.73 \times 10^{-10}$ & $1.14 \times 10^{-9}$ & $2.79 \times 10^{-9}$ \\
\hline 16 & $6 / 25$ & $3.33 \times 10^{-11}$ & $3.15 \times 10^{-10}$ & $5.74 \times 10^{-10}$ \\
\hline 17 & $16 / 25$ & $1.41 \times 10^{-10}$ & $3.13 \times 10^{-10}$ & $6.66 \times 10^{-10}$ \\
\hline 18 & $1 / 25$ & $-8.29 \times 10^{-11}$ & $7.55 \times 10^{-11}$ & $1.27 \times 10^{-10}$ \\
\hline 19 & $4 / 25$ & $-5.01 \times 10^{-10}$ & $1.07 \times 10^{-9}$ & $3.53 \times 10^{-9}$ \\
\hline 20 & $5 / 25$ & $1.22 \times 10^{-11}$ & $7.10 \times 10^{-11}$ & $1.81 \times 10^{-10}$ \\
\hline 21 & $10 / 25$ & $-3.59 \times 10^{-11}$ & $6.62 \times 10^{-10}$ & $1.58 \times 10^{-9}$ \\
\hline 22 & $13 / 25$ & $4.55 \times 10^{-12}$ & $9.81 \times 10^{-11}$ & $2.46 \times 10^{-10}$ \\
\hline
\end{tabular}


Table 5-5. Gross alpha and gross beta in air effluent samples from B251 monitored emission points summarized for 1995 (concluded).

\begin{tabular}{|c|c|c|c|c|}
\hline $\begin{array}{c}\text { Sampler } \\
\text { no. }\end{array}$ & $\begin{array}{l}\text { No. }>M D C(a) / \\
\text { Total samples }\end{array}$ & $\begin{array}{c}\text { Minimum } \\
(\mathrm{Bq} / \mathrm{mL})\end{array}$ & $\begin{array}{l}\text { Median } \\
(\mathrm{Bq} / \mathrm{mL})\end{array}$ & $\begin{array}{c}\text { Maximum } \\
\text { (Bq/mL) }\end{array}$ \\
\hline \multicolumn{5}{|c|}{ Gross beta (continued) } \\
\hline 23 & $3 / 25$ & $6.68 \times 10^{-11}$ & $1.07 \times 10^{-9}$ & $3.67 \times 10^{-9}$ \\
\hline 24 & $3 / 25$ & $-2.20 \times 10^{-11}$ & $1.34 \times 10^{-10}$ & $4.92 \times 10^{-10}$ \\
\hline 25 & $0 / 25$ & $-4.51 \times 10^{-11}$ & $1.52 \times 10^{-10}$ & $2.47 \times 10^{-10}$ \\
\hline 26 & $0 / 25$ & $-7.73 \times 10^{-11}$ & $1.42 \times 10^{-10}$ & $4.00 \times 10^{-10}$ \\
\hline 27 & $0 / 25$ & $-2.30 \times 10^{-11}$ & $2.29 \times 10^{-10}$ & $5.29 \times 10^{-10}$ \\
\hline 28 & $12 / 25$ & $-1.94 \times 10^{-11}$ & $3.25 \times 10^{-10}$ & $7.25 \times 10^{-10}$ \\
\hline 29 & $4 / 25$ & $-4.55 \times 10^{-11}$ & $1.41 \times 10^{-10}$ & $4.92 \times 10^{-10}$ \\
\hline 30 & $0 / 25$ & $-1.54 \times 10^{-11}$ & $1.59 \times 10^{-10}$ & $3.81 \times 10^{-10}$ \\
\hline 31 & $3 / 25$ & $-4.59 \times 10^{-10}$ & $1.28 \times 10^{-9}$ & $3.06 \times 10^{-9}$ \\
\hline 32 & $3 / 25$ & $-3.74 \times 10^{-11}$ & $1.51 \times 10^{-10}$ & $3.20 \times 10^{-10}$ \\
\hline 33 & $22 / 25$ & $9.51 \times 10^{-11}$ & $3.81 \times 10^{-10}$ & $7.62 \times 10^{-10}$ \\
\hline 34 & $21 / 25$ & $1.26 \times 10^{-10}$ & $4.29 \times 10^{-10}$ & $9.44 \times 10^{-10}$ \\
\hline 35 & $2 / 25$ & $-2.54 \times 10^{-11}$ & $9.47 \times 10^{-11}$ & $2.73 \times 10^{-10}$ \\
\hline 36 & $25 / 25$ & $7.76 \times 10^{-11}$ & $4.12 \times 10^{-10}$ & $9.23 \times 10^{-10}$ \\
\hline 37 & $16 / 25$ & $-6.57 \times 10^{-12}$ & $4.18 \times 10^{-10}$ & $8.81 \times 10^{-10}$ \\
\hline 38 & $1 / 25$ & $-1.66 \times 10^{-11}$ & $7.84 \times 10^{-11}$ & $1.35 \times 10^{-10}$ \\
\hline 39 & $6 / 25$ & $-1.45 \times 10^{-11}$ & $6.99 \times 10^{-11}$ & $1.05 \times 10^{-9}$ \\
\hline 40 & $8 / 25$ & $2.25 \times 10^{-11}$ & $9.01 \times 10^{-11}$ & $1.88 \times 10^{-10}$ \\
\hline 41 & $10 / 25$ & $-3.70 \times 10^{-11}$ & $3.27 \times 10^{-10}$ & $5.88 \times 10^{-10}$ \\
\hline 42 & $4 / 25$ & $-1.54 \times 10^{-11}$ & $5.48 \times 10^{-11}$ & $1.82 \times 10^{-10}$ \\
\hline 43 & $2 / 25$ & $-3.68 \times 10^{-11}$ & $5.81 \times 10^{-11}$ & $1.36 \times 10^{-10}$ \\
\hline 44 & $8 / 25$ & $1.18 \times 10^{-10}$ & $2.47 \times 10^{-10}$ & $4.74 \times 10^{-10}$ \\
\hline 45 & $3 / 25$ & $-1.04 \times 10^{-10}$ & $1.68 \times 10^{-10}$ & $4.85 \times 10^{-10}$ \\
\hline CAM 251034 & $24 / 50$ & $5.74 \times 10^{-12}$ & $2.01 \times 10^{-10}$ & $8.81 \times 10^{-10}$ \\
\hline CAM 251035 & $25 / 50$ & $-7.36 \times 10^{-11}$ & $2.16 \times 10^{-10}$ & $1.62 \times 10^{-9}$ \\
\hline CAM 251036 & $19 / 50$ & $-7.77 \times 10^{-11}$ & $1.04 \times 10^{-10}$ & $1.68 \times 10^{-9}$ \\
\hline CAM 251037 & $25 / 50$ & $-8.33 \times 10^{-11}$ & $2.27 \times 10^{-10}$ & $9.21 \times 10^{-10}$ \\
\hline
\end{tabular}

a Minimum detectible concentration. 
Table 5-6. Tritium in air effluent samples from B331 monitored emission points summarized for 1995.

\begin{tabular}{|l|c|c|c|c|}
\hline $\begin{array}{c}\text { Sampler } \\
\text { no. }\end{array}$ & $\begin{array}{c}\text { No. }>\text { MDC(a)/ } \\
\text { Total samples }\end{array}$ & $\begin{array}{c}\text { Minimum } \\
(\mathbf{B q} / \mathbf{m L})\end{array}$ & $\begin{array}{c}\text { Median } \\
(\mathrm{Bq} / \mathbf{m L})\end{array}$ & $\begin{array}{c}\text { Maximum } \\
(\mathrm{Bq} / \mathrm{mL})\end{array}$ \\
\hline HT & & & & \\
Stack 1 & $48 / 50$ & $8.80 \times 10^{-6}$ & $3.10 \times 10^{-5}$ & $2.91 \times 10^{-3}$ \\
Stack 2 & $49 / 49$ & $4.74 \times 10^{-5}$ & $2.43 \times 10^{-3}$ & $6.45 \times 10^{-3}$ \\
\hline HTO & & & & \\
Stack 1 & $50 / 50$ & $2.48 \times 10^{-4}$ & $6.13 \times 10^{-4}$ & $2.09 \times 10^{-3}$ \\
Stack 2 & $50 / 50$ & $1.79 \times 10^{-3}$ & $5.65 \times 10^{-3}$ & $9.62 \times 10^{-3}$ \\
\hline
\end{tabular}

a Minimum detectible concentration.

Table 5-7. Gross alpha and gross beta in air effluent samples from B332 summarized for 1995.

\begin{tabular}{|c|c|c|c|c|}
\hline $\begin{array}{c}\text { Sampler } \\
\text { no. }\end{array}$ & $\begin{array}{l}\text { No. >MDC(a)/ } \\
\text { Total samples }\end{array}$ & $\begin{array}{c}\text { Minimum } \\
(\mathrm{Bq} / \mathrm{mL})\end{array}$ & $\begin{array}{l}\text { Median } \\
(\mathrm{Bq} / \mathrm{mL})\end{array}$ & $\begin{array}{c}\text { Maximum } \\
\text { (Bq/mL) }\end{array}$ \\
\hline \multicolumn{5}{|l|}{ Gross alpha } \\
\hline SP-1 & $0 / 50$ & $-2.25 \times 10^{-11}$ & $1.99 \times 10^{-11}$ & $1.51 \times 10^{-10}$ \\
\hline SP-2 & $0 / 50$ & $-2.33 \times 10^{-11}$ & $1.82 \times 10^{-11}$ & $1.05 \times 10^{-10}$ \\
\hline SP-3 & $0 / 50$ & $-4.03 \times 10^{-11}$ & $1.75 \times 10^{-11}$ & $2.71 \times 10^{-10}$ \\
\hline SP-4 & $0 / 49$ & $-4.70 \times 10^{-11}$ & $1.95 \times 10^{-11}$ & $1.75 \times 10^{-10}$ \\
\hline SP-5 & $0 / 50$ & $-2.70 \times 10^{-11}$ & $1.73 \times 10^{-11}$ & $1.17 \times 10^{-10}$ \\
\hline SP-6 & $0 / 50$ & $-2.36 \times 10^{-11}$ & $3.45 \times 10^{-11}$ & $2.26 \times 10^{-10}$ \\
\hline SP-7 & $0 / 50$ & $-4.70 \times 10^{-11}$ & $3.50 \times 10^{-11}$ & $2.09 \times 10^{-10}$ \\
\hline SP-8 & $0 / 50$ & $-2.01 \times 10^{-11}$ & $1.85 \times 10^{-11}$ & $1.42 \times 10^{-10}$ \\
\hline SP-9 & $0 / 50$ & $-2.43 \times 10^{-11}$ & $1.96 \times 10^{-11}$ & $1.30 \times 10^{-10}$ \\
\hline SP-10 & $0 / 50$ & $-7.59 \times 10^{-11}$ & $3.41 \times 10^{-11}$ & $2.97 \times 10^{-10}$ \\
\hline SP-11 & $0 / 50$ & $-4.03 \times 10^{-11}$ & $2.07 \times 10^{-11}$ & $1.74 \times 10^{-10}$ \\
\hline SP-12 & $0 / 50$ & $-4.14 \times 10^{-11}$ & $3.41 \times 10^{-11}$ & $2.19 \times 10^{-10}$ \\
\hline \multicolumn{5}{|l|}{ Gross beta } \\
\hline $\mathrm{SP}-1$ & $4 / 50$ & $-1.24 \times 10^{-11}$ & $1.33 \times 10^{-10}$ & $5.51 \times 10^{-10}$ \\
\hline SP-2 & $6 / 50$ & $-3.85 \times 10^{-11}$ & $1.38 \times 10^{-10}$ & $3.74 \times 10^{-10}$ \\
\hline SP-3 & $1 / 50$ & $-6.62 \times 10^{-11}$ & $1.53 \times 10^{-10}$ & $5.94 \times 10^{-10}$ \\
\hline SP-4 & $0 / 50$ & $-1.93 \times 10^{-10}$ & $1.69 \times 10^{-10}$ & $6.55 \times 10^{-10}$ \\
\hline SP-5 & $1 / 50$ & $-8.73 \times 10^{-11}$ & $9.93 \times 10^{-11}$ & $3.38 \times 10^{-10}$ \\
\hline SP-6 & $1 / 50$ & $-2.80 \times 10^{-10}$ & $1.59 \times 10^{-10}$ & $7.92 \times 10^{-10}$ \\
\hline SP-7 & $4 / 50$ & $-1.09 \times 10^{-10}$ & $1.46 \times 10^{-10}$ & $7.92 \times 10^{-10}$ \\
\hline SP-8 & $0 / 50$ & $-3.03 \times 10^{-11}$ & $1.06 \times 10^{-10}$ & $2.78 \times 10^{-10}$ \\
\hline SP-9 & $3 / 50$ & $-4.81 \times 10^{-11}$ & $9.25 \times 10^{-11}$ & $4.00 \times 10^{-10}$ \\
\hline SP-10 & $5 / 50$ & $-2.84 \times 10^{-10}$ & $2.78 \times 10^{-10}$ & $1.12 \times 10^{-9}$ \\
\hline SP-11 & $0 / 50$ & $-7.33 \times 10^{-11}$ & $1.02 \times 10^{-10}$ & $5.51 \times 10^{-10}$ \\
\hline SP-12 & $4 / 50$ & $-2.36 \times 10^{-10}$ & $1.87 \times 10^{-10}$ & $6.96 \times 10^{-10}$ \\
\hline
\end{tabular}

a Minimum detectible concentration. 
Table 5-8. Gross alpha and gross beta in air effluent samples from B419 monitored emission points summarized for 1995.

\begin{tabular}{|c|c|c|c|c|}
\hline $\begin{array}{c}\text { Sampler } \\
\text { no. }\end{array}$ & $\begin{array}{c}\text { No. }>\text { MDC (a)/ } \\
\text { Total samples }\end{array}$ & $\begin{array}{c}\text { Minimum } \\
(\mathrm{Bq} / \mathrm{mL})\end{array}$ & $\begin{array}{c}\text { Median } \\
(\mathbf{B q} / \mathbf{m L})\end{array}$ & $\begin{array}{c}\text { Maximum } \\
(\mathrm{Bq} / \mathrm{mL})\end{array}$ \\
\hline Gross alpha & & & & \\
1 & $23 / 39$ & $1.22 \times 10^{-11}$ & $6.77 \times 10^{-11}$ & $2.07 \times 10^{-10}$ \\
2 & $27 / 40$ & $6.96 \times 10^{-12}$ & $6.88 \times 10^{-11}$ & $2.29 \times 10^{-10}$ \\
\hline Gross beta & & & & \\
1 & $40 / 40$ & $2.31 \times 10^{-10}$ & $5.64 \times 10^{-10}$ & $1.01 \times 10^{-9}$ \\
2 & $40 / 40$ & $1.68 \times 10^{-10}$ & $5.85 \times 10^{-10}$ & $1.02 \times 10^{-9}$ \\
\hline
\end{tabular}

a Minimum detectible concentration.

Table 5-9. Gross alpha and gross beta in air effluent samples from B490 monitored emission points summarized for 1995.

\begin{tabular}{|c|c|c|c|c|}
\hline $\begin{array}{c}\text { Sampler } \\
\text { no. }\end{array}$ & $\begin{array}{c}\text { No. }>\text { MDC(a)/ } \\
\text { Total samples }\end{array}$ & $\begin{array}{c}\text { Minimum } \\
(\mathrm{Bq} / \mathbf{m L})\end{array}$ & $\begin{array}{c}\text { Median } \\
(\mathbf{B q} / \mathbf{m L})\end{array}$ & $\begin{array}{c}\text { Maximum } \\
(\mathrm{Bq} / \mathbf{m L})\end{array}$ \\
\hline $\begin{array}{c}\text { Gross alpha } \\
1\end{array}$ & $0 / 25$ & $-9.44 \times 10^{-12}$ & $5.14 \times 10^{-12}$ & $5.51 \times 10^{-11}$ \\
2 & $1 / 23$ & $-9.18 \times 10^{-12}$ & $9.77 \times 10^{-12}$ & $1.50 \times 10^{-10}$ \\
3 & $0 / 25$ & $-2.02 \times 10^{-11}$ & $9.18 \times 10^{-12}$ & $5.51 \times 10^{-11}$ \\
4 & $2 / 22$ & $-2.06 \times 10^{-11}$ & $9.68 \times 10^{-12}$ & $8.99 \times 10^{-11}$ \\
\hline Gross beta & & & & \\
1 & $5 / 25$ & $-8.48 \times 10^{-11}$ & $-1.27 \times 10^{-11}$ & $6.11 \times 10^{-10}$ \\
2 & $7 / 23$ & $-1.82 \times 10^{-11}$ & $5.96 \times 10^{-11}$ & $1.38 \times 10^{-9}$ \\
3 & $8 / 25$ & $-2.96 \times 10^{-11}$ & $5.99 \times 10^{-11}$ & $4.96 \times 10^{-10}$ \\
4 & $8 / 23$ & $-2.45 \times 10^{-11}$ & $8.99 \times 10^{-11}$ & $5.81 \times 10^{-10}$ \\
\hline
\end{tabular}

a Minimum detectible concentration.

Table 5-10. Gross alpha and gross beta in air effluent samples from B491 monitored emission points summarized for 1995.

\begin{tabular}{|c|c|c|c|c|}
\hline $\begin{array}{c}\text { Sampler } \\
\text { no. }\end{array}$ & $\begin{array}{c}\text { No. }>\text { MDC(a)/ } \\
\text { Total samples }\end{array}$ & $\begin{array}{c}\text { Minimum } \\
(\mathrm{Bq} / \mathbf{m L})\end{array}$ & $\begin{array}{c}\text { Median } \\
(\mathrm{Bq} / \mathbf{m L})\end{array}$ & $\begin{array}{c}\text { Maximum } \\
(\mathrm{Bq} / \mathbf{m L})\end{array}$ \\
\hline $\begin{array}{c}\text { Gross alpha } \\
1\end{array}$ & $1 / 49$ & $-1.11 \times 10^{-11}$ & $-6.20 \times 10^{-12}$ & $1.84 \times 10^{-10}$ \\
\hline $\begin{array}{c}\text { Gross beta } \\
1\end{array}$ & $5 / 50$ & $-5.11 \times 10^{-11}$ & $2.82 \times 10^{-11}$ & $1.41 \times 10^{-9}$ \\
\hline
\end{tabular}

a Minimum detectible concentration. 



\section{Methods}


compositing mode, the sampler is programmed to acquire a 30-mL sample for every $30,280 \mathrm{~L}$ of effluent discharged. Operating as a single day composite sampler, the sampler runs for 24 hours, collecting a $150-\mathrm{mL}$ sample for every $7570 \mathrm{~L}$ of effluent discharged.

Aliquots are acquired each week from the weekly composite sample and every month from the 24-hour composite sample. From the weekly composite, one 1-L aliquot is transferred to a polyethylene bottle. This aliquot is submitted to a contract laboratory for aluminum, arsenic, beryllium, cadmium, chromium, copper, iron, lead, mercury, nickel, silver, and zinc analyses; the analytical results for these analyses are presented in Table 6-2; the EPA Methods used for these analyses are identified in Table 6-3. Two additional aliquots are submitted each week from the weekly composite. These two 500-mL aliquots are submitted to HCAL for analyses of the gross alpha, beta, and tritium activities. A subset of these results contribute to the completeness of the daily analytical results for gross alpha, gross beta, and tritium; this subset is reported and footnoted in the table for the daily results for gross alpha, gross beta, and tritium (Table 6-1).

Aliquots are submitted to the contract analytical laboratory for a far more extensive set of analyses on the 24-hour composite than the weekly composite sample. Under the heading of Composite sample parameters, the left column of Table 6-3 lists the requested analyses with corresponding analytical methods. The analytical methods are EPA methods unless otherwise indicated. The remainder of the table reports the results by the month during which the 24-hour composite was acquired. It should be noted that Table 6-2 also reports the monthly metals analytical results; these results are footnoted. In addition to the Table 6-3 aliquots from the 24-hour composite, there are two 500-mL aliquots submitted to HCAL. These aliquots are submitted for analyses of the gross alpha, beta, and tritium activities. The results for the analyses are recorded with the gross alpha, gross beta, and tritium results from the weekly composite.

Concurrent with the monthly acquisition of a 24-hour composite, a portable peristaltic pump sampler is used to collect instantaneous grab samples from the sewage stream in the vault adjacent to B196. These samples are submitted to a contract analytical laboratory for additional monitoring of water quality parameters and organic compounds. The results of this monitoring are found in Table 6-3 under the Grab sample parameters heading. The left column lists the parameters and the EPA method numbers used for the analyses. The last four entries in the column are for oil and grease analysis of samples that were acquired at 4-hour intervals during the day; the time of collection of each oil and grease sample is indicated in the column.

LLNL maintains flow monitoring equipment. A flow chart recorder is located inside of B196, and an ultrasonic flow sensor is installed in a vault adjacent to 
B196. A flow totalizer reading from the flow chart recorder is entered into the B196 daily sampling log every day when the B196 daily composite sample is acquired. The daily total flows are determined by subtracting sequentially recorded flow totalizer readings. For days that flow totalizer readings are not available, daily flow totals are calculated by averaging. Table 6-4 presents the daily total flows for 1995.

Two 500-mL aliquots of treated effluent from LWRP are collected daily by LWRP employees. These daily 500-mL aliquots are used to create two different composite samples. The first of the samples contains a week of daily aliquots. This weekly sample, composited in a 1-gallon polyethylene bottle, is collected each week by LLNL and submitted to HCAL for gross alpha, gross beta, and tritium analyses. Table 6-5 shows the tritium results for the LWRP weekly composite sample. The other composite sample contains a month of daily aliquots. This monthly sample, composited in a 5-gallon polyethylene carboy, is collected each month by LLNL. CES analyzes the monthly composite for ${ }^{137} \mathrm{Cs}$ using gamma spectroscopy and for ${ }^{239} \mathrm{Pu}$ using alpha spectroscopy.

Two 500-mL composite samples from the LWRP digesters are acquired monthly by LWRP employees. The composites consist of aliquots taken from the circulating sludge once a week. Every month LLNL collects the composite samples and submits one 500-mL composite to HCAL and one to CES. HCAL analyzes the monthly composite for gross radioactivity and metals. CES composites the monthly samples on a quarterly basis and analyzes the quarterly composites for plutonium, cesium, and gamma-emitting radionuclides, using alpha spectroscopy for the plutonium and gamma spectroscopy for the cesium and gamma-emitting radionuclides. Volume 1, Table 6-2 shows the results for the ${ }^{239} \mathrm{Pu}$ analyses.

Standard quality control and quality assurance procedures are followed. When each sewage field sample is collected, it is labeled with the sampling location and date of sampling. In the laboratory, each sample is assigned a number that accompanies that sample during analysis. Additionally, split samples account for approximately 20\% of the samples submitted for analytical work in 1995. 
Table 6-1. Daily monitoring results for gross alpha, gross beta, and tritium in the sanitary sewer effluent, 1995.

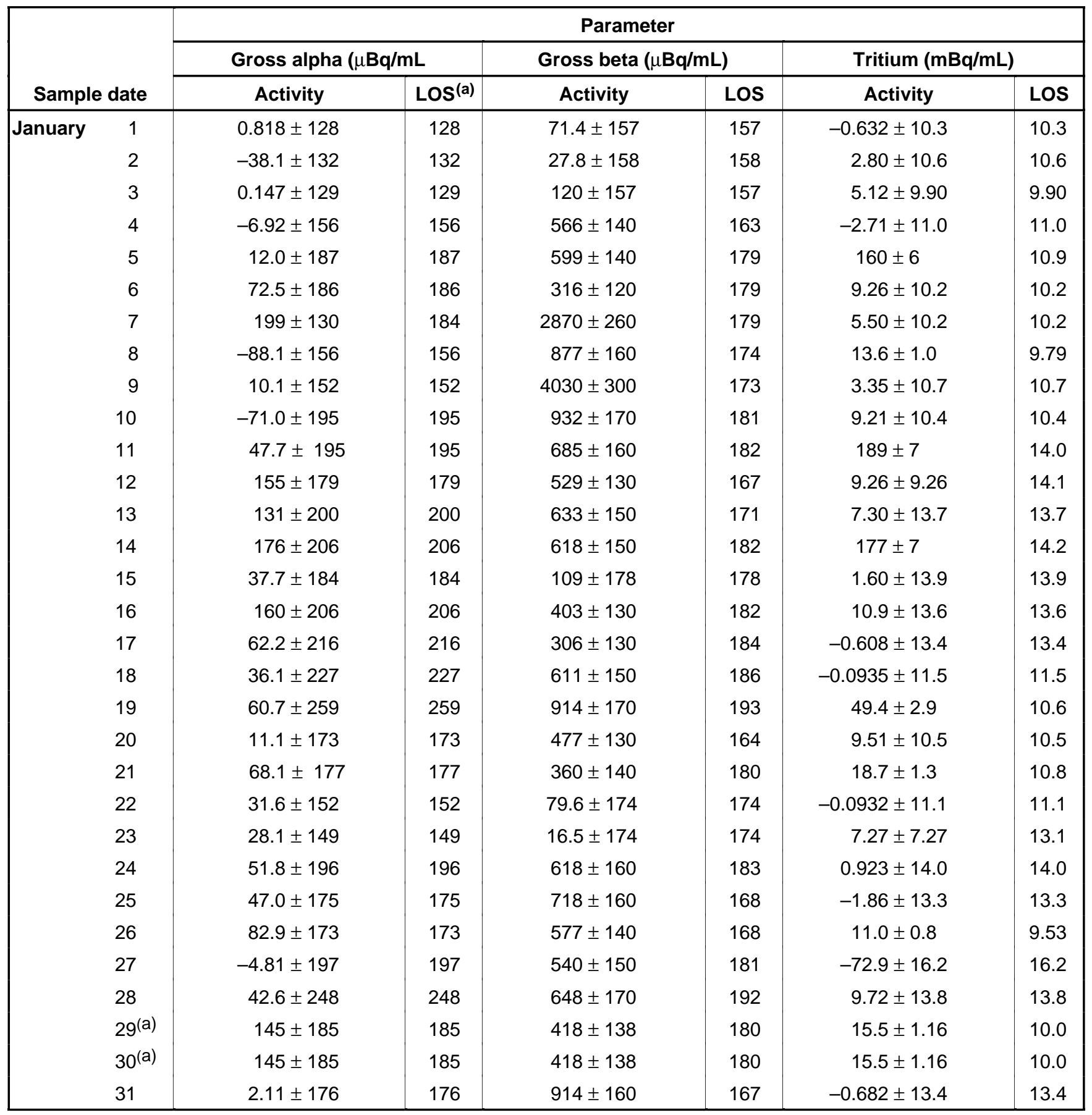


Table 6-1. Daily monitoring results for gross alpha, gross beta, and tritium in the sanitary sewer effluent, 1995 (continued).

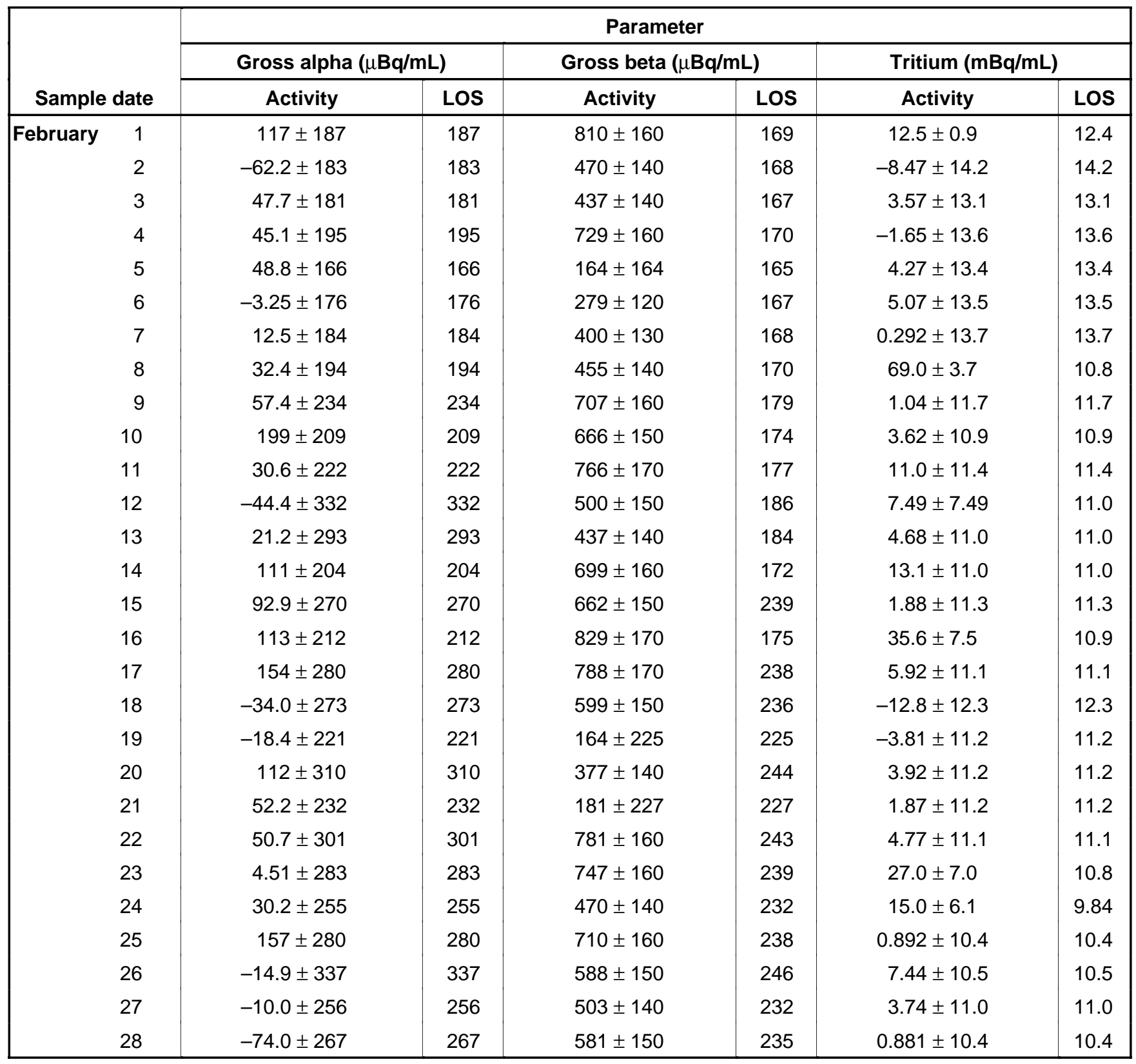


Table 6-1. Daily monitoring results for gross alpha, gross beta, and tritium in the sanitary sewer effluent, 1995 (continued).

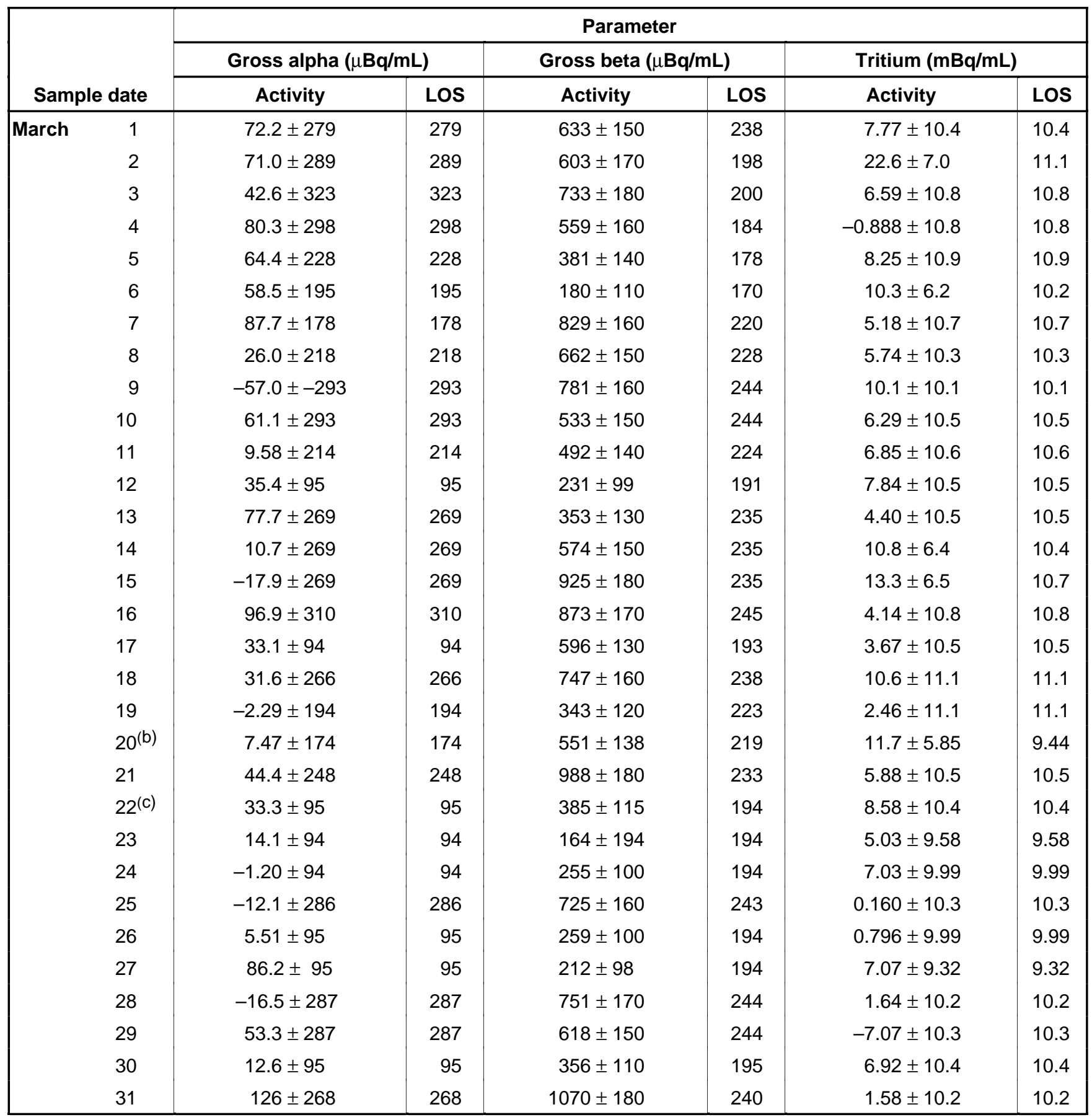


Table 6-1. Daily monitoring results for gross alpha, gross beta, and tritium in the sanitary sewer effluent, 1995 (continued).

\begin{tabular}{|c|c|c|c|c|c|c|c|}
\hline \multirow{3}{*}{\multicolumn{2}{|c|}{ Sample date }} & \multicolumn{6}{|c|}{ Parameter } \\
\hline & & \multicolumn{2}{|c|}{ Gross alpha $(\mu \mathrm{Bq} / \mathrm{mL})$} & \multicolumn{2}{|c|}{ Gross beta $(\mu \mathrm{Bq} / \mathrm{mL})$} & \multicolumn{2}{|c|}{ Tritium $(\mathrm{mBq} / \mathrm{mL})$} \\
\hline & & \multirow{2}{*}{$\begin{array}{l}\text { Activity } \\
20.6 \pm 95\end{array}$} & \multirow{2}{*}{$\frac{\text { LOS }}{95}$} & \multirow{2}{*}{$\begin{array}{c}\text { Activity } \\
603 \pm 130\end{array}$} & \multirow{2}{*}{$\frac{\text { LOS }}{194}$} & \multirow{2}{*}{$\begin{array}{c}\text { Activity } \\
3.30 \pm 10.2\end{array}$} & \multirow{2}{*}{$\frac{\text { LOS }}{10.2}$} \\
\hline April & 1 & & & & & & \\
\hline & 2 & $57.7 \pm 195$ & 195 & $161 \pm 224$ & 224 & $2.08 \pm 10.6$ & 10.6 \\
\hline & 3 & $25.7 \pm 95$ & 95 & $286 \pm 110$ & 194 & $9.29 \pm 10.3$ & 10.3 \\
\hline & 4 & $0.230 \pm 95$ & 95 & $511 \pm 120$ & 194 & $7.70 \pm 9.69$ & 9.69 \\
\hline & 5 & $-30.2 \pm 213$ & 213 & $525 \pm 140$ & 227 & $8.44 \pm 9.58$ & 9.58 \\
\hline & 6 & $45.5 \pm 94$ & 94 & $448 \pm 120$ & 192 & $37.0 \pm 6.7$ & 10.1 \\
\hline & 7 & $58.8 \pm 94$ & 94 & $525 \pm 130$ & 192 & $2.32 \pm 10.4$ & 10.4 \\
\hline & 8 & $65.5 \pm 94$ & 94 & $555 \pm 130$ & 192 & $-2.79 \pm 10.5$ & 10.5 \\
\hline & 9 & $21.1 \pm 94$ & 94 & $115 \pm 192$ & 192 & $7.51 \pm 10.1$ & 10.1 \\
\hline & 10 & $4.88 \pm 94$ & 94 & $243 \pm 100$ & 192 & $0.918 \pm 10.5$ & 10.5 \\
\hline & 11 & $56.6 \pm 211$ & 211 & $403 \pm 130$ & 225 & $6.11 \pm 9.81$ & 9.81 \\
\hline & 12 & $18.6 \pm 72$ & 72 & $740 \pm 140$ & 139 & $4.29 \pm 10.4$ & 10.4 \\
\hline & 13 & $18.4 \pm 175$ & 175 & $618 \pm 150$ & 166 & $4.07 \pm 10.3$ & 10.3 \\
\hline & 14 & $-4.44 \pm 72$ & 72 & $352 \pm 110$ & 140 & $1.78 \pm 10.7$ & 10.7 \\
\hline & 15 & $17.5 \pm 115$ & 115 & $320 \pm 120$ & 152 & $1.14 \pm 10.2$ & 10.2 \\
\hline & 16 & $-1.45 \pm 72$ & 72 & $159 \pm 95$ & 140 & $2.00 \pm 10.4$ & 10.4 \\
\hline & 17 & $5.22 \pm 72$ & 72 & $196 \pm 98$ & 140 & $8.33 \pm 9.81$ & 9.81 \\
\hline & 18 & $5.85 \pm 72$ & 72 & $154 \pm 94$ & 140 & $-0.773 \pm 10.4$ & 10.4 \\
\hline & 19 & $53.7 \pm 72$ & 72 & $330 \pm 110$ & 140 & $2.56 \pm 10.5$ & 10.5 \\
\hline & 20 & $85.8 \pm 149$ & 149 & $363 \pm 130$ & 163 & $13.3 \pm 6.2$ & 10 \\
\hline & 21 & $4.96 \pm 73$ & 73 & $358 \pm 110$ & 141 & $-2.22 \pm 10.2$ & 10.2 \\
\hline & 22 & $-2.99 \pm 73$ & 73 & $429 \pm 120$ & 141 & $-1.96 \pm 10.3$ & 10.3 \\
\hline & 23 & $-7.47 \pm 73$ & 73 & $131 \pm 130$ & 141 & $1.36 \pm 10.3$ & 10.3 \\
\hline & 24 & $29.2 \pm 73$ & 73 & $106 \pm 141$ & 141 & $2.36 \pm 10.5$ & 10.5 \\
\hline & 25 & $11.6 \pm 73$ & 73 & $429 \pm 120$ & 141 & $5.40 \pm 10.0$ & 10.0 \\
\hline & 26 & $-2.64 \pm 73$ & 73 & $392 \pm 110$ & 141 & $6.81 \pm 9.88$ & 9.88 \\
\hline & 27 & $33.9 \pm 73$ & 73 & $374 \pm 110$ & 141 & $3.45 \pm 10.6$ & 10.6 \\
\hline & 28 & $53.3 \pm 116$ & 116 & $481 \pm 130$ & 153 & $4.59 \pm 10.7$ & 10.7 \\
\hline & 29 & $5.55 \pm 73$ & 73 & $307 \pm 110$ & 141 & $2.89 \pm 11.0$ & 11.0 \\
\hline & 30 & $44.0 \pm 73$ & 73 & $105 \pm 141$ & 141 & $4.88 \pm 11.4$ & 11.4 \\
\hline
\end{tabular}

...continued on next page

Table 6-1. Daily monitoring results for gross alpha, gross beta, and tritium in the sanitary sewer effluent, 1995 (continued). 
Table 6-1. Daily monitoring results for gross alpha, gross beta, and tritium in the sanitary sewer effluent, 1995 (continued).

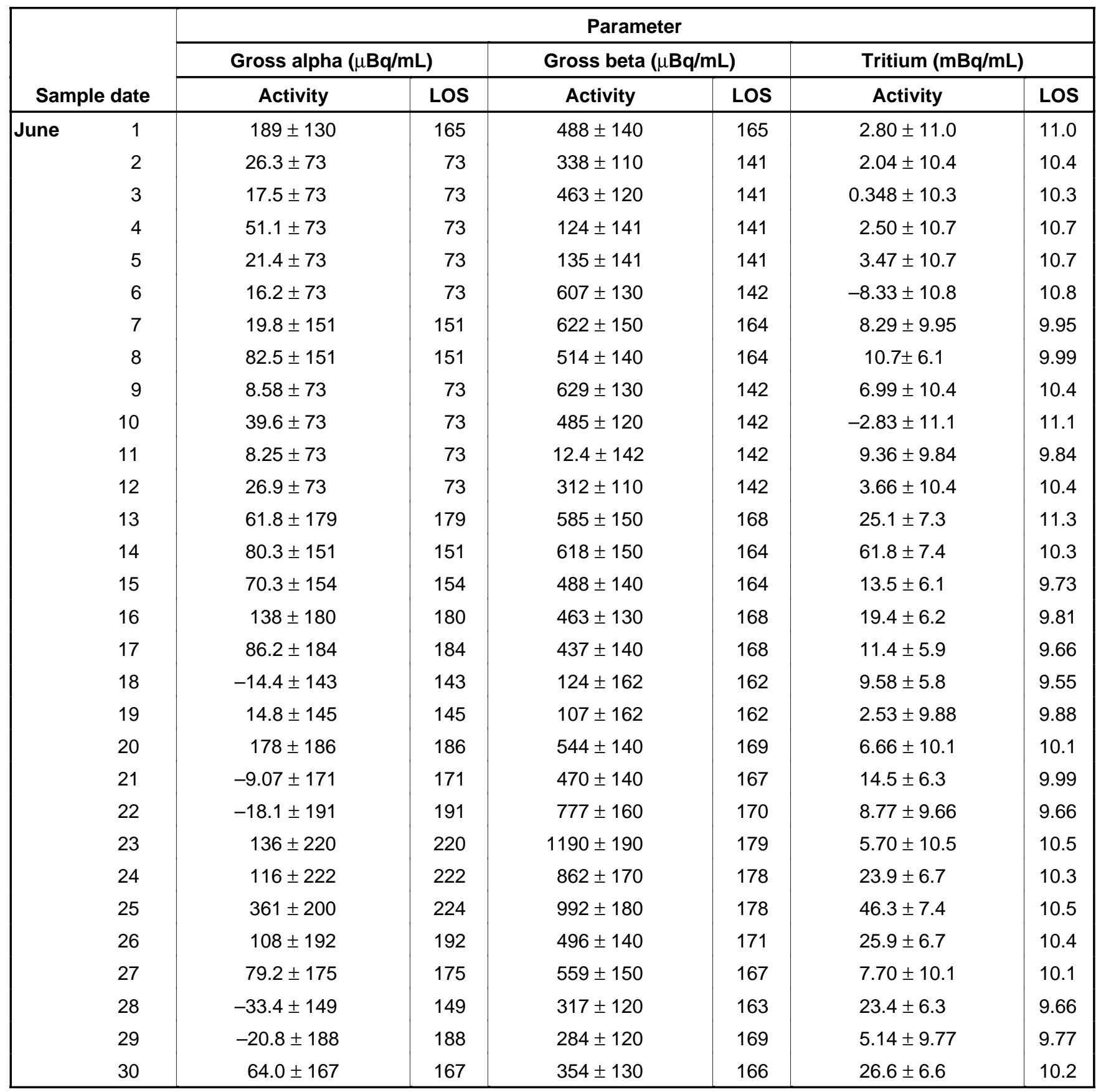

..continued on next page 
Table 6-1. Daily monitoring results for gross alpha, gross beta, and tritium in the sanitary sewer effluent, 1995 (continued).

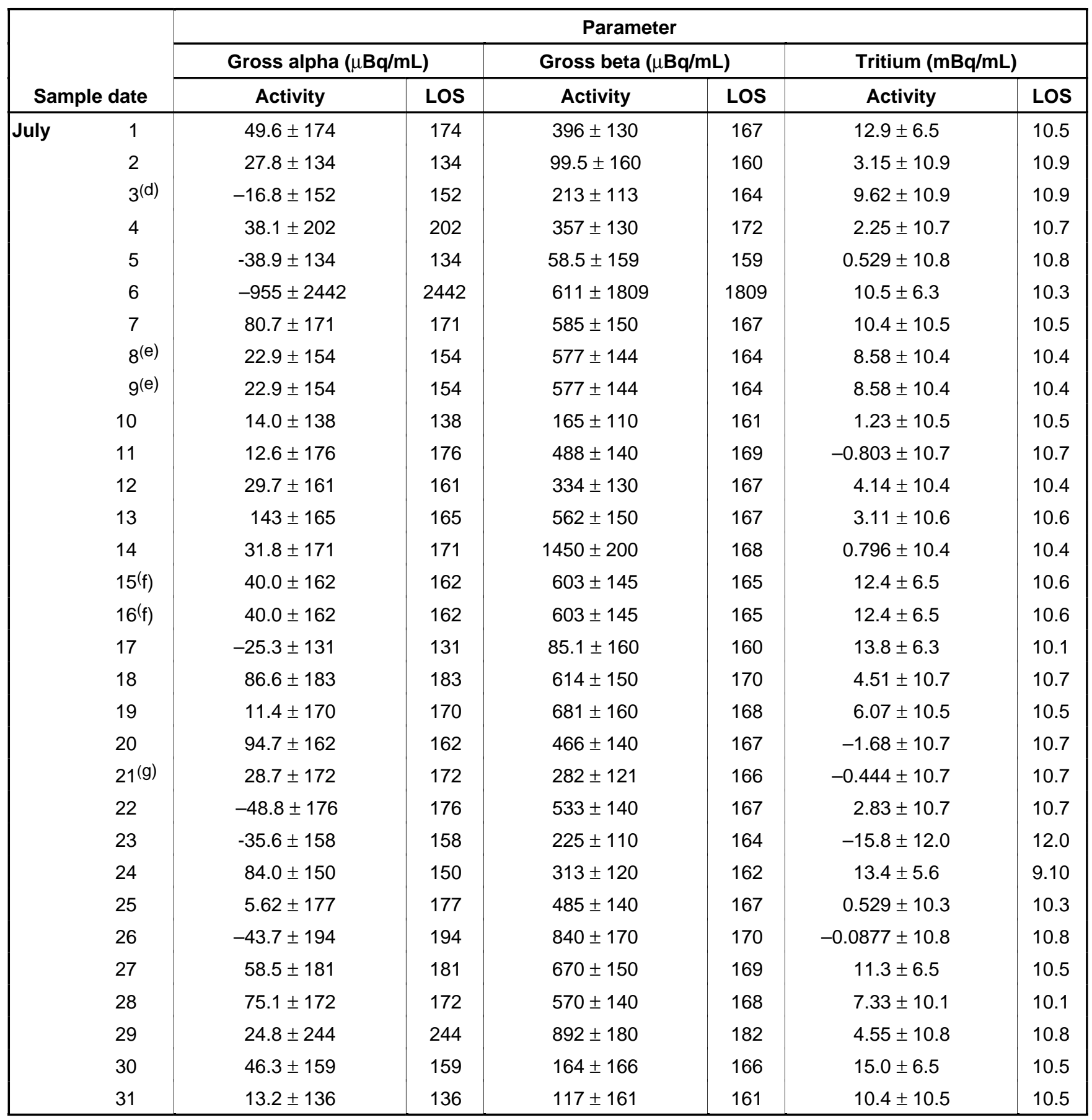


Table 6-1. Daily monitoring results for gross alpha, gross beta, and tritium in the sanitary sewer effluent, 1995 (continued).

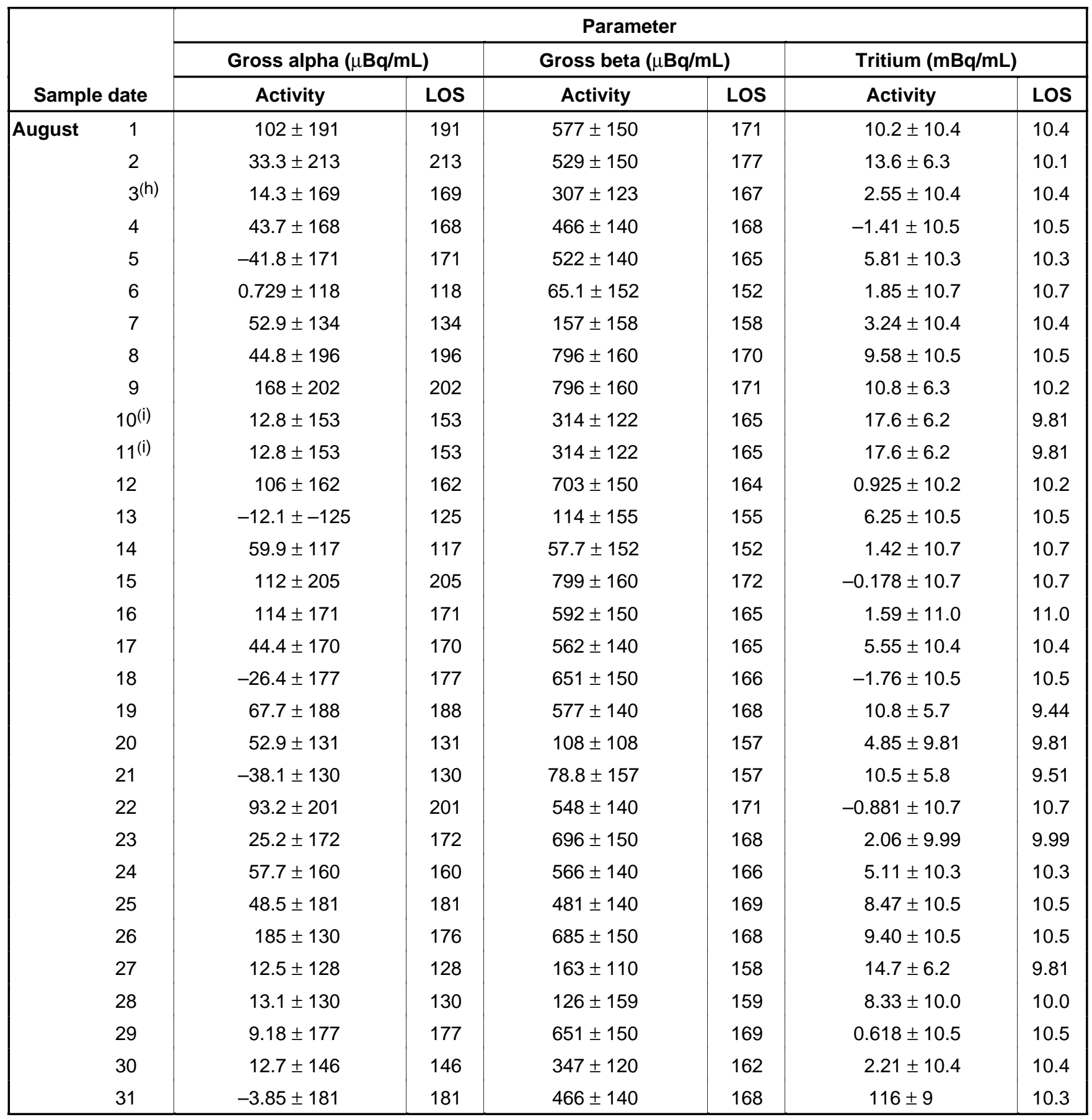

..continued on next page 
Table 6-1. Daily monitoring results for gross alpha, gross beta, and tritium in the sanitary sewer effluent, 1995 (continued).

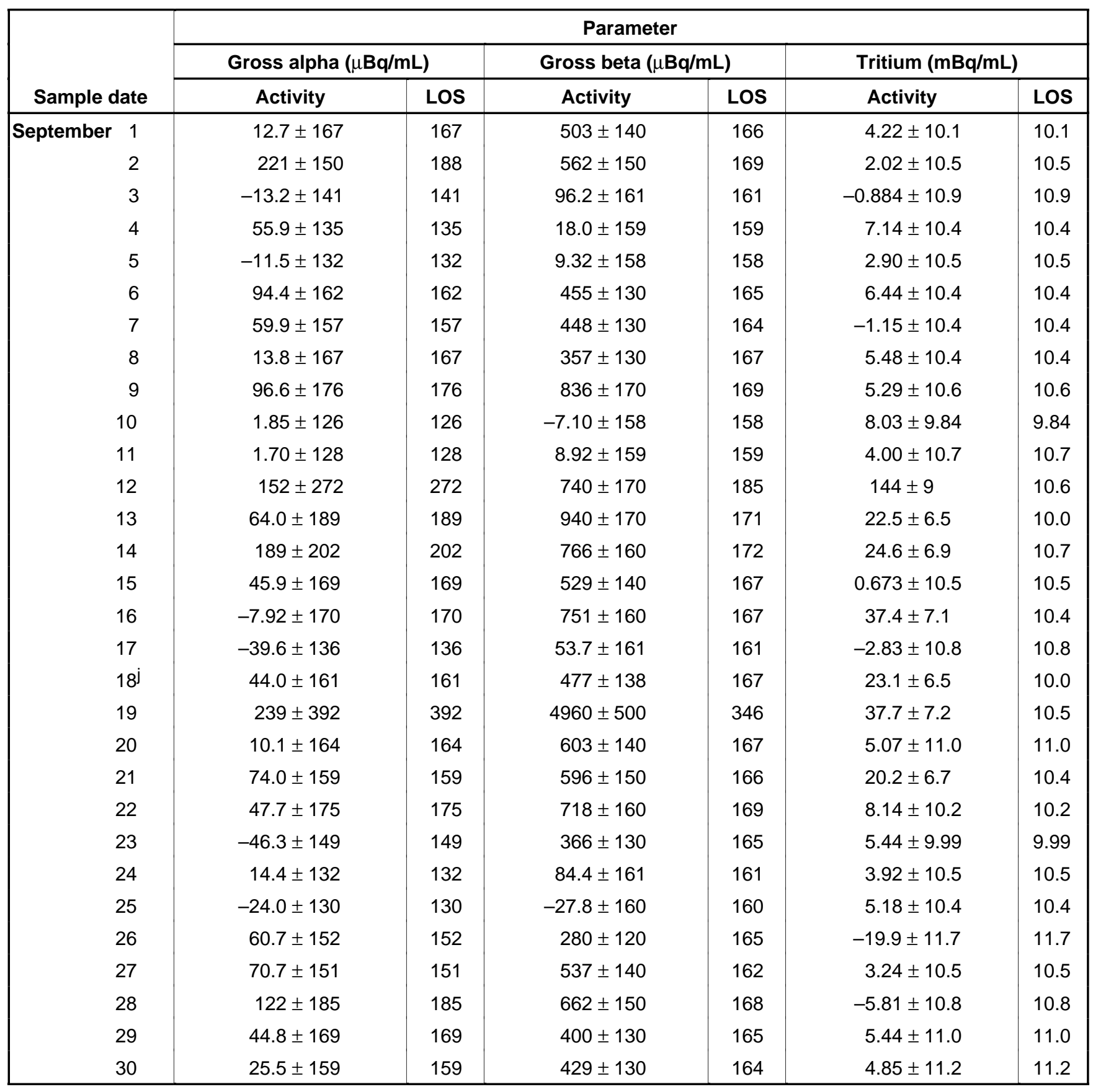


Table 6-1. Daily monitoring results for gross alpha, gross beta, and tritium in the sanitary sewer effluent, 1995 (continued).

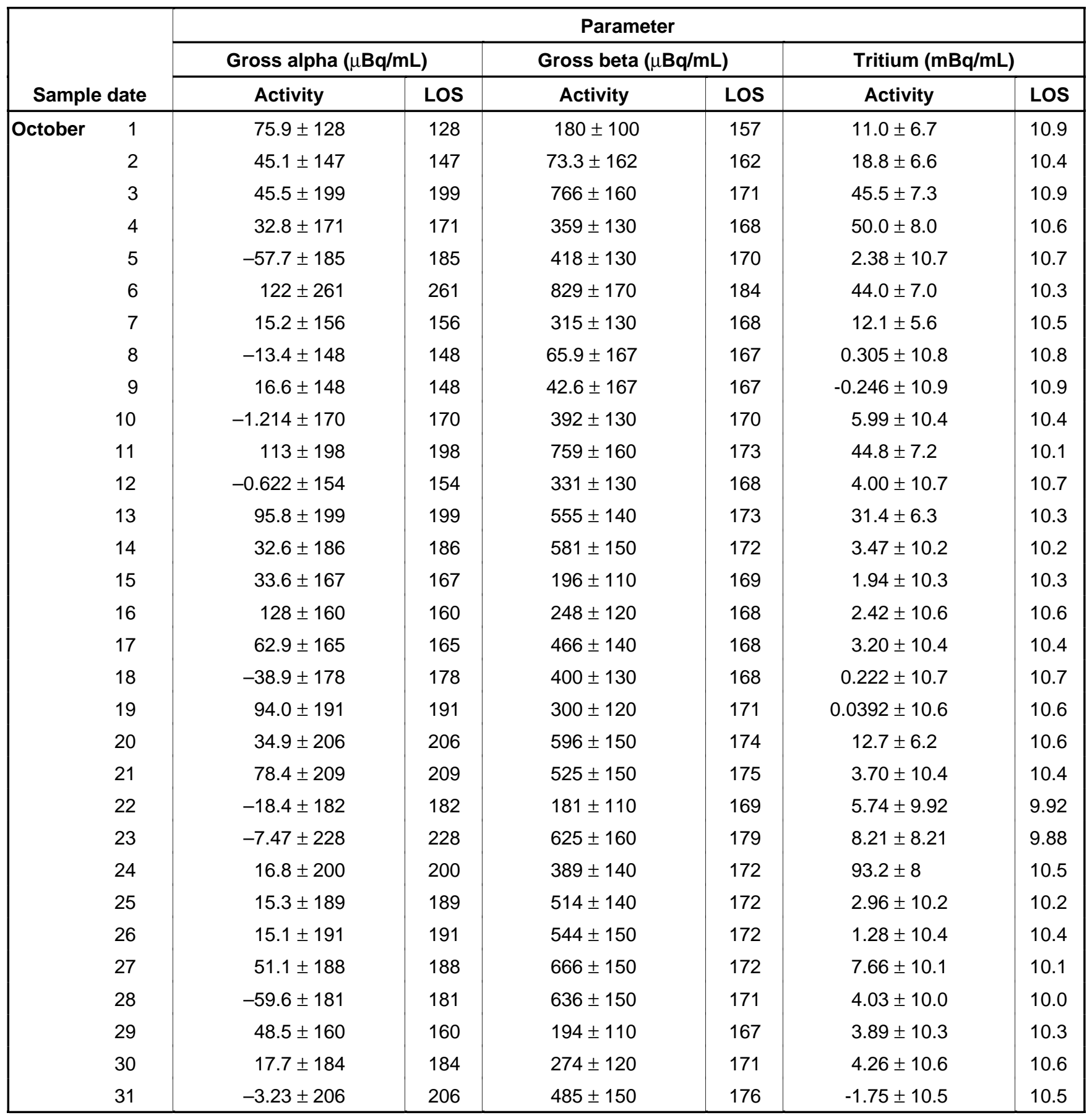

..continued on next page 
Table 6-1. Daily monitoring results for gross alpha, gross beta, and tritium in the sanitary sewer effluent, 1995 (continued).

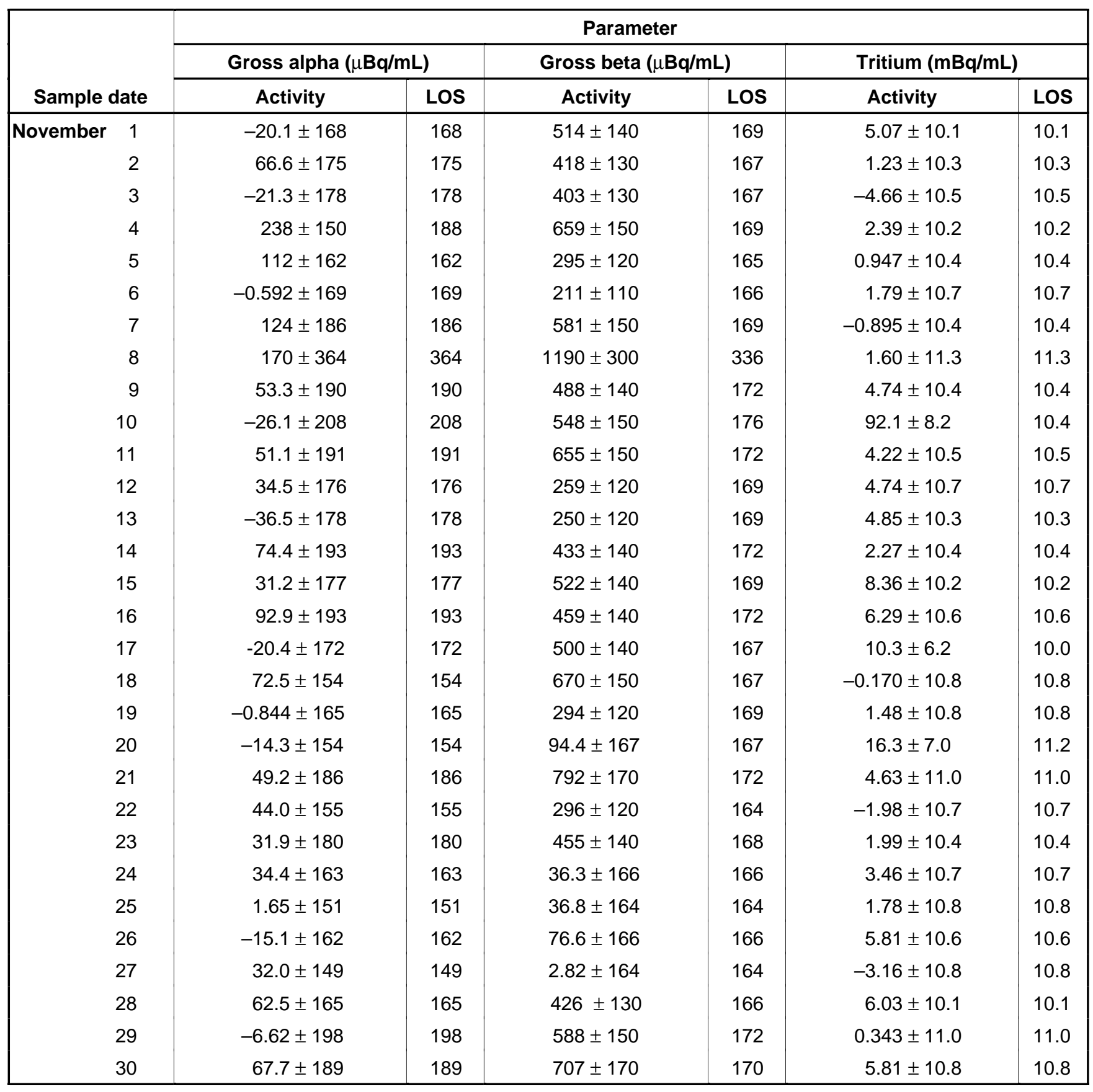


Table 6-1. Daily monitoring results for gross alpha, gross beta, and tritium in the sanitary sewer effluent, 1995 (concluded).

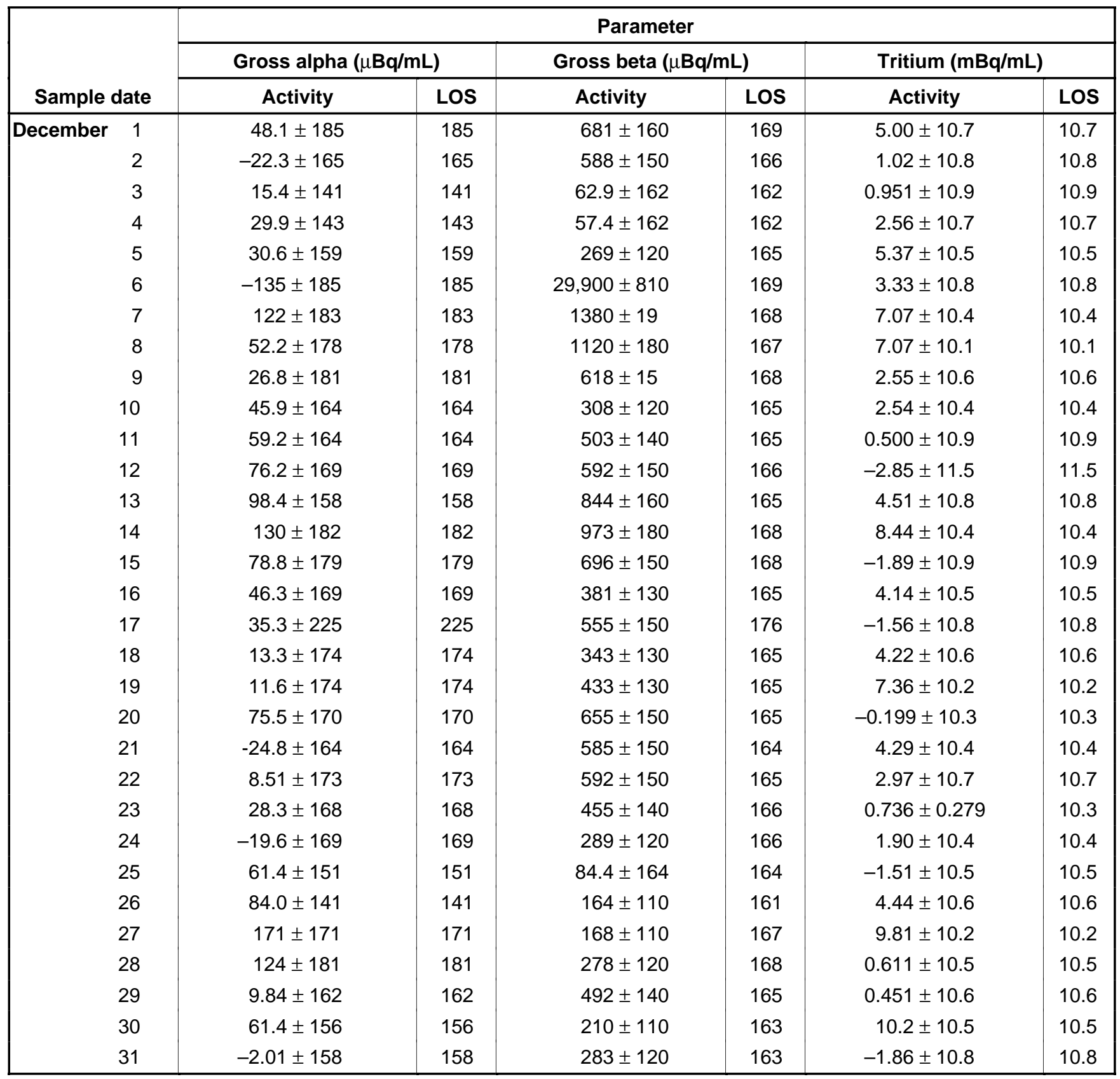

Note: Dates for which the daily monitoring results are not available have been footnoted. The results shown for these dates are the monitoring results for the weekly composite sample. The footnotes below indicate the sampling periods for the weekly composite samples.

a January $23-29,1995$.

bMarch 13-19, 1995.

cMarch 20-26, 1995. d June 26 - July 2, 1995.

e July $3-6$, and 8-9, 1995.

fJuly $10-16,1995$.
gJuly $17-23,1995$.

hJuly 31, and August 1, 3-6, 1995.

iAugust 7 - 13, 1995.

jSeptember 11 - 17, 1995. 
Table 6-2. Weekly and 24-hour composite results for metals in the sanitary sewer effluent, 1995.

\begin{tabular}{|c|c|c|c|c|c|c|}
\hline \multirow[b]{2}{*}{ Composite dates } & \multicolumn{6}{|c|}{ Parameter (mg/L) } \\
\hline & Al & As & $\mathrm{Be}$ & Cd & $\mathrm{Cr}$ & $\mathrm{Cu}$ \\
\hline Dec. 27, 1994-Jan.2, 1995 & 0.28 & 0.0024 & $<0.00050$ & $<0.005$ & $<0.010$ & 0.065 \\
\hline January 3-4, 6-8(a) & $<0.20$ & 0.0027 & $<0.00050$ & $<0.005$ & $<0.010$ & 0.062 \\
\hline January $5^{(b)}$ & 0.69 & $<0.0020$ & $<0.00050$ & $<0.005$ & 0.027 & 0.11 \\
\hline January 9-16 & 0.51 & 0.0042 & $<0.00050$ & $<0.005$ & 0.014 & 0.079 \\
\hline January $17-22$ & 0.30 & 0.0056 & $<0.00050$ & $<0.005$ & 0.016 & 0.071 \\
\hline January 23-29 & 0.39 & 0.0054 & $<0.00050$ & $<0.005$ & $<0.010$ & 0.090 \\
\hline Jan. 30-Feb.1, Feb. 3-5(a) & $<0.20$ & $<0.0020$ & $<0.00050$ & $<0.005$ & $<0.010$ & 0.092 \\
\hline February $2^{(b)}$ & $<0.20$ & $<0.0020$ & $<0.00050$ & $<0.005$ & $<0.010$ & 0.067 \\
\hline February 6-12 & 0.21 & 0.0049 & $<0.00050$ & $<0.005$ & 0.020 & 0.099 \\
\hline February $13-20$ & 0.32 & 0.0027 & $<0.00050$ & $<0.005$ & $<0.010$ & 0.12 \\
\hline February 21-26 & 0.31 & 0.0025 & $<0.00050$ & $<0.005$ & $<0.010$ & 0.15 \\
\hline February 27-March 5 & 0.32 & 0.0049 & $<0.00050$ & $<0.005$ & $<0.010$ & 0.10 \\
\hline March 6, 8-12(a) & 0.32 & 0.0062 & $<0.00050$ & $<0.005$ & $<0.010$ & 0.068 \\
\hline March $7^{(b)}$ & 1.0 & 0.0025 & $<0.00050$ & $<0.005$ & 0.011 & 0.13 \\
\hline March 13-19 & 0.28 & 0.0055 & $<0.00050$ & $<0.005$ & 0.011 & 0.099 \\
\hline March 20-26 & 1.3 & 0.0026 & $<0.00050$ & $<0.005$ & 0.011 & 0.085 \\
\hline March 27-April 2 & 0.47 & 0.0026 & $<0.00050$ & $<0.005$ & 0.010 & 0.088 \\
\hline April 3, 5-9(a) & 0.49 & 0.0039 & $<0.00050$ & $<0.005$ & $<0.010$ & 0.091 \\
\hline April $4^{(b)}$ & 0.66 & 0.0033 & $<0.00050$ & $<0.005$ & $<0.010$ & 0.077 \\
\hline April 10-17 & 0.26 & $<0.0020$ & $<0.00050$ & $<0.005$ & $<0.010$ & 0.068 \\
\hline April 18-23 & 0.55 & $<0.0020$ & $<0.00050$ & $<0.005$ & 0.011 & 0.12 \\
\hline April 24-30 & 0.33 & $<0.0020$ & $<0.00050$ & $<0.005$ & $<0.010$ & 0.14 \\
\hline May $1,3-7^{(a)}$ & 0.29 & $<0.0020$ & $<0.00050$ & $<0.005$ & $<0.010$ & 0.086 \\
\hline May $2^{(b)}$ & 0.63 & $<0.0020$ & $<0.00050$ & $<0.005$ & $<0.010$ & 0.16 \\
\hline May 8-14 & $<0.20$ & $<0.0020$ & $<0.00050$ & $<0.005$ & $<0.010$ & 0.090 \\
\hline May $15-21$ & 0.50 & $<0.0020$ & $<0.00050$ & $<0.005$ & 0.014 & 0.13 \\
\hline May 22-29 & 0.41 & $<0.0020$ & 0.00077 & $<0.005$ & 0.011 & 0.11 \\
\hline May 30-June 4 & 0.33 & 0.0030 & $<0.00050$ & $<0.005$ & $<0.010$ & 0.090 \\
\hline June $5,7-11^{(a)}$ & 0.36 & 0.0031 & $<0.00050$ & $<0.005$ & $<0.010$ & 0.083 \\
\hline June $6^{(\mathrm{b})}$ & 0.49 & 0.0025 & $<0.00050$ & $<0.005$ & $<0.010$ & 0.096 \\
\hline June $12-18$ & 0.27 & $<0.0020$ & $<0.00050$ & $<0.005$ & 0.011 & 0.093 \\
\hline June 19-25 & 0.37 & 0.0035 & $<0.00050$ & $<0.005$ & $<0.010$ & 0.071 \\
\hline June 26-July 2 & $<0.20$ & 0.0032 & $<0.00050$ & $<0.005$ & $<0.010$ & 0.053 \\
\hline July 3-6, 8-9(a) & $<0.20$ & 0.0025 & $<0.00050$ & $<0.005$ & 0.016 & 0.12 \\
\hline July $7^{(\mathrm{b})}$ & 0.20 & $<0.0020$ & $<0.00050$ & $<0.005$ & 0.017 & 0.14 \\
\hline July $10-16$ & 0.43 & $<0.0020$ & $<0.00050$ & $<0.005$ & 0.015 & 0.12 \\
\hline
\end{tabular}


Table 6-2. Weekly and 24-hour composite results for metals in the sanitary sewer effluent, 1995 (continued).

\begin{tabular}{|c|c|c|c|c|c|c|}
\hline \multirow[b]{2}{*}{ Composite dates } & \multicolumn{6}{|c|}{ Parameter (mg/L) } \\
\hline & $\mathrm{Fe}$ & $\mathrm{Pb}$ & $\mathrm{Hg}$ & $\mathrm{Ni}$ & $\mathrm{Ag}$ & $\mathrm{Zn}$ \\
\hline Dec. 27, 1994-Jan.2, 1995 & 0.87 & 0.0075 & 0.00024 & 0.0082 & $<0.010$ & 0.096 \\
\hline January 3-4, 6-8(a) & 0.89 & 0.013 & 0.00097 & 0.0096 & $<0.010$ & 0.11 \\
\hline January $5^{(b)}$ & 2.1 & 0.022 & 0.0076 & 0.011 & $<0.010$ & 0.22 \\
\hline January 9-16 & 1.1 & 0.014 & 0.0013 & 0.0064 & 0.010 & 0.18 \\
\hline January 17-22 & 1.0 & 0.0079 & 0.0013 & $<0.0050$ & 0.017 & 0.16 \\
\hline January 23-29 & 1.1 & $<0.002$ & 0.00086 & $<0.0050$ & $<0.010$ & 0.19 \\
\hline Jan. 30-Feb.1, Feb. 3-5(a) & 0.68 & 0.030 & 0.00052 & $<0.0050$ & 0.012 & 0.17 \\
\hline February $2^{(b)}$ & 0.36 & 0.019 & 0.00052 & $<0.0050$ & $<0.010$ & 0.12 \\
\hline February 6-12 & 1.1 & 0.010 & 0.00020 & 0.0069 & 0.016 & 0.20 \\
\hline February $13-20$ & 1.0 & 0.013 & 0.00056 & 0.0051 & 0.014 & 0.20 \\
\hline February 21-26 & 0.92 & 0.019 & 0.00044 & 0.0078 & 0.013 & 0.28 \\
\hline February 27-March 5 & 0.86 & 0.028 & 0.00041 & 0.0076 & 0.020 & 0.44 \\
\hline March 6, 8-12(a) & 0.98 & 0.016 & $<0.00020$ & 0.0066 & $<0.010$ & 0.11 \\
\hline March $7^{(b)}$ & 1.8 & 0.035 & $<0.00020$ & 0.0079 & 0.019 & 0.23 \\
\hline March 13-19 & 0.74 & 0.0079 & 0.0012 & $<0.0050$ & $<0.010$ & 0.17 \\
\hline March 20-26 & 1.8 & 0.0087 & 0.0012 & 0.0076 & $<0.010$ & 0.19 \\
\hline March 27-April 2 & 1.1 & 0.0093 & $<0.00020$ & $<0.0050$ & 0.018 & 0.19 \\
\hline April 3, 5-9(a) & 1.2 & 0.013 & 0.00024 & 0.0072 & $<0.010$ & 0.16 \\
\hline April $4^{(b)}$ & 1.4 & 0.009 & 0.00039 & 0.0051 & $<0.010$ & 0.18 \\
\hline April 10-17 & 1.1 & 0.0072 & 0.00021 & $<0.0050$ & $<0.010$ & 0.13 \\
\hline April 18-23 & 1.6 & 0.013 & 0.00039 & 0.0071 & 0.014 & 0.19 \\
\hline April 24-30 & 1.1 & 0.030 & 0.00023 & 0.0070 & 0.011 & 0.25 \\
\hline May $1,3-7^{(a)}$ & 1.0 & 0.014 & 0.00038 & $<0.0050$ & $<0.010$ & 0.18 \\
\hline May $2^{(b)}$ & 1.2 & 0.032 & 0.00071 & 0.0079 & 0.013 & 0.21 \\
\hline May 8-14 & 1.2 & 0.019 & 0.00033 & $<0.0050$ & $<0.010$ & 0.22 \\
\hline May $15-21$ & 1.6 & 0.049 & 0.00034 & 0.021 & 0.014 & 0.24 \\
\hline May 22-29 & 1.6 & 0.026 & 0.00033 & 0.0059 & 0.027 & 0.21 \\
\hline May 30-June 4 & 1.1 & 0.013 & 0.00034 & $<0.0050$ & 0.074 & 0.19 \\
\hline June $5,7-11^{(a)}$ & 1.0 & 0.018 & $<0.00020$ & 0.0051 & 0.012 & 0.20 \\
\hline June $6^{(b)}$ & 1.3 & 0.011 & 0.00042 & $<0.0050$ & $<0.010$ & 0.25 \\
\hline June 12-18 & 1.3 & 0.0085 & 0.00033 & $<0.0050$ & 0.012 & 0.20 \\
\hline June 19-25 & 0.93 & 0.0077 & 0.0011 & $<0.0050$ & $<0.010$ & 0.21 \\
\hline June 26-July 2 & 0.4 & 0.0067 & $<0.0002$ & $<0.0050$ & $<0.010$ & 0.08 \\
\hline July $3-6,8-9(a)$ & 1.1 & 0.016 & 0.00081 & $<0.0050$ & $<0.010$ & 0.51 \\
\hline July $7^{(\mathrm{b})}$ & 1.3 & 0.029 & 0.0010 & 0.0069 & 0.015 & 0.57 \\
\hline July $10-16$ & 1.1 & 0.013 & 0.00058 & $<0.0050$ & $<0.010$ & 0.39 \\
\hline
\end{tabular}


Table 6-2. Weekly and 24-hour composite results for metals in the sanitary sewer effluent, 1995 (continued).

\begin{tabular}{|l|c|c|c|c|c|c|}
\hline \multicolumn{1}{|c|}{ Composite dates } & \multicolumn{7}{|c|}{ Parameter $(\mathbf{m g} / \mathbf{L})$} \\
\cline { 2 - 7 } & Al & As & Be & Cd & Cr & Cu \\
\hline July 17-23 & $<0.2$ & 0.0033 & $<0.00050$ & $<0.005$ & $<0.010$ & 0.072 \\
July 24-30 & 0.64 & $<0.0020$ & $<0.00050$ & $<0.005$ & 0.015 & 0.18 \\
July 31, August 1, 3-6(a) & 0.61 & 0.0033 & $<0.00050$ & $<0.005$ & 0.015 & 0.22 \\
August 2 (b) & 1.0 & $<0.0020$ & $<0.00050$ & $<0.005$ & 0.019 & 0.15 \\
August 7-13 & 0.58 & 0.0043 & $<0.00050$ & $<0.005$ & $<0.010$ & 0.11 \\
August 14-20 & 0.43 & 0.0036 & $<0.00050$ & $<0.005$ & $<0.010$ & 0.13 \\
August 21-27 & 0.56 & $<0.0020$ & $<0.00050$ & $<0.005$ & 0.021 & 0.14 \\
August 28-September 3 & 0.26 & 0.0030 & $<0.00050$ & $<0.005$ & $<0.010$ & 0.082 \\
September 4-6, 8-10(a) & 0.53 & $<0.0020$ & $<0.00050$ & $<0.005$ & 0.012 & 0.15 \\
September 7 (b) & 0.71 & $<0.0020$ & $<0.00050$ & $<0.005$ & 0.019 & 0.095 \\
September 11-17 & 0.49 & $<0.0020$ & $<0.00050$ & $<0.005$ & 0.023 & 0.18 \\
September 18-24 & 0.47 & $<0.002$ & $<0.00050$ & $<0.005$ & 0.014 & 0.16 \\
September 25-October 1 & 0.52 & $<0.0020$ & $<0.00050$ & $<0.005$ & 0.011 & 0.18 \\
October 2, 4-8(a) & 0.44 & 0.0022 & $<0.00050$ & $<0.005$ & $<0.010$ & 0.17 \\
October 3(b) & 0.57 & $<0.0020$ & $<0.00050$ & $<0.005$ & 0.020 & 0.13 \\
October 9-15 & 0.84 & 0.0031 & $<0.00050$ & $<0.005$ & 0.021 & 0.15 \\
October 16-22 & 0.67 & 0.0020 & $<0.00050$ & $<0.005$ & 0.015 & 0.13 \\
October 23-29 & 0.33 & $<0.0020$ & $<0.00050$ & $<0.005$ & $<0.010$ & 0.043 \\
October 30-November 5 & 0.92 & 0.0020 & $<0.00050$ & $<0.005$ & 0.018 & 0.12 \\
November 6, 8-12(a) & 0.56 & 0.0029 & $<0.00050$ & $<0.005$ & 0.016 & 0.12 \\
November 7(b) & 1.4 & 0.0021 & $<0.00050$ & $<0.005$ & 0.020 & 0.16 \\
November 13-19 & 0.47 & 0.0024 & $<0.00050$ & $<0.005$ & $<0.010$ & 0.12 \\
November 20-26 & 0.45 & 0.0026 & $<0.00050$ & $<0.005$ & $<0.010$ & $<0.01$ \\
November 27-December 3 & $<0.20$ & $<0.0020$ & $<0.00050$ & $<0.005$ & $<0.010$ & 0.014 \\
December 4-5, 7-10(a) & 1.9 & $<0.0050$ & $<0.00050$ & $<0.001$ & 0.015 & 0.21 \\
December 6(b) & 0.60 & $<0.0050$ & $<0.00050$ & $<0.001$ & 0.020 & 0.12 \\
December 11-17 & 1.4 & $<0.0050$ & $<0.00050$ & $<0.001$ & 0.023 & 0.13 \\
December 18-24 & 0.80 & $<0.0050$ & $<0.00050$ & $<0.001$ & $<0.001$ & 0.10 \\
December 25-31 & 1.3 & 0.0055 & $<0.00050$ & $<0.005$ & $<0.010$ & 0.32 \\
\hline
\end{tabular}


Table 6-2. Weekly and 24-hour composite results for metals in the sanitary sewer effluent, 1995 (concluded).

\begin{tabular}{|c|c|c|c|c|c|c|}
\hline \multirow[b]{2}{*}{ Composite dates } & \multicolumn{6}{|c|}{ Parameter (mg/L) } \\
\hline & $\mathrm{Fe}$ & $\mathbf{P b}$ & $\mathrm{Hg}$ & $\mathrm{Ni}$ & $\mathrm{Ag}$ & $\mathbf{Z n}$ \\
\hline July 17-23 & 0.36 & 0.012 & $<0.00020$ & $<0.0050$ & $<0.010$ & 0.25 \\
\hline July 24-30 & 2.2 & 0.032 & 0.00066 & 0.0057 & 0.018 & 0.38 \\
\hline July 31 , August 1, 3-6(a) & 1.6 & 0.049 & 0.00055 & $<0.0050$ & 0.014 & 0.29 \\
\hline August $2^{(b)}$ & 1.9 & 0.023 & 0.0011 & $<0.0050$ & 0.017 & 0.31 \\
\hline August 7-13 & 1.4 & 0.024 & 0.00040 & 0.0064 & $<0.010$ & 0.21 \\
\hline August $14-20$ & 0.95 & 0.023 & 0.00046 & 0.0093 & $<0.010$ & 0.32 \\
\hline August 21-27 & 1.1 & 0.021 & 0.00032 & 0.0063 & 0.037 & 0.19 \\
\hline August 28-September 3 & 1.0 & 0.015 & $<0.00020$ & $<0.0050$ & $<0.010$ & 0.18 \\
\hline September 4-6, 8-10(a) & 1.4 & 0.018 & 0.00024 & $<0.0050$ & 0.011 & 0.20 \\
\hline September $7^{(b)}$ & 1.4 & 0.018 & 0.00042 & 0.0061 & $<0.010$ & 0.21 \\
\hline September 11-17 & 1.4 & 0.020 & 0.0014 & $<0.0050$ & $<0.010$ & 0.22 \\
\hline September 18-24 & 1.2 & 0.024 & 0.00043 & $<0.0050$ & $<0.010$ & 0.20 \\
\hline September 25 -October 1 & 1.7 & 0.045 & 0.0010 & 0.0062 & 0.010 & 0.29 \\
\hline October 2, 4-8(a) & 2.0 & 0.019 & 0.0011 & 0.010 & $<0.010$ & 0.32 \\
\hline October $3^{(b)}$ & 1.6 & 0.054 & 0.00078 & 0.013 & $<0.010$ & 0.26 \\
\hline October 9-15 & 1.5 & 0.031 & 0.00030 & 0.0056 & $<0.010$ & 0.24 \\
\hline October 16-22 & 1.4 & 0.021 & 0.00040 & 0.0053 & $<0.010$ & 0.27 \\
\hline October 23-29 & 0.64 & 0.015 & 0.00085 & 0.0053 & $<0.010$ & 0.11 \\
\hline October 30-November 5 & 1.8 & 0.0038 & 0.00034 & 0.0051 & $<0.010$ & 0.25 \\
\hline November $6,8-12^{(a)}$ & 1.3 & 0.017 & 0.00046 & 0.0056 & 0.015 & 0.20 \\
\hline November $7^{(b)}$ & 2.7 & 0.010 & 0.00076 & 0.0060 & 0.013 & 0.32 \\
\hline November 13-19 & 1.1 & 0.023 & $<0.00020$ & 0.0066 & $<0.010$ & 0.24 \\
\hline November $20-26$ & 1.1 & 0.017 & $<0.00020$ & $<0.0050$ & $<0.010$ & 0.27 \\
\hline November 27-December 3 & 0.72 & 0.017 & 0.00036 & 0.030 & $<0.010$ & 0.18 \\
\hline December 4-5, 7-10(a) & 1.2 & 0.095 & $<0.00020$ & $<0.0050$ & 0.007 & 0.29 \\
\hline December $6^{(b)}$ & 0.87 & 0.030 & $<0.00020$ & $<0.0050$ & $<0.005$ & 0.18 \\
\hline December 11-17 & 2.2 & 0.028 & 0.00030 & $<0.0050$ & 0.006 & 0.28 \\
\hline December 18-24 & 1.6 & 0.010 & 0.00020 & $<0.0050$ & $<0.005$ & 0.22 \\
\hline December 25-31 & 2.1 & 0.019 & $<0.00020$ & 0.012 & $<0.010$ & 1.0 \\
\hline
\end{tabular}

a Sampling for these weeks omitted one day because the sampling equipment was devoted to the monthly sample.

b Results from the monthly composite sample. Effluent from this date is not included in the normal weekly composite because the sampling equipment was devoted to the monthly sample. These results are included to complete reporting for that week. 
Table 6-3. Monthly monitoring results for physical and chemical characteristics of the sanitary sewer effluent, 1995.

\begin{tabular}{|c|c|c|c|c|c|c|}
\hline \multirow[b]{2}{*}{ Composite sample parameters } & \multicolumn{6}{|c|}{ Sample month } \\
\hline & January & February & March & April & May & June \\
\hline \multicolumn{7}{|l|}{ Oxygen demand (mg/L) } \\
\hline Biochemical oxygen demand - EPA 405.1 & 250 & 135 & 160 & 340 & 90 & 240 \\
\hline Chemical oxygen demand - EPA 410.4 & 140 & 100 & 130 & 300 & 360 & 120 \\
\hline \multicolumn{7}{|l|}{ Solids (mg/L) } \\
\hline Total settleable solids (mL/L/h) - EPA 160.5 & 25 & 13 & 17 & 5 & 27 & 23 \\
\hline Total dissolved solids (TDS) - EPA 160.1 & 210 & 360 & 470 & 250 & 300 & 230 \\
\hline Total suspended solids (TSS) - EPA 160.2 & 210 & 120 & 20 & 22 & 230 & 180 \\
\hline Volatile solids - EPA 160.4 & 82 & 72 & 100 & 100 & 79 & 80 \\
\hline \multicolumn{7}{|l|}{ Anions (mg/L) - 300.0} \\
\hline Bromide & $<0.5$ & $<0.5$ & $<0.5$ & $<0.5$ & $<0.5$ & $<0.5$ \\
\hline Nitrate (as N) & $<0.5$ & 1.1 & $<0.5$ & $<0.1^{(\mathrm{b})}$ & $<0.1^{(\mathrm{b})}$ & $<0.5$ \\
\hline Nitrate (as $\mathrm{NO}_{3}$ ) & $<22^{(b)}$ & $4.9^{(b)}$ & $<22^{(b)}$ & $<0.5$ & $<0.5$ & $<22^{(b)}$ \\
\hline Nitrite (as N) & $<0.5$ & $<0.5$ & 0.51 & $<0.2^{(\mathrm{b})}$ & $<0.2^{(\mathrm{b})}$ & $<0.5$ \\
\hline Nitrite $\left(\right.$ as $\left.\mathrm{NO}_{2}\right)$ & $<16^{(b)}$ & $<16^{(b)}$ & $1.7^{(b)}$ & $<0.5$ & $<0.5$ & $<16^{(\mathrm{b})}$ \\
\hline Chloride & 45 & 49 & 73 & 45 & 36 & 36 \\
\hline Sulfate & 16 & 49 & 66 & 35 & 24 & 22 \\
\hline \multicolumn{7}{|l|}{ Alkalinity (mg/L) - 310.1} \\
\hline Total alkalinity (as $\mathrm{CaCO}_{3}$ ) & 200 & 260 & 290 & 150 & 190 & 180 \\
\hline Bicarbonate alk $\left(\mathrm{as} \mathrm{CaCO}_{3}\right)$ & 200 & 260 & 290 & 150 & 190 & 180 \\
\hline Carbonate alk (as $\left.\mathrm{CaCO}_{3}\right)$ & $<1$ & $<1$ & $<1$ & $<1$ & $<1$ & $<1$ \\
\hline Hydroxide alk (as $\mathrm{CaCO}_{3}$ ) & $<1$ & $<1$ & $<1$ & $<1$ & $<1$ & $<1$ \\
\hline \multicolumn{7}{|l|}{ Nutrients (mg/L) } \\
\hline Ammonia nitrogen (as N) - EPA 350.2 & 32 & 26 & 40 & 21 & 0.3 & 39 \\
\hline Total Kjeldahl nitrogen - EPA 351.3 & 47 & 38 & 48 & $\_^{(\mathrm{c})}$ & 42 & 41 \\
\hline Total phosphorus (as P) - Standard 4500 & 5.2 & 5.0 & 8.2 & 4.4 & 6.8 & 6.4 \\
\hline \multicolumn{7}{|l|}{ Organic carbon (mg/L) - 415.1} \\
\hline Total organic carbon (TOC) & 41 & 35 & 60 & 29 & 53 & 45 \\
\hline \multicolumn{7}{|l|}{ Polychlorinated biphenyls $(\mu \mathrm{g} / \mathrm{L})$ - 608} \\
\hline Aroclor 1016 & $<0.5$ & $<0.5$ & $<0.5$ & $<0.5$ & $<0.5$ & $<0.5$ \\
\hline Aroclor 1221 & $<0.5$ & $<0.5$ & $<0.5$ & $<0.5$ & $<0.5$ & $<0.5$ \\
\hline Aroclor 1232 & $<0.5$ & $<0.5$ & $<0.5$ & $<0.5$ & $<0.5$ & $<0.5$ \\
\hline Aroclor 1242 & $<0.5$ & $<0.5$ & $<0.5$ & $<0.5$ & $<0.5$ & $<0.5$ \\
\hline Aroclor 1248 & $<0.5$ & $<0.5$ & $<0.5$ & $<0.5$ & $<0.5$ & $<0.5$ \\
\hline Aroclor 1254 & $<0.5$ & $<0.5$ & $<0.5$ & $<0.5$ & $<0.5$ & $<0.5$ \\
\hline Aroclor 1260 & $<0.5$ & $<0.5$ & $<0.5$ & $<0.5$ & $<0.5$ & $<0.5$ \\
\hline
\end{tabular}


Table 6-3. Monthly monitoring results for physical and chemical characteristics of the sanitary sewer effluent, 1995 (continued).

\begin{tabular}{|c|c|c|c|c|c|c|}
\hline \multirow[b]{2}{*}{ Composite sample parameters } & \multicolumn{6}{|c|}{ Sample Month } \\
\hline & July & August & September & October & November & December \\
\hline \multicolumn{7}{|l|}{ Oxygen demand (mg/L) } \\
\hline Biochemical oxygen demand - EPA 405.1 & 250 & 171 & 220 & 320 & 190 & 200 \\
\hline Chemical oxygen demand - EPA 410.4 & 60 & 470 & 180 & -(a) & 490 & 530 \\
\hline \multicolumn{7}{|l|}{ Solids (mg/L) } \\
\hline Total settleable solids (mL/L/h) - EPA 160.5 & 26 & 27 & 30 & 34 & 27 & 25 \\
\hline Total dissolved solids (TDS) - EPA 160.1 & 170 & 210 & 260 & 400 & 240 & 280 \\
\hline Total suspended solids (TSS) - EPA 160.2 & 220 & 230 & 280 & 330 & 150 & 410 \\
\hline Volatile solids - EPA160.4 & 44 & 91 & 64 & 78 & 98 & 110 \\
\hline \multicolumn{7}{|l|}{ Anions (mg/L) - 300.0} \\
\hline Bromide & $<0.5$ & $<0.5$ & $<0.5$ & - (a) $^{(1)}$ & $<0.5$ & $<10$ \\
\hline Nitrate (as N) & $<0.1^{(b)}$ & $<0.5$ & 0.5 & $-(\mathrm{a})$ & $0.25^{(b)}$ & $<0.1^{(b)}$ \\
\hline Nitrate $\left(\right.$ as $\left.\mathrm{NO}_{3}\right)$ & $<0.5$ & $<22^{(b)}$ & $2.2^{(b)}$ & $-(a)$ & 1.1 & $<5$ \\
\hline Nitrite (as N) & $<0.2^{\text {(b) }}$ & $<0.5$ & $<0.3^{(b)}$ & -(a) & $<15^{(b)}$ & $<15^{(b)}$ \\
\hline Nitrite $\left(\right.$ as $\mathrm{NO}_{2}$ ) & $<0.5$ & $<16^{(b)}$ & $<1$ & $-(\mathrm{a})$ & $<5$ & $<5$ \\
\hline Chloride & 30 & 51 & 71 & -(a) & 63 & 78 \\
\hline Sulfate & 16 & 17 & 20 & - (a) $^{(1)}$ & 18 & 59 \\
\hline \multicolumn{7}{|l|}{ Alkalinity (mg/L) - 310.1} \\
\hline Total alkalinity (as $\mathrm{CaCO}_{3}$ ) & 160 & 180 & 130 & - (a) $^{(1)}$ & 210 & 220 \\
\hline Bicarbonate alk (as $\left.\mathrm{CaCO}_{3}\right)$ & 160 & 180 & 130 & - (a) & 210 & 220 \\
\hline Carbonate alk (as $\left.\mathrm{CaCO}_{3}\right)$ & $<1$ & $<1$ & $<1$ & $-(\mathrm{a})$ & $<1$ & $<1$ \\
\hline Hydroxide alk (as $\left.\mathrm{CaCO}_{3}\right)$ & $<1$ & $<1$ & $<1$ & 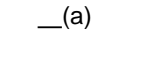 & $<1$ & $<1$ \\
\hline \multicolumn{7}{|l|}{ Nutrients (mg/L) } \\
\hline Ammonia nitrogen (as N) - EPa 350.2 & 35 & 45 & 40 & $-(\mathrm{a})$ & 48 & 37 \\
\hline Total Kjeldahl nitrogen - EPA 351.3 & 42 & 36 & 62 & $-(\mathrm{a})$ & 65 & 58 \\
\hline Total phosphorus (as P) - Standard 4500 & 2.9 & 3.3 & 3.5 & $-(\mathrm{a})$ & 1.1 & 1.2 \\
\hline \multicolumn{7}{|l|}{ Organic carbon (mg/L) - 415.1} \\
\hline Total organic carbon (TOC) & 31 & 40 & 54 & -(a) & 62 & 78 \\
\hline \multicolumn{7}{|l|}{ Polychlorinated biphenyls ( $\mu \mathrm{g} / \mathrm{L})$ - 608} \\
\hline Aroclor 1016 & $<0.5$ & $<0.5$ & $<0.5$ & $<0.5$ & $<0.5$ & $<0.5$ \\
\hline Aroclor 1221 & $<0.5$ & $<0.5$ & $<0.5$ & $<0.5$ & $<0.5$ & $<0.5$ \\
\hline Aroclor 1232 & $<0.5$ & $<0.5$ & $<0.5$ & $<0.5$ & $<0.5$ & $<0.5$ \\
\hline Aroclor 1242 & $<0.5$ & $<0.5$ & $<0.5$ & $<0.5$ & $<0.5$ & $<0.5$ \\
\hline Aroclor 1248 & $<0.5$ & $<0.5$ & $<0.5$ & $<0.5$ & $<0.5$ & $<0.5$ \\
\hline Aroclor 1254 & $<0.5$ & $<0.5$ & $<0.5$ & $<0.5$ & $<0.5$ & $<0.5$ \\
\hline Aroclor 1260 & $<0.5$ & $<0.5$ & $<0.5$ & $<0.5$ & $<0.5$ & $<0.5$ \\
\hline
\end{tabular}


Table 6-3. Monthly monitoring results for physical and chemical characteristics of the sanitary sewer effluent, 1995 (continued).

\begin{tabular}{|c|c|c|c|c|c|c|}
\hline \multirow[b]{2}{*}{ Composite sample parameters } & \multicolumn{6}{|c|}{ Sample month } \\
\hline & January & February & March & April & May & June \\
\hline \multicolumn{7}{|l|}{ Organochlorine pesticides $(\mu \mathrm{g} / \mathrm{L})$ - 608} \\
\hline Aldrin & $<0.05$ & $<0.05$ & $<0.05$ & $<0.05$ & $<0.25$ & $<0.05$ \\
\hline $\mathrm{BHC}$, alpha isomer & $<0.05$ & $<0.05$ & $<0.05$ & $<0.05$ & $<0.25$ & $<0.05$ \\
\hline $\mathrm{BHC}$, beta isomer & $<0.05$ & $<0.05$ & $<0.05$ & $<0.05$ & $<0.25$ & $<0.05$ \\
\hline $\mathrm{BHC}$, delta isomer & $<0.05$ & $<0.05$ & $<0.05$ & $<0.05$ & $<0.25$ & $<0.05$ \\
\hline $\mathrm{BHC}$, gamma isomer (Lindane) & $<0.05$ & $<0.05$ & $<0.05$ & $<0.05$ & $<0.25$ & $<0.05$ \\
\hline Chlordane & $<0.5$ & $<0.5$ & $<0.5$ & $<0.5$ & $<25$ & $<0.5$ \\
\hline Dieldrin & $<0.1$ & $<0.1$ & $<0.1$ & $<0.1$ & $<0.5$ & $<0.1$ \\
\hline Endosulfan I & $<0.05$ & $<0.05$ & $<0.05$ & $<0.05$ & $<0.25$ & $<0.05$ \\
\hline Endosulfan II & $<0.1$ & $<0.1$ & $<0.1$ & $<0.1$ & $<0.5$ & $<0.1$ \\
\hline Endosulfan sulfate & $<0.1$ & $<0.1$ & $<0.1$ & $<0.1$ & $<0.5$ & $<0.1$ \\
\hline Endrin & $<0.1$ & $<0.1$ & $<0.1$ & $<0.1$ & $<0.5$ & $<0.1$ \\
\hline Endrin aldehyde & $<0.1$ & $<0.1$ & $<0.1$ & $<0.1$ & $<0.5$ & $<0.1$ \\
\hline Heptachlor & $<0.05$ & $<0.05$ & $<0.05$ & $<0.05$ & $<0.25$ & $<0.05$ \\
\hline Heptachlor epoxide & $<0.05$ & $<0.05$ & $<0.05$ & $<0.05$ & $<0.25$ & $<0.05$ \\
\hline Methoxychlor & $<0.5$ & $<0.5$ & $<0.5$ & $<0.5$ & $<25$ & $<0.5$ \\
\hline Toxaphene & $<1$ & $<1$ & $<1$ & $<1$ & $<5$ & $<1$ \\
\hline$p, p^{\prime}-D D D$ & $<0.1$ & $<0.1$ & $<0.1$ & $<0.1$ & $<0.5$ & $<0.1$ \\
\hline$p, p^{\prime}-D D E$ & $<0.1$ & $<0.1$ & $<0.1$ & $<0.1$ & $<0.5$ & $<0.1$ \\
\hline$p, p^{\prime}-D D T$ & $<0.1$ & $<0.1$ & $<0.1$ & $<0.1$ & $<0.5$ & $<0.1$ \\
\hline \multicolumn{7}{|l|}{ Total metals (mg/L) } \\
\hline Aluminum - EPA 200.7 & 0.69 & $<0.20$ & 1.0 & 0.66 & 0.63 & 0.49 \\
\hline Arsenic - EPA 206.2 & $<0.0020$ & $<0.0020$ & 0.0025 & 0.0033 & $<0.0020$ & 0.0025 \\
\hline Beryllium - EPA 210.2 & $<0.0005$ & $<0.0005$ & $<0.0005$ & $<0.0005$ & $<0.0005$ & $<0.0005$ \\
\hline Cadmium - EPA 200.7 & $<0.005$ & $<0.005$ & $<0.005$ & $<0.005$ & $<0.005$ & $<0.005$ \\
\hline Calcium - EPA 200.7 & 11 & 33 & 35 & 20 & 13 & 13 \\
\hline Chromium - EPA 200.7 & 0.027 & $<0.010$ & 0.011 & $<0.010$ & $<0.010$ & $<0.010$ \\
\hline Copper - EPA 200.7 & 0.11 & 0.067 & 0.13 & 0.077 & 0.16 & 0.096 \\
\hline Iron - EPA 200.7 & 2.1 & 0.36 & 1.8 & 1.4 & 1.2 & 1.3 \\
\hline Lead - EPA 239.2 & 0.022 & 0.019 & 0.035 & 0.009 & 0.032 & 0.011 \\
\hline Magnesium - EPA 200.7 & 2.4 & 14 & 16 & 6.6 & 2.8 & 2.9 \\
\hline Mercury - EPA 245.2 & 0.0076 & 0.00052 & $<0.00020$ & 0.00039 & 0.00071 & 0.00042 \\
\hline Nickel - EPA 249.2 & 0.011 & $<0.0050$ & 0.0079 & 0.0051 & 0.0079 & $<0.0050$ \\
\hline Potassium - EPA 200.7 & 18 & 19 & 22 & 12 & 16 & 18 \\
\hline Selenium - EPA 270.2 & 0.0042 & $<0.0020$ & 0.0027 & $<0.0020$ & $<0.0020$ & $<0.0020$ \\
\hline Silver - EPA 200.7 & $<0.01$ & $<0.01$ & 0.019 & $<0.01$ & 0.013 & $<0.01$ \\
\hline
\end{tabular}


Table 6-3. Monthly monitoring results for physical and chemical characteristics of the sanitary sewer effluent, 1995 (continued).

\begin{tabular}{|c|c|c|c|c|c|c|}
\hline \multirow[b]{2}{*}{ Composite sample parameters } & \multicolumn{6}{|c|}{ Sample month } \\
\hline & July & August & September & October & November & December \\
\hline \multicolumn{7}{|l|}{ Organochlorine pesticides $(\mu \mathrm{g} / \mathrm{L})$ - 608} \\
\hline Aldrin & $<0.05$ & $<0.05$ & $<0.05$ & $<0.05$ & $<0.05$ & $<0.05$ \\
\hline $\mathrm{BHC}$, alpha isomer & $<0.05$ & $<0.05$ & $<0.05$ & $<0.05$ & $<0.05$ & $<0.05$ \\
\hline $\mathrm{BHC}$, beta isomer & $<0.05$ & $<0.05$ & $<0.05$ & $<0.05$ & $<0.05$ & $<0.05$ \\
\hline $\mathrm{BHC}$, delta isomer & $<0.05$ & $<0.05$ & $<0.05$ & $<0.05$ & $<0.05$ & $<0.05$ \\
\hline $\mathrm{BHC}$, gamma isomer (Lindane) & $<0.05$ & $<0.05$ & $<0.05$ & $<0.05$ & $<0.05$ & $<0.05$ \\
\hline Chlordane & $<0.5$ & $<0.5$ & $<0.5$ & $<0.5$ & $<0.5$ & $<0.5$ \\
\hline Dieldrin & $<0.1$ & $<0.1$ & $<0.1$ & $<0.1$ & $<0.1$ & $<0.1$ \\
\hline Endosulfan I & $<0.05$ & $<0.05$ & $<0.05$ & $<0.05$ & $<0.05$ & $<0.05$ \\
\hline Endosulfan II & $<0.1$ & $<0.1$ & $<0.1$ & $<0.1$ & $<0.1$ & $<0.1$ \\
\hline Endosulfan sulfate & $<0.1$ & $<0.1$ & $<0.1$ & $<0.1$ & $<0.1$ & $<0.1$ \\
\hline Endrin & $<0.1$ & $<0.1$ & $<0.1$ & $<0.1$ & $<0.1$ & $<0.1$ \\
\hline Endrin aldehyde & $<0.1$ & $<0.1$ & $<0.1$ & $<0.1$ & $<0.1$ & $<0.1$ \\
\hline Heptachlor & $<0.05$ & $<0.05$ & $<0.05$ & $<0.05$ & $<0.05$ & $<0.05$ \\
\hline Heptachlor epoxide & $<0.05$ & $<0.05$ & $<0.05$ & $<0.05$ & $<0.05$ & $<0.05$ \\
\hline Methoxychlor & $<0.5$ & $<0.5$ & $<0.5$ & $<0.5$ & $<0.5$ & $<0.5$ \\
\hline Toxaphene & $<1$ & $<1$ & $<1$ & $<1$ & $<1$ & $<1$ \\
\hline$p, p^{\prime}-D D D$ & $<0.1$ & $<0.1$ & $<0.1$ & $<0.1$ & $<0.1$ & $<0.1$ \\
\hline$p, p^{\prime}-D D E$ & $<0.1$ & $<0.1$ & $<0.1$ & $<0.1$ & $<0.1$ & $<0.1$ \\
\hline$p, p^{\prime}-D D T$ & $<0.1$ & $<0.1$ & $<0.1$ & $<0.1$ & $<0.1$ & $<0.1$ \\
\hline \multicolumn{7}{|l|}{ Total metals (mg/L) } \\
\hline Aluminum - EPA 200.7 & 0.20 & 1.0 & 0.71 & 0.57 & 1.4 & 0.60 \\
\hline Arsenic - EPA 206.2 & $<0.002$ & $<0.002$ & $<0.002$ & $<0.002$ & 0.0021 & $<0.005$ \\
\hline Beryllium - EPA 210.2 & $<0.0005$ & $<0.0005$ & $<0.0005$ & $<0.0005$ & $<0.0005$ & $<0.0005$ \\
\hline Cadmium - EPA 200.7 & $<0.005$ & $<0.005$ & $<0.005$ & $<0.005$ & $<0.005$ & $<0.001$ \\
\hline Calcium - EPA 200.7 & 9.4 & 11 & 11 & 15 & 18 & 27 \\
\hline Chromium - EPA 200.7 & 0.017 & 0.019 & 0.019 & 0.02 & 0.02 & 0.02 \\
\hline Copper - EPA 200.7 & 0.14 & 0.15 & 0.095 & 0.13 & 0.16 & 0.12 \\
\hline Iron - EPA 200.7 & 1.3 & 1.9 & 1.4 & 1.6 & 2.7 & 0.87 \\
\hline Lead - EPA 239.2 & 0.029 & 0.023 & 0.018 & 0.054 & 0.01 & 0.03 \\
\hline Magnesium - EPA 200.7 & 2.0 & 2.4 & 2.1 & 3.6 & 4.4 & 9.0 \\
\hline Mercury - EPA 245.2 & 0.001 & 0.0011 & 0.00042 & 0.00078 & 0.00076 & $<0.0002$ \\
\hline Nickel - EPA 249.2 & 0.0069 & $<0.005$ & 0.0061 & 0.013 & 0.006 & $<0.005$ \\
\hline Potassium - EPA 200.7 & 15 & 19 & 24 & 18 & 17 & 17 \\
\hline Selenium - EPA 270.2 & $<0.002$ & $<0.002$ & $<0.002$ & $<0.002$ & $<0.002$ & $<0.005$ \\
\hline Silver - EPA 200.7 & 0.015 & 0.017 & $<0.01$ & $<0.01$ & 0.013 & $<0.005$ \\
\hline
\end{tabular}


Table 6-3. Monthly monitoring results for physical and chemical characteristics of the sanitary sewer effluent, 1995 (continued).

\begin{tabular}{|c|c|c|c|c|c|c|}
\hline \multirow[b]{2}{*}{ Composite sample parameters } & \multicolumn{6}{|c|}{ Sample month } \\
\hline & January & February & March & April & May & June \\
\hline \multicolumn{7}{|l|}{ Total metals (mg/L) (continued) } \\
\hline Sodium - EPA 200.7 & 33 & 50 & 61 & 38 & 26 & 31 \\
\hline Zinc - EPA 200.7 & 0.22 & 0.12 & 0.23 & 0.18 & 0.21 & 0.25 \\
\hline \multicolumn{7}{|c|}{ Volatile organic compounds $(\mu \mathrm{g} / \mathrm{L})$ - EPA 624} \\
\hline 1,1,1-Trichloroethane & $<1$ & $<1$ & $<1$ & $<1$ & $<1$ & $<1$ \\
\hline 1,1,2,2-Tetrachloroethane & $<1$ & $<1$ & $<1$ & $<1$ & $<1$ & $<1$ \\
\hline $1,1,2$-Trichloroethane & $<1$ & $<1$ & $<1$ & $<1$ & $<1$ & $<1$ \\
\hline 1,1-Dichloroethane & $<1$ & $<1$ & $<1$ & $<1$ & $<1$ & $<1$ \\
\hline 1,1-Dichloroethene & $<1$ & $<1$ & $<1$ & $<1$ & $<1$ & $<1$ \\
\hline 1,2-Dichlorobenzene & $<1$ & $<1$ & $<1$ & $<1$ & $<1$ & $<1$ \\
\hline 1,2-Dichloroethane & $<1$ & $<1$ & $<1$ & $<1$ & $<1$ & $<1$ \\
\hline 1,2-Dichloroethene (total) & $<1$ & $<1$ & $<1$ & $<1$ & $<1$ & $<1$ \\
\hline 1,2-Dichloropropane & $<1$ & $<1$ & $<1$ & $<1$ & $<1$ & $<1$ \\
\hline 1,3-Dichlorobenzene & $<1$ & $<1$ & $<1$ & $<1$ & $<1$ & $<1$ \\
\hline 1,4-Dichlorobenzene & $<1$ & $<1$ & $<1$ & $<1$ & $<1$ & $<1$ \\
\hline 2-Butanone & $<40$ & $<40$ & $<40$ & $<40$ & $<40$ & $<40$ \\
\hline 2-Chloroethylvinylether & $<40$ & $<40$ & $<40$ & $<40$ & $<40$ & $<40$ \\
\hline 2-Hexanone & $<10$ & $<10$ & $<10$ & $<10$ & $<10$ & $<10$ \\
\hline 4-Methyl-2-pentanone & $<10$ & $<10$ & $<10$ & $<10$ & $<10$ & $<10$ \\
\hline Acetone & 76 & 110 & 43 & $<40$ & 57 & 44 \\
\hline Benzene & $<1$ & $<1$ & $<1$ & $<1$ & $<1$ & $<1$ \\
\hline Bromodichloromethane & $<1$ & 1.1 & 1.7 & 3.2 & $<1$ & $<1$ \\
\hline Bromoform & $<1$ & $<1$ & $<1$ & $<1$ & $<1$ & $<1$ \\
\hline Bromomethane & $<2$ & $<2$ & $<2$ & $<2$ & $<2$ & $<2$ \\
\hline Carbon disulfide & $<1$ & $<1$ & $<1$ & $<1$ & $<1$ & $<1$ \\
\hline Carbon tetrachloride & $<1$ & $<1$ & $<1$ & $<1$ & $<1$ & $<1$ \\
\hline Chlorobenzene & $<1$ & $<1$ & $<1$ & $<1$ & $<1$ & $<1$ \\
\hline Chloroethane & $<2$ & $<2$ & $<2$ & $<2$ & $<2$ & $<2$ \\
\hline Chloroform & 14 & 5.7 & 6.4 & 12 & 26 & 12 \\
\hline Chloromethane & $<2$ & $<2$ & $<2$ & $<2$ & $<2$ & $<2$ \\
\hline Dibromochloromethane & $<1$ & $<1$ & $<1$ & 1.4 & $<1$ & $<1$ \\
\hline Dibromomethane & $<1$ & $<1$ & $<1$ & $<1$ & $<1$ & $<1$ \\
\hline Dichlorodifluoromethane & $<2$ & $<2$ & $<2$ & $<2$ & $<2$ & $<2$ \\
\hline Ethylbenzene & $<1$ & $<1$ & $<1$ & $<1$ & $<1$ & $<1$ \\
\hline Freon 113 & $<1$ & $<1$ & $<1$ & $<1$ & $<1$ & $<1$ \\
\hline Methylene chloride & $<1$ & $<1$ & 1.0 & $<1$ & $<1$ & $<1$ \\
\hline
\end{tabular}


Table 6-3. Monthly monitoring results for physical and chemical characteristics of the sanitary sewer effluent, 1995 (continued).

\begin{tabular}{|c|c|c|c|c|c|c|}
\hline \multirow[b]{2}{*}{ Composite sample parameters } & \multicolumn{6}{|c|}{ Sample month } \\
\hline & July & August & September & October & November & December \\
\hline \multicolumn{7}{|l|}{ Total metals (mg/L) (continued) } \\
\hline Sodium - EPA 200.7 & 25 & 41 & 140 & 90 & 46 & 43 \\
\hline Zinc - EPA 200.7 & 0.57 & 0.31 & 0.21 & 0.26 & 0.32 & 0.18 \\
\hline \multicolumn{7}{|c|}{ Volatile organic compounds ( $\mu \mathrm{g} / \mathrm{L})$-EPA 624} \\
\hline 1,1,1-Trichloroethane & $<1$ & $<1$ & $<1$ & $<1$ & $<1$ & $<1$ \\
\hline 1,1,2,2-Tetrachloroethane & $<1$ & $<1$ & $<1$ & $<1$ & $<1$ & $<1$ \\
\hline 1,1,2-Trichloroethane & $<1$ & $<1$ & $<1$ & $<1$ & $<1$ & $<1$ \\
\hline 1,1-Dichloroethane & $<1$ & $<1$ & $<1$ & $<1$ & $<1$ & $<1$ \\
\hline 1,1-Dichloroethene & $<1$ & $<1$ & $<1$ & $<1$ & $<1$ & $<1$ \\
\hline 1,2-Dichlorobenzene & $<1$ & $<1$ & $<1$ & $<1$ & $<1$ & $<1$ \\
\hline 1,2-Dichloroethane & $<1$ & $<1$ & $<1$ & $<1$ & $<1$ & $<1$ \\
\hline 1,2-Dichloroethene (total) & $<1$ & $<1$ & $<1$ & $<1$ & $<1$ & $<1$ \\
\hline 1,2-Dichloropropane & $<1$ & $<1$ & $<1$ & $<1$ & $<1$ & $<1$ \\
\hline 1,3-Dichlorobenzene & $<1$ & $<1$ & $<1$ & $<1$ & $<1$ & $<1$ \\
\hline 1,4-Dichlorobenzene & $<1$ & $<1$ & $<1$ & $<1$ & $<1$ & $<1$ \\
\hline 2-Butanone & $<40$ & $<40$ & $<40$ & $<40$ & $<40$ & $<40$ \\
\hline 2-Chloroethylvinylether & $<40$ & $<40$ & $<40$ & $<40$ & $<40$ & $<40$ \\
\hline 2-Hexanone & $<10$ & $<10$ & $<10$ & $<10$ & $<10$ & $<10$ \\
\hline 4-Methyl-2-pentanone & $<10$ & $<10$ & $<10$ & $<10$ & $<10$ & $<10$ \\
\hline Acetone & 120 & 220 & 79 & 290 & $<200$ & 120 \\
\hline Benzene & $<1$ & $<1$ & $<1$ & $<1$ & $<1$ & $<1$ \\
\hline Bromodichloromethane & $<1$ & $<1$ & $<1$ & $<1$ & $<1$ & $<1$ \\
\hline Bromoform & $<1$ & $<1$ & $<1$ & $<1$ & $<1$ & $<1$ \\
\hline Bromomethane & $<2$ & $<2$ & $<2$ & $<2$ & $<2$ & $<2$ \\
\hline Carbon disulfide & $<1$ & $<1$ & $<1$ & $<1$ & $<1$ & $<1$ \\
\hline Carbon tetrachloride & $<1$ & $<1$ & $<1$ & $<1$ & $<1$ & $<1$ \\
\hline Chlorobenzene & $<1$ & $<1$ & $<1$ & $<1$ & $<1$ & $<1$ \\
\hline Chloroethane & $<2$ & $<2$ & $<2$ & $<2$ & $<2$ & $<2$ \\
\hline Chloroform & 7.2 & 9.2 & 6 & 5.3 & 11 & 7.5 \\
\hline Chloromethane & $<2$ & $<2$ & $<2$ & $<2$ & $<2$ & $<2$ \\
\hline Dibromochloromethane & $<1$ & $<1$ & $<1$ & $<1$ & $<1$ & $<1$ \\
\hline Dibromomethane & $<1$ & $<1$ & $<1$ & $<1$ & $<1$ & $<1$ \\
\hline Dichlorodifluoromethane & $<2$ & $<2$ & $<2$ & $<2$ & $<2$ & $<2$ \\
\hline Ethylbenzene & $<1$ & $<1$ & $<1$ & $<1$ & $<1$ & $<1$ \\
\hline Freon 113 & $<1$ & $<1$ & $<1$ & $<1$ & $<1$ & $<1$ \\
\hline Methylene chloride & $<1$ & 1.5 & 1.8 & $<1$ & $<1$ & $<1$ \\
\hline
\end{tabular}


Table 6-3. Monthly monitoring results for physical and chemical characteristics of the sanitary sewer effluent, 1995 (continued).

\begin{tabular}{|c|c|c|c|c|c|c|}
\hline \multirow[b]{2}{*}{ Composite sample parameters } & \multicolumn{6}{|c|}{ Sample month } \\
\hline & January & February & March & April & May & June \\
\hline \multicolumn{7}{|l|}{$\begin{array}{l}\text { Volatile organic compounds }(\mu \mathrm{g} / \mathrm{L})- \\
\text { EPA } 624 \text { (continued) }\end{array}$} \\
\hline Styrene & $<1$ & $<1$ & $<1$ & $<1$ & $<1$ & $<1$ \\
\hline Tetrachloroethene & $<1$ & $<1$ & $<1$ & $<1$ & $<1$ & $<1$ \\
\hline Toluene & $<1$ & $<1$ & $<1$ & $<1$ & $<1$ & $<1$ \\
\hline Total xylene isomers & $<2$ & $<2$ & $<2$ & $<2$ & $<2$ & $<2$ \\
\hline Trichloroethene & $<0.5$ & $<0.5$ & $<0.5$ & $<0.5$ & $<0.5$ & $<0.5$ \\
\hline Trichlorofluoromethane & $<1$ & $<1$ & $<1$ & $<1$ & $<1$ & $<1$ \\
\hline Vinyl acetate & $<10$ & $<10$ & $<10$ & $<10$ & $<10$ & $<10$ \\
\hline Vinyl chloride & $<2$ & $<2$ & $<2$ & $<2$ & $<2$ & $<2$ \\
\hline cis-1,3-Dichloropropene & $<1$ & $<1$ & $<1$ & $<1$ & $<1$ & $<1$ \\
\hline trans-1,3-Dichloropropene & $<1$ & $<1$ & $<1$ & $<1$ & $<1$ & $<1$ \\
\hline \multicolumn{7}{|l|}{$\begin{array}{l}\text { Semivolatile organic compounds }(\mu \mathrm{g} / \mathrm{L})- \\
\text { EPA } 625\end{array}$} \\
\hline 1,2,4-Trichlorobenzene & $<10$ & $<10$ & $<10$ & $<10$ & $<10$ & $<100$ \\
\hline 1,2-Dichlorobenzene & $<10$ & $<10$ & $<10$ & $<10$ & $<10$ & $<100$ \\
\hline 1,3-Dichlorobenzene & $<10$ & $<10$ & $<10$ & $<10$ & $<10$ & $<100$ \\
\hline 1,4-Dichlorobenzene & $<10$ & $<10$ & $<10$ & $<10$ & $<10$ & $<100$ \\
\hline 2,4,5-Trichlorophenol & $<10$ & $<10$ & $<10$ & $<10$ & $<10$ & $<100$ \\
\hline 2,4,6-Trichlorophenol & $<10$ & $<10$ & $<10$ & $<10$ & $<10$ & $<100$ \\
\hline 2,4-Dichlorophenol & $<10$ & $<10$ & $<10$ & $<10$ & $<10$ & $<100$ \\
\hline 2,4-Dimethylphenol & $<10$ & $<10$ & $<10$ & $<10$ & $<10$ & $<100$ \\
\hline 2,4-Dinitrophenol & $<50$ & $<50$ & $<50$ & $<50$ & $<50$ & $<500$ \\
\hline 2,4-Dinitrotoluene & $<10$ & $<10$ & $<10$ & $<10$ & $<10$ & $<100$ \\
\hline 2,6-Dinitrotoluene & $<10$ & $<10$ & $<10$ & $<10$ & $<10$ & $<100$ \\
\hline 2-Chloronaphthalene & $<10$ & $<10$ & $<10$ & $<10$ & $<10$ & $<100$ \\
\hline 2-Chlorophenol & $<10$ & $<10$ & $<10$ & $<10$ & $<10$ & $<100$ \\
\hline 2-Methylphenol & $<10$ & $<10$ & $<10$ & $<10$ & $<10$ & $<100$ \\
\hline 2-Methyl-4,6-dinitrophenol & $<50$ & $<50$ & $<50$ & $<50$ & $<50$ & $<500$ \\
\hline 2-Methylnaphthalene & $<10$ & $<10$ & $<10$ & $<10$ & $<10$ & $<100$ \\
\hline 2-Nitroaniline & $<50$ & $<50$ & $<50$ & $<50$ & $<50$ & $<500$ \\
\hline 2-Nitrophenol & $<10$ & $<10$ & $<10$ & $<10$ & $<10$ & $<100$ \\
\hline 3,3'-Dichlorobenzidine & $<20$ & $<20$ & $<20$ & $<20$ & $<20$ & $<200$ \\
\hline 3-Nitroaniline & $<50$ & $<50$ & $<50$ & $<50$ & $<50$ & $<500$ \\
\hline 4-Bromophenylphenylether & $<10$ & $<10$ & $<10$ & $<10$ & $<10$ & $<100$ \\
\hline 4-Chloro-3-methylphenol & $<20$ & $<20$ & $<20$ & $<20$ & $<20$ & $<200$ \\
\hline 4-Chloroaniline & $<20$ & $<20$ & $<20$ & $<20$ & $<20$ & $<200$ \\
\hline
\end{tabular}


Table 6-3. Monthly monitoring results for physical and chemical characteristics of the sanitary sewer effluent, 1995 (continued).

\begin{tabular}{|c|c|c|c|c|c|c|}
\hline \multirow[b]{2}{*}{ Composite sample parameters } & \multicolumn{6}{|c|}{ Sample month } \\
\hline & July & August & Septembe & October & November & December \\
\hline \multicolumn{7}{|l|}{$\begin{array}{l}\text { Volatile organic compounds }(\mu \mathrm{g} / \mathrm{L})- \\
\text { EPA } 624 \text { (continued) }\end{array}$} \\
\hline Styrene & $<1$ & $<1$ & $<1$ & $<1$ & $<1$ & $<1$ \\
\hline Tetrachloroethene & $<1$ & $<1$ & $<1$ & $<1$ & $<1$ & $<1$ \\
\hline Toluene & $<1$ & $<1$ & $<1$ & $<1$ & $<1$ & $<1$ \\
\hline Total xylene isomers & $<2$ & $<2$ & $<2$ & $<2$ & $<2$ & $<2$ \\
\hline Trichloroethene & $<0.5$ & $<0.5$ & $<0.5$ & $<0.5$ & $<0.5$ & $<0.5$ \\
\hline Trichlorofluoromethane & $<1$ & $<1$ & $<1$ & $<1$ & $<1$ & $<1$ \\
\hline Vinyl acetate & $<10$ & $<10$ & $<10$ & $<10$ & $<10$ & $<10$ \\
\hline Vinyl chloride & $<2$ & $<2$ & $<2$ & $<2$ & $<2$ & $<2$ \\
\hline cis-1,3-Dichloropropene & $<1$ & $<1$ & $<1$ & $<1$ & $<1$ & $<1$ \\
\hline trans-1,3-Dichloropropene & $<1$ & $<1$ & $<1$ & $<1$ & $<1$ & $<1$ \\
\hline \multicolumn{7}{|l|}{$\begin{array}{l}\text { Semivolatile organic compounds }(\mu \mathrm{g} / \mathrm{L})- \\
\text { EPA } 625\end{array}$} \\
\hline 1,2,4-Trichlorobenzene & $<10$ & $<10$ & $<10$ & $<10$ & $<10$ & $<10$ \\
\hline 1,2-Dichlorobenzene & $<10$ & $<10$ & $<10$ & $<10$ & $<10$ & $<10$ \\
\hline 1,3-Dichlorobenzene & $<10$ & $<10$ & $<10$ & $<10$ & $<10$ & $<10$ \\
\hline 1,4-Dichlorobenzene & $<10$ & $<10$ & $<10$ & $<10$ & $<10$ & $<10$ \\
\hline 2,4,5-Trichlorophenol & $<10$ & $<10$ & $<10$ & $<10$ & $<10$ & $<10$ \\
\hline 2,4,6-Trichlorophenol & $<10$ & $<10$ & $<10$ & $<10$ & $<10$ & $<10$ \\
\hline 2,4-Dichlorophenol & $<10$ & $<10$ & $<10$ & $<10$ & $<10$ & $<10$ \\
\hline 2,4-Dimethylphenol & $<10$ & $<10$ & $<10$ & $<10$ & $<10$ & $<10$ \\
\hline 2,4-Dinitrophenol & $<50$ & $<50$ & $<50$ & $<50$ & $<50$ & $<50$ \\
\hline 2,4-Dinitrotoluene & $<10$ & $<10$ & $<10$ & $<10$ & $<10$ & $<10$ \\
\hline 2,6-Dinitrotoluene & $<10$ & $<10$ & $<10$ & $<10$ & $<10$ & $<10$ \\
\hline 2-Chloronaphthalene & $<10$ & $<10$ & $<10$ & $<10$ & $<10$ & $<10$ \\
\hline 2-Chlorophenol & $<10$ & $<10$ & $<10$ & $<10$ & $<10$ & $<10$ \\
\hline 2-Methylphenol & $<10$ & $<10$ & $<10$ & $<10$ & $<10$ & $<10$ \\
\hline 2-Methyl-4,6-dinitrophenol & $<50$ & $<50$ & $<50$ & $<50$ & $<50$ & $<50$ \\
\hline 2-Methylnaphthalene & $<10$ & $<10$ & $<10$ & $<10$ & $<10$ & $<10$ \\
\hline 2-Nitroaniline & $<50$ & $<50$ & $<50$ & $<50$ & $<50$ & $<50$ \\
\hline 2-Nitrophenol & $<10$ & $<10$ & $<10$ & $<10$ & $<10$ & $<10$ \\
\hline 3,3'-Dichlorobenzidine & $<20$ & $<20$ & $<20$ & $<20$ & $<20$ & $<20$ \\
\hline 3-Nitroaniline & $<50$ & $<50$ & $<50$ & $<50$ & $<50$ & $<50$ \\
\hline 4-Bromophenylphenylether & $<10$ & $<10$ & $<10$ & $<10$ & $<10$ & $<10$ \\
\hline 4-Chloro-3-methylphenol & $<20$ & $<20$ & $<20$ & $<20$ & $<20$ & $<20$ \\
\hline 4-Chloroaniline & $<20$ & $<20$ & $<20$ & $<20$ & $<20$ & $<20$ \\
\hline
\end{tabular}


Table 6-3. Monthly monitoring results for physical and chemical characteristics of the sanitary sewer effluent, 1995 (continued).

\begin{tabular}{|c|c|c|c|c|c|c|}
\hline \multirow[b]{2}{*}{ Composite sample parameters } & \multicolumn{6}{|c|}{ Sample month } \\
\hline & January & February & March & April & May & June \\
\hline \multicolumn{7}{|l|}{$\begin{array}{l}\text { Semivolatile organic compounds }(\mu \mathrm{g} / \mathrm{L})- \\
\text { EPA } 625 \text { (continued) }\end{array}$} \\
\hline 4-Chlorophenylphenylether & $<10$ & $<10$ & $<10$ & $<10$ & $<10$ & $<100$ \\
\hline 4-Nitroaniline & $<50$ & $<50$ & $<50$ & $<50$ & $<50$ & $<500$ \\
\hline 4-Nitrophenol & $<50$ & $<50$ & $<50$ & $<50$ & $<50$ & $<500$ \\
\hline Acenaphthene & $<10$ & $<10$ & $<10$ & $<10$ & $<10$ & $<100$ \\
\hline Acenaphthylene & $<10$ & $<10$ & $<10$ & $<10$ & $<10$ & $<100$ \\
\hline Anthracene & $<10$ & $<10$ & $<10$ & $<10$ & $<10$ & $<100$ \\
\hline Benzo(a)anthracene & $<10$ & $<10$ & $<10$ & $<10$ & $<10$ & $<100$ \\
\hline Benzo(a)pyrene & $<10$ & $<10$ & $<10$ & $<10$ & $<10$ & $<100$ \\
\hline Benzo(a)fluoranthene & $<10$ & $<10$ & $<10$ & $<10$ & $<10$ & $<100$ \\
\hline Benzo(g,h,i)perylene & $<10$ & $<10$ & $<10$ & $<10$ & $<10$ & $<100$ \\
\hline Benzo(k)fluoranthene & $<10$ & $<10$ & $<10$ & $<10$ & $<10$ & $<100$ \\
\hline Benzoic acid & $<50$ & $<50$ & $<50$ & $<50$ & $<50$ & $<500$ \\
\hline Benzyl alcohol & $<20$ & 37 & $<20$ & 59 & 44 & 270 \\
\hline Bis(2-chloroethoxy)methane & $<10$ & $<10$ & $<10$ & $<10$ & $<10$ & $<100$ \\
\hline Bis(2-chloroethyl)ether & $<10$ & $<10$ & $<10$ & $<10$ & $<10$ & $<100$ \\
\hline Bis(2-chloroisopropyl)ether & $<10$ & $<10$ & $<10$ & $<10$ & $<10$ & $<100$ \\
\hline Bis(2-ethylhexyl)phthalate & $<10$ & $<10$ & $<10$ & $<10$ & 19. & $<100$ \\
\hline Butylbenzylphthalate & $<10$ & $<10$ & $<10$ & $<10$ & $<10$ & $<100$ \\
\hline Chrysene & $<10$ & $<10$ & $<10$ & $<10$ & $<10$ & $<100$ \\
\hline Di-n-butylphthalate & $<10$ & $<10$ & $<10$ & $<10$ & $<10$ & $<100$ \\
\hline Di-n-octylphthalate & $<10$ & $<10$ & $<10$ & $<10$ & $<10$ & $<100$ \\
\hline Dibenzo(a,h)anthracene & $<10$ & $<10$ & $<10$ & $<10$ & $<10$ & $<100$ \\
\hline Dibenzofuran & $<10$ & $<10$ & $<10$ & $<10$ & $<10$ & $<100$ \\
\hline Diethylphthalate & $<10$ & $<10$ & $<10$ & $<10$ & $<10$ & $<100$ \\
\hline Dimethylphthalate & $<10$ & $<10$ & $<10$ & $<10$ & $<10$ & $<100$ \\
\hline Fluoranthene & $<10$ & $<10$ & $<10$ & $<10$ & $<10$ & $<100$ \\
\hline Fluorene & $<10$ & $<10$ & $<10$ & $<10$ & $<10$ & $<100$ \\
\hline Hexachlorobenzene & $<10$ & $<10$ & $<10$ & $<10$ & $<10$ & $<100$ \\
\hline Hexachlorobutadiene & $<10$ & $<10$ & $<10$ & $<10$ & $<10$ & $<100$ \\
\hline Hexachlorocyclopentadiene & $<10$ & $<10$ & $<10$ & $<10$ & $<10$ & $<100$ \\
\hline Hexachloroethane & $<10$ & $<10$ & $<10$ & $<10$ & $<10$ & $<100$ \\
\hline Indeno(1,2,3-c,d)pyrene & $<10$ & $<10$ & $<10$ & $<10$ & $<10$ & $<100$ \\
\hline Isophorone & $<10$ & $<10$ & $<10$ & $<10$ & $<10$ & $<100$ \\
\hline
\end{tabular}


Table 6-3. Monthly monitoring results for physical and chemical characteristics of the sanitary sewer effluent, 1995 (continued).

\begin{tabular}{|c|c|c|c|c|c|c|}
\hline \multirow[b]{2}{*}{ Composite sample parameters } & \multicolumn{6}{|c|}{ Sample month } \\
\hline & July & August & Septembe & October & November & December \\
\hline \multicolumn{7}{|l|}{$\begin{array}{l}\text { Semivolatile organic compounds }(\mu \mathrm{g} / \mathrm{L})- \\
\text { EPA } 625 \text { (continued) }\end{array}$} \\
\hline 4-Chlorophenylphenylether & $<10$ & $<10$ & $<10$ & $<10$ & $<10$ & $<10$ \\
\hline 4-Nitroaniline & $<50$ & $<50$ & $<50$ & $<50$ & $<50$ & $<50$ \\
\hline 4-Nitrophenol & $<50$ & $<50$ & $<50$ & $<50$ & $<50$ & $<50$ \\
\hline Acenaphthene & $<10$ & $<10$ & $<10$ & $<10$ & $<10$ & $<10$ \\
\hline Acenaphthylene & $<10$ & $<10$ & $<10$ & $<10$ & $<10$ & $<10$ \\
\hline Anthracene & $<10$ & $<10$ & $<10$ & $<10$ & $<10$ & $<10$ \\
\hline Benzo(a)anthracene & $<10$ & $<10$ & $<10$ & $<10$ & $<10$ & $<10$ \\
\hline Benzo(a)pyrene & $<10$ & $<10$ & $<10$ & $<10$ & $<10$ & $<10$ \\
\hline Benzo afluoranthene & $<10$ & $<10$ & $<10$ & $<10$ & $<10$ & $<10$ \\
\hline Benzo(g,h,i)perylene & $<10$ & $<10$ & $<10$ & $<10$ & $<10$ & $<10$ \\
\hline Benzo(k)fluoranthene & $<10$ & $<10$ & $<10$ & $<10$ & $<10$ & $<10$ \\
\hline Benzoic acid & $<50$ & $<50$ & $<50$ & $<50$ & $<50$ & $<50$ \\
\hline Benzyl alcohol & $<20$ & $<20$ & 1,100 & $<20$ & $<20$ & 33 \\
\hline $\operatorname{Bis}(2$-chloroethoxy)methane & $<10$ & $<10$ & $<10$ & $<10$ & $<10$ & $<10$ \\
\hline Bis(2-chloroethyl)ether & $<10$ & $<10$ & $<10$ & $<10$ & $<10$ & $<10$ \\
\hline Bis(2-chloroisopropyl)ether & $<10$ & $<10$ & $<10$ & $<10$ & $<10$ & $<10$ \\
\hline Bis(2-ethylhexyl)phthalate & 12 & 14 & $<10$ & 29 & $<10$ & 17 \\
\hline Butylbenzylphthalate & $<10$ & $<10$ & $<10$ & $<10$ & $<10$ & $<10$ \\
\hline Chrysene & $<10$ & $<10$ & $<10$ & $<10$ & $<10$ & $<10$ \\
\hline Di-n-butylphthalate & $<10$ & $<10$ & $<10$ & $<10$ & $<10$ & $<10$ \\
\hline Di-n-octylphthalate & $<10$ & $<10$ & $<10$ & $<10$ & $<10$ & $<10$ \\
\hline Dibenzo(a,h)anthracene & $<10$ & $<10$ & $<10$ & $<10$ & $<10$ & $<10$ \\
\hline Dibenzofuran & $<10$ & $<10$ & $<10$ & $<10$ & $<10$ & $<10$ \\
\hline Diethylphthalate & $<10$ & $<10$ & $<10$ & $<10$ & $<10$ & $<10$ \\
\hline Dimethylphthalate & $<10$ & $<10$ & $<10$ & $<10$ & $<10$ & $<10$ \\
\hline Fluoranthene & $<10$ & $<10$ & $<10$ & $<10$ & $<10$ & $<10$ \\
\hline Fluorene & $<10$ & $<10$ & $<10$ & $<10$ & $<10$ & $<10$ \\
\hline Hexachlorobenzene & $<10$ & $<10$ & $<10$ & $<10$ & $<10$ & $<10$ \\
\hline Hexachlorobutadiene & $<10$ & $<10$ & $<10$ & $<10$ & $<10$ & $<10$ \\
\hline Hexachlorocyclopentadiene & $<10$ & $<10$ & $<10$ & $<10$ & $<10$ & $<10$ \\
\hline Hexachloroethane & $<10$ & $<10$ & $<10$ & $<10$ & $<10$ & $<10$ \\
\hline Indeno(1,2,3-c,d)pyrene & $<10$ & $<10$ & $<10$ & $<10$ & $<10$ & $<10$ \\
\hline Isophorone & $<10$ & $<10$ & $<10$ & $<10$ & $<10$ & $<10$ \\
\hline
\end{tabular}




\section{Sewage Monitoring}

Table 6-3. Monthly monitoring results for physical and chemical characteristics of the sanitary sewer effluent, 1995 (continued).

\begin{tabular}{|c|c|c|c|c|c|c|}
\hline \multirow[b]{2}{*}{ Composite sample parameters } & \multicolumn{6}{|c|}{ Sample month } \\
\hline & January & February & March & April & May & June \\
\hline \multicolumn{7}{|l|}{$\begin{array}{l}\text { Semivolatile organic compounds }(\mu \mathrm{g} / \mathrm{L})- \\
\text { EPA } 625 \text { (continued) }\end{array}$} \\
\hline N-Nitrosodi-n-propylamine & $<10$ & $<10$ & $<10$ & $<10$ & $<10$ & $<100$ \\
\hline N-Nitrosodiphenylamine & $<10$ & $<10$ & $<10$ & $<10$ & $<10$ & $<100$ \\
\hline Naphthalene & $<10$ & $<10$ & $<10$ & $<10$ & $<10$ & $<100$ \\
\hline Nitrobenzene & $<10$ & $<10$ & $<10$ & $<10$ & $<10$ & $<100$ \\
\hline Pentachlorophenol & $<50$ & $<50$ & $<50$ & $<50$ & $<50$ & $<500$ \\
\hline Phenanthrene & $<10$ & $<10$ & $<10$ & $<10$ & $<10$ & $<100$ \\
\hline Phenol & $<10$ & $<10$ & $<10$ & $<10$ & $<10$ & $<100$ \\
\hline Pyrene & $<10$ & $<10$ & $<10$ & $<10$ & $<10$ & $<100$ \\
\hline $\mathrm{m}$ - and p-Cresol & $<10$ & $<10$ & $<10$ & 15 & $<10$ & $<100$ \\
\hline \multicolumn{7}{|l|}{ Phenolics (mg/L)_ EPA 420.1} \\
\hline Total recoverable phenolics & 0.038 & 0.025 & 0.026 & 0.017 & 0.027 & 0.025 \\
\hline \multicolumn{7}{|l|}{ Cyanide (mg/L)_EPA 335.2} \\
\hline Total cyanide & $<0.02$ & $<0.02$ & $<0.02$ & $<0.02$ & $<0.02$ & $<0.02$ \\
\hline \multicolumn{7}{|l|}{ Oil and grease (mg/L)_EPA 413.1} \\
\hline Total oil and grease (6 A.M.) & $<5$ & 6.7 & 6.3 & $<5$ & $<5$ & $<5$ \\
\hline Total oil and grease (10 A.M.) & 26 & 17 & 20 & 36 & 41 & 33 \\
\hline Total oil and grease (2 P.M.) & 29 & 14 & 25 & 24 & 47 & 29 \\
\hline Total oil and grease (6 P.M.) & 66 & $<5$ & 8.2 & 8.6 & 9.6 & 16 \\
\hline
\end{tabular}


Table 6-3. Monthly monitoring results for physical and chemical characteristics of the sanitary sewer effluent, 1995 (concluded).

\begin{tabular}{|c|c|c|c|c|c|c|}
\hline \multirow[b]{2}{*}{ Composite sample parameters } & \multicolumn{6}{|c|}{ Sample month } \\
\hline & July & August & September & October & November & December \\
\hline \multicolumn{7}{|l|}{$\begin{array}{l}\text { Semivolatile organic compounds }(\mu \mathrm{g} / \mathrm{L})- \\
\text { EPA } 625 \text { (continued) }\end{array}$} \\
\hline N-Nitrosodi-n-propylamine & $<10$ & $<10$ & $<10$ & $<10$ & $<10$ & $<10$ \\
\hline N-Nitrosodiphenylamine & $<10$ & $<10$ & $<10$ & $<10$ & $<10$ & $<10$ \\
\hline Naphthalene & $<10$ & $<10$ & $<10$ & $<10$ & $<10$ & $<10$ \\
\hline Nitrobenzene & $<10$ & $<10$ & $<10$ & $<10$ & $<10$ & $<10$ \\
\hline Pentachlorophenol & $<50$ & $<50$ & $<50$ & $<50$ & $<50$ & $<50$ \\
\hline Phenanthrene & $<10$ & $<10$ & $<10$ & $<10$ & $<10$ & $<10$ \\
\hline Phenol & $<10$ & $<10$ & $<10$ & $<10$ & $<10$ & $<10$ \\
\hline Pyrene & $<10$ & $<10$ & $<10$ & $<10$ & $<10$ & $<10$ \\
\hline $\mathrm{m}$ - and $\mathrm{p}$-Cresol & $<10$ & $<10$ & $<10$ & $<10$ & $<10$ & $<10$ \\
\hline \multicolumn{7}{|l|}{ Phenolics (mg/L)_EPA 420.1} \\
\hline Total recoverable phenolics & 0.019 & 0.059 & 0.018 & 0.52 & 0.027 & 0.3 \\
\hline \multicolumn{7}{|l|}{ Cyanide (mg/L)_EPA 335.2} \\
\hline Total cyanide & $<0.02$ & $<0.02$ & $<0.02$ & $<0.02$ & $<0.02$ & $<0.02$ \\
\hline \multicolumn{7}{|l|}{ Oil and grease (mg/L)_EPA 413.1} \\
\hline Total oil and grease (6 A.M.) & $<5$ & $<5$ & 8.3 & $<5$ & $<5$ & 8.1 \\
\hline Total oil and grease (10 A.M.) & 23 & 19 & 55 & 24 & 51 & 20 \\
\hline Total oil and grease (2 P.M.) & 30 & 20 & 32 & 21 & 45 & 40 \\
\hline Total oil and grease (6 P.M.) & 14 & 8.2 & 22 & 16 & 21 & 66 \\
\hline
\end{tabular}

a Insufficient composite sample volume to test for this parameter. The LWRP removed sample from the October composite sample for routine verification of LLNL's analytical results.

b This result was not provided by the contract analytical laboratory. It was calculated from the provided nitrate or nitrite result, as appropriate.

c The analysis was not requested. 
6. Sewage Monitoring

Tabe 6-4. Daily flow totals for sanitary sewer effluent in megaliters (ML), 1995.

\begin{tabular}{|c|c|c|c|c|c|c|c|c|c|c|c|c|}
\hline Date & Jan & Feb & Mar & Apr & May & Jun & Jul & Aug & Sep & Oct & Nov & Dec \\
\hline 1 & 0.725 & 1.525 & 1.472 & 0.640 & 0.321 & 1.250 & 1.023 & 1.034 & 1.133 & 0.329 & 1.105 & 1.278 \\
\hline 2 & 0.655 & 1.178 & 1.707 & 0.640 & 1.120 & 1.090 & 0.431 & 1.535 & 1.114 & 0.224 & 1.020 & 0.913 \\
\hline 3 & 0.490 & 1.561 & 1.947 & 0.640 & 1.127 & 1.124 & 0.757 & 0.210 & 0.512 & 0.755 & 1.016 & 0.298 \\
\hline 4 & 1.525 & 1.612 & 1.947 & 2.370 & 1.408 & 0.638 & 0.757 & 0.821 & 0.498 & 0.804 & 1.022 & 0.219 \\
\hline 5 & 1.045 & 0.464 & 0.775 & 1.416 & 1.215 & 0.420 & 0.506 & 0.870 & 0.369 & 0.884 & 0.456 & 1.426 \\
\hline 6 & 1.290 & 0.296 & 0.289 & 1.273 & 1.159 & 1.118 & 1.114 & 0.412 & 1.112 & 0.932 & 0.522 & 1.284 \\
\hline 7 & 1.352 & 1.362 & 1.396 & 1.317 & 0.406 & 1.106 & 1.020 & 0.302 & 1.012 & 0.751 & 1.334 & 1.735 \\
\hline 8 & 0.487 & 1.356 & 1.710 & 1.849 & 0.316 & 1.554 & 0.961 & 1.068 & 1.055 & 0.254 & 1.188 & 1.110 \\
\hline 9 & 0.232 & 1.757 & 1.486 & 0.537 & 0.532 & 1.239 & 0.331 & 0.924 & 1.034 & 0.381 & 1.388 & 0.944 \\
\hline 10 & 1.352 & 1.452 & 1.499 & 0.248 & 1.000 & 1.202 & 0.218 & 0.981 & 0.793 & 0.833 & 1.489 & 0.328 \\
\hline 11 & 1.342 & 1.452 & 1.798 & 1.461 & 1.011 & 0.542 & 1.031 & 0.981 & 0.116 & 0.725 & 1.374 & 0.401 \\
\hline 12 & 1.488 & 0.771 & 0.725 & 1.461 & 1.319 & 0.366 & 1.207 & 0.981 & 1.079 & 0.923 & 0.678 & 1.077 \\
\hline 13 & 1.337 & 0.465 & 0.739 & 1.461 & 1.160 & 0.917 & 1.094 & 0.334 & 1.074 & 0.918 & 0.548 & 1.367 \\
\hline 14 & 1.591 & 1.372 & 1.541 & 1.419 & 0.573 & 1.159 & 1.022 & 0.119 & 1.163 & 0.835 & 1.162 & 0.901 \\
\hline 15 & 1.110 & 1.620 & 1.508 & 1.587 & 0.336 & 1.179 & 0.604 & 0.899 & 1.069 & 0.344 & 1.270 & 0.912 \\
\hline 16 & 0.728 & 1.523 & 1.577 & 0.933 & 1.392 & 1.392 & 0.604 & 1.457 & 1.030 & 0.223 & 1.182 & 0.950 \\
\hline 17 & 0.442 & 1.616 & 1.689 & 0.915 & 1.062 & 1.192 & 0.604 & 0.936 & 0.589 & 0.887 & 1.225 & 1.091 \\
\hline 18 & 1.540 & 1.689 & 1.056 & 0.322 & 1.072 & 0.697 & 1.158 & 0.924 & 0.451 & 0.972 & 0.967 & 0.508 \\
\hline 19 & 1.721 & 0.794 & 1.056 & 1.416 & 1.072 & 0.367 & 0.950 & 0.895 & 1.154 & 0.927 & 0.518 & 1.179 \\
\hline 20 & 1.463 & 1.008 & 1.056 & 1.365 & 0.998 & 1.272 & 1.031 & 0.178 & 0.760 & 0.936 & 0.222 & 0.840 \\
\hline 21 & 2.298 & 0.948 & 1.729 & 1.289 & 0.535 & 1.217 & 1.075 & 0.190 & 0.941 & 0.814 & 0.993 & 0.889 \\
\hline 22 & 1.654 & 0.948 & 2.059 & 1.399 & 0.416 & 1.218 & 0.959 & 1.154 & 1.150 & 0.385 & 0.183 & 0.916 \\
\hline 23 & 1.698 & 1.435 & 2.059 & 0.608 & 1.145 & 1.130 & 0.334 & 0.769 & 1.130 & 0.441 & 0.611 & 0.799 \\
\hline 24 & 1.290 & 1.479 & 1.800 & 0.243 & 1.049 & 1.236 & 0.363 & 0.938 & 0.749 & 1.121 & 0.453 & 0.303 \\
\hline 25 & 1.408 & 1.426 & 1.296 & 1.170 & 1.331 & 1.005 & 0.896 & 1.052 & 0.358 & 1.025 & 0.577 & 0.447 \\
\hline 26 & 1.349 & 0.780 & 1.296 & 1.160 & 1.142 & 0.317 & 1.175 & 0.885 & 1.113 & 1.067 & 0.486 & 0.354 \\
\hline 27 & 1.336 & 0.401 & 1.296 & 1.235 & 1.077 & 1.686 & 0.899 & 0.574 & 1.126 & 0.899 & 0.389 & 0.135 \\
\hline 28 & 2.319 & 1.420 & 1.656 & 1.131 & 0.450 & 1.586 & 0.982 & 0.287 & 1.064 & 0.919 & 1.157 & 0.907 \\
\hline 29 & 0.772 & & 1.616 & 1.243 & 0.507 & 1.521 & 0.797 & 1.293 & 1.094 & 0.381 & 1.171 & 0.750 \\
\hline 30 & 0.772 & & 1.590 & 0.466 & 0.299 & 1.723 & 0.405 & 0.913 & 0.866 & 0.211 & 1.160 & 0.894 \\
\hline 31 & 0.772 & & 1.553 & & 1.011 & & 0.249 & 1.121 & & 1.269 & & 0.427 \\
\hline
\end{tabular}

Note: Actual daily flow totals for dates in shaded areas are not available; estimated daily flow totals are shown in the shaded areas. 
Table 6-5. Weekly composite results for tritium (in $\mathrm{mBq} / \mathrm{L}$ ) for the LWRP effluent, 1995.

\begin{tabular}{|c|c|c|}
\hline Composite Dates & Activity & LOS \\
\hline December 26, 1994-January 1, 1995 & $10.4 \pm 0.8$ & 9.69 \\
\hline January 2-8 & $0.512 \pm 0.512$ & 10.6 \\
\hline January 9-15 & $6.08 \pm 6.08$ & 10.8 \\
\hline January 16-22 & $-3.96 \pm-3.96$ & 14.4 \\
\hline January 23-29 & $1.85 \pm 1.85$ & 13.5 \\
\hline January 30-February 5 & $2.63 \pm 2.63$ & 13.7 \\
\hline February 6-12 & $3.60 \pm 3.60$ & 10.7 \\
\hline February $13-19$ & $2.95 \pm 2.95$ & 11.3 \\
\hline February 20-26 & $5.44 \pm 5.44$ & 10.5 \\
\hline February 27-March 5 & $1.71 \pm 1.71$ & 10.1 \\
\hline March 6-12 & $7.47 \pm 7.47$ & 9.66 \\
\hline March 13-19 & $1.45 \pm 1.45$ & 9.47 \\
\hline March 20-26 & $-0.507 \pm-0.507$ & 10.2 \\
\hline March 27-April 2 & $5.03 \pm 5.03$ & 10.2 \\
\hline April 3-9 & $-1.46 \pm-1.46$ & 10.4 \\
\hline April 10-16 & $-9.10 \pm-9.10$ & 11.4 \\
\hline April 17-23 & $-4.18 \pm-4.18$ & 10.9 \\
\hline April 24-30 & $3.66 \pm 3.66$ & 10.4 \\
\hline May 1-7 & $1.51 \pm 1.51$ & 10.5 \\
\hline May 8-14 & $2.01 \pm 2.01$ & 10.4 \\
\hline May 15-21 & $-2.66 \pm-2.66$ & 10.5 \\
\hline May 22-28 & $-2.05 \pm-2.05$ & 10.7 \\
\hline May 29-June 4 & $0.766 \pm 0.766$ & 10.2 \\
\hline June 5-11 & $3.09 \pm 3.09$ & 10.1 \\
\hline June $12-18$ & $1.41 \pm 1.41$ & 10.6 \\
\hline June 19-25 & $4.40 \pm 4.40$ & 10.0 \\
\hline June $26-30$ & $-1.27 \pm-1.27$ & 11.2 \\
\hline July 2-9 & $1.05 \pm 1.05$ & 10.5 \\
\hline July 10-16 & $-1.46 \pm-1.46$ & 10.5 \\
\hline July 17-23 & $-1.24 \pm-1.24$ & 10.5 \\
\hline July 24-30 & $2.11 \pm 2.11$ & 10.3 \\
\hline July 31-August 6 & $-2.73 \pm-2.73$ & 10.9 \\
\hline August 7-13 & $0.176 \pm 0.176$ & 10.5 \\
\hline August 14-20 & $3.74 \pm 3.74$ & 10.1 \\
\hline August 21-27 & $1.50 \pm 1.50$ & 10.4 \\
\hline August 28-September 3 & $7.47 \pm 7.47$ & 9.92 \\
\hline
\end{tabular}




\section{Sewage Monitoring}

Table 6-5. Weekly composite results for tritium (in $\mathrm{mBq} / \mathrm{L}$ ) for the LWRP effluent, 1995 (concluded).

\begin{tabular}{|l|c|c|}
\hline Composite Dates & Activity & LOS \\
\hline September 4-10 & $-1.40 \pm-1.40$ & 10.5 \\
September 11-17 & $-2.46 \pm-2.46$ & 10.9 \\
September 18-24 & $-3.35 \pm-3.35$ & 9.77 \\
September 25-October 1 & $0.00736 \pm 0.00736$ & 10.8 \\
October 2-8 & $-3.60 \pm-3.60$ & 10.5 \\
October 9-15 & $-1.21 \pm-1.21$ & 10.6 \\
October 16-22 & $-1.92 \pm-1.92$ & 10.5 \\
October 23-29 & $4.03 \pm 4.03$ & 9.32 \\
October 30-November 5 & $3.10 \pm 3.10$ & 10.5 \\
November 6-12 & $1.97 \pm 1.97$ & 10.3 \\
November 13-19 & $-0.242 \pm-0.242$ & 10.6 \\
November 20-26 & $5.55 \pm 5.55$ & 10.4 \\
November 27-December 3 & $0.0640 \pm 0.0640$ & 10.7 \\
December 4-10 & $-2.46 \pm-2.46$ & 11.0 \\
December 11-17 & $0.327 \pm 0.327$ & 10.5 \\
December 18-24 & $-3.06 \pm-3.06$ & 10.7 \\
December 25-31 & $5.74 \pm 5.74$ & 10.6 \\
\hline
\end{tabular}

Note: The LWRP did not provide a sample aliquot for July 1. 



\section{Surface Water Monitoring}

Erich R. Brandstetter

Richard A. Brown

Eric Christofferson

Introduction

Surface Water Methods
Lawrence Livermore National Laboratory performs surface water monitoring at the Livermore site, in surrounding regions of the Livermore Valley, and at Site 300 and vicinity in the nearby Altamont Hills. At the first two locales, LLNL monitors reservoirs and ponds, the LLNL swimming pool, rainfall, tap water, and storm water runoff. Water samples are analyzed for radionuclides and a wide range of nonradioactive constituents. At Site 300 and vicinity, surface water monitoring encompasses rainfall and storm water runoff. These water samples are analyzed for radionuclides, explosives, total organic carbon, total organic halides, total suspended solids, conductivity, and $\mathrm{pH}$. Volume 1, Chapter 7, includes summary data tables and a detailed discussion and analysis of the data. This chapter presents the complete dataset for 1994, including a summary of analyses requested in storm water samples and a summary of constituents for which analyses were conducted but which were never detected.

Surface and drinking water near the Livermore site and in the Livermore Valley are sampled according to procedures EMP-W-L and EMP-W-S. LLNL technicians use a tethered pail to collect water samples from surface sources; other locations are sampled directly from the outfall. Samples for tritium analysis are collected in 500-mL, argon-flushed glass containers; those for other radiological analyses are collected in acidified $1000-\mathrm{mL}$ polyethylene bottles.

The on-site swimming pool and drinking water source (POOL and TAP) are sampled, as described above, for gross alpha, gross beta, and tritium. POOL is sampled monthly, and TAP is sampled quarterly.

\section{Rainfall Methods}

Detailed descriptions of station locations are given in EMS Procedure EMP-RA-L. Rainfall sampling and sample tracking protocols are described in EMS Procedure EMP-RA-S. Essentially, rainfall is collected in stainless steel buckets mounted about $1 \mathrm{~m}$ above the ground. Samples are decanted into 500-mL argon-flushed flint-glass bottles fitted with glass stoppers. 


\section{Surface Water Monitoring}

Storm Water Methods
Procedures EMP-RO-L and EM7P-RO-S describe storm water sampling procedures and locations. LLNL technicians collect storm water samples for nonradiological analysis directly into sample bottles for storm water runoff grab samples. Samples analyzed for tritium are collected in $250-\mathrm{mL}$, argon-flushed glass containers; samples for gross alpha and gross beta measurements are collected in 1,000-mL polyethylene bottles. 


\section{Surface Water Monitoring}

Table 7-1. Radioactivity in surface and drinking waters (Bq/L), Livermore Valley, 1995. (a)

\begin{tabular}{|c|c|c|c|c|}
\hline Location & Date & Tritium & Gross alpha & Gross beta \\
\hline \multicolumn{5}{|c|}{ Drinking waters } \\
\hline \multirow[t]{4}{*}{ BELL } & 01/13/95 & $0.614 \pm 0.111$ & $0.049 \pm 0.009$ & $0.141 \pm 0.011$ \\
\hline & 05/03/95 & $0.614 \pm 0.138$ & $0.018 \pm 0.048$ & $0.096 \pm 0.052$ \\
\hline & 09/21/95 & $0.518 \pm 0.162$ & $0.002 \pm 0.033$ & $0.044 \pm 0.048$ \\
\hline & $11 / 28 / 95$ & $0.455 \pm 0.158$ & $0.092 \pm 0.059$ & $0.089 \pm 0.052$ \\
\hline \multirow[t]{4}{*}{ GAS } & 01/13/95 & $0.844 \pm 0.125$ & $0.017 \pm 0.010$ & $0.100 \pm 0.010$ \\
\hline & 05/03/95 & $0.341 \pm 0.341$ & $-0.015 \pm 0.037$ & $0.111 \pm 0.052$ \\
\hline & $09 / 21 / 95$ & $0.492 \pm 0.138$ & $-0.022 \pm 0.041$ & $0.063 \pm 0.052$ \\
\hline & $11 / 27 / 95$ & $0.459 \pm 0.140$ & $-0.014 \pm 0.035$ & $0.063 \pm 0.052$ \\
\hline \multirow[t]{4}{*}{ PALM } & 01/13/95 & $0.633 \pm 0.113$ & $0.058 \pm 0.011$ & $0.222 \pm 0.012$ \\
\hline & 05/03/95 & $0.422 \pm 0.335$ & $0.044 \pm 0.056$ & $0.174 \pm 0.059$ \\
\hline & 09/21/95 & $0.603 \pm 0.154$ & $0.011 \pm 0.070$ & $0.081 \pm 0.067$ \\
\hline & $11 / 27 / 95$ & $0.440 \pm 0.151$ & $0.048 \pm 0.052$ & $0.078 \pm 0.052$ \\
\hline \multirow[t]{4}{*}{$\mathrm{ORCH}$} & 01/13/95 & $0.881 \pm 0.128$ & $0.174 \pm 0.035$ & $0.662 \pm 0.037$ \\
\hline & 05/03/95 & $0.725 \pm 0.133$ & $0.381 \pm 0.248$ & $0.588 \pm 0.181$ \\
\hline & 09/21/95 & $0.666 \pm 0.136$ & $0.089 \pm 0.163$ & $0.418 \pm 0.174$ \\
\hline & $11 / 27 / 95$ & $0.418 \pm 0.153$ & $-0.026 \pm 0.174$ & $0.229 \pm 0.174$ \\
\hline \multirow[t]{4}{*}{ TAP } & 01/13/95 & $0.821 \pm 0.122$ & $0.034 \pm 0.005$ & $0.022 \pm 0.009$ \\
\hline & 05/03/95 & $0.414 \pm 0.105$ & $0.016 \pm 0.025$ & $0.015 \pm 0.044$ \\
\hline & 09/21/95 & $0.381 \pm 0.118$ & $0.085 \pm 0.041$ & $0.037 \pm 0.048$ \\
\hline & $11 / 27 / 95$ & $0.481 \pm 0.133$ & $0.085 \pm 0.026$ & $0.026 \pm 0.048$ \\
\hline \multicolumn{5}{|c|}{ Surface waters } \\
\hline \multirow[t]{4}{*}{ CAL } & 01/13/95 & $0.466 \pm 0.099$ & $0.029 \pm 0.007$ & $0.079 \pm 0.010$ \\
\hline & 05/03/95 & $1.258 \pm 1.258$ & $-0.001 \pm 0.029$ & $0.041 \pm 0.048$ \\
\hline & 09/21/95 & $0.433 \pm 0.143$ & $0.026 \pm 0.041$ & $0.037 \pm 0.048$ \\
\hline & $11 / 28 / 95$ & $0.131 \pm 0.131$ & $0.115 \pm 0.059$ & $0.818 \pm 0.096$ \\
\hline \multirow[t]{4}{*}{ DEL } & $01 / 13 / 95$ & $0.533 \pm 0.098$ & $0.159 \pm 0.013$ & $0.266 \pm 0.012$ \\
\hline & 05/03/95 & $0.485 \pm 0.122$ & $0.011 \pm 0.048$ & $0.229 \pm 0.059$ \\
\hline & 09/21/95 & $0.688 \pm 0.172$ & $0.015 \pm 0.052$ & $0.067 \pm 0.052$ \\
\hline & $11 / 27 / 95$ & $0.294 \pm 0.192$ & $0.026 \pm 0.048$ & $0.070 \pm 0.052$ \\
\hline \multirow[t]{4}{*}{ DUCK } & 01/13/95 & $1.676 \pm 0.164$ & $0.168 \pm 0.057$ & $0.343 \pm 0.048$ \\
\hline & 05/03/95 & $1.373 \pm 0.404$ & $0.004 \pm 0.200$ & $0.318 \pm 0.281$ \\
\hline & 09/21/95 & $1.310 \pm 0.185$ & $0.074 \pm 0.481$ & $0.555 \pm 0.518$ \\
\hline & $11 / 27 / 95$ & $1.350 \pm 0.170$ & $0.037 \pm 0.592$ & $0.851 \pm 0.518$ \\
\hline
\end{tabular}

...concluded on next page 
Table 7-1. Radioactivity in surface and drinking waters (Bq/L), Livermore Valley, 1995a. (concluded)

\begin{tabular}{|c|c|c|c|c|}
\hline Location & Date & Tritium & Gross alpha & Gross beta \\
\hline \multirow[t]{4}{*}{ ALAG } & $01 / 13 / 95$ & $1.828 \pm 0.152$ & $0.109 \pm 0.013$ & $0.186 \pm 0.012$ \\
\hline & 05/03/95 & $1.180 \pm 0.160$ & $0.092 \pm 0.126$ & $0.078 \pm 0.100$ \\
\hline & 09/21/95 & $1.820 \pm 0.164$ & $0.252 \pm 0.178$ & $0.222 \pm 0.133$ \\
\hline & $11 / 28 / 95$ & $1.602 \pm 0.159$ & $0.022 \pm 0.152$ & $0.204 \pm 0.144$ \\
\hline \multirow[t]{4}{*}{ SHAD } & $01 / 13 / 95$ & $2.194 \pm 0.165$ & $0.095 \pm 0.015$ & $0.162 \pm 0.013$ \\
\hline & 05/03/95 & $1.913 \pm 0.362$ & $0.011 \pm 0.107$ & $0.096 \pm 0.130$ \\
\hline & 09/21/95 & $1.983 \pm 0.184$ & $0.096 \pm 0.118$ & $0.111 \pm 0.081$ \\
\hline & $11 / 28 / 95$ & $1.761 \pm 0.192$ & $-0.089 \pm 0.092$ & $0.144 \pm 0.115$ \\
\hline \multirow[t]{4}{*}{ ZON7 } & $01 / 13 / 95$ & $0.855 \pm 0.115$ & $0.021 \pm 0.010$ & $0.152 \pm 0.011$ \\
\hline & 05/03/95 & $0.343 \pm 0.343$ & $0.067 \pm 0.059$ & $0.115 \pm 0.056$ \\
\hline & 09/21/95 & $0.555 \pm 0.155$ & $0.010 \pm 0.033$ & $0.104 \pm 0.052$ \\
\hline & $11 / 27 / 95$ & $0.422 \pm 0.131$ & $0.081 \pm 0.052$ & $0.070 \pm 0.052$ \\
\hline \multicolumn{5}{|l|}{ Onsite pool } \\
\hline \multirow[t]{12}{*}{ POOL } & $01 / 13 / 95$ & $5.920 \pm 1.711$ & $0.0226 \pm 0.032$ & $0.201 \pm 0.042$ \\
\hline & 02/27/95 & $5.846 \pm 1.900$ & $-0.065 \pm 0.031$ & $0.142 \pm 0.026$ \\
\hline & 03/20/95 & $8.917 \pm 1.864$ & $0.001 \pm 0.022$ & $0.141 \pm 0.020$ \\
\hline & 04/28/95 & $7.289 \pm 2.048$ & $0.004 \pm 0.137$ & $0.170 \pm 0.192$ \\
\hline & 05/03/95 & $5.661 \pm 2.021$ & $0.348 \pm 0.259$ & $0.314 \pm 0.185$ \\
\hline & 06/29/95 & $8.029 \pm 2.762$ & $-0.007 \pm 0.152$ & $0.222 \pm 0.166$ \\
\hline & 07/27/95 & Not collected & Not collected & Not collected \\
\hline & 08/27/95 & Not collected & Not collected & Not collected \\
\hline & 09/21/95 & $6.068 \pm 2.227$ & $0.078 \pm 0.218$ & $0.144 \pm 0.200$ \\
\hline & $10 / 27 / 95$ & $2.327 \pm 2.327$ & $0.089 \pm 0.240$ & $0.255 \pm 0.170$ \\
\hline & $11 / 28 / 95$ & $2.327 \pm 2.327$ & $0.041 \pm 0.196$ & $0.289 \pm 0.192$ \\
\hline & $12 / 12 / 95$ & $4.366 \pm 2.179$ & $-0.033 \pm 0.152$ & $0.155 \pm 0.166$ \\
\hline
\end{tabular}

a Drinking water MCLs: tritium $=740 \mathrm{~Bq} / \mathrm{L}$, gross alpha $=0.555 \mathrm{~Bq} / \mathrm{L}$, gross beta $=1.85 \mathrm{~Bq} / \mathrm{L}$. 


\section{Surface Water Monitoring}

Table 7-2. Radioactivity in storm water runoff (Bq/L) at Livermore site, 1995.

\begin{tabular}{|c|c|c|c|c|}
\hline Location & Date & Tritium & Gross alpha & Gross beta \\
\hline \multirow[t]{3}{*}{ ALPE } & Mar 2 & $51.1 \pm 3.06$ & $0.100 \pm 0.0211$ & $0.286 \pm 0.0144$ \\
\hline & May 13 & $2.42 \pm 1.83$ & $0.111 \pm 0.0703$ & $0.207 \pm 0.0592$ \\
\hline & Dec 11 & $6.14 \pm 2.48$ & $0.107 \pm 0.0777$ & $0.348 \pm 0.0703$ \\
\hline ALPO & Dec 11 & $5.77 \pm 2.46$ & $0.962 \pm 0.407$ & $0.740 \pm 0.259$ \\
\hline \multirow[t]{3}{*}{ ASS2 } & Mar 3 & $4.74 \pm 1.77$ & $0.0881 \pm 0.0133$ & $0.235 \pm 0.0115$ \\
\hline & May 13 & $<1.77$ & $0.104 \pm 0.0481$ & $0.226 \pm 0.0592$ \\
\hline & Dec 11 & $6.59 \pm 2.49$ & $0.0777 \pm 0.0592$ & $0.248 \pm 0.0629$ \\
\hline \multirow[t]{3}{*}{ ASW } & Mar 2 & $38.1 \pm 2.78$ & $0.138 \pm 0.0078$ & $0.228 \pm 0.0111$ \\
\hline & May 13 & $<1.70$ & $0.0366 \pm 0.0296$ & $0.100 \pm 0.0518$ \\
\hline & Dec 11 & $9.92 \pm 2.60$ & $0.111 \pm 0.0851$ & $0.426 \pm 0.0777$ \\
\hline \multirow[t]{3}{*}{ CDB } & Mar 2 & $18.3 \pm 2.27$ & $0.117 \pm 0.0085$ & $0.234 \pm 0.0130$ \\
\hline & May 13 & $<1.77$ & $0.0352 \pm 0.0289$ & $0.100 \pm 0.0518$ \\
\hline & Dec 11 & $3.65 \pm 2.39$ & $0.0555 \pm 0.0407$ & $0.111 \pm 0.0518$ \\
\hline \multirow[t]{3}{*}{ CDB2 } & Mar 3 & $28.8 \pm 2.48$ & $0.0833 \pm 0.0107$ & $0.189 \pm 0.0122$ \\
\hline & May 13 & $12.5 \pm 2.18$ & $0.0740 \pm 0.0481$ & $0.189 \pm 0.0555$ \\
\hline & Dec 11 & $9.32 \pm 2.58$ & $0.0888 \pm 0.0703$ & $0.303 \pm 0.0666$ \\
\hline CDBX & Dec 12 & $14.13 \pm 2.49$ & $0.0481 \pm 0.0518$ & $0.181 \pm 0.0555$ \\
\hline \multirow[t]{3}{*}{ GRNE } & Mar 2 & $14.2 \pm 2.15$ & $0.122 \pm 0.0122$ & $0.222 \pm 0.0111$ \\
\hline & May 13 & $<1.82$ & $0.152 \pm 0.0814$ & $0.274 \pm 0.0666$ \\
\hline & Dec 11 & $3.06 \pm 2.38$ & $2.41 \pm 1.07$ & $1.89 \pm 0.703$ \\
\hline \multirow[t]{4}{*}{ WPDC } & Mar 2 & $16.9 \pm 2.14$ & $0.0988 \pm 0.0081$ & $0.178 \pm 0.0107$ \\
\hline & May 13 & $3.30 \pm 1.86$ & $0.107 \pm 0.0629$ & $0.259 \pm 0.0629$ \\
\hline & Dec 11 & $3.61 \pm 2.39$ & $0.167 \pm 0.107$ & $0.366 \pm 0.0925$ \\
\hline & Dec 12 & $11.3 \pm 2.40$ & $0.163 \pm 0.130$ & $0.485 \pm 0.118$ \\
\hline
\end{tabular}


Table 7-3. Tritium in rain (Bq/L), Livermore site and Livermore Valley.

\begin{tabular}{|c|c|c|c|c|c|c|c|}
\hline \multirow[b]{2}{*}{ Location } & \multicolumn{7}{|c|}{ Date } \\
\hline & 2/15/95 & 3/2/95 & 4/19/96 & $5 / 13 / 96$ & $6 / 16 / 96$ & 12/11/95 & $12 / 12 / 95$ \\
\hline \multicolumn{8}{|l|}{ Onsite } \\
\hline B343 & $20.239 \pm 2.4290$ & $36.741 \pm 2.6090$ & $72.89 \pm 3.5720$ & $44.03 \pm 2.9500$ & $22.422 \pm 2.4220$ & $7.955 \pm 2.4100$ & $4.92 \pm 2.0860$ \\
\hline B291 & $13.949 \pm 2.2320$ & $17.612 \pm 2.0960$ & $19.351 \pm 2.2830$ & $10.545 \pm 2.0770$ & $5.402 \pm 1.8800$ & $2.19 \pm 2.1900$ & $4.329 \pm 2.1640$ \\
\hline CDB & $9.842 \pm 2.1750$ & $18.241 \pm 2.1160$ & $24.457 \pm 2.4210$ & $11.544 \pm 2.2280$ & $5.735 \pm 1.8810$ & $2.168 \pm 2.1680$ & $3.363 \pm 2.0620$ \\
\hline VIS & $8.991 \pm 2.0860$ & $12.913 \pm 2.1180$ & $8.88 \pm 1.9270$ & $2.342 \pm 1.7780$ & $2.287 \pm 2.2870$ & $2.538 \pm 2.2850$ & $5.217 \pm 2.2020$ \\
\hline COW & $8.695 \pm 2.1300$ & $8.325 \pm 1.9560$ & $9.361 \pm 2.1530$ & $1.82 \pm 1.8200$ & $3.204 \pm 1.7880$ & $2.312 \pm 2.2270$ & $4.847 \pm 2.1760$ \\
\hline SALV & $14.837 \pm 2.3150$ & $31.45 \pm 2.4850$ & $9.176 \pm 2.5880$ & $3.7 \pm 1.8320$ & $1.754 \pm 1.7540$ & $2.198 \pm 2.1980$ & $2.168 \pm 2.0860$ \\
\hline MET & $2.405 \pm 2.4050$ & $7.955 \pm 1.9410$ & $2.02 \pm 1.8910$ & $3.101 \pm 1.8140$ & $2.183 \pm 2.1830$ & NA & $1.972 \pm 1.9720$ \\
\hline \multicolumn{8}{|l|}{ Offsite } \\
\hline ESAN & $55.87 \pm 3.2400$ & $55.87 \pm 3.0730$ & $6.105 \pm 1.8250$ & $1.857 \pm 1.8570$ & $1.794 \pm 1.7940$ & $2.128 \pm 2.1280$ & $4.81 \pm 2.1840$ \\
\hline ZON7 & $6.031 \pm 2.0140$ & $8.436 \pm 1.9490$ & $3.774 \pm 1.9620$ & $1.835 \pm 1.8350$ & $1.754 \pm 1.7540$ & $2.198 \pm 2.1980$ & $1.813 \pm 1.8130$ \\
\hline AQUE & $21.682 \pm 2.4720$ & $28.342 \pm 2.4090$ & $4.958 \pm 1.8000$ & $1.724 \pm 1.7240$ & $1.78 \pm 1.7800$ & $2.102 \pm 2.1020$ & $2.05 \pm 1.9920$ \\
\hline SLST & $1.824 \pm 1.8240$ & $2.797 \pm 1.5800$ & $2.164 \pm 2.1640$ & $1.68 \pm 1.6800$ & $2.079 \pm 1.8300$ & $2.172 \pm 2.1720$ & $1.968 \pm 1.9680$ \\
\hline GTES & NA & NA & $1.639 \pm 1.6390$ & $1.661 \pm 1.6610$ & $1.769 \pm 1.7690$ & $2.782 \pm 2.0200$ & $1.92 \pm 1.9200$ \\
\hline VINE & $7.77 \pm 2.0590$ & $9.546 \pm 1.8420$ & $1.687 \pm 1.6870$ & $1.672 \pm 1.6720$ & $1.783 \pm 1.7830$ & $2.176 \pm 2.1760$ & $1.917 \pm 1.9170$ \\
\hline BVA & $1.865 \pm 1.8650$ & $17.057 \pm 2.0810$ & $1.635 \pm 1.6350$ & $1.687 \pm 1.6870$ & $2.046 \pm 1.8070$ & $2.15 \pm 2.1500$ & $1.891 \pm 1.8910$ \\
\hline VET & $7.03 \pm 2.6860$ & $20.683 \pm 2.1920$ & $1.628 \pm 1.6280$ & $1.61 \pm 1.6100$ & $1.787 \pm 1.7870$ & NA & $1.865 \pm 1.8650$ \\
\hline
\end{tabular}




\section{Surface Water Monitoring}

Table 7-4. Storm water runoff, detected nonradioactive parameters, Livermore site, 1995.

\begin{tabular}{|c|c|c|c|c|c|c|c|c|c|}
\hline Parameter & $\begin{array}{c}\text { Storm } \\
\text { date }\end{array}$ & ALPE & ALPO(a) & ASS2 & ASW & CDB & CDB2 & GRNE & WPDC \\
\hline \multicolumn{10}{|c|}{ Metals and minerals and others (mg/L) } \\
\hline \multirow[t]{4}{*}{ Aluminum } & $3 / 2$ & $<0.2$ & & & $<0.2$ & $<0.2$ & & $<0.2$ & $<0.2$ \\
\hline & $3 / 3$ & & & $<0.2$ & & & $<0.2$ & & \\
\hline & $5 / 13$ & $<0.2$ & & $<0.2$ & $<0.2$ & $<0.2$ & $<0.2$ & $<0.2$ & $<0.2$ \\
\hline & $12 / 11$ & $<0.2$ & $<0.2$ & $<0.2$ & $<0.2$ & 0.3 & $<0.2$ & $<0.2$ & $<0.2$ \\
\hline \multirow[t]{4}{*}{ Antimony } & $3 / 2$ & $<0.06$ & & & $<0.06$ & $<0.06$ & & $<0.06$ & $<0.06$ \\
\hline & $3 / 3$ & & & $<0.06$ & & & $<0.06$ & & \\
\hline & $5 / 13$ & $<0.06$ & & $<0.06$ & $<0.06$ & $<0.06$ & $<0.06$ & $<0.06$ & $<0.06$ \\
\hline & $12 / 11$ & 0.009 & $<0.005$ & $<0.005$ & $<0.005$ & $<0.005$ & 0.71 & $<0.005$ & $<0.005$ \\
\hline \multirow[t]{4}{*}{ Arsenic } & $3 / 2$ & 0.0029 & & & $<0.002$ & 0.003 & & 0.0039 & 0.0053 \\
\hline & $3 / 3$ & & & 0.0029 & & & 0.0042 & & \\
\hline & $5 / 13$ & 0.0044 & & 0.0041 & $<0.002$ & 0.0022 & 0.0044 & 0.0066 & 0.0049 \\
\hline & $12 / 11$ & $<0.005$ & $<0.005$ & $<0.005$ & $<0.005$ & $<0.005$ & 0.78 & $<0.005$ & $<0.005$ \\
\hline \multirow[t]{4}{*}{ Barium } & $3 / 2$ & 0.1 & & & 0.029 & 0.086 & & 0.15 & 0.099 \\
\hline & $3 / 3$ & & & 0.11 & & & 0.11 & & \\
\hline & $5 / 13$ & 0.084 & & 0.12 & 0.042 & 0.048 & 0.11 & 0.24 & 0.17 \\
\hline & $12 / 11$ & 0.17 & 0.43 & 0.11 & 0.15 & 0.04 & 1 & 1.5 & 0.23 \\
\hline \multirow[t]{4}{*}{ Beryllium } & $3 / 2$ & 0.00054 & & & $<0.0005$ & $<0.0005$ & & $<0.0005$ & $<0.0005$ \\
\hline & $3 / 3$ & & & $<0.0005$ & & & $<0.0005$ & & \\
\hline & $5 / 13$ & $<0.0005$ & & $<0.0005$ & $<0.0005$ & $<0.0005$ & $<0.0005$ & 0.00069 & 0.00057 \\
\hline & $12 / 11$ & 0.002 & 0.0012 & $<0.0005$ & $<0.0005$ & $<0.0005$ & 0.86 & 0.0042 & $<0.0005$ \\
\hline \multirow[t]{4}{*}{ Bicarbonate alk (as $\mathrm{CaCO}_{3}$ ) } & $3 / 2$ & 130 & & & 10 & 9.5 & & 42 & 10 \\
\hline & $3 / 3$ & & & 70 & & & 17 & & \\
\hline & $5 / 13$ & 42 & & 19 & 12 & 7.6 & 19 & 38 & 18 \\
\hline & $12 / 11$ & 21 & 180 & 11 & 11 & 11 & 17 & 51 & 22 \\
\hline \multirow[t]{4}{*}{ Boron } & $3 / 2$ & 4.1 & & & $<0.1$ & $<0.1$ & & 0.23 & $<0.1$ \\
\hline & $3 / 3$ & & & 0.45 & & & $<0.1$ & & \\
\hline & $5 / 13$ & 1.5 & & $<0.1$ & $<0.1$ & $<0.1$ & $<0.1$ & 0.21 & 0.14 \\
\hline & $12 / 11$ & $<0.1$ & $<0.1$ & $<0.1$ & $<0.1$ & $<0.1$ & 0.9 & 0.4 & 0.1 \\
\hline \multirow[t]{4}{*}{ Cadmium } & $3 / 2$ & $<0.0005$ & & & $<0.0005$ & 0.00073 & & $<0.0005$ & $<0.0005$ \\
\hline & $3 / 3$ & & & $<0.0005$ & & & 0.0011 & & \\
\hline & $5 / 13$ & $<0.0005$ & & 0.0017 & $<0.0005$ & 0.0015 & 0.0011 & $<0.0005$ & $<0.0005$ \\
\hline & $12 / 11$ & $<0.001$ & $<0.001$ & $<0.001$ & $<0.001$ & $<0.001$ & 0.95 & $<0.001$ & $<0.001$ \\
\hline
\end{tabular}


Table 7-4. Storm water runoff, detected nonradioactive parameters, Livermore site, 1995 (continued).

\begin{tabular}{|c|c|c|c|c|c|c|c|c|c|}
\hline Parameter & $\begin{array}{c}\text { Storm } \\
\text { date }\end{array}$ & ALPE & ALPO(a) & ASS2 & ASW & CDB & CDB2 & GRNE & WPDC \\
\hline \multicolumn{10}{|c|}{ Metals and minerals and others (mg/L) (continued) } \\
\hline \multirow[t]{4}{*}{ Calcium } & $3 / 2$ & 32 & & & 3.6 & 5.3 & & 20 & 4.3 \\
\hline & $3 / 3$ & & & 32 & & & 6.3 & & \\
\hline & $5 / 13$ & 11 & & 5.1 & 3.4 & 2.5 & 6.2 & 10 & 5.6 \\
\hline & $12 / 11$ & 9 & 48 & 3.7 & 3.5 & 4.8 & 5.5 & 4.4 & 7.5 \\
\hline \multirow[t]{4}{*}{ Chemical oxygen demand } & $3 / 2$ & 37 & & & 24 & 31 & & 44 & 22 \\
\hline & $3 / 3$ & & & 20 & & & 29 & & \\
\hline & $5 / 13$ & 38 & & 18 & 16 & 18 & 25 & 23 & 14 \\
\hline & $12 / 11$ & 41 & 95 & 45 & 43 & 49 & 61 & 76 & 59 \\
\hline \multirow[t]{4}{*}{ Chloride } & $3 / 2$ & 170 & & & 1 & 1.4 & & 16 & 1.8 \\
\hline & $3 / 3$ & & & 35 & & & 2.2 & & \\
\hline & $5 / 13$ & 47 & & 3.9 & 3 & 2.5 & 5.2 & 7 & 7.8 \\
\hline & $12 / 11$ & 19 & 160 & 14 & 11 & 12 & 14 & 22 & 22 \\
\hline \multirow[t]{4}{*}{ Chromium } & $3 / 2$ & 0.017 & & & $<0.01$ & 0.015 & & 0.016 & 0.017 \\
\hline & $3 / 3$ & & & $<0.01$ & & & 0.021 & & \\
\hline & $5 / 13$ & 0.015 & & 0.018 & $<0.01$ & $<0.01$ & 0.017 & 0.026 & 0.025 \\
\hline & $12 / 11$ & 0.044 & 0.05 & 0.028 & 0.034 & 0.012 & 1 & 0.2 & 0.047 \\
\hline \multirow[t]{8}{*}{ Copper } & $3 / 2$ & $<0.05$ & & & $<0.05$ & $<0.05$ & & $<0.05$ & $<0.05$ \\
\hline & $3 / 2$ & 0.021 & & & 0.015 & 0.028 & & 0.017 & 0.031 \\
\hline & $3 / 3$ & & & $<0.05$ & & & $<0.05$ & & \\
\hline & $3 / 3$ & & & 0.013 & & & 0.026 & & \\
\hline & $5 / 13$ & $<0.05$ & & $<0.05$ & $<0.05$ & $<0.05$ & $<0.05$ & $<0.05$ & $<0.05$ \\
\hline & $5 / 13$ & 0.015 & & 0.019 & 0.01 & 0.012 & 0.019 & 0.017 & 0.016 \\
\hline & $12 / 11$ & 0.022 & 0.06 & 0.018 & 0.025 & 0.012 & 1 & 0.09 & 0.029 \\
\hline & $12 / 11$ & $<0.05$ & $<0.05$ & $<0.05$ & $<0.05$ & $<0.05$ & $<0.05$ & $<0.05$ & $<0.05$ \\
\hline \multirow[t]{5}{*}{ Fluoride } & $3 / 2$ & 0.51 & & & $<0.05$ & $<0.05$ & & 0.11 & $<0.05$ \\
\hline & $3 / 3$ & & & 0.09 & & & $<0.05$ & & \\
\hline & $5 / 13$ & 0.31 & & 0.068 & $<0.05$ & $<0.05$ & 0.06 & 0.22 & 0.079 \\
\hline & $5 / 13$ & 0.31 & & 0.068 & $<0.05$ & $<0.05$ & 0.06 & 0.22 & 0.079 \\
\hline & $12 / 11$ & 0.07 & 0.45 & $<0.05$ & $<0.05$ & $<0.05$ & 0.062 & 0.11 & 0.069 \\
\hline \multirow[t]{5}{*}{ Iron } & $3 / 2$ & $<0.1$ & & & $<0.1$ & $<0.1$ & & $<0.1$ & $<0.1$ \\
\hline & $3 / 2$ & 6.4 & & & 2 & 6.2 & & 7.4 & 7.9 \\
\hline & $3 / 3$ & & & $<0.1$ & & & $<0.1$ & & \\
\hline & $3 / 3$ & & & 4 & & & 8.3 & & \\
\hline & $5 / 13$ & $<0.1$ & & $<0.1$ & $<0.1$ & $<0.1$ & $<0.1$ & $<0.1$ & $<0.1$ \\
\hline
\end{tabular}


Table 7-4. Storm water runoff, detected nonradioactive parameters, Livermore site, 1995. (continued)

\begin{tabular}{|c|c|c|c|c|c|c|c|c|c|}
\hline Parameter & $\begin{array}{c}\text { Storm } \\
\text { date }\end{array}$ & ALPE & ALPO(a) & ASS2 & ASW & CDB & CDB2 & GRNE & WPDC \\
\hline \multicolumn{10}{|c|}{ Metals and minerals and others (mg/L) (continued) } \\
\hline \multirow[t]{3}{*}{ Iron } & $5 / 13$ & 5 & & 8.4 & 2.5 & 2.8 & 6.7 & 14 & 12 \\
\hline & $12 / 11$ & 14 & 22 & 8.4 & 11 & 1.6 & 2.2 & 120 & 18 \\
\hline & $12 / 11$ & $<0.1$ & $<0.1$ & 0.15 & 0.15 & 0.25 & 0.18 & 0.15 & 0.1 \\
\hline \multirow[t]{4}{*}{ Lead } & $3 / 2$ & 0.0086 & & & 0.0051 & 0.012 & & 0.0034 & 0.0086 \\
\hline & $3 / 3$ & & & 0.0039 & & & 0.013 & & \\
\hline & $5 / 13$ & 0.0067 & & 0.0071 & 0.003 & 0.0051 & 0.0081 & 0.0076 & 0.0085 \\
\hline & $12 / 11$ & 0.014 & 0.014 & 0.007 & 0.011 & $<0.005$ & 1.1 & 0.03 & $<0.005$ \\
\hline \multirow[t]{4}{*}{ Magnesium } & $3 / 2$ & 15 & & & 1 & 1.2 & & 6 & 1.3 \\
\hline & $3 / 3$ & & & 14 & & & 1.8 & & \\
\hline & $5 / 13$ & 4.1 & & 1.4 & 0.97 & 0.57 & 1.8 & 2.8 & 1.6 \\
\hline & $12 / 11$ & 2.2 & 15 & 1.1 & 1.1 & 1.4 & 1.8 & 1.5 & 2.2 \\
\hline \multirow[t]{8}{*}{ Manganese } & $3 / 2$ & $<0.03$ & & & $<0.03$ & $<0.03$ & & $<0.03$ & $<0.03$ \\
\hline & $3 / 2$ & 0.15 & & & 0.041 & 0.16 & & 0.11 & 0.16 \\
\hline & $3 / 3$ & & & $<0.03$ & & & $<0.03$ & & \\
\hline & $3 / 3$ & & & 0.08 & & & 0.14 & & \\
\hline & $5 / 13$ & $<0.03$ & & $<0.03$ & $<0.03$ & $<0.03$ & $<0.03$ & $<0.03$ & $<0.03$ \\
\hline & $5 / 13$ & 0.1 & & 0.17 & 0.049 & 0.062 & 0.12 & 0.2 & 0.23 \\
\hline & $12 / 11$ & 0.37 & 0.7 & 0.18 & 0.23 & 0.07 & 1.1 & 1.9 & 0.33 \\
\hline & $12 / 11$ & 0.066 & 0.082 & $<0.03$ & $<0.03$ & 0.058 & 0.08 & $<0.03$ & 0.061 \\
\hline \multirow[t]{8}{*}{ Nickel } & $3 / 2$ & $<0.1$ & & & $<0.1$ & $<0.1$ & & $<0.1$ & $<0.1$ \\
\hline & $3 / 2$ & 0.025 & & & 0.0067 & 0.017 & & 0.017 & 0.018 \\
\hline & $3 / 3$ & & & $<0.1$ & & & $<0.1$ & & \\
\hline & $3 / 3$ & & & 0.011 & & & 0.021 & & \\
\hline & $5 / 13$ & $<0.1$ & & $<0.1$ & $<0.1$ & $<0.1$ & $<0.1$ & $<0.1$ & $<0.1$ \\
\hline & $5 / 13$ & 0.018 & & 0.02 & 0.0061 & 0.0082 & 0.019 & $<0.005$ & 0.023 \\
\hline & $12 / 11$ & 0.18 & 0.35 & 0.035 & 0.031 & 0.06 & 1 & 0.28 & 0.036 \\
\hline & $12 / 11$ & $<0.1$ & $<0.1$ & $<0.1$ & $<0.1$ & $<0.1$ & $<0.1$ & $<0.1$ & $<0.1$ \\
\hline \multirow[t]{4}{*}{ Nitrate (as N) } & $3 / 2$ & 6.7 & & & 2.5 & 6.4 & & 31 & 4 \\
\hline & $3 / 3$ & & & 4.1 & & & 2.9 & & \\
\hline & $5 / 13$ & 17 & & 3.6 & 1.9 & 1.5 & 2.7 & 11 & 2.8 \\
\hline & $12 / 11$ & 4.3 & 4.8 & $<5$ & $<5$ & 4.4 & $<5$ & 9.2 & $<5$ \\
\hline \multirow[t]{2}{*}{ Ortho-phosphate } & $5 / 13$ & 1.4 & & $<1$ & $<1$ & $<1$ & $<1$ & $<1$ & $<1$ \\
\hline & $12 / 11$ & $<10$ & $<10$ & $<10$ & $<10$ & $<10$ & $<10$ & $<10$ & $<10$ \\
\hline
\end{tabular}


Table 7-4. Storm water runoff, detected nonradioactive parameters, Livermore site, 1995 (continued).

\begin{tabular}{|c|c|c|c|c|c|c|c|c|c|}
\hline Parameter & $\begin{array}{c}\text { Storm } \\
\text { date }\end{array}$ & ALPE & ALPO(a) & ASS2 & ASW & CDB & CDB2 & GRNE & WPDC \\
\hline \multicolumn{10}{|c|}{ Metals and minerals and others (mg/L) (continued) } \\
\hline \multirow[t]{4}{*}{ Potassium } & $3 / 2$ & 2.8 & & & 1.5 & 1.4 & & 2.4 & 1.2 \\
\hline & $3 / 3$ & & & 3.5 & & & 1.5 & & \\
\hline & $5 / 13$ & 3.1 & & 2.3 & 1.8 & 1.2 & 2 & 1.6 & 1.3 \\
\hline & $12 / 11$ & 1.3 & 3.7 & 2.3 & 2 & 2.3 & 2.1 & $<1$ & 2.4 \\
\hline \multirow[t]{4}{*}{ Selenium } & $3 / 2$ & $<0.002$ & & & $<0.002$ & $<0.002$ & & $<0.002$ & $<0.002$ \\
\hline & $3 / 3$ & & & $<0.002$ & & & $<0.002$ & & \\
\hline & $5 / 13$ & $<0.002$ & & $<0.002$ & $<0.002$ & $<0.002$ & $<0.002$ & $<0.002$ & $<0.002$ \\
\hline & $12 / 11$ & $<0.005$ & $<0.005$ & $<0.005$ & $<0.005$ & $<0.005$ & 0.65 & $<0.005$ & $<0.005$ \\
\hline \multirow[t]{4}{*}{ Silver } & $3 / 2$ & $<0.0005$ & & & $<0.0005$ & $<0.0005$ & & $<0.0005$ & $<0.0005$ \\
\hline & $3 / 3$ & & & $<0.0005$ & & & $<0.0005$ & & \\
\hline & $5 / 13$ & 0.0029 & & 0.00095 & 0.00098 & 0.0014 & 0.0012 & 0.0016 & 0.001 \\
\hline & $12 / 11$ & $<0.005$ & 0.011 & $<0.005$ & $<0.005$ & $<0.005$ & 0.81 & $<0.005$ & $<0.005$ \\
\hline \multirow[t]{4}{*}{ Sodium } & $3 / 2$ & 160 & & & 3 & 2.3 & & 19 & 3.6 \\
\hline & $3 / 3$ & & & 39 & & & 4.2 & & \\
\hline & $5 / 13$ & 53 & & 5.2 & 3.4 & 2.4 & 5.4 & 13 & 7.9 \\
\hline & $12 / 11$ & 7.2 & 86 & 1.8 & 2.1 & 2.4 & 3.4 & 16 & 7.6 \\
\hline \multirow[t]{4}{*}{ Sulfate } & $3 / 2$ & 110 & & & 2.2 & 3.3 & & 19 & 2.5 \\
\hline & $3 / 3$ & & & 79 & & & 5.1 & & \\
\hline & $5 / 13$ & 40 & & 2.3 & 1.8 & 1.4 & 4.8 & 6.7 & 8.1 \\
\hline & $12 / 11$ & 27 & 130 & 21 & 18 & 26 & 28 & 29 & 48 \\
\hline \multirow[t]{4}{*}{ Thallium } & $3 / 2$ & $<0.005$ & & & $<0.005$ & $<0.005$ & & $<0.005$ & $<0.005$ \\
\hline & $3 / 3$ & & & $<0.005$ & & & $<0.005$ & & \\
\hline & $5 / 13$ & $<0.001$ & & $<0.001$ & $<0.001$ & $<0.001$ & $<0.001$ & $<0.001$ & $<0.001$ \\
\hline & $12 / 11$ & $<0.001$ & $<0.001$ & $<0.02$ & $<0.001$ & $<0.001$ & 0.89 & $<0.001$ & $<0.001$ \\
\hline \multirow[t]{4}{*}{ Total alkalinity $\left(\mathrm{as} \mathrm{CaCO}_{3}\right)$} & $3 / 2$ & 130 & & & 10 & 9.5 & & 42 & 10 \\
\hline & $3 / 3$ & & & 70 & & & 17 & & \\
\hline & $5 / 13$ & 42 & & 19 & 12 & 7.6 & 19 & 38 & 18 \\
\hline & $12 / 11$ & 21 & 180 & 11 & 11 & 11 & 17 & 51 & 22 \\
\hline \multirow[t]{4}{*}{ Total dissolved solids (TDS) } & $3 / 2$ & 590 & & & 37 & 48 & & 170 & 40 \\
\hline & $3 / 3$ & & & 270 & & & 53 & & \\
\hline & $5 / 13$ & 250 & & 69 & 39 & 38 & 77 & 130 & 89 \\
\hline & $12 / 11$ & 110 & 450 & 45 & 55 & 61 & 57 & 74 & 85 \\
\hline
\end{tabular}




\section{Surface Water Monitoring}

Table 7-4. Storm water runoff, detected nonradioactive parameters, Livermore site, 1995 (continued).

\begin{tabular}{|c|c|c|c|c|c|c|c|c|c|}
\hline Parameter & $\begin{array}{l}\text { Storm } \\
\text { date }\end{array}$ & ALPE & ALPO(a) & ASS2 & ASW & CDB & CDB2 & GRNE & WPDC \\
\hline \multicolumn{10}{|c|}{ Metals and minerals and others (mg/L) (continued) } \\
\hline \multirow[t]{4}{*}{ Total hardness (as $\mathrm{CaCO}_{3}$ ) } & $3 / 2$ & 140 & & & 13 & 18 & & 75 & 16 \\
\hline & $3 / 3$ & & & 140 & & & 23 & & \\
\hline & $5 / 13$ & 44 & & 18 & 12 & 8.6 & 23 & 37 & 21 \\
\hline & $12 / 11$ & 32 & 180 & 14 & 13 & 18 & 21 & 17 & 28 \\
\hline \multirow[t]{4}{*}{ Total organic carbon (TOC) } & $3 / 2$ & 15 & & & 6.4 & 11 & & 9.3 & 6.4 \\
\hline & $3 / 3$ & & & 6.2 & & & 8.5 & & \\
\hline & $5 / 13$ & 15 & & 6.3 & 5.6 & 6.4 & 9.5 & 7.9 & 5.8 \\
\hline & $12 / 11$ & 11 & 16 & 11 & 12 & 16 & 21 & 16 & 20 \\
\hline \multirow[t]{2}{*}{ Total suspended solids (TSS) } & $5 / 13$ & 120 & & 64 & 37 & 39 & 86 & 150 & 210 \\
\hline & $12 / 11$ & 200 & 1000 & 210 & 310 & 45 & 210 & 2300 & 400 \\
\hline \multirow[t]{8}{*}{ Zinc } & $3 / 2$ & $<0.05$ & & & 0.056 & 0.16 & & 0.11 & 0.075 \\
\hline & $3 / 2$ & 0.054 & & & 0.095 & 0.26 & & 0.26 & 0.19 \\
\hline & $3 / 3$ & & & $<0.05$ & & & $<0.05$ & & \\
\hline & $3 / 3$ & & & 0.1 & & & 0.14 & & \\
\hline & $5 / 13$ & $<0.05$ & & $<0.05$ & $<0.05$ & 0.084 & $<0.05$ & $<0.05$ & $<0.05$ \\
\hline & $5 / 13$ & 0.037 & & 0.1 & 0.079 & 0.14 & 0.083 & 0.079 & 0.14 \\
\hline & $12 / 11$ & 0.09 & 0.12 & 0.37 & 0.13 & 0.18 & 1 & 0.4 & 0.21 \\
\hline & $12 / 11$ & $<0.05$ & $<0.05$ & 0.13 & $<0.05$ & 0.14 & $<0.05$ & $<0.05$ & $<0.05$ \\
\hline \multicolumn{10}{|l|}{ General indicator parameters } \\
\hline \multirow[t]{4}{*}{$\mathrm{pH}$ (Units) } & $3 / 2$ & 8 & & & 6.7 & 6.4 & & 7.3 & 6.6 \\
\hline & $3 / 3$ & & & 7.7 & & & 7 & & \\
\hline & $5 / 13$ & 7.6 & & 6.9 & 6.8 & 6.5 & 6.9 & 7.7 & 6.9 \\
\hline & $12 / 11$ & 7.6 & 7.4 & 6.8 & 6.8 & 6.6 & 6.8 & 8.4 & 6.9 \\
\hline \multirow{4}{*}{$\begin{array}{l}\text { Specific conductance } \\
(\mu \mathrm{mho} / \mathrm{cm})\end{array}$} & $3 / 2$ & 910 & & & 41 & 51 & & 230 & 48 \\
\hline & $3 / 3$ & & & 410 & & & 62 & & \\
\hline & $5 / 13$ & 330 & & 61 & 43 & 31 & 70 & 120 & 82 \\
\hline & $12 / 11$ & 92 & 730 & 38 & 57 & 54 & 59 & 100 & 120 \\
\hline
\end{tabular}


Table 7-4. Storm water runoff, detected nonradioactive parameters, Livermore site, 1995 (concluded).

\begin{tabular}{|c|c|c|c|c|c|c|c|c|c|}
\hline Parameter & $\begin{array}{c}\text { Storm } \\
\text { date }\end{array}$ & ALPE & ALPO(a) & ASS2 & ASW & CDB & CDB2 & GRNE & WPDC \\
\hline \multicolumn{10}{|l|}{ Bioassay (percent) ${ }^{(\mathbf{b})}$} \\
\hline Aquatic bioassay, LC-50 & $12 / 11$ & & & & & & & & \\
\hline Control & & & & & & & & & 90 \\
\hline $1 \%$ dilution & & & & & & & & & 98 \\
\hline $3 \%$ dilution & & & & & & & & & 100 \\
\hline $10 \%$ dilution & & & & & & & & & 55 \\
\hline $30 \%$ dilution & & & & & & & & & 93 \\
\hline $100 \%$ (undiluted) & & & & & & & & & 85 \\
\hline Aquatic bioassay, survival & $12 / 11$ & 100 & 95 & & & & & 100 & 95 \\
\hline \multicolumn{10}{|l|}{ EPA Method $615(\mu \mathrm{g} / \mathrm{L})$} \\
\hline \multirow[t]{4}{*}{$2,4,5-\mathrm{T}$} & $3 / 2$ & 1.4 & & & $<5$ & $<5$ & & $<5$ & $<5$ \\
\hline & $3 / 3$ & & & $<5$ & & & $<5$ & & \\
\hline & $5 / 13$ & $<50$ & & $<0.5$ & $<5$ & $<5$ & $<0.5$ & $<2500$ & $<5$ \\
\hline & $12 / 11$ & $<0.5$ & $<0.5$ & $<0.5$ & $<0.5$ & $<0.5$ & $<0.5$ & $<0.5$ & $<0.5$ \\
\hline \multirow[t]{4}{*}{$2,4-D$} & $3 / 2$ & 120 & & & $<10$ & $<10$ & & $<10$ & $<10$ \\
\hline & $3 / 3$ & & & $<10$ & & & $<10$ & & \\
\hline & $5 / 13$ & 1000 & & $<0.5$ & 7.2 & 14 & $<0.5$ & 17000 & 13 \\
\hline & $12 / 11$ & $<1$ & $<1$ & $<1$ & $<1$ & $<1$ & $<1$ & $<1$ & $<1$ \\
\hline \multicolumn{10}{|l|}{ EPA Method $624(\mu \mathrm{g} / \mathrm{L})$} \\
\hline \multirow[t]{4}{*}{ Chloroform } & $3 / 2$ & $<1$ & & & $<1$ & $<1$ & & $<1$ & $<1$ \\
\hline & $3 / 3$ & & & $<1$ & & & $<1$ & & \\
\hline & $5 / 13$ & 1.9 & & $<1$ & $<1$ & $<1$ & $<1$ & $<1$ & $<1$ \\
\hline & $12 / 11$ & $<1$ & $<1$ & $<1$ & $<1$ & $<1$ & $<1$ & $<1$ & $<1$ \\
\hline
\end{tabular}

a Location ALPO was added in the fall; therefore, there are no 1995 data prior to 12/11/95.

b In accordance with NPDES No. CA0030023/WDR 95-174, bioassay is conducted only at selected locations. 
Table 7-5. Summary of nondetects in storm water runoff, for Livermore site nonradioactive parameters .

\begin{tabular}{|c|c|c|}
\hline Parameter & $\begin{array}{c}\text { Number of } \\
\text { samples }\end{array}$ & $\begin{array}{l}\text { Detection } \\
\text { limit }\end{array}$ \\
\hline \multicolumn{3}{|l|}{ Metals and minerals and others (mg/L) } \\
\hline Antimony & 15 & $<0.06$ \\
\hline Bromide & 15 & $<5$ \\
\hline Carbonate alk (as $\left.\mathrm{CaCO}_{3}\right)$ & 23 & $<1$ \\
\hline Cobalt & 1 & $<0.05$ \\
\hline Chromium (VI) & 16 & $<0.01$ \\
\hline Hydroxide alk (as $\mathrm{CaCO}_{3}$ ) & 23 & $<1$ \\
\hline Mercury & 14 & $<0.0002$ \\
\hline Molybdenum & 1 & $<0.05$ \\
\hline Nitrite (as $\mathrm{NO}_{2}$ ) & 15 & $<5$ \\
\hline Oil and grease & 23 & $<5$ \\
\hline Selenium & 15 & $<0.005$ \\
\hline Surfactant & 23 & $<0.5$ \\
\hline Thallium & 15 & $<0.005$ \\
\hline Tin & 1 & $<0.005$ \\
\hline Diesel fuel ( $\mu \mathrm{g} / \mathrm{L})$ & 1 & $<50$ \\
\hline Gasoline fingerprint $(\mu \mathrm{g} / \mathrm{L})$ & 1 & $<50$ \\
\hline \multicolumn{3}{|l|}{ EPA Method 504 (mg/L) } \\
\hline Ethylene dibromide & 1 & $<0.00001$ \\
\hline \multicolumn{3}{|l|}{ EPA Method $601(\mu \mathrm{g} / \mathrm{L})$} \\
\hline 1,1,1-Trichloroethane & 1 & $<0.5$ \\
\hline 1,1,2,2-Tetrachloroethane & 1 & $<0.5$ \\
\hline 1,1,2-Trichloroethane & 1 & $<0.5$ \\
\hline 1,1-Dichloroethane & 1 & $<0.5$ \\
\hline 1,1-Dichloroethene & 1 & $<0.5$ \\
\hline 1,2-Dichlorobenzene & 1 & $<0.5$ \\
\hline 1,2-Dichloroethane & 1 & $<0.5$ \\
\hline 1,2-Dichloroethene (total) & 1 & $<0.5$ \\
\hline 1,2-Dichloropropane & 1 & $<0.5$ \\
\hline 1,3-Dichlorobenzene & 1 & $<0.5$ \\
\hline 1,4-Dichlorobenzene & 1 & $<0.5$ \\
\hline 2-Chloroethylvinylether & 1 & $<0.5$ \\
\hline Bromodichloromethane & 1 & $<0.5$ \\
\hline Bromoform & 1 & $<0.5$ \\
\hline Bromomethane & 1 & $<0.5$ \\
\hline Carbon tetrachloride & 1 & $<0.5$ \\
\hline
\end{tabular}


Table 7-5. Summary of nondetects in storm water runoff, for Livermore site nonradioactive parameters (continued).

\begin{tabular}{|c|c|c|}
\hline Parameter & $\begin{array}{c}\text { Number of } \\
\text { samples }\end{array}$ & $\begin{array}{c}\text { Detection } \\
\text { limit }\end{array}$ \\
\hline \multicolumn{3}{|l|}{ EPA Method $601(\mu \mathrm{g} / \mathrm{L})$ (continued) } \\
\hline Chlorobenzene & 1 & $<0.5$ \\
\hline Chloroethane & 1 & $<0.5$ \\
\hline Chloromethane & 1 & $<0.5$ \\
\hline Dibromochloromethane & 1 & $<0.5$ \\
\hline Dichlorodifluoromethane & 1 & $<0.5$ \\
\hline Freon 113 & 1 & $<0.5$ \\
\hline Methylene chloride & 1 & $<0.5$ \\
\hline Tetrachloroethene & 1 & $<0.5$ \\
\hline Trichloroethene & 1 & $<0.5$ \\
\hline Trichlorofluoromethane & 1 & $<0.5$ \\
\hline Vinyl chloride & 1 & $<0.5$ \\
\hline cis-1,3-Dichloropropene & 1 & $<0.5$ \\
\hline trans-1,3-Dichloropropene & 1 & $<0.5$ \\
\hline \multicolumn{3}{|l|}{ EPA Method $602(\mu \mathrm{g} / \mathrm{L})$} \\
\hline 1,2-Dichlorobenzene & 1 & $<0.3$ \\
\hline 1,3-Dichlorobenzene & 1 & $<0.3$ \\
\hline 1,4-Dichlorobenzene & 1 & $<0.3$ \\
\hline Benzene & 1 & $<0.3$ \\
\hline Chlorobenzene & 1 & $<0.3$ \\
\hline Ethylbenzene & 1 & $<0.3$ \\
\hline Toluene & 1 & $<0.3$ \\
\hline Total xylene isomers & 1 & $<0.6$ \\
\hline \multicolumn{3}{|l|}{ EPA Method $608(\mu \mathrm{g} / \mathrm{L})$} \\
\hline Aldrin & 22 & $<0.05$ \\
\hline $\mathrm{BHC}$, alpha isomer & 22 & $<0.05$ \\
\hline $\mathrm{BHC}$, beta isomer & 22 & $<0.05$ \\
\hline $\mathrm{BHC}$, delta isomer & 22 & $<0.05$ \\
\hline BHC, gamma isomer (Lindane) & 22 & $<0.05$ \\
\hline Chlordane & 22 & $<0.5$ \\
\hline Dieldrin & 22 & $<0.1$ \\
\hline Endosulfan I & 22 & $<0.05$ \\
\hline Endosulfan II & 22 & $<0.1$ \\
\hline Endosulfan sulfate & 22 & $<0.1$ \\
\hline
\end{tabular}


Table 7-5. Summary of nondetects in storm water runoff, for Livermore site nonradioactive parameters (continued).

\begin{tabular}{|c|c|c|}
\hline Parameter & $\begin{array}{c}\text { Number of } \\
\text { samples }\end{array}$ & $\begin{array}{c}\text { Detection } \\
\text { limit }\end{array}$ \\
\hline \multicolumn{3}{|l|}{ EPA Method $608(\mu \mathrm{g} / \mathrm{L})$ (continued) } \\
\hline Endrin & 22 & $<0.1$ \\
\hline Endrin aldehyde & 22 & $<0.1$ \\
\hline Heptachlor & 22 & $<0.05$ \\
\hline Heptachlor epoxide & 22 & $<0.05$ \\
\hline Methoxychlor & 22 & $<0.5$ \\
\hline Toxaphene & 22 & $<1$ \\
\hline$p, p^{\prime}-D D D$ & 22 & $<0.1$ \\
\hline$p, p^{\prime}-D D E$ & 22 & $<0.1$ \\
\hline $\mathrm{p}, \mathrm{p}^{\prime}-\mathrm{DDT}$ & 22 & $<0.1$ \\
\hline \multicolumn{3}{|l|}{ EPA Method $615(\mu \mathrm{g} / \mathrm{L})$} \\
\hline \multirow[t]{4}{*}{ 2,4,5-TP (Silvex) } & 10 & 0.2 \\
\hline & 10 & 2 \\
\hline & 1 & 20 \\
\hline & 1 & 1000 \\
\hline \multirow[t]{4}{*}{ 4-(2,4-Dichlorophenoxy)butyric acid } & 10 & 2 \\
\hline & 10 & 20 \\
\hline & 1 & 200 \\
\hline & 1 & 10,000 \\
\hline \multirow[t]{4}{*}{ Dalapon } & 10 & 2 \\
\hline & 10 & 20 \\
\hline & 1 & 200 \\
\hline & 1 & 10,000 \\
\hline \multirow[t]{4}{*}{ Dicamba } & 10 & 1 \\
\hline & 10 & 10 \\
\hline & 1 & 100 \\
\hline & 1 & 5000 \\
\hline \multirow[t]{4}{*}{ Dichloroprop } & 10 & 2 \\
\hline & 10 & 20 \\
\hline & 1 & 200 \\
\hline & 1 & 10,000 \\
\hline \multirow[t]{5}{*}{ Dinoseb } & 10 & 1 \\
\hline & 10 & 5 \\
\hline & 9 & 10 \\
\hline & 1 & 100 \\
\hline & 1 & 5000 \\
\hline
\end{tabular}


Table 7-5. Summary of nondetects in storm water runoff, for Livermore site nonradioactive parameters (continued).

\begin{tabular}{|c|c|c|}
\hline Parameter & $\begin{array}{c}\text { Number of } \\
\text { samples }\end{array}$ & $\begin{array}{c}\text { Detection } \\
\text { limit }\end{array}$ \\
\hline \multicolumn{3}{|l|}{ EPA Method $615(\mu \mathrm{g} / \mathrm{L})$ (continued) } \\
\hline \multirow[t]{4}{*}{ MCPA } & 10 & 250 \\
\hline & 10 & 2500 \\
\hline & 1 & 25,000 \\
\hline & 1 & $1,200,000$ \\
\hline \multirow[t]{4}{*}{ MCPP } & 10 & 250 \\
\hline & 10 & 2500 \\
\hline & 1 & 25,000 \\
\hline & 1 & $1,200,000$ \\
\hline \multicolumn{3}{|l|}{ EPA Method $624(\mu \mathrm{g} / \mathrm{L})$} \\
\hline 1,1,1-Trichloroethane & 22 & $<1$ \\
\hline 1,1,2,2-Tetrachloroethane & 22 & $<1$ \\
\hline 1,1,2-Trichloroethane & 22 & $<1$ \\
\hline 1,1-Dichloroethane & 22 & $<1$ \\
\hline 1,1-Dichloroethene & 22 & $<1$ \\
\hline 1,2-Dichlorobenzene & 22 & $<1$ \\
\hline 1,2-Dichloroethane & 22 & $<1$ \\
\hline 1,2-Dichloroethene (total) & 22 & $<1$ \\
\hline 1,2-Dichloropropane & 22 & $<1$ \\
\hline 1,3-Dichlorobenzene & 22 & $<1$ \\
\hline 1,4-Dichlorobenzene & 22 & $<1$ \\
\hline 2-Butanone & 22 & $<40$ \\
\hline 2-Chloroethylvinylether & 22 & $<40$ \\
\hline 2-Hexanone & 22 & $<10$ \\
\hline 4-Methyl-2-pentanone & 22 & $<10$ \\
\hline Acetone & 22 & $<40$ \\
\hline Benzene & 22 & $<1$ \\
\hline Bromodichloromethane & 22 & $<1$ \\
\hline Bromoform & 22 & $<1$ \\
\hline Bromomethane & 22 & $<2$ \\
\hline Carbon disulfide & 22 & $<1$ \\
\hline Carbon tetrachloride & 22 & $<1$ \\
\hline Chlorobenzene & 22 & $<1$ \\
\hline Chloroethane & 22 & $<2$ \\
\hline
\end{tabular}


Table 7-5. Summary of nondetects in storm water runoff, for Livermore site nonradioactive parameters (continued).

\begin{tabular}{|c|c|c|}
\hline Parameter & $\begin{array}{c}\text { Number of } \\
\text { samples }\end{array}$ & $\begin{array}{c}\text { Detection } \\
\text { limit }\end{array}$ \\
\hline \multicolumn{3}{|l|}{ EPA Method $624(\mu \mathrm{g} / \mathrm{L})$ (continued) } \\
\hline Chloromethane & 22 & $<2$ \\
\hline Dibromochloromethane & 22 & $<1$ \\
\hline Dibromomethane & 22 & $<1$ \\
\hline Dichlorodifluoromethane & 22 & $<2$ \\
\hline Ethylbenzene & 22 & $<1$ \\
\hline Freon 113 & 22 & $<1$ \\
\hline Methylene chloride & 22 & $<1$ \\
\hline Styrene & 22 & $<1$ \\
\hline Tetrachloroethene & 22 & $<1$ \\
\hline Toluene & 22 & $<1$ \\
\hline Total xylene isomers & 22 & $<2$ \\
\hline Trichloroethene & 22 & $<0.5$ \\
\hline Trichlorofluoromethane & 22 & $<1$ \\
\hline Vinyl acetate & 22 & $<10$ \\
\hline Vinyl chloride & 22 & $<2$ \\
\hline cis-1,3-Dichloropropene & 22 & $<1$ \\
\hline trans-1,3-Dichloropropene & 22 & $<1$ \\
\hline \multicolumn{3}{|l|}{ EPA Method $625(\mu \mathrm{g} / \mathrm{L})$} \\
\hline 1,2,4-Trichlorobenzene & 22 & $<10$ \\
\hline 1,2-Dichlorobenzene & 22 & $<10$ \\
\hline 1,3-Dichlorobenzene & 22 & $<10$ \\
\hline 1,4-Dichlorobenzene & 22 & $<10$ \\
\hline 2,4,5-Trichlorophenol & 22 & $<10$ \\
\hline 2,4,6-Trichlorophenol & 22 & $<10$ \\
\hline 2,4-Dichlorophenol & 22 & $<10$ \\
\hline 2,4-Dimethylphenol & 22 & $<10$ \\
\hline 2,4-Dinitrophenol & 22 & $<50$ \\
\hline 2,4-Dinitrotoluene & 22 & $<10$ \\
\hline 2,6-Dinitrotoluene & 22 & $<10$ \\
\hline 2-Chloronaphthalene & 22 & $<10$ \\
\hline 2-Chlorophenol & 22 & $<10$ \\
\hline 2-Methylphenol & 22 & $<10$ \\
\hline
\end{tabular}

...continued on next page 
Table 7-5. Summary of nondetects in storm water runoff, for Livermore site nonradioactive parameters (continued).

\begin{tabular}{|c|c|c|}
\hline Parameter & $\begin{array}{c}\text { Number of } \\
\text { samples }\end{array}$ & $\begin{array}{c}\text { Detection } \\
\text { limit }\end{array}$ \\
\hline \multicolumn{3}{|l|}{ EPA Method $625(\mu \mathrm{g} / \mathrm{L})$ (continued) } \\
\hline 2-Methyl-4,6-dinitrophenol & 22 & $<50$ \\
\hline 2-Methylnaphthalene & 22 & $<10$ \\
\hline 2-Nitroaniline & 22 & $<50$ \\
\hline 2-Nitrophenol & 22 & $<10$ \\
\hline 3,3'-Dichlorobenzidine & 22 & $<20$ \\
\hline 3-Nitroaniline & 22 & $<50$ \\
\hline 4-Bromophenylphenylether & 22 & $<10$ \\
\hline 4-Chloro-3-methylphenol & 22 & $<20$ \\
\hline 4-Chloroaniline & 22 & $<20$ \\
\hline 4-Chlorophenylphenylether & 22 & $<10$ \\
\hline 4-Nitroaniline & 22 & $<50$ \\
\hline 4-Nitrophenol & 22 & $<50$ \\
\hline Acenaphthene & 22 & $<10$ \\
\hline Acenaphthylene & 22 & $<10$ \\
\hline Anthracene & 22 & $<10$ \\
\hline Benzo(a)anthracene & 22 & $<10$ \\
\hline Benzo(a)pyrene & 22 & $<10$ \\
\hline Benzo(b)fluoranthene & 22 & $<10$ \\
\hline Benzo(g,h,i)perylene & 22 & $<10$ \\
\hline Benzo(k)fluoranthene & 22 & $<10$ \\
\hline Benzoic Acid & 22 & $<50$ \\
\hline Benzyl Alcohol & 22 & $<20$ \\
\hline Bis(2-chloroethoxy)methane & 22 & $<10$ \\
\hline Bis(2-chloroethyl)ether & 22 & $<10$ \\
\hline Bis(2-chloroisopropyl)ether & 22 & $<10$ \\
\hline Bis(2-ethylhexyl)phthalate & 22 & $<10$ \\
\hline Butylbenzylphthalate & 22 & $<10$ \\
\hline Chrysene & 22 & $<10$ \\
\hline Di-n-butylphthalate & 22 & $<10$ \\
\hline Di-n-octylphthalate & 22 & $<10$ \\
\hline Dibenzo(a,h)anthracene & 22 & $<10$ \\
\hline
\end{tabular}

...concluded on next page 
Table 7-5. Summary of nondetects in storm water runoff, for Livermore site nonradioactive parameters (concluded).

\begin{tabular}{|c|c|c|}
\hline Parameter & $\begin{array}{c}\text { Number of } \\
\text { samples }\end{array}$ & $\begin{array}{c}\text { Detection } \\
\text { limit }\end{array}$ \\
\hline \multicolumn{3}{|c|}{ EPA Method $625(\mu \mathrm{g} / \mathrm{L})$ (continued) } \\
\hline Dibenzofuran & 22 & $<10$ \\
\hline Diethylphthalate & 22 & $<10$ \\
\hline Dimethylphthalate & 22 & $<10$ \\
\hline Fluoranthene & 22 & $<10$ \\
\hline Fluorene & 22 & $<10$ \\
\hline Hexachlorobenzene & 22 & $<10$ \\
\hline Hexachlorobutadiene & 22 & $<10$ \\
\hline Hexachlorocyclopentadiene & 22 & $<10$ \\
\hline Hexachloroethane & 22 & $<10$ \\
\hline Indeno(1,2,3-c,d)pyrene & 22 & $<10$ \\
\hline Isophorone & 22 & $<10$ \\
\hline N-Nitrosodi-n-propylamine & 22 & $<10$ \\
\hline N-Nitrosodiphenylamine & 22 & $<10$ \\
\hline Naphthalene & 22 & $<10$ \\
\hline Nitrobenzene & 22 & $<10$ \\
\hline Pentachlorophenol & 22 & $<50$ \\
\hline Phenanthrene & 22 & $<10$ \\
\hline Phenol & 22 & $<10$ \\
\hline Pyrene & 22 & $<10$ \\
\hline $\mathrm{m}$ - and $\mathrm{p}$-Cresol & 22 & $<10$ \\
\hline
\end{tabular}



We obtained representative samples of ground water from monitoring wells by following written protocols contained in LLNL Livermore Site and Site 300 Environmental Restoration Project Standard Operating Procedures (Dibley and Depue 1995). The written protocols cover sampling techniques and specific information for the analytes that we routinely search for in ground water. We applied different sampling techniques to different wells depending on their construction, that is, whether they were fitted with submersible pumps, or had to be bailed, or contained Barcad devices, where we used pressurized nitrogen gas to extract water samples.

Typically, sampling technologists purged wells of standing water and waited for the wells to recover before they obtained water samples. They wore disposable vinyl gloves to prevent accidental contamination during sampling. They cleaned $\mathrm{pH}$ and depth-to-water probes with deionized water after each use. For quality assurance purposes, they obtained field blank samples and equipment blank samples to test the cleanliness of the sampling methods. They used clean sample containers and, where required, they used ultrapure chemicals (mostly acids) to preserve the samples. Off-site laboratories performed most of the water analyses under contract with LLNL. LLNL personnel primarily measured tritium activity. The analytical laboratories pre-acidified some of the sample containers for preservation purposes, but we halted this procedure after we detected phenols in some field blanks.

In Table 8-1, we list the inorganic and radioactive constituents of concern (COCs) in ground water and the EPA methods used to measure them. In Table 8-2, we list suites of organic COCs by EPA method. For each COC, we list a reporting limit (RL) of concentration or activity. An RL is the lowest concentration or activity at which the detection of a COC is certain. Concentration or activity of a COC below its RL is called a nondetection (n.d.). To indicate nondetection of an individual COC in data Tables 8-3 to 8-35, we use less-than $(<)$ with the RL for the constituent. To simplify reporting nondetections of entire suites of organic compounds that may have different RLs, we list the EPA method followed by (n.d.) in Tables 8-3 to 8-35. In such instances, the reader is referred to Table 8-2 for constituents and RLs. 
Site 300 Pit 1, Pit 7, and HE Process Areas
For compliance purposes during 1995, we obtained samples of ground water quarterly from 22 monitoring wells at Site 300 . We used 17 wells to monitor chemical concentrations and radioactivity in the ground water in the vicinity of two RCRA-closed landfills: Pit 1 ( 8 wells) and Pit 7 (9 wells). We used five wells (plus seven lysimeters and two leachate collection systems) to monitor ground water chemicals in the vicinity of two Class II surface impoundments, where process water is evaporated. During 1995, we complied with all of the monitoring and reporting requirements contained in the following documents:

1. Waste Discharge Requirements (WDR) Order 93-100 for Pits 1 and 7, administered by the California Central Valley Regional Water Quality Control Board (CVRWQCB), (CVRWQCB 1993);

2. WDR Order $85-188$ for the surface impoundments, administered by the CVRWQCB (CVRWQCB 1985); and

3. The Lawrence Livermore National Laboratory (LLNL) Site 300 Resource Conservation and Recovery Act (RCRA) Closure and PostClosure Plans for Landfill Pits 1 and 7 (Rogers/Pacific Corporation, 1990), approved by the California Department of Health Services, and administered under the Comprehensive Environmental Response, Compensation and Liability Act (CERCLA) Federal Facility Agreement.

As required by the monitoring and reporting sections of these documents, during 1995 we determined the ground water concentrations of toxic metals, highexplosive (HE) compounds, toxic organic compounds (including pesticides and herbicides), general radioactivity (gross alpha and gross beta activities) and the activities of certain radioisotopes, including tritium. We previously tabled and discussed the analytical data obtained during 1995 for Pit 1, Pit 7, and the HE Process Area in four quarterly monitoring reports and one annual report (Christofferson and MacQueen 1995a, 1995b, 1995c, 1996a, 1996b). We submitted these compliance monitoring reports to state and federal agencies, including the CVRWQCB and the DOE. Thus, the lengthy data tables are not repeated in this volume. However, we have summarized our compliance monitoring results for Pit 1, Pit 7, and the HE Process Area in Volume 1, Chapter 8.

\section{Pit 6}

We performed ground water surveillance monitoring in the vicinity of the closed landfill Pit 6 during 1995, where we obtained two sets of ground water samples from six monitoring wells. We analyzed the samples for toxic metals; volatile organic compounds, HE compounds, herbicides, pesticides, radioactivity (gross alpha and gross beta), and tritium activity. We present the analytical data for Pit 6 surveillance monitoring in Tables 8-3 to 8-8. We discuss the data in Volume 1, Chapter 8. 
Pit 2

Pit 9

\section{Elk Ravine Drainage Area}

We performed ground water surveillance monitoring in the vicinity of the closed landfill Pit 2 during 1995, where we obtained quarterly sets of ground water samples from seven multiple completion wells that are fitted with Barcad sampling devices. We analyzed the samples for toxic metals, radioactivity (gross alpha and gross beta), and tritium activity. We present the analytical data for Pit 2 surveillance monitoring in Tables 8-9 to 8-15. We discuss the data in Volume 1, Chapter 8.

We performed ground water surveillance monitoring in the vicinity of the closed landfill Pit 9 during 1995, where we obtained one set of ground water samples from four monitoring wells. For three wells, we analyzed the samples for toxic metals, radioactivity, radioisotopes, HE compounds, and volatile organic compounds. For a fourth monitoring well, number K9-04, we analyzed only for radioactivity, because the well did not produced sufficient water for additional analyses. We present the analytical data for Pit 9 surveillance monitoring in Table 8-16. We discuss the data in Volume 1, Chapter 8.

We performed ground water surveillance monitoring in the the Elk Ravine drainage area during 1995, where we obtained quarterly sets of ground water samples from nine monitoring wells and one spring. We analyzed the samples for toxic metals, radioactivity (gross alpha and gross beta), tritium activity, HE compounds, and volatile organic compounds. We present the analytical data for Elk Ravine surveillance monitoring in Tables 8-17 to 8-26. We discuss the data in Volume 1, Chap. 8.

We performed potable water surveillance monitoring of two on-site wells during 1995 , where we obtained monthly and quarterly ground water samples from wells number 20 and 18 . Well 20 is the primary potable water well at Site 300 and Well 18 is the backup well. We analyzed water samples monthly for volatile organic compounds. We analyzed water samples quarterly for toxic metals, general radioactivity, and tritium activity. We present the analytical data for wells 20 and 18 surveillance monitoring in Tables 8-27to 8-28. We discuss the data in Volume 1, Chapter 8. 
Off-Site WaterSupply Wells
We performed potable water surveillance monitoring of 12 off-site wells near Site 300 during 1995. We obtained quarterly samples from six of these wells. Of these six, we analyzed two for volatile organic compounds and four for organic compounds and toxic metals. We sampled six additional off-site wells once during 1995 and analyzed the samples for toxic metals, organic compounds, general radioactivity, and tritium activity. We present the analytical data for the 12 off-site potable water well surveillance monitoring in Tables 8-29 to 8-35. We discuss the data in Volume 1, Chapter 8. 
Table 8-1. List of ground water analyses showing inorganic constituent, EPA, or other standard measurement method used, and typical reporting limit used by analytical laboratory (a statistically determined concentration limit, above which detection is certain).

\begin{tabular}{|c|c|c|}
\hline Constituent & Method & Reporting limit \\
\hline \multicolumn{3}{|l|}{ Metals and minerals (mg/L) } \\
\hline All alkalinities & EPA 310.1 & 1 \\
\hline Aluminum & EPA 200.7 & 0.02 \\
\hline Ammonia nitrogen (as $\mathrm{N}$ ) & EPA 350.3 & 0.03 \\
\hline Antimony & EPA 200.7 & 0.06 \\
\hline Arsenic & EPA 206.2 & 0.002 \\
\hline Barium & EPA 200.7 & 0.05 \\
\hline Beryllium & EPA 210.2 & 0.0005 \\
\hline Cadmium & EPA 213.2 & 0.0005 \\
\hline Calcium & EPA 200.7 & 0.5 \\
\hline Chloride & EPA 325.3 & 1 \\
\hline Chromium & EPA 218.2 & 0.010 \\
\hline Cobalt & EPA 200.7 & 0.025 \\
\hline Copper & EPA 200.7 & 0.05 \\
\hline Fluoride & EPA 340.2 & 0.1 \\
\hline Hardness, total (as $\left.\mathrm{CaCO}_{3}\right)$ & EPA 2320B & 1 \\
\hline Iron & EPA 200.7 & 0.1 \\
\hline Lead & EPA 239.2 & 0.002 \\
\hline Magnesium & EPA 200.7 & 0.5 \\
\hline Manganese & EPA 200.7 & 0.03 \\
\hline Mercury & EPA 245.1 & 0.0002 \\
\hline Molybdenum & EPA 200.7 & 0.05 \\
\hline Nickel & EPA 249.2 & 0.005 \\
\hline Nitrate (as N) & EPA 353.2 & 0.1 \\
\hline Potassium & EPA 200.7 & 1 \\
\hline Selenium & EPA 270.2 & 0.002 \\
\hline Silver & EPA 272.2 & 0.010 \\
\hline Sodium & EPA 200.7 & 1 \\
\hline Sulfate & EPA 300.0 & 1 \\
\hline Surfactants & EPA 425.1 & 0.5 \\
\hline Thallium & EPA 279.2 & 0.005 \\
\hline Total dissolved solids & EPA 160.1 & 1 \\
\hline Total Kjeldahl nitrogen & EPA 351.4 & 0.2 \\
\hline Total suspended solids & EPA 160.2 & 1 \\
\hline
\end{tabular}


Table 8-1. List of ground water analyses showing inorganic constituent, EPA, or other standard measurement method used, and typical reporting limit used by analytical laboratory (a statistically determined concentration limit, above which detection is certain) (concluded).

\begin{tabular}{|l|l|l|}
\hline \multicolumn{1}{|c|}{ Constituent } & Method & Reporting limit \\
\hline Metals and minerals (mg/L) (continued) & & \\
$\quad$ Vanadium & EPA 200.7 & 0.05 \\
Zinc & EPA 200.7 & 0.02 \\
Phenolics $(\mathbf{m g} / \mathrm{L})$ & & \\
$\quad$ Phenolics & EPA 420.1 & 0.005 \\
General indicator parameters & & \\
pH, units & EPA 150.1 & none \\
Specific conductance $(\mu \mathrm{mh}$ ) $/ \mathrm{cm})$ & EPA 120.1 & 1 \\
Total organic carbon $(\mathrm{mg} / \mathrm{L})$ & EPA 415.1 & 0.5 \\
Total organic halides $(\mathrm{mg} / \mathrm{L})$ & EPA 9020 & 0.01 \\
Explosive compounds $(\mu \mathrm{g} / \mathrm{L})$ & & \\
HMX & HPLC & 5 \\
RDX & HPLC & 5 \\
TNT & HPLC & 5 \\
Radioactivity (Bq/L) & & \\
Gross alpha & EPA 900 & 0.06 \\
Gross beta & EPA 900 & 0.05 \\
Radioisotopes $(\mathrm{Bq} / \mathrm{L})$ & & \\
Radium-226 & EPA 903 & 0.003 \\
Thorium-228 & U-NAS-NS-3050 & 0.009 \\
Thorium-232 & U-NAS-NS-3050 & 0.006 \\
Tritium & LLNL-RAS-011 & 0.050 \\
Uranium-234 & U-NAS-NS-3050 & 0.004 \\
Uranium-235 & U-NAS-NS-3050 & 0.003 \\
Uranium-238 & U-NAS-NS-3050 & 0.004 \\
\hline
\end{tabular}


Table 8-2. List of ground water analyses showing EPA Method, organic constituent, and typical reporting limit used by analytical laboratory (a statistically determined concentration limit, above which detection is certain).

\begin{tabular}{|l|c|}
\hline \multicolumn{1}{|c|}{ Constituent } & $\begin{array}{c}\text { Reporting } \\
\text { limit }(\mu \mathbf{g} / \mathbf{L})\end{array}$ \\
\hline EPA Method 502.2 & \\
1,1,1,2-Tetrachloroethane & 0.2 \\
1,1,1-Trichloroethane & 0.2 \\
1,1,2,2-Tetrachloroethane & 0.2 \\
1,1,2-Trichloroethane & 0.2 \\
1,1-Dichloroethane & 0.2 \\
1,1-Dichloroethene & 0.2 \\
1,1-Dichloropropene & 0.2 \\
1,2,3-Trichlorobenzene & 0.2 \\
1,2,3-Trichloropropane & 0.2 \\
1,2,4-Trichlorobenzene & 0.2 \\
1,2,4-Trimethylbenzene & 0.2 \\
1,2-Dichlorobenzene & 0.2 \\
1,2-Dichloroethane & 0.2 \\
1,2-Dichloropropane & 0.2 \\
1,3,5-Trimethylbenzene & 0.2 \\
1,3-Dichlorobenzene & 0.2 \\
1,3-Dichloropropane & 0.2 \\
1,4-Dichlorobenzene & 0.2 \\
2,2-Dichloropropane & 0.2 \\
2-Chlorotoluene & 0.2 \\
4-Chlorotoluene & 0.2 \\
Benzene & 0.2 \\
Bromobenzene & 0.2 \\
Bromochloromethane & 0.2 \\
Bromodichloromethane & 0.2 \\
Bromoform & 0.2 \\
Bromomethane & 0.2 \\
Carbon tetrachloride & 0.2 \\
Chlorobenzene & 0.2 \\
\hline
\end{tabular}

\begin{tabular}{|c|c|}
\hline Constituent & $\begin{array}{r}\text { Reporting } \\
\text { limit }(\mu \mathbf{g} / \mathbf{L})\end{array}$ \\
\hline Chloromethane & 0.2 \\
\hline cis-1,2-Dichloroethene & 0.2 \\
\hline cis-1,3-Dichloropropene & 0.5 \\
\hline Dibromochloromethane & 0.2 \\
\hline Dibromomethane & 0.2 \\
\hline Dichlorodifluoromethane & 0.2 \\
\hline Ethylbenzene & 0.2 \\
\hline Freon-113 & 0.2 \\
\hline Hexachlorobutadiene & 0.2 \\
\hline Isopropylbenzene & 0.2 \\
\hline $\mathrm{m}$ - and $\mathrm{p}$-Xylene isomers & 0.2 \\
\hline Methylene chloride & 0.2 \\
\hline n-Butylbenzene & 0.2 \\
\hline n-Propylbenzene & 0.2 \\
\hline Naphthalene & 0.2 \\
\hline o-Xylene & 0.2 \\
\hline Isopropyl toluene & 0.2 \\
\hline sec-Butylbenzene & 0.2 \\
\hline Styrene & 0.2 \\
\hline tert-Butylbenzene & 0.2 \\
\hline Tetrachloroethene & 0.2 \\
\hline Toluene & 0.2 \\
\hline trans-1,2-Dichloroethene & 0.2 \\
\hline trans-1,3-Dichloropropene & 0.2 \\
\hline Trichloroethene & 0.2 \\
\hline Trichlorofluoromethane & 0.2 \\
\hline Vinyl chloride & 0.2 \\
\hline \multicolumn{2}{|l|}{ EPA Method 524.2} \\
\hline 1,1,1,2-Tetrachloroethane & 1 \\
\hline 1,1,1-Trichloroethane & 1 \\
\hline 1,1,2,2-Tetrachloroethane & 1 \\
\hline
\end{tabular}


Table 8-2. List of ground water analyses showing EPA Method, organic constituent, and typical lower limit of detection reported by analytical laboratory (continued).

\begin{tabular}{|l|c|}
\hline \multicolumn{1}{|c|}{ Constituent } & $\begin{array}{c}\text { Reporting } \\
\text { limit }(\mu \mathbf{g} / \mathbf{L})\end{array}$ \\
\hline EPA Method 524.2 (continued) & \\
1,1,2-Trichloroethane & 1 \\
1,1-Dichloroethane & 1 \\
1,1-Dichloroethene & 1 \\
1,1-Dichloropropene & 1 \\
1,2,3-Trichlorobenzene & 1 \\
1,2,3-Trichloropropane & 1 \\
1,2,4-Trichlorobenzene & 1 \\
1,2,4-Trimethylbenzene & 1 \\
1,2-Dibromo-3-chloropropane & 2 \\
1,2-Dichlorobenzene & 1 \\
1,2-Dichloroethane & 1 \\
1,2-Dichloropropane & 1 \\
1,3,5-Trimethylbenzene & 1 \\
1,3-Dichlorobenzene & 1 \\
1,3-Dichloropropane & 1 \\
1,4-Dichlorobenzene & 1 \\
2-Chlorotoluene & 1 \\
4-Chlorotoluene & 1 \\
Benzene & 1 \\
Bromobenzene & 1 \\
Bromodichloromethane & 1 \\
Bromoform & 1 \\
Bromomethane & 1 \\
Carbon tetrachloride & 1 \\
Chlorobenzene & 1 \\
Chloroethane & 1 \\
Chloroform & 1 \\
Chloromethane & 1 \\
Dibromochloromethane & 1 \\
\hline
\end{tabular}

\begin{tabular}{|c|c|}
\hline Constituent & $\begin{array}{l}\text { Reporting } \\
\text { limit }(\mu \mathrm{g} / \mathrm{L})\end{array}$ \\
\hline Dibromomethane & 1 \\
\hline Dichlorodifluoromethane & 2 \\
\hline Ethylbenzene & 1 \\
\hline Ethylene dibromide & 1 \\
\hline Freon-113 & 1 \\
\hline Hexachlorobutadiene & 1 \\
\hline Isopropylbenzene & 1 \\
\hline $\mathrm{m}$ - and $\mathrm{p}$-Xylene isomers & 1 \\
\hline Methylene chloride & 1 \\
\hline n-Butylbenzene & 1 \\
\hline n-Propylbenzene & 1 \\
\hline Naphthalene & 1 \\
\hline o-Xylene & 1 \\
\hline Isopropyl toluene & 1 \\
\hline sec-Butylbenzene & 1 \\
\hline Styrene & 1 \\
\hline tert-Butylbenzene & 1 \\
\hline Tetrachloroethene & 1 \\
\hline Toluene & 1 \\
\hline trans-1,2-Dichloroethene & 1 \\
\hline trans-1,3-Dichloropropene & 1 \\
\hline Trichloroethene & 0.5 \\
\hline Trichlorofluoromethane & 1 \\
\hline Vinyl chloride & 2 \\
\hline \multicolumn{2}{|l|}{ EPA Method 601} \\
\hline 1,1,1-Trichloroethane & 0.5 \\
\hline 1,1,2,2-Tetrachloroethane & 0.5 \\
\hline 1,1,2-Trichloroethane & 0.5 \\
\hline 1,1-Dichloroethane & 0.5 \\
\hline 1,1-Dichloroethene & 0.5 \\
\hline 1,2-Dichlorobenzene & 0.5 \\
\hline
\end{tabular}


Table 8-2. List of ground water analyses showing EPA Method, organic constituent, and typical lower limit of detection reported by analytical laboratory (continued).

\begin{tabular}{|l|c|}
\hline \multicolumn{1}{|c|}{ Constituent } & $\begin{array}{c}\text { Reporting } \\
\text { limit }(\mu \mathbf{g} / \mathbf{L})\end{array}$ \\
\hline EPA Method 601 (continued) & \\
1,2-Dichloroethane & 0.5 \\
1,2-Dichloroethene (total) & 0.5 \\
1,2-Dichloropropane & 0.5 \\
1,3-Dichlorobenzene & 0.5 \\
1,4-Dichlorobenzene & 0.5 \\
2-Chloroethylvinylether & 0.5 \\
Bromodichloromethane & 0.5 \\
Bromoform & 0.5 \\
Bromomethane & 0.5 \\
Carbon tetrachloride & 0.5 \\
Chlorobenzene & 0.5 \\
Chloroethane & 0.5 \\
Chloroform & 0.5 \\
Chloromethane & 0.5 \\
cis-1,3-Dichloropropene & 0.5 \\
Dibromochloromethane & 0.3 \\
Dichlorodifluoromethane & 0.5 \\
Freon-113 & 0.5 \\
Methylene chloride & 0.5 \\
Tetrachloroethene & 0.5 \\
trans-1,3-Dichloropropene & 0.5 \\
Trichloroethene & 0.5 \\
Trichlorofluoromethane & 0.5 \\
Vinyl chloride & 0.5 \\
1,2-Dichlorobenzene & 0.5 \\
1,3-Dichlorobenzene & 0.5 \\
1,4-Dichlorobenzene & 0.5 \\
Benzene & 0.5 \\
\hline
\end{tabular}

\begin{tabular}{|l|c|}
\hline \multicolumn{1}{|c|}{ Constituent } & $\begin{array}{c}\text { Reporting } \\
\text { limit }(\mu \mathbf{g} / \mathbf{L})\end{array}$ \\
\hline o-Xylene & 0.4 \\
Toluene & 0.3 \\
Total xylene isomers & 0.4 \\
EPA Method 608 & \\
Aldrin & \\
BHC, alpha isomer & 0.05 \\
BHC, beta isomer & 0.05 \\
BHC, delta isomer & 0.05 \\
BHC, gamma isomer (Lindane) & 0.05 \\
Chlordane & 0.05 \\
Dieldrin & 0.5 \\
Endosulfan I & 0.1 \\
Endosulfan II & 0.05 \\
Endosulfan sulfate & 0.1 \\
Endrin & 0.1 \\
Endrin aldehyde & 0.2 \\
Heptachlor & 0.1 \\
Heptachlor epoxide & 0.1 \\
Methoxychlor & 0.1 \\
4,4'-DDD & 0.1 \\
4,4'-DDE & 0.1 \\
4,4'-DDT & 05 \\
Toxaphene & \\
EPA Method 615 & \\
2,4,5-T & 0.5 \\
2,4,5-TP (Silvex) & \\
2,4-D & 0.1 \\
Dalapon & \\
Dicamba & \\
\hline
\end{tabular}


Table 8-2. List of ground water analyses showing EPA Method, organic constituent, and typical lower limit of detection reported by analytical laboratory (continued).

\begin{tabular}{|l|c|}
\hline \multicolumn{1}{|c|}{ Constituent } & $\begin{array}{c}\text { Reporting } \\
\text { limit }(\mu \mathbf{g} / \mathbf{L})\end{array}$ \\
\hline EPA Method 615 (continued) & 1 \\
Dinoseb & 250 \\
MCPA & 250 \\
MCPP & \\
EPA Method 624 & 1 \\
1,1,1-Trichloroethane & 1 \\
1,1,2,2-Tetrachloroethane & 1 \\
1,1,2-Trichloroethane & 1 \\
1,1-Dichloroethane & 1 \\
1,1-Dichloroethene & 1 \\
1,2-Dichlorobenzene & 1 \\
1,2-Dichloroethane & 1 \\
1,2-Dichloroethene (total) & 1 \\
1,2-Dichloropropane & 1 \\
1,3-Dichlorobenzene & 1 \\
1,4-Dichlorobenzene & 1 \\
2-Butanone & 10 \\
2-Chloroethylvinylether & 10 \\
2-Hexanone & 1 \\
4-Methyl-2-pentanone & 1 \\
Acetone & 1 \\
Benzene & 1 \\
Bromodichloromethane & 1 \\
Bromoform & 1 \\
Bromomethane & 1 \\
Carbon disulfide & 1 \\
Carbon tetrachloride & 1 \\
Chlorobenzene & 1 \\
Chloroethane & 1 \\
Chloroform & 1 \\
Chloromethane & 1 \\
\hline
\end{tabular}

\begin{tabular}{|l|c|}
\hline \multicolumn{1}{|c|}{ Constituent } & $\begin{array}{c}\text { Reporting } \\
\text { limit }(\mu \mathbf{g} / \mathbf{L})\end{array}$ \\
\hline cis-1,3-Dichloropropene & 1 \\
Dibromochloromethane & 1 \\
Dibromomethane & 1 \\
Dichlorodifluoromethane & 2 \\
Ethylbenzene & 1 \\
Freon-113 & 1 \\
Methylene chloride & 1 \\
Styrene & 1 \\
Tetrachloroethene & 1 \\
Toluene & 1 \\
Total xylene isomers & 2 \\
trans-1,3-Dichloropropene & 1 \\
Trichloroethene & 0.5 \\
Trichlorofluoromethane & 1 \\
Vinyl acetate & 10 \\
Vinyl chloride & 10 \\
EPA Method 625 & 10 \\
1,2,4-Trichlorobenzene & 10 \\
1,2-Dichlorobenzene & 10 \\
1,3-Dichlorobenzene & 10 \\
1,4-Dichlorobenzene & 10 \\
2,4,5-Trichlorophenol & 10 \\
2,4,6-Trichlorophenol & 10 \\
2,4-Dichlorophenol & 10 \\
2,4-Dimethylphenol & 10 \\
2,4-Dinitrophenol & 10 \\
2,4-Dinitrotoluene & 10 \\
2,6-Dinitrotoluene & 10 \\
2-Chloronaphthalene & 10 \\
2-Chlorophenol & 10 \\
\hline
\end{tabular}


Table 8-2. List of ground water analyses showing EPA Method, organic constituent, and typical lower limit of detection reported by analytical laboratory (continued).

\begin{tabular}{|l|c|}
\hline \multicolumn{1}{|c|}{ Constituent } & $\begin{array}{c}\text { Reporting } \\
\text { limit }(\mu \mathbf{g} / \mathbf{L})\end{array}$ \\
\hline EPA Method 625 (continued) & \\
2-Methyl-4,6-dinitrophenol & 50 \\
2-Methylnaphthalene & 10 \\
2-Nitroaniline & 50 \\
2-Nitrophenol & 10 \\
3,3'-Dichlorobenzidine & 20 \\
3-Nitroaniline & 50 \\
4-Bromophenylphenylether & 10 \\
4-Chloro-3-methylphenol & 20 \\
4-Chloroaniline & 20 \\
4-Chlorophenylphenylether & 10 \\
4-Nitroaniline & 50 \\
4-Nitrophenol & 50 \\
Acenaphthene & 10 \\
Acenaphthylene & 10 \\
Anthracene & 10 \\
Benzo(a)anthracene & 10 \\
Benzo(a)pyrene & 10 \\
Benzo(b)fluoranthene & 10 \\
Benzo(g,h,i)perylene & 10 \\
Benzo(k)fluoranthene & 10 \\
Benzoic acid & 10 \\
Benzyl alcohol & 20 \\
Bis(2-chloroethoxy)methane & 10 \\
Bis(2-chloroisopropyl)ether & 10 \\
Bis(2-ethylhexyl)phthalate & \\
\hline
\end{tabular}

\begin{tabular}{|l|c|}
\hline \multicolumn{1}{|c|}{ Constituent } & $\begin{array}{c}\text { Reporting } \\
\text { limit }(\mu \mathbf{g} / \mathbf{L})\end{array}$ \\
\hline Butylbenzylphthalate & 10 \\
Chrysene & 10 \\
Di-n-butylphthalate & 10 \\
Di-n-octylphthalate & 10 \\
Dibenzo(a,h)anthracene & 10 \\
Dibenzofuran & 10 \\
Diethylphthalate & 10 \\
Dimethylphthalate & 10 \\
Fluoranthene & 10 \\
Fluorene & 10 \\
Hexachlorobenzene & 10 \\
Hexachlorobutadiene & 10 \\
Hexachlorocyclopentadiene & 10 \\
Hexachloroethane & 10 \\
Indeno(1,2,3-c,d)pyrene & 10 \\
Isophorone & 10 \\
m- and p-Cresol & 10 \\
N-Nitrosodi-n-propylamine & 10 \\
N-Nitrosodiphenylamine & 10 \\
Naphthalene & 10 \\
Nitrobenzene & 10 \\
Pentachlorophenol & 50 \\
Phenanthrene & 10 \\
Phenol & 10 \\
Pyrene & \\
\hline
\end{tabular}


Table 8-3. Pit 6 Well K6-01.

\begin{tabular}{|c|c|c|}
\hline \multirow[b]{2}{*}{ Constituents of concern } & \multicolumn{2}{|c|}{ Sampled } \\
\hline & $1 / 27 / 95$ & $8 / 15 / 95$ \\
\hline \multicolumn{3}{|l|}{ Elements (mg/L) } \\
\hline Arsenic & 0.019 & 0.02 \\
\hline Barium & 0.033 & $<0.05$ \\
\hline Beryllium & $<0.0005$ & $<0.0005$ \\
\hline Cadmium & $<0.0005$ & $<0.0005$ \\
\hline Chromium & $<0.01$ & $<0.01$ \\
\hline Cobalt & $<0.025$ & $<0.05$ \\
\hline Copper & $<0.05$ & $<0.05$ \\
\hline Lead & $<0.002$ & $<0.002$ \\
\hline Manganese & 0.076 & 0.075 \\
\hline Mercury & $<0.0002$ & $<0.0002$ \\
\hline Nickel & $<0.1$ & $<0.1$ \\
\hline Selenium & $<0.002$ & $<0.002$ \\
\hline Silver & $<0.0005$ & $<0.01$ \\
\hline Thallium & $<0.005$ & $<0.001$ \\
\hline Vanadium & $<0.025$ & $<0.05$ \\
\hline Zinc & $<0.05$ & $<0.05$ \\
\hline \multicolumn{3}{|l|}{ HE compounds ( $\mu \mathrm{g} / \mathrm{L})$} \\
\hline HMX, RDX, TNT & $<15$ & $<5$ \\
\hline \multicolumn{3}{|l|}{ Organic compounds ${ }^{(a)}$} \\
\hline EPA Method 601 & (n.d.) & (n.d.) \\
\hline EPA Method 608 & (n.d.) & (n.d.) \\
\hline EPA Method 615 & (n.d.) & (n.d.) \\
\hline \multicolumn{3}{|l|}{ Radioactivity (Bq/L) } \\
\hline Gross alpha & 0.160 & 0.000 \\
\hline Gross beta & 0.305 & 0.374 \\
\hline \multicolumn{3}{|l|}{ Radioisotopes (Bq/L) } \\
\hline Tritium & $<1.5$ & $<1.8$ \\
\hline
\end{tabular}

a See Table 8-2 for method constituents and their reporting limits. n.d. = not detected above reporting limits. 
8. Routine Ground Water Monitoring at Site 300

Table 8-4. Pit 6 Well K6-03.

\begin{tabular}{|c|c|c|}
\hline \multirow[b]{2}{*}{ Constituents of concern } & \multicolumn{2}{|c|}{ Sampled } \\
\hline & $1 / 27 / 95$ & $8 / 16 / 95$ \\
\hline \multicolumn{3}{|l|}{ Elements (mg/L) } \\
\hline Arsenic & 0.025 & 0.022 \\
\hline Barium & $<0.025$ & $<0.05$ \\
\hline Beryllium & $<0.0005$ & $<0.0005$ \\
\hline Cadmium & $<0.0005$ & $<0.0005$ \\
\hline Chromium & $<0.01$ & $<0.01$ \\
\hline Cobalt & $<0.025$ & $<0.05$ \\
\hline Copper & $<0.05$ & $<0.05$ \\
\hline Lead & $<0.002$ & $<0.002$ \\
\hline Manganese & 0.072 & 0.068 \\
\hline Mercury & $<0.0002$ & $<0.0002$ \\
\hline Nickel & $<0.1$ & $<0.1$ \\
\hline Selenium & $<0.002$ & $<0.002$ \\
\hline Silver & $<0.0005$ & $<0.01$ \\
\hline Thallium & $<0.005$ & $<0.001$ \\
\hline Vanadium & $<0.025$ & $<0.05$ \\
\hline Zinc & $<0.05$ & $<0.05$ \\
\hline \multicolumn{3}{|l|}{ HE compounds $(\mu \mathrm{g} / \mathrm{L})$} \\
\hline HMX, RDX, TNT & $<15$ & $<5$ \\
\hline \multicolumn{3}{|l|}{ Organic compounds ${ }^{a}$} \\
\hline EPA Method 601 & (n.d.) & (n.d.) \\
\hline EPA Method 608 & (n.d.) & (n.d.) \\
\hline EPA Method 615 & (n.d.) & (n.d.) \\
\hline \multicolumn{3}{|l|}{ Radioactivity (Bq/L) } \\
\hline Gross alpha & 0.053 & 0.007 \\
\hline Gross beta & 0.287 & 0.278 \\
\hline \multicolumn{3}{|l|}{ Radioisotopes (Bq/L) } \\
\hline Tritium & $<1.6$ & $<1.9$ \\
\hline
\end{tabular}

a See Table 8-2 for method constituents and their reporting limits. n.d. = not detected above reporting limits. 
Table 8-5. Pit 6 Well K6-04.

\begin{tabular}{|c|c|c|}
\hline \multirow[b]{2}{*}{ Constituents of concern } & \multicolumn{2}{|c|}{ Sampled } \\
\hline & $1 / 27 / 95$ & $8 / 15 / 95$ \\
\hline \multicolumn{3}{|l|}{ Elements (mg/L) } \\
\hline Arsenic & 0.019 & 0.017 \\
\hline Barium & $<0.025$ & $<0.05$ \\
\hline Beryllium & $<0.0005$ & $<0.0005$ \\
\hline Cadmium & $<0.0005$ & $<0.0005$ \\
\hline Chromium & $<0.01$ & $<0.01$ \\
\hline Cobalt & $<0.025$ & $<0.05$ \\
\hline Copper & $<0.05$ & $<0.05$ \\
\hline Lead & 0.0027 & $<0.002$ \\
\hline Manganese & $<0.03$ & $<0.03$ \\
\hline Mercury & $<0.0002$ & $<0.0002$ \\
\hline Nickel & $<0.1$ & $<0.1$ \\
\hline Selenium & 0.0022 & $<0.002$ \\
\hline Silver & $<0.0005$ & $<0.01$ \\
\hline Thallium & $<0.005$ & $<0.001$ \\
\hline Vanadium & $<0.025$ & $<0.05$ \\
\hline Zinc & $<0.05$ & $<0.05$ \\
\hline \multicolumn{3}{|l|}{ HE compounds ( $\mu \mathrm{g} / \mathrm{L})$} \\
\hline HMX, RDX, TNT & $<15$ & $<5$ \\
\hline \multicolumn{3}{|l|}{ Organic compounds ${ }^{(a)}$} \\
\hline EPA Method 601 & (n.d.) & (n.d. except) \\
\hline Trichloroethene (TCE; $\mu \mathrm{g} / \mathrm{L})$ & (n.d.) & $0.53^{(b)}$ \\
\hline EPA Method 615 & (n.d.) & (n.d.) \\
\hline EPA Method 608 & (n.d.) & (n.d.) \\
\hline \multicolumn{3}{|l|}{ Radioactivity (Bq/L) } \\
\hline Gross alpha & 0.103 & 0.022 \\
\hline Gross beta & 0.35 & 0.281 \\
\hline \multicolumn{3}{|l|}{ Radioisotopes (Bq/L) } \\
\hline Tritium & $<1.5$ & $<1.8$ \\
\hline
\end{tabular}

a See Table 8-2 for method constituents and their reporting limits. n.d. = not detected above reporting limits.

b TCE was n.d. $(<0.5 \mu \mathrm{g} / \mathrm{L})$ when resampled 10/6/95 
8. Routine Ground Water Monitoring at Site 300

Table 8-6. Pit 6 Well EP6-07.

\begin{tabular}{|c|c|c|}
\hline \multirow[b]{2}{*}{ Constituents of concern } & \multicolumn{2}{|c|}{ Sampled } \\
\hline & 1/27/95 & 8/15/95 \\
\hline \multicolumn{3}{|l|}{ Elements (mg/L) } \\
\hline Arsenic & 0.025 & 0.024 \\
\hline Barium & $<0.025$ & $<0.05$ \\
\hline Beryllium & $<0.0005$ & $<0.0005$ \\
\hline Cadmium & $<0.0005$ & $<0.0005$ \\
\hline Chromium & $<0.01$ & $<0.01$ \\
\hline Cobalt & $<0.025$ & $<0.05$ \\
\hline Copper & $<0.05$ & $<0.05$ \\
\hline Lead & $<0.002$ & $<0.002$ \\
\hline Manganese & 0.15 & 0.12 \\
\hline Mercury & $<0.0002$ & $<0.0002$ \\
\hline Nickel & $<0.1$ & $<0.1$ \\
\hline Selenium & 0.0023 & $<0.002$ \\
\hline Silver & $<0.0005$ & $<0.01$ \\
\hline Thallium & $<0.005$ & $<0.001$ \\
\hline Vanadium & $<0.025$ & $<0.05$ \\
\hline Zinc & $<0.05$ & $<0.05$ \\
\hline \multicolumn{3}{|l|}{ HE compounds ( $\mu \mathrm{g} / \mathrm{L})$} \\
\hline HMX, RDX, TNT & $<15$ & $<5$ \\
\hline \multicolumn{3}{|l|}{ Organic compounds ${ }^{(a)}$} \\
\hline EPA Method 601 & (n.d.) & (n.d.) \\
\hline EPA Method 608 & (n.d.) & (n.d.) \\
\hline EPA Method 615 & (n.d.) & (n.d.) \\
\hline \multicolumn{3}{|l|}{ Radioactivity (Bq/L) } \\
\hline Gross alpha & 0.046 & -0.026 \\
\hline Gross beta & 0.206 & 0.292 \\
\hline \multicolumn{3}{|l|}{ Radioisotopes (Bq/L) } \\
\hline Tritium & $<1.5$ & 2.0 \\
\hline
\end{tabular}

a See Table 8-2 for method constituents and their reporting limits. n.d. = not detected above reporting limits. 
Table 8-7. Pit 6 Well EP6-08.

\begin{tabular}{|c|c|c|}
\hline \multirow[b]{2}{*}{ Constituents of concern } & \multicolumn{2}{|c|}{ Sampled } \\
\hline & $1 / 27 / 95$ & $8 / 15 / 95$ \\
\hline \multicolumn{3}{|l|}{ Elements (mg/L) } \\
\hline Arsenic & 0.021 & 0.019 \\
\hline Barium & $<0.025$ & $<0.05$ \\
\hline Beryllium & $<0.0005$ & $<0.0005$ \\
\hline Cadmium & 0.0007 & $<0.0005$ \\
\hline Chromium & $<0.01$ & $<0.01$ \\
\hline Cobalt & $<0.025$ & $<0.05$ \\
\hline Copper & $<0.05$ & $<0.05$ \\
\hline Lead & $<0.002$ & $<0.002$ \\
\hline Manganese & $<0.03$ & $<0.03$ \\
\hline Mercury & $<0.0002$ & $<0.0002$ \\
\hline Nickel & $<0.1$ & $<0.1$ \\
\hline Selenium & 0.0041 & $<0.002$ \\
\hline Silver & $<0.0005$ & $<0.01$ \\
\hline Thallium & $<0.005$ & $<0.001$ \\
\hline Vanadium & $<0.025$ & $<0.05$ \\
\hline Zinc & $<0.05$ & $<0.05$ \\
\hline \multicolumn{3}{|l|}{ HE compounds ( $\mu \mathrm{g} / \mathrm{L})$} \\
\hline HMX, RDX, TNT & $<15$ & $<5$ \\
\hline \multicolumn{3}{|l|}{ Organic compounds $^{(a)}$} \\
\hline EPA Method 601 & (n.d. except) & (n.d. except) \\
\hline Chloroform & 1.3 & 1.2 \\
\hline Tetrachloroethene (PCE) & 0.75 & 0.6 \\
\hline EPA Method 615 & (n.d.) & (n.d.) \\
\hline EPA Method 608 & (n.d.) & (n.d.) \\
\hline \multicolumn{3}{|l|}{ Radioactivity (Bq/L) } \\
\hline Gross alpha & 0.088 & $<0.218$ \\
\hline Gross beta & 0.207 & 0.370 \\
\hline \multicolumn{3}{|l|}{ Radioisotopes (Bq/L) } \\
\hline Tritium & $<1.5$ & $<1.9$ \\
\hline
\end{tabular}

a See Table 8-2 for method constituents and their reporting limits. n.d. = not detected above reporting limits. 
8. Routine Ground Water Monitoring at Site 300

Table 8-8. Pit 6 Well EP6-08.

\begin{tabular}{|c|c|c|}
\hline \multirow[b]{2}{*}{ Constituents of concern } & \multicolumn{2}{|c|}{ Sampled } \\
\hline & $1 / 27 / 95$ & $8 / 15 / 95$ \\
\hline \multicolumn{3}{|l|}{ Elements (mg/L) } \\
\hline Arsenic & 0.016 & 0.019 \\
\hline Barium & $<0.025$ & $<0.05$ \\
\hline Beryllium & $<0.0005$ & $<0.0005$ \\
\hline Cadmium & 0.0008 & $<0.0005$ \\
\hline Chromium & $<0.01$ & $<0.01$ \\
\hline Cobalt & $<0.025$ & $<0.05$ \\
\hline Copper & $<0.05$ & $<0.05$ \\
\hline Lead & $<0.002$ & $<0.002$ \\
\hline Manganese & $<0.03$ & $<0.03$ \\
\hline Mercury & $<0.0002$ & $<0.0002$ \\
\hline Nickel & $<0.1$ & $<0.1$ \\
\hline Selenium & 0.0058 & $<0.002$ \\
\hline Silver & $<0.0005$ & $<0.01$ \\
\hline Thallium & $<0.005$ & $<0.001$ \\
\hline Vanadium & $<0.025$ & $<0.05$ \\
\hline Zinc & $<0.05$ & $<0.05$ \\
\hline \multicolumn{3}{|l|}{ HE compounds ( $\mu \mathbf{g} / \mathbf{L})$} \\
\hline HMX, RDX, TNT & $<15$ & $<5$ \\
\hline \multicolumn{3}{|l|}{ Organic compounds ${ }^{(a)}(\mu \mathbf{g} / L)$} \\
\hline EPA Method 601 & (n.d. except) & (n.d. except) \\
\hline Trichloroethene (TCE; & 28 & 11 \\
\hline EPA Method 615 & (n.d.) & (n.d.) \\
\hline EPA Method 608 & (n.d.) & (n.d.) \\
\hline \multicolumn{3}{|l|}{ Radioactivity (Bq/L) } \\
\hline Gross alpha & 0.029 & 0.011 \\
\hline Gross beta & 0.291 & 0.455 \\
\hline \multicolumn{3}{|l|}{ Radioisotopes (Bq/L) } \\
\hline Tritium & $<1.5$ & $<1.8$ \\
\hline
\end{tabular}

a See Table 8-2 for method constituents and their reporting limits. n.d. = not detected above reporting limits. 


\section{Routine Ground Water Monitoring at Site 300}

Table 8-9. Pit 2 Barcad K1-01A.

\begin{tabular}{|l|c|c|c|}
\hline \multicolumn{1}{|c|}{ Constituents of concern } & \multicolumn{3}{|c|}{ Sampled } \\
\cline { 2 - 4 } Elements (mg/L) & $\mathbf{1 / 2 7 / 9 5}$ & $\mathbf{8 / 1 8 / 9 5}$ & $\mathbf{1 1 / 9 / 9 5}$ \\
Arsenic & 0.018 & 0.018 & 0.012 \\
Barium & 0.029 & $<0.025$ & $<0.025$ \\
Beryllium & $<0.0005$ & $<0.0005$ & $<0.0005$ \\
Cadmium & $<0.0005$ & $<0.0005$ & $<0.0005$ \\
Chromium & 0.0011 & $<0.01$ & $<0.01$ \\
Lead & $<0.002$ & $<0.002$ & $<0.002$ \\
Mercury & $<0.0002$ & $<0.0002$ & $<0.0002$ \\
Selenium & $<0.002$ & $<0.002$ & $<0.002$ \\
Silver & $<0.0005$ & $<0.01$ & $<0.01$ \\
Vanadium & $<0.025$ & $<0.025$ & $<0.025$ \\
& & & \\
Radioactivity (Bq/L) & & & \\
Gross alpha & \multirow{2}{*}{0.085} & 0.037 & 0.044 \\
Gross beta & 0.134 & 0.155 & 0.178 \\
Radioisotopes (Bq/L) & & & \\
Tritium & & & \\
\hline
\end{tabular}


8. Routine Ground Water Monitoring at Site $\mathbf{3 0 0}$

Table 8-10. Pit 2 Barcad K1-01B.

\begin{tabular}{|c|c|c|c|c|}
\hline \multirow[b]{2}{*}{ Constituents of concern } & \multicolumn{4}{|c|}{ Sample quarter } \\
\hline & 1st & 2nd & 3rd & 4th \\
\hline \multicolumn{5}{|l|}{ Elements (mg/L) } \\
\hline Arsenic & 0.013 & 0.015 & 0.012 & 0.012 \\
\hline Barium & 0.056 & 0.055 & 0.047 & 0.052 \\
\hline Beryllium & $<0.0005$ & $<0.0005$ & $<0.0005$ & $<0.0005$ \\
\hline Cadmium & $<0.0005$ & $<0.0005$ & $<0.0005$ & $<0.0005$ \\
\hline Chromium & $<0.001$ & $<0.001$ & $<0.01$ & $<0.01$ \\
\hline Lead & $<0.002$ & $<0.002$ & $<0.002$ & $<0.002$ \\
\hline Mercury & $<0.0002$ & $<0.0002$ & $<0.0002$ & $<0.0002$ \\
\hline Selenium & $<0.002$ & $<0.002$ & $<0.002$ & $<0.002$ \\
\hline Silver & $<0.0005$ & $<0.0005$ & $<0.01$ & $<0.01$ \\
\hline Vanadium & $<0.025$ & $<0.025$ & $<0.025$ & $<0.025$ \\
\hline \multicolumn{5}{|l|}{ Radioactivity (Bq/L) } \\
\hline Gross alpha & 0.056 & 0.184 & 0.011 & $<0.126$ \\
\hline Gross beta & 0.117 & 0.271 & 0.196 & 0.085 \\
\hline \multicolumn{5}{|l|}{ Radioisotopes (Bq/L) } \\
\hline Tritium & $<1.4$ & $<1.7$ & $<1.8$ & $<2.1$ \\
\hline
\end{tabular}


Table 8-11. Pit 2 Barcad K1-02A.

\begin{tabular}{|l|c|c|c|c|}
\hline \multirow{2}{*}{ Constituents of concern } & \multicolumn{3}{|c|}{ Sample quarter } \\
\cline { 2 - 5 } & 1st & 2nd & 3rd & 4th \\
\hline Elements (mg/L) & & & & \\
Arsenic & 0.016 & $<0.002$ & 0.015 & $<0.002$ \\
Barium & 0.052 & 0.026 & 0.035 & 0.036 \\
Beryllium & $<0.0005$ & $<0.0005$ & $<0.0005$ & $<0.0005$ \\
Cadmium & $<0.0005$ & $<0.0005$ & $<0.0005$ & 0.0008 \\
Chromium & 0.0015 & $<0.001$ & $<0.01$ & $<0.01$ \\
Lead & $<0.002$ & $<0.002$ & $<0.002$ & $<0.002$ \\
Mercury & $<0.0002$ & $<0.0002$ & $<0.0002$ & $<0.0002$ \\
Selenium & $<0.002$ & $<0.002$ & $<0.002$ & $<0.002$ \\
Silver & $<0.0005$ & $<0.0005$ & $<0.01$ & $<0.01$ \\
Vanadium & $<0.025$ & $<0.025$ & $<0.025$ & $<0.025$ \\
& & & & \\
Radioactivity (Bq/L) & & & & 0.007 \\
Gross alpha & 0.114 & 0.031 & 0.015 & 0.148 \\
Gross beta & 0.146 & 0.164 & 0.174 & \\
Radioisotopes (Bq/L) & & & & \\
Tritium & $<1.4$ & $<1.8$ & & \\
\hline
\end{tabular}


8. Routine Ground Water Monitoring at Site 300

Table 8-12. Pit 2 Barcad K2-01A.

\begin{tabular}{|l|l|l|l|l|}
\hline \multirow{2}{*}{ Constituents of concern } & \multicolumn{4}{c|}{ Sample quarter } \\
\cline { 2 - 5 } & 1st & 2nd & 3rd & 4th \\
\hline Elements (mg/L) & & & & \\
Arsenic & $<0.002$ & 0.018 & $<0.002$ & $<0.002$ \\
Barium & $<0.025$ & 0.044 & $<0.025$ & $<0.025$ \\
Beryllium & $<0.0005$ & $<0.0005$ & $<0.0005$ & $<0.0005$ \\
Cadmium & $<0.0005$ & $<0.0005$ & $<0.0005$ & $<0.0005$ \\
Chromium & $<0.001$ & $<0.001$ & $<0.01$ & $<0.01$ \\
Lead & $<0.002$ & $<0.002$ & $<0.002$ & $<0.002$ \\
Mercury & $<0.0002$ & $<0.0002$ & $<0.0002$ & $<0.0002$ \\
Selenium & $<0.002$ & $<0.002$ & $<0.002$ & $<0.002$ \\
Silver & $<0.0005$ & $<0.0005$ & $<0.01$ & $<0.01$ \\
Vanadium & $<0.025$ & $<0.025$ & $<0.025$ & $<0.025$ \\
& & & & \\
Radioactivity (Bq/L) & & & & -0.019 \\
Gross alpha & 0.107 & 0.142 & 0.026 & 0.126 \\
Gross beta & 0.117 & 0.139 & 0.133 & \\
Radioisotopes (Bq/L) & & & & $<1.8$ \\
Tritium & $<1.3$ & 2.8 & & \\
\hline
\end{tabular}


Table 8-13. Pit 2 Barcad K2-01B.

\begin{tabular}{|c|c|c|c|c|}
\hline \multirow[b]{2}{*}{ Constituents of concern } & \multicolumn{4}{|c|}{ Sample quarter } \\
\hline & 1st & 2nd & 3 rd & 4th \\
\hline \multicolumn{5}{|l|}{ Elements (mg/L) } \\
\hline Arsenic & 0.022 & 0.027 & 0.021 & 0.019 \\
\hline Barium & $<0.025$ & $<0.025$ & $<0.025$ & $<0.025$ \\
\hline Beryllium & $<0.0005$ & $<0.0005$ & $<0.0005$ & $<0.0005$ \\
\hline Cadmium & $<0.0005$ & $<0.0005$ & $<0.0005$ & 0.0007 \\
\hline Chromium & $<0.001$ & $<0.001$ & $<0.01$ & $<0.01$ \\
\hline Lead & $<0.002$ & $<0.002$ & $<0.002$ & $<0.002$ \\
\hline Mercury & $<0.0002$ & $<0.0002$ & $<0.0002$ & $<0.0002$ \\
\hline Selenium & $<0.002$ & $<0.002$ & $<0.002$ & $<0.002$ \\
\hline Silver & $<0.0005$ & $<0.0005$ & $<0.01$ & $<0.01$ \\
\hline Vanadium & $<0.025$ & $<0.025$ & $<0.025$ & $<0.025$ \\
\hline \multicolumn{5}{|l|}{ Radioactivity (Bq/L) } \\
\hline Gross alpha & 0.152 & 0.050 & 0.074 & 0.044 \\
\hline Gross beta & 0.162 & 0.151 & 0.167 & 0.111 \\
\hline \multicolumn{5}{|l|}{ Radioisotopes (Bq/L) } \\
\hline Tritium & 3.4 & 4.8 & 4.3 & 6.2 \\
\hline
\end{tabular}


8. Routine Ground Water Monitoring at Site $\mathbf{3 0 0}$

Table 8-14. Pit 2 Barcad K2-02A.

\begin{tabular}{|c|c|c|c|c|}
\hline \multirow[b]{2}{*}{ Constituents of concern } & \multicolumn{4}{|c|}{ Sample quarter } \\
\hline & 1st & 2nd & 3rd & 4th \\
\hline \multicolumn{5}{|l|}{ Elements (mg/L) } \\
\hline Arsenic & 0.052 & 0.06 & 0.046 & 0.048 \\
\hline Barium & $<0.025$ & $<0.025$ & $<0.025$ & 0.026 \\
\hline Beryllium & $<0.0005$ & $<0.0005$ & $<0.0005$ & $<0.0005$ \\
\hline Cadmium & $<0.0005$ & $<0.0005$ & $<0.0005$ & $<0.0005$ \\
\hline Chromium & $<0.001$ & $<0.001$ & $<0.01$ & $<0.01$ \\
\hline Lead & $<0.002$ & $<0.002$ & $<0.002$ & $<0.002$ \\
\hline Mercury & $<0.0002$ & $<0.0002$ & $<0.0002$ & $<0.0002$ \\
\hline Selenium & 0.0026 & $<0.002$ & $<0.002$ & $<0.002$ \\
\hline Silver & $<0.0005$ & $<0.0005$ & $<0.01$ & $<0.01$ \\
\hline Vanadium & $<0.025$ & $<0.025$ & $<0.025$ & $<0.025$ \\
\hline \multicolumn{5}{|l|}{ Radioactivity (Bq/L) } \\
\hline Gross alpha & 0.179 & 0.266 & 0.118 & 0.078 \\
\hline Gross beta & 0.133 & 0.154 & 0.207 & 0.185 \\
\hline \multicolumn{5}{|l|}{ Radioisotopes (Bq/L) } \\
\hline Tritium & $<1.4$ & $<1.7$ & $<2.1$ & $<1.7$ \\
\hline
\end{tabular}


Table 8-15. Pit 2 Barcad K2-02B.

\begin{tabular}{|c|c|c|c|c|}
\hline \multirow[b]{2}{*}{ Constituents of concern } & \multicolumn{4}{|c|}{ Sample quarter } \\
\hline & 1st & 2nd & 3 rd & 4th \\
\hline \multicolumn{5}{|l|}{ Elements (mg/L) } \\
\hline Arsenic & $<0.002$ & $<0.002$ & $<0.002$ & 0.0045 \\
\hline Barium & $<0.025$ & $<0.025$ & 0.025 & $<0.025$ \\
\hline Beryllium & $<0.0005$ & $<0.0005$ & $<0.0005$ & $<0.0005$ \\
\hline Cadmium & $<0.0005$ & $<0.0005$ & $<0.0005$ & $<0.0005$ \\
\hline Chromium & $<0.001$ & $<0.001$ & $<0.01$ & $<0.01$ \\
\hline Lead & $<0.002$ & $<0.002$ & $<0.002$ & $<0.002$ \\
\hline Mercury & $<0.0002$ & $<0.0002$ & $<0.0002$ & $<0.0002$ \\
\hline Selenium & $<0.002$ & 0.0022 & $<0.002$ & $<0.002$ \\
\hline Silver & $<0.0005$ & $<0.0005$ & $<0.01$ & $<0.01$ \\
\hline Vanadium & $<0.025$ & $<0.025$ & $<0.025$ & $<0.025$ \\
\hline \multicolumn{5}{|l|}{ Radioactivity (Bq/L) } \\
\hline Gross alpha & 0.063 & 0.049 & -0.015 & 0.033 \\
\hline Gross beta & 0.137 & 0.230 & 0.133 & 0.104 \\
\hline \multicolumn{5}{|l|}{ Radioisotopes (Bq/L) } \\
\hline Tritium & $<1.5$ & 1.9 & $<2.2$ & $<1.8$ \\
\hline
\end{tabular}


8. Routine Ground Water Monitoring at Site 300

Table 8-16. Pit 9 Wells.

\begin{tabular}{|c|c|c|c|c|}
\hline \multirow{3}{*}{\begin{tabular}{|l|} 
\\
Constituent of concern \\
\end{tabular}} & K9-01 & K9-02 & K9-03 & K9-04 \\
\hline & \multicolumn{4}{|c|}{ Sample quarter } \\
\hline & 1st & 2nd & 3rd & 4th \\
\hline \multicolumn{5}{|l|}{ Elements (mg/L) } \\
\hline Arsenic & 0.0047 & 0.0032 & 0.012 & 0.0038 \\
\hline Barium & $<0.05$ & $<0.05$ & $<0.05$ & $<0.05$ \\
\hline Beryllium & $<0.0005$ & $<0.0005$ & $<0.0005$ & $<0.0005$ \\
\hline Cadmium & $<0.0005$ & $<0.0005$ & $<0.0005$ & $<0.0005$ \\
\hline Chromium & $<0.01$ & $<0.01$ & $<0.01$ & $<0.01$ \\
\hline Copper & $<0.05$ & $<0.05$ & -(a) & $<0.05$ \\
\hline Lead & $<0.002$ & $<0.002$ & $<0.002$ & $<0.002$ \\
\hline Manganese & 0.072 & 0.042 & —(a) $^{(\mathrm{n}}$ & 0.16 \\
\hline Mercury & $<0.0002$ & $<0.0002$ & $<0.0002$ & $<0.0002$ \\
\hline Nickel & $<0.1$ & $<0.1$ & -(a) & $<0.1$ \\
\hline Selenium & $<0.002$ & $<0.002$ & $<0.002$ & $<0.002$ \\
\hline Silver & $<0.01$ & $<0.01$ & $<0.01$ & $<0.01$ \\
\hline Vanadium & $<0.05$ & $<0.05$ & $<0.05$ & $<0.05$ \\
\hline Zinc & $<0.05$ & $<0.05$ & -(a) $^{(\mathrm{n}}$ & $<0.05$ \\
\hline \multicolumn{5}{|l|}{ HE compounds $(\mu \mathrm{g} / \mathrm{L})$} \\
\hline HMX, RDX, TNT & $<5$ & $<5$ & $<5$ & $<5$ \\
\hline \multicolumn{5}{|l|}{ Organic compounds ${ }^{(\mathbf{b})}$} \\
\hline EPA Method 601 & (n.d.) & (n.d.) & (n.d.) & (n.d.) \\
\hline \multicolumn{5}{|l|}{ Radioactivity (Bq/L) } \\
\hline Gross alpha & -0.067 & 0.037 & 0.037 & 0.015 \\
\hline Gross beta & 0.263 & 0.518 & 0.518 & 0.562 \\
\hline \multicolumn{5}{|l|}{ Radioisotopes (Bq/L) } \\
\hline Radium-226 & 0.002 & 0.003 & -(a) $^{(\mathrm{n}}$ & 0.007 \\
\hline Tritium & 5.1 & $<2.0$ & $<2.0$ & $<2.0$ \\
\hline Uranium-234 & 0.009 & 0.016 & 0.020 & 0.017 \\
\hline Uranium-235 & 0.002 & 0.000 & 0.001 & 0.005 \\
\hline Uranium-238 & 0.003 & 0.007 & 0.007 & 0.009 \\
\hline
\end{tabular}

a Analysis not part of the sampling plan.

b See Table 8-2 for method constituents and their reporting limits. n.d. = not detected above reporting limits. 
Table 8-17. Elk Ravine Well K7-07.

\begin{tabular}{|c|c|c|c|}
\hline \multirow[b]{2}{*}{ Constituent of concern } & \multicolumn{3}{|c|}{ Sample quarter(a) } \\
\hline & 2nd & 3rd & 4th \\
\hline \multicolumn{4}{|l|}{ Elements (mg/L) } \\
\hline Arsenic & 0.014 & 0.014 & 0.015 \\
\hline Barium & 0.054 & 0.082 & 0.083 \\
\hline Beryllium & $<0.0005$ & $<0.0005$ & $<0.0005$ \\
\hline Cadmium & $<0.0005$ & $<0.0005$ & $<0.0005$ \\
\hline Chromium & $<0.01$ & $<0.01$ & $<0.01$ \\
\hline Cobalt & $<0.025$ & $<0.05$ & $<0.05$ \\
\hline Copper & $<0.05$ & $<0.05$ & $<0.05$ \\
\hline Lead & $<0.002$ & $<0.002$ & —(b) $^{(\mathrm{n}}$ \\
\hline Manganese & $<0.03$ & $<0.03$ & $<0.03$ \\
\hline Mercury & $<0.0002$ & $<0.0002$ & $<0.0002$ \\
\hline Nickel & $<0.1$ & $<0.1$ & $<0.1$ \\
\hline Selenium & $<0.002$ & $<0.002$ & $<0.002$ \\
\hline Silver & 0.001 & $<0.01$ & $<0.01$ \\
\hline Vanadium & $<0.025$ & 0.031 & $<0.025$ \\
\hline Zinc & $<0.05$ & $<0.05$ & $<0.05$ \\
\hline \multicolumn{4}{|l|}{ HE compounds ( $\mu \mathrm{g} / \mathrm{L})$} \\
\hline HMX, RDX, TNT & $<5$ & $<5$ & $<5$ \\
\hline \multicolumn{4}{|l|}{ Organic compounds ${ }^{(c)}$} \\
\hline EPA Method 601 & (n.d.) & (n.d.) & (n.d.) \\
\hline \multicolumn{4}{|l|}{ Radioactivity (Bq/L) } \\
\hline Gross alpha & 0.322 & 0.063 & 0.936 \\
\hline Gross beta & 0.190 & 0.255 & 1.132 \\
\hline \multicolumn{4}{|l|}{ Radioisotopes (Bq/L) } \\
\hline Tritium & 1160 & 962 & 833 \\
\hline
\end{tabular}

a Well dry during first quarter.

b Analysis not part of the sampling plan.

c See Table 8-2 for method constituents and their reporting limits. n.d. = not detected above reporting limits. 
8. Routine Ground Water Monitoring at Site 300

Table 8-18. Elk Ravine Well NC7-61.

\begin{tabular}{|c|c|c|c|c|}
\hline \multirow[b]{2}{*}{ Constituent of concern } & \multicolumn{4}{|c|}{ Sample quarter } \\
\hline & 1st & 2nd & 3rd & 4th \\
\hline \multicolumn{5}{|l|}{ Elements (mg/L) } \\
\hline Arsenic & 0.019 & 0.013 & 0.016 & 0.014 \\
\hline Barium & 0.11 & 0.12 & 0.13 & 0.11 \\
\hline Beryllium & $<0.0005$ & $<0.0005$ & $<0.0005$ & $<0.0005$ \\
\hline Cadmium & $<0.0005$ & $<0.0005$ & $<0.0005$ & $<0.0005$ \\
\hline Chromium & $<0.01$ & $<0.01$ & $<0.01$ & $<0.01$ \\
\hline Cobalt & $<0.05$ & $<0.025$ & $<0.05$ & $<0.025$ \\
\hline Copper & $<0.05$ & $<0.05$ & $<0.05$ & $<0.05$ \\
\hline Lead & $<0.002$ & $<0.002$ & $<0.002$ & $<0.002$ \\
\hline Manganese & $<0.03$ & $<0.03$ & $<0.03$ & $<0.03$ \\
\hline Mercury & $<0.0002$ & $<0.0002$ & $<0.0002$ & $<0.0002$ \\
\hline Nickel & $<0.1$ & $<0.1$ & $<0.1$ & $<0.1$ \\
\hline Selenium & $<0.002$ & $<0.002$ & $<0.002$ & $<0.002$ \\
\hline Silver & $<0.0005$ & $<0.001$ & $<0.01$ & $<0.01$ \\
\hline Vanadium & 0.097 & 0.085 & 0.091 & 0.076 \\
\hline Zinc & $<0.05$ & $<0.05$ & $<0.05$ & $<0.05$ \\
\hline \multicolumn{5}{|l|}{ HE compounds ( $\mu \mathrm{g} / \mathrm{L})$} \\
\hline HMX, RDX, TNT & $<15$ & $<5$ & $<5$ & $<5$ \\
\hline \multicolumn{5}{|l|}{ Organic compounds ${ }^{(a)}$} \\
\hline EPA Method 601 & (n.d.) & (n.d.) & (n.d.) & (n.d.) \\
\hline \multicolumn{5}{|l|}{ Radioactivity (Bq/L) } \\
\hline Gross alpha & 0.325 & 0.309 & 0.200 & 0.329 \\
\hline Gross beta & 0.368 & 0.236 & 0.355 & 0.466 \\
\hline \multicolumn{5}{|l|}{ Radioisotopes (Bq/L) } \\
\hline Tritium & 7290. & 7070. & 6620. & 6920. \\
\hline
\end{tabular}

a See Table 8-2 for method constituents and their reporting limits. n.d. = not detected above reporting limits. 
Table 8-19. Elk Ravine Well NC7-69.

\begin{tabular}{|c|c|c|c|c|}
\hline \multirow[b]{2}{*}{ Constituent of concern } & \multicolumn{4}{|c|}{ Sample quarter } \\
\hline & 1st & 2nd & 3 rd & 4th \\
\hline \multicolumn{5}{|l|}{ Elements (mg/L) } \\
\hline Arsenic & 0.0023 & 0.0025 & $<0.002$ & $<0.002$ \\
\hline Barium & 0.026 & 0.03 & $<0.025$ & 0.028 \\
\hline Beryllium & $<0.0005$ & $<0.0005$ & $<0.0005$ & $<0.0005$ \\
\hline Cadmium & $<0.0005$ & $<0.0005$ & $<0.0005$ & $<0.0005$ \\
\hline Chromium & $<0.01$ & $<0.01$ & $<0.01$ & $<0.01$ \\
\hline Cobalt & $<0.025$ & $<0.025$ & $<0.05$ & $<0.025$ \\
\hline Copper & $<0.05$ & $<0.05$ & $<0.05$ & $<0.05$ \\
\hline Lead & 0.0031 & $<0.002$ & $<0.002$ & $<0.002$ \\
\hline Manganese & 0.053 & 0.065 & 0.068 & 0.056 \\
\hline Mercury & $<0.0002$ & $<0.0002$ & $<0.0002$ & $<0.0002$ \\
\hline Nickel & $<0.1$ & $<0.1$ & $<0.1$ & $<0.1$ \\
\hline Selenium & $<0.002$ & $<0.002$ & $<0.002$ & $<0.002$ \\
\hline Silver & $<0.0005$ & 0.0015 & $<0.01$ & $<0.01$ \\
\hline Vanadium & $<0.025$ & $<0.025$ & $<0.025$ & $<0.025$ \\
\hline Zinc & $<0.05$ & $<0.05$ & $<0.05$ & $<0.05$ \\
\hline \multicolumn{5}{|l|}{ HE compounds $(\mu \mathrm{g} / \mathrm{L})$} \\
\hline HMX, RDX, TNT & $<15$ & $<5$ & $<5$ & $<5$ \\
\hline \multicolumn{5}{|l|}{ Organic compounds ${ }^{(a)}$} \\
\hline EPA Method 601 & (n.d.) & (n.d.) & (n.d.) & (n.d.) \\
\hline \multicolumn{5}{|l|}{ Radioactivity (Bq/L) } \\
\hline Gross alpha & 0.065 & 0.047 & -0.019 & -0.026 \\
\hline Gross beta & 0.132 & 0.151 & 0.178 & 0.237 \\
\hline \multicolumn{5}{|l|}{ Radioisotopes (Bq/L) } \\
\hline Tritium & $<0.1$ & $<0.1$ & $<0.1$ & $<0.1$ \\
\hline
\end{tabular}

a See Table 8-2 for method constituents and their reporting limits. n.d. = not detected above reporting limits. 
8. Routine Ground Water Monitoring at Site 300

Table 8-20. Elk Ravine Well K2-04D.

\begin{tabular}{|c|c|c|c|c|}
\hline \multirow[b]{2}{*}{ Constituent of concern } & \multicolumn{4}{|c|}{ Sample quarter } \\
\hline & 1st & 2nd & 3 rd & 4th \\
\hline \multicolumn{5}{|l|}{ Elements (mg/L) } \\
\hline Arsenic & 0.013 & 0.012 & 0.01 & 1.4 \\
\hline Barium & $<0.05$ & 0.032 & $<0.025$ & 0.036 \\
\hline Beryllium & $<0.0005$ & $<0.0005$ & $<0.0005$ & $<0.0005$ \\
\hline Cadmium & $<0.0005$ & $<0.0005$ & $<0.0005$ & $<0.0005$ \\
\hline Chromium & $<0.01$ & 一 (a) $^{(2)}$ & $<0.01$ & $<0.01$ \\
\hline Cobalt & $<0.05$ & -(a) $^{(a)}$ & $<0.05$ & $<0.025$ \\
\hline Copper & $<0.05$ & $<0.05$ & $<0.05$ & $<0.05$ \\
\hline Lead & $<0.002$ & $<0.002$ & $<0.002$ & $<0.002$ \\
\hline Manganese & $<0.03$ & $<0.03$ & $<0.03$ & $<0.03$ \\
\hline Mercury & $<0.0002$ & $<0.0002$ & $<0.0002$ & $<0.0002$ \\
\hline Nickel & $<0.1$ & $<0.1$ & $<0.1$ & $<0.1$ \\
\hline Selenium & 0.0028 & 0.021 & $<0.002$ & $<0.002$ \\
\hline Silver & $<0.0005$ & $<0.01$ & $<0.01$ & $<0.01$ \\
\hline Vanadium & 0.061 & —(a) $^{(\mathrm{n}}$ & 0.057 & 0.033 \\
\hline Zinc & $<0.05$ & $<0.05$ & $<0.05$ & $<0.05$ \\
\hline \multicolumn{5}{|l|}{ HE compounds $(\mu \mathrm{g} / \mathrm{L})$} \\
\hline HMX, RDX, TNT & $<15$ & $<5$ & $<5$ & $<5$ \\
\hline \multicolumn{5}{|l|}{ Organic compounds ${ }^{(\mathbf{b})}$} \\
\hline EPA Method 601 & (n.d.) & (n.d.) & (n.d.) & (n.d.) \\
\hline \multicolumn{5}{|l|}{ Radioactivity (Bq/L) } \\
\hline Gross alpha & 0.108 & 0.164 & 0.041 & 0.096 \\
\hline Gross beta & 0.100 & 0.137 & 0.107 & 0.104 \\
\hline \multicolumn{5}{|l|}{ Radioisotopes (Bq/L) } \\
\hline Tritium & 344 & 870 & 603 & 342 \\
\hline
\end{tabular}

a Analysis not part of sampling plan.

b See Table 8-2 for method constituents and their reporting limits. n.d. = not detected above reporting limits. 
Table 8-21. Elk Ravine Well K2-04S.

\begin{tabular}{|c|c|c|c|c|}
\hline \multirow[b]{2}{*}{ Constituent of concern } & \multicolumn{4}{|c|}{ Sample quarter } \\
\hline & 1st & 2nd & 3 rd & 4th \\
\hline \multicolumn{5}{|l|}{ Elements (mg/L) } \\
\hline Arsenic & 0.016 & 0.013 & 0.015 & 1.2 \\
\hline Barium & $<0.05$ & 0.044 & 0.056 & 0.061 \\
\hline Beryllium & $<0.0005$ & $<0.0005$ & $<0.0005$ & $<0.0005$ \\
\hline Cadmium & $<0.0005$ & $<0.0005$ & $<0.0005$ & $<0.0005$ \\
\hline Chromium & $<0.01$ & $<0.01$ & $<0.01$ & $<0.01$ \\
\hline Cobalt & $<0.05$ & $<0.025$ & $<0.05$ & $<0.025$ \\
\hline Copper & $<0.05$ & $<0.05$ & $<0.05$ & $<0.05$ \\
\hline Lead & $<0.002$ & $<0.002$ & $<0.002$ & $<0.002$ \\
\hline Manganese & $<0.03$ & $<0.03$ & $<0.03$ & $<0.03$ \\
\hline Mercury & $<0.0002$ & $<0.0002$ & $<0.0002$ & $<0.0002$ \\
\hline Nickel & $<0.1$ & $<0.1$ & $<0.1$ & $<0.1$ \\
\hline Selenium & 0.0022 & $<0.002$ & 0.002 & $<0.002$ \\
\hline Silver & $<0.0005$ & 0.0011 & $<0.01$ & $<0.01$ \\
\hline Vanadium & 0.072 & 0.053 & 0.053 & 0.040 \\
\hline Zinc & $<0.05$ & $<0.05$ & $<0.05$ & $<0.05$ \\
\hline \multicolumn{5}{|l|}{ HE compounds ( $\mu \mathrm{g} / \mathrm{L})$} \\
\hline HMX, RDX, TNT & $<15$ & $<5$ & $<5$ & $<5$ \\
\hline \multicolumn{5}{|l|}{ Organic compounds ${ }^{(a)}$} \\
\hline EPA Method 601 & (n.d.) & (n.d.) & (n.d.) & (n.d.) \\
\hline \multicolumn{5}{|l|}{ Radioactivity (Bq/L) } \\
\hline Gross alpha & 0.300 & 0.152 & 0.229 & 0.078 \\
\hline Gross beta & 0.278 & 0.105 & 0.226 & 0.159 \\
\hline \multicolumn{5}{|l|}{ Radioisotopes (Bq/L) } \\
\hline Tritium & 929 & 1195 & 1410 & 1373 \\
\hline
\end{tabular}

a See Table 8-2 for method constituents and their reporting limits. n.d. = not detected above reporting limits. 
8. Routine Ground Water Monitoring at Site 300

Table 8-22. Elk Ravine Well K2-01C.

\begin{tabular}{|c|c|c|c|c|}
\hline \multirow[b]{2}{*}{ Constituent of concern } & \multicolumn{4}{|c|}{ Sample quarter } \\
\hline & 1st & 2nd & 3 rd & 4th \\
\hline \multicolumn{5}{|l|}{ Elements (mg/L) } \\
\hline Arsenic & 0.0072 & 0.0044 & 0.0039 & $<0.002$ \\
\hline Barium & $<0.05$ & 0.068 & 0.042 & 0.058 \\
\hline Beryllium & $<0.0005$ & $<0.0005$ & $<0.0005$ & $<0.0005$ \\
\hline Cadmium & $<0.0005$ & $<0.0005$ & $<0.0005$ & $<0.0005$ \\
\hline Chromium & $<0.01$ & $<0.01$ & $<0.01$ & $<0.01$ \\
\hline Cobalt & $<0.05$ & $<0.025$ & $<0.05$ & $<0.025$ \\
\hline Copper & $<0.05$ & $<0.05$ & $<0.05$ & $<0.05$ \\
\hline Lead & $<0.002$ & $<0.002$ & $<0.002$ & $<0.002$ \\
\hline Manganese & $<0.03$ & $<0.03$ & $<0.03$ & $<0.03$ \\
\hline Mercury & $<0.0002$ & 0.00021 & $<0.0002$ & $<0.0002$ \\
\hline Nickel & $<0.1$ & $<0.1$ & $<0.1$ & $<0.1$ \\
\hline Selenium & $<0.002$ & $<0.002$ & $<0.002$ & $<0.002$ \\
\hline Silver & $<0.0005$ & 0.0069 & $<0.01$ & $<0.01$ \\
\hline Vanadium & $<0.05$ & $<0.025$ & 0.031 & $<0.025$ \\
\hline Zinc & $<0.05$ & $<0.05$ & $<0.05$ & $<0.05$ \\
\hline \multicolumn{5}{|l|}{ HE compounds ( $\mu \mathrm{g} / \mathrm{L})$} \\
\hline HMX, RDX, TNT & $<15$ & $<5$ & $<5$ & $<5$ \\
\hline \multicolumn{5}{|l|}{ Organic compounds ${ }^{(a)}$} \\
\hline EPA Method 601 & (n.d.) & (n.d.) & (n.d.) & (n.d.) \\
\hline \multicolumn{5}{|l|}{ Radioactivity (Bq/L) } \\
\hline Gross alpha & 0.518 & 0.847 & 0.337 & 0.503 \\
\hline Gross beta & 0.359 & 0.411 & 0.292 & 0.366 \\
\hline \multicolumn{5}{|l|}{ Radioisotopes (Bq/L) } \\
\hline Tritium & 374 & 121 & 212 & 200 \\
\hline
\end{tabular}

a See Table 8-2 for method constituents and their reporting limits. n.d. = not detected above reporting limits. 
Table 8-23. Elk Ravine Well NC2-11D.

\begin{tabular}{|c|c|c|c|c|}
\hline \multirow[b]{2}{*}{ Constituent of concern } & \multicolumn{4}{|c|}{ Sample quarter } \\
\hline & 1st & 2nd & 3rd & 4th \\
\hline \multicolumn{5}{|l|}{ Elements (mg/L) } \\
\hline Arsenic & 0.015 & 0.015 & 0.015 & 0.011 \\
\hline Barium & $<0.05$ & $<0.025$ & $<0.025$ & $<0.025$ \\
\hline Beryllium & $<0.0005$ & $<0.0005$ & $<0.0005$ & $<0.0005$ \\
\hline Cadmium & $<0.0005$ & $<0.0005$ & $<0.0005$ & $<0.0005$ \\
\hline Chromium & $<0.01$ & $<0.01$ & $<0.01$ & $<0.01$ \\
\hline Cobalt & $<0.05$ & $<0.025$ & $<0.05$ & $<0.025$ \\
\hline Copper & $<0.05$ & $<0.05$ & $<0.05$ & $<0.05$ \\
\hline Lead & $<0.002$ & $<0.002$ & $<0.002$ & $<0.002$ \\
\hline Manganese & $<0.03$ & $<0.03$ & $<0.03$ & $<0.03$ \\
\hline Mercury & $<0.0002$ & $<0.0002$ & $<0.0002$ & $<0.0002$ \\
\hline Nickel & $<0.1$ & $<0.1$ & $<0.1$ & $<0.1$ \\
\hline Selenium & 0.0025 & $<0.002$ & $<0.002$ & $<0.002$ \\
\hline Silver & $<0.0005$ & 0.0055 & $<0.01$ & $<0.01$ \\
\hline Vanadium & 0.051 & $<0.025$ & 0.050 & 0.029 \\
\hline Zinc & $<0.05$ & $<0.05$ & $<0.05$ & $<0.05$ \\
\hline \multicolumn{5}{|l|}{ HE compounds ( $\mu \mathrm{g} / \mathrm{L})$} \\
\hline HMX, RDX, TNT & $<15$ & $<5$ & $<5$ & $<5$ \\
\hline \multicolumn{5}{|l|}{ Organic compounds ${ }^{(a)}$} \\
\hline EPA Method 601 & (n.d.) & (n.d.) & (n.d.) & (n.d.) \\
\hline \multicolumn{5}{|l|}{ Radioactivity (Bq/L) } \\
\hline Gross alpha & 0.169 & 0.258 & 0.189 & 0.115 \\
\hline Gross beta & 0.195 & 0.181 & 0.303 & 0.196 \\
\hline \multicolumn{5}{|l|}{ Radioisotopes (Bq/L) } \\
\hline Tritium & 91 & 77 & 89 & 93 \\
\hline
\end{tabular}

a See Table 8-2 for method constituents and their reporting limits. n.d. = not detected above reporting limits. 
8. Routine Ground Water Monitoring at Site 300

Table 8-24. Elk Ravine Well NC2-12D.

\begin{tabular}{|c|c|c|c|c|}
\hline \multirow[b]{2}{*}{ Constituent of concern } & \multicolumn{4}{|c|}{ Sample quarter } \\
\hline & 1st & 2nd & 3 rd & 4th \\
\hline \multicolumn{5}{|l|}{ Elements (mg/L) } \\
\hline Arsenic & 0.014 & 0.011 & 0.014 & 0.011 \\
\hline Barium & $<0.05$ & $<0.025$ & $<0.025$ & $<0.025$ \\
\hline Beryllium & $<0.0005$ & $<0.0005$ & $<0.0005$ & $<0.0005$ \\
\hline Cadmium & $<0.0005$ & $<0.0005$ & $<0.0005$ & $<0.0005$ \\
\hline Chromium & $<0.01$ & 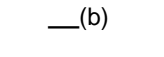 & $<0.01$ & $<0.01$ \\
\hline Cobalt & $<0.05$ & 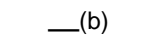 & $<0.05$ & $<0.025$ \\
\hline Copper & $<0.05$ & $<0.05$ & $<0.05$ & $<0.05$ \\
\hline Lead & $<0.002$ & $<0.002$ & $<0.002$ & $<0.002$ \\
\hline Manganese & $<0.03$ & $<0.03$ & $<0.03$ & $<0.03$ \\
\hline Mercury & $<0.0002$ & $<0.0002$ & $<0.0002$ & $<0.0002$ \\
\hline Nickel & $<0.1$ & $<0.1$ & $<0.1$ & $<0.1$ \\
\hline Selenium & 0.0022 & $<0.002$ & 0.0069 & $<0.002$ \\
\hline Silver & $<0.0005$ & $<0.01$ & $<0.01$ & $<0.01$ \\
\hline Vanadium & $<0.05$ & —(b) & 0.044 & 0.026 \\
\hline Zinc & $<0.05$ & $<0.05$ & $<0.05$ & $<0.05$ \\
\hline \multicolumn{5}{|l|}{ HE compounds ( $\mu \mathrm{g} / \mathrm{L})$} \\
\hline HMX, RDX, TNT & -(b) $^{(b)}$ & 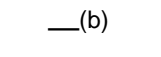 & $<5$ & $<5$ \\
\hline \multicolumn{5}{|l|}{ Organic compounds ${ }^{(a)}$} \\
\hline EPA Method 601 & (n.d.) & (n.d.) & (n.d.) & (n.d.) \\
\hline \multicolumn{5}{|l|}{ Radioactivity (Bq/L) } \\
\hline Gross alpha & 0.122 & 0.192 & 0.026 & 0.122 \\
\hline Gross beta & 0.249 & 0.192 & 0.192 & 0.137 \\
\hline \multicolumn{5}{|l|}{ Radioisotopes (Bq/L) } \\
\hline Tritium & 154 & 152 & 157 & 174 \\
\hline
\end{tabular}

a See Table 8-2 for method constituents and their reporting limits. n.d. = not detected above reporting limits.

b Analysis not part of sampling plan. 
Table 8-25. Elk Ravine Spring 812CRK.

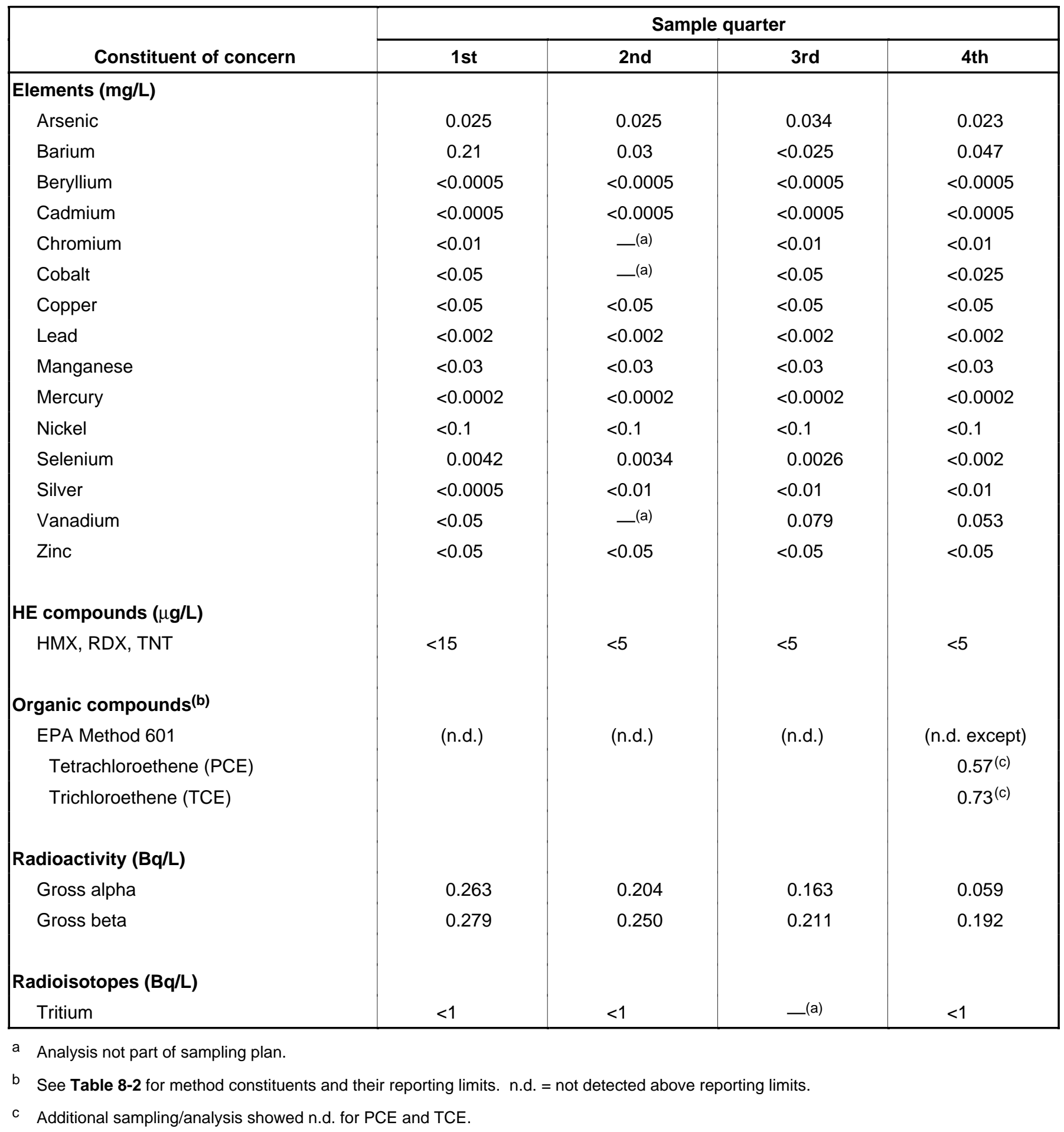


8. Routine Ground Water Monitoring at Site 300

Table 8-26. Elk Ravine Well NC2-07.

\begin{tabular}{|c|c|c|c|c|}
\hline \multirow[b]{2}{*}{ Constituent of concern } & \multicolumn{4}{|c|}{ Sample quarter } \\
\hline & 1st & 2nd & 3rd & 4th \\
\hline \multicolumn{5}{|l|}{ Elements (mg/L) } \\
\hline Arsenic & -(a) & -(a) & 0.031 & 0.034 \\
\hline Barium & -(a) & -(a) & $<0.025$ & 0.028 \\
\hline Beryllium & -(a) & -(a) & $<0.0005$ & $<0.0005$ \\
\hline Cadmium & -(a) & -(a) & $<0.0005$ & $<0.0005$ \\
\hline Chromium & 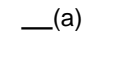 & 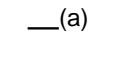 & $<0.01$ & $<0.01$ \\
\hline Cobalt & -(a) $^{\text {(a) }}$ & 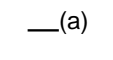 & $<0.05$ & $<0.025$ \\
\hline Copper & -(a) & - (a) $^{(2}$ & $<0.05$ & $<0.05$ \\
\hline Lead & -(a) & -(a) & $<0.002$ & $<0.002$ \\
\hline Manganese & 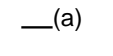 & - (a) $^{(2)}$ & $<0.03$ & $<0.03$ \\
\hline Mercury & 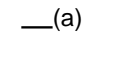 & 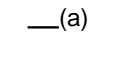 & $<0.0002$ & $<0.0002$ \\
\hline Nickel & -(a) & 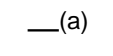 & $<0.1$ & $<0.1$ \\
\hline Selenium & -(a) & -(a) & $<0.002$ & $<0.002$ \\
\hline Silver & -(a) & 一(a) & $<0.01$ & $<0.01$ \\
\hline Vanadium & -(a) & 一(a) & 0.044 & 0.046 \\
\hline Zinc & -(a) & -(a) & $<0.05$ & $<0.05$ \\
\hline \multicolumn{5}{|l|}{ HE compound $(\mu \mathrm{g} / \mathrm{L}) \mathrm{s}$} \\
\hline HMX, RDX, TNT & 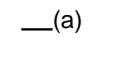 & -(a) $^{\text {(a) }}$ & $<5$ & $<5$ \\
\hline \multicolumn{5}{|l|}{ Organic compounds ${ }^{(\mathbf{b})}$} \\
\hline EPA Method 601 & (n.d.) & (n.d.) & (n.d.) & (n.d.) \\
\hline \multicolumn{5}{|l|}{ Radioactivity (Bq/L) } \\
\hline Gross alpha & 0.629 & 0.368 & 0.181 & 0.407 \\
\hline Gross beta & 0.334 & 0.396 & 0.192 & 0.292 \\
\hline \multicolumn{5}{|l|}{ Radioisotopes (Bq/L) } \\
\hline Tritium & $<2$ & $<2$ & $<2$ & $<2$ \\
\hline
\end{tabular}

a Analysis not part of sampling plan.

b See Table 8-2 for method constituents and their reporting limits. n.d. = not detected above reporting limits. 
Table 8-27. Water Supply Well 20.

\begin{tabular}{|c|c|c|c|c|}
\hline \multirow[b]{2}{*}{ Constituent of concern } & \multicolumn{4}{|c|}{ Sample quarter } \\
\hline & 1st & 2nd & 3rd & 4th \\
\hline \multicolumn{5}{|l|}{ Elements (mg/L) } \\
\hline Arsenic & $<0.002$ & $<0.002$ & $<0.002$ & $<0.002$ \\
\hline Barium & -(a) & $<0.025$ & -(a) & -(a) \\
\hline Beryllium & $<0.0005$ & $<0.0005$ & $<0.0005$ & $<0.0005$ \\
\hline Cadmium & $-^{(\mathrm{a})}$ & $<0.0005$ & 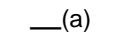 & —(a) \\
\hline Chromium & $<0.01$ & $<0.001$ & $<0.01$ & $<0.01$ \\
\hline Cobalt & —(a) & -(a) $^{(\mathrm{n}}$ & —(a) & —(a) \\
\hline Copper & $<0.05$ & $<0.05$ & $<0.05$ & $<0.05$ \\
\hline Lead & $<0.002$ & $<0.002$ & $<0.002$ & $<0.002$ \\
\hline Manganese & $<0.03$ & $<0.03$ & $<0.03$ & $<0.03$ \\
\hline Mercury & $<0.0002$ & $<0.0002$ & $<0.0002$ & $<0.0002$ \\
\hline Nickel & $<0.1$ & $<0.1$ & $<0.1$ & $<0.1$ \\
\hline Selenium & $<0.002$ & $<0.002$ & $<0.002$ & $<0.002$ \\
\hline Silver & -(a) & $<0.001$ & -(a) & -(a) \\
\hline Vanadium & -(a) & $<0.025$ & $<0.025$ & $<0.025$ \\
\hline Zinc & 0.053 & $<0.05$ & $<0.05$ & $<0.05$ \\
\hline \multicolumn{5}{|l|}{ Organic compounds ${ }^{(b)}$} \\
\hline EPA Method 502.2 & (n.d.) & (n.d.) & (n.d.) & (n.d.) \\
\hline \multicolumn{5}{|l|}{ Radioactivity (Bq/L) } \\
\hline Gross alpha & 0.001 & 0.094 & 0.033 & 0.085 \\
\hline Gross beta & 0.381 & 0.448 & 3.489 & 0.389 \\
\hline \multicolumn{5}{|l|}{ Radioisotopes (Bq/L) } \\
\hline Tritium & $<0.1$ & $<0.3$ & -(a) & $<0.1$ \\
\hline
\end{tabular}

a Analysis not part of sampling plan.

b See Table 8-2 for method constituents and their reporting limits. n.d. = not detected above reporting limits. 
8. Routine Ground Water Monitoring at Site 300

Table 8-28. Standby Supply Well 18.

\begin{tabular}{|c|c|c|c|c|}
\hline \multirow[b]{2}{*}{ Constituent of concern } & \multicolumn{4}{|c|}{ Sample quarter } \\
\hline & 1st & 2nd & 3rd & 4th \\
\hline \multicolumn{5}{|l|}{ HE compounds $(\mu \mathrm{g} / \mathrm{L})$} \\
\hline HMX, RDX, TNT ( $\mu \mathrm{g} / \mathrm{L})$ & $<15$ & -(a) & -(a) & -(a) \\
\hline \multicolumn{5}{|l|}{ Organic compounds ${ }^{(b)}$} \\
\hline EPA Method 601 & (n.d.) & (n.d.) & (n.d.) & (n.d.) \\
\hline EPA Method 502.2 & 一(a) $^{(\mathrm{a}}$ & (n.d. except) & (n.d. except) & (n.d. except) \\
\hline Trichloroethene (TCE) & & 0.2 & 0.4 & 0.5 \\
\hline \multicolumn{5}{|l|}{ Radioactivity (Bq/L) } \\
\hline Gross alpha & 0.031 & 0.104 & -0.045 & 0.006 \\
\hline Gross beta & 0.176 & 0.389 & 0.196 & 0.319 \\
\hline \multicolumn{5}{|l|}{ Radioisotopes (Bq/L) } \\
\hline Tritium & —(a) $^{(\mathrm{n}}$ & $<0.1$ & $<1$ & $<0.2$ \\
\hline
\end{tabular}

a Analysis not part of sampling plan.

b See Table 8-2 for method constituents and their reporting limits. n.d. = not detected above reporting limits. 
Table 8-29. Off-site Well CARNRW2.

\begin{tabular}{|c|c|c|c|c|}
\hline \multirow[b]{2}{*}{ Constituent of concern } & \multicolumn{4}{|c|}{ Sample quarter } \\
\hline & 1st & 2nd & 3rd & 4th \\
\hline \multicolumn{5}{|l|}{ Elements (mg/L) } \\
\hline Arsenic & 0.0029 & 0.0026 & 0.0021 & 0.0036 \\
\hline Barium & $<0.05$ & $<0.025$ & $<0.025$ & $<0.025$ \\
\hline Beryllium & $<0.0005$ & $<0.0005$ & $<0.0005$ & $<0.0005$ \\
\hline Cadmium & $<0.0005$ & $<0.0005$ & $<0.0005$ & $<0.0005$ \\
\hline Chromium & $<0.01$ & $<0.01$ & $<0.01$ & $<0.01$ \\
\hline Cobalt & $<0.05$ & $<0.025$ & —(a) & $<0.025$ \\
\hline Copper & $<0.05$ & $<0.05$ & $<0.05$ & $<0.05$ \\
\hline Lead & $<0.002$ & $<0.002$ & $<0.002$ & $<0.002$ \\
\hline Manganese & 0.04 & 0.034 & 0.04 & $<0.03$ \\
\hline Mercury & $<0.0002$ & $<0.0002$ & $<0.0002$ & $<0.0002$ \\
\hline Nickel & $<0.1$ & $<0.1$ & $<0.1$ & $<0.1$ \\
\hline Selenium & 0.0024 & $<0.002$ & $<0.002$ & $<0.002$ \\
\hline Silver & $<0.0005$ & $<0.0005$ & $<0.001$ & $<0.01$ \\
\hline Vanadium & —(a) $^{(\mathrm{a})}$ & $<0.025$ & $<0.025$ & $<0.025$ \\
\hline Zinc & 0.053 & $<0.05$ & $<0.05$ & $<0.05$ \\
\hline \multicolumn{5}{|l|}{ HE compounds ( $\mu \mathrm{g} / \mathrm{L})$} \\
\hline HMX, RDX, TNT & $<15$ & $<5$ & $<5$ & $<5$ \\
\hline \multicolumn{5}{|l|}{ Organic compounds ${ }^{(\mathbf{b})}$} \\
\hline EPA Method 608 & (n.d.) & (n.d.) & (n.d.) & (n.d.) \\
\hline EPA Method 615 & (n.d.) & -(a) $^{\text {(a) }}$ & (n.d.) & (n.d.) \\
\hline EPA Method 502.2 & (n.d.) & (n.d.) & (n.d.) & (n.d. except) \\
\hline Bromodichloromethane & & & & 1.0 \\
\hline Bromoform & & & & 2.4 \\
\hline Chloroform & & & & 0.6 \\
\hline Dibromochloromethane & & & & 2.1 \\
\hline \multicolumn{5}{|l|}{ Radioactivity (Bq/L) } \\
\hline Gross alpha & 0.027 & -0.048 & -0.078 & 0.052 \\
\hline Gross beta & 0.492 & 0.323 & 0.215 & 0.226 \\
\hline \multicolumn{5}{|l|}{ Radioisotopes (Bq/L) } \\
\hline Tritium & -(a) & -(a) & $<1$ & $<1$ \\
\hline
\end{tabular}

a Analysis not part of sampling plan.

b See Table 8-2 for method constituents and their reporting limits. n.d. = not detected above reporting limits. 
Table 8-30. Off-site Well CDF1.

\begin{tabular}{|c|c|c|c|c|}
\hline \multirow[b]{2}{*}{ Constituent of concern } & \multicolumn{4}{|c|}{ Sample quarter } \\
\hline & 1st & 2nd & 3rd & 4th \\
\hline \multicolumn{5}{|l|}{ Elements (mg/L) } \\
\hline Arsenic & 0.0042 & 0.0066 & 0.0021 & $<0.002$ \\
\hline Barium & $<0.05$ & 0.031 & $<0.025$ & $<0.025$ \\
\hline Beryllium & $<0.0005$ & $<0.0005$ & $<0.0005$ & $<0.0005$ \\
\hline Cadmium & $<0.0005$ & $<0.0005$ & $<0.0005$ & $<0.0005$ \\
\hline Chromium & $<0.01$ & $<0.01$ & $<0.01$ & $<0.01$ \\
\hline Cobalt & $<0.05$ & $<0.025$ & —(a) & $<0.025$ \\
\hline Copper & $<0.05$ & $<0.05$ & $<0.05$ & $<0.05$ \\
\hline Lead & $<0.002$ & $<0.002$ & $<0.002$ & $<0.002$ \\
\hline Manganese & $<0.03$ & $<0.03$ & 0.04 & $<0.03$ \\
\hline Mercury & $<0.0002$ & $<0.0002$ & $<0.0002$ & $<0.0002$ \\
\hline Nickel & $<0.1$ & $<0.1$ & $<0.1$ & $<0.1$ \\
\hline Selenium & 0.0039 & $<0.002$ & $<0.002$ & $<0.002$ \\
\hline Silver & $<0.0005$ & 0.0041 & $<0.001$ & $<0.01$ \\
\hline Vanadium & —(a) & 一 (a) $^{\text {(a) }}$ & $<0.025$ & $<0.025$ \\
\hline Zinc & 0.16 & $<0.05$ & $<0.05$ & 0.074 \\
\hline \multicolumn{5}{|l|}{ HE compounds $(\mu \mathrm{g} / \mathrm{L})$} \\
\hline HMX, RDX, TNT & $<15$ & $<5$ & $<5$ & $<5$ \\
\hline \multicolumn{5}{|l|}{ Organic compounds ${ }^{(b)}$} \\
\hline EPA Method 502.2 & (n.d.) & (n.d.) & (n.d.) & (n.d.) \\
\hline EPA Method 608 & (n.d.) & (n.d.) & (n.d.) & (n.d.) \\
\hline EPA Method 615 & (n.d.) & (n.d.) & (n.d.) & (n.d.) \\
\hline \multicolumn{5}{|l|}{ Radioactivity (Bq/L) } \\
\hline Gross alpha & 0.067 & -0.048 & 0.274 & 0.059 \\
\hline Gross beta & 0.335 & 0.323 & 0.370 & 0.303 \\
\hline \multicolumn{5}{|l|}{ Radioisotopes (Bq/L) } \\
\hline Tritium & -(a) $^{(\mathrm{a})}$ & -(a) $^{(\mathrm{n}}$ & 0.25 & 0.22 \\
\hline
\end{tabular}

a Analysis not part of sampling plan.

b See Table 8-2 for method constituents and their reporting limits. n.d. = not detected above reporting limits. 
Table 8-31. Off-site Well CON1.

\begin{tabular}{|c|c|c|c|c|}
\hline \multirow[b]{2}{*}{ Constituent of concern } & \multicolumn{4}{|c|}{ Sample quarter } \\
\hline & 1st & 2nd & 3rd & 4th \\
\hline \multicolumn{5}{|l|}{ Elements (mg/L) } \\
\hline Arsenic & $<0.002$ & 0.0043 & $<0.002$ & 0.0024 \\
\hline Barium & $<0.05$ & 0.025 & $<0.025$ & $<0.025$ \\
\hline Beryllium & $<0.0005$ & $<0.0005$ & $<0.0005$ & $<0.0005$ \\
\hline Cadmium & $<0.0005$ & $<0.0005$ & $<0.0005$ & $<0.0005$ \\
\hline Chromium & $<0.01$ & $<0.01$ & $<0.01$ & $<0.01$ \\
\hline Cobalt & $<0.05$ & $<0.025$ & $<0.025$ & $<0.025$ \\
\hline Copper & $<0.05$ & $<0.05$ & $<0.05$ & $<0.05$ \\
\hline Lead & $<0.002$ & $<0.002$ & $<0.002$ & $<0.002$ \\
\hline Manganese & 0.14 & 0.12 & 0.12 & 0.11 \\
\hline Mercury & $<0.0002$ & $<0.0002$ & $<0.0002$ & $<0.0002$ \\
\hline Nickel & $<0.1$ & $<0.1$ & $<0.1$ & $<0.1$ \\
\hline Selenium & $<0.002$ & $<0.002$ & $<0.002$ & $<0.002$ \\
\hline Silver & $<0.0005$ & 0.004 & $<0.01$ & $<0.01$ \\
\hline Vanadium & —(a) & —(a) & 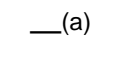 & $<0.025$ \\
\hline Zinc & $<0.05$ & $<0.05$ & $<0.05$ & $<0.05$ \\
\hline \multicolumn{5}{|l|}{ HE compounds ( $\mu \mathrm{g} / \mathrm{L})$} \\
\hline HMX, RDX, TNT & $<15$ & $<5$ & $<5$ & $<5$ \\
\hline \multicolumn{5}{|l|}{ Organic compounds ${ }^{(b)}$} \\
\hline EPA Method 502.2 & (n.d.) & (n.d.) & (n.d.) & (n.d.) \\
\hline EPA Method 608 & (n.d.) & (n.d.) & (n.d.) & (n.d.) \\
\hline EPA Method 615 & (n.d.) & (n.d.) & (n.d.) & (n.d.) \\
\hline \multicolumn{5}{|l|}{ Radioactivity (Bq/L) } \\
\hline Gross alpha & -0.053 & 0.015 & -0.122 & -0.056 \\
\hline Gross beta & 0.474 & 0.064 & 0.426 & 0.329 \\
\hline \multicolumn{5}{|l|}{ Radioisotopes (Bq/L) } \\
\hline Tritium & -(a) & -(a) & $<1$ & $<1$ \\
\hline
\end{tabular}

a Analysis not part of sampling plan.

b See Table 8-2 for method constituents and their reporting limits. n.d. = not detected above reporting limits. 
8. Routine Ground Water Monitoring at Site 300

Table 8-32. Off-site Well GALLO1.

\begin{tabular}{|c|c|c|c|c|}
\hline \multirow[b]{2}{*}{ Constituent of concern } & \multicolumn{4}{|c|}{ Sample quarter } \\
\hline & 1st & 2nd & 3 rd & 4th \\
\hline \multicolumn{5}{|l|}{ Elements (mg/L) } \\
\hline Arsenic & 0.0034 & 0.003 & 0.0029 & 0.0044 \\
\hline Barium & $<0.025$ & $<0.025$ & $<0.025$ & $<0.025$ \\
\hline Beryllium & $<0.0005$ & $<0.0005$ & $<0.0005$ & $<0.0005$ \\
\hline Cadmium & $<0.0005$ & $<0.0005$ & $<0.0005$ & $<0.0005$ \\
\hline Chromium & $<0.01$ & $<0.01$ & $<0.01$ & $<0.01$ \\
\hline Cobalt & $<0.025$ & $<0.025$ & $<0.05$ & $<0.025$ \\
\hline Copper & $<0.05$ & $<0.05$ & $<0.05$ & $<0.05$ \\
\hline Lead & $<0.002$ & $<0.002$ & $<0.002$ & $<0.002$ \\
\hline Manganese & $<0.03$ & $<0.03$ & $<0.03$ & $<0.03$ \\
\hline Mercury & $<0.0002$ & $<0.0002$ & $<0.0002$ & $<0.0002$ \\
\hline Nickel & $<0.1$ & $<0.1$ & $<0.1$ & $<0.1$ \\
\hline Selenium & $<0.002$ & $<0.002$ & $<0.002$ & $<0.002$ \\
\hline Silver & $<0.0005$ & $<0.0005$ & $<0.01$ & $<0.01$ \\
\hline Vanadium & $<0.025$ & $<0.025$ & $<0.05$ & $<0.025$ \\
\hline Zinc & $<0.05$ & $<0.05$ & $<0.05$ & $<0.05$ \\
\hline \multicolumn{5}{|l|}{ HE compounds $(\mu \mathrm{g} / \mathrm{L})$} \\
\hline HMX, RDX, TNT & $<15$ & $<5$ & $<5$ & $<5$ \\
\hline \multicolumn{5}{|l|}{ Organic compounds ${ }^{(a)}$} \\
\hline EPA Method 608 & (n.d.) & (n.d.) & (n.d.) & (n.d.) \\
\hline EPA Method 615 & (n.d.) & (n.d.) & (n.d.) & (n.d.) \\
\hline EPA Method 502.2 & (n.d. except) & (n.d. except) & (n.d. except) & (n.d. except) \\
\hline Trichloroethene (TCE) & 0.4 & 0.3 & 0.3 & 0.3 \\
\hline \multicolumn{5}{|l|}{ Radioactivity (Bq/L) } \\
\hline Gross alpha & -0.105 & 0.084 & 0.007 & -0.070 \\
\hline Gross beta & 0.065 & 0.196 & 0.078 & 0.163 \\
\hline \multicolumn{5}{|l|}{ Radioisotopes (Bq/L) } \\
\hline Tritium & -(b) $^{(\mathrm{b}}$ & -(b) & $<1$ & $<1$ \\
\hline
\end{tabular}

a See Table 8-2 for method constituents and their reporting limits. n.d. = not detected above reporting limits.

b Analysis not part of sampling plan. 
Table 8-33. Off-site Well CARNRW1.

\begin{tabular}{|l|c|c|c|c|}
\hline \multirow{2}{*}{\multicolumn{1}{c|}{ Constituent of concern }} & \multicolumn{4}{|c|}{ Sampled } \\
\cline { 2 - 5 } & $\mathbf{1 / 2 5 / 9 5}$ & $5 / 17 / 95$ & $8 / 18 / 95$ & $10 / 23 / 95$ \\
\hline $\begin{array}{l}\text { Organic compounds }{ }^{(a)} \\
\text { EPA Method } 601\end{array}$ & (n.d.) & (n.d.) & (n.d.) & (n.d.) \\
\hline
\end{tabular}

a See Table 8-2 for method constituents and their reporting limits. n.d. = not detected above reporting limits.

Table 8-34. Off-site Well CON2.

\begin{tabular}{|l|c|c|c|c|}
\hline \multirow{2}{*}{\multicolumn{1}{c|}{ Constituent of concern }} & \multicolumn{3}{|c|}{ Sampled } \\
\cline { 2 - 4 } & $\mathbf{1 / 2 5 / 9 5}$ & $\mathbf{5 / 1 7 / 9 5}$ & $\mathbf{8 / 1 8 / 9 5}$ & $\mathbf{1 0 / 2 3 / 9 5}$ \\
\hline $\begin{array}{l}\text { Organic compounds(a) } \\
\text { EPA Method 601 }\end{array}$ & (n.d.) & (n.d.) & (n.d.) \\
\hline
\end{tabular}

a See Table 8-2 for method constituents and their reporting limits. n.d. = not detected above reporting limits. 


\section{Routine Ground Water Monitoring at Site 300}

Table 8-35. Annually monitored off-site surveillance wells.

\begin{tabular}{|c|c|c|c|c|c|c|}
\hline \multirow{3}{*}{ Constituent of concern } & MUL1 & MUL2 & VIE1 & VIE2 & STN & W35A-04 \\
\hline & \multicolumn{6}{|c|}{ Sampled } \\
\hline & 8/23/95 & 8/23/95 & $8 / 24 / 95$ & $8 / 24 / 95$ & $8 / 2 / 95$ & $2 / 9 / 95$ \\
\hline \multicolumn{7}{|l|}{ Elements (mg/L) } \\
\hline Arsenic & 0.0047 & $<0.002$ & 0.013 & $<0.002$ & $<0.002$ & 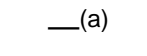 \\
\hline Barium & 0.033 & $<0.025$ & 0.052 & $<0.025$ & 0.031 & 0.040 \\
\hline Beryllium & $<0.0005$ & $<0.0005$ & $<0.0005$ & $<0.0005$ & $<0.0005$ & 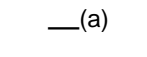 \\
\hline Cadmium & $<0.0005$ & $<0.0005$ & 0.00084 & $<0.0005$ & $<0.0005$ & $<0.0005$ \\
\hline Chromium & 0.013 & $<0.01$ & $<0.01$ & 0.031 & $<0.01$ & -(a) $^{(\mathrm{a})}$ \\
\hline Copper & $<0.05$ & $<0.05$ & $<0.05$ & $<0.05$ & $<0.05$ & $<0.05$ \\
\hline Lead & 0.0021 & $<0.002$ & $<0.002$ & 0.0084 & $<0.002$ & $<0.002$ \\
\hline Manganese & $<0.03$ & $<0.03$ & $<0.03$ & $<0.03$ & $<0.03$ & $<0.03$ \\
\hline Mercury & $<0.0002$ & $<0.0002$ & $<0.0002$ & $<0.0002$ & $<0.0002$ & $<0.0002$ \\
\hline Nickel & $<0.1$ & $<0.1$ & $<0.1$ & $<0.1$ & $<0.1$ & $<0.1$ \\
\hline Selenium & $<0.002$ & $<0.002$ & $<0.002$ & $<0.002$ & $<0.002$ & -(a) \\
\hline Silver & 0.021 & 0.024 & 0.014 & $<0.01$ & $<0.001$ & $<0.01$ \\
\hline Vanadium & $<0.025$ & $<0.025$ & $<0.025$ & $<0.025$ & $<0.025$ & - (a) $^{(2}$ \\
\hline Zinc & $<0.05$ & $<0.05$ & $<0.05$ & $<0.05$ & $<0.05$ & $<0.05$ \\
\hline \multicolumn{7}{|l|}{ Organic compounds ${ }^{(b)}$} \\
\hline EPA Method 502.2 & (n.d.) & (n.d.) & (n.d.) & (n.d.) & (n.d.) & $(\text { n.d. })^{(\mathrm{c})}$ \\
\hline EPA Method 608 & (n.d.) & (n.d.) & (n.d.) & (n.d.) & (n.d.) & $-\left({ }^{(a)}\right.$ \\
\hline EPA Method 615 & (n.d.) & (n.d.) & (n.d.) & (n.d.) & (n.d.) & -(a) $^{(\mathrm{n}}$ \\
\hline \multicolumn{7}{|l|}{ Radioactivity (Bq/L) } \\
\hline Gross alpha & 0.078 & -0.052 & 0.130 & 0.096 & -(a) $^{\text {(a) }}$ & -(a) $^{\mathrm{a}}$ \\
\hline Gross beta & 0.340 & 0.215 & 0.274 & 0.163 & -(a) $^{\text {(a) }}$ & -(a) $^{(\mathrm{n}}$ \\
\hline \multicolumn{7}{|l|}{ Radioisotopes (Bq/L) } \\
\hline Tritium & $<0.2$ & $<0.2$ & $<0.1$ & $<1.0$ & $<1.0$ & —(a) \\
\hline
\end{tabular}

a Analysis not part of sampling plan.

b See Table 8-2 for method constituents and their reporting limits. n.d. = not detected above reporting limits.

c Well W35A-04 analyzed by EPA Methods 601 and 602 (see Table 8-2). 



\section{Livermore Ground Water Protection Management Program}

Richard A. Brown

Richard C. Blake

\section{Methods}

Livermore Valley Wells
The Environmental Analyst or Analyst Assistant responsible for ground water develops a ground water sampling plan each quarter. This plan is documented and given to the Sampling Coordinator at least one month prior to the start of the quarter in which sampling will occur. Sampling personnel then sample the wells at the desired intervals according to Standard Operating Procedures (SOPs; Dibley and Depue 1995), which include special instructions for individual classes of analytes. The overall ground water sampling procedure is documented in EMP-GW-S (1996).

Wells are typically purged of standing water (via ERD SOPs 2.1 and 2.7) prior to extracting the representative ground water samples. Water samples for volatile organic compounds are taken first, followed by the other analytes. The sampling technologists also measure the following parameters in the field: depth to water, water temperature, $\mathrm{pH}$, and specific conductance, as well as gallons of water purged. Sample equipment is maintained and cleaned between sampling events so that the sample equipment does not contaminate the water samples.

Sampling technologists wear disposable gloves to avoid contaminating the samples.

All nonradiological ground water samples collected during 1995 were sent to CLS Analytical Laboratory on the same day as collected, if possible. All radiological samples collected during 1995 were delivered to and analyzed by the Chemistry and Materials Science's Environmental Services on-site laboratory (CES).

Tables 9-1 and 9-2 present all detections of organic data for the upgradient wells and downgradient wells, respectively; Tables 9-3 and 9-4 present all inorganic data results for the upgradient wells and downgradient wells, respectively; and Tables 9-5 and 9-6 present all calculated values for radioactivity for the upgradient wells and downgradient wells, respectively.

Water samples for tritium analysis were collected in $250-\mathrm{mL}$, argon-flushed, flintglass bottles fitted with glass stoppers. The CES laboratory measurements of tritium are performed utilizing liquid scintillation, achieving a minimum detectable activity of approximately $1.85 \mathrm{~Bq} / \mathrm{L}(50 \mathrm{pCi} / \mathrm{L})$. Four 50 -minute counting intervals were used for all sample measurements. Sample results for tritium are presented in Tables 9-8, 9-9, and 9-10 of Volume 1 and discussed in Volume 1, Chapter 9. 
Table 9-1. Analyses for organic compounds in upgradient wells in the southeastern corner of the Livermore site, 1995.

\begin{tabular}{|c|c|c|c|c|c|}
\hline \multirow[b]{2}{*}{ Organic compound ( $\mu \mathrm{g} / \mathrm{L})$} & \multirow[b]{2}{*}{ Date } & \multicolumn{4}{|c|}{ Monitor wells } \\
\hline & & W-017 & W-107 & W-117 & W-268 \\
\hline \multicolumn{6}{|l|}{ Volatile organic compounds (EPA 601) } \\
\hline \multirow[t]{4}{*}{ 1,1-Dichloroethene } & $3 / 9-17$ & $<0.5$ & $<0.5$ & $<0.5$ & $<0.5$ \\
\hline & $6 / 5-21$ & $<0.5$ & $<0.5$ & $<0.5$ & 1.2 \\
\hline & $9 / 5-8$ & $<0.5$ & $<0.5$ & $<0.5$ & 1.2 \\
\hline & $11 / 27-30$ & $<0.5$ & $<0.5$ & $<0.5$ & 1.4 \\
\hline \multirow[t]{4}{*}{ 1,2-Dichloroethane } & $3 / 9-17$ & $<0.5$ & $<0.5$ & $<0.5$ & $<0.5$ \\
\hline & $6 / 5-21$ & $<0.5$ & $<0.5$ & $<0.5$ & $<0.5$ \\
\hline & $9 / 5-8$ & $<0.5$ & $<0.5$ & $<0.5$ & $<0.5$ \\
\hline & $11 / 27-30$ & $<0.5$ & $<0.5$ & $<0.5$ & $<0.5$ \\
\hline \multirow[t]{4}{*}{ Carbon tetrachloride } & $3 / 9-17$ & $<0.5$ & $<0.5$ & $<0.5$ & $<0.5$ \\
\hline & $6 / 5-21$ & $<0.5$ & $<0.5$ & $<0.5$ & $<0.5$ \\
\hline & $9 / 5-8$ & $<0.5$ & $<0.5$ & $<0.5$ & $<0.5$ \\
\hline & $11 / 27-30$ & $<0.5$ & $<0.5$ & $<0.5$ & $<0.5$ \\
\hline \multirow[t]{4}{*}{ Chloroform } & & $<0.5$ & $<0.5$ & $<0.5$ & $<0.5$ \\
\hline & $6 / 5-21$ & $<0.5$ & $<0.5$ & $<0.5$ & $<0.5$ \\
\hline & $9 / 5-8$ & $<0.5$ & $<0.5$ & $<0.5$ & $<0.5$ \\
\hline & $11 / 27-30$ & $<0.5$ & $<0.5$ & $<0.5$ & $<0.5$ \\
\hline \multirow[t]{4}{*}{ Freon 113} & $3 / 9-17$ & $<0.5$ & 27 & $<0.5$ & 22 \\
\hline & $6 / 5-21$ & $<0.5$ & $<0.5$ & $<0.5$ & 29 \\
\hline & $9 / 5-8$ & $<0.5$ & 23 & $<0.5$ & 21 \\
\hline & $11 / 27-30$ & $<0.5$ & 30 & $<0.5$ & 27 \\
\hline \multirow[t]{4}{*}{ Tetrachloroethene } & $3 / 9-17$ & $<0.5$ & $<0.5$ & $<0.5$ & 0.78 \\
\hline & $6 / 5-21$ & $<0.5$ & $<0.5$ & $<0.5$ & $<0.5$ \\
\hline & $9 / 5-8$ & $<0.5$ & $<0.5$ & $<0.5$ & $<0.5$ \\
\hline & $11 / 27-30$ & $<0.5$ & $<0.5$ & $<0.5$ & $<0.5$ \\
\hline \multirow[t]{4}{*}{ Trichloroethene } & $3 / 9-17$ & $<0.5$ & 1.4 & 0.87 & 1.9 \\
\hline & $6 / 5-21$ & $<0.5$ & $<0.5$ & $<0.5$ & 1.1 \\
\hline & $9 / 5-8$ & $<0.5$ & $<0.5$ & $<0.5$ & 0.86 \\
\hline & 11/27-30 & $<0.5$ & $<0.5$ & $<0.5$ & 0.95 \\
\hline \multirow[t]{4}{*}{ Trichlorofluoromethane } & $3 / 9-17$ & $<0.5$ & $<0.5$ & $<0.5$ & $<0.5$ \\
\hline & $6 / 5-21$ & $<0.5$ & $<0.5$ & $<0.5$ & $<0.5$ \\
\hline & $9 / 5-8$ & $<0.5$ & $<0.5$ & $<0.5$ & $<0.5$ \\
\hline & $11 / 27-30$ & $<0.5$ & $<0.5$ & $<0.5$ & $<0.5$ \\
\hline \multicolumn{6}{|l|}{ Semivolatile organics (EPA 625) } \\
\hline \multirow[t]{4}{*}{ Bis(2-ethylhexyl)phthalate } & $3 / 9-17$ & $<10$ & $<10$ & $<10$ & $<10$ \\
\hline & $6 / 5-21$ & $<10$ & $<10$ & $<10$ & $<10$ \\
\hline & $9 / 5-8$ & $<10$ & 11 & $<10$ & $<10$ \\
\hline & 11/27-30 & $<10$ & $<10$ & $<10$ & $<10$ \\
\hline
\end{tabular}


Table 9-2. Analyses for organic compounds in downgradient wells in the southeastern corner of the Livermore site, 1995.

\begin{tabular}{|c|c|c|c|c|c|}
\hline \multirow[b]{2}{*}{ Organic compound $(\mu \mathrm{g} / \mathrm{L})$} & \multirow[b]{2}{*}{ Date } & \multicolumn{4}{|c|}{ Monitor wells } \\
\hline & & W-217 & W-270 & W-359 & W-622 \\
\hline \multicolumn{6}{|l|}{ Volatile organic compounds (EPA 601) } \\
\hline \multirow[t]{4}{*}{ 1,1-Dichloroethene } & $3 / 9-17$ & 17 & $<0.5$ & 6.7 & 110 \\
\hline & $6 / 5-21$ & 14 & $<0.5$ & 7.1 & 79 \\
\hline & $9 / 5-8$ & 15 & $<0.5$ & 5.6 & 83 \\
\hline & $11 / 27-30$ & 12 & $<0.5$ & 6.1 & 88 \\
\hline \multirow[t]{4}{*}{ 1,2-Dichloroethane } & $3 / 9-17$ & $<0.5$ & $<0.5$ & 1 & $<0.5$ \\
\hline & $6 / 5-21$ & $<0.5$ & $<0.5$ & 0.88 & $<0.5$ \\
\hline & $9 / 5-8$ & $<0.5$ & $<0.5$ & 0.81 & $<0.5$ \\
\hline & $11 / 27-30$ & $<0.5$ & $<0.5$ & 0.94 & $<0.5$ \\
\hline \multirow[t]{4}{*}{ Carbon tetrachloride } & $3 / 9-17$ & 31 & $<0.5$ & 1.2 & 210 \\
\hline & $6 / 5-21$ & 29 & $<0.5$ & 1.2 & 84 \\
\hline & 9/5-8 & 28 & $<0.5$ & 0.86 & 110 \\
\hline & $11 / 27-30$ & 23 & $<0.5$ & 0.83 & 110 \\
\hline \multirow[t]{4}{*}{ Chloroform } & $3 / 9-17$ & 2 & 1.4 & 6.1 & 15 \\
\hline & $6 / 5-21$ & 2 & $<0.5$ & 6.5 & 7.4 \\
\hline & 9/5-8 & 1.6 & $<0.5$ & 4 & 9.5 \\
\hline & $11 / 27-30$ & 1.9 & $<0.5$ & 5 & 12 \\
\hline \multirow[t]{4}{*}{ Freon 113} & $3 / 9-17$ & 2 & $<0.5$ & 31 & 46 \\
\hline & $6 / 5-21$ & 3.4 & $<0.5$ & 34 & 23 \\
\hline & 9/5-8 & 2.8 & $<0.5$ & 27 & 26 \\
\hline & $11 / 27-30$ & 2.4 & $<0.5$ & 29 & 20 \\
\hline \multirow[t]{4}{*}{ Tetrachloroethene } & $3 / 9-17$ & 2.7 & $<0.5$ & 13 & 290 \\
\hline & $6 / 5-21$ & 3.3 & $<0.5$ & 10 & 69 \\
\hline & 9/5-8 & 3.5 & $<0.5$ & 9.9 & 160 \\
\hline & $11 / 27-30$ & 5.3 & $<0.5$ & 10 & 140 \\
\hline \multirow[t]{4}{*}{ Trichloroethene } & $3 / 9-17$ & 42 & $<0.5$ & 180 & 290 \\
\hline & $6 / 5-21$ & 30 & $<0.5$ & 120 & 230 \\
\hline & 9/5-8 & 29 & $<0.5$ & 140 & 190 \\
\hline & $11 / 27-30$ & 28 & $<0.5$ & 130 & 220 \\
\hline \multirow[t]{4}{*}{ Trichlorofluoromethane } & $3 / 9-17$ & 3.8 & $<0.5$ & $<0.5$ & 1.3 \\
\hline & $6 / 5-21$ & 7.8 & $<0.5$ & $<0.5$ & $<2.5$ \\
\hline & 9/5-8 & $<0.5$ & $<0.5$ & $<0.5$ & $<0.5$ \\
\hline & $11 / 27-30$ & 4 & $<0.5$ & $<0.5$ & 1.2 \\
\hline \multicolumn{6}{|l|}{ Semivolatile organics (EPA 625) } \\
\hline \multirow[t]{4}{*}{ Bis(2-ethylhexyl)phthalate } & $3 / 9-17$ & $<10$ & $<10$ & $<10$ & $<10$ \\
\hline & $6 / 5-21$ & $<10$ & $<10$ & 11 & $<10$ \\
\hline & 9/5-8 & $<10$ & $<10$ & 32 & $<10$ \\
\hline & $11 / 27-30$ & $<10$ & $<10$ & $<10$ & $<10$ \\
\hline
\end{tabular}


Table 9-3. Analyses for inorganic constituents in upgradient wells.

\begin{tabular}{|c|c|c|c|c|c|}
\hline & & & Mon & wells & \\
\hline & Date & W-017 & W-107 & W-117 & W-268 \\
\hline General indicators & & & & & \\
\hline $\mathrm{pH}$ & $3 / 9-17$ & 7.2 & 7.4 & 8.7 & 7.2 \\
\hline & $6 / 5-21$ & 7.3 & 7.5 & 9.7 & 7.4 \\
\hline & 9/5-8 & 7.5 & 7.5 & 8.9 & 7.4 \\
\hline & $11 / 27-30$ & 7.4 & 7.3 & 9.5 & 7.2 \\
\hline Specific conductance $(\mu \mathrm{mho} / \mathrm{cm})$ & $3 / 9-17$ & 770 & 560 & 530 & 700 \\
\hline & $6 / 5-21$ & 850 & 620 & 49 & 700 \\
\hline & 9/5-8 & 990 & 740 & 640 & 740 \\
\hline & $11 / 27-30$ & 840 & 590 & 410 & 740 \\
\hline Total dissolved solids (mg/L) & $3 / 9-17$ & 581 & 411 & 380 & 431 \\
\hline & $6 / 5-21$ & 671 & 421 & 240 & 501 \\
\hline & $9 / 5-8$ & 511 & 401 & 280 & 461 \\
\hline & $11 / 27-30$ & 531 & 410 & 240 & 431 \\
\hline Water table elevation (m) & $3 / 9-17$ & 169.40 & 168.08 & 165.09 & 165.38 \\
\hline & $6 / 5-21$ & 169.53 & 167.96 & 165.18 & 135.35 \\
\hline & $9 / 5-8$ & 169.68 & 168.24 & 165.37 & 135.71 \\
\hline & $11 / 27-30$ & 169.69 & 168.21 & 165.35 & 165.74 \\
\hline Metals and minerals (mg/L) & & & & & \\
\hline Bicarbonate alkalinity $\left(\right.$ as $\left.\mathrm{CaCO}_{3}\right)$ & $3 / 9-17$ & 180 & 170 & 190 & 150 \\
\hline & $6 / 5-21$ & 180 & 160 & 10 & 150 \\
\hline & 9/5-8 & 180 & 160 & 340 & 190 \\
\hline & $11 / 27-30$ & 180 & 160 & 92 & 150 \\
\hline Carbonate alkalinity $\left(\mathrm{as} \mathrm{CaCO}_{3}\right)$ & $3 / 9-17$ & $<1$ & $<1$ & 37 & $<1$ \\
\hline & $6 / 5-21$ & $<1$ & $<1$ & 100 & $<1$ \\
\hline & 9/5-8 & $<1$ & $<1$ & 18 & $<1$ \\
\hline & $11 / 27-30$ & $<1$ & $<1$ & 19 & $<1$ \\
\hline Hydroxide alkalinity $\left(\mathrm{as} \mathrm{CaCO}_{3}\right)$ & $3 / 9-17$ & $<1$ & $<1$ & $<1$ & $<1$ \\
\hline & $6 / 5-21$ & $<1$ & $<1$ & $<1$ & $<1$ \\
\hline & 9/5-8 & $<1$ & $<1$ & $<1$ & $<1$ \\
\hline & $11 / 27-30$ & $<1$ & $<1$ & $<1$ & $<1$ \\
\hline Total alkalinity $\left(\mathrm{as} \mathrm{CaCO}_{3}\right)$ & $3 / 9-17$ & 180 & 170 & 230 & 150 \\
\hline & $6 / 5-21$ & 180 & 160 & 110 & 150 \\
\hline & 9/5-8 & 180 & 160 & 360 & 190 \\
\hline & $11 / 27-30$ & 180 & 160 & 110 & 150 \\
\hline
\end{tabular}




\section{Livermore Ground Water Protection Management Program}

Table 9-3. Analyses for inorganic constituents in upgradient wells (continued).

\begin{tabular}{|c|c|c|c|c|c|}
\hline & \multirow[b]{2}{*}{ Date } & \multicolumn{4}{|c|}{ Monitor wells } \\
\hline & & W-017 & W-107 & W-117 & W-268 \\
\hline \multirow[t]{4}{*}{ Aluminum } & $3 / 9-17$ & $<0.2$ & $<0.2$ & $<0.2$ & $<0.2$ \\
\hline & $6 / 5-21$ & $<0.2$ & $<0.2$ & $<0.2$ & $<0.2$ \\
\hline & 9/5-8 & $<0.2$ & $<0.2$ & $<0.2$ & $<0.2$ \\
\hline & $11 / 27-30$ & $<0.2$ & $<0.2$ & $<0.2$ & $<0.2$ \\
\hline \multirow[t]{4}{*}{ Antimony } & 3/9-17 & $<0.01$ & $<0.01$ & $<0.01$ & $<0.005$ \\
\hline & $6 / 5-21$ & $<0.06$ & $<0.06$ & $<0.06$ & $<0.005$ \\
\hline & 9/5-8 & $<0.005$ & $<0.005$ & $<0.005$ & $<0.005$ \\
\hline & $11 / 27-30$ & $<0.005$ & $<0.005$ & $<0.005$ & $<0.005$ \\
\hline \multirow[t]{4}{*}{ Arsenic } & $3 / 9-17$ & $<0.002$ & 0.0021 & 0.0041 & 0.0068 \\
\hline & $6 / 5-21$ & 0.0026 & 0.002 & 0.0022 & $<0.002$ \\
\hline & 9/5-8 & 0.0035 & 0.003 & 0.007 & $<0.002$ \\
\hline & $11 / 27-30$ & 0.0025 & $<0.002$ & 0.0027 & 0.0028 \\
\hline \multirow[t]{4}{*}{ Barium } & 3/9-17 & 0.21 & 0.13 & 0.36 & 0.19 \\
\hline & $6 / 5-21$ & -(a) & -(a) & -(a) & 0.2 \\
\hline & $9 / 5-8$ & 0.2 & 0.13 & 0.52 & 0.19 \\
\hline & $11 / 27-30$ & 0.21 & 0.12 & 0.36 & 0.18 \\
\hline \multirow[t]{4}{*}{ Beryllium } & 3/9-17 & $<0.0005$ & $<0.0005$ & $<0.0005$ & $<0.0005$ \\
\hline & $6 / 5-21$ & $<0.0005$ & $<0.0005$ & $<0.0005$ & $<0.0005$ \\
\hline & $9 / 5-8$ & $<0.0005$ & $<0.0005$ & $<0.0005$ & $<0.0005$ \\
\hline & $11 / 27-30$ & $<0.0005$ & $<0.0005$ & $<0.0005$ & $<0.0005$ \\
\hline \multirow[t]{4}{*}{ Boron } & 3/9-17 & 0.45 & 0.17 & 0.1 & 0.29 \\
\hline & $6 / 5-21$ & 0.61 & 0.24 & 0.18 & 0.35 \\
\hline & $9 / 5-8$ & 0.48 & 0.22 & 0.24 & 0.31 \\
\hline & $11 / 27-30$ & 0.34 & 0.11 & 0.12 & 0.21 \\
\hline \multirow[t]{4}{*}{ Bromide } & $3 / 9-17$ & 0.91 & $<0.5$ & $<0.5$ & $<0.5$ \\
\hline & $6 / 5-21$ & 0.9 & 0.72 & $<0.5$ & 0.78 \\
\hline & $9 / 5-8$ & $<0.5$ & $<0.5$ & $<0.5$ & $<0.5$ \\
\hline & $11 / 27-30$ & $<5$ & $<5$ & $<5$ & $<5$ \\
\hline \multirow[t]{4}{*}{ Cadmium } & 3/9-17 & $<0.0005$ & $<0.0005$ & $<0.0005$ & $<0.0005$ \\
\hline & $6 / 5-21$ & $<0.0005$ & $<0.0005$ & $<0.0005$ & $<0.0005$ \\
\hline & $9 / 5-8$ & $<0.0005$ & $<0.0005$ & $<0.0005$ & $<0.0005$ \\
\hline & $11 / 27-30$ & $<0.0005$ & $<0.0005$ & $<0.0005$ & $<0.0005$ \\
\hline \multirow[t]{4}{*}{ Calcium } & 3/9-17 & 71 & 37 & 17 & 52 \\
\hline & $6 / 5-21$ & 63 & 34 & 8.2 & 49 \\
\hline & $9 / 5-8$ & 67 & 82 & 25 & 48 \\
\hline & $11 / 27-30$ & 70 & 38 & 8.9 & 53 \\
\hline
\end{tabular}

a Analysis not done 
Table 9-3. Analyses for inorganic constituents in upgradient wells (continued).

\begin{tabular}{|c|c|c|c|c|c|}
\hline & \multirow[b]{2}{*}{ Date } & \multicolumn{4}{|c|}{ Monitor wells } \\
\hline & & W-017 & W-107 & W-117 & W-268 \\
\hline \multirow[t]{4}{*}{ Chloride } & $3 / 9-17$ & 180 & 100 & 78 & 140 \\
\hline & $6 / 5-21$ & 180 & 110 & 78 & 120 \\
\hline & $9 / 5-8$ & 180 & 110 & 76 & 130 \\
\hline & $11 / 27-30$ & 190 & 100 & 100 & 160 \\
\hline \multirow[t]{4}{*}{ Chromium (VI) } & 3/9-17 & 0.012 & 0.012 & 0.032 & 0.012 \\
\hline & $6 / 5-21$ & 0.011 & 0.011 & $<0.01$ & $<0.01$ \\
\hline & 9/5-8 & 0.014 & 0.012 & 0.016 & 0.01 \\
\hline & $11 / 27-30$ & 0.011 & 0.016 & 0.016 & 0.0099 \\
\hline \multirow[t]{4}{*}{ Copper } & $3 / 9-17$ & $<0.05$ & $<0.05$ & $<0.05$ & $<0.05$ \\
\hline & $6 / 5-21$ & $<0.05$ & $<0.05$ & $<0.05$ & $<0.05$ \\
\hline & $9 / 5-8$ & $<0.05$ & $<0.05$ & $<0.05$ & $<0.05$ \\
\hline & $11 / 27-30$ & $<0.05$ & $<0.05$ & $<0.05$ & $<0.05$ \\
\hline \multirow[t]{4}{*}{ Cyanide } & 3/9-17 & $<0.02$ & $<0.02$ & $<0.02$ & $<0.02$ \\
\hline & $6 / 5-21$ & $<0.02$ & $<0.02$ & $<0.02$ & $<0.02$ \\
\hline & $9 / 5-8$ & $<0.02$ & $<0.02$ & $<0.02$ & $<0.02$ \\
\hline & $11 / 27-30$ & $<0.02$ & $<0.02$ & $<0.02$ & $<0.02$ \\
\hline \multirow[t]{4}{*}{ Fluoride } & 3/9-17 & 0.46 & 0.53 & 0.37 & 0.45 \\
\hline & $6 / 5-21$ & 0.42 & 0.5 & 0.27 & 0.49 \\
\hline & 9/5-8 & 0.46 & 0.54 & 0.48 & 0.4 \\
\hline & $11 / 27-30$ & 0.46 & 0.53 & 0.31 & 0.4 \\
\hline \multirow[t]{4}{*}{ Total hardness $\left(\mathrm{as} \mathrm{CaCO}_{3}\right)$} & $3 / 9-17$ & 370 & 200 & 210 & 240 \\
\hline & $6 / 5-21$ & 330 & 270 & 86 & 410 \\
\hline & $9 / 5-8$ & 360 & 340 & 260 & 230 \\
\hline & $11 / 27-30$ & 370 & 210 & 100 & 250 \\
\hline \multirow[t]{4}{*}{ Iron } & $3 / 9-17$ & $<0.1$ & $<0.1$ & $<0.1$ & $<0.1$ \\
\hline & $6 / 5-21$ & $<0.1$ & $<0.1$ & $<0.1$ & $<0.1$ \\
\hline & $9 / 5-8$ & $<0.1$ & $<0.1$ & $<0.1$ & $<0.1$ \\
\hline & $11 / 27-30$ & $<0.1$ & $<0.1$ & $<0.1$ & $<0.1$ \\
\hline \multirow[t]{4}{*}{ Lead } & $3 / 9-17$ & $<0.002$ & $<0.002$ & $<0.002$ & $<0.002$ \\
\hline & $6 / 5-21$ & $<0.002$ & $<0.002$ & $<0.002$ & 0.0032 \\
\hline & $9 / 5-8$ & $<0.002$ & $<0.002$ & $<0.002$ & $<0.002$ \\
\hline & $11 / 27-30$ & $<0.002$ & $<0.002$ & $<0.002$ & $<0.002$ \\
\hline \multirow[t]{4}{*}{ Magnesium } & $3 / 9-17$ & 46 & 27 & 41 & 27 \\
\hline & $6 / 5-21$ & 42 & 25 & 16 & 26 \\
\hline & $9 / 5-8$ & 46 & 33 & 49 & 27 \\
\hline & $11 / 27-30$ & 48 & 29 & 20 & 29 \\
\hline
\end{tabular}




\section{Livermore Ground Water Protection Management Program}

Table 9-3. Analyses for inorganic constituents in upgradient wells (continued).

\begin{tabular}{|c|c|c|c|c|c|}
\hline & \multirow[b]{2}{*}{ Date } & \multicolumn{4}{|c|}{ Monitor wells } \\
\hline & & W-017 & W-107 & W-117 & W-268 \\
\hline \multirow[t]{4}{*}{ Manganese } & $3 / 9-17$ & $<0.03$ & $<0.03$ & $<0.03$ & $<0.03$ \\
\hline & $6 / 5-21$ & $<0.03$ & $<0.03$ & $<0.03$ & $<0.03$ \\
\hline & $9 / 5-8$ & $<0.03$ & $<0.03$ & $<0.03$ & $<0.03$ \\
\hline & $11 / 27-30$ & $<0.03$ & $<0.03$ & $<0.03$ & $<0.03$ \\
\hline \multirow[t]{4}{*}{ Mercury } & 3/9-17 & $<0.0002$ & $<0.0002$ & $<0.0002$ & $<0.0002$ \\
\hline & $6 / 5-21$ & $<0.0002$ & $<0.0002$ & $<0.0002$ & $<0.0002$ \\
\hline & $9 / 5-8$ & $<0.0002$ & $<0.0002$ & $<0.0002$ & $<0.0002$ \\
\hline & $11 / 27-30$ & $<0.0002$ & $<0.0002$ & $<0.0002$ & $<0.0002$ \\
\hline \multirow[t]{4}{*}{ Molybdenum } & $3 / 9-17$ & $<0.05$ & $<0.05$ & $<0.05$ & $<0.025$ \\
\hline & $6 / 5-21$ & —a) $^{(\mathrm{a})}$ & -(a) $^{(\mathrm{a})}$ & -(a) $^{(\mathrm{a}}$ & $<0.025$ \\
\hline & 9/5-8 & $<0.025$ & $<0.025$ & $<0.025$ & $<0.025$ \\
\hline & $11 / 27-30$ & $<0.025$ & $<0.025$ & $<0.025$ & $<0.025$ \\
\hline \multirow[t]{4}{*}{ Nickel } & 3/9-17 & $<0.1$ & $<0.1$ & $<0.1$ & $<0.1$ \\
\hline & $6 / 5-21$ & $<0.1$ & $<0.1$ & $<0.1$ & $<0.1$ \\
\hline & 9/5-8 & $<0.1$ & $<0.1$ & $<0.1$ & $<0.1$ \\
\hline & $11 / 27-30$ & $<0.1$ & $<0.1$ & $<0.1$ & $<0.1$ \\
\hline \multirow[t]{4}{*}{ Nitrate $\left(\right.$ as $\left.\mathrm{NO}_{3}\right)$} & $3 / 9-17$ & 11 & 13 & $<0.5$ & 16 \\
\hline & $6 / 5-21$ & 11 & 13 & 0.54 & 16 \\
\hline & 9/5-8 & 11 & 13 & $<0.5$ & 15 \\
\hline & $11 / 27-30$ & 9 & 8.8 & $<5$ & 12 \\
\hline \multirow[t]{4}{*}{ Orthophosphate } & $3 / 9-17$ & $<1$ & $<1$ & $<1$ & $<1$ \\
\hline & $6 / 5-21$ & $<1$ & $<1$ & $<1$ & $<1$ \\
\hline & 9/5-8 & $<1$ & $<1$ & $<1$ & $<1$ \\
\hline & $11 / 27-30$ & $<10$ & $<10$ & $<10$ & $<10$ \\
\hline \multirow[t]{4}{*}{ Potassium } & 3/9-17 & 1.6 & 1.2 & 2.2 & 1.5 \\
\hline & $6 / 5-21$ & 1.5 & 1.1 & 2.8 & 1.4 \\
\hline & 9/5-8 & 1.6 & 2.5 & 2.5 & 1.5 \\
\hline & $11 / 27-30$ & 1.7 & 1.3 & 2.9 & 1.6 \\
\hline \multirow[t]{4}{*}{ Selenium } & $3 / 9-17$ & $<0.002$ & $<0.002$ & $<0.002$ & $<0.002$ \\
\hline & $6 / 5-21$ & $<0.002$ & $<0.002$ & $<0.002$ & $<0.002$ \\
\hline & $9 / 5-8$ & $<0.002$ & $<0.002$ & $<0.002$ & $<0.002$ \\
\hline & $11 / 27-30$ & $<0.002$ & $<0.002$ & $<0.002$ & $<0.002$ \\
\hline \multirow[t]{4}{*}{ Silver } & $3 / 9-17$ & $<0.0005$ & $<0.0005$ & $<0.0005$ & $<0.0005$ \\
\hline & $6 / 5-21$ & $<0.0005$ & $<0.0005$ & $<0.0005$ & $<0.0005$ \\
\hline & 9/5-8 & $<0.01$ & $<0.01$ & $<0.0005$ & $<0.0005$ \\
\hline & $11 / 27-30$ & $<0.0005$ & 0.0005 & $<0.0005$ & 0.0005 \\
\hline
\end{tabular}


Table 9-3. Analyses for inorganic constituents in upgradient wells (concluded).

\begin{tabular}{|c|c|c|c|c|c|}
\hline & \multirow[b]{2}{*}{ Date } & \multicolumn{4}{|c|}{ Monitor wells } \\
\hline & & W-017 & W-107 & W-117 & W-268 \\
\hline \multirow[t]{4}{*}{ Sodium } & $3 / 9-17$ & 61 & 69 & 66 & 64 \\
\hline & $6 / 5-21$ & 57 & 65 & 63 & 61 \\
\hline & 9/5-8 & 62 & 76 & 74 & 66 \\
\hline & $11 / 27-30$ & 66 & 73 & 68 & 70 \\
\hline \multirow[t]{4}{*}{ Sulfate } & $3 / 9-17$ & 42 & 24 & 7.9 & 29 \\
\hline & $6 / 5-21$ & 45 & 23 & 6.1 & 28 \\
\hline & 9/5-8 & 52 & 25 & 6 & 28 \\
\hline & $11 / 27-30$ & 66 & 73 & 68 & 54 \\
\hline \multirow[t]{4}{*}{ Surfactant } & $3 / 9-17$ & $<0.5$ & $<0.5$ & $<0.5$ & $<0.5$ \\
\hline & $6 / 5-21$ & $<0.5$ & $<0.5$ & $<0.5$ & $<0.5$ \\
\hline & 9/5-8 & $<0.5$ & $<0.5$ & $<0.5$ & $<0.5$ \\
\hline & $11 / 27-30$ & $<0.5$ & $<0.5$ & $<0.5$ & $<0.5$ \\
\hline \multirow[t]{4}{*}{ Thallium } & $3 / 9-17$ & $<0.005$ & $<0.005$ & $<0.005$ & $<0.005$ \\
\hline & $6 / 5-21$ & $<0.001$ & $<0.001$ & $<0.001$ & $<0.001$ \\
\hline & 9/5-8 & $<0.001$ & $<0.001$ & $<0.001$ & $<0.001$ \\
\hline & $11 / 27-30$ & $<0.001$ & $<0.001$ & $<0.001$ & $<0.001$ \\
\hline \multirow[t]{4}{*}{ Vanadium } & 3/9-17 & $<0.02$ & $<0.02$ & $<0.02$ & $<0.025$ \\
\hline & $6 / 5-21$ & - (a) $^{(2)}$ & - (a) $^{(2)}$ & - (a) $^{\text {(a) }}$ & $<0.025$ \\
\hline & 9/5-8 & $<0.025$ & $<0.025$ & $<0.025$ & $<0.025$ \\
\hline & $11 / 27-30$ & $<0.025$ & $<0.025$ & $<0.025$ & $<0.025$ \\
\hline \multirow[t]{4}{*}{ Zinc } & $3 / 9-17$ & $<0.05$ & $<0.05$ & $<0.05$ & $<0.05$ \\
\hline & $6 / 5-21$ & $<0.05$ & $<0.05$ & $<0.05$ & $<0.05$ \\
\hline & 9/5-8 & $<0.05$ & $<0.05$ & $<0.05$ & $<0.05$ \\
\hline & $11 / 27-30$ & $<0.05$ & $<0.05$ & $<0.05$ & $<0.05$ \\
\hline
\end{tabular}

a Analysis not done. 


\section{Livermore Ground Water Protection Management Program}

Table 9-4. Analyses for inorganic compounds in downgradient wells in the southeastern corner of the Livermore site, 1995.

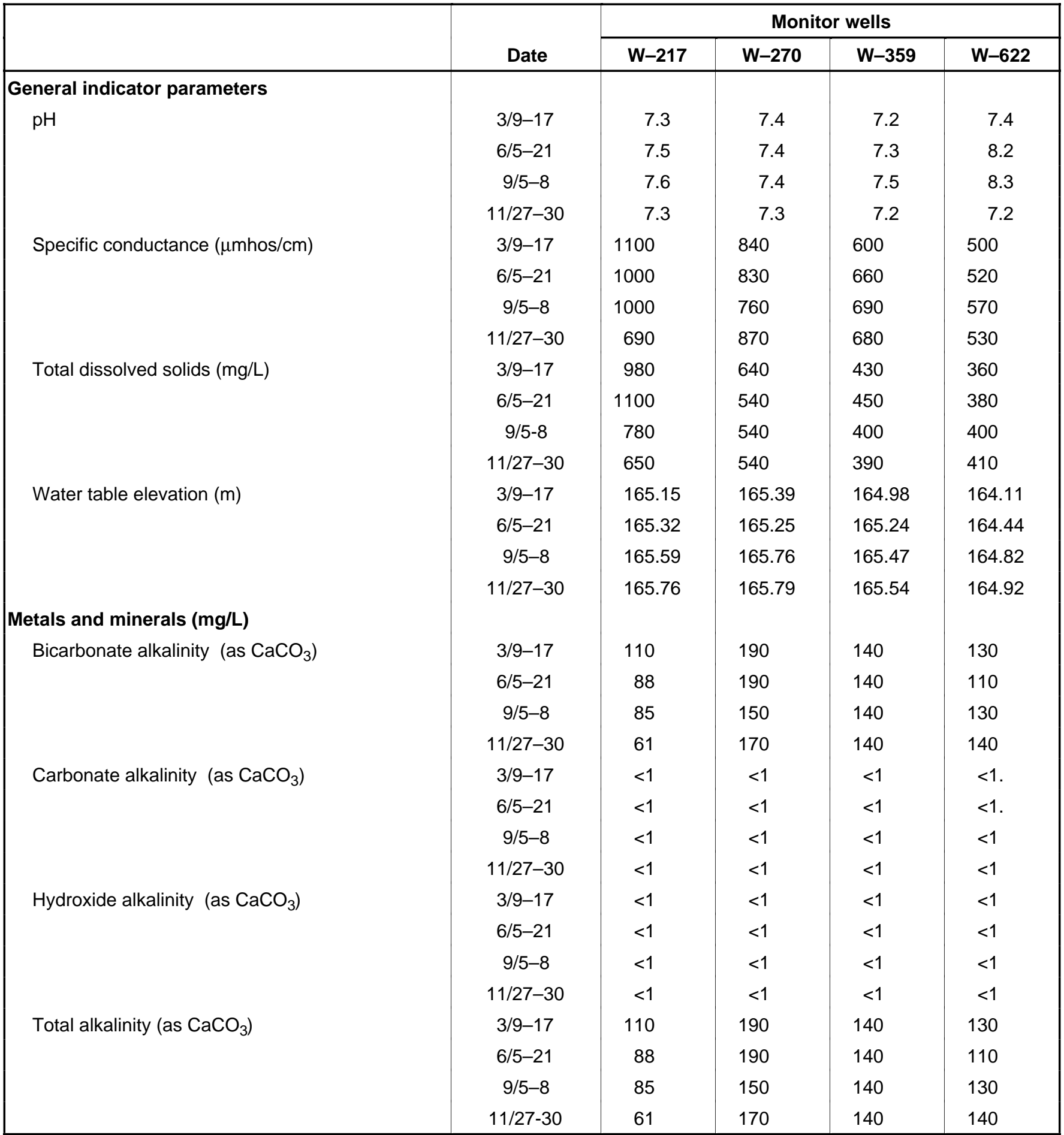

...continued on next page 
Table 9-4. Analyses for inorganic compounds in downgradient wells in the southeastern corner of the Livermore site, 1995 (continued).

\begin{tabular}{|c|c|c|c|c|c|}
\hline & \multirow[b]{2}{*}{ Date } & \multicolumn{4}{|c|}{ Monitor wells } \\
\hline & & W-217 & $W-270$ & W-359 & W-622 \\
\hline \multirow[t]{4}{*}{ Aluminum } & $3 / 9-17$ & $<0.2$ & $<0.2$ & $<0.2$ & $<0.2$ \\
\hline & $6 / 5-21$ & $<0.2$ & $<0.2$ & $<0.2$ & $<0.2$ \\
\hline & $9 / 5-8$ & $<0.2$ & $<0.2$ & $<0.2$ & $<0.2$ \\
\hline & $11 / 27-30$ & $<0.2$ & $<0.2$ & $<0.2$ & $<0.2$ \\
\hline \multirow[t]{4}{*}{ Antimony } & $3 / 9-17$ & $<0.01$ & $<0.01$ & $<0.01$ & $<0.011$ \\
\hline & $6 / 5-21$ & $<0.005$ & $<0.005$ & $<0.005$ & $<0.005$ \\
\hline & $9 / 5-8$ & $<0.005$ & $<0.005$ & $<0.005$ & $<0.005$ \\
\hline & $11 / 27-30$ & $<0.005$ & $<0.005$ & $<0.005$ & $<0.005$ \\
\hline \multirow[t]{4}{*}{ Arsenic } & $3 / 9-17$ & 0.0027 & $<0.002$ & $<0.002$ & $<0.002$ \\
\hline & $6 / 5-21$ & $<0.002$ & $<0.002$ & $<0.002$ & $<0.002$ \\
\hline & $9 / 5-8$ & $<0.002$ & $<0.002$ & $<0.002$ & $<0.002$ \\
\hline & $11 / 27-30$ & 0.003 & $<0.002$ & $<0.002$ & $<0.002$ \\
\hline \multirow[t]{4}{*}{ Barium } & $3 / 9-17$ & 0.72 & 0.17 & 0.17 & 0.34 \\
\hline & $6 / 5-21$ & 0.57 & 0.19 & 0.17 & 0.37 \\
\hline & $9 / 5-8$ & 0.49 & 0.18 & 0.16 & 0.37 \\
\hline & $11 / 27-30$ & 0.5 & 0.18 & 0.16 & 0.32 \\
\hline \multirow[t]{4}{*}{ Beryllium } & $3 / 9-17$ & $<0.0005$ & $<0.0005$ & $<0.0005$ & $<0.0005$ \\
\hline & $6 / 5-21$ & $<0.0005$ & $<0.0005$ & $<0.0005$ & $<0.0005$ \\
\hline & $9 / 5-8$ & $<0.0005$ & $<0.0005$ & $<0.0005$ & $<0.0005$ \\
\hline & $11 / 27-30$ & $<0.0005$ & $<0.0005$ & $<0.0005$ & $<0.0005$ \\
\hline \multirow[t]{4}{*}{ Boron } & $3 / 9-17$ & 0.12 & 0.23 & 0.38 & 0.21 \\
\hline & $6 / 5-21$ & 0.23 & 0.31 & 0.4 & 0.32 \\
\hline & 9/5-8 & 0.14 & 0.25 & 0.33 & 0.25 \\
\hline & $11 / 27-30$ & $<0.1$ & 0.15 & 0.35 & 0.16 \\
\hline \multirow[t]{4}{*}{ Bromide } & $3 / 9-17$ & 0.91 & $<0.5$ & $<0.5$ & $<0.5$ \\
\hline & $6 / 5-21$ & 0.89 & 0.61 & 0.88 & $<0.5$ \\
\hline & $9 / 5-8$ & $<0.5$ & $<0.5$ & $<0.5$ & $<0.5$ \\
\hline & $11 / 27-30$ & $<5$ & $<5$ & $<5$ & $<5$ \\
\hline \multirow[t]{4}{*}{ Cadmium } & $3 / 9-17$ & $<0.0005$ & $<0.0005$ & $<0.0005$ & $<0.0005$ \\
\hline & 6/5-21 & $<0.0005$ & $<0.0005$ & $<0.0005$ & $<0.0005$ \\
\hline & $9 / 5-8$ & $<0.0005$ & $<0.0005$ & $<0.0005$ & $<0.0005$ \\
\hline & $11 / 27-30$ & $<0.0005$ & $<0.0005$ & $<0.0005$ & $<0.0005$ \\
\hline \multirow[t]{4}{*}{ Calcium } & 3/9-17 & 130 & 62 & 54 & 59 \\
\hline & $6 / 5-21$ & 100 & 49 & 50 & 54 \\
\hline & $9 / 5-8$ & 91 & 48 & 48 & 54 \\
\hline & 11/27-30 & 76 & 59 & 55 & 63 \\
\hline
\end{tabular}




\section{Livermore Ground Water Protection Management Program}

Table 9-4. Analyses for inorganic compounds in downgradient wells in the southeastern corner of the Livermore site, 1995 (continued).

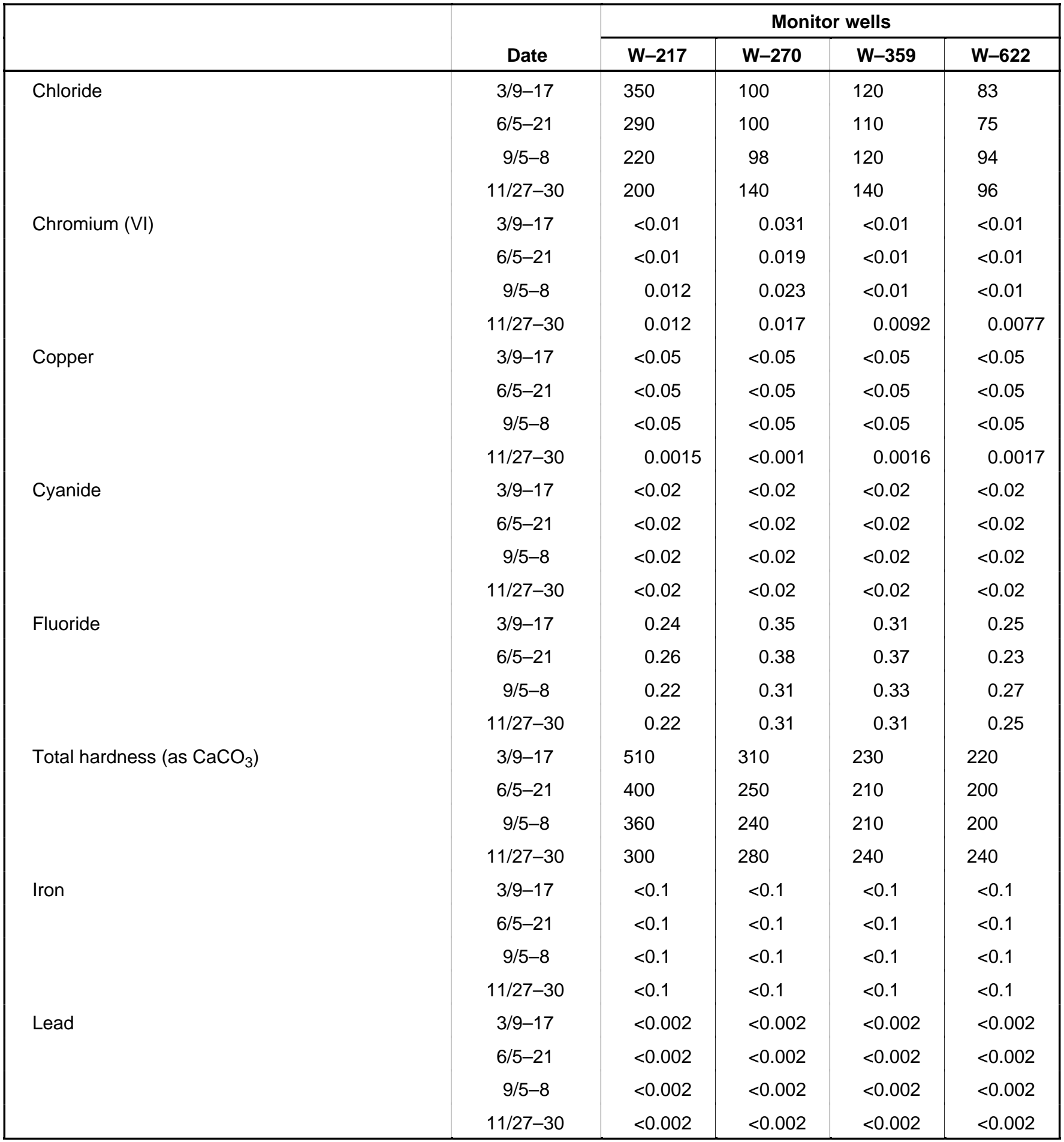


Table 9-4. Analyses for inorganic compounds in downgradient wells in the southeastern corner of the Livermore site, 1995 (continued).

\begin{tabular}{|c|c|c|c|c|c|}
\hline & \multirow[b]{2}{*}{ Date } & \multicolumn{4}{|c|}{ Monitor wells } \\
\hline & & W-217 & $W-270$ & W-359 & W-622 \\
\hline \multirow[t]{4}{*}{ Magnesium } & $3 / 9-17$ & 45 & 37 & 23 & 17 \\
\hline & $6 / 5-21$ & 34 & 30 & 21 & 16 \\
\hline & $9 / 5-8$ & 31 & 29 & 22 & 16 \\
\hline & $11 / 27-30$ & 26 & 33 & 24 & 20 \\
\hline \multirow[t]{4}{*}{ Manganese } & $3 / 9-17$ & $<0.03$ & $<0.03$ & $<0.03$ & $<0.03$ \\
\hline & $6 / 5-21$ & $<0.03$ & $<0.03$ & $<0.03$ & $<0.03$ \\
\hline & $9 / 5-8$ & $<0.03$ & $<0.03$ & $<0.03$ & $<0.03$ \\
\hline & $11 / 27-30$ & $<0.03$ & $<0.03$ & $<0.03$ & $<0.03$ \\
\hline \multirow[t]{4}{*}{ Mercury } & $3 / 9-17$ & $<0.0002$ & $<0.0002$ & $<0.0002$ & $<0.0002$ \\
\hline & $6 / 5-21$ & $<0.0002$ & $<0.0002$ & $<0.0002$ & $<0.0002$ \\
\hline & $9 / 5-8$ & $<0.0002$ & $<0.0002$ & $<0.0002$ & $<0.0002$ \\
\hline & 11/27-30 & $<0.0002$ & $<0.0002$ & $<0.0002$ & $<0.0002$ \\
\hline \multirow[t]{4}{*}{ Molybdenum } & $3 / 9-17$ & $<0.05$ & $<0.05$ & $<0.05$ & $<0.025$ \\
\hline & $6 / 5-21$ & $<0.025$ & $<0.025$ & $<0.025$ & $<0.025$ \\
\hline & $9 / 5-8$ & $<0.025$ & $<0.025$ & $<0.025$ & $<0.025$ \\
\hline & $11 / 27-30$ & $<0.025$ & $<0.025$ & $<0.025$ & $<0.025$ \\
\hline \multirow[t]{4}{*}{ Nickel } & $3 / 9-17$ & $<0.1$ & $<0.1$ & $<0.1$ & $<0.1$ \\
\hline & $6 / 5-21$ & $<0.1$ & $<0.1$ & $<0.1$ & $<0.1$ \\
\hline & 9/5-8 & $<0.1$ & $<0.1$ & $<0.1$ & $<0.1$ \\
\hline & 11/27-30 & $<0.1$ & $<0.1$ & $<0.1$ & $<0.1$ \\
\hline \multirow[t]{4}{*}{ Nitrate $\left(\right.$ as $\left.\mathrm{NO}_{3}\right)$} & 3/9-17 & 46 & 15 & 14 & 19 \\
\hline & $6 / 5-21$ & 39 & 18 & 15 & 17 \\
\hline & 9/5-8 & 42 & 17 & 15 & 18 \\
\hline & $11 / 27-30$ & 29 & 12 & 14 & 12 \\
\hline \multirow[t]{4}{*}{ Orthophosphate } & $3 / 9-17$ & $<1$ & $<1$ & $<1$ & $<1$ \\
\hline & $6 / 5-21$ & $<1$ & $<1$ & $<1$ & $<1$ \\
\hline & $9 / 5-8$ & $<1$ & $<1$ & $<1$ & $<1$ \\
\hline & $11 / 27-30$ & $<1$ & $<1$ & $<1$ & $<1$ \\
\hline \multirow[t]{4}{*}{ Potassium } & $3 / 9-17$ & 2.6 & 2.4 & 1.8 & 2.9 \\
\hline & $6 / 5-21$ & 2.4 & 2.2 & 1.7 & 2.8 \\
\hline & $9 / 5-8$ & 2.5 & 2.2 & 1.8 & 2.8 \\
\hline & $11 / 27-30$ & 2.2 & 2.3 & 1.9 & 2.8 \\
\hline \multirow[t]{4}{*}{ Selenium } & $3 / 9-17$ & $<0.002$ & $<0.002$ & $<0.002$ & $<0.002$ \\
\hline & 6/5-21 & $<0.002$ & $<0.002$ & $<0.002$ & $<0.002$ \\
\hline & 9/5-8 & $<0.002$ & $<0.002$ & $<0.002$ & $<0.002$ \\
\hline & 11/27-30 & $<0.002$ & $<0.002$ & $<0.002$ & $<0.002$ \\
\hline
\end{tabular}




\section{Livermore Ground Water Protection Management Program}

Table 9-4. Analyses for inorganic compounds in downgradient wells in the southeastern corner of the Livermore site, 1995 (concluded).

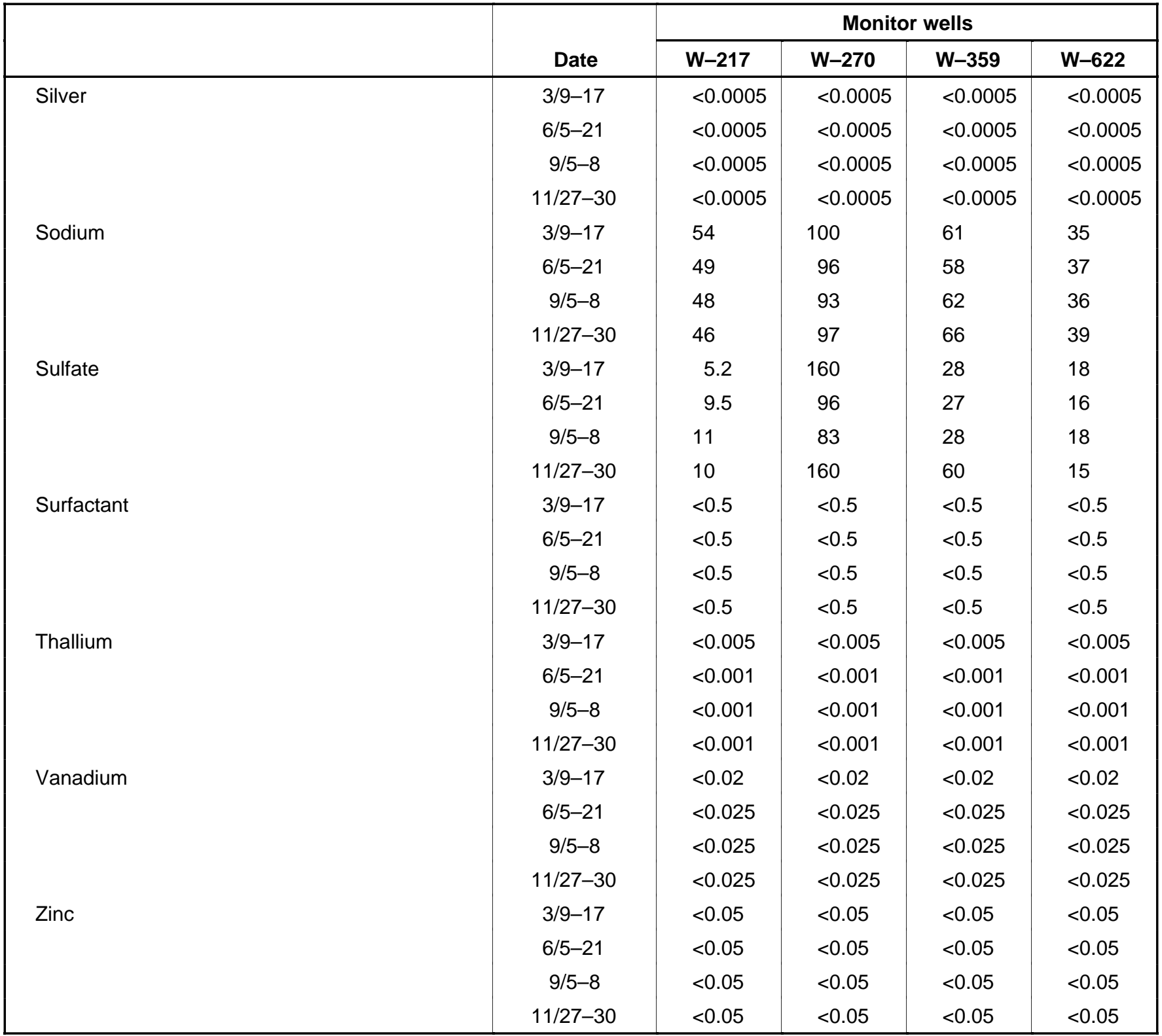


Table 9-5. Radiological analyses for upgradient wells in the southeastern corner of the Livermore site, 1995.

\begin{tabular}{|c|c|c|c|c|c|c|}
\hline & \multirow[b]{2}{*}{ Date } & \multirow[b]{2}{*}{$\operatorname{MCL}(a)$} & \multicolumn{4}{|c|}{ Monitor wells } \\
\hline & & & W-017 & W-107 & W-117 & W-268 \\
\hline \multirow[t]{4}{*}{ Gross alpha (Bq/L) } & $3 / 9-17$ & 0.56 & 0.0562 & -0.0361 & 0.0213 & -0.00363 \\
\hline & $6 / 5-21$ & & -0.0135 & -0.0114 & -0.0392 & -0.0388 \\
\hline & $9 / 5-8$ & & 0.0977 & -0.0411 & -0.0681 & -0.0282 \\
\hline & $11 / 27-30$ & & 0.119 & 0.03 & 0.013 & 0.00729 \\
\hline \multirow[t]{4}{*}{ Gross beta $(\mathrm{Bq} / \mathrm{L})$} & $3 / 9-17$ & 1.85 & 0.146 & 0.0507 & 0.272 & 0.0866 \\
\hline & $6 / 5-21$ & & 0.37 & 0.137 & 0.297 & 0.221 \\
\hline & $9 / 5-8$ & & 0.186 & 0.0788 & 0.0536 & 0.0518 \\
\hline & $11 / 27-30$ & & 0.217 & 0.101 & 0.107 & 0.0881 \\
\hline \multicolumn{7}{|l|}{ Radioisotopes } \\
\hline \multirow[t]{4}{*}{${ }^{238} \mathrm{Pu}(\mathrm{mBq} / \mathrm{L})$} & $3 / 9-17$ & None & 0.0388 & 0.0492 & -0.00252 & -0.0201 \\
\hline & $6 / 5-21$ & & 0.0958 & -0.057 & 0.154 & 0.0208 \\
\hline & $9 / 5-8$ & & 0.194 & 0.0211 & 0.107 & 0.173 \\
\hline & 11/27-30 & & 0.418 & 0.105 & -0.00429 & 0.102 \\
\hline \multirow[t]{4}{*}{${ }^{239,240} \mathrm{Pu}(\mathrm{mBq} / \mathrm{L})$} & $3 / 9-17$ & None & -0.0138 & -0.0233 & 0.04 & 0.0176 \\
\hline & $6 / 5-21$ & & 0.105 & -0.0633 & 0.0625 & 0.0208 \\
\hline & $9 / 5-8$ & & 0.169 & -0.084 & 0.0622 & -0.205 \\
\hline & $11 / 7$ & & 0.0881 & -0.00437 & -0.0385 & 0.0255 \\
\hline \multirow[t]{4}{*}{${ }^{226} \mathrm{Ra}(\mathrm{Bq} / \mathrm{L})$} & $3 / 9-17$ & 0.185 & 0.0266 & 0.00762 & 0.0182 & 0.00187 \\
\hline & $6 / 5-21$ & & 0.0111 & 0.00183 & 0.0111 & 0.00167 \\
\hline & $9 / 5-8$ & & 0.105 & 0.0544 & 0.0544 & 0.0403 \\
\hline & 11/27-30 & & 0.0444 & 0.0313 & 0.0596 & 0.0559 \\
\hline \multirow[t]{4}{*}{${ }^{228} \mathrm{Th}(\mathrm{mBq} / \mathrm{L})$} & $3 / 9-17$ & None & 0.648 & -0.836 & 2.53 & 1.75 \\
\hline & $6 / 5-21$ & & 2.09 & 0.899 & 0.899 & 0.77 \\
\hline & $9 / 5-8$ & & 0.625 & 0.733 & 0.00811 & 0.311 \\
\hline & $11 / 27-30$ & & 0.448 & 0.34 & 0.625 & -0.0503 \\
\hline \multirow[t]{4}{*}{ 232Th (mBq/L) } & $3 / 9-17$ & None & 0.0307 & 0.566 & 0.818 & -1.26 \\
\hline & $6 / 5-21$ & & 0.313 & 0.275 & 6.88 & 1.22 \\
\hline & $9 / 5-8$ & & 0.192 & 0.181 & 0.0459 & 0.0666 \\
\hline & 11/27-30 & & 0.0307 & -0.0544 & 0.0947 & 0.0966 \\
\hline \multirow[t]{4}{*}{ Tritium (Bq/L) } & $3 / 9-17$ & 740 & $<1.59$ & 1.81 & $<1.61$ & $<1.62$ \\
\hline & $6 / 5-21$ & & $<1.78$ & 2.46 & $<1.84$ & $<1.86$ \\
\hline & $9 / 5-8$ & & 2.63 & 2.64 & 2.51 & 2.51 \\
\hline & $11 / 27-30$ & & 2.97 & 2.56 & 3.0 & 2.13 \\
\hline
\end{tabular}




\section{Livermore Ground Water Protection Management Program}

Table 9-5. Radiological analyses for upgradient wells in the southeastern corner of the Livermore site, 1995 (concluded).

\begin{tabular}{|c|c|c|c|c|c|c|}
\hline & \multirow[b]{2}{*}{ Date } & \multirow[b]{2}{*}{$\operatorname{MCL}(\mathbf{a})$} & \multicolumn{4}{|c|}{ Monitor wells } \\
\hline & & & W-017 & W-107 & W-117 & W-268 \\
\hline \multirow[t]{4}{*}{${ }^{234} \mathrm{U}(\mathrm{Bq} / \mathrm{L})$} & $3 / 9-17$ & 0.74 & 0.104 & 0.0317 & 0.0451 & 0.0265 \\
\hline & $6 / 5-21$ & & 0.0907 & 0.0403 & 0.0166 & 0.03 \\
\hline & $9 / 5-8$ & & 0.121 & 0.0392 & 0.031 & 0.0303 \\
\hline & $11 / 27-30$ & & 0.111 & 0.0332 & 0.0134 & 0.0282 \\
\hline \multirow[t]{4}{*}{${ }^{235} \mathrm{U}(\mathrm{Bq} / \mathrm{L})$} & 3/9-17 & 0.74 & 0.00312 & 0.00117 & 0.0013 & 0.000814 \\
\hline & $6 / 5-21$ & & 0.00268 & 0.00358 & 0.000377 & 0.000238 \\
\hline & $9 / 5-8$ & & 0.00385 & 0.00188 & 0.000289 & 0.000485 \\
\hline & $11 / 27-30$ & & 0.0024 & 0.00184 & 0.000969 & 0.00135 \\
\hline \multirow[t]{4}{*}{${ }^{238} \mathrm{U}(\mathrm{Bq} / \mathrm{L})$} & $3 / 9-17$ & 0.74 & 0.0648 & 0.0204 & 0.0241 & 0.016 \\
\hline & $6 / 5-21$ & & 0.0614 & 0.0251 & 0.00696 & 0.0159 \\
\hline & $9 / 5-8$ & & 0.0773 & 0.0264 & 0.0167 & 0.0171 \\
\hline & $11 / 27-30$ & & 0.0644 & 0.0206 & 0.0077 & 0.0172 \\
\hline
\end{tabular}

a $\mathrm{MCL}=$ Maximum allowable contaminant level. 
Table 9-6. Radiological analyses for downgradient wells in the southeastern corner of the Livermore site, 1995.

\begin{tabular}{|c|c|c|c|c|c|c|}
\hline & & \multirow[b]{2}{*}{$M C L^{(a)}$} & \multicolumn{4}{|c|}{ Monitor wells } \\
\hline & & & W-217 & W-270 & W-359 & W-622 \\
\hline \multirow[t]{4}{*}{ Gross alpha (Bq/L) } & $3 / 9-17$ & 0.56 & -0.0736 & 0.0116 & -0.00518 & -0.0126 \\
\hline & $6 / 5-21$ & & -0.0681 & 0.0167 & -0.0555 & -0.02 \\
\hline & 9/5-8 & & -0.0451 & -0.0692 & -0.0255 & -0.0655 \\
\hline & $11 / 27-30$ & & 0.00273 & 0.0807 & 0.0396 & 0.0344 \\
\hline \multirow[t]{4}{*}{ Gross beta $(\mathrm{Bq} / \mathrm{L})$} & 3/9-17 & 1.85 & 0.113 & 0.159 & 0.0426 & 0.141 \\
\hline & $6 / 5-21$ & & 0.0662 & 0.158 & 0.0455 & 0.103 \\
\hline & 9/5-8 & & 0.199 & 0.0211 & -0.00221 & 0.0308 \\
\hline & $11 / 27-30$ & & 0.171 & 0.125 & 0.0921 & 0.139 \\
\hline \multicolumn{7}{|l|}{ Radioisotopes: } \\
\hline \multirow[t]{4}{*}{${ }^{238} \mathrm{Pu}(\mathrm{mBq} / \mathrm{L})$} & $3 / 9-17$ & None & 0.0363 & -0.0138 & -0.0574 & -0.0414 \\
\hline & $6 / 5-21$ & & 0.0585 & -0.00781 & 0.0448 & 0.11 \\
\hline & $9 / 5-8$ & & -0.173 & -0.0799 & 0.451 & 0.0585 \\
\hline & $11 / 27-30$ & & 0.007 & -0.00728 & -0.00264 & 0.0014 \\
\hline \multirow[t]{4}{*}{${ }^{239,240} \mathrm{Pu}(\mathrm{mBq} / \mathrm{L})$} & 3/9-17 & None & 0.0585 & -0.00781 & 0.0448 & -0.0305 \\
\hline & $6 / 5-21$ & & -0.00903 & 0.0176 & -0.0503 & -0.0305 \\
\hline & $9 / 5-8$ & & -0.0688 & -0.0133 & -0.0696 & -0.161 \\
\hline & $11 / 27-30$ & & -0.00093 & 0.00131 & 0.0470 & 0.000877 \\
\hline \multirow[t]{4}{*}{${ }^{226} \mathrm{Ra}(\mathrm{Bq} / \mathrm{L})$} & 3/9-17 & 0.185 & 0.00362 & 0.0218 & 0.00224 & 0.00522 \\
\hline & $6 / 5-21$ & & 0.00437 & 0.00544 & 0.00137 & 0.00803 \\
\hline & $9 / 5-8$ & & 0.122 & 0.0253 & 0.0236 & 0.0411 \\
\hline & $11 / 27-30$ & & 0.0466 & 0.0184 & 0.0444 & 0.0548 \\
\hline \multirow[t]{4}{*}{${ }^{228} \mathrm{Th}(\mathrm{mBq} / \mathrm{L})$} & 3/9-17 & None & 0.666 & 2.94 & 0.175 & -0.636 \\
\hline & $6 / 5-21$ & & 1.41 & 1.32 & 1.62 & 2.34 \\
\hline & 9/5-8 & & 0.722 & 0.111 & 0.112 & 0.477 \\
\hline & $11 / 27-30$ & & 0.566 & 0.0574 & 0.206 & 0.282 \\
\hline \multirow[t]{4}{*}{${ }^{232} \mathrm{Th}(\mathrm{mBq} / \mathrm{L})$} & 3/9-17 & None & 0.4 & 1.04 & -0.316 & 0.574 \\
\hline & $6 / 5-21$ & & 1.46 & 0.0766 & 3.56 & 2.03 \\
\hline & 9/5-8 & & 0.0559 & -0.0198 & 0.0525 & -0.121 \\
\hline & $11 / 27-30$ & & 0.136 & -0.0551 & -0.122 & -0.106 \\
\hline \multirow[t]{4}{*}{ Tritium (Bq/L) } & 3/9-17 & 740 & 28.8 & 1.63 & 15.4 & 19.4 \\
\hline & $6 / 5-21$ & & 17.7 & 1.86 & 11.3 & 16.1 \\
\hline & 9/5-8 & & 11.6 & 2.52 & 19 & 18.2 \\
\hline & $11 / 27-30$ & & 8.95 & 2.03 & 13.7 & 13.1 \\
\hline
\end{tabular}

...concluded on next page 


\section{Livermore Ground Water Protection Management Program}

Table 9-6. Radiological analyses for downgradient wells in the southeastern corner of the Livermore site, 1995 (concluded).

\begin{tabular}{|c|c|c|c|c|c|c|}
\hline & & \multirow[b]{2}{*}{$\mathrm{MCL}^{(a)}$} & \multicolumn{4}{|c|}{ Monitor wells } \\
\hline & & & W-217 & W-270 & W-359 & W-622 \\
\hline \multirow[t]{4}{*}{${ }^{234} \mathrm{U}(\mathrm{Bq} / \mathrm{L})$} & $3 / 9-17$ & 0.74 & 0.022 & 0.0599 & 0.0213 & 0.0151 \\
\hline & $6 / 5-21$ & & 0.0221 & 0.0496 & 0.0209 & 0.0121 \\
\hline & $9 / 5-8$ & & 0.0235 & 0.0511 & 0.025 & 0.0171 \\
\hline & $11 / 27-30$ & & 0.019 & 0.0533 & 0.0206 & 0.0162 \\
\hline \multirow[t]{4}{*}{${ }^{235} \mathrm{U}(\mathrm{Bq} / \mathrm{L})$} & 3/9-17 & 0.74 & 0.000781 & 0.00171 & 0.000807 & 0.000429 \\
\hline & $6 / 5-21$ & & 0.000714 & 0.000747 & 0.000198 & 0.000836 \\
\hline & $9 / 5-8$ & & 0.000855 & 0.00169 & 0.000829 & 0.000688 \\
\hline & $11 / 27-30$ & & 0.000733 & 0.00151 & 0.000555 & 0.000832 \\
\hline \multirow[t]{4}{*}{${ }^{238} \mathrm{U}(\mathrm{Bq} / \mathrm{L})$} & 3/9-17 & 0.74 & 0.0141 & 0.0364 & 0.013 & 0.0105 \\
\hline & $6 / 5-21$ & & 0.0107 & 0.0283 & 0.0111 & 0.00803 \\
\hline & $9 / 5-8$ & & 0.0162 & 0.0307 & 0.0158 & 0.012 \\
\hline & $11 / 27-30$ & & 0.0122 & 0.0299 & 0.0133 & 0.0094 \\
\hline
\end{tabular}

a $\mathrm{MCL}=$ Maximum allowable contaminant level. 



\section{Soil and Sediment Monitoring}

Prior to 1988, soil samples were collected at sites selected at random from Livermore Valley locations previously sampled for a 1971-1972 study. That earlier study was conducted to determine background concentrations of radionuclides in area soils. In 1988, Livermore Valley surveillance soil sampling locations were chosen to coincide with air sampling locations or to give coverage to areas with contaminants from past incidents or of other special concern. In 1991, five additional soil sampling locations associated with air sampling locations were established. The 1995 Livermore site soil samples were collected from the same locations as those in 1991 to 1994 . The 1995 Site 300 soil samples were collected from the same 14 sampling locations as in 1990 to 1994 . The use of constant sampling locations from year to year allows more meaningful trending of data.

Sampling locations at areas with known or suspected contaminants were monitored to delimit the extent of the contaminants and to track the contaminants from year to year. For example, six soil sampling locations were located near the Livermore Water Reclamation Plant (LWRP) to monitor soils that contain slightly elevated plutonium levels originating from a 1967 accidental release to the sewer.

Soil sampling is conducted according to written, standardized procedures contained in the Environmental Monitoring Plan (Tate et al. 1995). Samples are collected from undisturbed areas near the permanent sampling location marker. These areas generally are level, free of rocks, and are unsheltered by trees or buildings. The sampling technician chooses two 1-m squares from which to collect the sample and records how far away and in what direction from the permanent marker the sample is collected. Each sample is a composite consisting of 10 subsamples that are collected with a $8.25-\mathrm{cm}$-diameter stainless steel core sampler at the four corners and the center of each square. All subsamples are collected from the top $5 \mathrm{~cm}$ of soil because surface deposition from the air is the primary pathway for potential contamination.

Quality assurance (QA) samples are submitted with each batch of soil samples. Two identical samples are collected and, at locations chosen for duplicate sampling, adjacent cores are collected from the corners and center of the sampling squares. Separate composites of 10 cores each are made, and the duplicate samples are identified with unique sample identifier codes. 


\section{Soil and Sediment Monitoring}

Samples are delivered to LLNL's Chemistry and Materials Sciences Environmental Services (CES) laboratory for analyses. Soil samples are dried, ground, sieved, and blended. The plutonium content of a sample aliquot is determined by alpha spectroscopy (Hall and Edwards 1994). Other sample aliquots $(300 \mathrm{~g})$ are analyzed for more than 150 radionuclides by gamma spectroscopy, using a high-purity germanium (HPGe) detector (Hall and Edwards 1994). The 10-g subsamples of samples from Site 300 are sent to a contract analytical laboratory and are analyzed by graphite-furnace atomic absorption spectroscopy for beryllium. Chain-of-custody procedures are followed throughout the sampling, delivery, and analytical processes.

\section{Sediment Methods}

Samples of recent sediment are collected annually from drainages at and around the Livermore site after the cessation of spring runoff. For 1995, samples were analyzed for radionuclides. The analytical results from 5 years of sediment sampling for heavy metals and organic compounds did not yield sufficient evidence of contamination to warrant further yearly sampling for these materials (Tate et al. 1995). A new monitoring program conducted in arroyo channels as part of the Ground Water Protection Management Plan will be instituted in 1996 to determine if materials present in the channels could lead to contamination of the ground water.

Sediment was sampled from seven Livermore-site drainages. The sediment sampling locations coincide with storm water runoff sampling locations so it would be possible to compare the sampling results from these two media.

A culvert, bridge, or other permanent marker serves as a reference point for each sampling location. Ten subsamples, 5 -cm deep, are collected at 1-m intervals along a transect of the arroyo or drainage channel. At one of the subsample locations, a 15-cm deep sample is acquired for tritium analysis. The sample collection technicians record how far away and in what direction from the permanent marker the samples are actually collected. As with soils samples, QA samples are submitted with each batch of sediment samples.

Samples are delivered to LLNL's CES laboratory for analysis. For samples collected for tritium analyses, CES uses freeze-drying techniques to recover water from the samples and determines the tritium content of the water by liquid-scintillation counting. The plutonium content of a sample aliquot is determined by alpha spectroscopy. Other sample aliquots are analyzed for more than 150 radionuclides using gamma spectroscopy as described above for soil samples. The radioanalytical methods employed by the CES laboratory enable detection of concentrations at levels far more sensitive than regulatory limits. Chain-of-custody procedures are followed throughout the sampling, delivery, and analytical processes. 


\section{Soil and Sediment Monitoring}

Data

Table 10-1 presents the analytical data for radionuclides and beryllium for soils and sediments samples collected in 1995. The data generally reflect historic data values for these analytes at these locations. A detailed discussion of these results is provided in Volume 1 of this report. 
Table 10-1. Radionuclides and beryllium in soils and sediments, 1995.

\begin{tabular}{|c|c|c|c|c|c|}
\hline & $\begin{array}{c}\text { Plutonium-239 } \\
10^{-3} \mathrm{~Bq} / \mathrm{dry} \mathrm{g}\end{array}$ & $\begin{array}{c}\text { Americium-241(a) } \\
\text { Bq/dry g }\end{array}$ & $\begin{array}{l}\text { Cobalt-60(b) } \\
10^{-3} \mathrm{~Bq} / \text { dry g }\end{array}$ & $\begin{array}{c}\text { Cesium-137 } \\
10^{-3} \mathrm{~Bq} / \mathrm{dry} \mathrm{g}\end{array}$ & $\begin{array}{c}\text { Potassium-40 } \\
\text { Bq/dry g }\end{array}$ \\
\hline \multicolumn{6}{|c|}{ Livermore Valley soils } \\
\hline L-ALTA-SO & $0.26 \pm 0.030$ & -(a) $^{(\mathrm{a})}$ & -(b) & $0.94 \pm 0.31$ & $0.640 \pm 0.022$ \\
\hline L-CAFE-SO & $0.63 \pm 0.035$ & -(a) $^{(\mathrm{a})}$ & -(b) $^{\text {(b) }}$ & $2.6 \pm 0.2$ & $0.429 \pm 0.012$ \\
\hline L-COW-SO & $0.028 \pm 0.005$ & - $^{(\mathrm{a})}$ & —(b) $^{(\mathrm{n}}$ & $0.44 \pm 0.13$ & $0.592 \pm 0.017$ \\
\hline L-ERCH-SO & $0.090 \pm 0.010$ & - $^{(\mathrm{a})}$ & - $^{\text {(b) }}$ & $4.7 \pm 0.2$ & $0.347 \pm 0.012$ \\
\hline L-FCC-SO & $0.077 \pm 0.008$ & - (a) $^{(\mathrm{n})}$ & -(b) $^{\text {(b) }}$ & $2.8 \pm 0.2$ & $0.463 \pm 0.037$ \\
\hline L-HOSP-SO & $0.13 \pm 0.01$ & - (a) $^{(\mathrm{n})}$ & 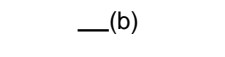 & $4.8 \pm 0.3$ & $0.500 \pm 0.016$ \\
\hline L-MESQ-SO & $0.041 \pm 0.006$ & - (a) $^{(\mathrm{n})}$ & -(b) $^{\text {(b) }}$ & $1.2 \pm 0.2$ & $0.525 \pm 0.015$ \\
\hline L-MET-SO & $0.050 \pm 0.007$ & -(a) & -(b) $^{(\mathrm{n})}$ & $1.8 \pm 0.2$ & $0.551 \pm 0.024$ \\
\hline L-NEP-SO & $0.081 \pm 0.008$ & - (a) $^{(a)}$ & -(b) $^{\text {(b) }}$ & $2.6 \pm 0.3$ & $0.463 \pm 0.011$ \\
\hline L-PATT-SO & $0.018 \pm 0.004$ & -(a) & 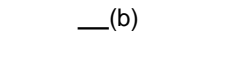 & $1.0 \pm 0.2$ & $0.585 \pm 0.022$ \\
\hline L-RRCH-SO & $0.031 \pm 0.005$ & - $^{(\mathrm{a})}$ & —(b) & $8.1 \pm 0.5$ & $0.474 \pm 0.012$ \\
\hline L-SALV-SO & $0.27 \pm 0.02$ & -(a) & -(b) $^{(\mathrm{n})}$ & $2.8 \pm 0.2$ & $0.463 \pm 0.016$ \\
\hline L-TANK-SO & $0.15 \pm 0.01$ & -(a) $^{(\mathrm{a})}$ & -(b) $^{(\mathrm{c})}$ & $4.9 \pm 0.3$ & $0.374 \pm 0.010$ \\
\hline L-VIS-SO & $1.1 \pm 0.1$ & -(a) $^{(\mathrm{n}}$ & -(b) $^{(\mathrm{n})}$ & $1.5 \pm 0.2$ & $0.437 \pm 0.017$ \\
\hline L-ZON7-SO & $0.22 \pm 0.02$ & - $^{(\mathrm{a})}$ & - $^{(b)}$ & $4.1 \pm 0.3$ & $0.507 \pm 0.014$ \\
\hline Median & 0.090 & & & 2.6 & 0.474 \\
\hline Interquartile range & 0.19 & & & 3.1 & 0.089 \\
\hline \multicolumn{6}{|c|}{ LWRP soils } \\
\hline L-WRP1-SO & $25 \pm 1.0$ & $0.008 \pm 0.002$ & $0.36 \pm 0.12$ & $6.2 \pm 0.3$ & $0.332 \pm 0.013$ \\
\hline L-WRP2-SO & $8.8 \pm 0.3$ & $<0.002$ & $0.45 \pm 0.21$ & $7.4 \pm 0.3$ & $0.459 \pm 0.014$ \\
\hline L-WRP3-SO & $5.3 \pm 0.2$ & $<0.002$ & $<0.065$ & $2.5 \pm 0.2$ & $0.370 \pm 0.010$ \\
\hline L-WRP4-SO & $1.4 \pm 0.1$ & $<0.002$ & $<0.067$ & $0.63 \pm 0.2$ & $0.403 \pm 0.019$ \\
\hline L-WRP5-SO & $0.33 \pm 0.04$ & $<0.001$ & $<0.049$ & $0.38 \pm 0.1$ & $0.302 \pm 0.011$ \\
\hline L-WRP6-SO & $1.7 \pm 0.1$ & $<0.001$ & $<0.097$ & $1.2 \pm 0.3$ & $0.407 \pm 0.017$ \\
\hline Median & 3.5 & $<0.002$ & $<0.082$ & 1.8 & 0.386 \\
\hline Interquartile range & 6.4 & -(h) & - $^{(\mathrm{h})}$ & 4.5 & 0.065 \\
\hline \multicolumn{6}{|c|}{ Livermore site sediments } \\
\hline L-ALPE-SD & $2.3 \pm 0.2$ & 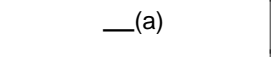 & -(b) $^{(\mathrm{n}}$ & $1.4 \pm 0.3$ & $0.481 \pm 0.020$ \\
\hline L-ASS2-SD & $0.017 \pm 0.007$ & - (a) $^{(\mathrm{n}}$ & -(b) $^{(\mathrm{n}}$ & $0.63 \pm 0.19$ & $0.488 \pm 0.015$ \\
\hline L-ASW-SD & $0.006 \pm 0.002$ & $-^{(\mathrm{a})}$ & - (b) $^{(\mathrm{n}}$ & $<0.09$ & $0.492 \pm 0.017$ \\
\hline L-CDB-SD & $0.074 \pm 0.009$ & - (a) $^{(\mathrm{n}}$ & -(b) $^{(\mathrm{n}}$ & $0.74 \pm 0.19$ & $0.392 \pm 0.013$ \\
\hline L-ESB-SD & $3.3 \pm 0.1$ & - (a) $^{(\mathrm{n})}$ & -(b) $^{(\mathrm{n})}$ & $0.80 \pm 0.23$ & $0.481 \pm 0.014$ \\
\hline L-GRNE-SD & $0.070 \pm 0.008$ & - (a) $^{(\mathrm{n}}$ & -(b) $^{(\mathrm{n}}$ & $0.92 \pm 0.15$ & $0.492 \pm 0.016$ \\
\hline L-WPDC-SD & $0.022 \pm 0.005$ & -(a) & -(b) & $0.12 \pm 0.10$ & $0.529 \pm 0.016$ \\
\hline Median & 0.07 & & & 0.74 & 0.488 \\
\hline Interquartile range & 1.2 & & & 0.48 & 0.011 \\
\hline
\end{tabular}


Table 10-1. Radionuclides and beryllium in soils and sediments, 1995 (continued).

\begin{tabular}{|c|c|c|c|c|c|}
\hline & $\begin{array}{c}\text { Thorium-232 (c) } \\
\mu \mathrm{g} / \text { dry } \mathbf{g}\end{array}$ & $\begin{array}{c}\text { Uranium-235(d) } \\
\mu \mathrm{g} / \mathrm{dry} \mathbf{g}\end{array}$ & $\begin{array}{c}\text { Uranium-238(e) } \\
\mu \mathrm{g} / \mathrm{dry} \mathbf{g}\end{array}$ & $\begin{array}{c}\text { Tritium(f) }_{\text {Bq/L }} \\
\end{array}$ & $\begin{array}{c}\text { Beryllium } \\
\mathrm{mg} / \mathrm{kg}\end{array}$ \\
\hline \multicolumn{6}{|c|}{ Livermore Valley soils } \\
\hline L-ALTA-SO & $10 \pm 0.3$ & $0.025 \pm 0.007$ & $2.5 \pm 0.9$ & 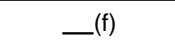 & -(g) \\
\hline L-CAFE-SO & $4.8 \pm 0.1$ & $0.016 \pm 0.004$ & $1.7 \pm 1.0$ & 一(f) $^{(\mathrm{n}}$ & —(g) \\
\hline L-COW-SO & $5.9 \pm 0.2$ & $0.018 \pm 0.005$ & $1.9 \pm 0.6$ & 一(f) $^{(\mathrm{n}}$ & —(g) \\
\hline L-ERCH-SO & $6.1 \pm 0.2$ & $0.016 \pm 0.005$ & $1.9 \pm 1.1$ & 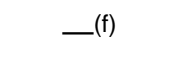 & 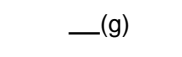 \\
\hline L-FCC-SO & $6.2 \pm 0.2$ & $0.021 \pm 0.005$ & $1.7 \pm 0.9$ & 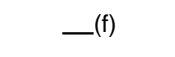 & -(g) \\
\hline L-HOSP-SO & $6.0 \pm 0.2$ & $0.018 \pm 0.007$ & $1.2 \pm 0.5$ & -(f) $^{(\mathrm{n}}$ & -(g) \\
\hline L-MESQ-SO & $6.7 \pm 0.3$ & $0.025 \pm 0.006$ & $2.0 \pm 0.9$ & -(f) $^{(\mathrm{n}}$ & -(g) \\
\hline L-MET-SO & $6.0 \pm 0.2$ & $0.023 \pm 0.006$ & $2.0 \pm 0.6$ & 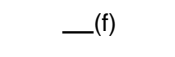 & 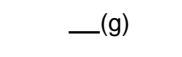 \\
\hline L-NEP-SO & $5.5 \pm 0.2$ & $0.018 \pm 0.004$ & $1.7 \pm 0.6$ & 一(f) $^{(\mathrm{n}}$ & —(g) \\
\hline L-PATT-SO & $8.1 \pm 0.3$ & $0.023 \pm 0.007$ & $2.8 \pm 1.0$ & -(f) $^{(\mathrm{n}}$ & -(g) \\
\hline L-RRCH-SO & $6.5 \pm 0.2$ & $<0.018$ & $1.7 \pm 0.9$ & -(f) $^{(\mathrm{n}}$ & -(g) \\
\hline L-SALV-SO & $7.3 \pm 0.2$ & $0.021 \pm 0.005$ & $2.2 \pm 0.7$ & 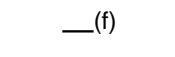 & 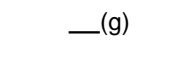 \\
\hline L-TANK-SO & $5.9 \pm 0.2$ & $0.017 \pm 0.004$ & $1.7 \pm 0.9$ & -(f) $^{(\mathrm{n}}$ & -(g) \\
\hline L-VIS-SO & $7.2 \pm 0.3$ & $0.022 \pm 0.007$ & $1.8 \pm 1.2$ & -(f) $^{(t)}$ & - (g) \\
\hline L-ZON7-SO & $7.8 \pm 0.2$ & $0.021 \pm 0.004$ & $<1.5$ & -(f) $^{(\mathrm{n}}$ & —(g) \\
\hline Median & 6.2 & 0.021 & 1.8 & & \\
\hline Interquartile range & 1.3 & 0.005 & 0.3 & & \\
\hline \multicolumn{6}{|c|}{ LWRP soils } \\
\hline L-WRP1-SO & $5.2 \pm 0.2$ & $0.023 \pm 0.004$ & $2.9 \pm 0.52$ & 一(f) $^{(\mathrm{n}}$ & 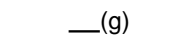 \\
\hline L-WRP2-SO & $7.1 \pm 0.2$ & $0.029 \pm 0.005$ & $2.1 \pm 1.20$ & 一(f) $^{(\mathrm{n}}$ & —(g) \\
\hline L-WRP3-SO & $5.8 \pm 0.3$ & $0.023 \pm 0.006$ & $2.3 \pm 1.30$ & -(f) & —(g) \\
\hline L-WRP4-SO & $7.2 \pm 0.2$ & $0.018 \pm 0.005$ & $1.5 \pm 1.12$ & -(f) $^{(\mathrm{n}}$ & —(g) \\
\hline L-WRP5-SO & $5.5 \pm 0.2$ & $0.016 \pm 0.004$ & $1.6 \pm 0.63$ & 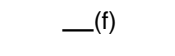 & 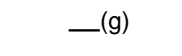 \\
\hline L-WRP6-SO & $6.5 \pm 0.2$ & $0.021 \pm 0.006$ & $2.0 \pm 0.70$ & 一 $^{(\mathrm{f})}$ & -(g) $^{(\mathrm{g}}$ \\
\hline Median & 6.1 & 0.022 & 2.1 & & \\
\hline Interquartile range & 1.3 & 0.004 & 0.5 & & \\
\hline \multicolumn{6}{|c|}{ Livermore site sediments } \\
\hline L-ALPE-SD & $8.0 \pm 0.2$ & $0.024 \pm 0.005$ & $2.0 \pm 0.6$ & $4.8 \pm 2.4$ & -(g) \\
\hline L-ASS2-SD & $5.4 \pm 0.2$ & $0.016 \pm 0.004$ & $1.4 \pm 1.1$ & $8.6 \pm 2.6$ & -(g) \\
\hline L-ASW-SD & $8.2 \pm 0.2$ & $<0.018$ & $1.6 \pm 0.7$ & $6.3 \pm 2.5$ & 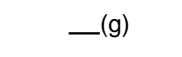 \\
\hline L-CDB-SD & $5.3 \pm 0.2$ & $<0.015$ & $<1.0$ & $14 \pm 3$ & 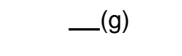 \\
\hline L-ESB-SD & $7.8 \pm 0.3$ & $0.024 \pm 0.005$ & $3.0 \pm 1.2$ & $20 \pm 3$ & -(g) $^{(\mathrm{g}}$ \\
\hline L-GRNE-SD & $5.2 \pm 0.3$ & $0.020 \pm 0.004$ & $1.9 \pm 0.8$ & $4.0 \pm 2.4$ & 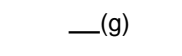 \\
\hline L-WPDC-SD & $4.9 \pm 0.3$ & $0.020 \pm 0.006$ & $1.6 \pm 1.1$ & $5.2 \pm 2.5$ & 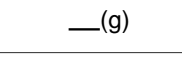 \\
\hline Median & 5.4 & 0.019 & 1.6 & 6.3 & \\
\hline Interquartile range & 2.7 & -(h) $^{(\mathrm{n}}$ & 0.4 & 6.3 & \\
\hline
\end{tabular}


Table 10-1. Radionuclides and beryllium in soils and sediments, 1995 (continued).

\begin{tabular}{|c|c|c|c|c|c|}
\hline & $\begin{array}{c}\text { Plutonium-239 } \\
10^{-3} \mathrm{~Bq} / \mathrm{dry} \mathrm{g}\end{array}$ & $\begin{array}{c}\text { Americium-241(a) } \\
\text { Bq/dry g }\end{array}$ & $\begin{array}{l}\text { Cobalt-60(b) } \\
10^{-3} \mathrm{~Bq} / \text { dry } \mathrm{g}\end{array}$ & $\begin{array}{c}\text { Cesium-137 } \\
10^{-3} \mathrm{~Bq} / \text { dry } \mathrm{g}\end{array}$ & $\begin{array}{c}\text { Potassium-40 } \\
\text { Bq/dry g }\end{array}$ \\
\hline \multicolumn{6}{|c|}{ Site 300 soils } \\
\hline 3-801E-SO & $0.051 \pm 0.009$ & -(a) & -(b) $^{(\mathrm{b})}$ & $1.9 \pm 0.3$ & $0.511 \pm 0.019$ \\
\hline $3-801 \mathrm{~N}-\mathrm{SO}$ & $0.19 \pm 0.014$ & -(a) $^{(a)}$ & 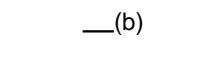 & $7.4 \pm 0.4$ & $0.629 \pm 0.018$ \\
\hline 3-801W-SO & $0.070 \pm 0.011$ & -(a) & -(b) $^{(\mathrm{c}}$ & $2.5 \pm 0.3$ & $0.459 \pm 0.018$ \\
\hline 3-812N-SO & $0.14 \pm 0.01$ & -(a) & -(b) $^{(\mathrm{c}}$ & $5.2 \pm 0.4$ & $0.481 \pm 0.013$ \\
\hline 3-834W-SO & $0.055 \pm 0.008$ & -(a) $^{(\mathrm{n}}$ & -(b) $^{(\mathrm{n}}$ & $2.0 \pm 0.3$ & $0.400 \pm 0.018$ \\
\hline $\begin{array}{l}\text { 3-834W-SO } \\
\text { (reanalysis) }\end{array}$ & -(i) $^{(\mathrm{i})}$ & -(i) $^{(i)}$ & —(i) & -(i) & $-^{(\mathrm{i})}$ \\
\hline $\begin{array}{c}\text { 3-834W2-SO } \\
\text { (resample) }\end{array}$ & 一(i) & -(i) & —(i) & -(i) & -(i) \\
\hline $3-851 \mathrm{~N}-\mathrm{SO}$ & $0.17 \pm 0.02$ & -(a) $^{(\mathrm{a}}$ & -(b) $^{(\mathrm{c}}$ & $6.8 \pm 0.3$ & $0.603 \pm 0.025$ \\
\hline $3-856 \mathrm{~N}-\mathrm{SO}$ & $0.17 \pm 0.02$ & -(a) & -(b) $^{(\mathrm{c}}$ & $7.0 \pm 0.3$ & $0.562 \pm 0.016$ \\
\hline 3-858S-SO & $0.095 \pm 0.016$ & -(a) $^{(\mathrm{n}}$ & -(b) $^{(\mathrm{n}}$ & $3.5 \pm 0.3$ & $0.429 \pm 0.013$ \\
\hline 3-DSW-SO & $0.025 \pm 0.008$ & -(a) $^{(\mathrm{a}}$ & -(b) $^{(\mathrm{n}}$ & $1.0 \pm 0.3$ & $0.403 \pm 0.011$ \\
\hline 3-EOBS-SO & $0.052 \pm 0.008$ & -(a) $^{(\mathrm{a}}$ & -(b) $^{(\mathrm{n}}$ & $1.3 \pm 0.3$ & $0.422 \pm 0.019$ \\
\hline 3-EVAP-SO & $0.16 \pm 0.03$ & -(a) $^{(\mathrm{n}}$ & -(b) $^{(\mathrm{c}}$ & $6.0 \pm 0.3$ & $0.470 \pm 0.017$ \\
\hline 3-GOLF-SO & $0.20 \pm 0.02$ & -(a) $^{(\mathrm{n}}$ & -(b) $^{(\mathrm{c}}$ & $7.1 \pm 0.4$ & $0.611 \pm 0.013$ \\
\hline 3-NPS-SO & $0.19 \pm 0.02$ & -(a) & -(b) $^{(\mathrm{c}}$ & $7.1 \pm 0.3$ & $0.474 \pm 0.015$ \\
\hline 3-WOBS-SO & $0.17 \pm 0.02$ & -(a) $^{(\mathrm{n}}$ & -(b) $^{(\mathrm{c}}$ & $5.6 \pm 0.4$ & $0.625 \pm 0.033$ \\
\hline Median & 0.15 & & & 5.4 & 0.477 \\
\hline Interquartile range & 0.12 & & & 4.8 & 0.156 \\
\hline
\end{tabular}

...concluded on next page

Note: Radionuclides with $100 \%$ error are reported as less than the measured value.

a Americium-241 only detected in LWRP samples.

b Cobalt-60 is only detected in LWRP samples.

c Thorium-232 activities in Bq/dry g can be determined by dividing the weight in $\mu \mathrm{g} / \mathrm{dry} \mathrm{g}$ by 247.3 , and $\mathrm{pCi} / \mathrm{dry} \mathrm{g}$ can be determined by dividing by 9.15 .

d Uranium-235 activities in Bq/dry g can be determined by dividing the weight in $\mu \mathrm{g} / \mathrm{dry} \mathrm{g}$ by 12.5 , and $\mathrm{pCi} / \mathrm{dry} \mathrm{g}$ can be determined by dividing by 0.463 . 


\section{Soil and Sediment Monitoring}

Table 10-1. Radionuclides and beryllium in soils and sediments, 1995 (concluded).

\begin{tabular}{|c|c|c|c|c|c|}
\hline & $\begin{array}{c}\text { Thorium-232 (c) } \\
\mu \mathrm{g} / \text { dry } \mathbf{g}\end{array}$ & $\begin{array}{c}\text { Uranium-235(d) } \\
\mu \mathrm{g} / \mathrm{dry} \mathbf{g}\end{array}$ & $\begin{array}{c}\text { Uranium-238(e) } \\
\mu \mathrm{g} / \mathrm{dry} \mathbf{g}\end{array}$ & $\begin{array}{c}\text { Tritium }^{(\mathbf{f})} \\
\mathrm{Bq} / \mathrm{L}\end{array}$ & $\begin{array}{c}\text { Beryllium } \\
\mathrm{mg} / \mathrm{kg}\end{array}$ \\
\hline \multicolumn{6}{|c|}{ Site 300 soils } \\
\hline 3-801E-SO & $10 \pm 0.3$ & $<0.026$ & $<2.7$ & $-^{(\mathrm{f})}$ & 0.77 \\
\hline $3-801 \mathrm{~N}-\mathrm{SO}$ & $10 \pm 0.4$ & $0.063 \pm 0.009$ & $24 \pm 3$ & $-^{(\mathrm{f})}$ & 0.85 \\
\hline 3-801W-SO & $12 \pm 0.4$ & $0.034 \pm 0.010$ & $8.6 \pm 2.8$ & 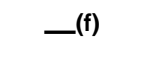 & 1.3 \\
\hline 3-812N-SO & $10 \pm 0.4$ & $0.016 \pm 0.004$ & $2.6 \pm 1.3$ & -(f) $^{(1)}$ & 1.4 \\
\hline 3-834W-SO & $13 \pm 0.5$ & $0.33 \pm 0.02$ & $140 \pm 10$ & -(f) $^{(\mathrm{s}}$ & 5.7 \\
\hline $\begin{array}{l}\text { 3-834W-SO } \\
\text { (reanalysis) }\end{array}$ & -(i) $^{(\mathrm{i})}$ & $0.34 \pm 0.02$ & $140 \pm 10$ & -(f) $^{(-1)}$ & 1.5 \\
\hline $\begin{array}{l}\text { 3-834W2-SO } \\
\text { (resample) }\end{array}$ & -(i) & $<0.025$ & $<2.1$ & 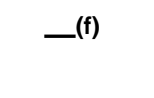 & 1.6 \\
\hline $3-851 \mathrm{~N}-\mathrm{SO}$ & $9.3 \pm 0.3$ & $0.030 \pm 0.009$ & $3.2 \pm 1.7$ & -(f) $^{(1)}$ & 0.79 \\
\hline $3-856 \mathrm{~N}-\mathrm{SO}$ & $9.2 \pm 0.4$ & $0.028 \pm 0.006$ & $3.4 \pm 0.8$ & -(f) $^{(\mathrm{s})}$ & 0.81 \\
\hline 3-858S-SO & $10 \pm 0.4$ & $0.025 \pm 0.006$ & $2.5 \pm 0.9$ & 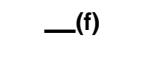 & 1.2 \\
\hline 3-DSW-SO & $8.8 \pm 0.2$ & $0.025 \pm 0.006$ & $2.5 \pm 0.6$ & 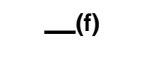 & 1.0 \\
\hline 3-EOBS-SO & $9.1 \pm 0.3$ & $0.024 \pm 0.008$ & $2.7 \pm 2.7$ & $-_{(f)}^{(f)}$ & 1.2 \\
\hline 3-EVAP-SO & $8.4 \pm 0.4$ & $0.036 \pm 0.008$ & $4.7 \pm 1.5$ & $-_{(f)}^{(f)}$ & 0.87 \\
\hline 3-GOLF-SO & $9.4 \pm 0.3$ & $<0.021$ & $1.6 \pm 0.6$ & -(f) $^{(\mathrm{f}}$ & 0.68 \\
\hline 3-NPS-SO & $8.0 \pm 0.2$ & $0.016 \pm 0.004$ & $1.8 \pm 0.8$ & -(f) $^{(-1)}$ & 0.79 \\
\hline 3-WOBS-SO & $8.3 \pm 0.3$ & $0.025 \pm 0.006$ & $1.9 \pm 0.6$ & -(f) $^{(\mathrm{s})}$ & 0.62 \\
\hline Median & 9.4 & $<0.025$ & $<2.7$ & & 0.9 \\
\hline Interquartile range & 1.3 & -(h) $^{(\mathrm{h}}$ & -(h) & & 0.5 \\
\hline
\end{tabular}

Note: Radionuclides with $100 \%$ error are reported as less than the measured value.

e Uranium-238 activities in Bq/dry $g$ can be determined by dividing the weight in $\mu \mathrm{g} / \mathrm{dry} \mathrm{g}$ by 80.3 , and $\mathrm{pCi} / \mathrm{dry} \mathrm{g}$ can be determined by dividing by 2.97 .

f Tritium analysis is only conducted on sediment samples.

g Beryllium analysis is only conducted on Site 300 soils samples; the analysis is a chemical, not a radiochemical analysis.

h Interquartile range could not be calculated.

i Reanalysis and resample were conducted to investigate elevated levels of uranium and slightly elevated levels of beryllium. See Vol. 1, Ch. 10. 



\section{Vegetation and Foodstuff Monitoring}

Gretchen M. Gallegos

Joel $H$. White

\section{Vegetation Sampling Methods}

Wine Sampling Methods
When obtaining vegetation samples, LLNL avoids frequently tilled or disturbed areas and locations near buildings or other obstructions. Areas with unusual wind, precipitation, or irrigation influences also are avoided. Practical considerations also temper the location selections. These include access during inclement weather, personnel safety in vehicle operation, vehicle parking, or sample collection requirements.

The selected areas are unshaded and exhibit native vegetation for much of the year. The routine vegetation sampling locations are designated with permanent location markers. Consistent use of the same general sampling locations allows for more meaningful trending of data and closer monitoring of areas of concern. For example, every year at Site 300, LLNL examines vegetation from areas where tritium is known to be present in the subsurface soil.

In 1995, vegetation samples usually consisted of the green leaves and green stems of annual grasses. Other herbaceous vegetation or even perennial vegetation was sampled if grasses were not available. Approximately 0.5 to $1 \mathrm{~kg}$ of vegetation was collected for analysis. Standard chain-of-custody procedures were followed (Tate et al. 1995).

Samples are delivered on the day of collection to LLNL's Chemistry and Materials Science's Environmental Services laboratory and are kept frozen prior to processing. Water from the vegetation is collected using freeze-drying techniques (lyophilization), and the tritium content of the water is determined by liquid-scintillation counting.

Approximately $10 \%$ of the sites are sampled in duplicate to comply with quality assurance protocols (Garcia and Failor 1993). Duplicate samples are preserved, stored, processed, and analyzed with methods identical to those employed for all other samples.

Wine samples were purchased in 750-mL to 1-L bottles. One wine from six of the eight non-Livermore, California, wine growing regions and one wine from four of the thirteen European wine growing regions was purchased and submitted for tritium analyses. The selection of samples from all the wines available within a geographic area was random. Any estate wine from a designated area was considered representative of that area. The most recent vintages available were 
collected, with an equal mix of red and white wines. Approximately $10 \%$ of the total complement of wines were sampled in duplicate to comply with quality assurance protocols. Because of the importance of the wine sampling network, LLNL sampled and analyzed as many of the available Livermore Valley wines as possible. Twelve Livermore Valley estate wines not previously sampled were purchased and analyzed.

The wine samples were submitted for analysis unopened to prevent airborne tritium contamination. Chain-of-custody procedures were followed when delivering samples and throughout the analytical process. Wines were analyzed for tritium using ${ }^{3} \mathrm{He}$ mass spectrometry in the LLNL Isotope Sciences Division Noble Gas Mass Spectrometry Laboratory (Surano et al. 1991). LLNL used this highly sensitive method for the wine analysis to determine the small differences in the tritium content of the samples. Had less sensitive methods been used, such as those employed by commercial analytical laboratories, the tritium content of all samples would be near or below detection limits and no differences would be apparent. 
Table 11-1. Tritium (in Bq/L) in vegetation, 1995.

\begin{tabular}{|c|c|c|c|c|c|c|c|}
\hline & $\begin{array}{l}\text { First } \\
\text { quarter }\end{array}$ & $\begin{array}{l}\text { Second } \\
\text { quarter }\end{array}$ & $\begin{array}{l}\text { Third } \\
\text { quarter }\end{array}$ & $\begin{array}{l}\text { Fourth } \\
\text { quarter }\end{array}$ & Median & $\begin{array}{l}\text { Interquar- } \\
\text { tile range }\end{array}$ & $\begin{array}{c}\text { Dose } \\
(\mu \mathrm{Sv} / \mathrm{y})\end{array}$ \\
\hline \multicolumn{8}{|c|}{ Sampling locations near Livermore site } \\
\hline AQUE & $27 \pm 2.6$ & $78 \pm 3.5$ & $6.4 \pm 2.2$ & $11 \pm 2.3$ & 19 & 30 & 0.090 \\
\hline VIS & $21 \pm 2.5$ & $20 \pm 2.2$ & $11 \pm 2.4$ & $14 \pm 2.4$ & 17 & 7.3 & 0.080 \\
\hline RAIL & $5.5 \pm 2.0$ & $<1.5$ & $2.9 \pm 2.1$ & $9.1 \pm 2.3$ & 4.2 & 3.8 & 0.020 \\
\hline MET & $2.9 \pm 1.9$ & $2.9 \pm 1.6$ & $3.7 \pm 2.1$ & $5.1 \pm 2.1$ & 3.3 & 1.1 & 0.016 \\
\hline MESQ & $4.4 \pm 1.9$ & $8.2 \pm 1.8$ & $<2.0$ & $13 \pm 2.4$ & 6.3 & 5.7 & 0.030 \\
\hline GARD & $6.5 \pm 2.0$ & $3.7 \pm 1.6$ & $<2.0$ & $2.4 \pm 2.0$ & 3.1 & 2.0 & 0.015 \\
\hline \multicolumn{8}{|c|}{ Sampling locations an intermediate distance from Livermore site } \\
\hline PATT & $<1.8$ & $3.4 \pm 1.6$ & $<2.1$ & $3.3 \pm 2.1$ & $<2.7$ & 1.3 & $<0.013$ \\
\hline ZON7 & $12 \pm 2.2$ & $5.0 \pm 1.7$ & $6.1 \pm 2.2$ & $6.3 \pm 2.2$ & 6.2 & 1.9 & 0.030 \\
\hline 1580 & $<1.8$ & $<1.5$ & $5.7 \pm 2.2$ & $7.3 \pm 2.2$ & $<3.7$ & 4.4 & $<0.018$ \\
\hline TESW & $4.8 \pm 1.9$ & $<1.5$ & $<2.0$ & $<2.0$ & $<2.0$ & -(a) & $<0.010$ \\
\hline \multicolumn{8}{|c|}{ Sampling locations far from Livermore site } \\
\hline FCC & $2.1 \pm 1.9$ & $<1.5$ & $<2.0$ & $<2.0$ & $<2.0$ & -(a) & $<0.010$ \\
\hline PARK & $<1.8$ & $2.0 \pm 1.6$ & $3.0 \pm 2.1$ & $<2.0$ & $<2.0$ & 0.3 & $<0.010$ \\
\hline CAL & $2.2 \pm 1.9$ & $<1.5$ & $<2.0$ & $<2.0$ & $<2.0$ & —(a) & $<0.010$ \\
\hline \multicolumn{8}{|c|}{ Sampling locations at Site $\mathbf{3 0 0}$} \\
\hline CARN & $2.0 \pm 1.8$ & $<1.7$ & $<2.1$ & $<2.2$ & $<2.1$ & -(a) & $<0.010$ \\
\hline GOLF & $<1.8$ & $2.7 \pm 1.8$ & $<2.1$ & $<2.2$ & $<2.1$ & -(a) & $<0.010$ \\
\hline GEO & $<1.8$ & $<1.7$ & $<2.0$ & $<2.2$ & $<1.9$ & -(a) & $<0.009$ \\
\hline DSW & $<1.7$ & $39 \pm 3$ & $5.1 \pm 2.2$ & $530 \pm 10$ & 22 & 160 & 0.11 \\
\hline $801 \mathrm{E}$ & $2.3 \pm 1.8$ & $<1.7$ & $2.9 \pm 2.1$ & $<2.2$ & $<2.2$ & 0.4 & $<0.011$ \\
\hline EVAP & $<1.7$ & $64 \pm 3.3$ & $14 \pm 2.6$ & $10 \pm 2.5$ & 12 & 18 & 0.059 \\
\hline
\end{tabular}

Note: Maps of sampling locations are provided in Volume 1, Figures 11-1 and 11-2.

a Insufficient data to calculate interquartile range. 
Table 11-2. Tritium (in Bq/L) in retail wine, 1995.(a)

\begin{tabular}{|c|c|c|c|}
\hline \multirow{2}{*}{ Sample } & \multicolumn{3}{|c|}{ Area of production } \\
\cline { 2 - 4 } & Livermore Valley & California & Europe \\
\hline 1 & $1.56 \pm 0.24$ & $0.45 \pm 0.14$ & $1.75 \pm 0.26$ \\
3 & $1.91 \pm 0.27$ & $0.41 \pm 0.11$ & $2.76 \pm 0.33$ \\
4 & $2.16 \pm 0.28$ & $0.42 \pm 0.19$ & $1.18 \pm 0.22$ \\
5 & $1.49 \pm 0.24$ & $1.21 \pm 0.22$ & $2.00 \pm 0.19$ \\
6 & $2.43 \pm 0.31$ & $0.74 \pm 0.20$ & \\
7 & $4.03 \pm 0.44$ & $0.44 \pm 0.19$ & \\
8 & $4.85 \pm 0.37$ & & \\
9 & $6.02 \pm 0.63$ & & \\
10 & $3.66 \pm 0.29$ & & \\
11 & $2.51 \pm 0 . .22$ & & $\mathbf{1 . 8 7}$ \\
12 & $5.05 \pm 0.54$ & & $\mathbf{0 . 5 8}$ \\
Median & $2.69 \pm 0.23$ & $\mathbf{1 . 9 2}$ \\
Interquartile range & $\mathbf{2 . 6 0}$ & $\mathbf{0 . 4 5}$ & $\mathbf{0 . 6 6}$ \\
\hline Mean & $\mathbf{3 . 2 0}$ & $\mathbf{0 . 2 2}$ & \\
Standard deviation & $\mathbf{1 . 5 0}$ & $\mathbf{0 . 6 2}$ & \\
\hline
\end{tabular}

Note: radionuclide results are reported $\pm 2 \sigma$ in Bq/L. See Chapter 14, Quality Assurance.

a Wines from a variety of vintages were purchased and analyzed during 1995 . The concentrations shown are not decay-corrected to vintage year. 


\section{Environmental Radiation Monitoring $\alpha_{\beta} \gamma$}

Barbara C. Fields

Joel H. White

\section{Methods of Gamma Radiation Monitoring}

External doses from gamma radiation are monitored at 14 Livermore site perimeter locations, 23 Livermore Valley locations, and 10 Site 300 perimeter locations. Each quarter the TLDs are exchanged, data are read and analyzed, and the doses are subsequently calculated in millirem. Thermoluminescent dosimeters (TLDs) are prepared for field deployment every quarter. The process involves heat sealing TLDs into a foil sample pouch $8.9 \mathrm{~cm} \times 4.5 \mathrm{~mm}$ thick for protection against light and moisture. Direct gamma radiation doses are measured with reusable TLDs mounted in the field on preexisting structures (such as fences) at approximately $1 \mathrm{~m}$ above ground to comply with DOE Order 5400.1. The TLDs are installed with an LLNL identification label on each pouch. Additionally, duplicate, trip blanks, and transit control TLDs are prepared as well as calibration control TLDs. Each quarter, the TLDs in the field are collected and replaced with a new batch of TLDs. The exposed TLDs are placed in a reading magazine by location and taken to the Dosimetry Laboratory for processing. A chain-of-custody form accompanies the collection and field deployment of the TLDs so that each responsible party, from collection to archiving, signs the form acknowledging that the task of assigned duties has been completed.

When a TLD is damaged or missing, its annual dose value is calculated from its mean quarterly dose, as determined from available data, multiplied by four. Data from TLDs found on the ground open or damaged are not used to calculate the quarterly or annual totals. These TLDs tend to trap moisture, and the readings can yield erroneous data.

LLNL uses the Panasonic Model UD-814AS1 TLD, which contains three components of thallium-activated calcium sulfate $\left(\mathrm{CaSO}_{4}\right)$ and one component of lithium borate $\left(\mathrm{Li}_{2} \mathrm{~B}_{4} \mathrm{O}_{7}\right)$. Energy is stored when these compounds are exposed to gamma radiation. Impurities in the TLD crystal form low-temperature trapping sites for electrons that have been excited to higher energy states by gamma radiation at normal ambient temperatures. When the TLDs are heated in the analytical laboratory, the electrons return to lower energy states, and light is emitted. The light intensity is proportional to the original absorbed energy and is measured with a photomultiplier tube. After the TLD is read, it is heated again and reread. This second reading should be near zero, indicating that all the stored energy in the traps has been released and measured. This process, called annealing, also verifies that the TLD is again ready for field deployment. 
Direct gamma radiation exposures are measured in milliroentgens $(\mathrm{mR})$. The measured exposure is converted to dose by calibrating the dosimeters against sources that deliver a known absorbed dose and then applying a quality factor for a beta/gamma radiation field. The resultant dose equivalents, in millisieverts (mSv) or millirem (mrem), are compared to the DOE Order 5400.5 radiation protection standards. The doses at the site boundaries are also compared to background measurements to determine the contribution, if any, from LLNL operations.

To ensure accuracy in TLD measurements, some TLDs are irradiated each quarter to specific exposures for calibration purposes, and others are irradiated to specific exposures to serve as quality control accuracy checks. Duplicate TLDs are located in the field at several locations each quarter to assess TLD measurement precision. This year we instituted methods in our procedures and policies that ensure minimum holding times so that we remain consistent with 90-day standard quarters. Additionally, we participate in the National Intercomparison Laboratory Study for external gamma radiaiton measurements.

Tables

Presented below are data tables for the 1995 gamma radiation monitoring network. Table 12-1 presents the Livermore site perimeter data, Table 12-2 presents the Livermore Valley data, Table 12-3 presents the Site 300 perimeter, data, and Table 12-4 presents Tracy and Site 300 off-site data. Summary data are discussed in detail in Volume 1 of this report. 
Table 12-1. TLD environmental radiation measurements (in $\mathrm{mSv}$ ), Livermore site perimeter, 1995.

\begin{tabular}{|c|c|c|c|c|c|}
\hline Location & Jan-Mar & Apr-Jun & Jul-Sep & Oct-Dec & Total \\
\hline 1 & 0.181 & 0.148 & 0.144 & 0.142 & 0.614 \\
\hline 4 & 0.140 & 0.156 & 0.156 & 0.148 & 0.600 \\
\hline 5 & 0.140 & 0.162 & 0.154 & 0.144 & 0.601 \\
\hline 6 & 0.139 & 0.156 & 0.158 & 0.149 & 0.601 \\
\hline 11 & 0.119 & 0.118 & 0.115 & 0.120 & 0.471 \\
\hline 14 & 0.125 & 0.145 & 0.134 & 0.132 & 0.536 \\
\hline 16 & 0.131 & 0.139 & 0.138 & 0.136 & 0.544 \\
\hline 42 & 0.137 & 0.139 & 0.148 & 0.136 & 0.561 \\
\hline 43 & 0.150 & 0.157 & 0.151 & 0.132 & 0.591 \\
\hline 47 & 0.127 & 0.136 & 0.137 & 0.135 & 0.536 \\
\hline 52 & 0.131 & 0.149 & 0.132 & 0.134 & 0.544 \\
\hline 56 & 0.135 & 0.140 & 0.145 & 0.136 & 0.557 \\
\hline 68 & 0.129 & 0.149 & 0.145 & 0.135 & 0.559 \\
\hline 69 & 0.131 & 0.141 & 0.137 & 0.129 & 0.538 \\
\hline \multicolumn{6}{|c|}{$\mathrm{mSv}$} \\
\hline Mean & 0.137 & 0.145 & 0.142 & 0.136 & 0.561 \\
\hline Std. dev. & 0.015 & 0.011 & 0.011 & 0.008 & 0.051 \\
\hline \multicolumn{6}{|c|}{ mrem } \\
\hline Mean & 13.7 & 14.5 & 14.2 & 13.6 & 55.8 \\
\hline Std. dev. & 1.5 & 1.1 & 1.1 & 0.8 & 5.1 \\
\hline
\end{tabular}


Table 12-2. TLD environmental radiation measurements (in mSv), Livermore Valley, 1995.

\begin{tabular}{|c|c|c|c|c|c|}
\hline Location & Jan-Mar & Apr-Jun & Jul-Sep & Oct-Dec & Total \\
\hline 18 & 0.107 & 0.114 & 0.110 & 0.117 & 0.448 \\
\hline 19 & 0.122 & 0.138 & 0.128 & 0.128 & 0.515 \\
\hline 22 & 0.135 & 0.154 & 0.152 & 0.144 & 0.586 \\
\hline 24 & 0.134 & 0.154 & 0.149 & 0.142 & 0.580 \\
\hline 27 & 0.140 & 0.162 & 0.158 & 0.149 & 0.609 \\
\hline 28 & 0.143 & 0.162 & 0.164 & 0.154 & 0.622 \\
\hline 30 & 0.129 & - (a) $^{(2)}$ & 0.143 & 0.134 & $0.541^{(b)}$ \\
\hline 32 & 0.130 & 0.151 & 0.142 & 0.137 & 0.560 \\
\hline 33 & 0.133 & 0.146 & 0.145 & 0.143 & 0.567 \\
\hline 35 & -(a) & 0.149 & 0.159 & 0.143 & $0.602^{(b)}$ \\
\hline 37 & -(a) & -(a) & 0.142 & 0.135 & $0.552^{(b)}$ \\
\hline 45 & 0.125 & 0.140 & 0.133 & 0.130 & 0.528 \\
\hline 57 & 0.140 & 0.151 & 0.151 & 0.142 & 0.584 \\
\hline 60 & 0.131 & 0.150 & 0.145 & 0.141 & 0.566 \\
\hline 61 & 0.120 & 0.129 & 0.123 & -(a) & $0.495^{(b)}$ \\
\hline 66 & 0.133 & 0.148 & 0.148 & 0.139 & 0.568 \\
\hline 70 & 0.128 & 0.146 & 0.145 & 0.138 & 0.557 \\
\hline 72 & 0.148 & 0.162 & 0.164 & 0.147 & 0.621 \\
\hline 73 & 0.134 & 0.146 & 0.145 & 0.142 & 0.568 \\
\hline 74 & 0.121 & 0.129 & 0.134 & 0.128 & 0.511 \\
\hline 75 & 0.116 & 0.119 & 0.112 & 0.110 & 0.457 \\
\hline 76 & 0.111 & 0.122 & 0.113 & 0.116 & 0.462 \\
\hline 77 & 0.126 & 0.132 & 0.128 & 0.129 & 0.516 \\
\hline \multicolumn{6}{|c|}{$\mathrm{mSv}$} \\
\hline Mean & 0.129 & 0.143 & 0.141 & 0.136 & 0.548 \\
\hline Std. dev. & 0.010 & 0.014 & 0.016 & 0.011 & 0.051 \\
\hline \multicolumn{6}{|c|}{ mrem } \\
\hline Mean & 12.9 & 14.3 & 14.1 & 13.6 & 54.9 \\
\hline Std. dev. & 1.0 & 1.4 & 1.6 & 1.1 & 5.1 \\
\hline
\end{tabular}

a No data available for these samples.

b When a TLD is missing, the annual dose is calculated as four times the mean quarterly dose, as determined from available data. 
Table 12-3. TLD environmental radiation measurements (in $\mathrm{mSv}$ ), Site 300 perimeter location, 1995.

\begin{tabular}{|c|c|c|c|c|c|}
\hline Location & Jan-Mar & Apr-Jun & Jul-Sep & Oct-Dec & Total \\
\hline 78 & 0.129 & 0.138 & 0.143 & 0.141 & 0.551 \\
\hline 81 & 0.161 & 0.182 & 0.191 & 0.181 & 0.715 \\
\hline 82 & 0.140 & 0.160 & -(a) & -(a) & $0.640^{(b)}$ \\
\hline 84 & 0.136 & -(a) & -(a) & -(a) & $0.544^{(b)}$ \\
\hline 85 & - (a) $^{(a)}$ & -(a) $^{(\mathrm{a})}$ & 0.165 & - (c) $^{(\mathrm{c})}$ & $0.660^{(b)}$ \\
\hline 86 & -(a) & - $^{(\mathrm{a})}$ & 0.164 & - $^{(\mathrm{c})}$ & $0.656^{(b)}$ \\
\hline 88 & 0.153 & 0.160 & 0.164 & 0.159 & 0.636 \\
\hline 89 & 0.153 & 0.170 & 0.174 & 0.163 & 0.661 \\
\hline 91 & 0.152 & 0.160 & 0.170 & 0.164 & 0.646 \\
\hline 121 & -(d) & -(a) & 0.185 & 0.177 & $0.724^{(b)}$ \\
\hline \multicolumn{6}{|c|}{ mSv } \\
\hline Mean & 0.146 & 0.162 & 0.169 & 0.164 & 0.637 \\
\hline Std. dev. & 0.012 & 0.015 & 0.015 & 0.014 & $0.0-55$ \\
\hline \multicolumn{6}{|c|}{ mrem } \\
\hline Mean & 14.6 & 16.2 & 16.9 & 16.4 & 63.7 \\
\hline Std. dev. & 1.2 & 1.5 & 1.5 & 1.4 & 5.5 \\
\hline
\end{tabular}

a No data available for these samples because TLDs were lost in field.

b When a TLD is missing, the annual dose is calculated as four times the mean quarterly dose, as determined from available data.

c TLD was open or damaged.

d TLD was in the field for more than one quarter and could not be properly corrected. 
Table 12-4. TLD environmental radiation measurements (in $\mathrm{mSv}$ ), Site 300 vicinity, 1995.

\begin{tabular}{|c|c|c|c|c|c|}
\hline Location & Jan-Mar & Apr-Jun & Jul-Sep & Oct-Dec & Total \\
\hline \multicolumn{6}{|l|}{ Tracy } \\
\hline 92 & 0.138 & 0.138 & 0.149 & 0.144 & 0.569 \\
\hline 93 & 0.121 & 0.130 & 0.124 & 0.125 & 0.501 \\
\hline \multicolumn{6}{|c|}{ mSv } \\
\hline Mean & 0.130 & 0.134 & 0.137 & 0.135 & 0.535 \\
\hline Std. dev. & 0.012 & 0.006 & 0.017 & 0.014 & 0.049 \\
\hline \multicolumn{6}{|c|}{ mrem } \\
\hline Mean & 13.0 & 13.4 & 13.7 & 13.5 & 53.5 \\
\hline Std. dev. & 1.2 & 0.6 & 1.7 & 1.4 & 4.9 \\
\hline \multicolumn{6}{|l|}{ Off site } \\
\hline 90 & 0.148 & 0.168 & 0.176 & 0.160 & 0.652 \\
\hline 94 & 0.184 & 0.224 & 0.222 & 0.211 & 0.841 \\
\hline 95 & 0.158 & - (a) $^{(\mathrm{a})}$ & —(a) $^{(\mathrm{a})}$ & -(a) $^{(\mathrm{a})}$ & $0.632^{(b)}$ \\
\hline 96 & 0.160 & 0.192 & 0.186 & 0.183 & 0.721 \\
\hline 99 & 0.140 & 0.149 & 0.159 & 0.147 & 0.595 \\
\hline 120 & —(c) & 0.149 & 0.166 & 0.151 & $0.621^{(b)}$ \\
\hline \multicolumn{6}{|c|}{ mSv } \\
\hline Mean & 0.158 & 0.176 & 0.182 & 0.170 & 0.674 \\
\hline Std. dev. & 0.016 & 0.032 & 0.025 & 0.027 & 0.087 \\
\hline \multicolumn{6}{|c|}{ mrem } \\
\hline Mean & 15.8 & 17.6 & 18.2 & 17.0 & 67.4 \\
\hline Std. dev. & 1.6 & 3.2 & 2.5 & 2.7 & 8.7 \\
\hline
\end{tabular}

a No data available because sampling at this location was discontinued after the first quarter.

b When a TLD is missing, the annual dose is calculated as four times the mean quarterly dose, as determined from available data.

c TLD was in the field for more than one quarter and could not be properly corrected. 


\section{Radiological Dose Assessment}

There is no supplemental data in this chapter.

Please see Volume 1 for details about Radiological Dose Assessment. 

Allen R. Grayson

Robert J. Vellinger

Richard A. Brown

Karen J. Folks

Sandra Mathews

Introduction This chapter provides detailed data on monitoring of the Drainage Retention Basin (DRB) at the Livermore site and the cooling towers at Site 300. This data supplements material provided in Chapter 14 of Volume 1.

Drainage

Retention Basin
Sampling locations at the Drainage Retention Basin (DRB) used to monitor compliance with Waste Discharge Requirement (WDR) Order No. 91-091, NPDES Permit NO. CA0029289 and the Livermore site CERCLA Record of Decision are shown in Figure 14-4, Volume 1. Figure 14-5, Volume 1 shows the sampling locations used to determine the maintenance of water quality objectives. Weekly sampling for dissolved oxygen and temperature occurs at all eight locations identified in Figure 14-5. Weekly turbidity measurements and monthly, quarterly, semiannual, and annual samples are collected at sample location CDBE. Table 14-1 shows the compliance monitoring data for the single sample collected from the Drainage Retention Basin on December 12, 1995. Monthly, quarterly, semiannual, and yearly maintenance monitoring data for 1995, that were collected at sample location CDBE are shown in Tables 14-2, $\mathbf{a}, \mathbf{b}, \mathbf{c}$, and $\mathbf{d}$. Table 14-3 provides the weekly field measurements collected from sample locations CDBA, CDBC, CDBD, CDBE, CDBF, CDBJ, CDBK, and CDBL. 
Table 14-1. Compliance monitoring data for the single release from the DRB.

\begin{tabular}{|c|c|c|c|}
\hline Requested analysis & Analyte & Units & $12 / 12 / 95$ result \\
\hline $\mathrm{BIO}$ & Aquatic bioassay, survival & $\%$ & 80 \\
\hline EPA504 & Ethylene dibromide & $\mu \mathrm{g} / \mathrm{L}$ & $<0.01$ \\
\hline \multirow[t]{30}{*}{ EPA601 } & 1,1,1-Trichloroethane & $\mu \mathrm{g} / \mathrm{L}$ & $<0.5$ \\
\hline & 1,1,2,2-Tetrachloroethane & $\mu g / L$ & $<0.5$ \\
\hline & 1,1,2-Trichloroethane & $\mu \mathrm{g} / \mathrm{L}$ & $<0.5$ \\
\hline & 1,1-Dichloroethane & $\mu \mathrm{g} / \mathrm{L}$ & $<0.5$ \\
\hline & 1,1-Dichloroethene & $\mu \mathrm{g} / \mathrm{L}$ & $<0.5$ \\
\hline & 1,2-Dichlorobenzene & $\mu g / L$ & $<0.5$ \\
\hline & 1,2-Dichloroethane & $\mu \mathrm{g} / \mathrm{L}$ & $<0.5$ \\
\hline & 1,2-Dichloroethene (total) & $\mu g / L$ & $<0.5$ \\
\hline & 1,2-Dichloropropane & $\mu \mathrm{g} / \mathrm{L}$ & $<0.5$ \\
\hline & 1,3-Dichlorobenzene & $\mu \mathrm{g} / \mathrm{L}$ & $<0.5$ \\
\hline & 1,4-Dichlorobenzene & $\mu \mathrm{g} / \mathrm{L}$ & $<0.5$ \\
\hline & 2-Chloroethylvinylether & $\mu \mathrm{g} / \mathrm{L}$ & $<0.5$ \\
\hline & Bromodichloromethane & $\mu \mathrm{g} / \mathrm{L}$ & $<0.5$ \\
\hline & Bromoform & $\mu \mathrm{g} / \mathrm{L}$ & $<0.5$ \\
\hline & Bromomethane & $\mu \mathrm{g} / \mathrm{L}$ & $<0.5$ \\
\hline & Carbon tetrachloride & $\mu \mathrm{g} / \mathrm{L}$ & $<0.5$ \\
\hline & Chlorobenzene & $\mu \mathrm{g} / \mathrm{L}$ & $<0.5$ \\
\hline & Chloroethane & $\mu \mathrm{g} / \mathrm{L}$ & $<0.5$ \\
\hline & Chloroform & $\mu \mathrm{g} / \mathrm{L}$ & $<0.5$ \\
\hline & Chloromethane & $\mu \mathrm{g} / \mathrm{L}$ & $<0.5$ \\
\hline & Dibromochloromethane & $\mu \mathrm{g} / \mathrm{L}$ & $<0.5$ \\
\hline & Dichlorodifluoromethane & $\mu \mathrm{g} / \mathrm{L}$ & $<0.5$ \\
\hline & Freon 113 & $\mu \mathrm{g} / \mathrm{L}$ & $<0.5$ \\
\hline & Methylene chloride & $\mu g / L$ & $<0.5$ \\
\hline & Tetrachloroethene & $\mu \mathrm{g} / \mathrm{L}$ & $<0.5$ \\
\hline & Trichloroethene & $\mu \mathrm{g} / \mathrm{L}$ & $<0.5$ \\
\hline & Trichlorofluoromethane & $\mu g / L$ & $<0.5$ \\
\hline & Vinyl chloride & $\mu \mathrm{g} / \mathrm{L}$ & $<0.5$ \\
\hline & cis-1,3-Dichloropropene & $\mu g / L$ & $<0.5$ \\
\hline & trans-1,3-Dichloropropene & $\mu \mathrm{g} / \mathrm{L}$ & $<0.5$ \\
\hline \multirow[t]{8}{*}{ EPA602 } & 1,2-Dichlorobenzene & $\mu \mathrm{g} / \mathrm{L}$ & $<0.3$ \\
\hline & 1,3-Dichlorobenzene & $\mu \mathrm{g} / \mathrm{L}$ & $<0.3$ \\
\hline & 1,4-Dichlorobenzene & $\mu g / L$ & $<0.3$ \\
\hline & Benzene & $\mu \mathrm{g} / \mathrm{L}$ & $<0.3$ \\
\hline & Chlorobenzene & $\mu \mathrm{g} / \mathrm{L}$ & $<0.3$ \\
\hline & Ethylbenzene & $\mu \mathrm{g} / \mathrm{L}$ & $<0.3$ \\
\hline & Toluene & $\mu g / L$ & $<0.3$ \\
\hline & Total xylene isomers & $\mu g / L$ & $<0.6$ \\
\hline
\end{tabular}


Table 14-1. Compliance monitoring data for the single release from the DRB (continued).

\begin{tabular}{|c|c|c|c|}
\hline Requested analysis & Analyte & Units & $12 / 12 / 95$ result \\
\hline EPA625 & $\begin{array}{l}\text { 1,2,4-Trichlorobenzene } \\
\text { 1,2-Dichlorobenzene } \\
\text { 1,3-Dichlorobenzene } \\
\text { 1,4-Dichlorobenzene } \\
\text { 2,4,5-Trichlorophenol } \\
\text { 2,4,6-Trichlorophenol } \\
\text { 2,4-Dichlorophenol } \\
\text { 2,4-Dimethylphenol } \\
\text { 2,4-Dinitrophenol } \\
\text { 2,4-Dinitrotoluene } \\
\text { 2,6-Dinitrotoluene } \\
\text { 2-Chloronaphthalene } \\
\text { 2-Chlorophenol } \\
\text { 2-Methylphenol } \\
\text { 2-Methyl-4,6-dinitrophenol } \\
\text { 2-Methylnaphthalene } \\
\text { 2-Nitroaniline } \\
\text { 2-Nitrophenol } \\
\text { 3,3'-Dichlorobenzidine } \\
\text { 3-Nitroaniline } \\
\text { 4-Bromophenylphenylether } \\
\text { 4-Chloro-3-methylphenol } \\
\text { 4-Chloroaniline } \\
\text { 4-Chlorophenylphenylether } \\
\text { 4-Nitroaniline } \\
\text { 4-Nitrophenol } \\
\text { Acenaphthene } \\
\text { Acenaphthylene } \\
\text { Anthracene } \\
\text { Benzo(a)anthracene } \\
\text { Benzo(a)pyrene } \\
\text { Benzo(b)fluoranthene } \\
\text { Benzo(g,h,i)perylene } \\
\text { Benzo(k)fluoranthene } \\
\text { Benzoic Acid } \\
\text { Benzyl Alcohol } \\
\text { Bis(2-chloroethoxy)methane }\end{array}$ & $\begin{array}{l}\mu \mathrm{g} / \mathrm{L} \\
\mu \mathrm{g} / \mathrm{L} \\
\mu \mathrm{g} / \mathrm{L} \\
\mu \mathrm{g} / \mathrm{L} \\
\mu \mathrm{g} / \mathrm{L} \\
\mu \mathrm{g} / \mathrm{L} \\
\mu \mathrm{g} / \mathrm{L} \\
\mu \mathrm{g} / \mathrm{L} \\
\mu \mathrm{g} / \mathrm{L} \\
\mu \mathrm{g} / \mathrm{L} \\
\mu \mathrm{g} / \mathrm{L} \\
\mu \mathrm{g} / \mathrm{L} \\
\mu \mathrm{g} / \mathrm{L} \\
\mu \mathrm{g} / \mathrm{L} \\
\mu \mathrm{g} / \mathrm{L} \\
\mu \mathrm{g} / \mathrm{L} \\
\mu \mathrm{g} / \mathrm{L} \\
\mu \mathrm{g} / \mathrm{L} \\
\mu \mathrm{g} / \mathrm{L} \\
\mu \mathrm{g} / \mathrm{L} \\
\mu \mathrm{g} / \mathrm{L} \\
\mu \mathrm{g} / \mathrm{L} \\
\mu \mathrm{g} / \mathrm{L} \\
\mu \mathrm{g} / \mathrm{L} \\
\mu \mathrm{g} / \mathrm{L} \\
\mu \mathrm{g} / \mathrm{L} \\
\mu \mathrm{g} / \mathrm{L} \\
\mu \mathrm{g} / \mathrm{L} \\
\mu \mathrm{g} / \mathrm{L} \\
\mu \mathrm{g} / \mathrm{L} \\
\mu \mathrm{g} / \mathrm{L} \\
\mu \mathrm{g} / \mathrm{L} \\
\mu \mathrm{g} / \mathrm{L} \\
\mu \mathrm{g} / \mathrm{L} \\
\mu \mathrm{g} / \mathrm{L} \\
\mu \mathrm{g} / \mathrm{L} \\
\mu \mathrm{g} / \mathrm{L}\end{array}$ & $\begin{array}{l}<10 \\
<10 \\
<10 \\
<10 \\
<10 \\
<10 \\
<10 \\
<10 \\
<50 \\
<10 \\
<10 \\
<10 \\
<10 \\
<10 \\
<50 \\
<10 \\
<50 \\
<10 \\
<20 \\
<50 \\
<10 \\
<20 \\
<20 \\
<10 \\
<50 \\
<50 \\
<10 \\
<50 \\
<10 \\
<10 \\
<10 \\
<10 \\
<10 \\
<10 \\
<10 \\
<10 \\
<0\end{array}$ \\
\hline
\end{tabular}


Table 14-1. Compliance monitoring data for the single release from the DRB (continued).

\begin{tabular}{|c|c|c|c|}
\hline Requested analysis & Analyte & Units & $12 / 12 / 95$ result \\
\hline \multirow[t]{28}{*}{ EPA 625 (continued) } & Bis(2-chloroethyl)ether & $\mu \mathrm{g} / \mathrm{L}$ & $<10$ \\
\hline & Bis(2-chloroisopropyl)ether & $\mu \mathrm{g} / \mathrm{L}$ & $<10$ \\
\hline & Bis(2-ethylhexyl)phthalate & $\mu g / L$ & $<10$ \\
\hline & Butylbenzylphthalate & $\mu \mathrm{g} / \mathrm{L}$ & $<10$ \\
\hline & Chrysene & $\mu \mathrm{g} / \mathrm{L}$ & $<10$ \\
\hline & Di-n-butylphthalate & $\mu g / L$ & $<10$ \\
\hline & Di-n-octylphthalate & $\mu \mathrm{g} / \mathrm{L}$ & $<10$ \\
\hline & Dibenzo(a,h)anthracene & $\mu \mathrm{g} / \mathrm{L}$ & $<10$ \\
\hline & Dibenzofuran & $\mu \mathrm{g} / \mathrm{L}$ & $<10$ \\
\hline & Diethylphthalate & $\mu \mathrm{g} / \mathrm{L}$ & $<10$ \\
\hline & Dimethylphthalate & $\mu \mathrm{g} / \mathrm{L}$ & $<10$ \\
\hline & Fluoranthene & $\mu \mathrm{g} / \mathrm{L}$ & $<10$ \\
\hline & Fluorene & $\mu \mathrm{g} / \mathrm{L}$ & $<10$ \\
\hline & Hexachlorobenzene & $\mu \mathrm{g} / \mathrm{L}$ & $<10$ \\
\hline & Hexachlorobutadiene & $\mu \mathrm{g} / \mathrm{L}$ & $<10$ \\
\hline & Hexachlorocyclopentadiene & $\mu \mathrm{g} / \mathrm{L}$ & $<10$ \\
\hline & Hexachloroethane & $\mu \mathrm{g} / \mathrm{L}$ & $<10$ \\
\hline & Indeno(1,2,3-c,d)pyrene & $\mu \mathrm{g} / \mathrm{L}$ & $<10$ \\
\hline & Isophorone & $\mu \mathrm{g} / \mathrm{L}$ & $<10$ \\
\hline & N-Nitrosodi-n-propylamine & $\mu g / L$ & $<10$ \\
\hline & N-Nitrosodiphenylamine & $\mu \mathrm{g} / \mathrm{L}$ & $<10$ \\
\hline & Naphthalene & $\mu \mathrm{g} / \mathrm{L}$ & $<10$ \\
\hline & Nitrobenzene & $\mu \mathrm{g} / \mathrm{L}$ & $<10$ \\
\hline & Pentachlorophenol & $\mu \mathrm{g} / \mathrm{L}$ & $<50$ \\
\hline & Phenanthrene & $\mu \mathrm{g} / \mathrm{L}$ & $<10$ \\
\hline & Phenol & $\mu \mathrm{g} / \mathrm{L}$ & $<10$ \\
\hline & Pyrene & $\mu g / L$ & $<10$ \\
\hline & $\mathrm{m}$ - and $\mathrm{p}$-Cresol & $\mu \mathrm{g} / \mathrm{L}$ & $<10$ \\
\hline \multirow[t]{8}{*}{ GENMIN } & Aluminum & $\mathrm{mg} / \mathrm{L}$ & 2.6 \\
\hline & Bicarbonate alk (as $\mathrm{CaCO}_{3}$ ) & $\mathrm{mg} / \mathrm{L}$ & 56 \\
\hline & Calcium & $\mathrm{mg} / \mathrm{L}$ & 14 \\
\hline & Carbonate alk (as $\left.\mathrm{CaCO}_{3}\right)$ & $\mathrm{mg} / \mathrm{L}$ & $<1$ \\
\hline & Chloride & $\mathrm{mg} / \mathrm{L}$ & 4.8 \\
\hline & Copper & $\mathrm{mg} / \mathrm{L}$ & $<0.05$ \\
\hline & Fluoride & $\mathrm{mg} / \mathrm{L}$ & 0.11 \\
\hline & Hydroxide alk (as $\mathrm{CaCO}_{3}$ ) & $\mathrm{mg} / \mathrm{L}$ & $<1$ \\
\hline
\end{tabular}


Table 14-1. Compliance monitoring data for the single release from the DRB (continued).

\begin{tabular}{|c|c|c|c|}
\hline Requested analysis & Analyte & Units & $12 / 12 / 95$ result \\
\hline \multirow[t]{15}{*}{ GENMIN (continued) } & Iron & $\mathrm{mg} / \mathrm{L}$ & 1.7 \\
\hline & Magnesium & $\mathrm{mg} / \mathrm{L}$ & 3.9 \\
\hline & Manganese & $\mathrm{mg} / \mathrm{L}$ & $<0.03$ \\
\hline & Nickel & $\mathrm{mg} / \mathrm{L}$ & $<0.1$ \\
\hline & Nitrate (as NO3) & $\mathrm{mg} / \mathrm{L}$ & 1.2 \\
\hline & Potassium & $\mathrm{mg} / \mathrm{L}$ & 3.4 \\
\hline & Sodium & $\mathrm{mg} / \mathrm{L}$ & 5.3 \\
\hline & Specific conductance & $\mu \mathrm{mho} / \mathrm{cm}$ & 110 \\
\hline & Sulfate & $\mathrm{mg} / \mathrm{L}$ & 4.5 \\
\hline & Surfactant & $\mathrm{mg} / \mathrm{L}$ & $<0.5$ \\
\hline & Total alkalinity (as CaCO3) & $\mathrm{mg} / \mathrm{L}$ & 56 \\
\hline & Total hardness (as $\mathrm{CaCO} 3$ ) & $\mathrm{mg} / \mathrm{L}$ & 50 \\
\hline & Total dissolved solids (TDS) & $\mathrm{mg} / \mathrm{L}$ & 85 \\
\hline & Zinc & $\mathrm{mg} / \mathrm{L}$ & $<0.05$ \\
\hline & $\mathrm{pH}$ & Units & 7.2 \\
\hline INORG & Total suspended solids (TSS) & $\mathrm{mg} / \mathrm{L}$ & 77 \\
\hline OG & Oil and grease & $\mathrm{mg} / \mathrm{L}$ & $<5$ \\
\hline OXYDEM & Chemical oxygen demand & $\mathrm{mg} / \mathrm{L}$ & 29 \\
\hline \multirow[t]{3}{*}{ RAD } & Gross alpha & $\mathrm{pCi} / \mathrm{L}$ & $<2.3$ \\
\hline & Gross beta & $\mathrm{pCi} / \mathrm{L}$ & 4.9 \\
\hline & Tritium & $\mathrm{pCi} / \mathrm{L}$ & 382 \\
\hline \multirow[t]{16}{*}{ SW846-6000 } & Aluminum & $\mathrm{mg} / \mathrm{L}$ & 5.6 \\
\hline & Antimony & $\mathrm{mg} / \mathrm{L}$ & $<0.005$ \\
\hline & Arsenic & $\mathrm{mg} / \mathrm{L}$ & 0.018 \\
\hline & Barium & $\mathrm{mg} / \mathrm{L}$ & 0.1 \\
\hline & Beryllium & $\mathrm{mg} / \mathrm{L}$ & $<0.0005$ \\
\hline & Cadmium & $\mathrm{mg} / \mathrm{L}$ & $<0.001$ \\
\hline & Calcium & $\mathrm{mg} / \mathrm{L}$ & 13 \\
\hline & Chromium & $\mathrm{mg} / \mathrm{L}$ & 0.029 \\
\hline & Cobalt & $\mathrm{mg} / \mathrm{L}$ & $<0.05$ \\
\hline & Copper & $\mathrm{mg} / \mathrm{L}$ & 0.011 \\
\hline & Chromium (VI) & $\mathrm{mg} / \mathrm{L}$ & $<0.01$ \\
\hline & Iron & $\mathrm{mg} / \mathrm{L}$ & 4.7 \\
\hline & Lead & $\mathrm{mg} / \mathrm{L}$ & 0.008 \\
\hline & Magnesium & $\mathrm{mg} / \mathrm{L}$ & 4.3 \\
\hline & Molybdenum & $\mathrm{mg} / \mathrm{L}$ & $<0.05$ \\
\hline & Nickel & $\mathrm{mg} / \mathrm{L}$ & $<0.005$ \\
\hline
\end{tabular}


Table 14-1. Compliance monitoring data for the single release from the DRB (concluded).

\begin{tabular}{|l|l|c|c|}
\hline Requested analysis & \multicolumn{1}{|c|}{ Analyte } & Units & 12/12/95 result \\
\hline \multirow{5}{*}{ SW846-7000 } & Potassium & $\mathrm{mg} / \mathrm{L}$ & $<1$ \\
& Sodium & $\mathrm{mg} / \mathrm{L}$ & 5 \\
& Thallium & $\mathrm{mg} / \mathrm{L}$ & $<0.001$ \\
& Tin & $\mathrm{mg} / \mathrm{L}$ & $<0.005$ \\
& Vanadium & $\mathrm{mg} / \mathrm{L}$ & $<0.02$ \\
& Zinc & $\mathrm{mg} / \mathrm{L}$ & 0.07 \\
& Mercury & $\mathrm{mg} / \mathrm{L}$ & $<0.0002$ \\
& Selenium & $\mathrm{mg} / \mathrm{L}$ & $<0.005$ \\
& Silver & $\mathrm{mg} / \mathrm{L}$ & $<0.005$ \\
& Diesel fuel & $\mu \mathrm{g} / \mathrm{L}$ & $<50$ \\
& Gasoline fingerprint & $\mu \mathrm{g} / \mathrm{L}$ & $<50$ \\
\hline
\end{tabular}


Table 14-2a. Annual maintenance monitoring data collected at sampling location CDBE.

\begin{tabular}{|c|c|c|c|c|c|c|c|c|}
\hline \multirow[b]{2}{*}{ Analyte } & \multicolumn{3}{|c|}{ Results (1995) } & \multirow[b]{2}{*}{ Minimum } & \multirow[b]{2}{*}{ Maximum } & \multirow[b]{2}{*}{ Median } & \multirow[b]{2}{*}{$\begin{array}{l}\text { Interquartile } \\
\text { range }\end{array}$} & \multirow[b]{2}{*}{$\begin{array}{c}\text { No. of } \\
\text { samples }\end{array}$} \\
\hline & 20-Apr & 25-Sep & 19-Dec & & & & & \\
\hline \multicolumn{9}{|l|}{ BIO (\%) } \\
\hline Aquatic bioassay, survival & & 90 & & 90 & 90 & 90 & -(a) $^{(\mathrm{n}}$ & 1 \\
\hline \multicolumn{9}{|l|}{ EPA $610(\mu \mathrm{g} / \mathrm{L})$} \\
\hline Acenaphthene & $<2$ & & & $<2$ & $<2$ & $<2$ & -(a) $^{(\mathrm{n}}$ & 1 \\
\hline Acenaphthylene & $<2$ & & & $<2$ & $<2$ & $<2$ & -(a) $^{(\mathrm{n}}$ & 1 \\
\hline Anthracene & $<1$ & & & $<1$ & $<1$ & $<1$ & -(a) & 1 \\
\hline Benzo(a)anthracene & $<0.5$ & & & $<0.5$ & $<0.5$ & $<0.5$ & -(a) $^{\text {(a) }}$ & 1 \\
\hline Benzo(a)pyrene & $<0.5$ & & & $<0.5$ & $<0.5$ & $<0.5$ & -(a) & 1 \\
\hline Benzo(b)fluoranthene & $<0.5$ & & & $<0.5$ & $<0.5$ & $<0.5$ & -(a) $^{(\mathrm{n}}$ & 1 \\
\hline Benzo(g,h,i)perylene & $<0.5$ & & & $<0.5$ & $<0.5$ & $<0.5$ & -(a) & 1 \\
\hline Benzo(k)fluoranthene & $<0.5$ & & & $<0.5$ & $<0.5$ & $<0.5$ & -(a) $^{\text {(a) }}$ & 1 \\
\hline Chrysene & $<0.5$ & & & $<0.5$ & $<0.5$ & $<0.5$ & -(a) & 1 \\
\hline Dibenzo(a,h)anthracene & $<0.5$ & & & $<0.5$ & $<0.5$ & $<0.5$ & -(a) & 1 \\
\hline Fluoranthene & $<0.5$ & & & $<0.5$ & $<0.5$ & $<0.5$ & -(a) & 1 \\
\hline Fluorene & $<2$ & & & $<2$ & $<2$ & $<2$ & -(a) & 1 \\
\hline Indeno(1,2,3-c,d)pyrene & $<0.5$ & & & $<0.5$ & $<0.5$ & $<0.5$ & -(a) & 1 \\
\hline Naphthalene & $<2$ & & & $<2$ & $<2$ & $<2$ & -(a) & 1 \\
\hline Phenanthrene & $<1$ & & & $<1$ & $<1$ & $<1$ & -(a) & 1 \\
\hline Pyrene & $<0.5$ & & & $<0.5$ & $<0.5$ & $<0.5$ & -(a) $^{(\mathrm{n}}$ & 1 \\
\hline $\begin{array}{l}\text { 1,2-Dibromo-3- } \\
\text { chloropropane }\end{array}$ & $<0.01$ & & & $<0.01$ & $<0.01$ & $<0.01$ & -(a) $^{(a)}$ & 1 \\
\hline \multicolumn{9}{|l|}{ EPA615 $(\mu \mathrm{g} / \mathrm{L})$} \\
\hline $2,4,5-\mathrm{T}$ & & & $<0.5$ & $<0.5$ & $<0.5$ & $<0.5$ & -(a) $^{\text {(a) }}$ & 1 \\
\hline 2,4,5-TP (Silvex) & & & $<0.2$ & $<0.2$ & $<0.2$ & $<0.2$ & -(a) & 1 \\
\hline $2,4-D$ & & & $<1$ & $<1$ & $<1$ & $<1$ & -(a) $^{\text {(a) }}$ & 1 \\
\hline $\begin{array}{l}4-(2,4- \\
\text { Dichlorophenoxy)butyric } \\
\text { acid }\end{array}$ & & & $<2$ & $<2$ & $<2$ & $<2$ & -(a) & 1 \\
\hline Dalapon & & & $<2$ & $<2$ & $<2$ & $<2$ & -(a) $^{(\mathrm{n}}$ & 1 \\
\hline Dicamba & & & $<1$ & $<1$ & $<1$ & $<1$ & -(a) & 1 \\
\hline Dichloroprop & & & $<2$ & $<2$ & $<2$ & $<2$ & -(a) & 1 \\
\hline Dinoseb & & & $<1$ & $<1$ & $<1$ & $<1$ & -(a) $^{\text {(a) }}$ & 1 \\
\hline MCPA & & & $<250$ & $<250$ & $<250$ & $<250$ & -(a) $^{\text {(a) }}$ & 1 \\
\hline MCPP & & & $<250$ & $<250$ & $<250$ & $<250$ & - (a) $^{(a)}$ & 1 \\
\hline
\end{tabular}

a Insufficient data top calculate interquartile range. 
Table 14-2b. Semiannual maintenance monitoring data collected at sampling location CDBE.

\begin{tabular}{|c|c|c|c|c|c|c|c|}
\hline \multirow[b]{2}{*}{ Analyte } & \multicolumn{2}{|c|}{ Results (1995) } & \multirow[b]{2}{*}{ Minimum } & \multirow[b]{2}{*}{ Maximum } & \multirow[b]{2}{*}{ Median } & \multirow[b]{2}{*}{$\begin{array}{c}\text { Interquartile } \\
\text { Range }\end{array}$} & \multirow[b]{2}{*}{$\begin{array}{c}\text { No. of } \\
\text { Samples }\end{array}$} \\
\hline & 20-Apr & 25-Sep & & & & & \\
\hline \multicolumn{8}{|l|}{ EPA $504(\mu \mathrm{g} / \mathrm{L})$} \\
\hline Ethylene Dibromide & $<0.2$ & $<0.2$ & $<0.02$ & $<0.2$ & $<0.2$ & -(a) & 2 \\
\hline \multicolumn{8}{|l|}{ EPA601 } \\
\hline 1,1,1-Trichloroethane & $<0.5$ & $<0.5$ & $<0.5$ & $<0.5$ & $<0.5$ & -(a) & 2 \\
\hline 1,1,2,2-Tetrachloroethane & $<0.5$ & $<0.5$ & $<0.5$ & $<0.5$ & $<0.5$ & -(a) $^{(a)}$ & 2 \\
\hline 1,1,2-Trichloroethane & $<0.5$ & $<0.5$ & $<0.5$ & $<0.5$ & $<0.5$ & -(a) & 2 \\
\hline 1,1-Dichloroethane & $<0.5$ & $<0.5$ & $<0.5$ & $<0.5$ & $<0.5$ & —(a) & 2 \\
\hline 1,1-Dichloroethene & $<0.5$ & $<0.5$ & $<0.5$ & $<0.5$ & $<0.5$ & -(a) & 2 \\
\hline 1,2-Dichlorobenzene & $<0.5$ & $<0.5$ & $<0.5$ & $<0.5$ & $<0.5$ & -(a) $^{(\mathrm{n}}$ & 2 \\
\hline 1,2-Dichloroethane & $<0.5$ & $<0.5$ & $<0.5$ & $<0.5$ & $<0.5$ & - (a) $^{\text {(a) }}$ & 2 \\
\hline 1,2-Dichloroethene (total) & $<0.5$ & $<0.5$ & $<0.5$ & $<0.5$ & $<0.5$ & -(a) & 2 \\
\hline 1,2-Dichloropropane & $<0.5$ & $<0.5$ & $<0.5$ & $<0.5$ & $<0.5$ & -(a) & 2 \\
\hline 1,3-Dichlorobenzene & $<0.5$ & $<0.5$ & $<0.5$ & $<0.5$ & $<0.5$ & -(a) & 2 \\
\hline 1,4-Dichlorobenzene & $<0.5$ & $<0.5$ & $<0.5$ & $<0.5$ & $<0.5$ & -(a) & 2 \\
\hline 2-Chloroethylvinylether & $<0.5$ & $<0.5$ & $<0.5$ & $<0.5$ & $<0.5$ & -(a) & 2 \\
\hline Bromodichloromethane & $<0.5$ & $<0.5$ & $<0.5$ & $<0.5$ & $<0.5$ & -(a) $^{(\mathrm{n}}$ & 2 \\
\hline Bromoform & $<0.5$ & $<0.5$ & $<0.5$ & $<0.5$ & $<0.5$ & -(a) $^{\text {(a) }}$ & 2 \\
\hline Bromomethane & $<0.5$ & $<0.5$ & $<0.5$ & $<0.5$ & $<0.5$ & -(a) $^{\text {(a) }}$ & 2 \\
\hline Carbon tetrachloride & $<0.5$ & $<0.5$ & $<0.5$ & $<0.5$ & $<0.5$ & -(a) & 2 \\
\hline Chlorobenzene & $<0.5$ & $<0.5$ & $<0.5$ & $<0.5$ & $<0.5$ & -(a) $^{(\mathrm{n}}$ & 2 \\
\hline Chloroethane & $<0.5$ & $<0.5$ & $<0.5$ & $<0.5$ & $<0.5$ & -(a) $^{\text {(a) }}$ & 2 \\
\hline Chloroform & $<0.5$ & $<0.5$ & $<0.5$ & $<0.5$ & $<0.5$ & -(a) $^{(\mathrm{n}}$ & 2 \\
\hline Chloromethane & $<0.5$ & $<0.5$ & $<0.5$ & $<0.5$ & $<0.5$ & -(a) $^{\text {(a) }}$ & 2 \\
\hline Dibromochloromethane & $<0.5$ & $<0.5$ & $<0.5$ & $<0.5$ & $<0.5$ & - (a) $^{\text {(a) }}$ & 2 \\
\hline Dichlorodifluoromethane & $<0.5$ & $<0.5$ & $<0.5$ & $<0.5$ & $<0.5$ & -(a) $^{(\mathrm{n}}$ & 2 \\
\hline Freon 113 & $<0.5$ & $<0.5$ & $<0.5$ & $<0.5$ & $<0.5$ & -(a) $^{\text {(a) }}$ & 2 \\
\hline Methylene chloride & $<0.5$ & $<0.5$ & $<0.5$ & $<0.5$ & $<0.5$ & -(a) & 2 \\
\hline Tetrachloroethene & $<0.5$ & $<0.5$ & $<0.5$ & $<0.5$ & $<0.5$ & -(a) $^{\text {(a) }}$ & 2 \\
\hline Trichloroethene & $<0.5$ & $<0.5$ & $<0.5$ & $<0.5$ & $<0.5$ & -(a) $^{(\mathrm{n}}$ & 2 \\
\hline Trichlorofluoromethane & $<0.5$ & $<0.5$ & $<0.5$ & $<0.5$ & $<0.5$ & -(a) $^{\text {(a) }}$ & 2 \\
\hline Vinyl chloride & $<0.5$ & $<0.5$ & $<0.5$ & $<0.5$ & $<0.5$ & -(a) $^{(a)}$ & 2 \\
\hline cis-1,3-Dichloropropene & $<0.5$ & $<0.5$ & $<0.5$ & $<0.5$ & $<0.5$ & -(a) $^{\text {(a) }}$ & 2 \\
\hline trans-1,3-Dichloropropene & $<0.5$ & $<0.5$ & $<0.5$ & $<0.5$ & $<0.5$ & -(a) $^{(\mathrm{a}}$ & 2 \\
\hline
\end{tabular}


Table 14-2b. Semiannual maintenance monitoring data collected at sampling location CDBE (continued).

\begin{tabular}{|c|c|c|c|c|c|c|c|c|}
\hline \multirow[b]{2}{*}{ Analyte } & \multicolumn{3}{|c|}{ Results (1995) } & \multirow[b]{2}{*}{ Minimum } & \multirow[b]{2}{*}{ Maximum } & \multirow[b]{2}{*}{ Median } & \multirow{2}{*}{\begin{tabular}{|c|}
$\begin{array}{c}\text { Interquartile } \\
\text { Range }\end{array}$ \\
\end{tabular}} & \multirow{2}{*}{$\begin{array}{c}\text { No. of } \\
\text { Samples }\end{array}$} \\
\hline & 20-Apr & 25-Sep & 9-May & & & & & \\
\hline \multicolumn{9}{|l|}{ EPA602 $(\mu \mathrm{g} / \mathrm{L})$} \\
\hline 1,2-Dichlorobenzene & $<0.3$ & $<0.3$ & & $<0.3$ & $<0.3$ & $<0.3$ & - (a) $^{\text {(a) }}$ & 2 \\
\hline 1,3-Dichlorobenzene & $<0.3$ & $<0.3$ & & $<0.3$ & $<0.3$ & $<0.3$ & - (a) $^{(a)}$ & 2 \\
\hline 1,4-Dichlorobenzene & $<0.3$ & $<0.3$ & & $<0.3$ & $<0.3$ & $<0.3$ & - (a) $^{\text {(a) }}$ & 2 \\
\hline Benzene & $<0.3$ & $<0.3$ & & $<0.3$ & $<0.3$ & $<0.3$ & -(a) & 2 \\
\hline Chlorobenzene & $<0.3$ & $<0.3$ & & $<0.3$ & $<0.3$ & $<0.3$ & -(a) $^{\text {(a) }}$ & 2 \\
\hline Ethylbenzene & $<0.3$ & $<0.3$ & & $<0.3$ & $<0.3$ & $<0.3$ & -(a) $^{(a)}$ & 2 \\
\hline Toluene & $<0.3$ & $<0.3$ & & $<0.3$ & $<0.3$ & $<0.3$ & -(a) $^{(\mathrm{a}}$ & 2 \\
\hline Total xylene isomers & $<0.6$ & $<0.6$ & & $<0.6$ & $<0.6$ & $<0.6$ & -(a) $^{(\mathrm{n}}$ & 2 \\
\hline \multicolumn{9}{|l|}{ EPA625 ( $\mu \mathrm{g} / \mathrm{L})$} \\
\hline 1,2,4-Trichlorobenzene & $<10$ & $<10$ & & $<10$ & $<10$ & $<10$ & -(a) $^{(\mathrm{n}}$ & 2 \\
\hline 1,2-Dichlorobenzene & $<10$ & $<10$ & & $<10$ & $<10$ & $<10$ & -(a) $^{(\mathrm{n}}$ & 2 \\
\hline 1,3-Dichlorobenzene & $<10$ & $<10$ & & $<10$ & $<10$ & $<10$ & -(a) $^{(\mathrm{n}}$ & 2 \\
\hline 1,4-Dichlorobenzene & $<10$ & $<10$ & & $<10$ & $<10$ & $<10$ & -(a) $^{(\mathrm{n}}$ & 2 \\
\hline 2,4,5-Trichlorophenol & $<10$ & $<10$ & & $<10$ & $<10$ & $<10$ & - (a) $^{\text {(a) }}$ & 2 \\
\hline 2,4,6-Trichlorophenol & $<10$ & $<10$ & & $<10$ & $<10$ & $<10$ & - (a) $^{\text {(a) }}$ & 2 \\
\hline 2,4-Dichlorophenol & $<10$ & $<10$ & & $<10$ & $<10$ & $<10$ & - (a) $^{\text {(a) }}$ & 2 \\
\hline 2,4-Dimethylphenol & $<10$ & $<10$ & & $<10$ & $<10$ & $<10$ & - (a) $^{\text {(a) }}$ & 2 \\
\hline 2,4-Dinitrophenol & $<50$ & $<50$ & & $<50$ & $<50$ & $<50$ & -(a) $^{\text {(a) }}$ & 2 \\
\hline 2,4-Dinitrotoluene & $<10$ & $<10$ & & $<10$ & $<10$ & $<10$ & -(a) $^{(a)}$ & 2 \\
\hline 2,6-Dinitrotoluene & $<10$ & $<10$ & & $<10$ & $<10$ & $<10$ & -(a) $^{\text {(a) }}$ & 2 \\
\hline 2-Chloronaphthalene & $<10$ & $<10$ & & $<10$ & $<10$ & $<10$ & -(a) $^{\text {(a) }}$ & 2 \\
\hline 2-Chlorophenol & $<10$ & $<10$ & & $<10$ & $<10$ & $<10$ & -(a) $^{\text {(a) }}$ & 2 \\
\hline 2-Methyl Phenol & $<10$ & $<10$ & & $<10$ & $<10$ & $<10$ & -(a) & 2 \\
\hline 2-Methyl-4,6-dinitrophenol & $<50$ & $<50$ & & $<50$ & $<50$ & $<50$ & -(a) $^{(a)}$ & 2 \\
\hline 2-Methylnaphthalene & $<10$ & $<10$ & & $<10$ & $<10$ & $<10$ & 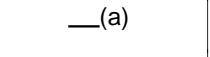 & 2 \\
\hline 2-Nitroaniline & $<50$ & $<50$ & & $<50$ & $<50$ & $<50$ & 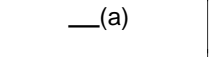 & 2 \\
\hline 2-Nitrophenol & $<10$ & $<10$ & & $<10$ & $<10$ & $<10$ & - (a) $^{\text {(a) }}$ & 2 \\
\hline 3,3'-Dichlorobenzidine & $<20$ & $<20$ & & $<20$ & $<20$ & $<20$ & -(a) & 2 \\
\hline 3-Nitroaniline & $<50$ & $<50$ & & $<50$ & $<50$ & $<50$ & -(a) $^{(a)}$ & 2 \\
\hline 4-Bromophenylphenylether & $<10$ & $<10$ & & $<10$ & $<10$ & $<10$ & -(a) & 2 \\
\hline 4-Chloro-3-methylphenol & $<20$ & $<20$ & & $<20$ & $<20$ & $<20$ & -(a) & 2 \\
\hline 4-Chloroaniline & $<20$ & $<20$ & & $<20$ & $<20$ & $<20$ & -(a) $^{\text {(a) }}$ & 2 \\
\hline 4-Chlorophenylphenylether & $<10$ & $<10$ & & $<10$ & $<10$ & $<10$ & -(a) $^{(\mathrm{a})}$ & 2 \\
\hline
\end{tabular}


Table 14-2b. Semiannual maintenance monitoring data collected at sampling location CDBE (continued).

\begin{tabular}{|c|c|c|c|c|c|c|c|c|}
\hline \multirow[b]{2}{*}{ Analyte } & \multicolumn{3}{|c|}{ Results (1995) } & \multirow[b]{2}{*}{ Minimum } & \multirow[b]{2}{*}{ Maximum } & \multirow[b]{2}{*}{ Median } & \multirow{2}{*}{$\begin{array}{c}\text { Interquartile } \\
\text { Range }\end{array}$} & \multirow{2}{*}{$\begin{array}{c}\text { No. of } \\
\text { Samples }\end{array}$} \\
\hline & 20-Apr & 25-Sep & 9-May & & & & & \\
\hline 4-Nitroaniline & $<50$ & $<50$ & & $<50$ & $<50$ & $<50$ & 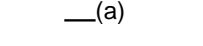 & 2 \\
\hline 4-Nitrophenol & $<50$ & $<50$ & & $<50$ & $<50$ & $<50$ & - $^{(\mathrm{a})}$ & 2 \\
\hline Acenaphthene & $<10$ & $<10$ & & $<10$ & $<10$ & $<10$ & 一 $^{(\mathrm{a})}$ & 2 \\
\hline Acenaphthylene & $<10$ & $<10$ & & $<10$ & $<10$ & $<10$ & - $^{(\mathrm{a})}$ & 2 \\
\hline Anthracene & $<10$ & $<10$ & & $<10$ & $<10$ & $<10$ & -(a) & 2 \\
\hline Benzo(a)anthracene & $<10$ & $<10$ & & $<10$ & $<10$ & $<10$ & - $^{(\mathrm{a})}$ & 2 \\
\hline Benzo(a)pyrene & $<10$ & $<10$ & & $<10$ & $<10$ & $<10$ & -(a) $^{(\mathrm{a}}$ & 2 \\
\hline Benzo(b)fluoranthene & $<10$ & $<10$ & & $<10$ & $<10$ & $<10$ & 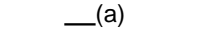 & 2 \\
\hline Benzo(g,h,i)perylene & $<10$ & $<10$ & & $<10$ & $<10$ & $<10$ & -(a) $^{(a)}$ & 2 \\
\hline Benzo(k)fluoranthene & $<10$ & $<10$ & & $<10$ & $<10$ & $<10$ & -(a) $^{(\mathrm{a}}$ & 2 \\
\hline Benzoic Acid & $<50$ & $<50$ & & $<50$ & $<50$ & $<50$ & 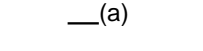 & 2 \\
\hline Benzyl Alcohol & $<20$ & $<20$ & & $<20$ & $<20$ & $<20$ & 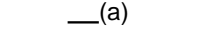 & 2 \\
\hline Bis(2-chloroethoxy)methane & $<10$ & $<10$ & & $<10$ & $<10$ & $<10$ & $-^{(a)}$ & 2 \\
\hline Bis(2-chloroethyl)ether & $<10$ & $<10$ & & $<10$ & $<10$ & $<10$ & - $^{(\mathrm{a})}$ & 2 \\
\hline Bis(2-chloroisopropyl)ether & $<10$ & $<10$ & & $<10$ & $<10$ & $<10$ & - $^{(\mathrm{a})}$ & 2 \\
\hline Bis(2-ethylhexyl)phthalate & $<10$ & $<10$ & & $<10$ & $<10$ & $<10$ & - $^{(\mathrm{a})}$ & 2 \\
\hline Butylbenzylphthalate & $<10$ & $<10$ & & $<10$ & $<10$ & $<10$ & - $^{(\mathrm{a})}$ & 2 \\
\hline Chrysene & $<10$ & $<10$ & & $<10$ & $<10$ & $<10$ & -(a) $^{(\mathrm{n}}$ & 2 \\
\hline Di-n-butylphthalate & $<10$ & $<10$ & & $<10$ & $<10$ & $<10$ & - $^{(\mathrm{a})}$ & 2 \\
\hline Di-n-octylphthalate & $<10$ & $<10$ & & $<10$ & $<10$ & $<10$ & - (a) $^{(\mathrm{n}}$ & 2 \\
\hline Dibenzo(a,h)anthracene & $<10$ & $<10$ & & $<10$ & $<10$ & $<10$ & -(a) $^{(\mathrm{n}}$ & 2 \\
\hline Dibenzofuran & $<10$ & $<10$ & & $<10$ & $<10$ & $<10$ & - $^{(\mathrm{a})}$ & 2 \\
\hline Diethylphthalate & $<10$ & $<10$ & & $<10$ & $<10$ & $<10$ & $-^{(a)}$ & 2 \\
\hline Dimethylphthalate & $<10$ & $<10$ & & $<10$ & $<10$ & $<10$ & - $^{(\mathrm{a})}$ & 2 \\
\hline Fluoranthene & $<10$ & $<10$ & & $<10$ & $<10$ & $<10$ & -(a) & 2 \\
\hline Fluorene & $<10$ & $<10$ & & $<10$ & $<10$ & $<10$ & - $^{(\mathrm{a})}$ & 2 \\
\hline Hexachlorobenzene & $<10$ & $<10$ & & $<10$ & $<10$ & $<10$ & - $^{(\mathrm{a})}$ & 2 \\
\hline Hexachlorobutadiene & $<10$ & $<10$ & & $<10$ & $<10$ & $<10$ & $-^{(\mathrm{a})}$ & 2 \\
\hline Hexachlorocyclopentadiene & $<10$ & $<10$ & & $<10$ & $<10$ & $<10$ & - (a) $^{(2)}$ & 2 \\
\hline Hexachloroethane & $<10$ & $<10$ & & $<10$ & $<10$ & $<10$ & $-^{(a)}$ & 2 \\
\hline Indeno(1,2,3-c,d)pyrene & $<10$ & $<10$ & & $<10$ & $<10$ & $<10$ & 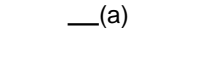 & 2 \\
\hline Isophorone & $<10$ & $<10$ & & $<10$ & $<10$ & $<10$ & - $^{(\mathrm{a})}$ & 2 \\
\hline N-Nitrosodi-n-propylamine & $<10$ & $<10$ & & $<10$ & $<10$ & $<10$ & - $^{(\mathrm{a})}$ & 2 \\
\hline N-Nitrosodiphenylamine & $<10$ & $<10$ & & $<10$ & $<10$ & $<10$ & -(a) & 2 \\
\hline
\end{tabular}




\section{Compliance Self-Monitoring}

Table 14-2b. Semiannual maintenance monitoring data collected at sampling location CDBE (concluded).

\begin{tabular}{|c|c|c|c|c|c|c|c|c|}
\hline \multirow[b]{2}{*}{ Analyte } & \multicolumn{3}{|c|}{ Results (1995) } & \multirow[b]{2}{*}{ Minimum } & \multirow[b]{2}{*}{ Maximum } & \multirow[b]{2}{*}{ Median } & \multirow[b]{2}{*}{$\begin{array}{c}\text { Inter-quartile } \\
\text { Range }\end{array}$} & \multirow[b]{2}{*}{$\begin{array}{c}\text { No. of } \\
\text { Samples }\end{array}$} \\
\hline & 20-Apr & 25-Sep & 9-May & & & & & \\
\hline Naphthalene & $<10$ & $<10$ & & $<10$ & $<10$ & $<10$ & -(a) & 2 \\
\hline Nitrobenzene & $<10$ & $<10$ & & $<10$ & $<10$ & $<10$ & -(a) & 2 \\
\hline Pentachlorophenol & $<50$ & $<50$ & & $<50$ & $<50$ & $<50$ & -(a) & 2 \\
\hline Phenanthrene & $<10$ & $<10$ & & $<10$ & $<10$ & $<10$ & -(a) & 2 \\
\hline Phenol & $<10$ & $<10$ & & $<10$ & $<10$ & $<10$ & -(a) & 2 \\
\hline Pyrene & $<10$ & $<10$ & & $<10$ & $<10$ & $<10$ & -(a) & 2 \\
\hline $\mathrm{m}$ - and $\mathrm{p}$ - Cresol & $<10$ & $<10$ & & $<10$ & $<10$ & $<10$ & -(a) & 2 \\
\hline \multicolumn{9}{|l|}{ ORGCARB (mg/L) } \\
\hline Total organic carbon (TOC) & 12 & 4.5 & & 4.5 & 12 & 8.25 & 3.75 & 2 \\
\hline \multicolumn{9}{|l|}{ RAD (pCi/L) } \\
\hline Gross alpha & 1.3 & 4.1 & & 1.3 & 2 & 1.65 & 0.35 & 2 \\
\hline Gross beta & 3.2 & 4.1 & & 3.2 & 4.1 & 3.65 & 0.45 & 2 \\
\hline Tritium & 422 & 402 & & 402 & 422 & 412 & 10 & 2 \\
\hline \multicolumn{9}{|l|}{ TPH $(\mu \mathrm{g} / \mathrm{L}$} \\
\hline Gasoline fingerprint & $<50$ & & & $<50$ & $<50$ & $<50$ & -(a) & 2 \\
\hline Diesel fuel & $<50$ & & $<50$ & $<50$ & $<50$ & $<50$ & -(a) & 2 \\
\hline
\end{tabular}

a Insufficient data to calculate interquartile range.

Table 14-2c. Quarterly maintenance monitoring data collected at sampling location CDBE.

\begin{tabular}{|c|c|c|c|c|c|c|c|c|c|}
\hline \multirow[b]{2}{*}{ Analyte } & \multicolumn{4}{|c|}{ Results (1995) } & \multirow[b]{2}{*}{ Minimum } & \multirow[b]{2}{*}{ Maximum } & \multirow[b]{2}{*}{ Median } & \multirow[b]{2}{*}{$\begin{array}{c}\text { Interquartile } \\
\text { Range }\end{array}$} & \multirow[b]{2}{*}{$\begin{array}{c}\text { No. of } \\
\text { Samples }\end{array}$} \\
\hline & 19-Jan & 20-Apr & 11-Jul & 7-Nov & & & & & \\
\hline BIO (MPN/100 mL) & & & & & & & & & \\
\hline Fecal coliform & & 13 & 4 & & 480 & 50 & 10.5 & 15.25 & 4 \\
\hline $\begin{array}{l}\text { Total coliform } \\
\text { OXYDEM (mg/L) }\end{array}$ & 900 & 30 & 13 & 13 & 13 & 900 & 21.5 & 234.5 & 4 \\
\hline Chemical oxygen demand & 19 & 22 & 17 & 19 & 17 & 22 & 19 & 1.25 & 4 \\
\hline
\end{tabular}


Table 14-2d. Monthly maintenance monitoring data collected at sampling location CDBE.

\begin{tabular}{|c|c|c|c|c|c|c|c|c|c|c|c|c|}
\hline \multirow[b]{2}{*}{ Analyte } & \multicolumn{7}{|c|}{ Results (1995) } & \multirow[b]{2}{*}{ Min } & \multirow[b]{2}{*}{ Max } & \multirow[b]{2}{*}{ Med } & \multirow[b]{2}{*}{$\begin{array}{c}\text { Inter-quartile } \\
\text { Range }\end{array}$} & \multirow[b]{2}{*}{$\begin{array}{c}\text { No. of } \\
\text { Samples }\end{array}$} \\
\hline & $\begin{array}{l}\text { 19-Jan/ } \\
14-F e b\end{array}$ & $\begin{array}{c}\text { 14-Mar/ } \\
\text { 20-Apr }\end{array}$ & $\begin{array}{l}\text { 9-May/ } \\
\text { 6-Jun }\end{array}$ & $\begin{array}{l}\text { 11-Jul/ } \\
\text { 11-Aug }\end{array}$ & $\begin{array}{c}25-\mathrm{Sep} / \\
17-\text { Oct }\end{array}$ & $\begin{array}{l}\text { 7-Nov/ } \\
\text { 19-Dec }\end{array}$ & 28-Dec & & & & & \\
\hline \multicolumn{13}{|l|}{ GEMIN (mg/L) } \\
\hline Aluminum & $\begin{array}{l}<0.2 / \\
<0.2\end{array}$ & $\begin{array}{l}<0.2 / \\
<0.2\end{array}$ & $\begin{array}{l}<0.2 / \\
<0.2\end{array}$ & $\begin{array}{l}<0.2 / \\
<0.2\end{array}$ & $\begin{array}{l}<0.2 / \\
<0.2\end{array}$ & $\begin{array}{l}<0.2 / \\
<0.2\end{array}$ & & $<0.02$ & $<3.2$ & $<0.2$ & - $^{(\mathrm{a})}$ & 12 \\
\hline $\begin{array}{l}\text { Bicarbonate } \\
\text { alk } \\
\left(\text { as } \mathrm{CaCO}_{3}\right)\end{array}$ & $37 / 42$ & $28 / 36$ & $41 / 46$ & $52 / 45$ & $43 / 70$ & $71 / 45$ & & 28 & 71 & 44 & 7.5 & 12 \\
\hline Calcium & $13 / 14$ & $10 / 11$ & $11 / 12$ & $13 / 15$ & $17 / 19$ & $20 / 13$ & & 10 & 20 & 13 & 3.8 & 12 \\
\hline $\begin{array}{l}\text { Carbonate alk } \\
\left(\text { as } \mathrm{CaCO}_{3}\right)\end{array}$ & $<1 /<1$ & $<1 /<1$ & $<1 /<1$ & $<1 /<1$ & $<1 /<1$ & $<1 /<1$ & & $<1$ & $<1$ & $<1$ & - $^{(\mathrm{a})}$ & 12 \\
\hline Chloride & $7.7 / 8.1$ & $3.9 / 3.1$ & $2.9 / 3.7$ & $3.6 / 9.8$ & $4.8 / 5.4$ & $4.8 / 19$ & & 2.9 & 19 & 4.8 & 4.1 & 12 \\
\hline Copper & $\begin{array}{l}<0.05 / \\
<0.05\end{array}$ & $\begin{array}{l}<0.05 / \\
<0.05\end{array}$ & $\begin{array}{l}<0.05 / \\
<0.05\end{array}$ & $\begin{array}{l}<0.05 / \\
<0.05\end{array}$ & $\begin{array}{l}<0.05 / \\
<0.05\end{array}$ & $\begin{array}{l}<0.05 / \\
<0.05\end{array}$ & & $<0.5$ & $<0.5$ & $<0.5$ & -(a) $^{(a)}$ & 12 \\
\hline Fluoride & $\begin{array}{l}0.066 / \\
0.071\end{array}$ & $\begin{array}{l}0.07 / \\
0.068\end{array}$ & $\begin{array}{l}0.073 / \\
0.069\end{array}$ & $\begin{array}{c}0.082 ? \\
0.081\end{array}$ & $\begin{array}{c}0.089 / \\
0.1\end{array}$ & $\begin{array}{c}0.093 / \\
0.1\end{array}$ & & 0.066 & 0.1 & 0.077 & 0.020 & 12 \\
\hline $\begin{array}{l}\text { Hydroxide alk } \\
\left(\text { as } \mathrm{CaCO}_{3}\right)\end{array}$ & $<1 /<1$ & $<1 /<1$ & $<1 /<1$ & $<1 /<1$ & $<1 /<1$ & $<1 /<1$ & & $<1$ & $<1$ & $<1$ & - $^{(\mathrm{a})}$ & 12 \\
\hline Iron & $\begin{array}{l}<0.1 / \\
<0.1\end{array}$ & $\begin{array}{c}<0.11 / \\
<0.1\end{array}$ & $\begin{array}{l}<0.1 / \\
<0.1\end{array}$ & $\begin{array}{l}<0.1 / \\
<0.1\end{array}$ & $\begin{array}{l}<0.1 / \\
<0.1\end{array}$ & $\begin{array}{r}<0.1 / \\
2.2\end{array}$ & & $<0.1$ & 2.2 & $<0.1$ & - $^{(\mathrm{a})}$ & 12 \\
\hline Magnesium & $3.7 / 3.9$ & $2.9 / 2.7$ & $2.7 / 3$ & $3.2 / 3.7$ & $4.2 / 4.6$ & $4.7 / 3.7$ & & 2.7 & 4.7 & 3.7 & 1 & 12 \\
\hline Manganese & $\begin{array}{l}<0.3 / \\
<0.3\end{array}$ & $\begin{array}{l}<0.3 / \\
<0.3\end{array}$ & $\begin{array}{l}<0.3 / \\
<0.3\end{array}$ & $\begin{array}{l}<0.3 / \\
<0.3\end{array}$ & $\begin{array}{l}<0.3 / \\
<0.3\end{array}$ & $\begin{array}{l}<0.3 / \\
<0.3\end{array}$ & & $<0.3$ & $<0.3$ & $<0.3$ & - $^{(\mathrm{a})}$ & 12 \\
\hline Nickel & $\begin{array}{l}<0.1 / \\
<0.1\end{array}$ & $\begin{array}{l}<0.1 / \\
<0.1\end{array}$ & $\begin{array}{l}<0.1 / \\
<0.1\end{array}$ & $\begin{array}{l}<0.1 / \\
<0.1\end{array}$ & $\begin{array}{l}<0.1 / \\
<0.1\end{array}$ & $\begin{array}{l}<0.1 / \\
<0.1\end{array}$ & & $<0.1$ & $<0.1$ & $<0.1$ & - $^{(\mathrm{a})}$ & 12 \\
\hline Potassium & $2.5 / 2.8$ & $2.2 / 2.5$ & $2.5 / 2.7$ & $2.8 / 3.2$ & $3.4 / 3.8$ & $3.6 / 3.4$ & & 2.2 & 3.8 & 2.8 & 0.9 & 12 \\
\hline Sodium & $6.7 / 9$ & $5 / 4.3$ & $4.5 / 4.9$ & $5 / 6.9$ & $6.4 / 7.9$ & $7.4 / 4.8$ & & 4.3 & 9 & 5.7 & 2.2 & 12 \\
\hline $\begin{array}{l}\text { Specific } \\
\text { conductance } \\
(\mu \mathrm{mho} / \mathrm{cm})\end{array}$ & $110 / 110$ & $91 / 89$ & $92 / 100$ & $110 / 130$ & $120 / 150$ & $150 / 110$ & & 89 & 150 & 110 & 24.5 & 12 \\
\hline Sulfate & $<5 / 7.1$ & $3.7 / 2.8$ & $2.8 / 3.4$ & $3.1 /<1$ & $4.4 / 5.2$ & $4.3 / 10$ & & $<1$ & 10 & 4 & 2.0 & 12 \\
\hline Surfactant & $\begin{array}{l}<0.5 / \\
<0.5\end{array}$ & $\begin{array}{l}<0.5 / \\
<0.5\end{array}$ & $\begin{array}{l}<0.5 / \\
<0.5\end{array}$ & $\begin{array}{l}<0.5 / \\
<0.5\end{array}$ & $\begin{array}{l}<0.5 / \\
<0.5\end{array}$ & $\begin{array}{l}<0.5 / \\
<0.5\end{array}$ & & $<0.5$ & $<0.5$ & $<0.5$ & - $^{(a)}$ & 12 \\
\hline $\begin{array}{l}\text { Total } \\
\text { alkalinity (as } \\
\mathrm{CaCO}_{3} \text { ) }\end{array}$ & $37 / 42$ & $28 / 36$ & $41 / 46$ & $52 / 45$ & $43 / 70$ & $71 / 45$ & & 28 & 71 & 44 & 7.5 & 12 \\
\hline $\begin{array}{l}\text { Total } \\
\text { hardness } \\
\left(\text { as } \mathrm{CaCO}_{3} \text { ) }\right.\end{array}$ & $48 / 51$ & $37 / 39$ & $39 / 42$ & $47 / 53$ & $60 / 67$ & $70 / 47$ & & 37 & 70 & 47.5 & 13.5 & 12 \\
\hline
\end{tabular}


Table 14-2d. Monthly maintenance monitoring data collected at sampling location CDBE (continued).

\begin{tabular}{|c|c|c|c|c|c|c|c|c|c|c|c|c|}
\hline \multirow[b]{2}{*}{ Analyte } & \multicolumn{7}{|c|}{ Results (1995) } & \multirow[b]{2}{*}{ Min } & \multirow[b]{2}{*}{ Max } & \multirow[b]{2}{*}{ Med } & \multirow[b]{2}{*}{$\begin{array}{c}\text { Interquartile } \\
\text { Range }\end{array}$} & \multirow[b]{2}{*}{$\begin{array}{c}\text { No. of } \\
\text { Samples }\end{array}$} \\
\hline & $\begin{array}{l}\text { 19-Jan/ } \\
14-F e b\end{array}$ & $\begin{array}{l}\text { 14-Mar/ } \\
\text { 20-Apr }\end{array}$ & $\begin{array}{l}\text { 9-May/ } \\
\text { 6-Jun }\end{array}$ & $\begin{array}{l}\text { 11-Jul/ } \\
11-\text { Aug }\end{array}$ & $\begin{array}{c}25-S e p / \\
17-O c t\end{array}$ & $\begin{array}{l}\text { 7-Nov/ } \\
\text { 19-Dec }\end{array}$ & 28-Dec & & & & & \\
\hline $\begin{array}{l}\text { Total } \\
\text { dissolved } \\
\text { solids (TDS) }\end{array}$ & $77 / 78$ & $37 / 81$ & $120 / 130$ & $130 / 130$ & $120 / 130$ & $120 / 100$ & & 37 & 130 & 120 & 49.8 & 12 \\
\hline Zinc & $\begin{array}{l}<0.5 / \\
<0.5\end{array}$ & $\begin{array}{l}<0.5 / \\
<0.5\end{array}$ & $\begin{array}{l}<0.5 / \\
<0.5\end{array}$ & $\begin{array}{l}<0.5 / \\
<0.5\end{array}$ & $\begin{array}{l}<0.5 / \\
<0.5\end{array}$ & $\begin{array}{l}<0.5 / \\
<0.5\end{array}$ & & $<0.5$ & $<0.5$ & $<0.5$ & - $^{\text {(a) }}$ & 12 \\
\hline $\begin{array}{c}\mathrm{pH} \text { (units) } \\
\text { INORG (mg/L) }\end{array}$ & $7.1 / 6.7$ & $6.8 / 7$ & $6.9 / 7.2$ & $7.4 / 7.5$ & $7.6 / 7.5$ & $7.6 / 6.7$ & & 6.7 & 7.6 & 7.15 & 0.63 & 12 \\
\hline $\begin{array}{l}\text { Total } \\
\text { suspended } \\
\text { solids (TSS) } \\
\text { NPDES } \\
\text { METAL (mg/L) }\end{array}$ & $22 / 21$ & $31 / 31$ & $11 / 15$ & $9 / 12$ & $18 / 24$ & $6 / 28$ & & 6 & 31 & 19.5 & 13.25 & 12 \\
\hline Aluminum & & & & & $/ 4.2$ & & & 4.2 & 4.2 & 4.2 & -(a) $^{(\mathrm{a})}$ & 1 \\
\hline Antimony & & $1<0.06$ & & $\begin{array}{l}<0.06 / \\
<0.06\end{array}$ & $\begin{array}{l}<0.06 / \\
<0.06\end{array}$ & $\begin{array}{l}<0.06 / \\
<0.005\end{array}$ & & $<0.005$ & $<0.06$ & $<0.06$ & 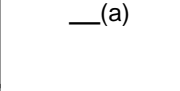 & 7 \\
\hline Arsenic & & $/ 0.0045$ & & $\begin{array}{l}0.0031 / \\
0.0063\end{array}$ & $\begin{array}{l}0.0036 / \\
0.0048\end{array}$ & $\begin{array}{l}<0.002 / \\
<0.005\end{array}$ & & $<0.002$ & 0.0063 & 0.0045 & 0.0016 & 7 \\
\hline Barium & & $/ 0.12$ & & $\begin{array}{l}0.086 / \\
0.096\end{array}$ & & $\begin{array}{c}0.089 / \\
0.08\end{array}$ & & 0.08 & $<0.12$ & 0.089 & 0.01 & 5 \\
\hline Beryllium & & $\mid<0.0005$ & & $\begin{array}{l}<0.0005 / \\
<0.0005\end{array}$ & $\begin{array}{l}<0.0005 / \\
<0.0005\end{array}$ & $\begin{array}{l}<0.0005 / \\
<0.0005\end{array}$ & & $<.0005$ & $<.0005$ & $<0.0005$ & -(a) $^{(\mathrm{a})}$ & 7 \\
\hline Boron & & $\mid<0.1$ & & $\begin{array}{l}<0.1 / \\
<0.12\end{array}$ & $\begin{array}{l}<0.1 / \\
<0.1\end{array}$ & $\begin{array}{l}<0.1 / \\
<0.1\end{array}$ & & $<0.1$ & $<0.12$ & $<0.1$ & -(a) & 7 \\
\hline Cadmium & & $\mid<0.005$ & & $\begin{array}{l}<0.0005 / \\
<0.0005\end{array}$ & $\begin{array}{l}<0.0005 / \\
<0.0005\end{array}$ & $\begin{array}{c}<0.0005 / \\
<0.001\end{array}$ & & $<.0005$ & $<.001$ & $<.0005$ & -(a) $^{(a)}$ & 7 \\
\hline Chromium & & $/ 0.019$ & & $\begin{array}{l}0.02 / \\
0.011\end{array}$ & $\begin{array}{l}0.011 / \\
<0.01\end{array}$ & $\begin{array}{l}<0.01 / \\
0.014\end{array}$ & & $<0.01$ & 0.02 & 0.011 & 0.006 & 7 \\
\hline Chromium(VI) & & $\mid<0.01$ & & & $<0.01 /$ & & & $<0.01$ & $<0.01$ & $<0.01$ & -(a) $^{(a)}$ & 2 \\
\hline Copper & & $/ 0.011$ & & $\begin{array}{l}0.006 / \\
0.0088\end{array}$ & $\begin{array}{l}0.012 / \\
<0.01\end{array}$ & $\begin{array}{c}<0.001 / \\
0.01\end{array}$ & & $<0.001$ & 0.012 & 0.01 & 0.0031 & 7 \\
\hline Iron & & $/ 6.8$ & & $4.6 / 4.4$ & $4.1 / 3$ & $2.4 / 3.2$ & & 2.4 & 6.8 & 4.1 & 1.4 & 7 \\
\hline Lead & & $/ 0.0048$ & & $\begin{array}{l}0.006 / \\
0.0044\end{array}$ & $\begin{array}{l}0.0035 / \\
<0.002\end{array}$ & $\begin{array}{l}<0.002 / \\
<0.005\end{array}$ & & $<0.002$ & 0.006 & 0.0044 & 0.0022 & 7 \\
\hline Manganese & & $/ 0.096$ & & $\begin{array}{l}0.055 / \\
0.061\end{array}$ & $\begin{array}{l}0.53 / \\
0.036\end{array}$ & $\begin{array}{l}<0.03 / \\
0.05\end{array}$ & & $<0.03$ & 0.096 & 0.053 & 0.015 & 7 \\
\hline Mercury & & $/<0.0002$ & & $\begin{array}{l}<0.0002 / \\
<0.0002\end{array}$ & $\begin{array}{l}<0.0002 / \\
<0.0002\end{array}$ & $\begin{array}{l}<0.0002 / \\
<0.0002\end{array}$ & & $\begin{array}{c}<0.000 \\
2\end{array}$ & $<0.0002$ & $<0.0002$ & —(a) & 7 \\
\hline
\end{tabular}


Table 14-2d. Monthly maintenance monitoring data collected at sampling location CDBE (concluded).

\begin{tabular}{|c|c|c|c|c|c|c|c|c|c|c|c|c|}
\hline \multirow[b]{2}{*}{ Analyte } & \multicolumn{7}{|c|}{ Results (1995) } & \multirow[b]{2}{*}{ Min } & \multirow[b]{2}{*}{ Max } & \multirow[b]{2}{*}{ Med } & \multirow[b]{2}{*}{$\begin{array}{c}\text { Inter-quartile } \\
\text { Range }\end{array}$} & \multirow[b]{2}{*}{$\begin{array}{c}\text { No. of } \\
\text { Samples }\end{array}$} \\
\hline & $\begin{array}{l}\text { 19-Jan/ } \\
14-F e b\end{array}$ & $\begin{array}{l}\text { 14-Mar/ } \\
\text { 20-Apr }\end{array}$ & $\begin{array}{l}\text { 9-May/ } \\
\text { 6-Jun }\end{array}$ & $\begin{array}{l}\text { 11-Jul/ } \\
\text { 11-Aug }\end{array}$ & $\begin{array}{c}25-S e p / \\
17-O c t\end{array}$ & $\begin{array}{l}\text { 7-Nov/ } \\
\text { 19-Dec }\end{array}$ & 28-Dec & & & & & \\
\hline Nickel & & $/ 0.017$ & & $\begin{array}{c}0.0071 / \\
0.013\end{array}$ & $\begin{array}{l}0.011 / \\
0.012\end{array}$ & $\begin{array}{c}0.0052 / \\
0.017\end{array}$ & & 0.0052 & 0.017 & 0.012 & 0.00595 & 7 \\
\hline Selenium & & $\mid<0.002$ & & & & $\begin{array}{l}<0.002 / \\
<0.005\end{array}$ & & $<0.002$ & $<0.005$ & $<0.002$ & -(a) $^{(2)}$ & 7 \\
\hline Silver & & $\mid<0.0005$ & & $\begin{array}{l}<0.0005 / \\
<0.0005\end{array}$ & $\begin{array}{l}<0.0005 / \\
<0.0005\end{array}$ & $\begin{array}{c}<0.0005 / \\
<0.005\end{array}$ & & $<0.0005$ & $<0.005$ & $<0.0005$ & -(a) $^{(a)}$ & 7 \\
\hline Thallium & & $\mid<0.005$ & & $\begin{array}{l}<0.001 / \\
<0.001\end{array}$ & $\begin{array}{l}<0.001 / \\
<0.001\end{array}$ & $\begin{array}{l}<0.001 / \\
<0.005\end{array}$ & & $<0.001$ & $<0.005$ & $<0.001$ & 0.002 & 7 \\
\hline Zinc & & $/ 0.058$ & & $\begin{array}{l}0.41 / \\
0.051\end{array}$ & $\begin{array}{l}0.058 / \\
0.021\end{array}$ & $\begin{array}{l}0.02 / \\
0.07\end{array}$ & & $<0.02$ & 0.41 & 0.058 & 0.028 & 7 \\
\hline \multicolumn{13}{|l|}{$\begin{array}{l}\text { NUTRIENTS } \\
\text { (mg/L) }\end{array}$} \\
\hline $\begin{array}{l}\text { Ammonia } \\
\text { Nitrogen } \\
\text { (as N) }\end{array}$ & $\begin{array}{l}<0.1 / \\
<0.1\end{array}$ & $\begin{array}{l}<0.1 / \\
<0.1\end{array}$ & $\begin{array}{l}<0.12 \\
<0.12\end{array}$ & $\begin{array}{l}0.32 / \\
0.21\end{array}$ & $\begin{array}{l}0.3 / \\
<0.1\end{array}$ & $<0.1 /$ & 0.12 & $<0.1$ & 0.32 & 0.11 & 0.04 & 12 \\
\hline $\begin{array}{l}\text { Nitrate } \\
\text { (as N) }\end{array}$ & $\begin{array}{l}<0.5 / \\
0.74\end{array}$ & & $\mid<0.5$ & & & & & $<0.5$ & 0.74 & 0.5 & 0.12 & 3 \\
\hline $\begin{array}{l}\text { Nitrate } \\
\left(\text { as } \mathrm{NO}_{3}\right)\end{array}$ & $\begin{array}{l}<2.215 / \\
3.2782\end{array}$ & $1.8 / 1.9$ & $1.9 /$ & $1.5 /<0.5$ & $\begin{array}{l}<0.5 / \\
<0.5\end{array}$ & $<0.5 /$ & 3.4 & $<0.5$ & 3.4 & 1.8 & 1.6 & 11 \\
\hline Nitrite (as N) & $\begin{array}{l}<0.5 / \\
<0.5\end{array}$ & & $\mid<0.5$ & $<0.5 /$ & & & & $<0.5$ & $<0.5$ & $<0.5$ & -(a) $^{(\mathrm{a}}$ & 4 \\
\hline $\begin{array}{l}\text { Nitrite } \\
\text { (as } \mathrm{NO}_{2} \text { ) }\end{array}$ & & $\begin{array}{l}<0.5 / \\
<0.5\end{array}$ & $<0.5 /$ & $\mid<0.5$ & $\begin{array}{l}<0.5 / \\
<0.5\end{array}$ & $<0.5 /$ & $<0.5$ & $<0.5$ & $<0.5$ & $<0.5$ & -(a) $^{(\mathrm{a}}$ & 8 \\
\hline $\begin{array}{l}\text { Ortho- } \\
\text { phosphate }\end{array}$ & $\begin{array}{l}<0.5 / \\
0.051\end{array}$ & $\begin{array}{c}0.067 / \\
0.17\end{array}$ & $\begin{array}{l}0.15 / \\
0.13\end{array}$ & $\begin{array}{l}0.12 / \\
0.11\end{array}$ & $\begin{array}{l}0.07 / \\
0.069\end{array}$ & $\begin{array}{l}0.1 / \\
0.15\end{array}$ & & $<0.05$ & 0.17 & 0.105 & 0.067 & 12 \\
\hline $\begin{array}{l}\text { Total kjeldahl } \\
\text { nitrogen }\end{array}$ & $\begin{array}{l}0.46 / \\
<0.2\end{array}$ & $\begin{array}{l}<0.2 / \\
0.54\end{array}$ & $\begin{array}{l}0.52 / \\
<0.5\end{array}$ & $\begin{array}{l}0.47 / \\
0.27\end{array}$ & $\begin{array}{l}<0.5 / \\
<0.5\end{array}$ & $\begin{array}{l}0.85 / \\
0.71\end{array}$ & 0.54 & $<0.2$ & 0.85 & 0.5 & 0.08 & 13 \\
\hline $\begin{array}{l}\text { Total } \\
\text { phosphorus } \\
\text { (as P) } \\
\text { OG (mg/L) }\end{array}$ & $\begin{array}{l}0.076 / \\
0.096\end{array}$ & $\begin{array}{l}0.12 / \\
0.22\end{array}$ & $\begin{array}{l}0.23 / \\
0.22\end{array}$ & $\begin{array}{l}0.17 / \\
0.21\end{array}$ & $\begin{array}{c}0.18 / \\
0.1\end{array}$ & $\begin{array}{l}0.1 / \\
0.17\end{array}$ & & 0.076 & 0.23 & 0.17 & 0.11 & 12 \\
\hline $\begin{array}{l}\text { Oil and } \\
\text { grease } \\
\text { ORGANICS } \\
(\mu \mathrm{g} / \mathrm{L})\end{array}$ & $<5 /$ & $\mid<5$ & & & $<5 /$ & $<5 /$ & & $<5$ & $<5$ & $<5$ & -(a) $^{(a)}$ & 4 \\
\hline Chlorophyll a & $\begin{array}{l}3.1 / \\
4.3\end{array}$ & $\begin{array}{c}3.1 / \\
3\end{array}$ & $\begin{array}{l}4.9 / \\
2.6\end{array}$ & $\begin{array}{l}3.6 / \\
5.2\end{array}$ & $\begin{array}{l}2.7 / \\
4.1\end{array}$ & $\begin{array}{l}2 / \\
1.5\end{array}$ & & 1.5 & 5.2 & 3.1 & 1.475 & 12 \\
\hline
\end{tabular}

a Insufficient data to calculate interquartile range. 
14. Compliance Self-Monitoring

Table 14-3. Field data collected from Drainage Retention Basin locations. (a)

\begin{tabular}{|c|c|c|c|c|c|c|c|c|c|}
\hline Date & Analysis & CDBA & CDBC & CDBD & CDBE & CDBF & CDBJ & CDBK & CDBL \\
\hline 01/06/95 & $\begin{array}{l}\text { Dissolved oxygen }(\mathrm{mg} / \mathrm{L}) \\
\text { Temperature }\left({ }^{\circ} \mathrm{C}\right) \\
\text { Turbidity }(\mathrm{m})\end{array}$ & $\begin{array}{l}8.6 \\
8.5\end{array}$ & $\begin{array}{l}8.5 \\
8.3\end{array}$ & $\begin{array}{l}8.6 \\
8.3\end{array}$ & $\begin{array}{l}8.6 \\
8.3 \\
0.25\end{array}$ & $\begin{array}{l}8.4 \\
8.3\end{array}$ & $\begin{array}{l}8.5 \\
8.7\end{array}$ & $\begin{array}{l}8.3 \\
8.9\end{array}$ & $\begin{array}{l}8.3 \\
8.9\end{array}$ \\
\hline 01/13/95 & $\begin{array}{l}\text { Dissolved oxygen }(\mathrm{mg} / \mathrm{L}) \\
\text { Temperature }\left({ }^{\circ} \mathrm{C}\right) \\
\text { Turbidity }(\mathrm{m})\end{array}$ & $\begin{array}{c}7 \\
12.9\end{array}$ & $\begin{array}{c}7 \\
11.4\end{array}$ & $\begin{array}{c}7 \\
11.5\end{array}$ & $\begin{array}{c}7 \\
11.5 \\
0.30\end{array}$ & $\begin{array}{r}6.4 \\
10.7\end{array}$ & $\begin{array}{r}7.7 \\
12.3\end{array}$ & $\begin{array}{r}7.5 \\
11.7\end{array}$ & $\begin{array}{r}6.6 \\
11.3\end{array}$ \\
\hline 01/19/95 & $\begin{array}{l}\text { Dissolved oxygen }(\mathrm{mg} / \mathrm{L}) \\
\text { Temperature }\left({ }^{\circ} \mathrm{C}\right) \\
\text { Turbidity }(\mathrm{m})\end{array}$ & $\begin{array}{c}7.8 \\
10\end{array}$ & $\begin{array}{l}7.4 \\
9.7\end{array}$ & $\begin{array}{l}7.7 \\
9.7\end{array}$ & $\begin{array}{l}7.6 \\
9.7 \\
0.20\end{array}$ & $\begin{array}{l}7.6 \\
9.7\end{array}$ & $\begin{array}{l}7.5 \\
9.8\end{array}$ & $\begin{array}{l}7.4 \\
9.9\end{array}$ & $\begin{array}{l}7.4 \\
9.9\end{array}$ \\
\hline 01/24/95 & $\begin{array}{l}\text { Dissolved oxygen }(\mathrm{mg} / \mathrm{L}) \\
\text { Temperature }\left({ }^{\circ} \mathrm{C}\right) \\
\text { Turbidity }(\mathrm{m})\end{array}$ & $\begin{array}{r}7.7 \\
10.7\end{array}$ & $\begin{array}{r}8.3 \\
11.1\end{array}$ & $\begin{array}{c}8.5 \\
11\end{array}$ & $\begin{array}{c}8 \\
10.6 \\
0.20\end{array}$ & $\begin{array}{l}7.1 \\
9.9\end{array}$ & $\begin{array}{c}8 \\
10.3\end{array}$ & $\begin{array}{r}7.5 \\
10.4\end{array}$ & $\begin{array}{r}7.5 \\
10.4\end{array}$ \\
\hline 02/02/95 & $\begin{array}{l}\text { Dissolved oxygen }(\mathrm{mg} / \mathrm{L}) \\
\text { Temperature }\left({ }^{\circ} \mathrm{C}\right) \\
\text { Turbidity }(\mathrm{m})\end{array}$ & $\begin{array}{r}6.8 \\
11.5\end{array}$ & $\begin{array}{r}8.9 \\
14.8\end{array}$ & $\begin{array}{r}9.2 \\
14.9\end{array}$ & $\begin{array}{l}6.5 \\
11 \\
0.20\end{array}$ & $\begin{array}{l}5.7 \\
10.7\end{array}$ & $\begin{array}{r}8.1 \\
13.6\end{array}$ & $\begin{array}{r}6.6 \\
11.4\end{array}$ & $\begin{array}{r}5.5 \\
10.7\end{array}$ \\
\hline 02/10/95 & $\begin{array}{l}\text { Dissolved oxygen }(\mathrm{mg} / \mathrm{L}) \\
\text { Temperature }\left({ }^{\circ} \mathrm{C}\right)\end{array}$ & $\begin{array}{r}9.3 \\
12.5 \\
\end{array}$ & $\begin{array}{l}10.2 \\
15.4\end{array}$ & $\begin{array}{r}9.4 \\
14.9 \\
\end{array}$ & $\begin{array}{r}7.9 \\
11.7 \\
\end{array}$ & $\begin{array}{r}5.6 \\
11.4 \\
\end{array}$ & $\begin{array}{r}8.8 \\
12.8 \\
\end{array}$ & $\begin{array}{r}8.3 \\
11.7 \\
\end{array}$ & $\begin{array}{r}5.5 \\
11.4 \\
\end{array}$ \\
\hline 02/14/95 & $\begin{array}{l}\text { Dissolved oxygen }(\mathrm{mg} / \mathrm{L}) \\
\text { Temperature }\left({ }^{\circ} \mathrm{C}\right)\end{array}$ & $\begin{array}{r}8.3 \\
11.5 \\
\end{array}$ & $\begin{array}{r}9.2 \\
12.4 \\
\end{array}$ & $\begin{array}{r}8.3 \\
11.9 \\
\end{array}$ & $\begin{array}{r}8.3 \\
11.9 \\
\end{array}$ & $\begin{array}{r}8.3 \\
11.9 \\
\end{array}$ & $\begin{array}{r}8.2 \\
12.6 \\
\end{array}$ & $\begin{array}{r}8.2 \\
11.8 \\
\end{array}$ & $\begin{array}{r}7.3 \\
11.9 \\
\end{array}$ \\
\hline 02/24/95 & $\begin{array}{l}\text { Dissolved oxygen }(\mathrm{mg} / \mathrm{L}) \\
\text { Temperature }\left({ }^{\circ} \mathrm{C}\right) \\
\text { Turbidity }(\mathrm{m})\end{array}$ & $\begin{array}{r}7.1 \\
13.6\end{array}$ & $\begin{array}{r}8.2 \\
13.8\end{array}$ & $\begin{array}{r}8.7 \\
13.7\end{array}$ & $\begin{array}{c}7.5 \\
13.7 \\
0.20\end{array}$ & $\begin{array}{r}7.9 \\
13.7\end{array}$ & $\begin{array}{r}8.6 \\
13.9\end{array}$ & $\begin{array}{r}7.9 \\
14.1\end{array}$ & $\begin{array}{r}7.8 \\
14.2\end{array}$ \\
\hline 03/03/95 & $\begin{array}{l}\text { Dissolved oxygen }(\mathrm{mg} / \mathrm{L}) \\
\text { Temperature }\left({ }^{\circ} \mathrm{C}\right) \\
\text { Turbidity }(\mathrm{m})\end{array}$ & $\begin{array}{r}7.1 \\
14.3\end{array}$ & $\begin{array}{r}8 \\
14\end{array}$ & $\begin{array}{r}7.9 \\
13.7\end{array}$ & $\begin{array}{c}7.6 \\
13.5 \\
0.30\end{array}$ & $\begin{array}{r}7.5 \\
13.4\end{array}$ & $\begin{array}{r}7.7 \\
13.9\end{array}$ & $\begin{array}{r}7.4 \\
13.8\end{array}$ & $\begin{array}{r}7.3 \\
13.5\end{array}$ \\
\hline 04/04/95 & $\begin{array}{l}\text { Dissolved oxygen }(\mathrm{mg} / \mathrm{L}) \\
\text { Temperature }\left({ }^{\circ} \mathrm{C}\right) \\
\text { Turbidity }(\mathrm{m})\end{array}$ & $\begin{array}{l}\text {-(a) }^{(\mathrm{a}} \\
\text {-(a) }^{-}\end{array}$ & $\begin{array}{l}-^{(\mathrm{a})} \\
-_{(\mathrm{a})}\end{array}$ & $\begin{array}{l}\text {-(a) }^{(\mathrm{a})} \\
\text { - }^{(\mathrm{a})}\end{array}$ & $\begin{array}{l}-^{(a)} \\
-^{(a)} \\
0.10\end{array}$ & $\begin{array}{l}\text {-(a) }^{(\mathrm{a}} \\
\text {-(a) }^{-}\end{array}$ & $\begin{array}{l}\text {-(a) }^{(\mathrm{a}} \\
\text {-(a) }^{-}\end{array}$ & $\begin{array}{l}\text {-(a) } \\
\text {-(a) }^{(\mathrm{a})}\end{array}$ & $\begin{array}{l}\text {-(a) }^{(\mathrm{a})} \\
\text { - }^{\mathrm{a})}\end{array}$ \\
\hline 04/14/95 & $\begin{array}{l}\text { Dissolved oxygen }(\mathrm{mg} / \mathrm{L}) \\
\text { Temperature }\left({ }^{\circ} \mathrm{C}\right) \\
\text { Turbidity }(\mathrm{m})\end{array}$ & $\begin{array}{l}-^{(a)} \\
-^{(a)}\end{array}$ & $\begin{array}{l}-^{(\mathrm{a})} \\
\text {-(a) }^{(\mathrm{a})}\end{array}$ & $\begin{array}{l}\text {-(a) }^{(\mathrm{a}} \\
\text {-(a) }^{(\mathrm{a})}\end{array}$ & $\begin{array}{l}-^{(a)} \\
-^{(a)} \\
0.15\end{array}$ & $\begin{array}{l}\text {-(a) }^{(\mathrm{a}} \\
\text {-(a) }^{-}\end{array}$ & $\begin{array}{l}\text {-(a) }^{(\mathrm{a})} \\
\text {-(a) }^{-}\end{array}$ & $\begin{array}{l}\text {-(a) } \\
\text {-(a) }^{(\mathrm{a})}\end{array}$ & $\begin{array}{l}\text {-(a) }^{(\text {a) }} \\
\text { (a) }^{\text {(a) }}\end{array}$ \\
\hline 04/20/95 & $\begin{array}{l}\text { Dissolved oxygen }(\mathrm{mg} / \mathrm{L}) \\
\text { Temperature }\left({ }^{\circ} \mathrm{C}\right) \\
\text { Turbidity }(\mathrm{m})\end{array}$ & $\begin{array}{l}\text {-(a) }^{(\mathrm{a}} \\
\text { - (a) }^{-}\end{array}$ & $\begin{array}{l}\text {-(a) }^{(\mathrm{a}} \\
\text { - }^{(\mathrm{a})}\end{array}$ & $\begin{array}{l}\text {-(a) }^{(\mathrm{a}} \\
\text {-(a) }^{(2}\end{array}$ & $\begin{array}{l}\text {-(a) }^{(\mathrm{a})} \\
0.13\end{array}$ & $\begin{array}{l}\text {-a) }^{(\mathrm{a}} \\
\text { - }^{(\mathrm{a})}\end{array}$ & $\begin{array}{l}\text {-(a) }^{(\mathrm{a}} \\
\text { (a) }^{(2}\end{array}$ & $\begin{array}{l}\text {-(a) }^{(\mathrm{a}} \\
\text {-(a) }^{(2}\end{array}$ & $\begin{array}{l}\text {-(a) }^{(\mathrm{a}} \\
\text { - }^{(\mathrm{a})}\end{array}$ \\
\hline 05/09/95 & $\begin{array}{l}\text { Dissolved oxygen }(\mathrm{mg} / \mathrm{L}) \\
\text { Temperature }\left({ }^{\circ} \mathrm{C}\right) \\
\text { Turbidity }(\mathrm{m})\end{array}$ & $\begin{array}{l}\text {-(a) }^{(2)} \\
\text { - }^{(a)}\end{array}$ & $\begin{array}{l}\text {-(a) }^{(\mathrm{a})} \\
\text { (a) }^{\text {(a) }}\end{array}$ & $\begin{array}{l}\text { - (a) }^{(\mathrm{a})} \\
\text { (a) }^{(1)}\end{array}$ & $\begin{array}{l}\text {-(a) }^{(a)} \\
\text { (a) }^{(20}\end{array}$ & $\begin{array}{l}\text {-(a) }^{(\mathrm{a}} \\
\text { (a) }^{\text {(a) }}\end{array}$ & $\begin{array}{l}\text {-(a) }^{(\mathrm{a}} \\
\text { - }^{(\mathrm{a})}\end{array}$ & $\begin{array}{l}\text {-(a) }^{(\mathrm{a}} \\
\text { - }^{(\mathrm{a})}\end{array}$ & $\begin{array}{l}\text {-(a) }^{(\mathrm{a})} \\
\text { - }^{(\mathrm{a})}\end{array}$ \\
\hline
\end{tabular}

... continued on next page 
Table 14-3. Field data collected from Drainage Retention Basin locations (continued).(a)

\begin{tabular}{|c|c|c|c|c|c|c|c|c|c|}
\hline Date & Analysis & CDBA & CDBC & CDBD & CDBE & CDBF & CDBJ & CDBK & CDBL \\
\hline $05 / 16 / 95$ & $\begin{array}{l}\text { Dissolved oxygen }(\mathrm{mg} / \mathrm{L}) \\
\text { Temperature }\left({ }^{\circ} \mathrm{C}\right) \\
\text { Turbidity }(\mathrm{m})\end{array}$ & $\begin{array}{l}\text {-(a) }^{\left({ }^{(a)}\right.}\end{array}$ & $\begin{array}{l}\text {-(a) }^{(\mathrm{a}} \\
\text {-(a) }^{-}\end{array}$ & $\begin{array}{l}\text {-(a) }^{(\mathrm{a})} \\
\text { (a) }^{-}\end{array}$ & $\begin{array}{l}-^{(a)} \\
\text { (a) }^{(\mathrm{a})} \\
0.22\end{array}$ & $\begin{array}{l}\text {-(a) }^{\left({ }^{(a)}\right.}\end{array}$ & $\begin{array}{l}\text {-(a) }^{(\mathrm{a})} \\
\text { (a) }^{-1}\end{array}$ & $\begin{array}{l}\text {-(a) }^{(\mathrm{a})} \\
\text { (a) }^{(2}\end{array}$ & $\begin{array}{l}\text {-(a) }^{(\text {a) }} \\
\text { (a) }^{\text {(a) }}\end{array}$ \\
\hline 05/23/95 & $\begin{array}{l}\text { Dissolved oxygen }(\mathrm{mg} / \mathrm{L}) \\
\text { Temperature }\left({ }^{\circ} \mathrm{C}\right) \\
\text { Turbidity }(\mathrm{m})\end{array}$ & $\begin{array}{l}\text { - (a) }^{(\mathrm{a})} \\
\text { (a) }^{-1}\end{array}$ & $\begin{array}{l}\text {-(a) }^{(\mathrm{a}} \\
\text { - }^{(\mathrm{a})}\end{array}$ & $\begin{array}{l}\text {-(a) }^{(\mathrm{a})} \\
\text { (a) }^{(1)}\end{array}$ & $\begin{array}{l}-^{(a)} \\
-^{(a)} \\
0.23\end{array}$ & $\begin{array}{l}\text {-(a) }^{(\mathrm{a})} \\
\text { (a) }^{(2)}\end{array}$ & $\begin{array}{l}\text {-(a) }^{\left({ }^{\prime}\right)} \\
\text { (a) }^{-1}\end{array}$ & $\begin{array}{l}\text {-(a) }^{(\mathrm{a})} \\
\text { (a) }^{(1)}\end{array}$ & $\begin{array}{l}\text {-(a) }^{(\mathrm{a})} \\
\text { (a) }^{(2)}\end{array}$ \\
\hline 06/02/95 & $\begin{array}{l}\text { Dissolved oxygen }(\mathrm{mg} / \mathrm{L}) \\
\text { Temperature }\left({ }^{\circ} \mathrm{C}\right) \\
\text { Turbidity }(\mathrm{m})\end{array}$ & $\begin{array}{l}\text { - (a) }^{(\mathrm{a})} \\
\text { (a) }^{(2)}\end{array}$ & $\begin{array}{l}\text { - (a) }^{(\mathrm{a})} \\
\text { (a) }^{-}\end{array}$ & $\begin{array}{l}\text {-(a) }^{(\mathrm{a}} \\
\text { - }^{(\mathrm{a})}\end{array}$ & $\begin{array}{l}-^{(a)} \\
-^{(a)} \\
0.23\end{array}$ & $\begin{array}{l}\text { - (a) }^{(a)} \\
\text { - }^{(a)}\end{array}$ & $\begin{array}{l}\text {-(a) }^{(\mathrm{a})} \\
\text { (a) }^{\text {(a) }}\end{array}$ & $\begin{array}{l}\text {-(a) }^{(\mathrm{a})} \\
\text { (a) }^{(1)}\end{array}$ & $\begin{array}{l}\text {-(a) }^{(\mathrm{a}} \\
\text { (a) }^{-}\end{array}$ \\
\hline 06/06/95 & $\begin{array}{l}\text { Dissolved oxygen }(\mathrm{mg} / \mathrm{L}) \\
\text { Temperature }\left({ }^{\circ} \mathrm{C}\right) \\
\text { Turbidity }(\mathrm{m})\end{array}$ & $\begin{array}{l}\text { - (a) }^{(\mathrm{a})} \\
\text { (a) }^{\text {(a) }}\end{array}$ & $\begin{array}{l}\text { - }^{(\mathrm{a})} \\
\text { - }^{(\mathrm{a})}\end{array}$ & $\begin{array}{l}\text {-(a) }^{(a)} \\
\text { (a) }^{(2)}\end{array}$ & $\begin{array}{l}\text { (a) }^{(\mathrm{a})} \\
0.23\end{array}$ & $\begin{array}{l}\text {-(a) }^{(\mathrm{a}} \\
\text { (a) }^{\text {(a) }}\end{array}$ & $\begin{array}{l}\text {-(a) }^{(\mathrm{a})} \\
\text { (a) }^{-}\end{array}$ & $\begin{array}{l}\text {-(a) }^{(\mathrm{a}} \\
\text { (a) }^{(2}\end{array}$ & $\begin{array}{l}\text { - (a) }^{(\mathrm{a})} \\
\text { (a) }^{(2)}\end{array}$ \\
\hline 06/13/95 & $\begin{array}{l}\text { Dissolved oxygen }(\mathrm{mg} / \mathrm{L}) \\
\text { Temperature }\left({ }^{\circ} \mathrm{C}\right) \\
\text { Turbidity }(\mathrm{m})\end{array}$ & $\begin{array}{l}\text {-(a) }^{(\mathrm{a}} \\
\text { (a) }^{(1)}\end{array}$ & $\begin{array}{l}\text { - (a) }^{(\mathrm{a})} \\
\text { (a) }^{(2)}\end{array}$ & $\begin{array}{l}\text {-(a) }^{(\mathrm{a})} \\
\text { (a) }^{-}\end{array}$ & $\begin{array}{l}-^{(\mathrm{a})} \\
\text {-(a) }^{(\mathrm{a})} \\
0.20\end{array}$ & 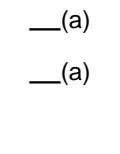 & $\begin{array}{l}-^{(\mathrm{a})} \\
\text { - (a) }^{\text {(a) }}\end{array}$ & $\begin{array}{l}\text {-(a) }^{(\mathrm{a}} \\
\text { - }^{(\mathrm{a})}\end{array}$ & $\begin{array}{l}\text {-(a) }^{(\mathrm{a})} \\
\text { (a) }^{(2)}\end{array}$ \\
\hline 06/20/95 & $\begin{array}{l}\text { Dissolved oxygen }(\mathrm{mg} / \mathrm{L}) \\
\text { Temperature }\left({ }^{\circ} \mathrm{C}\right) \\
\text { Turbidity }(\mathrm{m})\end{array}$ & $\begin{array}{l}\text { - }^{(\mathrm{a})} \\
\text { - }^{(\mathrm{a})}\end{array}$ & $\begin{array}{l}\text { - (a) }^{(\mathrm{a})} \\
\text { (a) }^{(2)}\end{array}$ & $\begin{array}{l}\text {-(a) }^{(\mathrm{a})} \\
\text { (a) }^{(2}\end{array}$ & $\begin{array}{l}-^{(a)} \\
-^{(a)} \\
0.25\end{array}$ & $\begin{array}{l}\text { - }^{(\mathrm{a})} \\
\text { - }^{(\mathrm{a})}\end{array}$ & $\begin{array}{l}\text { - (a) }^{(\mathrm{a})} \\
\text { (a) }^{-}\end{array}$ & $\begin{array}{l}\text {-(a) }^{(\mathrm{a})} \\
\text { (a) }^{(1)}\end{array}$ & $\begin{array}{l}\text {-a }^{(\mathrm{a})} \\
\text {-(a) }^{(\mathrm{a})}\end{array}$ \\
\hline 06/30/95 & $\begin{array}{l}\text { Dissolved oxygen }(\mathrm{mg} / \mathrm{L}) \\
\text { Temperature }\left({ }^{\circ} \mathrm{C}\right) \\
\text { Turbidity }(\mathrm{m})\end{array}$ & $\begin{array}{r}8.9 \\
28.5\end{array}$ & $\begin{array}{r}8.6 \\
26.5\end{array}$ & $\begin{array}{r}7.5 \\
24.9\end{array}$ & $\begin{array}{r}7.3 \\
24.5 \\
0.25\end{array}$ & $\begin{array}{r}7.1 \\
24.5\end{array}$ & $\begin{array}{r}7.8 \\
25.3\end{array}$ & $\begin{array}{r}7.5 \\
24.6\end{array}$ & $\begin{array}{r}7.3 \\
24.6\end{array}$ \\
\hline 07/11/95 & $\begin{array}{l}\text { Dissolved oxygen }(\mathrm{mg} / \mathrm{L}) \\
\text { Temperature }\left({ }^{\circ} \mathrm{C}\right) \\
\text { Turbidity }(\mathrm{m})\end{array}$ & $\begin{array}{r}8.1 \\
25.5\end{array}$ & $\begin{array}{r}8.2 \\
24.1\end{array}$ & $\begin{array}{r}7.1 \\
23.5\end{array}$ & $\begin{array}{c}7 \\
23.3 \\
0.33\end{array}$ & $\begin{array}{r}6.9 \\
23.3\end{array}$ & $\begin{array}{c}7 \\
24.2\end{array}$ & $\begin{array}{r}6.8 \\
23.8\end{array}$ & $\begin{array}{r}7.6 \\
23.5\end{array}$ \\
\hline 07/18/95 & $\begin{array}{l}\text { Dissolved oxygen }(\mathrm{mg} / \mathrm{L}) \\
\text { Temperature }\left({ }^{\circ} \mathrm{C}\right) \\
\text { Turbidity }(\mathrm{m})\end{array}$ & $\begin{array}{r}8.7 \\
27.5\end{array}$ & $\begin{array}{r}7.2 \\
26.5\end{array}$ & $\begin{array}{c}7 \\
25.3\end{array}$ & $\begin{array}{c}6.7 \\
24.7 \\
0.28\end{array}$ & $\begin{array}{r}6.5 \\
24.5\end{array}$ & $\begin{array}{c}7 \\
25.9\end{array}$ & $\begin{array}{r}6.8 \\
24.9\end{array}$ & $\begin{array}{r}6.7 \\
24.9\end{array}$ \\
\hline 07/28/95 & $\begin{array}{l}\text { Dissolved oxygen }(\mathrm{mg} / \mathrm{L}) \\
\text { Temperature }\left({ }^{\circ} \mathrm{C}\right) \\
\text { Turbidity }(\mathrm{m})\end{array}$ & $\begin{array}{r}9.2 \\
30.4\end{array}$ & $\begin{array}{r}9.2 \\
25.6\end{array}$ & $\begin{array}{r}9.1 \\
25.5\end{array}$ & $\begin{array}{c}9 \\
25.1 \\
0.33 \\
\end{array}$ & $\begin{array}{c}9 \\
24.8\end{array}$ & $\begin{array}{l}10.2 \\
27.5\end{array}$ & $\begin{array}{r}9.4 \\
25.1\end{array}$ & $\begin{array}{r}9.4 \\
25.0\end{array}$ \\
\hline 08/04/95 & $\begin{array}{l}\text { Dissolved oxygen }(\mathrm{mg} / \mathrm{L}) \\
\text { Temperature }\left({ }^{\circ} \mathrm{C}\right) \\
\text { Turbidity }(\mathrm{m})\end{array}$ & $\begin{array}{r}9.8 \\
29.6\end{array}$ & $\begin{array}{r}7.6 \\
27.1\end{array}$ & $\begin{array}{r}7.2 \\
26.1\end{array}$ & $\begin{array}{c}6.9 \\
25.7 \\
0.30\end{array}$ & $\begin{array}{r}6.9 \\
25.6\end{array}$ & $\begin{array}{l}7.9 \\
27\end{array}$ & $\begin{array}{r}7.1 \\
25.7\end{array}$ & $\begin{array}{c}7 \\
25.7\end{array}$ \\
\hline $08 / 11 / 95$ & $\begin{array}{l}\text { Dissolved oxygen }(\mathrm{mg} / \mathrm{L}) \\
\text { Temperature }\left({ }^{\circ} \mathrm{C}\right) \\
\text { Turbidity }(\mathrm{m})\end{array}$ & $\begin{array}{r}9.1 \\
29.6\end{array}$ & $\begin{array}{c}8 \\
26.6\end{array}$ & $\begin{array}{r}7.6 \\
24.7\end{array}$ & $\begin{array}{r}7.4 \\
23.8 \\
0.23\end{array}$ & $\begin{array}{r}7.3 \\
23.7\end{array}$ & $\begin{array}{r}8.5 \\
25.9\end{array}$ & $\begin{array}{r}7.7 \\
23.9\end{array}$ & $\begin{array}{r}7.6 \\
23.9\end{array}$ \\
\hline
\end{tabular}


14. Compliance Self-Monitoring

Table 14-3. Field data collected from Drainage Retention Basin locations (continued).(a)

\begin{tabular}{|c|c|c|c|c|c|c|c|c|c|}
\hline Date & Analysis & CDBA & CDBC & CDBD & CDBE & CDBF & CDBJ & CDBK & CDBL \\
\hline 08/17/95 & $\begin{array}{l}\text { Dissolved oxygen }(\mathrm{mg} / \mathrm{L}) \\
\text { Temperature }\left({ }^{\circ} \mathrm{C}\right) \\
\text { Turbidity }(\mathrm{m})\end{array}$ & $\begin{array}{r}8.3 \\
22.9\end{array}$ & $\begin{array}{l}8.6 \\
23\end{array}$ & $\begin{array}{c}7 \\
22.6\end{array}$ & $\begin{array}{r}6.9 \\
22.3 \\
0.28\end{array}$ & $\begin{array}{r}6.5 \\
22.2\end{array}$ & $\begin{array}{r}7.2 \\
22.7\end{array}$ & $\begin{array}{c}7 \\
22.5\end{array}$ & $\begin{array}{r}6.9 \\
22.4\end{array}$ \\
\hline 08/22/95 & $\begin{array}{l}\text { Dissolved oxygen }(\mathrm{mg} / \mathrm{L}) \\
\text { Temperature }\left({ }^{\circ} \mathrm{C}\right) \\
\text { Turbidity }(\mathrm{m})\end{array}$ & $\begin{array}{l}8.8 \\
29\end{array}$ & $\begin{array}{r}8.3 \\
25.8\end{array}$ & $\begin{array}{l}7.3 \\
26\end{array}$ & $\begin{array}{l}4.3 \\
23 \\
0.33\end{array}$ & $\begin{array}{r}2.8 \\
22.7\end{array}$ & $\begin{array}{r}7.6 \\
27.8\end{array}$ & $\begin{array}{r}4.4 \\
23.8\end{array}$ & $\begin{array}{r}4.2 \\
24.2\end{array}$ \\
\hline 09/01/95 & $\begin{array}{l}\text { Dissolved oxygen }(\mathrm{mg} / \mathrm{L}) \\
\text { Temperature }\left({ }^{\circ} \mathrm{C}\right) \\
\text { Turbidity }(\mathrm{m})\end{array}$ & $\begin{array}{r}7.3 \\
22.1\end{array}$ & $\begin{array}{r}8.4 \\
22.4\end{array}$ & $\begin{array}{c}8 \\
22.1\end{array}$ & $\begin{array}{l}7.9 \\
22\end{array}$ & $\begin{array}{l}7.9 \\
22\end{array}$ & $\begin{array}{r}7.3 \\
22.1\end{array}$ & $\begin{array}{r}7.2 \\
22.1\end{array}$ & $\begin{array}{l}7.1 \\
22\end{array}$ \\
\hline 09/08/95 & $\begin{array}{l}\text { Dissolved oxygen }(\mathrm{mg} / \mathrm{L}) \\
\text { Temperature }\left({ }^{\circ} \mathrm{C}\right)\end{array}$ & $\begin{array}{l}8.5 \\
29 \\
\end{array}$ & $\begin{array}{r}7.7 \\
24.4\end{array}$ & $\begin{array}{r}7.7 \\
23.9\end{array}$ & $\begin{array}{r}7.5 \\
23.3\end{array}$ & $\begin{array}{r}7.4 \\
23.2\end{array}$ & $\begin{array}{r}7.5 \\
24.5 \\
\end{array}$ & $\begin{array}{c}7 \\
23.3\end{array}$ & $\begin{array}{r}6.8 \\
23.2 \\
\end{array}$ \\
\hline 09/25/95 & $\begin{array}{l}\text { Dissolved oxygen }(\mathrm{mg} / \mathrm{L}) \\
\text { Temperature }\left({ }^{\circ} \mathrm{C}\right)\end{array}$ & & $\begin{array}{r}5.8 \\
22.3\end{array}$ & $\begin{array}{l}8.8 \\
22\end{array}$ & $\begin{array}{l}8.2 \\
22\end{array}$ & $\begin{array}{l}8.5 \\
22\end{array}$ & $\begin{array}{r}8.1 \\
22.3\end{array}$ & $\begin{array}{r}7.8 \\
22.2\end{array}$ & $\begin{array}{c}7 \\
22.1\end{array}$ \\
\hline $10 / 09 / 95$ & $\begin{array}{l}\text { Dissolved oxygen }(\mathrm{mg} / \mathrm{L}) \\
\text { Temperature }\left({ }^{\circ} \mathrm{C}\right) \\
\text { Turbidity }(\mathrm{m})\end{array}$ & $\begin{array}{c}7.2 \\
19\end{array}$ & $\begin{array}{c}7.5 \\
19\end{array}$ & $\begin{array}{c}7.6 \\
19\end{array}$ & $\begin{array}{l}7.4 \\
19 \\
0.33\end{array}$ & $\begin{array}{c}7.3 \\
19\end{array}$ & $\begin{array}{r}7.7 \\
19.2\end{array}$ & $\begin{array}{c}7.6 \\
19\end{array}$ & $\begin{array}{r}6.4 \\
19.1\end{array}$ \\
\hline $10 / 17 / 95$ & $\begin{array}{l}\text { Dissolved oxygen }(\mathrm{mg} / \mathrm{L}) \\
\text { Temperature }\left({ }^{\circ} \mathrm{C}\right) \\
\text { Turbidity }(\mathrm{m})\end{array}$ & $\begin{array}{l}7.8 \\
23\end{array}$ & $\begin{array}{r}7.8 \\
19.9\end{array}$ & $\begin{array}{r}7.7 \\
19.6\end{array}$ & $\begin{array}{l}7.6 \\
19 \\
0.28\end{array}$ & $\begin{array}{r}7.5 \\
18.9\end{array}$ & $\begin{array}{r}7.8 \\
19.6\end{array}$ & $\begin{array}{c}7.7 \\
19\end{array}$ & $\begin{array}{r}7.7 \\
19.1\end{array}$ \\
\hline $10 / 24 / 95$ & $\begin{array}{l}\text { Dissolved oxygen }(\mathrm{mg} / \mathrm{L}) \\
\text { Temperature }\left({ }^{\circ} \mathrm{C}\right) \\
\text { Turbidity }(\mathrm{m})\end{array}$ & $\begin{array}{r}9.5 \\
18.7\end{array}$ & $\begin{array}{r}8.6 \\
18.4\end{array}$ & $\begin{array}{r}8.3 \\
17.8\end{array}$ & $\begin{array}{c}8.2 \\
17.9 \\
0.34\end{array}$ & $\begin{array}{c}8.2 \\
18\end{array}$ & $\begin{array}{l}10 \\
19.3\end{array}$ & $\begin{array}{r}8.9 \\
18.4\end{array}$ & $\begin{array}{r}8.7 \\
18.7\end{array}$ \\
\hline 10/31/95 & $\begin{array}{l}\text { Dissolved oxygen }(\mathrm{mg} / \mathrm{L}) \\
\text { Temperature }\left({ }^{\circ} \mathrm{C}\right) \\
\text { Turbidity }(\mathrm{m})\end{array}$ & $\begin{array}{r}9 \\
19\end{array}$ & $\begin{array}{r}8.6 \\
18.1\end{array}$ & $\begin{array}{r}8.6 \\
17.6\end{array}$ & $\begin{array}{r}8.6 \\
17.5 \\
0.36 \\
\end{array}$ & $\begin{array}{r}8.6 \\
17.5\end{array}$ & $\begin{array}{r}9.4 \\
17.9\end{array}$ & $\begin{array}{c}9.3 \\
18\end{array}$ & $\begin{array}{r}9 \\
18\end{array}$ \\
\hline $11 / 07 / 95$ & $\begin{array}{l}\text { Dissolved oxygen }(\mathrm{mg} / \mathrm{L}) \\
\text { Temperature }\left({ }^{\circ} \mathrm{C}\right) \\
\text { Turbidity }(\mathrm{m})\end{array}$ & $\begin{array}{r}8.1 \\
16.4\end{array}$ & $\begin{array}{r}8.4 \\
16.9\end{array}$ & $\begin{array}{r}8.6 \\
16.1\end{array}$ & $\begin{array}{c}8.4 \\
16.1 \\
0.44\end{array}$ & $\begin{array}{r}8.1 \\
16.1\end{array}$ & $\begin{array}{r}8.9 \\
16.4\end{array}$ & $\begin{array}{r}8.6 \\
16.3\end{array}$ & $\begin{array}{r}8.7 \\
16.4\end{array}$ \\
\hline $11 / 16 / 95$ & $\begin{array}{l}\text { Dissolved oxygen }(\mathrm{mg} / \mathrm{L}) \\
\text { Temperature }\left({ }^{\circ} \mathrm{C}\right) \\
\text { Turbidity }(\mathrm{m})\end{array}$ & $\begin{array}{l}9.6 \\
20\end{array}$ & $\begin{array}{c}9.3 \\
18\end{array}$ & $\begin{array}{r}9.6 \\
16.9\end{array}$ & $\begin{array}{c}9.1 \\
16.8 \\
0.58\end{array}$ & $\begin{array}{r}9.2 \\
16.8\end{array}$ & $\begin{array}{r}9.4 \\
17.7\end{array}$ & $\begin{array}{r}9.1 \\
16.9\end{array}$ & $\begin{array}{c}8.8 \\
17\end{array}$ \\
\hline 11/21/95 & $\begin{array}{l}\text { Dissolved oxygen }(\mathrm{mg} / \mathrm{L}) \\
\text { Temperature }\left({ }^{\circ} \mathrm{C}\right)\end{array}$ & $\begin{array}{l}10.2 \\
16.6\end{array}$ & $\begin{array}{l}10.1 \\
16.6\end{array}$ & $\begin{array}{r}9.7 \\
16.3 \\
\end{array}$ & $\begin{array}{r}9.4 \\
16.3\end{array}$ & $\begin{array}{r}9.2 \\
16.3\end{array}$ & $\begin{array}{c}8 \\
16.5\end{array}$ & $\begin{array}{r}7.9 \\
16.5\end{array}$ & $\begin{array}{r}7.8 \\
16.5\end{array}$ \\
\hline $12 / 08 / 95$ & $\begin{array}{l}\text { Dissolved oxygen }(\mathrm{mg} / \mathrm{L}) \\
\text { Temperature }\left({ }^{\circ} \mathrm{C}\right) \\
\text { Turbidity }(\mathrm{m})\end{array}$ & $\begin{array}{r}8.4 \\
15.3\end{array}$ & $\begin{array}{r}9.6 \\
15.7\end{array}$ & $\begin{array}{l}9.3 \\
15\end{array}$ & $\begin{array}{r}8.6 \\
14.9 \\
0.66\end{array}$ & $\begin{array}{l}8.4 \\
15\end{array}$ & $\begin{array}{r}7.9 \\
15.4\end{array}$ & $\begin{array}{r}7.5 \\
15.3\end{array}$ & $\begin{array}{r}7.5 \\
15.1\end{array}$ \\
\hline
\end{tabular}


Table 14-3. Field data collected from Drainage Retention Basin locations(concluded). (a)

\begin{tabular}{|c|c|c|c|c|c|c|c|c|c|}
\hline Date & Analysis & CDBA & CDBC & CDBD & CDBE & CDBF & CDBJ & CDBK & CDBL \\
\hline $12 / 19.95$ & $\begin{array}{l}\text { Dissolved oxygen }(\mathrm{mg} / \mathrm{L}) \\
\text { Temperature }\left({ }^{\circ} \mathrm{C}\right) \\
\text { Turbidity }(\mathrm{m})\end{array}$ & $\begin{array}{r}6.3 \\
13.9\end{array}$ & $\begin{array}{r}5.3 \\
11.9\end{array}$ & $\begin{array}{r}6.2 \\
12.1\end{array}$ & $\begin{array}{c}5.8 \\
11.4 \\
0.25\end{array}$ & $\begin{array}{r}5.4 \\
11.4\end{array}$ & $\begin{array}{r}5.6 \\
12.9\end{array}$ & $\begin{array}{r}5.3 \\
11.6\end{array}$ & $\begin{array}{r}5.2 \\
11.6\end{array}$ \\
\hline $12 / 28.95$ & $\begin{array}{l}\text { Dissolved oxygen }(\mathrm{mg} / \mathrm{L}) \\
\text { Temperature }\left({ }^{\circ} \mathrm{C}\right) \\
\text { Turbidity }(\mathrm{m})\end{array}$ & $\begin{array}{r}6.7 \\
10.3\end{array}$ & $\begin{array}{r}7.2 \\
10.5\end{array}$ & $\begin{array}{r}7.4 \\
10.2\end{array}$ & $\begin{array}{l}7.3 \\
9.9 \\
0.30\end{array}$ & $\begin{array}{l}6.5 \\
9.6\end{array}$ & $\begin{array}{r}5.8 \\
10.4\end{array}$ & $\begin{array}{l}5.5 \\
9.8\end{array}$ & $\begin{array}{l}5.5 \\
9.9\end{array}$ \\
\hline Minimum & $\begin{array}{l}\text { Dissolved oxygen }(\mathrm{mg} / \mathrm{L}) \\
\text { Temperature }\left({ }^{\circ} \mathrm{C}\right) \\
\text { Turbidity }(\mathrm{m})\end{array}$ & $\begin{array}{l}6.3 \\
8.5\end{array}$ & $\begin{array}{l}5.3 \\
8.3\end{array}$ & $\begin{array}{l}6.2 \\
8.3\end{array}$ & $\begin{array}{l}4.3 \\
8.3 \\
0.10\end{array}$ & $\begin{array}{l}2.8 \\
8.3\end{array}$ & $\begin{array}{l}5.6 \\
8.7\end{array}$ & $\begin{array}{l}4.4 \\
8.9\end{array}$ & $\begin{array}{l}4.2 \\
8.9\end{array}$ \\
\hline Maximum & $\begin{array}{l}\text { Dissolved oxygen }(\mathrm{mg} / \mathrm{L}) \\
\text { Temperature }\left({ }^{\circ} \mathrm{C}\right) \\
\text { Turbidity }(\mathrm{m})\end{array}$ & $\begin{array}{l}10.2 \\
30.4\end{array}$ & $\begin{array}{l}10.2 \\
27.1\end{array}$ & $\begin{array}{r}9.7 \\
26.1\end{array}$ & $\begin{array}{r}9.4 \\
25.7 \\
0.66\end{array}$ & $\begin{array}{r}9.2 \\
25.6\end{array}$ & $\begin{array}{l}10.2 \\
27.8\end{array}$ & $\begin{array}{r}9.4 \\
25.7\end{array}$ & $\begin{array}{r}9.4 \\
25.7\end{array}$ \\
\hline Median & $\begin{array}{l}\text { Dissolved oxygen }(\mathrm{mg} / \mathrm{L}) \\
\text { Temperature }\left({ }^{\circ} \mathrm{C}\right) \\
\text { Turbidity }(\mathrm{m})\end{array}$ & $\begin{array}{r}8.3 \\
18.7\end{array}$ & $\begin{array}{c}8.3 \\
18.05\end{array}$ & $\begin{array}{r}7.95 \\
17.25\end{array}$ & $\begin{array}{c}7.6 \\
17.15 \\
0.25\end{array}$ & $\begin{array}{r}7.45 \\
17.15\end{array}$ & $\begin{array}{r}7.9 \\
17.8\end{array}$ & $\begin{array}{c}7.5 \\
17.45\end{array}$ & $\begin{array}{r}7.3 \\
17.5\end{array}$ \\
\hline $\begin{array}{l}\text { Inter- } \\
\text { quartile } \\
\text { range }\end{array}$ & $\begin{array}{l}\text { Dissolved oxygen }(\mathrm{mg} / \mathrm{L}) \\
\text { Temperature }\left({ }^{\circ} \mathrm{C}\right) \\
\text { Turbidity }(\mathrm{m})\end{array}$ & $\begin{array}{r}1.7 \\
12.6\end{array}$ & $\begin{array}{l}0.975 \\
9.975\end{array}$ & $\begin{array}{l}1.25 \\
9.575\end{array}$ & $\begin{array}{c}1.2 \\
11.075 \\
0.11\end{array}$ & $\begin{array}{l}1.675 \\
11.05\end{array}$ & $\begin{array}{c}0.975 \\
10.75\end{array}$ & $\begin{array}{c}1.1 \\
11.375\end{array}$ & $\begin{array}{c}1.05 \\
11.325\end{array}$ \\
\hline $\begin{array}{l}\text { Number } \\
\text { of } \\
\text { samples }\end{array}$ & $\begin{array}{l}\text { Dissolved oxygen }(\mathrm{mg} / \mathrm{L}) \\
\text { Temperature }\left({ }^{\circ} \mathrm{C}\right) \\
\text { Turbidity }(\mathrm{m})\end{array}$ & $\begin{array}{l}29 \\
29\end{array}$ & $\begin{array}{l}30 \\
30\end{array}$ & $\begin{array}{l}30 \\
30\end{array}$ & $\begin{array}{l}30 \\
30 \\
35\end{array}$ & $\begin{array}{l}30 \\
30\end{array}$ & $\begin{array}{l}30 \\
30\end{array}$ & $\begin{array}{l}30 \\
30\end{array}$ & $\begin{array}{l}30 \\
30\end{array}$ \\
\hline
\end{tabular}

a Data not collected because of instrument failure. 
Lucinda M. Garcia

Donald H. MacQueen

\section{Sampling Location Designators}

As described in Volume 1, the LLNL environmental monitoring program uses alpha-numeric location designator codes to define sampling locations. Tables 15-1 and 15-2 decode sampling location designators used in 1995 and provide a cross-reference between current designators and those used in previous years. Changes to location designators made during 1995 are shown on those tables. Table 15-3 decodes sampling location designators that were used prior to 1995 but were not used in 1995 .

During 1995, the LLNL Chemistry and Materials Science's Environmental Services Environmental Monitoring Radiation Laboratory (CES EMRL) and the Hazards Control Department's Analytical Laboratory (HCAL) participated in both the EPA's Environmental Monitoring Systems Laboratory (EMSL) intercomparison studies program and the DOE Environmental Monitoring Laboratory (EML) intercomparison studies program.

The results of CES EMRL's participation in the EMSL studies are presented in Table 15-4. A review of these data indicates that 28 of 30 analyses fell within established acceptance control limits. The results of two analyses, one for natural uranium and the other for gross alpha, fell outside of the acceptance control limits. The cause of the unacceptable results for the natural uranium sample, included in the September 15 study, is still under investigation. The unacceptable results for the October 27 gross alpha analysis were probably due to a bias in the method. This is indicated by the fact that $39.5 \%$ of the 195 participants in this study exceeded the 3-sigma acceptance control limits for gross alpha and another 23.1\% had results in the warning zone (between 2- and 3-sigma). EPA research indicates that matrix differences between the salt solids used to prepare the calibration curve and the salts in the sample are the source of this bias.

The results of HCAL's participation in 1995 EMSL studies are presented in Table 15-5. A review of these data indicates that 6 of 8 sample results fell within the 3-sigma acceptance control limits. Both samples that fell outside the acceptance control limits had gross alpha results below the lower control limit. One of these samples was from the October 27 study described above. Conversations with EMSL personnel revealed that a new solids matrix, containing nitrates, was used for the two failed tests. The HCAL double checked its results using the single-point calibration methods used by the EMSL and reconfirmed their initial results. In the single point method, the original sample was spiked with thorium-230 solution of known activity. Laboratory personnel 
suspect that some of this material reacted with the plastic sample bottle during shipping. The HCAL plans to do the single-point calibration on all future EPA gross alpha in water tests.

The results of CES EMRL's participation in the EML studies are presented in Table 15-6. Review of these results shows that 54 of 54 results were within the established acceptance control limits; there were no unacceptable results.

HCAL's results are presented in Table 15-7. Review of these results show that 10 of 10 results were within the established acceptance control limits.

The HCAL also participated in four EPA Water Pollution (WP) and Water Supply (WS) intercomparison studies for metals during 1995, as shown in Table 15-8. The HCAL measures aluminum, arsenic, beryllium, cadmium, chromium, copper, iron, lead, mercury, nickel, silver, and zinc in sewage effluent for the LLNL environmental monitoring program. Review of these results shows that 68 of 70 samples fell within established acceptance control limits. The results of a sample analyzed for beryllium and a sample analyzed for molybdenum by inductively coupled plasma-atomic emission spectroscopy fell outside the acceptance control limits. Both of these samples were the lower concentration of the pair of samples supplied for each element. The larger discrepancy for beryllium appears to be due to uncompensated spectral interference by vanadium. The wavelength used for beryllium analysis has since been changed to one that is not subject to this interference. In addition, to improve accuracy for elements present in low concentrations, the HCAL is evaluating the effect of either switching from a three-point calibration to a two-point calibration or using a forced-zero calibration curve fit with the three-point calibration.

Contract laboratories are also required to participate in laboratory intercomparison programs; however, permission to publish their results for comparison purposes has not been granted. 
Table 15-1. Livermore site and Livermore Valley sampling location designators for 1995.

\begin{tabular}{|c|c|c|c|}
\hline Medium/Location & $\begin{array}{c}\text { Current } \\
\text { designator }\end{array}$ & $\begin{array}{c}\text { Previous } \\
\text { designator(s) }\end{array}$ & Notes \\
\hline $\begin{array}{l}\text { Air particulate } \\
\text { Altamont Pass } \\
\text { Near Building } 531 \\
\text { South Cafeteria (East Avenue) } \\
\text { Cow barn (northeast of Building 592) } \\
\text { UNCLE Credit Union (Greenville Road) } \\
\text { Residence (Livermore) } \\
\text { FCC Station } \\
\text { Firehouse (East Avenue) } \\
\text { Livermore VA Hospital } \\
\text { LWRP } \\
\text { West parking lot (Mesquite Way) } \\
\text { Met. Tower (northwest perimeter) } \\
\text { Patterson Pass } \\
\text { Residence (Livermore) } \\
\text { Salvage (East Avenue) } \\
\text { Sandia tanks } \\
\text { Visitors Center (east perimeter) } \\
\text { Zone } 7\end{array}$ & $\begin{array}{l}\text { L-ALTA } \\
\text { L-B531 } \\
\text { L-CAFE } \\
\text { L-COW } \\
\text { L-CRED } \\
\text { L-ERCH } \\
\text { L-FCC } \\
\text { L-FIRE } \\
\text { L-HOSP } \\
\text { L-LWRP } \\
\text { L-MESQ } \\
\text { L-MET } \\
\text { L-PATT } \\
\text { L-RRCH } \\
\text { L-SALV } \\
\text { L-TANK } \\
\text { L-VIS } \\
\text { L-ZON7 }\end{array}$ & $\begin{array}{l}90-07 \\
- \\
90-12 \\
90-15 \\
- \\
90-11 \\
90-08 \\
90-17 \\
90-10 \\
90-16 \\
90-02 \\
90-13 \\
90-05 \\
90-06 \\
90-01 \\
90-03 \\
90-14 \\
90-04\end{array}$ & Abandoned 10/95 \\
\hline $\begin{array}{l}\text { Air tritium } \\
\text { Altamont Pass } \\
\text { Building } 292 \text { area } \\
\text { Building } 331 \text { yard } \\
\text { Building } 514 \text { yard } \\
\text { Building } 624 \text { (612 yard) } \\
\text { South Cafeteria (East Avenue) } \\
\text { Cow barn (northeast of Building 592) } \\
\text { Firehouse (East Avenue) } \\
\text { West parking lot (Mesquite Way) } \\
\text { Met. Tower (northwest perimeter) } \\
\text { LLNL pool } \\
\text { Salvage (East Avenue) } \\
\text { Residence (west of Sandia) } \\
\text { Visitors Center (east perimeter) } \\
\text { Residence (Cross Rd.) } \\
\text { Zone } 7\end{array}$ & $\begin{array}{l}\text { L-ALTA } \\
\text { L-B292 } \\
\text { L-B331 } \\
\text { L-B514 } \\
\text { L-B624 } \\
\text { L-CAFE } \\
\text { L-COW } \\
\text { L-FIRE } \\
\text { L-MESQ } \\
\text { L-MET } \\
\text { L-POOL } \\
\text { L-SALV } \\
\text { L-VET } \\
\text { L-VIS } \\
\text { L-XRDS } \\
\text { L-ZON7 }\end{array}$ & $\begin{array}{l}93-07 \\
- \\
- \\
- \\
- \\
93-12 \\
93-15 \\
93-17 \\
93-02 \\
93-13 \\
- \\
93-01 \\
93-S 2 \\
93-14 \\
93-51 \\
93-04\end{array}$ & \\
\hline
\end{tabular}


Table 15-1. Livermore site and Livermore Valley sampling location designators for 1995 (continued).

\begin{tabular}{|c|c|c|c|}
\hline Medium/Location & $\begin{array}{c}\text { Current } \\
\text { designator }\end{array}$ & $\begin{array}{c}\text { Previous } \\
\text { designator(s) }\end{array}$ & Notes \\
\hline \multicolumn{4}{|l|}{ Vegetation } \\
\hline Aqueduct & L-AQUE & $95-23$ & \\
\hline Calaveras Reservoir & $\mathrm{L}-\mathrm{CAL}$ & - & \\
\hline FCC Station & L-FCC & $95-33$ & \\
\hline LLNL on-site garden & L-GARD & & \\
\hline I-580 and Greenville Road & L-1580 & $95-20$ & \\
\hline Mesquite Way & L-MESQ & - & Replaced VASW \\
\hline Met. Tower (northwest perimeter) & L-MET & - & Replaced VASW \\
\hline Camp Parks & L-PARK & - & \\
\hline Patterson Pass & L-PATT & $95-04$ & \\
\hline North of LLNL (railroad tracks) & L-RAIL & $95-29$ & \\
\hline Tesla Road (west) & L-TESW & $95-32$ & \\
\hline Visitors Center (east perimeter) & L-VIS & - & \\
\hline Zone 7 & L-ZON7 & $95-15$ & \\
\hline \multicolumn{4}{|l|}{ Arroyo Sediment } \\
\hline Arroyo Seco South No. 2 & L-ASS2 & - & Replaced L-ASS \\
\hline Arroyo Seco West & L-ASW & L-ASN & \\
\hline Drainage Retention Basin & L-CDB & CDB & \\
\hline Drainage Retention Basin 2 & L-CDB2 & - & \\
\hline Eastern Settling Basin & L-ESB & - & \\
\hline Greenville Road, northeast perimeter & L-GRNE & - & \\
\hline West perimeter drainage channel & L-WPDC & - & \\
\hline \multicolumn{4}{|l|}{ Soil } \\
\hline Altamont Pass & L-ALTA & - & \\
\hline South Cafeteria (East Avenue) & L-CAFE & - & \\
\hline Cow barn (northeast of Building 592) & L-COW & $L-15$ & \\
\hline Residence (Livermore) & L-ERCH & - & \\
\hline FCC Station & L-FCC & $\mathrm{L}-08$ & \\
\hline Livermore VA Hospital & L-HOSP & $L-10$ & \\
\hline West parking lot (Mesquite Way) & L-MESQ & L-02 & \\
\hline Met. Tower (northwest perimeter) & L-MET & $L-13$ & \\
\hline Northeast corner perimeter fence & L-NEP & $\mathrm{L}-18$ & \\
\hline Patterson Pass & L-PATT & $\mathrm{L}-05$ & \\
\hline Residence (Livermore) & $\mathrm{L}-\mathrm{RRCH}$ & - & \\
\hline Salvage (East Avenue) & L-SALV & - & \\
\hline
\end{tabular}


Table 15-1. Livermore site and Livermore Valley sampling location designators for 1995 (continued).

\begin{tabular}{|c|c|c|c|}
\hline Medium/Location & $\begin{array}{c}\text { Current } \\
\text { designator }\end{array}$ & $\begin{array}{c}\text { Previous } \\
\text { designator(s) }\end{array}$ & Notes \\
\hline \multicolumn{4}{|l|}{ Soil (continued) } \\
\hline Sandia tanks & L-TANK & L-03 & \\
\hline Visitors Center (east perimeter) & L-VIS & L-14 & \\
\hline LWRP (1/3 North) & L-WRP1 & L-19 & \\
\hline LWRP (2/3 North) & L-WRP2 & $\mathrm{L}-20$ & \\
\hline LWRP (Northwest) & L-WRP3 & L-21 & \\
\hline LWRP (1/3 West) & L-WRP4 & L-22 & \\
\hline LWRP (2/3 West) & L-WRP5 & L-23 & \\
\hline LWRP (Southwest) & L-WRP6 & L-24 & \\
\hline Zone 7 & L-ZON7 & L-04 & \\
\hline \multicolumn{4}{|l|}{ Sewage } \\
\hline Building 196 (daily composite) & L-B196 & LLNL & \\
\hline Building 196 (weekly composite) & L-C196 & - & \\
\hline LWRP (digestor) & L-WRD1 & - & \\
\hline LWRP (digestor) & L-WRD2 & - & \\
\hline LWRP (digestor) & L-WRD3 & - & \\
\hline LWRP (effluent) & L-WRPE & - & \\
\hline \multicolumn{4}{|l|}{ Runoff } \\
\hline Arroyo Las Positas (east of LLNL) & L-ALPE & 01 & \\
\hline Greenville Road (south of L-GRNE) & L-ALPO & & Reinstated mid-1995 \\
\hline Arroyo Seco South No. 2 & L-ASS2 & - & Replaced L-ASS \\
\hline Arroyo Seco West (Vasco/East Avenue) & L-ASW & L-ASN;06 & \\
\hline Drainage Retention Basin & L-CDB & 02 & \\
\hline Drainage Retention Basin effluent & L-CDBX & - & Drainage Retention Basin release \\
\hline Greenville Road (northeast perimeter) & L-GRNE & - & \\
\hline West perimeter drainage channel & L-WPDC & - & Drainage Retention Basin release \\
\hline \multicolumn{4}{|l|}{ Rain } \\
\hline Aqueduct & L-AQUE & - & \\
\hline Building 291 & L-B291 & - & \\
\hline Building 343 & L-B343 & - & \\
\hline Residence (Livermore) & L-BVA & - & Reinstated in 1995 \\
\hline Drainage Retention Basin & L-CDB & - & \\
\hline Cow barn (northeast of Building 592) & L-COW & - & \\
\hline East of Sandia & L-ESAN & - & \\
\hline
\end{tabular}


Table 15-1. Livermore site and Livermore Valley sampling location designators for 1995 (concluded).

\begin{tabular}{|c|c|c|c|}
\hline Medium/Location & $\begin{array}{c}\text { Current } \\
\text { Designator }\end{array}$ & $\begin{array}{c}\text { Previous } \\
\text { Designator(s) }\end{array}$ & Notes \\
\hline \multicolumn{4}{|l|}{ Rain (continued) } \\
\hline Greenville and Tesla Roads & L-GTES & - & Reinstated in 1995 \\
\hline Met. Tower (northwest perimeter) & L-MET & - & \\
\hline Salvage (East Avenue) & L-SALV & - & \\
\hline Residence (Livermore) & L-SLST & - & \\
\hline Residence (west of Sandia) & L-VET & - & \\
\hline Vineyard & L-VINE & - & Reinstated in 1995 \\
\hline Visitors Center (east parameter) & L-VIS & - & \\
\hline Zone 7 & L-ZON7 & - & \\
\hline \multicolumn{4}{|l|}{ Water } \\
\hline Arroyo de Laguna (Sunol) & L-ALAG & $92-24$ & \\
\hline Residence (Livermore) & L-BELL & $92-37$ & \\
\hline Calaveras Reservoir & L-CAL & $92-29$ & \\
\hline Del Valle Lake & L-DEL & $92-11$ & \\
\hline Springtown duck pond & L-DUCK & $92-16$ & \\
\hline Gas station tap water & L-GAS & $92-19$ & \\
\hline Private well & $\mathrm{L}-\mathrm{ORCH}$ & $92-34$ & \\
\hline Residence (Livermore) & L-PALM & $92-31$ & \\
\hline LLNL pool & L-POOL & $92-43$ & \\
\hline Shadow Cliffs & L-SHAD & $92-26$ & \\
\hline Building 151 tap water & L-TAP & $92-30$ & \\
\hline Zone 7 & L-ZON7 & $92-15$ & \\
\hline \multicolumn{4}{|l|}{ Drainage Retention Basin } \\
\hline Surface water (shallow) location & L-CDBA & & \\
\hline Surface water (shallow) location & L-CDBC & & \\
\hline Surface water location & L-CDBD & & \\
\hline Mid-depth location & L-CDBE & & Sampling location \\
\hline Bottom location & L-CDBF & & \\
\hline Surface water location & L-CDBJ & & \\
\hline Mid-depth location & L-CDBK & & \\
\hline Bottom location & L-CDBL & & \\
\hline
\end{tabular}


Table 15-2. Site 300 sampling location designators for 1995.

\begin{tabular}{|c|c|c|c|}
\hline Medium/Location & $\begin{array}{c}\text { Current } \\
\text { designator }\end{array}$ & $\begin{array}{c}\text { Previous } \\
\text { designator(s) }\end{array}$ & Notes \\
\hline \multicolumn{4}{|l|}{ Air particulate } \\
\hline East of Building 801 & 3-801E & $40-10$ & \\
\hline East control post & 3-ECP & $40-02$ & \\
\hline East observation point & 3-EOBS & $40-01$ & \\
\hline West of main gate & 3-GOLF & $40-05$ & \\
\hline Linac Road & 3-LIN & $40-04$ & \\
\hline North power station & 3-NPS & $40-08$ & \\
\hline Tracy firehouse & 3-TFIR & $40-06$ & \\
\hline West control post & 3-WCP & $40-03$ & \\
\hline West observation point & 3-WOBS & $40-09$ & \\
\hline \multicolumn{4}{|l|}{ Soil } \\
\hline East of Building 801 & 3-801E & $3 \mathrm{NXXH01}$ or 1114 & \\
\hline North of Building 801 & $3-801 \mathrm{~N}$ & 1117 & \\
\hline West of Building 801 & 3-801W & 3NNWG01 or 1113 & \\
\hline Behind Building 812 & $3-812 \mathrm{~N}$ & $3 N X X C 01$ or 1115 & \\
\hline West of Building 834 & $3-834 \mathrm{~W}$ & 3ESEI01 or 1103 & \\
\hline North of road to Building 851 & $3-851 \mathrm{~N}$ & 3WNWI01 or 1107 & \\
\hline North of Building 856 & $3-856 \mathrm{~N}$ & 3WXXK01 or 1106 & \\
\hline Near Building 858 & 3-858S & 3WSWI01 or 1104 & \\
\hline West landfill (Disposal Site West) & 3-DSW & 3NWXP02 or 1111 & \\
\hline North of east observation point & 3-EOBS & 3NNWL01 or 1112 & \\
\hline Evaporator (north of Well 8) & 3-EVAP & 3WNWK01 or 1109 & \\
\hline Golf course (west of main gate) & 3-GOLF & 3SEXL01 or 1116 & \\
\hline North Power Station & 3-NPS & 3NWXP01 or 1110 & \\
\hline West Observation Post & 3-WOBS & 3WNWN01 or 1108 & \\
\hline \multicolumn{4}{|l|}{ Vegetation } \\
\hline East of Building 801 & 3-801E & $45-12$ & \\
\hline Carnegie & 3-CARN & $45-01$ & \\
\hline West landfill (Disposal Site West) & 3-DSW & $45-06$ & \\
\hline Near Well 8 & 3-EVAP & $45-13$ & \\
\hline Geodetic Creek & 3-GEO & $45-03$ & \\
\hline West of main gate & 3-GOLF & $45-02$ & \\
\hline \multicolumn{4}{|l|}{ Water } \\
\hline Monitoring well & 3-W35A04 & & Replaced GALLO2 \\
\hline Well 1 & 3-WELL01 & $42-01$ & \\
\hline Private well & $3-\mathrm{CON} 1$ & $42-07$ & \\
\hline Private well & 3-CON2 & - & \\
\hline
\end{tabular}

...continued on next page 
Table 15-2. Site 300 sampling location designators for 1995 (continued).

\begin{tabular}{|c|c|c|c|}
\hline Medium/Location & $\begin{array}{c}\text { Current } \\
\text { designator }\end{array}$ & $\begin{array}{c}\text { Previous } \\
\text { designator(s) }\end{array}$ & Notes \\
\hline Well 18 & 3-WELL18 & $42-22$ & \multirow{14}{*}{ Transferred to runoff network in 1995.} \\
\hline Geodetic creek & 3-GEOCRK & $42-14$ & \\
\hline Rain & 3-RAIN & $42-20$ & \\
\hline 812 creek & 3-812CRK & $42-21$ & \\
\hline Carnegie Retention Well 1 & 3-CARNRW1 & $42-23$ & \\
\hline Carnegie Retention Well 2 & 3-CARNRW2 & $42-24$ & \\
\hline Well 20 & 3-WELL20 & $42-31$ & \\
\hline Private well & 3-GALLO1 & $42-28$ & \\
\hline CDF well & 3-CDF1 & $42-27$ & \\
\hline Private well & 3-MUL1 & - & \\
\hline Private well & 3-MUL2 & - & \\
\hline Private well & 3-VIE1 & - & \\
\hline Private well & 3-VIE2 & - & \\
\hline Private well & 3-STN & - & \\
\hline \multicolumn{4}{|l|}{ Cooling towers } \\
\hline Building 801 & 3-B801 & - & \\
\hline Building 805 & 3-B805 & - & \\
\hline Building 809 & 3-B809 & - & \\
\hline Building 810 & 3-B810 & - & \\
\hline Building 812 & 3-B812 & - & \\
\hline Building 815 & 3-B815 & - & \\
\hline Building 817 & 3-B817 & - & \\
\hline Building 826 & 3-B826 & - & \\
\hline Building 827, Tower No. 1 & 3-B827-1 & - & \\
\hline Building 827, Tower No. 2 & 3-B827-2 & - & \\
\hline Building 828 & 3-B828 & - & \\
\hline Building 836, Tower A & 3-B836A & - & \\
\hline Building 836, Tower B & 3-B836D & - & \\
\hline Building 851, Tower No. 1 & 3-B851-1 & - & \\
\hline Building 851, Tower No. 2 & 3-B851-2 & - & \\
\hline Building 854 & 3-B854 & - & \\
\hline Building 865 & 3-B865 & - & \\
\hline
\end{tabular}


Table 15-2. Site 300 sampling location designators for 1995 (concluded).

\begin{tabular}{|l|l|c|c|}
\hline \multicolumn{1}{|c|}{ Medium/Location } & $\begin{array}{c}\text { Current } \\
\text { designator }\end{array}$ & $\begin{array}{c}\text { Previous } \\
\text { designator(s) }\end{array}$ & Notes \\
\hline Runoff & 3-NLIN & - & - \\
North of Well NC2-07 & 3-N829 & - & \\
East of Pit 6 & 3-N883 & - & \\
South of B873 & 3-NPT7 & - & \\
Pit 7 North Stilling Basin & 3-NSTN & - & \\
Corral Hollow Creek & 3-NPT6 & - & \\
South East End of Pit 6 & 3-GEOCRK & 3-CARN & \\
Geodetic Creek & &
\end{tabular}


Table 15-3. Previously used sampling location designators not used in 1995.

\begin{tabular}{|c|c|c|c|}
\hline Medium/Location & $\begin{array}{l}\text { Location } \\
\text { designator }\end{array}$ & $\begin{array}{c}\text { Previous } \\
\text { designator(s) }\end{array}$ & Notes \\
\hline \multicolumn{4}{|c|}{ Livermore Site and Livermore Valley } \\
\hline $\begin{array}{l}\text { Air particulate } \\
\text { Livermore City Corp Yard }\end{array}$ & L-LCCY & $90-09$ & Abandoned in 1994 \\
\hline $\begin{array}{l}\text { Air tritium } \\
\text { Livermore City Corp Yard }\end{array}$ & L-LCCY & 93-09 & Abandoned in 1994 \\
\hline $\begin{array}{l}\text { Cow milk } \\
\text { Residence (Livermore) }\end{array}$ & L-WRD & - & Abandoned prior to 1994 \\
\hline $\begin{array}{l}\text { Goat milk } \\
\text { Cartoned milk } \\
\text { Residence (Modesto) } \\
\text { Residence (Modesto) } \\
\text { Residence (Ripon) } \\
\text { Residence (Stevenson) } \\
\text { Prepasteurized (Turlock) } \\
\text { Residence (Brentwood) } \\
\text { Residence (Livermore) } \\
\text { Residence (Livermore) } \\
\text { Residence (Livermore) } \\
\text { Residence (Livermore) }\end{array}$ & $\begin{array}{l}\text { C-CART } \\
\text { C-MOD } \\
\text { C-MOD2 } \\
\text { C-RIP } \\
\text { C-STEV } \\
\text { C-TUR } \\
\text { C-WOOD } \\
\text { L-COOL } \\
\text { L-LUP } \\
\text { L-MZF } \\
\text { L-WRD }\end{array}$ & $\begin{array}{c}91-97 \\
91-12 \\
- \\
- \\
- \\
- \\
- \\
- \\
91-13 \\
91-07 \\
91-05\end{array}$ & $\begin{array}{l}\text { Abandoned in } 1994 \\
\text { Abandoned in } 1994 \\
\text { Abandoned in } 1994 \\
\text { Abandoned in } 1994 \\
\text { Abandoned in } 1994 \\
\text { Abandoned in } 1994 \\
\text { Abandoned in } 1994 \\
\text { Abandoned prior to } 1994 \\
\text { Replaced prior to } 1994 \\
\text { Abandoned prior to } 1994 \\
\text { Abandoned in } 1994\end{array}$ \\
\hline $\begin{array}{l}\text { Vegetation } \\
\text { Residence (Modesto) } \\
\text { Residence (Danville) } \\
\text { Vasco Road (west of LLNL) }\end{array}$ & $\begin{array}{l}\text { C-MOD } \\
\text { L-DAN } \\
\text { L-VASW }\end{array}$ & $95-31$ & $\begin{array}{l}\text { Abandoned prior to } 1995 \\
\text { Abandoned prior to } 1995 \\
\text { Replaced by L-MESQ and L-MET }\end{array}$ \\
\hline $\begin{array}{l}\text { Arroyo sediment } \\
\text { East of Building } 438 \\
\text { 4th and A Streets } \\
\text { Arroyo Las Positas North } \\
\text { Arroyo Las Positas West } \\
\text { Arroyo Seco East } \\
\text { Arroyo Seco South }\end{array}$ & $\begin{array}{l}\text { L-438E } \\
\text { L-4THA } \\
\text { L-ALPN } \\
\text { L-ALPW } \\
\text { L-ASE } \\
\text { L-ASS }\end{array}$ & $\begin{array}{l}- \\
- \\
- \\
\text { ALPW } \\
\text { ASE } \\
\text { ASS }\end{array}$ & $\begin{array}{l}\text { Abandoned in } 1994 \\
\text { Abandoned in } 1994 \\
\text { Abandoned in } 1994 \\
\text { Abandoned in } 1994 \\
\text { Abandoned prior to } 1994 \\
\text { Replaced by L-ASS2 }\end{array}$ \\
\hline $\begin{array}{l}\text { Sewage } \\
\text { Manhole 163A (Sandia) } \\
\text { LWRP } \\
\text { Manhole 125C } \\
\text { Manhole 177E } \\
\text { Manhole 185F } \\
\text { Manhole 231A }\end{array}$ & $\begin{array}{l}\text { L-163A } \\
\text { L-LWRP } \\
\text { L-M125 } \\
\text { L-M177 } \\
\text { L-M185 } \\
\text { L-M231 }\end{array}$ & $\begin{array}{l}- \\
\text { LWRP } \\
\text { L-125C } \\
\text { L-177E } \\
\text { L-185F } \\
\text { L-231A }\end{array}$ & Replaced by L-WRPE \\
\hline
\end{tabular}


Table 15-3. Previously used sampling location designators not used in 1995 (concluded).

\begin{tabular}{|c|c|c|c|}
\hline Medium/Location & $\begin{array}{l}\text { Location } \\
\text { designator }\end{array}$ & $\begin{array}{c}\text { Previous } \\
\text { designator(s) }\end{array}$ & Notes \\
\hline \multicolumn{4}{|l|}{ Sewage (continued) } \\
\hline Manhole 238C & L-M238 & L-238C & \\
\hline Manhole 40B & L-M40 & $L-40 C$ & \\
\hline Manhole 51A & L-M51 & $L-51 A$ & \\
\hline Manhole 53A & L-M53 & $L-53 A$ & \\
\hline Manhole 69A & L-M69 & L-69A & \\
\hline Manhole 86B & L-M86 & L-86B & \\
\hline \multicolumn{4}{|l|}{ Runoff } \\
\hline 4th and A Streets & L-4THA & 07 & Abandoned prior to 1994 \\
\hline $\begin{array}{l}\text { Arroyo Las Positas (north at } \\
\text { cowbarn) }\end{array}$ & L-ALPN & 09 & Abandoned prior to 1994 \\
\hline $\begin{array}{l}\text { Arroyo Las Positas (northwest } \\
\text { boundary) }\end{array}$ & L-ALPW & 03 & Abandoned prior to 1994 \\
\hline Arroyo Seco East (influent to Sandia) & L-ASE & 04 & Abandoned prior to 1994 \\
\hline Arroyo Seco South (west parking lot) & L-ASS & 06 & Replaced by L-ASS2 \\
\hline East of Building 438 & L-B438 & 08 & Abandoned prior to 1994 \\
\hline \multicolumn{4}{|l|}{ Rain } \\
\hline Altamont & L-ALTA & - & Abandoned prior to 1994 \\
\hline Del Valle/Zone 7 & L-DEL7 & - & Abandoned prior to 1994 \\
\hline FCC station & L-FCC & - & Abandoned prior to 1994 \\
\hline Camp parks & L-PARK & - & Abandoned prior to 1994 \\
\hline Patterson Pass & L-PATT & - & Abandoned prior to 1994 \\
\hline \multicolumn{4}{|l|}{ Site 300} \\
\hline \multicolumn{4}{|l|}{ Water } \\
\hline Private well & 3-GALLO2 & - & Abandoned prior to 1994 \\
\hline
\end{tabular}


Table 15-4. LLNL Chemistry and Materials Science's Environmental Services Environmental Monitoring Radiation Laboratory (CES EMRL) performance in the EPA Environmental Monitoring Systems Laboratory (EMSL) Intercomparison Studies Program for Water, 1995.

\begin{tabular}{|c|c|c|c|c|c|c|}
\hline Analysis & Date & $\begin{array}{l}\text { LLNL value } \\
\qquad(\mathrm{pCi} / \mathrm{L})\end{array}$ & $\begin{array}{c}\text { Known value } \\
(\mathrm{pCi} / \mathrm{L})\end{array}$ & $\begin{array}{l}\text { Control limits } \\
\qquad(3 \sigma)\end{array}$ & $\begin{array}{l}\text { Warning limits } \\
\qquad(2 \sigma)\end{array}$ & Performance $^{(a)}$ \\
\hline Gross Alpha & $\begin{array}{l}4 / 18 \\
10 / 27\end{array}$ & $\begin{array}{l}48.83 \\
24.47\end{array}$ & $\begin{array}{l}47.5 \\
51.2\end{array}$ & $\begin{array}{l}26.9-68.1 \\
29.0-73.4\end{array}$ & $\begin{array}{l}33.7-61.3 \\
36.4-66.0\end{array}$ & $\begin{array}{l}\text { Acceptable } \\
\text { Unacceptable }\end{array}$ \\
\hline Gross Beta & $\begin{array}{l}7 / 21 \\
10 / 27\end{array}$ & $\begin{array}{l}21.6 \\
29.07\end{array}$ & $\begin{array}{l}19.4 \\
24.8\end{array}$ & $\begin{array}{l}10.7-28.1 \\
16.1-33.5\end{array}$ & $\begin{array}{l}13.6-25.2 \\
19.0-30.6\end{array}$ & $\begin{array}{l}\text { Acceptable } \\
\text { Acceptable }\end{array}$ \\
\hline Tritium & $\begin{array}{l}3 / 10 \\
8 / 4\end{array}$ & $\begin{array}{l}7056.67 \\
4523.33\end{array}$ & $\begin{array}{l}7435.0 \\
4872.0\end{array}$ & $\begin{array}{l}6144.2-8725.8 \\
4027.1-5716.9\end{array}$ & $\begin{array}{l}6573.8-8296.2 \\
4308.3-5435.7\end{array}$ & $\begin{array}{l}\text { Acceptable } \\
\text { Acceptable }\end{array}$ \\
\hline $\mathrm{Ba}-133$ & $\begin{array}{l}6 / 9 \\
11 / 3\end{array}$ & $\begin{array}{l}73.00 \\
99.00\end{array}$ & $\begin{array}{l}79.0 \\
99.0\end{array}$ & $\begin{array}{l}65.1-92.9 \\
81.7-116.3\end{array}$ & $\begin{array}{l}69.7-88.3 \\
87.4-110.6\end{array}$ & $\begin{array}{l}\text { Acceptable } \\
\text { Acceptable }\end{array}$ \\
\hline Co-60 & $\begin{array}{l}4 / 18 \\
6 / 9 \\
11 / 3\end{array}$ & $\begin{array}{l}26.67 \\
35.00 \\
55.00\end{array}$ & $\begin{array}{l}29.0 \\
40.0 \\
60.0\end{array}$ & $\begin{array}{l}20.3-37.7 \\
31.3-48.7 \\
51.3-68.7\end{array}$ & $\begin{array}{l}23.2-34.8 \\
34.2-45.8 \\
54.2-65.8\end{array}$ & $\begin{array}{l}\text { Acceptable } \\
\text { Acceptable } \\
\text { Acceptable }\end{array}$ \\
\hline Cs-134 & $\begin{array}{l}4 / 18 \\
6 / 9 \\
11 / 3\end{array}$ & $\begin{array}{l}17.00 \\
42.33 \\
35.33\end{array}$ & $\begin{array}{l}20.0 \\
50.0 \\
40.0\end{array}$ & $\begin{array}{l}11.3-28.7 \\
41.3-58.7 \\
31.3-48.7\end{array}$ & $\begin{array}{l}14.2-25.8 \\
44.2-55.8 \\
34.2-45.8\end{array}$ & $\begin{array}{l}\text { Acceptable } \\
\text { Check for Error } \\
\text { Acceptable }\end{array}$ \\
\hline Cs-137 & $\begin{array}{l}4 / 18 \\
6 / 9 \\
11 / 3\end{array}$ & $\begin{array}{l}11.00 \\
33.67 \\
52.33\end{array}$ & $\begin{array}{l}11.0 \\
35.0 \\
49.0\end{array}$ & $\begin{array}{r}2.3-19.7 \\
26.3-43.7 \\
40.3-57.7\end{array}$ & $\begin{array}{r}5.2-16.8 \\
29.2-40.8 \\
43.2-54.8\end{array}$ & $\begin{array}{l}\text { Acceptable } \\
\text { Acceptable } \\
\text { Acceptable }\end{array}$ \\
\hline Pu-239 & $3 / 17$ & 10.97 & 11.1 & $9.2-13.0$ & $9.8-12.4$ & Acceptable \\
\hline U-natural & $\begin{array}{l}2 / 10 \\
4 / 18 \\
6 / 16 \\
9 / 15\end{array}$ & $\begin{array}{r}22.8 \\
9.27 \\
14.07 \\
24.33\end{array}$ & $\begin{array}{l}25.5 \\
10.0 \\
15.2 \\
30.5\end{array}$ & $\begin{array}{r}20.3-30.7 \\
4.8-15.2 \\
10.0-20.4 \\
25.3-35.7\end{array}$ & $\begin{array}{r}22.0-29.0 \\
6.5-13.5 \\
11.7-18.7 \\
27.0-34.0\end{array}$ & $\begin{array}{l}\text { Acceptable } \\
\text { Acceptable } \\
\text { Acceptable } \\
\text { Unacceptable }\end{array}$ \\
\hline Zn-65 & $\begin{array}{l}6 / 9 \\
11 / 3\end{array}$ & $\begin{array}{r}74.00 \\
131.33\end{array}$ & $\begin{array}{r}76.0 \\
125.0\end{array}$ & $\begin{array}{c}62.1-89.9 \\
102.4-147.6\end{array}$ & $\begin{array}{c}66.7-85.3 \\
110.0-140.0\end{array}$ & $\begin{array}{l}\text { Acceptable } \\
\text { Acceptable }\end{array}$ \\
\hline Ra-226 & $\begin{array}{l}4 / 18 \\
6 / 16 \\
9 / 15\end{array}$ & $\begin{array}{l}17.17 \\
14.20 \\
27.13\end{array}$ & $\begin{array}{l}14.9 \\
14.8 \\
24.8\end{array}$ & $\begin{array}{l}11.1-18.7 \\
11.0-18.6 \\
18.4-31.2\end{array}$ & $\begin{array}{l}12.4-17.4 \\
12.3-17.3 \\
20.5-29.1\end{array}$ & $\begin{array}{l}\text { Acceptable } \\
\text { Acceptable } \\
\text { Acceptable }\end{array}$ \\
\hline Ra-228 & $\begin{array}{l}4 / 18 \\
6 / 16 \\
9 / 15\end{array}$ & $\begin{array}{l}18.07 \\
14.47 \\
19.70\end{array}$ & $\begin{array}{l}15.8 \\
15.0 \\
20.0\end{array}$ & $\begin{array}{r}8.9-22.7 \\
8.4-21.6 \\
11.3-28.7\end{array}$ & $\begin{array}{l}11.2-20.4 \\
10.6-19.4 \\
14.2-25.8\end{array}$ & $\begin{array}{l}\text { Acceptable } \\
\text { Acceptable } \\
\text { Acceptable }\end{array}$ \\
\hline
\end{tabular}

a Data are considered acceptable when they fall within the $2 \sigma$ warning limits. Data should be checked for error when they are between the $2 \sigma$ warning limits and the $3 \sigma$ control limits. Data are considered unacceptable when they are outside the $3 \sigma$ control limits. 
Table 15-5. LLNL Hazards Control Analytical Laboratory (HCAL) performance in the EPA Environmental Monitoring Systems Laboratory (EMSL) Intercomparison Program for Water, 1995.

\begin{tabular}{|c|c|c|c|c|c|c|}
\hline Analysis & Date & $\begin{array}{l}\text { LLNL value } \\
\qquad(\mathrm{pCi} / \mathrm{L})\end{array}$ & $\begin{array}{c}\text { Known value } \\
(\mathrm{pCi} / \mathrm{L})\end{array}$ & $\begin{array}{c}\text { Control limits } \\
(3 \sigma)\end{array}$ & $\begin{array}{l}\text { Warning limits } \\
(2 \sigma)\end{array}$ & Performance ${ }^{(a)}$ \\
\hline Gross alpha & $\begin{array}{l}1 / 27 \\
7 / 21 \\
10 / 27\end{array}$ & $\begin{array}{l}4.33 \\
12.67 \\
51.2\end{array}$ & $\begin{array}{l}5.0 \\
27.5 \\
23.60\end{array}$ & $\begin{array}{r}0.0-13.7 \\
15.5-39.5 \\
29.0-73.4\end{array}$ & $\begin{array}{r}0.0-10.8 \\
19.5-35.5 \\
36.4-73.4\end{array}$ & $\begin{array}{l}\text { Acceptable } \\
\text { Not acceptable } \\
\text { Not acceptable }\end{array}$ \\
\hline Gross beta & $\begin{array}{l}1 / 27 \\
7 / 21 \\
10 / 27\end{array}$ & $\begin{array}{r}5.00 \\
16.57 \\
24.47\end{array}$ & $\begin{array}{r}5.0 \\
19.4 \\
24.8\end{array}$ & $\begin{array}{r}0.0-13.7 \\
10.7-28.1 \\
16.1-33.5\end{array}$ & $\begin{array}{r}0.0-10.8 \\
13.6-25.2 \\
19.0-30.6\end{array}$ & $\begin{array}{l}\text { Acceptable } \\
\text { Acceptable } \\
\text { Acceptable }\end{array}$ \\
\hline Tritium & $\begin{array}{l}3 / 10 \\
8 / 4\end{array}$ & $\begin{array}{l}6886.67 \\
4211.0\end{array}$ & $\begin{array}{l}7435.0 \\
4872.0\end{array}$ & $\begin{array}{l}6144.2-8725.8 \\
4027.1-5716.9\end{array}$ & $\begin{array}{l}6573.8-8296.2 \\
4308.3-5435.7\end{array}$ & $\begin{array}{l}\text { Acceptable } \\
\text { Acceptable }\end{array}$ \\
\hline
\end{tabular}

a Data are considered acceptable when they fall within the $2 \sigma$ warning limits. Data should be checked for error when they are between the $2 \sigma$ warning limits and the $3 \sigma$ control limits. Data are considered unacceptable when they are outside the $3 \sigma$ control limits. 
Table 15-6. LLNL's Chemistry and Materials Science's Environmental Services Environmental Monitoring Radiation Laboratory's results from the DOE Environmental Measurements Laboratory (EML) Quality Assurance Program, 1995.

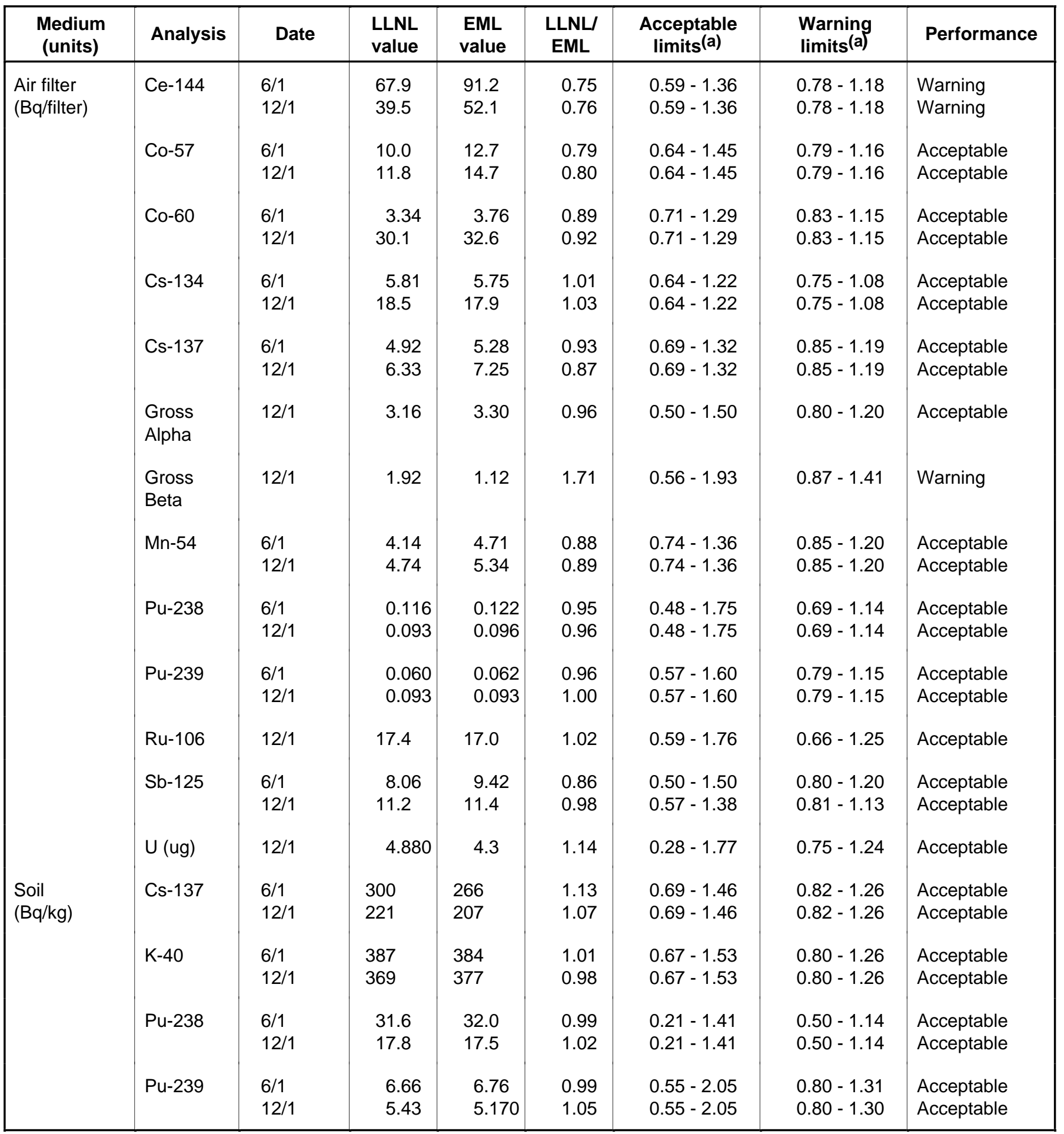


Table 15-6. LLNL's Chemistry and Materials Sciences Environmental Service's Environmental Monitoring Radiation Laboratory's results from the DOE Environmental Measurements Laboratory (EML) Quality Assurance Program, 1995. (concluded)

\begin{tabular}{|c|c|c|c|c|c|c|c|c|}
\hline $\begin{array}{l}\text { Medium } \\
\text { (units) }\end{array}$ & Analysis & Date & $\begin{array}{l}\text { LLNL } \\
\text { value }\end{array}$ & $\begin{array}{l}\text { EML } \\
\text { value }\end{array}$ & $\begin{array}{l}\text { LLNL/ } \\
\text { EML }\end{array}$ & $\begin{array}{c}\text { Acceptable } \\
\operatorname{limits}^{(a)}\end{array}$ & $\begin{array}{l}\text { Warning } \\
\text { limits(a) }^{(a)}\end{array}$ & Performance \\
\hline \multirow[t]{5}{*}{$\begin{array}{l}\text { Vegetation } \\
(\mathrm{Bq} / \mathrm{kg})\end{array}$} & Co-60 & $\begin{array}{r}6 / 1 \\
12 / 1\end{array}$ & $\begin{array}{l}7.88 \\
6.74\end{array}$ & $\begin{array}{l}9.60 \\
9.17\end{array}$ & $\begin{array}{l}0.82 \\
0.74\end{array}$ & $\begin{array}{l}0.69-1.40 \\
0.69-1.40\end{array}$ & $\begin{array}{l}0.84-1.24 \\
0.84-1.24\end{array}$ & $\begin{array}{l}\text { Warning } \\
\text { Warning }\end{array}$ \\
\hline & Cs-137 & $\begin{array}{r}6 / 1 \\
12 / 1\end{array}$ & $\begin{array}{l}131 \\
115\end{array}$ & $\begin{array}{l}117 . \\
97.2\end{array}$ & $\begin{array}{l}1.12 \\
1.18\end{array}$ & $\begin{array}{l}0.69-1.55 \\
0.69-1.55\end{array}$ & $\begin{array}{l}0.86-1.29 \\
0.86-1.29\end{array}$ & $\begin{array}{l}\text { Acceptable } \\
\text { Acceptable }\end{array}$ \\
\hline & $\mathrm{K}-40$ & $\begin{array}{r}6 / 1 \\
12 / 1\end{array}$ & $\begin{array}{l}1040 \\
354\end{array}$ & $\begin{array}{l}1030 \\
352\end{array}$ & $\begin{array}{l}1.01 \\
1.01\end{array}$ & $\begin{array}{l}0.43-1.48 \\
0.43-1.48\end{array}$ & $\begin{array}{l}0.78-1.24 \\
0.78-1.24\end{array}$ & $\begin{array}{l}\text { Acceptable } \\
\text { Acceptable }\end{array}$ \\
\hline & Pu-238 & $6 / 1$ & 0.089 & 0.089 & 1.00 & $0.72-2.08$ & $0.83-1.20$ & Acceptable \\
\hline & Pu-239 & $\begin{array}{r}6 / 1 \\
12 / 1\end{array}$ & $\begin{array}{l}1.030 \\
0.853\end{array}$ & $\begin{array}{l}1.12 \\
0.980\end{array}$ & $\begin{array}{l}0.92 \\
0.87\end{array}$ & $\begin{array}{l}0.56-1.94 \\
0.56-1.94\end{array}$ & $\begin{array}{l}0.75-1.42 \\
0.75-1.42\end{array}$ & $\begin{array}{l}\text { Acceptable } \\
\text { Acceptable }\end{array}$ \\
\hline \multirow[t]{10}{*}{$\begin{array}{l}\text { Water } \\
(\mathrm{Bq} / \mathrm{L})\end{array}$} & Co-60 & $\begin{array}{r}6 / 1 \\
12 / 1\end{array}$ & $\begin{array}{l}200 \\
193\end{array}$ & $\begin{array}{l}196 \\
196\end{array}$ & $\begin{array}{l}1.02 \\
0.99\end{array}$ & $\begin{array}{l}0.79-1.18 \\
0.79-1.18\end{array}$ & $\begin{array}{l}0.89-1.10 \\
0.79-1.18\end{array}$ & $\begin{array}{l}\text { Acceptable } \\
\text { Acceptable }\end{array}$ \\
\hline & Cs-134 & $6 / 1$ & 92.0 & 83.5 & 1.10 & $0.74-1.29$ & $0.83-1.17$ & Acceptable \\
\hline & Cs-137 & $\begin{array}{r}6 / 1 \\
12 / 1\end{array}$ & $\begin{array}{l}83.5 \\
82.1\end{array}$ & $\begin{array}{l}76.8 \\
75.2\end{array}$ & $\begin{array}{l}1.09 \\
1.09\end{array}$ & $\begin{array}{l}0.82-1.29 \\
0.82-1.29\end{array}$ & $\begin{array}{l}0.93-1.15 \\
0.93-1.15\end{array}$ & $\begin{array}{l}\text { Acceptable } \\
\text { Acceptable }\end{array}$ \\
\hline & $\begin{array}{l}\text { Gross } \\
\text { Alpha }\end{array}$ & $12 / 1$ & 1330 & 1310 & 1.02 & $0.46-1.35$ & $0.84-1.25$ & $\begin{array}{l}\text { Acceptable } \\
\text { Acceptable }\end{array}$ \\
\hline & $\begin{array}{l}\text { Gross } \\
\text { Beta }\end{array}$ & $12 / 1$ & 597 & 410 & 1.46 & $0.75-1.64$ & $0.98-1.47$ & Acceptable \\
\hline & Tritium & $\begin{array}{r}6 / 1 \\
12 / 1\end{array}$ & $\begin{array}{l}56.7 \\
151 .\end{array}$ & $\begin{array}{l}60.3 \\
168 .\end{array}$ & $\begin{array}{l}0.94 \\
0.90\end{array}$ & $\begin{array}{l}0.64-1.85 \\
0.64-1.85\end{array}$ & $\begin{array}{l}0.83-1.28 \\
0.83-1.28\end{array}$ & $\begin{array}{l}\text { Acceptable } \\
\text { Acceptable }\end{array}$ \\
\hline & $M n-54$ & $\begin{array}{r}6 / 1 \\
12 / 1\end{array}$ & $\begin{array}{l}44.6 \\
49.3\end{array}$ & $\begin{array}{l}43.5 \\
44.9\end{array}$ & $\begin{array}{l}1.03 \\
1.10\end{array}$ & $\begin{array}{l}0.81-1.25 \\
0.81-1.25\end{array}$ & $\begin{array}{l}0.93-1.14 \\
0.93-1.14\end{array}$ & $\begin{array}{l}\text { Acceptable } \\
\text { Acceptable }\end{array}$ \\
\hline & Pu-238 & $12 / 1$ & 1.33 & 1.41 & 0.94 & $0.39-1.78$ & $0.73-1.22$ & Acceptable \\
\hline & Pu-239 & $\begin{array}{r}6 / 1 \\
12 / 1\end{array}$ & $\begin{array}{l}0.678 \\
0.272\end{array}$ & $\begin{array}{l}0.591 \\
0.272\end{array}$ & $\begin{array}{l}1.15 \\
1.00\end{array}$ & $\begin{array}{l}0.54-1.34 \\
0.54-1.34\end{array}$ & $\begin{array}{l}0.70-1.16 \\
0.70-1.16\end{array}$ & $\begin{array}{l}\text { Acceptable } \\
\text { Acceptable }\end{array}$ \\
\hline & U (ug) & $12 / 1$ & 0.028 & 0.025 & 1.13 & $0.07-1.27$ & $0.86-1.15$ & Acceptable \\
\hline
\end{tabular}

a Data are considered acceptable when they fall within the $2 \sigma$ warning limits. Data should be checked for error when they are between the $2 \sigma$ warning limits and the $3 \sigma$ control limits. Data are considered unacceptable when they are outside the $3 \sigma$ control limits. 
Table 15-7. LLNL's Hazards Control Analytical Laboratory results from the DOE Environmental Measurements Laboratory (EML) Quality Assurance Program, 1995.

\begin{tabular}{|c|c|c|c|c|c|c|c|c|}
\hline $\begin{array}{l}\text { Medium } \\
\text { (units) }\end{array}$ & Analysis & Date & $\begin{array}{l}\text { LLNL } \\
\text { value }\end{array}$ & $\begin{array}{c}\text { EML } \\
\text { value }\end{array}$ & $\begin{array}{l}\text { LLNL/ } \\
\text { EML }\end{array}$ & $\begin{array}{c}\text { Acceptable } \\
\text { limits }^{(a)}\end{array}$ & $\begin{array}{l}\text { Warning } \\
\text { limits }^{(a)}\end{array}$ & Performance \\
\hline \multirow{2}{*}{$\begin{array}{l}\text { Air filters } \\
\text { (Bq/filter) }\end{array}$} & Gross & 6/1 & $\begin{array}{l}4.80 \\
277\end{array}$ & 3.22 & 1.49 & $0.50-1.50$ & $0.80-1.20$ & Warning \\
\hline & $\begin{array}{l}\text { Gross } \\
\text { beta }\end{array}$ & $\begin{array}{r}6 / 1 \\
12 / 1\end{array}$ & $\begin{array}{l}2.60 \\
1.63\end{array}$ & $\begin{array}{l}1.85 \\
1.12\end{array}$ & $\begin{array}{l}1.41 \\
1.46\end{array}$ & $\begin{array}{l}0.50-1.50 \\
0.56-1.93\end{array}$ & $\begin{array}{l}0.80-1.20 \\
0.87-1.41\end{array}$ & $\begin{array}{l}\text { Warning } \\
\text { Warning }\end{array}$ \\
\hline \multirow{2}{*}{ Water $(\mathrm{Bq} / \mathrm{L})$} & $\begin{array}{l}\text { Gross } \\
\text { beta }\end{array}$ & $\begin{array}{r}6 / 1 \\
12 / 1\end{array}$ & $\begin{array}{l}844 \\
513\end{array}$ & $\begin{array}{l}653 . \\
410\end{array}$ & $\begin{array}{l}1.29 \\
1.25\end{array}$ & $\begin{array}{l}0.50-1.50 \\
0.75-1.64\end{array}$ & $\begin{array}{l}0.80-1.20 \\
0.98-1.47\end{array}$ & $\begin{array}{l}\text { Warning } \\
\text { Acceptable }\end{array}$ \\
\hline & Tritium & $\begin{array}{r}6 / 1 \\
12 / 1\end{array}$ & $\begin{array}{l}50.1 \\
148\end{array}$ & $\begin{array}{l}60.3 \\
168\end{array}$ & $\begin{array}{l}0.83 \\
0.88\end{array}$ & $\begin{array}{l}0.64-1.85 \\
0.64-1.85\end{array}$ & $\begin{array}{l}0.83-1.28 \\
0.83-1.28\end{array}$ & $\begin{array}{l}\text { Acceptable } \\
\text { Acceptable }\end{array}$ \\
\hline
\end{tabular}

a Data are considered acceptable when they fall within the $2 \sigma$ warning limits. Data should be checked for error when they are between the $2 \sigma$ warning limits and the $3 \sigma$ control limits. Data are considered unacceptable when they are outside the $3 \sigma$ control limits. 
Table 15-8. Hazards Control Department Analytical Laboratory results from the Environmental Protection Agency (EPA) Water Pollution and Water Supply Studies. (a)

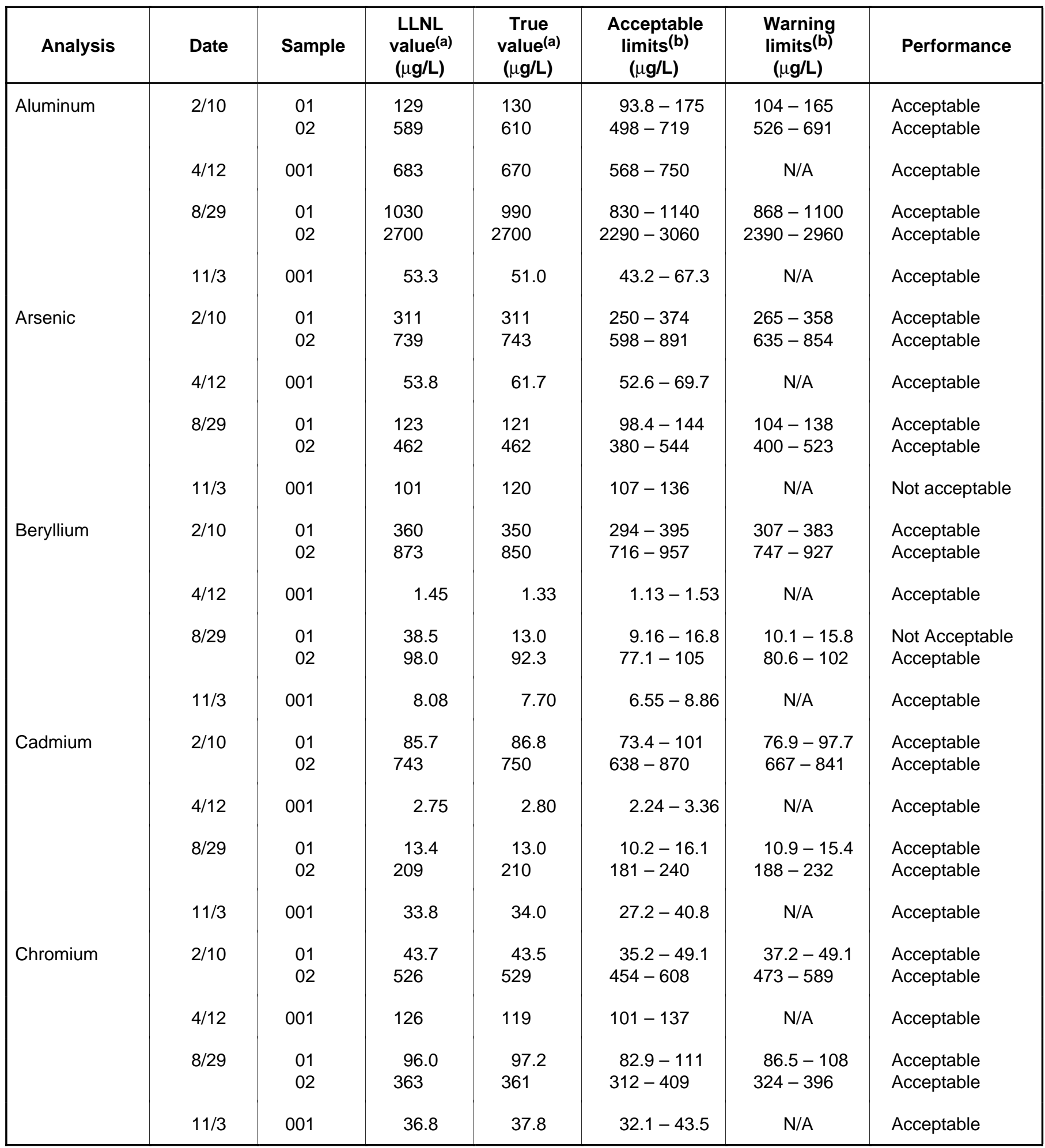


Table 15-8. Hazards Control Department Analytical Laboratory results from the Environmental Protection Agency (EPA) Water Pollution and Water Supply Studies (continued). (a)

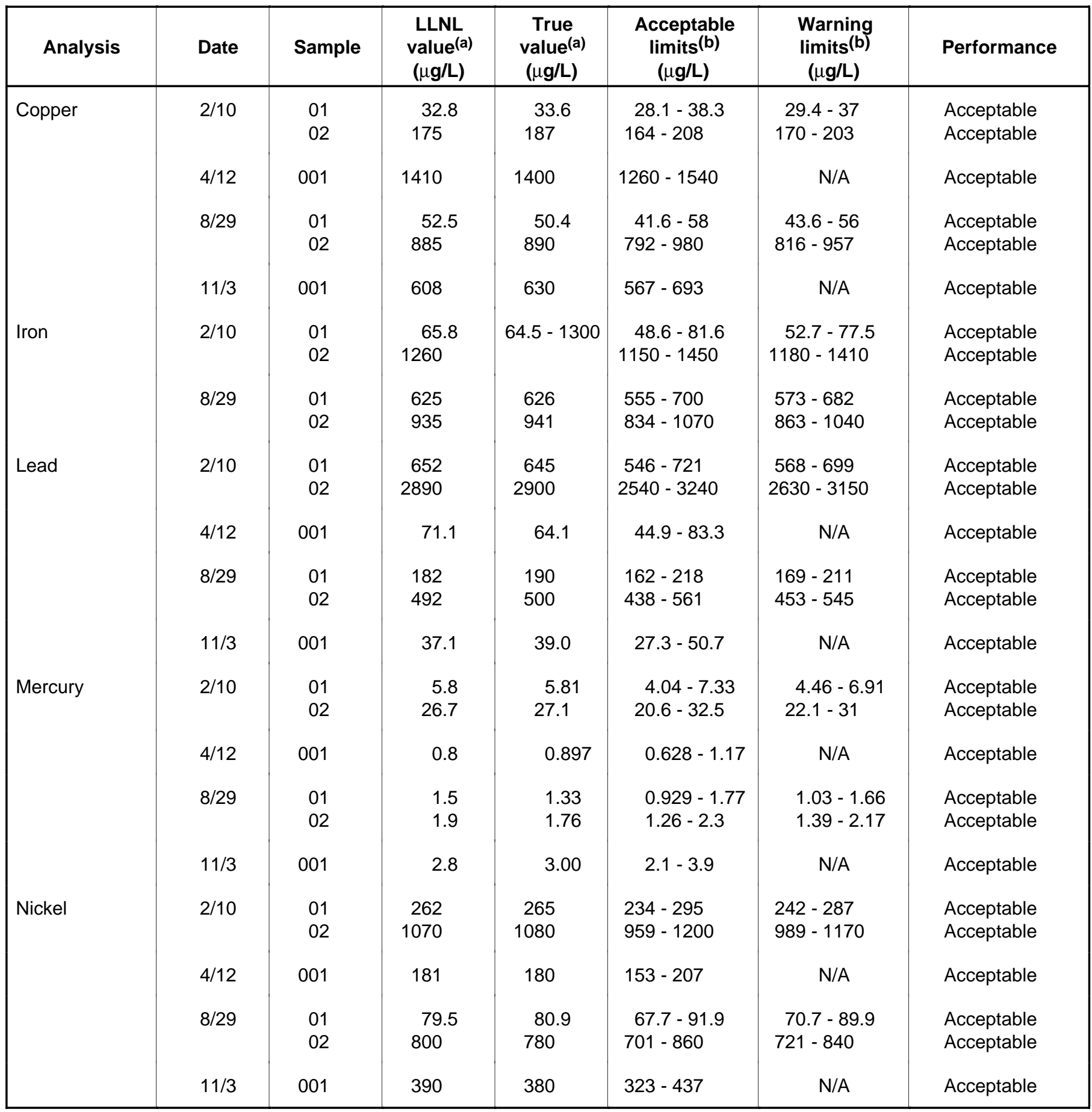


Table 15-8. Hazards Control Department Analytical Laboratory results from the Environmental Protection Agency (EPA) Water Pollution and Water Supply Studies (concluded). (a)

\begin{tabular}{|c|c|c|c|c|c|c|c|}
\hline Analysis & Date & Sample & $\begin{array}{l}\text { LLNL } \\
\text { value }{ }^{(a)} \\
(\mu \mathbf{g} / \mathbf{L})\end{array}$ & $\begin{array}{c}\text { True } \\
\text { value } \\
(\mu \mathbf{a}) \\
(\mu)\end{array}$ & $\begin{array}{c}\text { Acceptable } \\
\operatorname{limits}^{(\mathbf{b})} \\
(\mu \mathbf{g} / \mathbf{L})\end{array}$ & $\begin{array}{c}\text { Warning } \\
\text { limits }(b) \\
(\mu \mathbf{g} / \mathbf{L})\end{array}$ & Performance \\
\hline \multirow[t]{4}{*}{ Silver } & $2 / 10$ & $\begin{array}{l}03 \\
04\end{array}$ & $\begin{array}{l}90.2 \\
400\end{array}$ & $\begin{array}{l}84.0 \\
410\end{array}$ & $\begin{array}{l}70-98.1 \\
342-479\end{array}$ & $\begin{array}{l}73.5-94.6 \\
359-461\end{array}$ & $\begin{array}{l}\text { Acceptable } \\
\text { Acceptable }\end{array}$ \\
\hline & $4 / 12$ & 002 & 78.8 & 76.2 & $65.9-85.2$ & $\mathrm{~N} / \mathrm{A}$ & Acceptable \\
\hline & $8 / 29$ & $\begin{array}{l}03 \\
04\end{array}$ & $\begin{array}{l}36.3 \\
245\end{array}$ & $\begin{array}{l}36.9 \\
260\end{array}$ & $\begin{array}{l}31.2-42.7 \\
225-296\end{array}$ & $\begin{array}{l}32.6-41.3 \\
234-287\end{array}$ & $\begin{array}{l}\text { Acceptable } \\
\text { Acceptable }\end{array}$ \\
\hline & $11 / 3$ & 002 & 52.5 & 54.2 & $47.2-60.2$ & $N / A$ & Acceptable \\
\hline \multirow[t]{4}{*}{ Zinc } & $2 / 10$ & $\begin{array}{l}01 \\
02\end{array}$ & $\begin{array}{l}30.9 \\
706\end{array}$ & $\begin{array}{l}31.9 \\
726\end{array}$ & $\begin{array}{l}23.9-40.3 \\
640-813\end{array}$ & $\begin{array}{l}26-38.3 \\
661-791\end{array}$ & $\begin{array}{l}\text { Acceptable } \\
\text { Acceptable }\end{array}$ \\
\hline & $4 / 12$ & 001 & 793 & 818 & $751-877$ & $\mathrm{~N} / \mathrm{A}$ & Acceptable \\
\hline & $8 / 29$ & $\begin{array}{l}01 \\
02\end{array}$ & $\begin{array}{l}494 \\
980\end{array}$ & $\begin{array}{l}484 \\
967\end{array}$ & $\begin{array}{l}428-541 \\
848-1080\end{array}$ & $\begin{array}{l}443-527 \\
877-1050\end{array}$ & $\begin{array}{l}\text { Acceptable } \\
\text { Acceptable }\end{array}$ \\
\hline & $11 / 3$ & 001 & 1430 & 1410 & $1280-1530$ & $\mathrm{~N} / \mathrm{A}$ & Acceptable \\
\hline
\end{tabular}

a All results reported in $\mu \mathrm{g} / \mathrm{L}$. Based upon theoretical calculations or a reference value when necessary. Samples from 2/10/95 were from Water Pollution Study Number WP033. Samples from 4/12/95 were from Water Supply Study Number WS035. Samples from 8/29/95 were from Water Pollution Study Number WP034. Samples from 11/03/95 were from Water Supply Study Number WS036.

b Acceptance limits are a $99 \%$ confidence interval calculated from available performance evaluation data of EPA and state laboratories. Warning limits are a 95\% confidence interval produced in the same way as the acceptable limits. Results should fall within acceptable limits 99 times out of 100. Results outside warning limits but inside acceptable limits should be reviewed for possible problems but not necessarily considered unacceptable. 




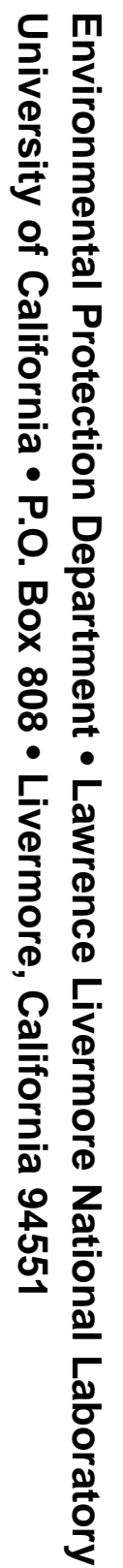

